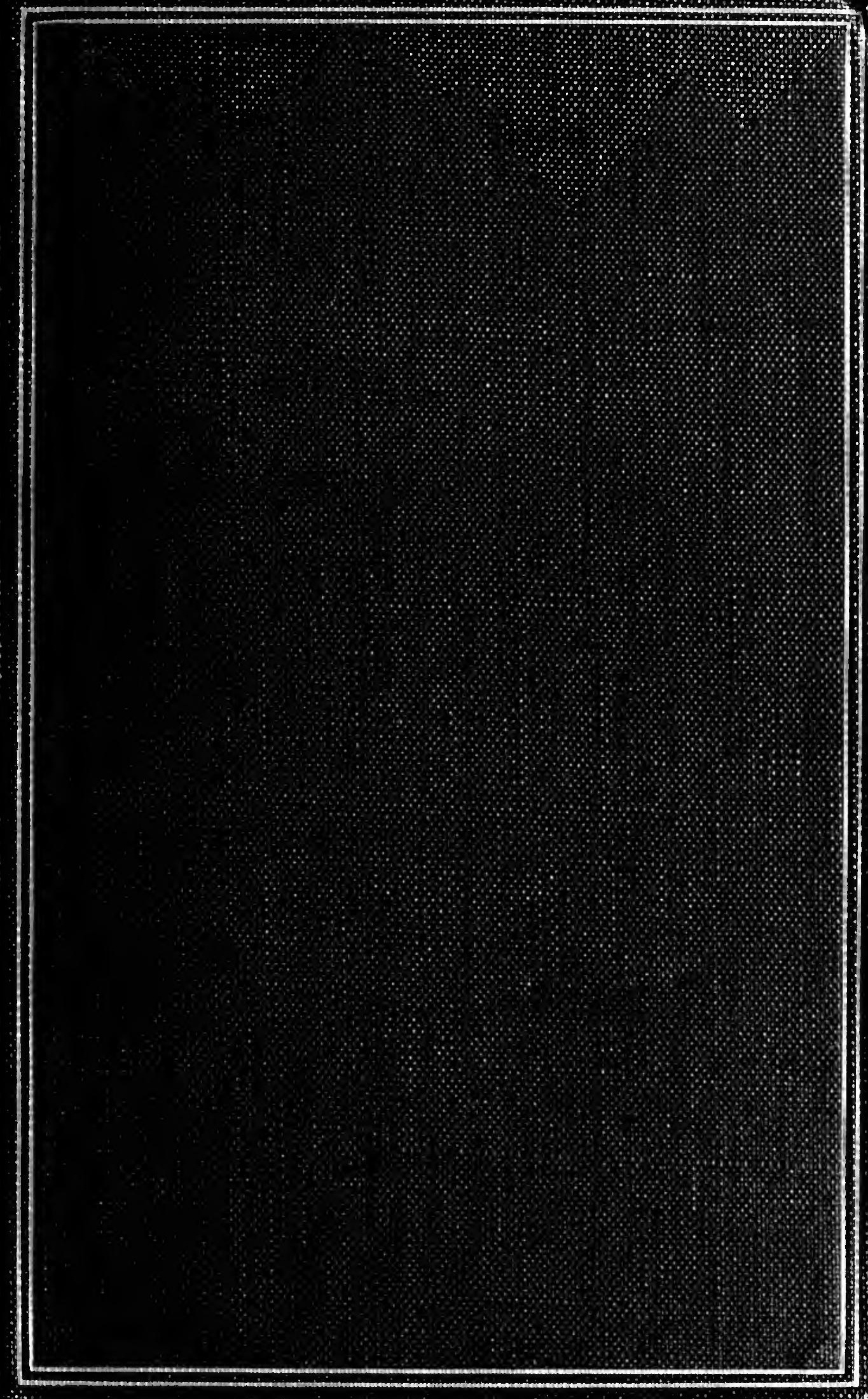




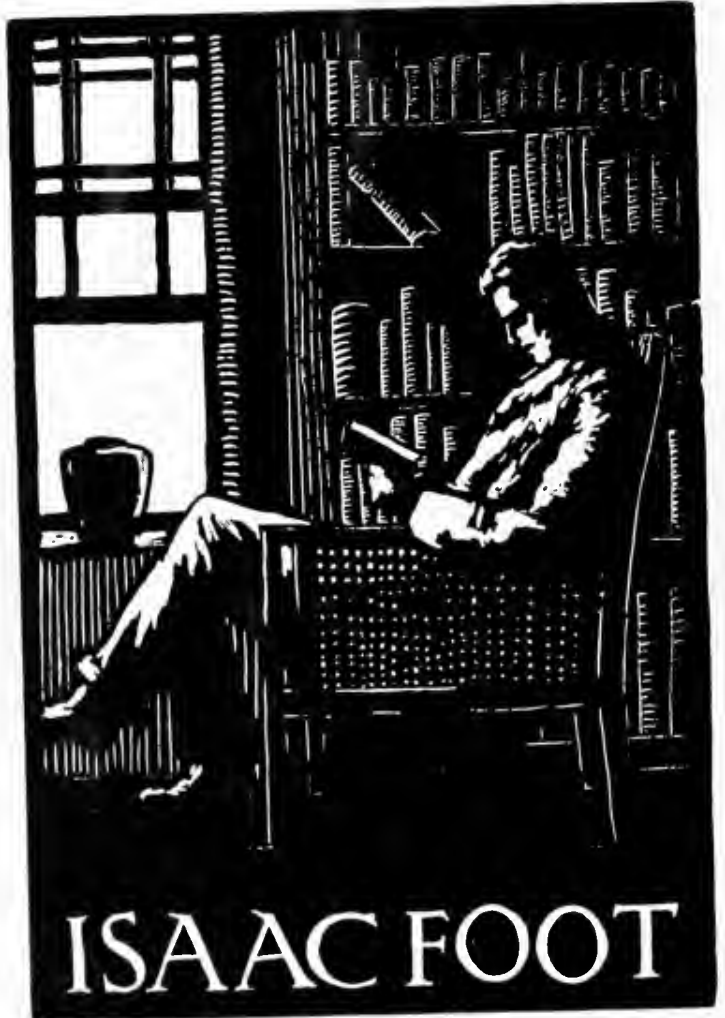


$\mid t a s e^{5}$

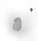




\section{Digitized by the Internet Archive in 2008 with funding from Microsoft Corporation}





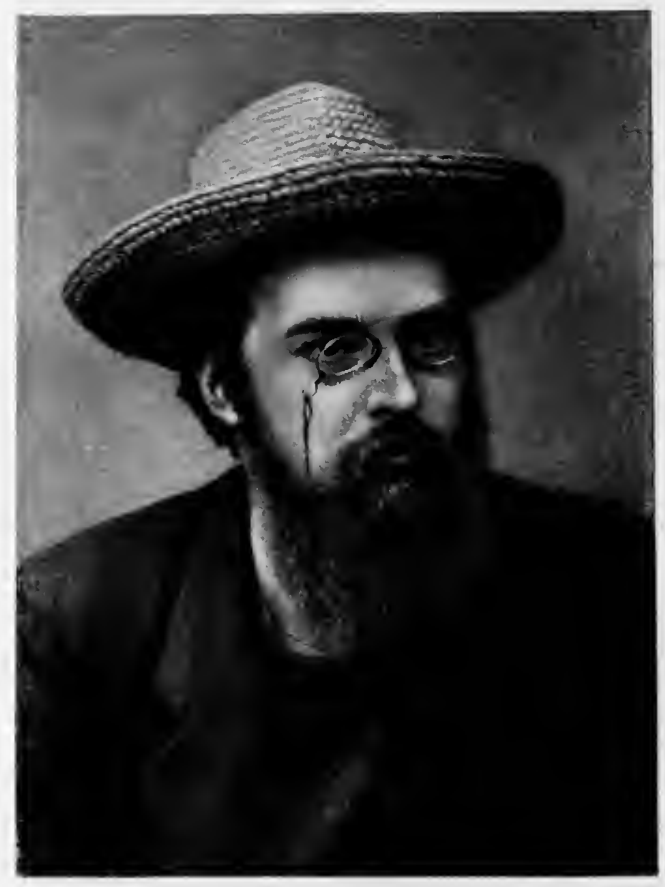

$$
\begin{aligned}
& -1.1 .27 \\
& \text { fu..." "phererymple }
\end{aligned}
$$




\title{
FREDERICK YORK POWELL
}

\section{A LIFE}

AND A SELECTION FROM HIS LETTERS AND OCCASIONAL WRITINGS

\author{
BY \\ OLIVER ELTON
}

IN TWO VOLUMES

VOL. I: MEMOIR AND LETTERS

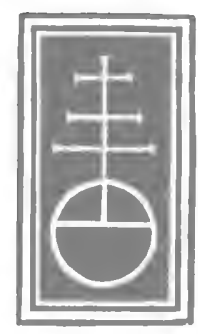

OXFORD

A'T 'THE CLARENDON PRESS

1906 
HENRY FROWDH, M.A.

PUBLISHER TO THE UNIVERSITY OF OXFORD LONDON, EDINBURGH NEW YORK AND TORONTO 
TO THE MEMORY

OF

\section{GUDBRAND VIGFÚSSON}





\section{PREFACE}

THE following Memoir, like all such labours, is something of a mosaic ; and many of the clearer and happier colours in the pattern are due to York Powell's friends. For the adding and inlaying, as well as for the choice of all materials, the editor has to answer. Various reasons have led me to include more of the handiwork of others than is common in biographies. I have come on few letters written by Powell before his twenty-eighth year, though in recompense there are some lively pictures of his youth and boyhood. He kept no diary. Hardly any of the letters he received, except those from Dr. Gudbrand Vigfússon, are in existence. I did not know him till he was thirty-five, and we were neighbours for only a few years, though we regularly met and corresponded. Another reason for quoting freely is that there were many sides, and thus many readings, of Powell. There is but one voice as to the strength and beauty of his affections. But his mind was so hospitable that he tonched many persons and circles far apart from one another: 'different packs of cards' (as one of his oldest friends writes) 'which were never dealt out together.' Hence he is best shown by many witnesses speaking independently. And as he spent himself so freely on his friends, that his letters are much taken up with their affairs or their writings, I have urged upon them to permit, wherever it was possible, such letters to be printed, withont always erasing his generosities of praise and admiration, or his criticisms; and have done the like in 
my own case, not expecting to be misunderstood. Thus the reader has both Powell's own words and the judgement of many who knew him, some of them being his older friends, whilst other and younger observers have borne noticeable witness too.

The debt to those who have thus made common cause in behalf of Powell's memory is too great to specify fully. The Memoiv is itself a record by name of nearly all those who have furnished letters, facts, memories, or impressions. Yet some call for special note. The work has been furthered in every way by his mother and his daughter. The passages from his correspondence have been approved for publication by his executors, Professor J. A. Stewart, of Oxford, and Mr. J. Ashton Cross, of Lincoln's Inn. Two well-known Icelandic scholars, the Rev. John Sephton, of Liverpool University, and Professor W. P. Ker, of University College, London, have seen and strengthened what I was able to say of Powell's Northern studies and of his ties with Vigfússon ; and Mr. Sephton, as a labour of love, has put in order a mass of Vigfússon's papers, which are to be stored in the Bodleian (see Appendix A to vol. i). Mr. R. L. Poole, the editor of the English Historical Revieu, has written with authority on Powell's services to that journal. Mr. Herbert Fisher and Mr. Robert S. Rait, both of New College, have read and emriched from their own experience the pages upon his work as an historian and teacher of history. I am also glad to have their general concurrence in the choice of the historical articles and reviews. Mr. Owen Edwards, of Lincoln College, and several other writers, have chronicled their memories of Powell as a teacher either of history or of letters. Professor C. H. Firth has also given valuable help and information as to Powell's ()xford career and other matters.

The Memoir will show something of what is due to 
Powell's colleagues at Christ Chureh. Dr. Kitchin, Dean of Durham ; Dr. Paget, Bishop of Oxford; his successor in the deanery of Christ Chureh, Dr. T. B. Strong; Mr. S. J. Owen, the Rev. W. Warner, and Mr. H. W. Blunt, have all recorded their recollections. Mr. A. Hassall has furnished further particulars; and Professor Stewart's counsel, throughout this attenpt to do honour to our common friend, has been of signal service.

In another and younger foundation than Wolsey's, the University of Liverpool, there are several of Powell's friends, my obligations to whom it is not easy to recount. Such are Dr. Kuno Meyer, who was closely associated with Powell in his Celtic studies and interests; Professor J. M. Mackay, who has given assistance in the selection of historical passages ; and Mr. John Sampson, the University Librarian, who has spared no skill and pains, often as I have consulted him on literary and other questions To Mr. Sampson the Catalogue of Writings owes its plan, and it was first drafted (upon material sent by Mr. Rait) by Miss Dora Yates, a member of Mr. Sampson's Bibliographical class, and Tutor in English Literature. Miss Yates is also entirely responsible for the Index, a work of labour.

I have to thank another colleague, Professor Charles Bonnier, for permission to print his $\boldsymbol{E x}$-Voto at the end of vol. $\mathrm{i}$; it is a memorial of importance for the right appreciation of Powell, and the same is to be said of the pages contributed to chap. ix by Mr. J. B. Yeats, of the Royal Hibernian Acadeny. Gratitude is also due to Mrs. J. R. Green and to Mr. W. L. Mellersh for their accounts. Others, whose names do not all appear in the book, but to whom it is indebted in varions ways, are: Mrs. R. $\Lambda$. M. Stevenson; Mrs. I. C. Osborne; Mrs. James Sime; Miss M. Pope, and other members of Somerville College, 
especially Miss Cécile Hugon; Mr. Arthur Sidgwick; the President of Magdalen; Mr. Andrew Lang; Dr. J. Todhunter; Mr. Percy Addleshaw ; Mr. G. E. Morrison; Sir Charles Eliot (for notes on the Finnish and Esthonian articles); Mr. Thomas Bateson (for notes on Defoe); Mr. Thomas Graham, of the Liverpool University Library (for many verifications); Mr. P. C. Yorke, as well as Mr. Ivor James and other Welsh gentlemen (for genealogical researches).

The contents of vol. ii supplement Powell's published volumes of Icelandic scholarship and those on English history, as well as his more technical reviews and articles; the latter are safe and signed in the pages of the Academy (under Mr. J. S. Cotton's editorship), of the English Historical Review, and of Folklore. The most important of those reviews are noted in the Catalogue of Writings, and it was not part of our plan to reprint them here. But Powell also wrote much in a freer style, more usually without his name, in the daily and weekly press. Part of this material he saved in a scrap-book, adding corrections as if for the press, though there is nothing else to show whether or not he thought of reprinting any of it. No one knows better than a reviewer the objections to reviving work of this kind. But I am led to the conviction (and have argued for it more fully in vol. i. pp. 137-8) that in Powell's case they do not apply, and that it would do him wrong not to save some of these pages from that strange form of oblivion, or life-in-death, peculiar to the modern world, the files of a journal. Such fragments, even when not additions to positive knowledge, are full of glimpses into unfrequented lore, and of life and illumination. We seem to turn over the portfolios of some diffident artist, who has left nothing that fully represents his power, but a mass of studies, sketches, beginnings, full of 'the play, the insight, 
and the stretch' that we seek: by no means, therefore, to be sacrificed, but worthy of sifting and mounting. These press notices often have the same sort of attraction as Powell's letters, and complete our view of his mind. The longer articles and prefaces have a different interest. They are carefully finished, and often came out in books and magazines that are now very rare. The text of all these writings has been scanned for errors of detail. Powell seldom saw a proof-sheet of his notices for daily papers, and his handwriting though beantiful was sometimes mysterious. His spelling of foreign or Old Germanic proper names was not always orthodox or consistent, and has mostly been left as he chose it to be. In some articles, and in his verses, his old-fashioned habit (shared by FitzGerald) of sprinkling capital initials has been kept to show his idiosyncrasy. Omissions are siguified by dots, editorial matter by square brackets. A few connecting notes have been inserted between the sections or extracts in vol. ii; a list of the items now first printed from MS. is given in the Catalogue of Writings; and there also are set out the particular debts to the many authors, editors, proprietors, and publishers who have courteously granted the use of copyright matter, or assisted in tracing Powell's contributions, often of distant date and unsigned. The chief newspaper for which he wrote was the Manchester Guardian, whose editor, Mr. C. P. Scott, and his colleagues, have given every encouragement and facilities for consulting records. The circumstances under which the Survey of the late Queen's reign was published are explained in vol. i. pp. 243-6. All prose articles in vol. ii, unless otherwise specified, are from the pages of the Manchester Gurrdian. The Academy, the Morning Post, the Pall Mall Ganette, and the Speatier, are also represented. 
Amongst magazines, the main creditors are the Quarterly Review, the English Historical Review (see vol. i. pp. 845), Folklore, the North American Review, the English Illustrated Magazine, the Quarto, the Pageant, Saint George, and the Green Sheaf.

Mr. Elkin Mathews, of Vigo Street, the present holder of the copyright and the separate copies of the Omar (both Quatr(ains and Note), has generously allowed republication; and Messrs. Swan Sonnenschein \& Co. have done the same in the case of Teutonic Heathendom, which appears in Religions of the World, and of Thoughts on Democrcicy, which first came out as a preface to Mr. Charles Beard's Industrial Revolution and afterwards under the auspices of Saint George. The 'Sette of Odd Volumes' issued the paper Some Words on English Allegory among their private publications, and have been good enough to allow its inclusion here. The same permission is accorded by Mrs. Barmby and Messrs. Archibald Constable \& Co. for the preface to the late Miss Barmby's Gisli Surrsson; by Mr. Jack B. Yeats and Mr. Elkin Mathews, for poems from the Broal Sheet; by Mrs. Gleeson White and Mrs. Richard Shute, for the papers on the late Mr. Gleeson White and the late Mr. Shute; by Mr. Alfred Nutt, for extracts from The Tale of Thrond of Gate; by Mr. Grant Richards, for the preface to the late Grant Allen's County and Toun in England; by Mr. Edward Clodd, for the passage by Powell in his memoir of Grant Allen (also published by Mr. Grant Richards); by Mr. John Murray, for the preface to M. Nazarbek's Through the Storm; by the Society for Promoting Christian Knowledge, for a passage from Powell's unpublished fragment on Scandinavian Britain; by Messrs. Duckworth \& Co., for quotations from the translation of the work of MM. Langlois and Seignobos on the Study of History; by 
Mr. Joseph Clayton, for passages from his story Grace Marlow, wherein Powell is depicted ; by the Horace Club at Oxford, in which he took much interest, and to whose good offices is due the text of two poems, one hitherto unprinted; by Dr. Douglas Hyde and the Gaelic League, for the use of two letters printed in the pamphlets of the League; and by Mr. W. Rothenstein and Messrs. Hacon and Ricketts, for a passage on Verlaine.

The portraits of Vigfússon and of Powell by Mr. H. M. Paget, and the pencil drawing of Powell by Mr. J. B. Yeats, are specially welcome. Acknowledgement is also due to Mr. Frederick Hollyer, of Pembroke Place, and to Messrs. Window and Grove, of Baker Street, for liberty to reproduce photographs; and to Mr. E. Strange and Messrs. G. Bell \& Sons for the use of Powell's designs (founded on an old legal script) from Mr. Strange's work on Alphabets.

The best thanks of the editor are offered to all these ladies and gentlemen for their services and concessions.

O. E.

Liverpool, Oct., 1906.

Since the paragraphs relating to Sergius Stcpniak (vol. i. pp. 224-5) were in print $I$ have come on another testimony by Powell to his friend. Mr. G. H. Perris (and his publishers, Messrs. Chapman \& Hall) has allowed me to reprint a letter from his work, Russia in Revolution (1905), pp. 250-1, which should not be lost, and I insert it here.

It was as a charming companion and a most appreciative student and critic of literature that Sergius Stepniak was known to me. He was absolutely sincere, sound in his judgement, and anxious to get at the fairest point of view. In these characteristics and in his wide reading in many tongues (he could read, I believe, every European language 
save Bask), he reminded me of my master, Gudbrand Vigfússon. He was quick, too, in seizing the ideas of others and understanding their aspects. He was either silent, or he spoke frankly and directly, never hesitating to speak the whole truth as he understood it and felt it, but with a noble kind of courtesy that could not but appease the most sensitive. He was so hard-working, so earnest, so stern to himself, so sympathetic, that I think he had it in him to have done good work in literature later on. A truthful, unselfish, upright, warm-hearted, and determined man, reasonable in all his thoughts and ways, as free from vanity and every base taint as any being I have known.

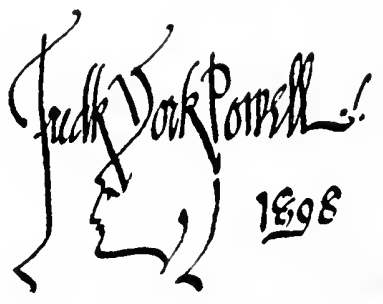




\section{CONTENTS OF VOL. I}

\section{CHAPTER I \\ EARLY YEARS AND MARRIAGE: 1850-1874

Race and birth. Childhood: the Sandgate fishers. The Manor House, and first schooling. Letters reminiscent. Rugby: Temple and Moberly. Bonchurch: early lore. Oxford: Unattached Student. Migrates to Christ Church. Powell as undergraduate: temper, tastes, and friends. First Class. Law Lecturer. Early Marriage: settles in Clapton; decorates room. Powell's youth imagined

\section{CHAPTER II}

\section{VIGFÚSSON : 1875-1883}

Where should Powell's learning centre? Old English History and Northern studies competing. Interlude at Trinity. Creighton's help: Early England to the Norman Conquest: other books for the young. Attraction of the matter of Iceland: meeting with Vigfússon. Life and labours of Vigfússon: MS. note. Scheme of Vigfússon fourfold. First work with Powell: Sturlunga Saga: mutual recognitions. Icelandic Prose Reader: larger plan frustrated. Corpus Poeticum Boreale: scope; worth of the poetry, merits and drawbacks of the book. Powell as translator: his principles at length, and examples. Move of the Powells to Priory Gardens, Bedford Park: new friends. Letters on Pusey and on the Paston Letters

\section{CHAP'TER III}

\section{I.ABOURS, 1884-1889}

Jass Law work: irony of position: Powell's own attitude. Studentship and tutorship at Christ Chureh: no post in History for Powell at Oxford. Visit to Manchester: examining. Work for Women's Association. Visit to Copenhagen: Vigfússon on the Fire. Origines Islandicue accepted hy Oxford Press. Powell's 
projected Scandinavian Britain: quoted: unfinished. Reads Old English verse. Grimm Centenary volume with Vigfússon: Ballad in Seots. First meeting with Powell. His part in founding English Historical Review. Publication of History of England to 1509: character of the work. Reeommends Provençal. Letter on life and the award of the gods. Sallies against Oxford. Arthur Johnstone and James Sime. Deaths of Mrs. Powell and of Vigfússon: last letter to Vigfússon: MS. note again. The delay of Origines: sketeh of it, examples of translation. No more long books: Powell's future métier

\section{CHAPTER IV}

\section{LIFE, 1889-1894}

Teutonic Heathendom. Saxo Grammaticus; Powell's habits of work and punctuality. School of English at Oxford. Deelines suggestion to move to Liverpool. Views on Scottish history. Dreams; the railway station; The Little Man. Canon Liddon. Manchester landseape. Ibsen's Rosmersholm. Zola's Thérèse Raquin. Blake's Book of Los. Lyra Heroica. Reviewing in Manchester Guardiar and elsewhere; value of Powell's reviews. The Rosicrucian dream. Letters: Rabelais Club: hookbinding. Visit to Cornwall. Portuguese hiterature. Dante. Visit of Paul Verlaine described; Powell on Verlaine. Visit of Stéphane Mallarmé. Brumo and the Pope. First visit to Ambleteuse. Notes on Powell's life and habits at Christ Cherrch; and on his tuition in law and life . . . . . . . . 112-168

\section{CHAPTER V}

\section{THE REGIUS PROFESSORSHIP. WORK IN OXFORD}

Opinion on Froude. Position in Oxford: movement for Powell to be Regius Professor of MLodern History. A mislaid bill from the Prime Minister. Acceptance of offer: misgivings on congratulations. Mr. William Hines: note on Songs of Labour. Letters of acknowledgement. On proposed memorial to J. R. Green: Irish history: attitude to Ireland illustrated. Death of Sime. Inaugural leeture, its fortunes: extraets. Address at Reading on the study of history. Ties with the College at Reading. Powell's conduct of the Chair: what he did not effect. 'T'estimonies, 1895-9, as to what he did effect : pietures of him in the lecture-room and out of it. His part in university business: Clarendon l'ress and Taylorian Institution . . 169-219 


\section{CHAPTER VI}

LIFE, 1895-189S

Work for National Home Reading Union: for Social England. Oxford. Bedford Park: death of Stepniak. Letters on Mr. G. Meredith. Ambleteuse eloudscapes. A Londoners' meeting. Opinion on William Morris. Fcereyinga Saga. Ibsen again. The Manchester Guardian: Survey of the Queen's Reign. Journey to Holland. Death of Herry Stone. Lecture on King Alfred. Mrr. Wells's stories. Powell's increasing 'Toryism'.

The Casket Sonnets. Ambleteuse, 1898 . . . . 220-283

\section{CHAPTER VII}

\section{LAST YEARS IN LONDON : 1900-1902}

R. A. M. Stevenson; affinities witl Powell: view of 'culture' Death of Grant Allen; Powell's tributes and political feelings. Death of Stevenson; letters. Ambleteuse; letters on boxing, French poetiry, and the 'historic hearen'; letters in verse. Writings of 1900 . John Ruskin; Association with Ruskin College. Preface to Gist Sursson; Thoughts on Democracy. Powell's 'Toryism '. 1901 ; letters ; L'Aiglon, Lefroy's Poems. A Note on Omar, and Quatrains. Letters on literatmre; Browning, M. Arnold, \&c. Horoscope. 1902; visit to Eton; and (April) to Ireland; Lecture in Dublin; tour described. Article on Lord Acton. Address at Bangor on The Study of History in Universities. Visits to Liverpool and Rugby, to Ambleteuse and Templeuve

\section{CHAPTER VIII}

\section{OXFORD : $1902-4$}

Migration to Oxford; reluctance and regret. Letters on The Wings of the Dove. Celtic evening at Liverpool: speech. Powell and mysticism. Moving lrouse. Change of political view. Portrayal of Powell in fiction. Pictures and painters. Letters to a child. Teaching at Somerville: testimonies. Irish discussions. Visits to Knole and Gorleston. Signs of illness. Hard work: articles on Mr. Swinburne and Mr. Kipling. General Survey of Modern Iristory. Edward $I I$ at Oxford. Last stay in Ambleteuse. Death of Hines. Stay at Folkestone. Tradition and its Conditions. Last visit to London and pictures. 'The Oxford garden. Last letters: spring. Note on Schopenhaner. Closing days; death; burial at Wolvercote. 


\section{CHAPTER IX}

TRAITS AND OPINIONS

Powell's conception of written history: contrast with Lord Acton's. Origins of Powell's view. Relationship of literature and history. Powell's historical style and diction. His languages, erudition, library: acquaintance with Spanish literature. Taste in letters and mode of criticism. His love for les jeunes: indulgences, severities. Mental position in Oxford: testimonies from Oxford: Bishop Paget, Dean Strong: Dr. Charles Bonnier. Religious views. Peculiar attitude towards death. Letters of sympathy, praise, advice. Theories on the feminine nature. Description and analysis of Powell by Mr. J. B. Yeats, quoted. Personal appearance and talk. Notes on ethical standards. Perplexing attributes. Leading characteristic.

\section{APPENDIX A}

'THE LIFE OF VIGFÚSSON

\section{LIST OF ILLUSTRATIONS TO VOL. I}

FREderick YoRk Powell, at. 27

Frontispiece

From a privately taken photograph lent by

F. P. Balnard.

Frederick York Powklu, at. 23

From a photograph by Window and Grove,

lent by Canon Punchard.

Gudbrand Vigfússon

From an oil painting by H. M. laget.

Frederick York P'owell, at. 44 .

From a photograph by Frederick Hollyer.

Facsimile of Handwriting

From a letter to Arthur Johnstone.

Frederick YoRk PowelL, at. 49

From a pencil drawing by J. B. Yeats. 


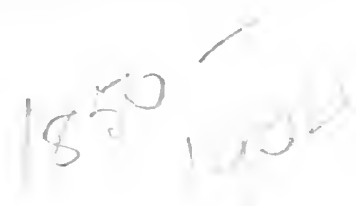

\section{MEMOIR AND LETTERS}

\section{CHAPTER I}

\section{EARLY YEARS AND MARRIAGE: 1850-1874}

Race and birth. Childhood: the Sandgate fishers. The Manor House, and first schooling. Letters reminiscent. Rugby: Temple and Moberly. Bonchurch : early lore. Oxford: Unattached Student. Migrates to Christ Chmrch. Powell as undergraduate: tenper, tastes, and friends. First Class. Law Leeturer. Early Marriage: settles in Clapton; decorates room. Powell's youth imagined.

Frederick York Powell was boln on Jan. 14, 1850, at 43 Woburn Place, Bloomsbury. He was of Welsh and English blood. We may share his wise distrust of racetheorizing, and yet feel that traits of both the peoples mingled in his nature. He had the quick prophetic wit often called Celtic, that sees in flashes and leaps to the end of an argument; he also craved like an Englishman for facts and proofs. He was a man of emotions and intuitions, holding to the faith and methods of positive science. He was proud of being a son of Wales, ${ }^{1}$ and also understood the temper of Sonth Irishmen and High-

1 In 1890 he wrote with ardour of "Welsh statesmen like Cromwell and 'llomas, Welsh poets like Vaugham and Herhert, Welsh merchants and sailors, pamplileteers and divines ly dozens, hinging anong the English people their own peculiar qualities of logieal thonght and harmonious expression and persistency of action.... Wales in tho Middle Agres had revolutionized all buropean literature at a single stroke, and onr present poet lameate owes much of lis fame (justly or unjustly we will not question here) to a poetical paraphase of the story first set down in Latin hy a Welsh elerk some seven and a half centuries ago.... ['l'he share of Wales in momlding lingland] is a subject for a Welshman knowing English history, or an linglisman knowing Welsh literature, and both are unfortumately to scek. Tut must Wales always wait?' 
landers, amongst whom he had many friends. His father, Frederick Powell, who came of a South Welsh family, was a commissariat merchant, settled early in London, and shared in the work of provisioning Paris after 1870: his office was in Mincing Lane. Like his son, he was in middle life a handsome, ruddy, dark-eyed man : there was also a marked likeness in the line and carriage of the head and the modelling of the face. Frederick was the eldest child and only son in a family of six. His mother, Miss Mary York, was the daughter of Dr. James York, 'a very clever and good physician, and a pretty Spanish scholar, and a handsome man, and I have always been glad to bear his name.' Family tradition and an inherited chart, which inquiry has neither confirmed nor disproved, trace the line of the Yorks to a brother of Philip Yorke, the first Earl Hardwicke, the Lord Chancellor. Powell never investigated the tree himself, though he wrote in the last year of his life :-

I have found I am related (by marriage, not by blood unluckily) to Claverhouse, 'Bonnie Dundee.' I am delighted even with this slight bond. 'This is on my mother's side, but I fancy I am really related by blood on the father's side, but 'on the wrong side of the blanket', as folks say in Essex.

I am also descended from the mistress of Richard the Third: so my mother told me the other day, so scandalous are the revelations that await the poor genealogist. What further light ladies and murderous gentlemen I shall come across I don't know. What fun to be Viscount Dundec, for a socialist (the title is attainted at present)!

Powell's childhood was happy; he always spoke with pleasure of his life with his parents and his five young sisters, though one of these 'was snatched from us to our lasting grief, whom I remcmber with much regret'. He would tell how his father, 'with his gentle Welsh generosity of soul,' would show no temper when he made boyish mistakes, but would reason with him and point 
them out kindly. He kept this example in mind, and with young men was never a harsh elder or dominie. He was markedly precocions ; many of his lifelong tastes and gifts appeared early, perhaps because his health was poor and broken for a long while, and his mind, as sometimes happens, was thus stimulated. When he was four years old his life was despaired of. $\mathrm{He}$ was therefore often taken from Walthamstow, which was the home of his family till he was fourteen, to Sandgate, where he stayed in charge, either of one of his parents, or of his old nurse, to whom he was much attached, and who had a face 'just like that of Bellini's Doge'. In 1902 he wrote: 'I always keep a photograph of that picture as her portrait.' His early affection for the little fishing-village of Sandgate never ended. There he learned to love the sea and its folk, and it will be seen that some of the Sandgate fishermen were among his first friends, and he esteemed them as having taught him something of the best of life. In 1885 he wrote:-

\section{To G. Vigfússon.}

July $15,188 \tilde{5}$.

My old fishermen friends live there, and I want to see them before they die. My mother was there lately, and she told me unless I went soon they would all be dead. They are fine fellows, the best friends a boy conld have had, gentle, honest, true, and upright in all their ways. They are the men I respect most of all I knew as a boy.

Other letters will show his affection for Henry Stone the boatman, and for Stone's brother's. It was a good training for the historian of the Northern sea-rovers and of the poets who sang them. Powell always had an intimate knowledge of the parts of a ship, and some of his most eloquent sallies are on the sixteenth-century sailors. He liked sailors' dress, and to the last favoured the suit of blue serge and peaked cap, which made him look at first view like a dark-bearded skipper wondering at the sights 
of the land after a long voyage. In this as in all ways his exceptional tenacity to his boyish bent and impressions is clearly to be traced. He had a memory on which shapes, objects, colours, traits, and details were at once and ineffaceably engraved, and with them his passions, affections, and antipathies. When he came to read, what he read remained with him in the same way. Such a memory sometimes cumbered his power of exposition, but never his thinking; it never became mechanical, for his vitality of mind kept pace with it. Foree of memory is almost required, though it is not enough, for a strong talent, and it may act as a cement to the whole natme. In Powell it was developed soon, as his teachers at once noticed when he was able to repeat the mechanical or muemonic sentences, hundreds in number, of the work called 'Slater's Chronology'. He was at times irritable through bad health, but cheerful and companionable. He was also duly independent. In his ninth year he rebelled against his governess, saying to his mother, 'the truth is, mother, I am too old to be under petticoat govermment.' Accordingly in the autumn of 1859 he was put to a preparatory school, where he stayed until July, 1862. The Manor House, Hastings, left good recollections; it was in no wise one of the dismal, insufficient 'acarlemies' that are even now to be found in corners. Mr. Alexander Murray, the head master, was clearly impressed on Powell's memory as 'a very remarkable as well as a very good man', as a letter to Mr. Murray's son and successor testifies.

I was made an honorary LL.D. of Glasgow last year [1901]. I wish your father conld have known of it, and mine. It would have pleased them. Your father was very patient with me, and he let me read his books, which was a kindness and a benefit I shall never forget. I have not disgraced the old Manor Honse teaching, thongh I should be the first to confess that I have not mofited by it, and by your father's noble example, as I might. 
During the last weeks of his life, Powell liung his old master's photograph in a spot where he could see it, on his bedroom wall. This is good testimony, when we think how most men's memory of those who have taught them at ten years of age is faint, where it is not cold. To others of the family he did not cease to own his debt. Of the Miss Murrays he says, 'I have never forgotten what they taught me so carefully and minutely'. For the school was conducted not only by Mr. and Mrs. Murray, but by their three danghters; and Miss Charlotte Murray tells that 'in those days it was more like a big family than auything else, as you will judge by the boys calling us by our Christian names: and we were all young together'. In a letter written long after, Powell pays his tribute to Miss Emily and Miss Elsie Murray.

To Miss Charlotte Murray.

July 1,1903 .

Many thanks for your poems and the little tract ${ }^{1}$ and your letter. My mother is staying with us, and is reading them with pleasure.

Emily was very brave and sincere, one of the most just women I have ever known. (Justice is a rare quality in women according to my experience; women are merciful and forgiving, and even generous, but rarely just.) I respected her as we all did, and loved and admired her. She was a fine teacher too, to any one that wished to be taught. Her summary of the 'Scheme of Redemption' is excellent, and concise, and clear like herself. Her bravery and assurance in the face of death has the heroic in it, to my mind.

In the Midst is a pretty anecdote; the naivete of children reminds one of the best mediaeval thought. There is something really pathetic in it.

You and I may explain things differently, but I don't think we are so far apart in the essentials as would seem. When I get the inner sense of your thought, I find I can wholly sympathize with very much of it.

The portrait is very good.

I A menoir ly Miss Charlotte Muray of her sister. 
Is there any account of Elsie's last days? Elsie was very good, and we all trusted her. She was just, like Emily, though she had not, at first, the intellectual attraction Emily had, and the enthusiasm that carried you along with it. She was like a firm rock of character, and a very fearless, damtless person-wonld risk friendship, even, for right's sake, and that is hard to do. Her example has helped me several times in my youth to speak when I would rather not have spoken, and I was glad afterwards.

I think all the old boys who were with you in my time thought as I do about Emily and Elsie, and probably they would have told you so, but still I put it down as my persistent impression.

There is a poetess of a rather different school of thought to yours whom I admire greatly, Christina Rossetti; and one more in sympathy, Jean Ingelow (whose Two Brothers and $A$ Sermon I think much of and feel). I expect you like them both.

I am yours very faithfully and gratefully.

At the Manor House Powell was remembered for his usually immaculate clothes, sometimes of shepherd's plaid; for his good bearing, his somewhat sudden though not brooding temper, and for his love of fighting. 'This pastime was forbidden; but he was once reported by the matron for using his fists as an expression of opinion on the question whether black was a colour or not. She leseribed the combatants, in a phrase that struck root, as 'like Cain and Abel in the death-struggle'. It does not appear which of the two was Powell; he had forgotten the incident, but when reminded of it he

first indulger in one of his heartiest peals of laughter and then remarked that 'many a war in the history of nations had arisen on quite as trivial a question as that'.

Before he went to Rugloy his mother let him have lessons from Harrison, a well-known instruetor, lest he should be too much battered in a big school. His pugnacity only dwinlled as he learnt the art and fancy 
of boxing. Of this he became and remained a connoisseur, knowing well the histories, successes, and burialplaces of the great English pugilists. With his temper he had from the first to reckon. He expressed its character long afterwards when he wrote, in answer to some one who had praised his tolerance, 'I am tolerant, and I have a childlike ferocity.' All his life both these qualities appeared in his judgements, as many of his letters will show.

He was already fond of history, and pored over books. His school Bible is preserved, with the preface to King James crossed out, which he did not consider should find a place in the Scriptures. No doubt he objected on grounds of style and seemliness: and many have felt the same thing, though seldom at so tender an age. He read his Bible, as a story shows: 'One Sunday afternoon,' writes his schoolfellow Mr. John D. Murray, 'when the boys were saying the catechism, after repeating the tenth commandment, Powell somewhat startled the class by volunteering an "eleventh", and then quoted our Lord's words, "A new commandment I give unto you that ye love one another." To his memory of this little school he held fast. He went down with his wife to visit it, he had a picture-frame made of his old mahogany desk; he asked for a halfholiday when he became professor; he contributed to the boys' magazine, St. Clare, in 1895 (the school had moved meanwhile to Walmer and taken this name), the pleasing paper on historical study (see vol. ii. pp. 95-8; and he tried as late as 1903 to unite the old boys of the school into a club.

\section{To Alexander Murray.}

Jan. 6, 1903.

So let's make an Old Boys' Club and have a dinner in the winter once a year, and a meeting at St. Clare in the summer. We should rally round these dates, I am sure. There are lots of Old Boys I should be very glad to see... I am very keen about the Club. I think it will do good in many ways. Your pupils are a picked lot, very wholesome 
Englishmen and Scots, people it is good should be knit together for good.

Powell was already judged to be a clever boy; but the sharpness of all these early feelings shows a precocity of heart and enthusiasm rather than of pure brain. Large, retentive affections and venerations, as well as firm dislikes, hidden moler high spirits, evidently marked his boyhood. From the Manor House he passed for the better part of two years to a preparatory school ontside Rugby, kept by the late Mr. Fumess. Of this time little is remembered save his weak health. He had a sunstroke, and travelled with his mother for several months, visiting Spain and the Pyrenees in the summer of 1863. He also had a serious attack of lung inflammation which called his mother to Rugby. She had friends in common with Mr. Jex Blake, afterwards head master of Rugby, and now Dean of Wells; and Powell entered his house in the autumn of 1864. He was at Rugby two years.

The workings of original talent, which no school can perfectly hinder, were left in comparative freedom at Rugby, a place less ridden than others by the classical monopoly. Latin and Greek scholarship, such as is called in England 'pure', and exacts a curious skill in mimicking the prose and verse of the best classical age, is still the nearest road to collegiate honour and lucre. It was then almost the only road except mathematics. The studies of the ancient life and mind, or of history or science, were barely introduced. But in 1864 such reforms had advanced further in Rugby than in other schools. Arnold had shown some of the realities of politics and history to his pupils. Temple had promoted, or reformed, the courses in modern languages and natural science, and above all had established regular lessons in English. The Commission of 1862 had reported that Rugby led in this and other imperative changes. Powell, while not strong, and of desultory habit, seized some of his opportunities. Though he cared little for the classical 
routine, in time he read Greek and Latin freely. Virgil, in particular, penetrated and remained with him. But he won no special distinction at school. He was ever unambitious, content to be second or third. He was also vowed in heart to history and modern literature, and seems to have begun Icelandic while at Rugby. He read and ransacked English poetry. In many ways he was visibly far better equipped than most of his companions. In his form he had a name for uncamny stores and remote species of knowledge, and one of his schoolfellows, the Rev. W. Warner, writes that

To boys whose work was mainly confined to Latin and Greek, it was astonishing to listen to a boy who knew about so many other things. The form-master would sometimes almost forget the subject of the lesson in an interesting conversation with 'old Powell'. Probably we rather resented this.

In the house he was regarded with wonder, amounting almost to a superstitious terror. His tastes and amusements were not like ours. His study was furnished on a different plan, and contained strange and dangerous weapons, which he was believed capable of using on provocation. And provocation of course there was: such an abnormal schoolboy was incvitably exposed to 'pinpricks'.

Powell was awhile in the form of a man who was a teacher of genius, who had the passion for letters, and who, though not altogether cast for a disciplinarian, must have impressed a sensitive pupil with his rarity and integrity of character. This was the Rev. C. E. Moberly, an enthusiast for literature, especially for poetry, who opened new horizons up to any that would attend. Powell must have seen at once through any practical deficiencics and inadvertences to the spirit shining within. late in life, Mr. Moberly, after leaving Rughy, resigned his orders and sacrificed a living because he could not in conscience any longer accept the doctines of the English church. Powell liked simple and single characters, and his regard 
for his old teacher remained. But the growth of a schoolboy's mind can only be guessed and groped for. Of Powell's look and nature at this time we have, as it were, one of those black old scissored silhonettes in expressive line that are better than any touched-up glaring photograph. One of the masters then at Rugby just recalls him as a 'rather slim, silent, dark-eyed youth, almost incredibly unlike the mature man', and different from his fellows. Dr. Jex Blake remarks on his quick and responsive intelligence, warmth of nature, and modesty, on his taste for English poetry, and further on his frequent ailments. The Midland winters were too cold, and cold was one of the few things that always hindered and depressed him. He was low in the school (in the Lower Fifth) considering his parts. He did not thrive sufficiently, and in July, 1866, he left. One thing he took away from Rugby: a comprehension of the English boy, into whom he always saw with good-tempered clearness and lighthanded sympathy, and whose foibles and superstitions, whose childishness and hard manfulness intertwisted, were evident to him. Part of Powell's personal influenee came from his keen memory for what the ordinary man halfforgets, his own youth, and this was a good qualification for one who was to teach and befriend so many boys at the university. Perhaps the main use of an English public school is to give this knowledge, so that a man of alien bent and idea may yet make his account with English society and move about in it. Powell kept his affection for Rugby, and his respect for 'Temple and for the best of Temple's shepherds. When Temple passed from the see of Exeter to London, Powell was one of the most enthusiastic of Old Rugbeians in congratulation. He had another spell of self-education,between sixteen and eighteen, and it seems to have done him good. Again he went south for the sum, and was with his mother and one of his sisters for some time at Biarritz. We are safe in thinking that his zest for Provengal and Peninsular things, and his 
knowledge of the Spanish and Portuguese tongues, date from these wanderings. In his articles written thirty years later on Portugal and on the Cid, in his somet to Camoens, in his concern for the technique and skill of the bull-fight, as well as in a partly theoretic disrespect, Latin and not merely humorons, for the value of buman life as such, we trace the play of the South in his many-stranded nature. He also afterwards travelled with his mother in Sweden, and soon began to use the langnage. He was to finish a somewhat broken schooling under fortmate eonditions. He went to Bonchurch, in the Isle of Wight, into the care of Mr. Henry Tull Rhoades, whose description of Powell at eighteen must be quoted :-

He came to Bonchureh as my pupil in 1868 from Rugby, which he had left, partly on account of health, partly becanse he was low down in the school for his age. His house-master, the present Dean of Wells, had told me that he was full of information about early editions and rare books, but I was not prepared to find him so remarkably mature in mind and character, and with so many and such varied interests. . . . He had no great difficulty in getting up his Latin and Greek books for Matriculation, but I never heard him, either then or afterwards, express much appreciation of classical literature. What really interested him were the subjects in which he afterwards became known. At an age when boys are given to decorating their schoolbooks with more or less libellous portraits of their masters, he had covered his with early alphabets, or Runic scrolls, and he was beginning to work at Old French and German, and at Icelandic. One of his favourite books at this time was Dasent's Burnt Njal, and long afterwards he told me that he seldom passed a year without re-reading it.

He had ripened early, and had both read and thought for himself. When he came to me he already held strong agnostic and socialistic opinions, but he was neither irreverent nor intolerant. One of his great aversions in history was the First Napoleon, and I can remember that soon after he came, a bust of him as First Consul, which stood on my drawing-room mantelpiece, alled forth his serio-comic indignation. Ilis quarrel with him was for 
his having prematurely stopped the Revolution, so that it would have to be repeated with as much, or even greater, bloodshed.

Every one who knew him will recall his hearty laugh, his buoyant spirits, and his wide range of sympatly. He was a great favourite with my children, and would enter with as keen an interest into the dressing of a girl's doll, or the rigging of a boy's boat, as be did into such questions as the early migrations, or the primitive forms of society.

The picture I retain of him in those days, borne out by his photograph, is of a boy of a genial sunny disposition, of keen intelligence, and with a mind so active, so manysided, and so vigorous, as to give every promise of future distinction.

A boyish serapbook of this date tells us something of the persistent interests of Powell's eye and fancy. It shows a sufficient power of drawing and no small delicacy in copying. He repeats amongst other things some of the writhen or soaring figures of William Blake, an artist whom he loved all his life, and of whose poetry he inspired one of his latest friends to make a monumental edition. There are copies also of Leech and of Gavarni, and grotesques of his own. Weapons and their forms attracted him early, and the book is full of carefully traced helmets, axes, and swords. The taste would hardly be worth naming, but that we see the poetical side of it in a review of 1890 :-

There are, of course, lacumce in the history of the sword which are not filled up therein, but on the whole the story is clearly made out; and a curious chapter in the development of human culture it is. And then the art of it! No jewels ever wrought by man can rival in perfection and beanty of work the elove-scented swords of Japan; no work in steel can rival for stern and superb use of a single material a fine Malay hris or a true Toledo or Damascus blade; there never was such imaginative art put into a small space as is lavished on the guard, gripstuds, and pommel of the Daimio's weapon; never was 
the beauty of line more truly observed than in the yellow blades of the bronze age, with their exquisite leaf-curves. Again, no weapon has ever so thoronghly expressed the feelings of its wearer as the sword: the dress-sword of the bean of the ancien regime, the cross-hilted ballpommelled broadsword of his Crusading ancestor, the sharp-curved scimitar of the Turk, the heavy keen liuliri of the Goorkha, the long murderous Italian rapier, the bluff English back-sword (weapon beloved of Captain Godfrey and Hogarth), the huge two-handled flamberge of the Swiss footman, the long sword of the bold dragoon at Waterloo and in the Peninsula, the short broad-bladed thrusting sword of the Roman centurion; each one is in some sort the very epitome of the times and civilization to which it belongs.

Such a boy might apparently have turned into a mere jolly professor, learned, domestic, and humane. Some afterwards thought that Powell was little else. But others quickly perceived a chemic difference between him and the admirable tribe of such men. He was something of a foreigner amid the English life, where he moved so easily, laughing so hard. One of his deepest qualities was his intelligence for different races and their mental habits; and this quality was already being formed by his own mixture of blood and the variety of his travel, as well as by his quick, vital, endless, and even shoreless reading. There is no clue to the influences that thus early had decided his opinions. He had never been dragooned into orthodoxy : he was not a heretic by revulsion; probably he was aloof by nature. His stay at Bonchurch can only have strengthened the natural freedom of his judgement. He had stimulating companions. He often spoke of the gifted and delightful Walter Ferrier, cut off too young, with whom he consorted much. Ferrier was the brotherin-law of Mr. Rhoades, and other members of the same family were Powell's friends for life. They confirm the report of his radiant gaiety, good spirits, and responsiveness at this period. Bonchurch also restored his health, which remained good almost without interruption till his latter 
years. A photograph of that date has an air that is set and grave for a boy of eighteen; and gives some inkling of the good looks soon to be noticed by his college friends. As to his interests, it may have been doubtful whether history or letters would win. He loved them equally, as it proved, but he was not equally gifted for them in his youth. For while in historic lore and perception he developed early, his style was slower in formation : and, when it came, he long applied it more to the matter of history than to pure letters or criticism. But he could never be classed among those savants in whom a poet is smothered; for one mark of his learning was a nicelypicturing imagination. The special lines of his historical work were not to be decided by his student days at Oxford; not till he began to labour with Vigfússon; though Oxford, whither he was now to go, showed him that to history of some kind he would eleave.

His entrance to the University, and the circumstance that led to his life-long connexion with Christ Chureh, may best be told in the words of the present Dean of Durham, Dr. Kitehin, who at that time was the Censor of the 'unattached' students.

I had a good deal to do with his Oxford career, for though he was well off, he fell into my hands quite at the beginning of the Oxford Non-Collegiate students. It was in this way. His name was down for Univ. Coll. for entry. He came up for the Matriculation Examination, and in his Divinity papers, I don't know how, scared the tender susceptibilities of the Master. In fact, he showed some originality even then: and the college showed him the loor. He came on to me, forthwith; and I told him that we held no inquisition on a man's religious opinions, and would willingly take him. So he entered.

Then after a year or so, I discerned that he had fine gold in him; and, in a selfish kind of way, went off to Dean Liddell, and begged him to take him in at Christ Church, beeause I knew he would do well by the 'House'. And Liddell liked him and took him, with eapital results to our Collegre and to him. 
Dean Liddell, one of the best types of Anglican dignitary, erect in his own convictions, and generous to merit and promise, trusted to the insight of $\mathrm{Mr}$. Kitehin, and won the lasting respect and liking of Powell. To his memory, and to that of Henry Stone the Sandgate fisherman, Powell was long after to dedicate his translation of the saga of the Faroe Islanders, which he had drafted as a boy. Liddell's reception and recognition were only an earnest of those always accorded to Powell by Christ Church, the most aristocratic and wealthy, as well as the most orthodox of the colleges; identified more with well-born, well-bred, well-to-do English society than any other foundation. But such a place, curiously, is in some ways as tolerant as any in the world. For one thing, it is itself impregnable in its social and doctrinal ideas, and far beyond compromise ; it has none of the uneasiness of the half-believer. Also it looks first of all at personal qualities, not at opinions. It meets tact with tact, and assumes that gentlemen do not say anything to jar on one another's convictions. It was easy to see tact in Powell, to see that he was a gentleman. He himself loved those qualities; had, indeed, the practical weakness of never being able to act long with any one whom he did not think a gentleman, in the better English or French sense of the term. He felt that a college, in self-preservation, must admit only such persons, and no mere brains or jower could compensate in his opinion for want of breeding. IIere, then, was harmony. It is to the credit of Christ Church that it sheltered and loved for thirty years a man who probably never set foot in its cathedral during serviee. At present, however, we are merely speaking of an molergraduate, whose pertinacity in his heresies there was no neans of estimating. Powell had matriculated in the antumn of 1868, as onc of the first set of students who availed themselves of the new non-collegiate system. He went into Christ Church at the end of his first year, duly passing Moderations. 
History was visibly his calling. But the Modern History School, with its ruck of students, most of whom will never be historians, and its regiment of tutors who equip them for degrees, did not yet exist. Law and History were conjoined in one school; a noble alliance, which, if it made a training in special method the less available, enriched the resource of a born inquirer like Powell, who was never in danger of second-hand knowledge. His training in the elements of law served him well, not only by finding him a livelihood for many years, but in his Icelandic scholarship. The sagas are steeped in law, which in old Scandinavia was profoundly organized, and which filled much of the Northern life. Powell, too, sped to conclusions, and disliked formal philosophic trains of thought; law, though he never became a pundit in it, helped to drill him in rigid and consequent reasoning. He came at once under the instruction of a tutor who saw his power and treated him as an exception. Mr. Sidney Owen, of Christ Church, who taught both law and history, did not trouble Powell much with lectures, but set him difficult subjects for his essays, and helped him with method and guidance. Mr. Owen was struck above all with his early development; and these essays, he writes,

showed so much originality, maturity of judgement, and fertility of illustration from wide reading, as seemed quite beyond his years; and this was the more remarkable because of his massuming simplicity, and apparent miconsciousness that he was doing anything out of the common way, and (so to speak), almost mmatural at his age. I used to tell him that he was sailing under false colours, and that I half believed that he was an old and practised hand re-embodied.

Powell's undergraduate record, on the official side, is soon told. He worked with concentration and easily won that lonour, a first class, which doubtless gives more satisfaction to an educated English youth than any other thinkible. So highly does our custom rate the average 
worth of fifty short and hasty essays, done under cruel pressure of time, by a young man just of age, as the fruit of a few years' training. It is indeed not strictly a training for any occupation except journalism, where the conditions of the Schools are nightly more or less reproduced. However enlightened the tutor, of the Schools he has to think. The real discipline in the craft of research comes later, if at all, and its first step is to unlearn undergraduate method. It has to be said that a true student, if he has good health and a rapid pen, is unlikely to escape recognition in the Schools. Powell evidently did well; but he was only to understand and attain the full discipline and therefore the full freedom of the scholar five or six years later, when he found Vigfússon. He had sat with profit under Stubbs and Creighton, both of whom he much respected. The deep accuracy and grasp of the one, the candid, detached mental play of the other, and his lucid unprejudiced interpretations of character and motive in other ages, were not lost upon Powell. But, as the system then went, he could only see the results that these men attained; he could not go into their workshop and learn his trade by handling and spoiling their spare clay. But this would have been just the training for him : to be set down, under one or other of such master's, to struggle towards method with their guidance, by toiling at some fragment of inquiry. But a small thesis as an element in the graduation test was derided till the other day, save in the newer or 'provincial' universities. The loss mattered less in the end, for Powell did find Vigfússon, and in any case he would have redeemed it somehow: but he must have lost time. There was one excellent fruit of his experience. He became one of the firmest preachers in Oxford or in England of a better way of historical training. His views are lucidly given in the address The Study of History in Universities, spoken at Bangor in 1902. ${ }^{1}$

We are able to discover too little about Powell at twenty 1 see rol. ii. pp. $80-95$. 
years of age. No letters are left; nothing is directly told of his inner life; there is no record, like Creighton's, of strenuous curious sclf-exploring and a clear call; and though Powell's lively brilliancy must have covered a sharp and tender conscience, both as to his dealing with others and his private service of truth, this can only be divined. We lack any pictures of him, such as those which he drew, tenderly accurate by consent of those who know, of his comrades Shute and Grant Allen. Still these accounts ${ }^{1}$ are a reflex of their common life, gay inquisitive discussions and generous friendliness; and some outward features of Powell and touches of his habits and character can be saved from the accounts of other companions. He was handsome, he dressed well; he was sometimes seen in a velvet coat; he used a pince-nea ; he wore as yet no beard. We get an impression of an ardent, apparently communicative nature, full of sympathy, intensely companionable. In bewildering variety of learning he probably had and kept the start of his associates. His feeling (the rarer part of him) for the exotic, the primitive and the reckless in history and letters must have been there, but is unreported. When he won his first class, 'his sympathy,' it is said, for those who 'were only seconds can never be forgotten'. One of his friends, Dr. Punchard, now Canon of Ely, gives the following reminiscences:

My first recollection of Powell dates from a dinner at New Inn Hall, to which he had been brought by a Rugby schoolfellow in 1870. Tall, slim, somewhat shy and awkward: with a charm of face and manner which captured us at once. Silent for a while, and greatly worried with his pince-nes, he all at once took the lead in talk, and closed in Homeric laughter. From that night he was a constant visitor, and we all loved him : racing men, or followers of hounds; foilers, boxers, or boating men; fastidious or untidy, scholars or smugs, busy or idle ; saints and sinners.

In the years that followed, some of us were with him

1 See vol. ii. pp. 350-61 and 68-79. 
daily; almost always on the river in the afternoon. He quickly learned to row, though he never ceased to hug his oar; and bore all abuse with smiles. Increasing in weight, we made him 'three' in our favourite boat; and there he was when the Frenchmen came for refuge. Out of the wrack of Paris these Communards appeared, mostly unkempt and woebegone: but very gentle ruffians indeed, wonderful beyond words.

Canon Punchard mentions M. Besnard, the well-known painter, as one of the set, and adds some interesting notes on Powell's views and tastes, as they appeared to himself, who was of quite another camp of opinion. Powell's ties of friendship with churchmen and others with whom he differed in belief were always remarkable; and to this quality and its origin I shall return. Dr. Punchard continues :

His politics were ardent and enthusiastic; he loved the past too greatly to become destructive, though his generous nature throbbed in sympathy with all efforts for liberty. The oddest mixture of old and new, he walked like Ralph the Ganger, and talked like a modem Parisian. The Northman in him-and it was large-softened into Norman French ; he loved St. Louis ; Villehardouin and Froissart moved him almost to tears. History was of course his great field ; and, being of the school of Freeman, he, like his master, abhorred metaphysics. The philosophy of Herbert Spencer dominated Oxford in the seventies; but Powell's keen intelligence saw the rifts in the system, and was nerer clouded by it: in spite of his affection for -Richard Shute, its ablest exponent. And he liked the new Hegelianism even less.

Whatever his religious faith may have been, he was always reverent himself, and tolerant of others. And ever, it seemed to me, of the same school as his favourite beroes. Reading our English Chronicles, the Heimskringla, or the Nibelungenlied (as a small diversion he once urged the writer of these notes to translate it afresh!), quoting Victor Hugo, Heine, or Villon, he impersonated whoever was the speaker. Poetry lived in him ; and his prose was full of cadence and beanty. Harsh criticism worried him : and I never saw him angry, except at affected knowledge. 
Powell's talk remained always swift and opulent, and his transitions equally quick, so that it was hard, except for definite business, to get him to thresh anything out at one sitting. His ideas ran with shuttle-speed, by paths of their own, from one end of the world to the other. He disliked systems of philosophy as such, not any particular system. He was through life considerate of the creed of those with whom he was speaking. Later, he became a sterner critic, and full of spurts of scorn and indignation when he was sure of his company. Through this mixture of gifts, pursuits, impulses, and literatures seething in his brain, he became harder to umderstand the more one knew him. One of his tutors, a shrewd observer, speaks of his modesty, gratitude, and 'absurd humility', and remarks on the enigmatic element in him, which seemed to deepen with intercourse. It was more than the immer confusion of a gifted youth, who has not yet arranged his riches, and to whom his own mental destiny is obscure. It was not merely due to his greater scope of knowledge and nature than those who tried to understand him, or to his dislike of formula. We shall see that he had a few simple and immovable principles of belief and ethics. But, otherwise, it often looked as though nothing was erer final with Powell. The margin of unsolved matters on which he was open to fresh light was to the day of his death enormous. The sceptical, Montaignesque instinct seemed at times the decpest thing in him, despite the decisive clearness of his opinion at any given moment about almost any given thing. His mind kept more alive and firee than that of others, and up to a later time of life. His change of temper in politics, which will be noticed hereafter, is a case in point. Even in youth, however, beneath his splendid spirits and catholic sympathy, we seem to trace this mental habit, which prevented him from ever becoming the slave, like most of us, of his ideas: a habit that was the spring of his life and part of the secret of his power.

Some other glimpses remain of the outer Powell in his 
student days. Another friend, Mr. William Evans, now Judge of the County Court in Mid Wales, met him at a literary undergraduates' club in 1870, and formed a friendship with him. Powell admired Swinburne, William Morris, Walt Whitman, D. G. Rossetti, and Shelley.

How the earlier lyric tumes of Swinburne fell on young ears in the seventies may be seen in the paper, half critical, half retrospective, written by Powell thirty years later. It intimates how he himself had moved away from his liberalism, his Mazzinism, in the meanwhile, or rather how that sentiment had become crossed with others. Yet his 'whole-hearted sympathy' with the temper of the poet 'toward the nanifestations of official Christianity in Rome and Moscow' was to alter little. In 1903 he tells of "what I read and re-read and what I know by heart' of Swinburne: and his inclusions are still generous; he likes best the 'lyrical or pensive moods', and the writing done in those moods seems 'to grow even more lovely as the years pass'. In a letter we find him saying of Swinburne, 'there is nothing of the morning about him, he is always afternoon'. Whitman he welcomed for other reasons and with fewer reserves, though he could not at the last share Whitman's regardless hopes for democracy ; least of all had Powell faith in American democraey. But the bold frank naturalism of the man, his tried compassion for suffering and love of his kind, his ultimate faith that good is the permanent and evil the ranishing element in the world, all kept Powell's sympathy; and he never ceased to believe in the future of cadenced irregular verse, or prose, such as Blake and Whitman wrote in different styles. He helped to raise some money that was sent out to Whitman when in straits; and he wrote about him fervently. To Whitman, therefore, he was always faithful, saying that he was 'the only' man I would cross the water to see'; for he thought little of most Americans, was grad when his friends did not go and settle on 'that side', and had a 'Tory's 
distrust of their culture and civilization. He reviewed American books, however, with laborious equity. To Wordsworth he was long indifferent. He was one of the many men who come to admire Wordsworth after some delay and with distinet surprise at finding that they do so.

Judge Evans also remembers Powell taking him to a small café on or near the site of the present Empire Theatre. It was full of foreign exiles who knew Powell and greeted him. It was what he liked; and his exclamation 'Is not this ripping?' is remembered. We hear little else: and so this bright figure flits across the strip of light, ever narrowing with the years, that is thrown upon the lanternscreen of the Past.

In 1872, after winning his first class in the Law and History School, Powell left Oxford for two years and lived at his father's house in Lancaster Gate. But Oxford was to claim him back. The Schools of Law and History were separated, and a consequent redistribution of the teaching work in Christ Church left a lectureship vacant in Law. Mr. Sidney Owen, Powell's old tutor, brought his name before Dean Liddell. Here was a man who had already translated a saga, and laid the masonry of learning. Liddell had an eye for such a man, and Powell, luckier than many a gifted youth of his years, was appointed to this modest position in 1874 .

He felt that the promotion justified further adrenture, and his marriage took place in the same year. He always spoke of this as the most fortunate event in his life, and was glad he had gone on his own way despite the apparent imprudence. The young widow, Mrs. Batten (born Miss Silke) with whom he fell in love, had two small daughters. All depended on Powell's labours, which were to be incessant. But he was now full of happiness and power, and encountered a laborious life without a moment's hesitation or regret. The Powells settled in No. 6 Stamford Grove West, Upper Clapton, and stayed there for seven years. A few glimpses remain of the cheerfulness 
and happiness of the household. One of their neighbours well remembers the gracious impression produced by the host and hostess. Powell was in part his own decorator. One of the rooms he painted himself in fresco, and his designs, long covered up under whitewash, have been disclosed and saved by the present occupant. One intimate with him recalls 'the brooding demons, fiendish devils, and grotesques of all sorts, in black, white, and red chalk', Beyond some details we have only the general impression, that has come down from these years, of hopefulness and hard work. It was not till three years later, as will appear, that Powell began actual co-operation with Vigfússon.

He now, therefore, had his hearth in London and pursued his calling at Oxford. This division of himself was to be an essential part of his scheme of life till within two years of his death. His varying feelings towards Oxford will be heard in many of his letters. He loved it for some things, but could not bear the thought of living there altogether. No doubt much of the width and compass of his character, and much of the freedom of his spirit, was due to the programme which gave him the best of the university city without the risk of his suffering from its incrustations. His wife, like himself, preferred London. Accordingly his way for many years was usually to remain throngh the working week in Oxford, and to return for the week-end.

If we could safely le-image Powell in his youth, from the scattered reports of others and our own knowledge of the later man, we might fancy him absorbing knowledge with enormous, even indiscriminate zest-he was said to be prone to read a shelf of books in the order in which he found them; aceepting pleasure and beauty freely; langhing loud and living, as it might seem earelessly, in his affections and friendships, but baftling his comrades by sallies and preferences of his own that took him as far from the routine of Bohemia as from that of 
convention; sound and wholly free from any unmasculine or hysterical element, yet with an understream of rare natural melancholy, which personal happiness could only refine and ncver cancel, while personal distress or loss could never turn it acrid. This seal of unconscious distinction was already to be noticed; he always remained so young in talk and spirit that guesswork may go thus far. Morcover, we seem to perceive a mind that was aware, though slowly, amidst its unusual fullness, of its own ruling bent and powers, but was not yet harnessed to any definite task : waiting, perhaps, as youth does wait, for its choice, its will, to be decided by some easually fertilizing and genially controlling influcnce. Powell must have required some subject of study-since study and not action was to be his lot-that should satisfy his passion for the concrete facts of mankind and history, and also his need for clear form and right expression. He wanted to be oceupied with somcthing simple, subtle, and positive, like himself. This he was to find, as we shall see, in the matter and the art of Iceland, to the methodical knowledge of which he was led by Vigfússon. 



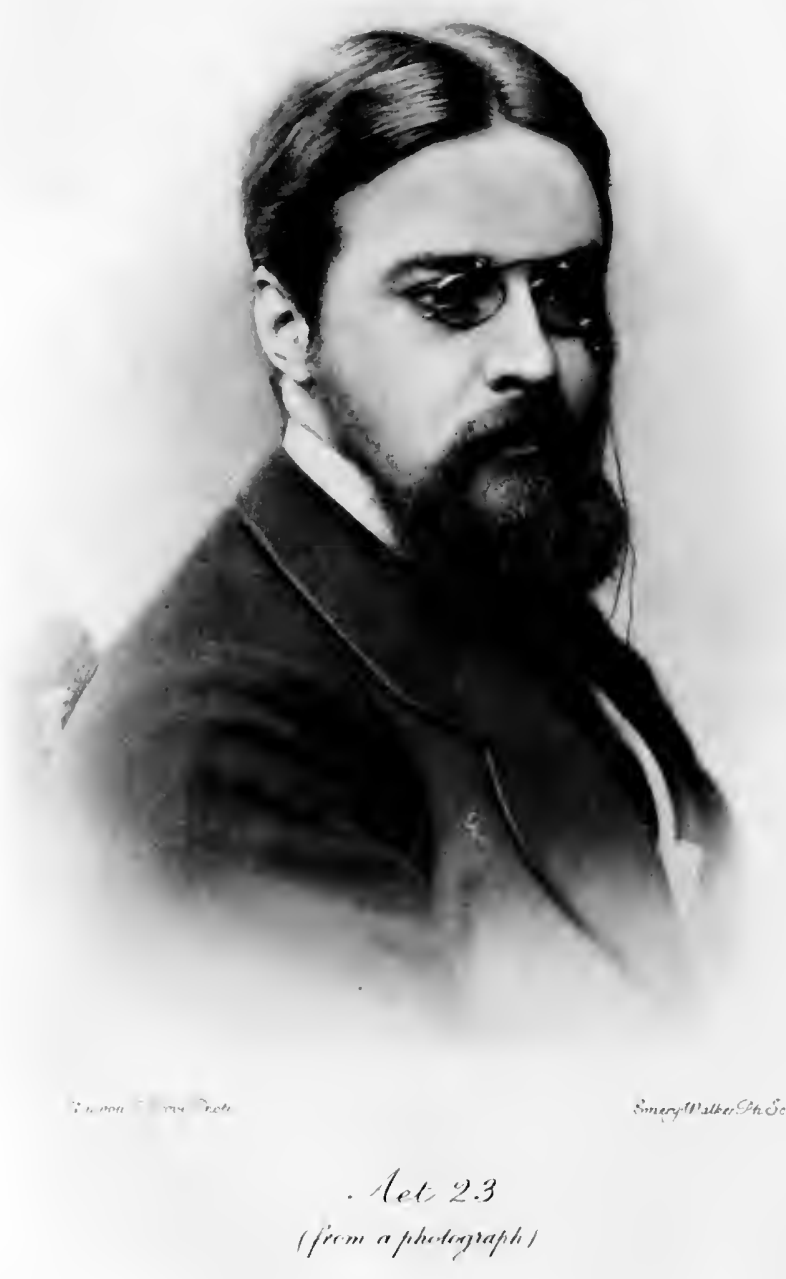




\section{CHAPTER II}

\section{VIGFÚSSON : 1875-1883}

Where should Powell's learning centre? Old English History and Northern studies competing. Interinde at Trinity. Creighton's help: Early England to the Norman Conquest: other books for the young. Attraction of the matter of Iceland: meeting with Vigfússon. Life and labours of Vigfússon: MS. note. Scheme of Vigfússon fourfold. Fïst work with Powell: Sturlunga Saga: mutual recognitions. Icelandic Prose Reader: larger plan frustrated. Corpus Poeticum Boreale: scope; worth of the poetry, merits and drawbacks of the book. Powell as translator: his principles at length, and examples. Move of the Powells to Priory Gardens, Bedford Park: new friends. Letters on Pusey and on the Paston Letters.

Thus early, in his twenty-fifth year, Powell was planted in life, with his natural spring of happiness doubled by marriage. He was receiving a certain wage; and although, to mend his income, he had also to be a reviewer, a private tutor, and an examiner, ${ }^{1}$ he had force to spare. He had now to ask for what purpose he should use his better powers. He must make some sacrifice, must turn away from some of the shining pathways of study that opened up all around him, and must find his line, his task. Any one of several kinds of scholarship he was already fitted to ehoose. He had early acquired the keys of the ehief Northern and Southern languages. It was in him to become chiefly a critic and man of letters. But this impulse, though always strong, was never the strongest. He had the nature of the artist, but also the savant's hunger for acquisition, and, as has been said, the creed of science. His true field was the science of history. He saw and said from the first that the writing of history is rooted not in the craft of composition, but in the methods of science. That cratt, indeed, Powell practised well and sensitively; but as a

1 He was also ealled to the bar, but never tried to practice. 
vehicle, not as a substitute, for reasoned conclusions. He was led first of all to spadework, for which he had the gift, and he made himself one of the learned men of his time and country, though there was much of his learning that he was never to set forth in order.

But where, first of all, was Powell's learning to centre? The reviews that are saved in these volumes show how far his reading finally travelled, and how wide was his historic vision. We feel they are the words of one who has thought from his youth up about mediaeval and modern history, ever accumulating, or rather inhaling, knowledge. Yet we could scarce gather from these fugitive pages, on Islam, on the Jesuits, on Italy, to what subject the writer had given his force. In truth he had two master-interests, which grew together and enriched each other. One was earlier English history, the other was Northern lore and letters; and up to Powell's fortieth year these were his chief engrossments, though he also had excursions and interludes that would have sufficed for many men. His studies in Dante and older French helped him to perspective and proportion, and gave him many a sidelight on what was his real province, the old Germanic world. His work on Icelandic was to make his name. Much less ample, though of true worth and accomplishment, were his writings on English history. Here it was his fate to produce no book that was not addressed ostensibly to childien or school-pupils. But his letters from the age of twenty-seven to thirty-four mark the laborious completeness of his excavations in the original authorities for the history of early and mediaeval lingland. 'I am bowling over king after king, in pretty good form, but slowly,' he says once; and we can partly date the series of his else undated letters by such notices. The fruit was to be three small manuals for the young, and the History of England to 1509, "written with an especial view to its use in schools, and among younger students who read the subject.' 'This did not appear till 1885, and will be 
noticed in its place. It was delayed, for it was done concurrently with his heavy labours at the Icelandic. The smaller books are offshoots and first experiments in the same kind, and merit a word, since they still hold the audience for whom they were intended.

Now law tutor in Christ Church, Powell had an early stumble in his academic life at Oxford. He had been successfully recommended by Creighton for a small post as lecturer and tutor at Trinity. Creighton had examined Powell in the Schools, and been struck, says Mr. Owen, with the way in which he 'drew from unconventional and recondite sources'. Powell was to supervise the work of the college in English history, and to lecture on the Wars of the Roses. In spite of his freshness and knowledge, his method was probably too irregular and haphazard and too little planned for the Schools, and it was not liked by all his pupils. His appointment, at the end of the year, was, owing to the representations of some among them, not renewed. As it proved, three of those whom he had taught won first classes. He felt this rebuff sharply for some time, though he would point with laughter to the three 'firsts'. It may have been regretted more in the end by those who were led to inflict it. To him, at worst, it was an incident; he went on with his real business of reading and writing.

Recompense of another kind soon came. Creighton, who from his country living at Embleton was editing a series of 'Epochs of English History' for Messr's. Longman, gave the first volume-Early England to the Norman Conquest - to Powell, whom he called 'a very competent though untried man'. It was published in 1876. The editor, a judge hard to satisfy, liked the result well, and said that the book was written 'in a charmingly simple, almost Biblical style'.

I think Powell's book is very good. It is really too good for its purpose, which is always what happens. It is most difficult to get good men to confine themselves 
within narrow limits. But Powell's book makes the whole history live. ${ }^{1}$

This was true, for one of Powell's gifts was always that of speaking to the young in the right key, and not with the silly kind of simplicity that soon makes them angry and rouses their dignity. The bookshops are strewn with primers that are wrecked on this offence. For a cunning and true simplicity he found his pattern in the sagas, and his English was more saga-like than 'Biblical'. 'Plain and homely' was his description of its aim, but its fineness of texture is also remarkable. This gift he improred or discovered through his practice in translating from the Old Norse prose classics. He also brought out Alfred the Great and William the Conqueror in 1881, and next year Old Stories from British History. These little volumes, directed to still younger persons than Early England, have lasted well. The needs were elementary: in Old Stories there are lists of the longer words, with their accents, at the ends of the chapters. Most people, however, might learn something from the book. There are not only the ever-cited tales of Caedmon and Lear, but those of Egil, Havelock, Cuculain, and Ossian, with lists of proverbs from Old English and Old Welsh, and carefully chosen pictures. The ehild that was never to die in Powell himself picked out the right points and the right words by instinct.

Yet many of Powell's powers and interests could hardly find their best nomrishment even in the matter of early England. The original documents for its history are seldom stored in works of high literary skill. We have no chronicle, like the Icelanders, of the ancestral settlement. We have no sagas-no histories, that is, quasi-epical in build, of the wars, coastings, fends, cults, and usages of the chief families through the course of several centuries.

${ }^{1}$ Life and Letters of Mandell Creighton, hy his Wife, 1904, vol. i. p. 183. 
We have fewer tales of the troubles and compromises that were due to the Conversion, which came four centuries later in Iceland than in England, and was therefore more fully recorded. The sagas lived on as part of the spoken prose of the folk, which was so picturesque, various, and subtle, as to do much of the work for the artist, and was never broken by any such radical changes of rocabulary and idiom as England underwent for her good in the eleventh century. Most English prose from Alfred to Malory was a secondery prose; derivative in source, educational in aim. Well as it did its national work, it left only a few pages that rank beside the greater stories of Iceland. Old English verse fares much better in comparison, and both in epic and in lyric achieved some things denied to the Icelandic. But the latter, besides flowering into a different sort of perfection, gives us decper glimpses into the old heathen life and thought, and into the dissolving views of the change of faith, than our own earliest poems, which are so often inlaid, whilst also rescued, by Christian clerks.

Powell loved heathendom, being himself a heathen. The Northern writings furnish the richest extant material both for the old Germanic religion, in its many layers and stages, and for its defeat. He was always drawn to folklore, or the comparative study of popular doctrines and fancies. This indeed became later one of his ruling interests, and he thought it the most important of all arenues to the study of human beliefs in the unseen. He held that this study must become a recognized branch of natural history. In this material Iceland is very rich. But above all there was something in himself akin to the Icclandic style and temper. Under the northern light, at first seeming so prosaic, men and things are seen in their real proportion and values, withont glamour and yet with imaginative truth. Powell's own mind was essentially achromatic, in spite of his darting apprehensiveness of sympathy. He resented any hues that are not in the 
object but only in the rim of the lens. He loved detail, he was close to the earth, he took at once to the talk of seafarers and shore-dwellers and yeomen. He shared the deeply masculine and unsentimental yet not unromantic attitude of the Norseman towards women. He loved the deceptive simplicity of the saga style, full of traps to the translator, humorous, reticent, popular and yet deeply civilized, like Scots; and the complex vision of character, often hit off in a schoolboy's nickname. He also had the first requisite of the anthropologist, the power to shake himself free, in estimating behaviour, of later moral codes and alien scruples, and to see that the complexities of a race nearer to barbarism are not the same as our own.

The bent of his erudition also drew him to Iccland. The question of chronology comes up everywhere in its literature, and the whole truth of perspective often turns upon approximately dating, and so localizing, a saga. The date has to be settled by intricate considerations of language, allusion, and style. Most of the accessory sciences that help the historian are here wanted in no ordinary measure; he must be a master of MS. sources and diplomatic, must be immersed in geography, mythology, genealogy, primitive law, parallel literature, and metric. Powell did not profess to be expert in all these things, and the popular legend of his omniscience made him duly angry. In several of them, however, he became profound, especially in the domains of law and custom, and of literature proper; and he came to take his bearings in all of them, with the probable exception of manuscript learning. He had taught himself not a little Icelandic even while a boy. He is said to have been inspired by Sir G. Dasent's translation of Njalssaga, called Burnt Njal, by reading it on Billington's bookstall at Rugby. He certainly studied it before he was eighteen. At the same age he made his translation already named, of which the MS. remains and which he rewrote and published in 1896, of the saga of the Faroe Islanders: and there are 
manuscripts of two others, in a hand only a little less youthful: they are Gullthorissaga and Hervorarsaga. Powell was no doubt almost the only English boy of his generation thus engaged. But it is scarcely likely he would ever have undertaken alone, or accomplished alone, any monumental work. He was too diffident, and had too little concentration, to shoulder very long or heavy tasks in solitude. His achievement would have been very different, and might have been far less, but for the chief event of his mental life, his acquaintance with Gudbrand Vigfússon, the master of Northern learning.

As early as 1869 the two scholars had met in London, but for seven or eight years there is no record of their fraternity. By more than twenty years the elder, Vigfússon, a most notable man, left on those near him the impression of a greatness that was defined, but in no way restricted, by his chosen range. He was a sort of incarnation of his country, and the treasurer of its classic writings : they were all in his head, and he was informed with their genius. He was one of the great scholars of his time. A memoir of Powell is imperfect without some sketch of one whom he called his 'master'. He would say that he had learnt more from Vigfússon than from any other man, and that whenever he heard of a good man he thought of Vigfússon.

Powell made three sketches of the life and labours of his friend, one in The Acculemy after his death, and two others afterwards for works of reference. The first and least formal of these can be real in our second volume, but something may be added to the story here, especially as Powell veils much of his own share in it. ${ }^{1}$ Gudbrand (in his own tongue Gudbrandr) Vigfússon, born in the north-west of Iceland in 1827, was of old family. On the

1 See vol.ii.pp.344-50; also Catalogne of Writings; and vol. i.adfin., Appendix A. In the text above I draw freely on the various sources there recounted, and also from Powell's own phrases. 'The Icelandio obituary by Jon Thorkelsson has been of especial use. 
father's side, his collateral ancestor was a famous Gudbrand, Bishop of Holar, who in 1584 edited and partly translated the classic version of the whole Bible in vernaeular. This, though we hear it is unwisely discarded in modern Iceland, is known to be one of the nobler among European translations. Parts of it are given in the Prose Reader Vigfússon wrote with Powell, and he had to face a sharp controversy as to its merits. Vigfússon was brought up on the old literature, on the great sagas, so often still repeated in Northern farmsteads. 'A little anthology of modern rhyming epigrams, which he had made up out of his own early memories,' portrays his ehildhood, and some of the complets translated by Powell are reprinted now. ${ }^{1}$ He had an innate, rather guarled, yet kindly humour, like that of the Lowland Scots without their bluntness; he was like some salient personage who had walked out of a saga. His memory - not only the lexicographer's memory for words-for trait, incident, and custom, was immense and tenacious, and reached far back in his life. Some notes on his own ehildhood, dietated to Powell, may give an idea of the sharp, simple clearness of his perceptions. They also show the partners' way of work, which was carried on through many volumes. Powell kept the phrasing as it stood, with its simple colouring, only correcting details of grammar and idiom, which it became less and less needful to do. ${ }^{2}$

Vigfísson was brought up by his aunt and foster-mother, Katrim, who had adopted him whilst a baby, and who cared for him till he was old enough to be set to his book and put to school at Bessastad. . . . He would often talk of his childhood before he went to Bessastad. Of his aunt he spoke with high veneration. [But] he told me how he got the scar on his brow close to the left eye by ruming out

1 See vol. ii. pp. 408-10, and for all the originals Corp. Poet. Bor., vol. ii. pp. $410-18$.

${ }^{2}$ The extracts quoted are verbally from this dietated note, now first published. 
in the hayfield to escape reading ${ }^{1}$ to his aunt, and stumbling over a haymaker that lay in the grass, on to a sharp flint. He told me how when his aunt thought he ought to be prepared for the college, she took him to the family where his tutor was, and left him there asleep, rising early in the morning to avoid the parting that she could not bear. When he woke he was in an agony of grief that nothing was able to appease, and he wandered out crying till he came to a little waterfall, by which he lay down : and the sound of it calmed and soothed him at last to sleep; and there he was found still asleep when they went out to scarch for him. He found it very hard, amid the distraction of new surroundings, to learn the Catechism, which is the chief task of young Icelanders for several years, so that the good folk to whom he was committed began to disbelieve his aunt's estimate of his powers. But at last he took his book into a little room where the weaver was sitting at work, and the merry swift irregular clatter of the shuttle, and the tapping and hammering of the weaver, seemed to be exactly the stimulus his brain wanted; so that in a few weeks he had done what usually took years, and was able to be confirmed far below the average age. He told me of long coast-rides on beloved ponies, sure-footed and kindly and wise, and of hearty welcome at farms on the way. And of one well-remenbered journey with the father he had so rarely seen, in which they slept the night in the summer air on the Moot-Plain. And as they passed in their travel cairn, and barrow, and rock, his father would tell him of the saga-heroes after whom each was named. He told me that Mr. Heath, an old friend and servant of mine at Oxford, looks not unlike his father in face and form.

Of his school life he also spoke; how they could hear the sound of Egilsson's fiddle across the moor, how Egilsson would come and look on at the wrestling and match the boys fairly, and how he himself had wrestled and thrown his man ; and how the classic tradition of wrestling had survived at Bessastad, where it was an organized sport. He told me how he spent great part of his holidays once staying with an old priest and making up his registers

1 'At my present time of lifo I am an excessive rearler, and it amuses me to think that my earliest recollection of a book is that I ran away from it.' (Vigfússon's MS. in Danish.)

T. P. I 
for him, unkept save by head for many years; the events being remembered by curious traits - deaths of cows, casualties, and the like; but the whole thing got into remarkable order in the end:-a good instance of the way the ancients mauaged their chronology; and he could, he said, picture one of Are's informants reckoning out his facts in the same sort of way.

He always regretted the removing of the school to Reykjavík as a mistake in every way.

In 1849 Vigfússon left school, well equipped as to knowledge though not as to funds, for Copenhagen, which was to be his home, save for excursions, during fifteen years. The University library contains the great collection made by Arne Magnússon of the chief vellum and paper manuscripts of the old Norse literature. Here, during and after his academic course, he installed himself; he mastered, collated, and copied the materials for the work of his life. He became a kind of guardian genius, or watching familiar, of these records, which are of central importance. His treatise (Timatal), written when he was twenty-eight, on the chronology of the sagasa subject which of course involves the facts of their whole history and grouping-founded his reputation, and is still called authoritative. About this time he got a small but sufficient post as Stipendiarius Arnamagnceanus. Through the years that followed he showed surprising energy in transcribing, editing, and publishing; his chicf production was the text of the sagas of the Northern bishops. In 1859 he visited Germany, and paid the call on Jacob Grimm which he describes with such vivid precision in his preface to the Grimm Centenary papers. He remembered with pride how Grimm, the veteran of German folklore and philological scholarship, greeted him: Sie haben schïne Dinge gethan. After sojourns in Munich with the scholars Maurer and Möbius, he returned to spend five years more at Copenhagen, largely in copying out the vast vellum, Flateybok, which he printed with his partner, the Norwegian savant Unger. 
He often talked of his life in Denmark, and Powell's note continues, alluding to a visit paid by the friends in 1884 :-

[He spoke] of Copenhagen and his student life there. We visited together the [old rooms] in the SE. corner of Regentsen and on the N. ground-floor. From this latter he migrated, when his time was up, to lodgings in the street opposite, flitting his goods through the window for convenience. He used to speak with sorrow of the temptations of drink, and the unwholesome food, and the phthisis which wrecked many a fine young Icelander in the city. He spoke of Madvig's lectures, and of student friends, and of the winter when with some of them he crossed the Sound on foot to meet a welcome from Swedish students. Of Larpent, a promising young Hanover student, and his early and regretted death, he often spoke, and he gave me copies of some of his translations of Molière. He had much to say of Jón Sigurdsson, and the friendship which linked them till death took Sigurdsson, of their talks and work together, and of Sigurdsson's magnanimous nature. From Niel Matthias Petersen he said he learnt much, and he considered him a man of singular ability and insight. He liked to recall the long days he spent in the roof of the church over Arne Magnússon's books and MSS. Even then he saw the immense value of Arne's information respecting MSS. ; and his copies and well-chosen transcripts were of permanent value to him long afterwards.

To him a MS. was a piece of life, not a mere scrap of vellum blotted more or less regularly; he wanted to know how, why, when, and by whom it was written; he would follow any trace like a sleuth-hound, and no Indian ever read sign more skilfully than he could interpret the faintest signs a scrap of vellum offered by which its age and provenance might be inferred. He was a wonderful reader of faded letters, and has recovered many important lost passages by his method, a very safe one (taught him by Sigurdsson, as he says ${ }^{1}$ ), of putting water on the injured vellum for a while, and then taking it out and placing it in a good sidelight, watching till at a certain moment the ink seems to grow visible once more for a few seconds, ere it dies back as before.

${ }^{1}$ Cp. Corp. Poet. Bor., vol. i. p. jut footnote.

D 2 
He showed me the walls (since then done away with, in the rage for a Parisian faubourg which has vulgarized the whole place) by the old bastions where he and Sigurdsson and other friends had walked and talked of sagas and history and diplomatic. The house where he wrote, in a few weeks of the winter, the Timatal, is still standing, as is Sigurdsson's house.

The visit to Norway [in 1854] was a really inspiring voyage. The vivid memory he preserved of the Norwegian people and their country was of use to him continually, and gave him a feeling of sympathy with Norway which he always retained, regarding her as the mother-country whence, though indirectly, Iceland, especially West Iceland, was peopled.

By now, therefore, Vigfússon had spent his youth on his appointed task, resigning even the prospect, which at one time shone before him, of marriage. He gave himself to his work like a kind of lay monk, and he was to keep his cheeriness and humanity untouched in spite of the sharp struggle which lay in front. In Scandinavia and in Germany he failed of preferment: the chair of Norse humanities, which he was the man to fill, was not forthcoming; and fate led him to England, and finally to Powell. He had paid his last visit to Iceland : in 1864 he accepted the invitation, made through Dr. G. W. Dasent, by the trustees of Richard Cleasby, that he should come to England to work up the materials left by Cleasby for his Icelandic Dictionary. After two years in London he settled in Oxford for the rest of his days. The work took ten years; the Dictionary was all published in 1874. In course of it Vigfússon suffered chagrins and even deceptions ${ }^{1}$ which need not here be described. Dean Liddell took an admirable part in the work, appreciating the

1 See letter by Powell in Athenaeum, Oct. 5, 1898, stating that Cleasby's extracts had been sent to Vigfússon by persons in Denmark in useless and imperfect form, the 'finished material' being 'deliberately kept back' until the 'dictionary was approaching completion'. It was not even then used by Vigfússon. 'This affair was one of the old scholar's worst troubles, costing him endless extra toil, though it left lim a larger share of the honour and achievement. 
importance of this, the first exhaustive index to a great literature, serving Vigfússon with his own experience in the making of dictionaries, aiding and condensing his then defective English, and smoothing over some of the troubles that beset a proud and sensitive scholar working at an unpopular subject in a foreign land. ${ }^{1}$ About the Dictionary itself, which is not only a great monument of exegesis, but full of life, colour, and personal memories, the words of Dr. Thorkelsson, Vigfússon's biographer, fall within the truth, and they are not the less true because philological science has admittedly moved far since Vigfússon wrote :-

That book, more than all other writings, is to thank for the great flowering of Icelandic and Northern studies during the last ten or twenty years. . . And above all it opened a glimpse for English readers into the sanctuary of those old Northern tales and poems, which would otherwise have been simply and solely a sealed book to them. ${ }^{2}$

This work, and the prefaces to his editions of the classics, had, in Powell's words, opened a new era of Icelandic scholarship. Vigfússon's further aim was nothing less than to elucidate the whole history of the classic Scandinavian literature. But this labour he had only begun: and until the Dictionary appeared he had written almost entirely in his own language, with its very limited public. It was the service of Oxford to Vigfússon and to herself that she found him an English audience, and also his predestined interpreter. He proceeded to realize his plan of presenting the master-writings of his country in their true perspective and importance. In this labour Powell was his partner, and the two names camnot be separated.

1 The story is told in Liddell's words in the Menoia's of him by II. L. Thompson, 1899, r'p. 205-8. 'He was a thorough scholar,' says the Dean, 'worked like a horse, and was altogether a capital fellow.'

2 'Nekrolog' in Arkiv für Nordisk Filologi, 1889, p. 159. 
To judge Powell's achievement, it is needful to see what was the scope of their common plan, and how much of it has been carried out. It is sometimes said or implied that its aim, or fruit, was little more than to introduce the matter of Iceland to the English reader. But, in fact, each of Vigfússon's works, whether English was its medium or not, was, with the partial exception of the Icelandic Prose Reader, a new achievement in scholarship. The English language was simply a great sounding-board, by which he patriotically hoped that his voice would carry farther. Had he found a post in Germany, he would no doubt have tried to use German in the same way. But he never felt at home in Germany, and his own temper and the temper of his nation is in many ways nearer to the English than it is to the German temper, being less pedantic and sentimental. In any case, in England he found himself, and by good luck and natural affinity he came on Powell, whose actual share in the performance, as will soon appcar, must never be judged by his own expressions of humility and was never underrated by Vigfússon for a moment. Together they formed and executed, as far as could be, the double purpose of promoting Icelandic scholarship and placing their results before all who could read English.

Vigfússon, working single-handed, had already given, in his Dictionary, the keys of the language. With Powcll he gradually shaped a scheme of labour which might fill much of the remainder of his own life, and which was to be made possible by the Oxford University Press. It had four distinct scctions. (1) A sketch-history of Icelandic literature, especially of the prose, was required, with a statement of all the manuscript sources, groupings of sagas, outstanding problems, and critical verdicts. This was realized in the Prolegomena to Sturlunga Saga. (2) Further, English students and beginners must have a grammar in English, and representative extracts annotated. This was realized in the Icelandic Prose Reader. (3) There 
nust be a complete and ordered collection, with full commentary, and with English versions, of the best classical writings, of the old Icelandic poems. This was made in the Corpus Poeticum Boreale. (4) The largest task remained. There was to be a complete library, with texts and translations, of all that is really classic in the old Northern prose: a presentment, in fact, of one of the finest and nost individual literatures of the Middle Ages. It will be seen how that crowning portion of the scheme was only carried through in respect of one great section, which is contained in the Origines Islandicae, and how this work was only published sixteen years after Vigfússon's and one year after Powell's death. But the whole enterprise was a great and comprehensive one, and in spite of certain clear abatements that have to be mentioned, the part of it that is executed is both in quality and mass a noble legacy to scholarship.

The first two of these works, the literary history and the Prose Reculer, went forward together. When Powell's handwriting ${ }^{1}$ first comes to our view, in 1877 , he is already immersed in both tasks, and nearing the end of the former. They may be touched on separately. Vigfússon wrote in 1878 that he had

hoped some years ago to accompany my Lexicon, as lexicographers do, with an introduction to the ancient language and literature: but this was not to be. However, now one-half of that task is performed, though the second had remained undone.

1 Down to about 1880 Vigfússon and Powell seldom dated their letters to each other, so that the order has to be, and uswally is, settled by internal indieations. But I lave seen no letter written by Powell to any one which is probably earlier than 1877, and few before 1880 written to any one but Vigfússon. In one of September, 1877, to Mr. F. I. Barnard, Powell is found signing a petition on behalf of the Penge murderers ('I bar people being' hanged at all'); and picking up 'an old translation, Italian, of Suetonius, 1550, for $2 d$., and an italic 'Terence, Godfroy of Lugd., 1561, for the samo'. 
These words are in the preface to Sturlunga Saga, an edited but untranslated text of the histories written by or assigned to Sturla Thordsson, who died late in the thirteenth century, and was the last classic historian of the North. The Prolegomena to this edition, about two hundred pages long, are in Powell's English. Literary histories are usually hard to read; they are not like the sagas; they cannot be a true narrative. They do not move in a straight line, but go round in a spiral, or series of orerlapping circles. Such books are profitable when they lead the reader away from themselves to the originals, and it may be said that their usual end and warrant is to be forgotten. They group schools, and interpret tendencies, but they are not so much living springs as, in Powell's phrase, tanks; and, when they are built on the foursquare, solidly-cemented German plan, they are an undoubted convenience in the scholar's home. But sometimes their result is far higher than this; it is higher in Gaston Paris's sketch of mediaeval French literature; it is higher in Vigfússon's Prolegomena. Here the work is new, it is an irrigation of new and unclaimed territory. It long remains unbettered save by the further thoughts of the writer, and, as Powell says, it is a thing 'no one but himself could have done'. Behind it is the picture of him. He has lived among the 'dark begrimed vellums', which no one else knows so well: and he has not only deciphered them, but they have told him their respective worth and dates and mutual connexions, as he patiently names one hypothesis after another till he has rested in that which he finds most valid. His knowledge is rooted in the crafts of palaeography, language, genealogy, and local history ; but it reaches up to the overtones of style, and is warmed and pervaded by his vision of men and women dead seven centuries ago. The tongue that he reads is essentially that of his native parish, with its rescrved humour and varied expressiveness. Vigfússon states that he handled every Icelandic vellum and frag- 
ment of vellum in the Northern lands, ${ }^{1}$ and we can well believe it. This is literary history and criticism indeed, such as we should all like to write 'if we had the mind'. But for Powell, it might have been limited to Icelandic or to Danish and Norwegian readers. Powell's English already, even at this date, catches the apt simplicity of the writings it describes, and it is not hard to guess where many a turn and example comes from his hand. Vigfússon had a keen outlook on general history, and welcomed the peculiar power of his colleague to open windows and light up vistas by sudden parallel and citation. Their composite but happily-wedded style is well seen in the passage that describes the outlets found by the early Icelanders into the great world of Europe ; and though nothing warrants us in precisely discerning their shares, the long sight of Powell is probably here apparent. In any case it is a good instance of their joint work, and reminds us of Powell's later reviews.

The period during which the sagas were making was but brief, nor could it have been otherwise ; the combination of circumstances which will produce such a literature is rare and transitory. The Sagas of Iceland, like the Elizabethan drama, are the outward expression of the innermost heart of a great Age, the passion-flower, as it were, which blooms and fades in a day. Just as the discovery of America, the Reformation, the struggle with Spain, the spread of Classical Literature, metamorphosed the Englishmen of the sixteenth century and drew them up into a higher region of mental life, so the discovery of the Western Lands (as new and strange to the Norsemen as Mexico and Peru to the Conquistadores), the sudden outburst of the Wiking life (like the free career of the half-pirate adventurers of the Spanish Main) with all its adventure and danger on sea and land, the close contact in peace and war with the Kelts, whose ancient civilisation was, as far as we can tell, in many points superior to that

${ }^{1}$ Pref. pp. xxviii-xxix to Orkneyinga Saga, London, 1887, 2 vols., Rolls Series; an older work, late finished, and done by Vigfússon alone; quoted by Thorkelsson in Arkiv, l. c., p. 160. See too Corp. Poet. Bor., vol. i. p. xlii. 
of the invaders, and therefore the stronger in its influence,-all seem to have deeply affected the Northern mind and wrought it to a higher pitch than it had ever before attained. So soon as the right note is struck, the right form of expression hit on, the Saga, the Heroic Lay, or the Drama, starts into life 'full-armed' as it were, lasts a few years in full beauty and power, and sinks quickly back into decay. We have indeed the Epigonic poetry and pseudo-Sagas of the Decadence in Iceland, but we could almost regret that the change had not come sooner and snapped the thread of continuity before their birth. ${ }^{1}$

As the Sturlunga volumes are not accessible to all, a criticism may also be quoted of the great Saga of Njal, Powell's early favourite in boyhood. It is the best known to English students of all old Northern books. The passage also illustrates his ever-present sense of the higher bearings of primitive law.

This Saga has always, and justly, been placed foremost of all. In many respects it stands alone, belonging to no school, and peculiar in matter, style, and spirit, in area the widest, in interest the most universal, having the Althing, the focus of Icelandic political life, for its centre, but noticing men and places throughout the whole Scandinavian empire. The Saga of Law, por excellence, it is based on the most important element of carly society, and the lesson it teaches is of a Divine retribution, and that evil brings its own reward, in spite of all that human wisdom and courage, even innocence, can do to oppose it. Hence, while inspiring the deepest interest and the warmest pleasure, it has almost the character of a sacred book, and is read with reverence. The very spirit indeed of Early Law scems to breathe through its pages, showing the modern English reader the high ideal which his kinsmen strove long ago to attain. 'To judge of this work fairly it must be read in the original, for much of the subtle beauty of its style, the admirable play of its dialogue, and at timcs the very technical peculiarity of its matter, must of necessity be lost in any translation however faithful. ${ }^{2}$

These extracts are made partly becausc, though the 1 Prolegomena, p. xxvi. \& Ibid., p. xlii. 
matter must be chiefly Vigfússon's, they show for the first time the movement of Powell's original writing in its historical and appreciative vein. They have its simplicity, natural cadence, picturesque (never muddy) colour, and sometimes breathless pace. There was a kinship of expression between the two partners, which use and intercourse drew closer. The apparition that Powell must have been in the life of his solitary friend! The genial glow and Welsh sympathy, never requiring explanations, of the younger man were like a fire bringing out the secret writing in the mind of the elder. Human ties, we may seriously say, are not often so little amiss. Here it is well to copy once for all, as it holds good of the whole of their later life in common, the picture that each man drew of his intercourse with the other. The workroom in London or Oxford was cleared for the day of irrelevant books and furniture, and the even happy routine of dictation, converse, and transcription was followed for weeks on end. Vigfússon's account appears in his preface to Sturlunga, dated Dec. 4, 1878. He refers to his friend's services in drafting Prolegomena:-

I am under great obligation to my friend, Mr. Frederick York Powell, Law-lecturer of Christ Church, without whose generous and ever-ready help and sympathy they would hardly have appeared. Suffice it to say, that we have day after day sat closeted together, he taking down across the table my thoughts and theories, one talking, one writing and putting into shape. Thus, though the substance and drift of arguments are mine, the English, with the exception of bits and phrases here and there, is Mr. Powell's throughout. Many improvements also bear his marks, such as the application to English Law in $\$ 35$, besides many touches, especially in $\$ 3$ (the Saga Characteristics). But even more than this, the constant exchange of thought, and the sympathetic conversation on every kind of subject, has been a great benefit to me, ealling forth and unlocking many thoughts and things hidden away and half forgotten, besides relieving me of the irksome solitary task of writing. 
And Powell wrote of Vigfússon :-

It was on the Prolegomena that I first began to work with him; and from the day that I began taking notes at his dictation, in 1877, until the day he died, I passed more time with him than with any other friend I had. In Oxford we used to work together at his rooms two or three afternoons a week, and often of evenings at my rooms. In the vacations he used to take lodgings near where I lived in London, and we worked from 10 till 7.30 or later in my house (breaking off only for meals and a brisk afternoon walk) for weeks together, for almost three months of each year. In this way we finished the Prolegomena, and then set to work on the Icelandic Prose Reader. It was while we were on this that I stayed six weeks with him at St. John's Villas one long vacation. $^{1}$

The value of this alliance and diseipline to Powell's mind is apparent. It gave him what he ought to have had, but had missed, at Oxford. He could now satisfy the dream, that was once cherished in our universities, of sitting in the study of the master of learning, watching his ways, helping to produce his works, and soon becoming his indispensable partner. Powell was, of course, himself already learned for so young a man : but now he received 'a baptism of such as are of riper years'. It was the baptism of method, and method Powell had neither by nature nor, hitherto, by training. And from a pedant he would never have endured to learn method, so that he was happy in learning it from a man of genius. Moreover he was forced for a long while to concentrate his powers. Nothing could turn Vigfússon, though he was not in the least narrow in his ontlook. A man who has written out every word of a big dictionary could hardly unlearn, if he tried, the art of being persistent. To know that five years hence one will be doing just the same work, though on a later letter of the alphabet, deadens all but very strong minds. With this habit behind him, Vigfússon moved for

${ }^{1}$ From obituary notice in The Academy. See vol. ii. pp. 344-50. 
the rest of his life in an iron regularity on his chosen path. Powell needed such a man to work with, to hold his imagination and affeetion, to keep the end in view, and to save his force from being distracted. And he had this companionship for twelve years.

Sturlunga Saga was published in December, 1878, and in May of the next year came out the Icelandic Prose Reader, which had been taking shape for many months: a skilful and valuable piece of missionary work, which has led many to Northern studies. It is more than a grammar and introduction to the simpler prose ; it ineludes many preliminaries to advanced study in its remarks on the manuscript sources, the runes, and the law-texts. The work of framing the notes fell to Powell : but in this and their later books the whole responsibility was shared. The bits of translation, however, contained in these notes were a kind of rehearsal for Powell of the great labour soon to follow.

Before describing the next great venture, the Corpus Poeticum Boreale, we may choose a few notes from Powell's letters of these years. All are to Vigfússon; most of them deal with the details of Sturlunga and the Reader; and none from Vigfússon are extant, apparently, till 1880. The first that need be quoted was written some time late in 1878 :-

I wished to thank you before I went down from Oxford for the very kind mention you made of me in the Sturlunga preface, which was so much more flattering and kind than I deserved, and I should like also to express my gratitude to you for the great trouble and patience you have taken with me. I have never learnt so much from any one in my life as I have from you, and it will be always a subject of great pride to me to have been of such slight assistance to you as I have been permitted to be.

I have written you this, beeause I always feel that I cannot thank you properly in talk, and I slould not like you to think that I do not feel the obligation I am under to you.

In the same year he writes on Schopenhauer, one of the 
few German philosophers whom he ever cared to read. He was too much in love with life to be touched by pessimistic theory, and his own strain of melancholy was quite different-there was less will and no rancour in itfrom that of the great dogmatic German.

I am glad you are pleased with Schopenhauer. I think he is the only readable or likeable German philosopher since Kant. You will like his Aphorisms if you have not read them yet. They are very witty, and decisive to the utmost. I think they express the man very well. I have never read his great book, but they say it is clever and clear. He had the most splendid set of prejudices, and was quite unlike a German. There ought to be a really good life of him, short and leaving out all but the personal part of it ; the philosophy doesn't much matter and speaks for itself. Miss Zimmern's book is dull, but has enough to make one wish for more, and the little French book I have on him is too much given to the philosophy.

Powell may have been reading the Parerga und Paralipomena, where the creed of pessimism is popularly set forth in Schopenhauer's sharpest style. The desired book is spoken of again in one of Powell's last letters (1904): it has, we may remark, never been written in English. In other letters of this period come glimpses of an onerous if happy life. Powell was teaching, doing masses of examining, working in Bloomsbury at his Early English authorities, and drafting for the Encyclopaedia Britannica the article 'Icelandic Language and Literature', which was to appear in 1881 . He owns and probably overstates his debt to Vigfússon for this article: is afraid it is 'too much of a réchauffé of Prolegomena; but I think it will rather send readers there than stand in any way in its place.' But bcfore this task was finished a disappointment awaited the two friends. In January, 1879, between the issue of Sturlunga and that of the Reader, they made a proposal to the Oxford Press to issue the Landnama-Bok, the Book of the Settlement, which is the foundation-stone of Icelandic history: and with it the Prose Edda, chicfly 
consisting of the famous tales of the old gods, put together long after the Couversion by Snorri the historian. The former work was destined at last to appear in 1905 in Origines Islandicae. But the Press could not then see its way to accept the project. Vigfússon's remarks on this refusal are not extant; but Powell answered them, and his letter may be given entire, in order to show his style at this date: it has not all the life, whim, and iridescence of his later years, but his heart and generosity are there.

\section{Stamford Grove West, Upper Clapton, E. London.}

Dear Dr. Vigfússon,-Mr. Price wrote me as to the Delegates' decision, which I am very sorry about. I wish I were a rich man, as I could then guarantee a certain amount of the money to the Press and get them to undertake the books, and if ever I get any money so that I am able to do so, I certainly will.

In case you think of offering Landnama-Bók to the Rolls Series, if I can make out any statement for you, or see any one, please make any use of me you can. I shall be at the Museum on Saturday next, when I shall see Liddisdale, as I leave here on Tuesday next. I'm afraid I shan't be able to see Swcet till I return.

I will send you my address when I move.

Yesterday I went to the Academy, but there are not many good pictures in it, and it rained very badly nearly all day. To-day is the first really fine day, and the fields and trees look beautiful. I am just recovering from my laziness of the end of term, and getting to work a little bit, copying out all the notices for Mr. Price, and setting some examination papers.

I picked up yesterday for $3 d$. one of the beautiful Nos. of the Mémoires [de la] Société [des] Antiquaire[s] du Nord, full of plates. The letterpress as usual worth little, the drawings exquisite.

I have finished and sent back to Rhys the Taylor Runebook. It is ingenious in parts, but he is not really master of his subject nor has he read Bugge's pamphlets, but it doesn't matter one way or another much.

I hope you will have some better news next time I hear 
from you. I am very much disappointed about these two books, Edda and Landnáma-Bók. I had hoped so much to see them published in England in a proper form under your care. However, I hope that the time will yet come when that may be.

My mother is coming back from Russia to-morrow, through France. I shall hear about my sister, and Russian ways at present, which seem very curious.

I hope when you have not much to do and your 'letterday' comes round, you will send me a few words if you can spare the time; till when believe me, dear Dr. Vigfússon,

Yours very faithfully,

F. York PowelL.

Vigfússon now fell back on the idea of a Poetry Reader on a small scale to follow the Prose Reader. It was at Powell's instance, in the course of 1879 , that a larger plan was pressed instead. It was felt that the little book, if accepted, might only block the great book. Powell wished to have 'a large, permanent, and monumental one'. This was the Corpus Poeticum Boreale, the third instalment of the scheme already deseribed. It was to be an edition of the whole ancient Northern poetry, with translations and full commentary. 'They must see,' he observed, 'that it is the greatest honour to them, in fact their only raison d'être, as a University Press, to publish books which won't immediately pay.' The Clarendon Press did see it, accepted the venture in May 1880, and published it in 1883. The work filled nearly three years of anxious, persistent toil, founded, in Vigfússon's case, on the thoughts of nearly forty years : and it was the first and best chance for Powell to show the freshness of his learning and his hitherto half-tested gifts as a translator. It was the last work on a generous scale that received the final revision of both partners. It remains the best-known of their labours, and they must long be remembered, for good or ill, as the editors of the Corpus Poeticum Boreale. They answered in common for the work, and 
did it in common, though their shares can at several points be clearly distinguished. Without the expert's claim to judge it with authority, one may call it a book that did noble solid service and is left standing, despite distinct and admitted faults, and despite that advance of Yorthern scholarship which is due so greatly to its authors themselves.

It is the first complete collection of the texts, only a few of quite minor note being omitted. It contains all the Northern verse, from the tenth to the fifteenth century, that is of any value, as well as much that is only of erudite interest. Of the latter and less interesting portion, in a general way representing the decadence, and called the 'Court Poetry', the Corpus is actually the first collected text in existence; and this portion fills most of the second of the two volumes. The first volume is taken up with the verse of the classic age and stamp. This, of course, had been edited before by a series of scholars, of whom the latest, in 1867, had been Dr. Bugge, of Christiania. But the whole scheme of Vigfísson, the whole battery he brought to bear, were fresh. He aimed at an approximate grouping of the classic verse into its true periods and historic schools; and at radical reconstructions of the text, founded on his unequalled knowledge of the MSS. and of his own tongue. He also had a wholly new theory to promulgate as to the locality of the Eddic poems. He pleaded that they were written neither in lceland nor Norway at all, but in the Western, or Britisl, Isles. He wished to illuminate them, by his new analysis, as regards time, place, and provenance, of their pervading mythological elements. He had original views on the alliterative metre which is common to all the old Germanic racesTeutonic, English, and Northern. He brought together tables of that peculiar poetic diction of synonyms which makes these verses, like those of Anglo-Saxon, alien, and perhaps for ever alien, to our minds, trained as we are in classic styles and Southern rhythms. He wished to illus- 
trate the poetry at every point from the prose or sagaliterature. Nor does the weight of so erudite and complex a purpose deaden his human or critical sympathy, for he judges, appreciates, lives in and with the past, and his verdicts on men and styles are not the facile elegant ones of ill-trained journalistic mother-wit, but rooted in lifelong knowledge. It is quite clear that for this vast enterprise, and for the main conclusions reached, Vigfísson himself has to answer. The service and responsibilities of Powell, great as they were, had their fairly well-defined field, to which I presently return. He added much and shaped more, but in the main he interpreted Vigfússon and the originals. He signed, and was convinced by, his friend's theories, and time did not shake his allegiance to them, but the most important of them were in the first instance not his own.

Taking it merely as it thus stands revealed to the English reader, the Icelandic poetry is indeed worthy this pious care. The best part of it, assigned to the tenth and eleventh centuries, when our own English verse falls so nearly mute, or at any rate is so often lost, is in matter as in temper both noble and unique. Its cast is peculiar, for it is neither lyric, though it is full of lyrical passion and clamour: nor yet is it epic, for the poems are too short for epics, and are not laid ont on the scheme that we associate with the term epical. But they are nearer to epic than lyric, for they usually tell a heroic story, and the poet's personality is suppressed. They are miniature epics or heroic lays. As to their stories, and sometimes partially in their form, they are dramatic. They have many an analogy with tragic ballad, but they are seldom popular and simple in language, and to call them ballads would bring in false associations of manner and metre from The Hunting of the Cheviot, or The Wife of Usher's Well, or Lord Thomas and Fair Annet. They often touch the same chords of ghostly terror and valorous tenderness as the best ballads, but their instrument is of different 
quality, complexity, and compass. They contain, for one thing, the chief heathen and mythologic matter written down in Europe during the Christian era, and this is hardly ever to be found in epic, or ballad, or anywhere else at all, save in some of the later prose of Iceland itself. The heroic and humorous bride-hunts of Frey and Thor, and the scandalons tales of Loki, that Thersites of Valhalla, are superb examples of the bluster of the old gods, soon to be dispossessed, but not yet conscions of their successors. The doom of Balder, told to Odin by the Sibyl in Hell, forms the great tragedy of the heathen heaven, and was put by Gray into imposing, metallic eighteenth-century diction.

The same rerse, in the Sibyl's Prophecy, 'the highest spiritual effort of the heathen poetry of the North,' tells, in fragmentary wise, of the origin of the sun and worlds from the gap of chaos, and of the final break-up of the world, when its destructive forces and imprisoned monsters shall be unloosed :-

From the south comes Giant Swart, fire in hand: the sword of the Demon of Death shines like the sun. The granite rocks are rending, the ravines fall in, the dead are marching up the road of Hell, the Heavens are riven... . The sun tmins to darkness, Earth sinks into the deep, the bright stars vanish from out the heavens, fume and flame rage together; the lofty blaze plays against the very heavens. ${ }^{1}$

By the side of this poem, written by a 'heathen with glimpses of Christianity', stands the equally noble SunSong, by 'a Christian with heathen remembrances'; its pictures of the doomsday, and of the dwellers in hell and in heaven, have a clear intensity of image, a sharpness both of terror and of tenderness, which reeall Dante rather than the Apoealypse. A few lines of it may be given here, as perhaps it shows the highest seope of Powell's English as a translator:-

1 Corp. Poet. Bor., vol. i. pp. 199-200.

E 2 
Now I shall begin to tell what I saw first when I went into the place of Torment :-

Scorched birds that were souls were fluttering about as thick as flies.

From the West I saw the Dragons of Despair fly, leaving behind them wakes of fire; they shook their wings as if, methought, heaven and earth would fall asunder...

The wind lulled, the waters stilled, then I heard an awful clash. Traitorous women were grinding dust into meal for their paramours. Bloody stones were these dark women piteonsly whirling; gory hearts hung out of their bosoms, heaving with many sorrows.

I saw many maimed men walking on those glowing paths ; their faces were smeared all over, methought, with witches' blood ...

I saw men that dearly cherish envy of others' good hap : bloody signs were painfully engraven on their breasts.

I saw many sore distressed, bewildered and astray: this is their reward that ape the follies of this world.

I saw men, who in divers ways had defrauded others of their own : in crowds they were jommeying to the City of Greed, bearing burdens of lead.

... I saw men that had borne false witness against their neighbour: the Ravens of Hell were pitilessly tearing the eyes out of their heads. ${ }^{1}$

The old lays are also a treasury of tragic and dramatic situations, wherein the personages are either human, or supernatural, or both. The slaying of Atli, or Attila, by Gudrun his wife, after she has served him the flesh of their sons in revenge for his treacherous slaughter of her brothers, - a tale which echoes that of the Lombard Rosamund as told by Paul the Deacon,--is perhaps at once the most terrible and the most dramatically complete of all the heroic vendettas. But a higher human pathos is reached in the Waking of Angantheow. Here the daughter, amid terrors and portents, calls the dead father from his home in order to win the irremediable sword, that both slays its victim and curses its owner: the ghost in solemn intimation sadly yields it to her before he fackes back, and the

${ }^{1}$ Corp. Poet. Bor., vol. i. 1p. $207-3$. 
daughter departs ; 'surely,' she says, 'I felt between Life and Death when the fires were burning all about me!' One more poem must be named, The Wreck of the Sons, written by the poet Egil, and told of in his Saga. Woden has taken his sons from him, but has left him the gift of song for solace. This poem was a special delight to both Vigfísson and Powell, and his final version of it is given in the article we have reprinted on Teutonic Heathendom?

Little more need be said here to show what a gift the Corpus was to lovers of poetry, whether professed scholars or not. It is not within the range of this memoir or of its writer to judge the scholarship of Vigfísson. The criticisms passed on the Corpus ${ }^{2}$ mainly concern those clements in it for which Vigfísson had first of all to answer, though Powell shared in his conclusions and aided him to work them out. It seems to be granted now that many of the poems suffered at their hands from a too adventurous rearrangement and reconstruction; such are the Sibyl's Song, and such the series on Helgi, on the whole the most imaginative of all the Northern lays. Nor is it suggested that the text with its emendations is at all final. The experts speak further of Vigfússon's defective philology ; it appears that he was born and trained too soon. On the other hand, if his editorial processes are sometimes rash, he makes them quite clear, reasoning out and explaining his views, so that we have not to do with the exasperating

1 See vol. ii. pp. $238-40$.

$2 A$ review by $\mathrm{Dr}$. Heinzel, of Vienna, in the Zeitsclerift fü Deutsches Alterthum for 1885 (Anzeiger, pp. 38-69), sets forth nany eriticisms in detail, while warmly recognizing Vigfússon's achierement. 'The chief complaint is that he fails to give a full apparatus criticus to show the processes on which his text, often a novel one, is founded. Heinzel also controverts the view that much of the Comt l'oetry must have come down in a mere remaniement; and speaks of the "riflinierte Unberpemliehkeit' of the ordering in the volumes. Vigfísion and Powell never answered, so far as I know, any criticisms. 'T'le wealth of the Corpus is but poorly inclicated in the text above; if some of it is 'sumken wreck', it has also 'sumless treisuries'. 
kind of theorist who suppresses his evidence. Some difficulty is also caused by the method of seattering critical and historical matter through the book, and by the crop of second thoughts, afterthoughts, and final readings. It was hard to aroid this in pioneering work, and to overeome the difficulty is only a matter of patience. The index is claborate, and the scores of short and long dissertations which environ the text can soon be got at.

Apart from its merits as a learned book, and its disclosure to English eyes of a poctry they had hardly seen save in bits of versified paraphrase, the Corpus has one pervading excellence that comes out plain after nearly a quarter of a century. It is alive. The editors quote the proverb, Tout savant est m peu culavre, and they disprove it as they speak. The lays hummed in their brain, and had been known to one of them from childhood. Even when most deeply immersed in the craft of scholarship, they cannot repress their enthusiasm. In a very technical and often tentative diseussion of those alliterative metres in which all the old poems are written, we feel that Vigfússon and Powell are reading by ear, and not, like the ordinary metrist, by eye. They assail what seems to them the fatal 'error, which strikes at the very life and soul of the old poetry, ... the idea that the older metres depend on a striet number of syllables'. 'They feel the peculiar music, to which modern or Southern ears so rarely respond, as keenly as most of us feel that of Spenser or Ronsard. It was a revelation to hear Vigfússon scan ont this poetry in his curious, harsh, but sympathetic voice.

There is a fine solemnity and an instinetive and harmonious variety about this old Epic line, which finds perhaps its nearest parallel in modern times, as far as the effect on the mind, in the weightier of Milton's lines. .. . The skilful alternation of light dactylic measures and weighty monosyllabic ones, with the use of an oecasional slur, give possibility of almost endless modifications of this 
metre, which for ductility and power of expression was not equalled till the Elizabethan dramatists developed the full powers of iambic blank verse. ${ }^{1}$

Thus, if the Corpus is in some disorder, and can at times be accused of temerity, the book is everywhere full of humanity and light. The historic imagination works withont effort, and speaks without rhetoric. To see the past with a rare simplicity was one of the strongest of the links between Vigfússon and Powell. They can tell a story: while following the fortunes of the MSS. containing the Poctic Edda, they pause to describe the career of the famous scholar-bishop, Bryniolf, and his tragic loss of his children, which incidentally led to the dispersal of his library and its treasures. The pages given to this digression have the virtues of an episode in a saga. In another place Vigfússon, as quoted above, relates his mode of reading almost effaced vellums, with a revival of the thrill that he felt at seeing words that apparently had been blotted ont for two centuries. Often there is eloquence: the style that the two partners ereated together, with its clear expressive outline and its tints that are gentle but fast in grain, takes on, though it is never imitative, a Carlylean richness: and it need not be forgotten that Carlyle had distinctly seen and set forth fifty years before the importance of the Icelandic records and poetic imagination to the English student. As a typical passage of the Cormes ${ }^{2}$ we may take its words mpon the religious poems of the North. They may correct any mistake as to the way in which Powell approached religious history.

The Wicking religion will always be a noble memory to us, as representing one aspect of the master-minds of the Seandinavian peoples at a period when they were helping to mould modern Europe. Its armed angels are splendid figures; its unselfish, single-hearted, fate-defying heroes are of a noble type; its god, albeit bloody and boastful, is yet not beyond onr sympathies as he sits foasting in

1 Corp. Poet. Bor., vol. i. 11). 136, 112.

2 Vol. i. p. ce. 
heaven with his friends, ever ready for the final deathgrapple, in which he must fall, as he knows, before the fiends of hell.

But there are also among the Eddic poems records, happily preserved, which tell us how the nevv world of thought and life looked to the Northern sage (just as Walhall shows the impressions of the Northern sea-rover). In the strange, beautiful myths of the gallows-tree, that fills the whole universe, holy, life-giving, sprinkled with the white ooze, there is indeed plainly to be seen the reflection of the Cross ; while in the eschatology, with its Doomsday and battle of Armageddon, and the glorious myths of the golden age that has gone, but will come back again with the new heaven and new earth, we can feel the very echo of the mighty vision that has inspired poet, and painter, and thinker ever since it was told by the seer who had seen the fate of Jerusalem.

And of the ballads he writes :-

The religion of the Scottish ballads, save for the few poems that deal with the popular Catholic mythology, is absolntely as heathen as that of the Helgi Lays; the sacredness of revenge, remorse, and love, the horror of treason, cruelty, lust, and fraud are well given, but of Christianized feelings there are no traces. The very scheme, on which ballads and lays are alike built, the hapless immocent death of a hero or heroine, is as heathen as the plot of any Athenian tragedy can be.

As Powell was an artist in translation, and spent much of his life upon the art, and laid down the principles upon which he practised it in a chapter of the Corpus that is more separately his than any other in the book, his own words on the subject are the more noteworthy. He had, following Goethe, an exalted view of the translator's international duty and service; and he pointed out to critics the delicate and severe standards by which alone, with whatever result upon the verdict, he himself would care to be judged. His task in the Corpus was different from any that he had yet had, or was to have afterwards when he put the sagas into English. There, he had to find prose

1 Corp. Poet. Bor., vol. i. p. 507. 
as an equivalent for prose: he now had to use prose as the medium for a verse original: and this task implicd a different call on his cadence and vocabulary, and a different set of English models. One of the truest canons that he lays down is the need for that union, achieverl by few translators, of scientific aim and artistic method. The first need, he holds, is to be faithful to the meaning, without glossing over the difficulties. But to be faithful, the words must have the right atmosphere and colour. He felt he must go back to the fountains of diction, the lyrical Scriptures on the one hand, Defoe and Carlyle on the other, in order to call up associations as nearly as possible like those which the Icelandic raised to the mind of an Icelander. Here he was helped by the tie of race and idiom, which appears at so many points, between Icelandic and English. To get the bare meaning, he worked throughout with Vigfússon, whose hold on English and power to hail the right rendering was rcmarkable. But for the invisible turns of phrase, the hairbreadth choice between seeming synonyms, and the judicious occasional use of older English words, which yet must never fall into canting archaism, Powell had to trust to himself. He rose to the task; and apart from actually disputed interpretations, from some needless abridgements of the originals, especially in the Court Poctry, and from his uncxplained and capricious habit of anglicizing proper names, he did noble service. His long practice in translating did much to found his original style; and his chapter in the Corpus on the art of translation is the earliest essay he printed on a literary matter. It is also, I believe, on the whole one of the best things on the subject since Dryden: and after making such a challenge $I$ at once reprint portions of it, since here, though of some length, it seems best in plaee, and since tle $C(m p)$ s is not in every man's hands. With it may close this accomt of the Corpus, the most congenial and also the hardest and most continuous labour of Powell's life. 
It will be right, if only in self-defence, to say something about the translations included in these volumes. They are primarily intended as a help to the scholar, and a faithful rendering for those who wish to know the contents of the various poems and citations, without having mastered the tongues in which they are composed. This aim has been, as far as could be, kept in view throughout; and it is from this point of view, rather than from a purely literary standpoint, that they are to be judged.

There were no light difficulties in the translator's way, and they have not, by any means, always been overcome, though they have at least been honestly faced and grappled with. In the first place, it is no light task to deal with songs of such high beauty and power as many of these poems are, it is only a great thinker and poet that could worthily achieve a noble transfusion of them. Like all masterpieces of literature they have a style, a phraseology, and a savour of their own, which it is easy to feel, but singularly hard to transmit to another who is not already en rapport with the tongue or the age in which the poems were composed. Then the syntax, simple as it looks at first sight, is really very difficult; so delicate and fine are the minute shades of difference which the same tense, for example, may express in several phrases, - a peculiarity which readers of Professor Driver's monograph on the tenses in Hebrew will see elosely paralleled in that tongue. Then there are numerous technical phrases, legal, political, martial, naval, colloquial, economic, not found elsewhere, the meaning of which has to be discovered, settled, and duly brought out, a process often of extremest difficulty. All this is work, which not even a born Icelander is at all fitted for, unless he has not only studied the old tongue, but the old life in all the extant evidence possible; indeed, it would be easier in many cases to get help from old English and old French seholars than from Icelanders, so different is the old diction and the old circumstance of the poems from modern speech and social existence in lceland. Again, it will not do for a scholar, who is merely a philologist, to presume to deal with the translation or edition of the old literature of our own or any other tongue. The letter, sacred as it is, kills; and one, whose chief interest in a poet is to know how often he uses such and such a word, and who is mainly taken up with con. sidering how far the 'copyist' is changing the ' $\mathrm{e}$ ' into ' $\mathrm{e}$ ', 
should not (without help from some one who knows and feels the life and beauties of the literature in question) deal with literary matters at all, or he will be likely to fall into some such error as a certain distinguished scholar did when he mistook verse for prose, and gravely told his reader to take the poems he was noticing as models of classic prose style. The philologist's work is of the very highest value; but in precise proportion as a man is a good philologist, or indeed a specialist of any kind, he must take especial eare to prevent his interest from becoming contracted, and his senses blinded to other than the small round of daily objects which his particular specialty brings before him. There is perhaps no work more likely to turn a man into a gerund-grinding machine, 'sans teeth, sans eyes, sans taste, sans everytling,' wholly insensible to the real beauty and worth of literature, than what is often misnamed 'pure scholarship'; while, on the other hand, no critic can enjoy the best books so well as the rightly educated, widely read, and thoughtful philologist.

It must also be remarked, that it will not do to use one style of English to render the wide varieties of poem and prose met with in these volumes. 'The Biblieal phraseology, which will aptly render Paul the Deacon's paraphrase, would not give the quaint half-pedantic effeet of Saxo for instance; while the calm, unruffled serenity and purity of diction, which marks the poet of Wolospá, is very different to the rugged, passion-wrung lamentation of Egil. The legal phrases of the Greenland Lay of Attila and the Euripidean softuess of the Gadrun Lays are very far removed from the antique Homeric beauty of the old Attila and Hamtheow Lays.

There is one grave error into which too many English translators of old Northern and Icelandic writings have fallen, to wit, the affectation of archaism, and the abuse of archaic, Scottish, pseudo-Mliddle-English words. This abominable fault makes a saga, for instance, sound unreal, unfamiliar, false ; it conceals all diversities of style and tone beneath a fictitions mask of monotonous uniformity, and slurs over the real difficulties by a speeious nullity of false phrasing. The idiomatic spoken tongue of the saga-makers should be rendered as far as posisible into an idiomatic spoken tongue.

One great advantage the translator has had. English 
is, of all existing tongues, from the richness of its vocabulary, the laconic power of its idioms, and the simplicity of syntax which it admits of, the best vehicle for a translator from the old Northern speech to work in. The Elizabethan dramatists, the Bible, and more modern classics, such as Defoe and Carlyle, pithy, phraseful, idiomatic, give the translator an inexhaustless mine in which to quarry. There is always the right worl somewhere in English, though it is not always that one can hit upon it at the right time. Especially useful also to him who would attempt to English the songs and sagas of old, is a knowledge of the spoken English of the country-folk, who (as Mr. Barnes has proved to those who refused to see it before) often preserve the best English phrases which the miserable, conventional, hack-English of this and the preceding century has scornfully passed by. Some knowledge of Greek, especially of Homer, Hesiod, and Herodotus, and some acquaintance with what is known of the older Greek life and ways, will often avail the translator when nothing else can. It is obvious that he should know something of Old Enghish literature, law, and history, familiarity with which again and again will prove his best guide against mistake, and his best help to the right handling of his subject-matter.

The task is not one to be entered upon with a light heart, and the translator may at least claim to have been aware for years of the obstacles in his way; now that he has gone through with the work, he cannot profess to be satisfied with his results, save in a very modified degree. At best his version is to the original as the thin, muffled, meagre, telephone-rendering is to the full rich tones which it transmits, faitlsfully, it is true, but with what a difference to the hearer!

There are many instances in which the translator has had to choose between a poetical rendering, and one which, awkward though it was, yet had the quality of suggesting the real meaning; and in every ease he has preferred the latter. Had he been making a purely literary version, which should not be merely, as it were, an interpretation, but a representation of the original, he would have decided otherwise. Hence in the qualities of rhythm, flow, and roundness of phrase, the present version is obviously all too often lacking, and this is, as the writer feels, a very serious defect; but there seemed no help for 
it. A translator, even of Chapman's or North's calibre, could such a one be found, must sometimes come to a place where two roads fork, and will not always follow the right branch of the Pythagorean letter. Moreover, in the present case, it was necessary very often to decide quickly.

Wherever, too, there were phrases which, though 'they construed', would not 'make sense', the translator' has chosen to omit them rather than give a guess rendering, which would make his version read more easily, but at the same time mislead the innocent reader.

It is not with a desire to forestall criticism, that thus much has been said, but from a wish to sct forth plainly the aims, object, and scope of the present version.

Besides the poems, the translator has in the course of these two volumes given a rendering of all that part of the Prose Edda which has not yet been translated or printed in England, a version of the paraphrase of the lost Lays of $R,^{1}$ and an anthology of all the best passages relating to poetry or poets which occur in the Iceland Book of Settlement or Landnáma-bók, the Kings' Lives, and the Icelandic Family Sagas, as well as many of the most noteworthy parts of Jordanis, Paul the Deacon, and other writers, of which there is either none or no accessible English translation.

The translator must in fairness add that he has received no help from any former versions, English or foreign; his success or failure, such as it is, is his own. When he took up his task the text of most of the poems was in such a chaotic condition that, till the work of arrangement and reconstruction was well under weigh, it was impossible really to make a beginning at all. Every word and phrase has been reviewed three times; and, though there are far too many slips and shorteonings even upon the face of the translation, yet considerable pains have been taken to bring it into harmony with the finally settled text above it. In the case of the Wolospais and Hyndlu-liód, the translation in the Appendix is of course to be preferred.

The hope with which the translator has laboured has always been that of inducing Englishmen and Americans to seek back for themselves into the Ilomeric age of their forefathers, to turn to the rock from which we are hewn,

$1 \mathrm{R}$ is 'Corlex Regins, the chief of all Icelandie MSS., the treasure of the Royal Library at Copenlagen'. Corp. Poet. Bor., vol.i. p. xli. 
and to make it possible for those who cannot go straight to the original work of this period to get some knowledge at second-hand of its glories and its greatness, of its highest creations and its deepest thoughts. Any real, however scanty, knowledge of these old Northmen's finest poetry and noblest era of history is of solid value and interest; the men from whom these poems sprung took no small share in the making of England, their blood is in our veins, their speech in our mouths, their law in our courts, their faith in our hearts; and if there be, as the sage has said, no ingratitude so base as self-forgetfulness, surely we of all men should look back to the great Wicking-tide, to which the finest of the Lays in these volumes are due, as a momentous era in the world's history and our own.

Let Goethe speak on this head-'The most singular and deepest themes in the History of the Universe and Mankind, to which all the rest are subordinate, are those in which there is a conflict between Belief and Unbelief, and all epochs, wherein Belief prevails, under what form it will, are splendid, heart-elevating, and fruitful. All epochs, on the contrary, where Unbelief, in what form soever, maintains its sorry victory, should they even for a moment glitter with a sham splendour, vanish from the eyes of posterity, because no one chooses to burden himself with the study of the unfruitful.' ${ }^{1}$

The Corpus was well received, though there were few scholars then in England equipped to review it. Any criticisms, wrote Powell to Vigfússon,

I shan't answer, because I don't care. Those who know me won't mind it, and those who don't I don't care for now.

Here can be taken up the private record, still somewhat scanty, of 1880-3. In 1880 Powell's home was still in Clapton, whence in vacation he sallied to the Museum, with occasional runs to the South coast or to Henley. In 1880 we hear :-

1 have had a pleasant vacation too: got through a fair amount of grinding work, and enjoyed the fine weather.

\footnotetext{
${ }^{1}$ Corp. Poet. Bor., vol, i. pp. cxiv-cxvii.
} 
The elections too have made me very happy. I am very thankful to have got rid of that old humbug Disraeli, and hope for really radical reforms.

About this time Powell thought of standing for a university chair in New Zealand, but abandoned the idea, preferring to stay in the old country, even if he must eke out his moderate income by examining; and he was glad that he had so decided. Part of the summer, it seems, of 1880, was passed at Henley in lodgings, and he writes thence to Vigfússon :--

I am at present still wrestling with examinations, for 'pot-boiling' as the Painters say, but I hope to get rid of this incubus in a week or two-I have done half the work of it now.

The Court-poetry must have been a hard task, but there is one comfort, that it is done for this century at all events, and it is interesting to have it in a form such as it has not been in since it was first recited. There is some real poetry in a few of the earlier poets. I liked the pieces I read with you, the Shield-songs, very much. 'They will shine out anong the 'red gloom' of the rest.

We are having charming weather at last here. Lovely skies, blue as those of France, and beautiful clear air for the trees to show through. Scotland will look lovely in this weather.

In January 1881, during bitter days, when the roads were snowed over and tight with frost, Powell moved from Clapton after seven years' residence. This change shaped his future life and many of its friendships. Westward of Hammersmith, on the rim of the region where London mortifies into the waste gardens around Acton, which are now being filled with jerry-built shop and cottage; and parted by the Kew railway line from Turnham Green, the inland frontier of Chiswick; is the small estate of Bedford Park, an oasis of green gardens and red houses, ringed by rapidly perishing orchards. The suburb has its own countenance, cheerful and self-contained amid the stucco and often squalid surroundings. Mr. Norman Shaw 
was well inspired to build this pocket settlement, with its own schools, store, and church, which soon became a resort of painters, players, poets, journalists, schoolmasters, exiles, Bohemians mostly innocent, 'nephews of Rameau', stray city men and bourgeois. It was known to some as the 'pauper's paradise', but it was long rich in talk and in the gifts of the spirit. The Irish element, rebel and other, was quickly to be noticed, and was indispensable. Here Powell was to live for twenty-one years, and the break when he left it in 1902 was bitter. The place contributed much to his peace and satisfaction. It was bright to look on, and he depended much on what he saw. There was none of the luxury which he hated. There was much camaraderie, without that giving of banquets, or dressing up to eat them, which he also hated. There was good conversation, and as good listeners. There were many children about, and Powell would point with pride to their good looks and condition, explaining that they came of parents who had married, like himself, young, and for love, and imprudently. He would explain that the more good people, of sound race and breed, that there were in the world the better, and he steadily advised his young friends of both sexes of this his opinion.

It is a duty, and not an unpleasant one, to beget and bring up children. If nice people don't do it nasty ones will, and we have to begin the struggle over again each generation. We ought to breed for brains a little.

Moreover, from Bedford Park it was easier to get down into London or to Oxford. He lived for three years at 2 Priory Gardens, and in the winter of 1884-5 went into 6 Priory Gardens, 'The Corner,' where he remained. His life here was long of the happiest kind, elouded only by the threat of ill-health to one of his step-daughters. In 1884 his own daughter was born. As before, he lived at Oxford through the week in term, and came home at the end of almost every weck and for vacations. The year 1881 seems to have no annals. The only letters extant 
are to Vigfísson, and show little but the steady progress of the Corpus. For these few year's some letters from Vigfússon survive, and two can here be given. The first is on the Wreck of the Sons (Sonatorreli), the poem named before.

From G. Viafísson.

April 18, $18 s 1$.

I quite agree with you abont Egil. The Sonatorrel is some thirty years later than his stay in England. Only, his deep sorrow may have called forth old dim memories of what he heard there. I only mean, there is a seed-corn of Hebrew spirit in his song. It is in my mind the deepest and earnestest and most genuine of all Norse songs, and what if we had it whole and without blemish? It stands alone-such a reality is there about it. All other songs are more or less play and poctry.

In the summer of 1882 Powell's maternal grandfather, James York, died. 'He did not want any one with him,' wrote Powell, 'or' I should have gone down. I think he was right.'

\section{To F. P. Barnard.}

2 Priory Gardens, Bedford Park,

[Aug. 5, 1882].

I have just read Swinburne's last volume. ${ }^{1}$ There is a lot of silly stuff about children, but some glorious Sommets, and a splendid piece called 'Athens'. The main poem is very fine, classical, and not at all unlike, in the impression it leaces, Hero and Leander, though its form and phrasing are very different. Altogether there are fine things in the volume : it is better than anything since the 'Deserted Garden' in the second Poems and Brillarls-you remember that.

... He [Mr. York] was a good old fellow of great humour and a delicate irony that is almost a lost art. very charming manners too. He and I always got on very well, and I avoided the Shakespeare idea, and we talked on subjects we agreed on and could feel alike on. I am sorry he is dead.

\section{Tristram of Lyonesse.}


Vigfússon wrote on hearing this news:-

Oxford, Aug. 3, 1882.

I an right sorry to hear of your old grandfather's death: but you may be sure that, spite what you mention, the old man in his bright moments has often felt proud and comforted to have a grandson like you. Well, it is a backward world when the grandfathers bury their grandchildren. It is after all far better that we should bury grandpapas, and parents too, as old Herodotus defines it: who would not, he says, prefer peace to war, when the fathers bury their children;-the peace, when the children bury their parents? But for all that it is pathetically true, what good old Dr. Johnson says, how we manage to have anything worth having done, just when those whom we would have to see it, and be proud and glad of it, are 'muder green earth'. Be so good as to give my heartiest condolation and sympathies to your mother. When the old die, it is as if some old work of art, some precious MS. were destroyed which never can be restored.

In 1882 comes a clear statement of Powell's ecclesiastical attitude, from which, so far as I know, he never receded. His words on the Jesuits may be checked by his review, written years afterwards, of a book on Loyola .

\section{To G. Vigfússon.}

I well remember abont the Iceland trade. Good Latimer uses the phrase 'stockfish from Iceland' as a regular saw, like 'coals from Newcastle'.

Good S- deserved to be happy; he is a nice fellow, so gentle and quiet, and worth a hundred of the idle talkers we have in plenty - 'God amend them!' as Latimer says...

I dare say he ${ }^{2}$ has done some good, but I feel to him as I do towards those poor Jesuit fathers that suffered in Elizabeth's reign. 'They are to be respected, pitied, and condemned, as fighter's against the light. When a man can't be at ease without a priest to bolster up his debility or nullity of conscience, it is time he went into a convent and stayed there. He isn't fit for wholesome workaday life, and his influence can't be good. It is a pity to see Liddon and such fine fellows warped by this miserable

${ }^{1}$ Sce vol. ii. pp. 146-9. $\quad$ a Referring to the recent death of Pusey. 
little man's teachings. He was not even a good scholar, and has never written a line worth reading. However, he was very charitable, lived meanly, and gave away his money to those whom he believed wanted it, and I dare say he lived up to his lights far better than I ever have to mine, and quis juclicet? But one has a right to judge his teachings.

This year Powell kept firmly to the Corpus, though at times "vehemently tempted to read old English Poetry instead'. He sends Vigfússon a letter full of lyrical fifteenth-century scraps and burdens. In another he drops the remark on Morris, Longfellow, and Temyson ${ }^{1}$ :

To G. Vigfússon. Bedford Park [no date, about July, 1882].

None of the three (Temnyson included) are great poets. I only mention them as specimens of men who drew subjects from Eddic poems. English people like to have such things mentioned, so I put it in, but I don't hold it of much account. Temyson's borrowing is not generally known; that is one of the reasons of mentioning his name.

By the middle of Augnst they had finished:

To G. Vigfússon.

Beelford Park, Aug. 18, 1882.

We have done our damndest, I think, and the book will sail quietly into port, I hope. I have added two or three paragraphs on the Metric Excursus and chronology, so as to show folk what is in it. 1 an glad that it looks so well as it does. I wish the translations were worthier with all my heart. I will try and make it better, however, as I can. I often find a happier word as I $\mathrm{mm}$ reading it over, but I did my best at the time, and it is done. It is the horrible inadequacy in the finer parts that strikes one more and more: the power and music of the original sounds as through a telephone, meagre, and thin, and faint. ...

There is a nice fellow here with whom I have strolls of an evening before dimer, an Irishman, a poet and critic, a really good fellow and capable. I am very pleased to

1 The 'mention' is in Cory. Poet. Bor., vol. i. p. xevi, where Swin burne is substituted for Morris. 
get a man here with whom I can talk. It is like being in a foreign country when you have to bottle up all your thoughts for months, because there is no one who understands the tongue of literary men or matters.

More than one of Powell's neighbours answered to the picture of this Irishman. At this time, and for some years, he felt that he conld not talk freely at Oxford on the matters for which he cared most; and the society of Bedford Park he regarded as in this way a resource.

The late summer of 1883 was spent by the Powells on the South coast. Powell bathed, and walked, and visited the Norman churches. We have his opinion of new Edinburgh, and also a sketch of the Pastom Letters. It is given here for its vivid promise of his later style as a reviewer.

\section{To G. Vigfinsson. Bedford Park [no date, abont Nov., 1883].}

I hate Edinburgh, and I am glad you are ontside the town rather than in it. There is a bumptiousness about the streets of the new town, a self-consciousness which is very irritating. The old town and the suburbs have not this aggravating air. Nor have all the Edinborough (sic) folk, but some hare. . . .

I have just read through the Paston letters. They are interesting like a novel. Old Madam Paston, the managing mother; the scape-grace eldest son: the practical younger son, who after many trials at last gets a rich wife (good honest girl, who is full of fun and writes him the most amusing letters) and ultimately comes into the property. A gresping nonele, who is always trying to cheat the two young fellows, who outwit him in the end. The father and grandmother too, great characters in their day, shrewd, worldly, but honestly sticking to their work, and above all retermined to die richer than they were born.

Then the Oxford student, as shrewd as the others but dying young; the lad at Lton; the servant-bailiff who falls in love with the sister of his masters, and with great courage (on the girl's part) is enabled to marry her. The fumny old friar, who is a sworn friend of the Paston father, and writes scandal in Latin and English 
mixed. Then the Duke and Duchess of Norfoll, who try by main force to oust the Pastons from the estates they got by Sir John Fastolf's will; and thus arises a crop of lawsuits, processes, distresses, armed occupation and resistance, court solicitation, backstair jobbing, appeals to bishops, chamberlains, queens, kings, and lawyers, which last for generations but end in the Pastons getting all they claimed. 'It's dogged does it' (as the old fellow said in the story), and there is no better example. The whole story as set forth in those old bundles of letters is quite a good novel, and strikingly like bits of the best of Thackeray ; the women especially. Yon must read them some day, all at once, quickly, so one does not lose the thread and keeps the characters before one.

When the Corpus was being praised and aeclaimed, he repeated his usmal expressions of thanks to Vigfússon, adding :

Oxford [no date, early in 1884].

I must write you all this, because people are very goodnatured to me about the Corpus, and I feel and tell them that it is your thonght and work that has given the book its worth. I am only a channel-pipe, earved and gilded in places perhaps, but still merely a chamnel-pipe.

We know by now what to think of this self-estimate; and the present chapter may close with Vigfüsson's opinion:

\section{Vigfísson to the Rev. J. Sephton.}

March $26,1883$.

Mr. Powell has been a friend indeed to me; we have worked together like brothers, in constant intercourse of thought, and schemes, and ideas, apploving or rejecting. The translations are all essentially Powell's, and hence idiomatic and good English; and lots of other things besides we have translated, bits of Sagas, a little 'noctes Atticate', especially anything mythological or biographical: also sundries from foreign writers, e. g. Paul the Deacon, Ballads discovered there (in lceland), Old Teutonic. of the text-emendations there is a second crop, and much remains, what we have failed to put aright. After all this I feel like empty, toom, having no more sweet visits of bright thoughts; and so we are about to close our shop and sell no more. 


\section{CHAPTER III}

\section{LABOURS, 1884-1889}

Pass Law work: irony of position: Powell's own attitude. Studentship and tutorship at Christ Church: no post in History for Powell at Oxford. Visit to Manchester: examining. Work for Women's Association. Visit to Copenhagen: Vigfússon on the Fire. Origines Islandicae accepted by Oxford Press. Powell's projected Scandinavian Britain: quoted: unfinisher. Reads Old English verse. Grimm Centenary volume with Vigfússon: Ballad in Scots. First meeting with Powell. :His part in founding English Historical Review. Publication of History of England to 1509: character of the work. Recommends Provençal. Letter on life and the award of the gods. Sallies against Oxford. Arthur Johnstone and James Sime. Deaths of Mrs. Powell and of Vigfísson : last letter to Vigfísson: MIS. note again. The delay of Origines: sketeh of it, examples of translation. No more long books: Powell's future métier.

LEARNED books do not leave the author rich, and it is much if they do not leave him poorer. Powell had done most of his literary work for love. He made a fair living chiefly by injecting certain rudiments of law into average undergraduates. Any learned German, who in the future dares to chronicle the older Universities of Britain as they were in the later nineteenth century, will be vexed by the position of a man like Powell, known all over Oxford for historical learning and productive scholarship, yet furnished with no position or salary as a teacher of history. 'Um Gottes Willen, why not?' such an inquirer might say. "He was one of their best Gelehrten, but had he died at forty-three his official record would have been that he was honoured and paid by his college, 
but that his work was to help men to pass, as they called it, in Law.' We, however, can leave some clue for this earnest inquirer. The system did not lend itself to the recognition of Powell. It was the business of no man and no college to find him appropriate work. In his own House historical tuition was provided already. Elsewhere funds were not available. It was not for any other college - not its duty' - to invite and salary a man merely because he was a good writer or of proved erudition, or because he had his share of genius. Such gifts, taken alone, would not qualify him as an instructor for the examination schools: they could not be trusted to increase the number of first classes won for the college. Powell's strength, beyond doubt, did not lie in this direction: he would hardly have respected himself if it had. Doubtless others, rather than he, must lave been the losers. He was not to be one of the gifted men who spend themselves on college tuition, and sterilize themselves for the good, real or seeming, of their pupils. Still, in a foreign University he would at least have had titular advancement as a 'professor extraordinary'; but in Oxford there was no such thing: there was no place for him until the death of Froude, when he was put into the vacant Chair by general agreement:-a deed which our foreign chronicler, though still bewildered, should set down to the eredit of the place. Thus, between the colleges and the University, Powell remained a minor teacher of law : an arrangement that, quaintly irrational as it was, cannot be treated in the spirit of high invective which wonld be so unlike Powell's own spirit. He could be often indignant for others, he might blaspheme at times when weary; but as to his own fortunes he was ever something of a fatalist, with a touch of irony. Like many dispensations, his own was, he thought, an odd one: but it had so to be, and many better men were worse off; and he supposed it was all right, and he did not imagine he deserved anything better; yet he found it was comic. 
So he did not repine; and in the more serious things of life he was to the end, even when visited by sorrows, resigned, if not exactly content.

\section{I have had my due,}

Nore than my due, and why should I complain?

So he wrote in later years in one of his beautiful somets, all too few. Another reason that he did not get on was that he did not try to do so. He had less than his share of pushing power; he pushed far less than was lawful. Still less had he any element of the professional getter-on, what he afterwards liked to call the crriviste, who thrives so strangely in academic as in other societies, steadily presses or machinates in his own behalf, and ends in positions of power and emolument without any one either quite knowing why or protesting. Of such persons Powell had no envy: his frequent and true expression was that they had 'got the facts of life all wrong'. These traits may be noted here once for all and remembered through the story of his after-life.

Powell, however, did not miss his turn of material good luck. Though few of the sons of Oxford received his historical teaching, and his gifts in that kind had therefore no formal acknowledgement, he received in 1884 college promotion which materially relieved him. Greatly through the grood offices of Dean Liddell, he was appointed to a vacant official studentship of Christ Church (the Fellows at that House are termed 'Students'), and to a tutorship in the year following. Both these posts he held till he became professor ten years later. He was pleased with the honour, and still more with 'getting at voice for history on the General Board'. He had also been cheered by the birth of his daughter in the spring, and his home life was so peenliarly happy that we find him, as already noted, steadily advising many a young friend to found a family : to 'marry and beget children, 
and have the same pleasure and care' as himself. 'It is, I think, good for one.' Once he wrote :-

Get married soon, and you will find that what keeps one will keep two or three just as well. I have never repented marrying, so I don't speak as the fox with the cut tail.

We can find in his letters many repetitions of this counsel, which is a proof that he was happy and believed in happiness. And we have one clear picture of Powell as he appeared at this date to a friend and fellow-historian. Mr. (now Professor) Dill was the High Master of the Manchester Grammar School. He lived in Birch Hall, one of the few beantiful houses that have been spared near the dark eity: it lies out, just beyond the clamour of stony thoroughfares, in a plot of fields that is still undevoured by the builder, with its own flowery coppicegarden, shining black oaken rafters, and Cromwellian memories or legends. Mr. Dill had organized afresh the examination system of his school. One of the four examiners, who came down yearly to hear and inspect the work, was Powell: he paid three visits, about the years 1880-2, to review the Mlodern Language teaching. As his undoubted want of orderly business system, punctuality, and the like, has been steadily exaggerated by legend, I take the chance of saying that my own experience of him through twenty years is in full accord with Dr. Dill's, whose words may follow.

He generally stayed with me at Birch Hall when he came down. I need hardly say that he was an excellent examiner. Nothing escaped lim, and yet he made the inquisitorial process pleasant for both masters and boys. I believe the boys quite liked his hour of viva voce, as he enjoyed it himself. And after it all he would have a friendly talk with the master, in which the criticism was so veiled as to seem to the most sensitive to be only friendly suggestion, with praise where that was due. We were then building up a great Hodern Side, and have 
always thought that in that promising bit of construetion Y. Powell had a great share of the eredit.

I unfortmately saw little of him in the last fifteen years. But I always look back with pleasure to the weeks he spent with me at Bireh. I never met a man with such a power of spreading about him a sense of downy, comfortable calm, as if there were no such thing as work and worly. When he could be got to come down in time for breakfast, his cheery ways made the day brighter, and the morning stroll in my old-fashioned garden at Birch was so pleasant that it sometimes encroached on school hours. When we met again at dimner, the talk was often prolonged far into the night. And yet, such was his quickness and power of concentration, his work was always ready in good time, though one could hardly guess when it was done. He was a man of singular power, disguised under an air of nonchalance and easygoing enjoyment of the hour.

I need hardly say that he always impressed one with his immense range of reading. But this came ont only accidentally and fitfully. No one was ever less of a pedant, or more free from any tendency to display. But I was more than once struck by his familiarity with obscure and little-known writers in the fifth and sixth centuries, when I happened to be working in that period. And the knowledge was close and accurate, as if he had read them the day before.

It always seemed to me that Y. Powell's unique power of rapid reading and assimilation impaired his productiveness. He would have written more if he had read less. And probably his ideal of the command of a subject, necessary for a final treatment of it, as in the case of M. Pattison, deprived the world of work which they alone in their time could have done.

Such excursions varied the labour at the mill. Powell also gave time in Oxford to an activity that may here be mentioned. It was an article of faith with him that he 'hated "educated" women', who were often 'silly boshwriters and miserable poetasteresses, conceited, ugly'; that book-culture was not what women wanted, that it ought to be carefully hidden if they had it, and that only good looks could atone for its possession. His deflections from 
this stern and lofty ideal were frequent and delightful. He did all he could to better the status and teaching of women in his own University. For ten years, and from the first, he worked for the Association for the Education of Women in Oxford, teaching Old English, Old French, and even for a while, to tide over a difficulty, Old German. He sat on the Council of this body and constantly subscribed to it. His enthusiasm and warmth as a teacher are well remembered. When he was asked how he reconciled such doings with his principles, he answered that the women he taught were mostly going to be teachers, and that that made a difference. We shall hear of some lectures on modern French poetry that he gave to women students in the last years of his life, and of their response to his teaching.

One other letter must be given before proceeding:

To Wilfrid Scaven Blunt. Christ Church, Nov. 1883.

I wonder whether you ever remember a boy for whom you drew the portrait of your dog at $S$. Sauverin in the Pyrenees twenty-one years ago. I have that little picture now, and it was one of the greatest pleasures I have had, to read your poems, and remember my long-past acquaintance with you, whom I looked up so much to in those old days. I often meant to write to you and ask you to let me meet you again, but I have not done so till now. I have just been reading and re-reading your noble protest on the Egyptian treason, and I can't resist doing so any longer.

When you come back to England, if you will allow me, I should like to call and see you again and thank you for the great pleasure your poems have given me. If you remember me, I dare say you will not mind giving me time and place to speak to you. I shall not take ul much of your time, nor ask any favours of you save this.

If you are ever at Oxford or near it, and would stop an hour, I should be very pleased to show you what I conld of the things we have best worth secing, and I should be very happy to do so.

I have been working here more than ten years, mostly at history and literature, and the ideas which your last 
poem ${ }^{1}$ speaks have grown very strongly upon me, so there is at all events one link between us. I am yours very faithfully.

From Powell himself we have little record at this season of his life, except of his literary plans, which rapidly took form. The Prolegomena, the Reader, and the Corpus, in which he had borne his part, as well as the Dictionary, done by Vigfússon alone, were now in existence; and yet a great duty remained. Vigfússon and Powell wished to crown their labours by producing both an edition and a translation of all the best classics in the Northern prose. In February their proposals, drafted by Powell, went in to the Clarendon Press. The reasons that might be held to warrant the enterprise and ontlay were set forth with weight. Vigfússon had long hoped to present these originals in an edition embodying the fruits of his long inquiries. Powell mrged that this part of the scheme, at any rate, should be accepted, and the services of such a scholar, now long resident in Oxford, be put to use. He cited the honomable reception given to the Corpus by authorities who were personal strangers to its editors. The plan covered three separate items, each calling for heavy labour. First, the Lives of the Kings of Norway and Denmark from the ninth to the eleventh centuries. Secondly, the Sagas of the classic period (900-1030). Thirdly, the Books of the Settlement and Colonization of Iceland. When all this was done, the colleagues would feel that their task would be over: the rest of the Northern literature was of more local interest, and could be left to other hands. Five volumes would be wanted. Powell also pleaded for and offered to make a complete translation. It was very necessary. Most of the originals had never been put into English at all, and some of the existing versions were only in rare issues and founded on imperfect texts. Historians of early England, like J. R. Green and Freeman, had long been cut off in this way from the

${ }^{1}$ The Wind and the Whirluind, 1883. 
light that Iceland throws on the whole of old Gernamic culture.

Memorandum to Unicersity Press.

Feb. 22, 1881.

While I am aware of the difficulty of making a really good translation, I do not think it impossible to make one which shall be both faithful and readable, so that those who are not reading for historical purposes might enjoy it for itself. The originals here are so fresh and beautiful that they only need to be known to be admired. I may, in my own defence, mention that I have worked at the subject for more than firteen years, and especially with regard to these books, the Kings Lives, \&c. ; and that it has always been my hope to be able to give English people, in so far as a translation might, part of the great profit and pleasure I have had in reading them in the originals.

This, Powell rightly said, was not the 'mere fad of a specialist, but a sober scheme of distinct historical importance'. The offer was in part accepted. 'The Press agreed to publish the Book of the Settlement: and this grew into the larger Origines Islandicae, which occupied Vigfússon and Powell during the rest of their common life, and most of which was to be finished, though never finally revised, by them.

In the summer of this year Vigfússon visited the Copenhagen libraries, and there in August Powell joined him for a fortnight. Their converse has been described already in Powell's words. He studied, walked on Elsinore, and

enjoyed Denmark immensely :-splendid weather, ample facilities for seeing the MSS.; and very delightful voyages to and fro.

In October Vigfússon, who had stayed on, wrote him an account of a great fire, in which the treasures that were his own lifeblood were nearly consumed. 'The letter leaves us with a picture of a scholar deep in tranquil work and startled by the sudden threat of flame to his manuscript Penates. Vigfússon's English has been left its it stands, and needs no mending. 
From G. Vigfüsson.

Copenhagen,

Hotel 'T're Hiorter, Oct. 7, 1884.

I have got deeper into the vellums than I dreamt of when we last shook hands and said goodbye in Havnegade. The next Monday I turned to the work in my cave, and continued day by day till Monday week (Sept. 29), mapping ont the work day by day. The main things done are: [a long list follows].

At last I went to the Geheime Archiv (the Rolls), and I went through many letters from 1660-1730, A. Magnusson's and Widalin's time. This last week I had just finished when the Fire broke out. Last Friday I was in the Rolls Office to 2 o'clock, when they close; thence to the Royal Library, more for pleasure than for work, and stayed there till a quarter past three. $\Lambda$ few hours afterwards the Firc broke out. There is but a narrow lane between the Library and the Archive (both in Tojjhusgade) and the Slot. By the mercy of God the wind blew from Töjhusgaden, and both Library and Archive were saved, as if a good genius had directed the head of the wind. It was just so in 1794. It was a terrible sight; on the other hand, had the wind been blowing a gale, the whole of old Copenhagen, University and Arne-Magnusson Library would have been ashes in the course of the night. The Old Block of Castle was but a hideous mass of stones; still it is a pity for the poor King, it was his Burgh. The Copenhageners scem to take it easy: they have had a firework, nothing can match that. I was one of the sightseers, and though at a safe distance, covered with ashes and scoria like from a volcano: hope nerer to see such a sight again. But let us bless the Fates that our old scrolls and vellums are still [safe and somd] upon their shelves. I am now quite easy, have given up going to Norway, and await return of letter from Oxford, remittance of pounds and pennies, for else I cannot come.

In 1884 Powell was labouring hard. He was finishing his portion of the English history for Rivingtons, he was trying to organize the sequel, which was in the hands of two other friends, and he wrote to one of them of his hopes of having

the ultimate terminus in view, and we shall be the great twin brethren of a generation of schoolboys who will no 
doubt curse our names, as representatives of the brighter sciences, as they curse Euclid and the authors of the Catechisms.

Another book, besides Origines, also oecupied him. It is a pity that he never finished and brought out his little volume on Scandinavian Britain, of which a single proofsheet survives: for no one was better fitted to write it. It dragged on for some four years, and for reasons unknown was dropped. The fragment that remains has some happy examples of his younger historical style, and he is on ground even better known and loved than that of early England. One passage may be given, as it comes really from his own experience, and shows his eager seafaring spirit and his instinct of realizing the past through the present.

Any one who knows one of our larger fishing ports will have a better idea of the organization, composition, and character of a wicking fleet than aught else could give him. The preparation of gear, clothes, stores; the overhauling of the craft, hull, sails, rigging; the making up of the crews, the final sailing with a fair breeze, the whole place emptied of its young and middle-aged men for the two or three months that the cruise lasts; the homecoming, the rejoicing, the burst of trade, the influx of riches, won from the sea, the steady flourishing of the whole countryside as long as the cruises are gainful; the building of new vessels, the eagerness of the young for the life of adventure, mehecked by the terrible disasters that ever and anon mar the good fortune of the fleet, disasters that may sweep away nearly all the men folk of the place and check its growth for a dozen years-such phenomena are common to our fishing-life now-a-days, and to the old Northman's buccancering life so long ago. And when crossing the North Sea one steams through the Grimsby or Lowestoft fleet, hundreds of big boats out for the herring, one can form even a visible image of what a wicking fleet must lave looked like as the ships in great groups sped out with a fair north-easter, eager for the work before them, or hurried homewards with a sou'-wester behind them, deeply laden with English and lrish gold and silver, and raiment and jewels, and slaves and wine and weapons 
And how strong was his feeling for the fates and the service of our sailors, may be seen from a review, written much later, of a book on the English Navy :

The needless suffering of British sailors is something frightful to look back upon; they gave us security, honour, prosperity, and in return all they got from England, as a rule, was bad food, bad pay, and bad treatment. This state of things went on in the eighteenth century, as well as in the serenteenth and sixteenth. It was not the fault of the mass of their fellow countrymen, save in so far as they knew the facts; it was the fanlt of bad organization, of insufficient control, of the shameful and cruel carelessness of high officials, and of the helplessness of the sailor himself, who found it difficult to combine with his mates, and was glad if he escaped from a cruise with his bare life, and satisfied with a few pence in his pocket. The reckless, thonghtless, generons daring that made him such a fine fighting man made him live for the day and take much ill-treatment as all in the day's work. He grumbled at the bad beer, he cursed the greedy pursers that cheated him of food, but he was ready to fight as long as he was strong enough to stand, and he was able to navigate his pitching, unweatherly, topheavy old tubs with extraordinary skill and success past unlit coasts into unbuoyed ports and out again over uncharted waters in evil weather.

In the letters of these years there is a good deal about old English poetry, which he naturally studied for his history book and for the light it cast on the Northern verse. A correspondence with Lieut.-Col. Lumsden, whose translation of Biomulf Powell had praised in The Academy, shows his minute conversance with the secular Anglo-Saxon verse. After some elaborate notes on the poem of Wallhere, he proceeds:

... I hope you will give us Déor (or the Siingers Tröst) and the little gromp of melancholy laments-Ruin, Lady's Lament, Wamderer, Serifarer, \&c. They are all half-epic in character. Dror is the best for your purposes, and most interesting from the epic point of view, but the others are very beantiful. I have often tried to fix them to epic persons, but ann not yet sure of my ground. I dare say you 
may be able to light upon some hint which may identify them with some of our known epics.

There is the Song of Maldon, too, a really fine poem (not mere bookwork like Bruncuburh, though that has its merits), and most Iliadic in tone and execution. It would go eapitally into your ringing verse.

Colonel Lumsden's translation of the Maldon-Song came out some jear's later in Macmillan's Magazine. Meantime Powell writes him notes on this and other poems: asks leave to use a piece of the translation for his 'little book for the Christian Knowledge Society'-the book that never came out: and in the middle of 1884 develops his view that the site of Brunanburh was near Carlisle. One more letter to the same friend, probably late in 1885 or early in $\mathbf{1 8 8 6}$, may be given here. There is no other sign of the 'book on the early and mediaeval literature of England', or of any definite plan for its production. The subject had always drawn Powell powerfully; but he was probably too sanguine, and was scheming to do more than strength or time left possible. Origines, for one thing, must have taken up all his spare force for several years. The letter is also touching in its note of warning on behalf of Shute, whom Powell was to lose in 1886: the first of his closer companions that preceded him.

I don't think I have very much new to tell you, save that I am going to write, I hope, a book (not a big one) on the Early and Mediaeval literature of England ; but it will take me a great deal of time, as I do not by any means feel sure of all $\mathrm{my}$ gromnl yet, and the whole subject is bristling with problems which must be at least attacked.

I shall have lots of questions to ask you on the Early period.

Do you know the Wrouderer? It strikes me as a translation at present, but whence I do not know. I shall have to read the late Latin poets again, for it may most likely be from one of them that certain turns of idea have come. How does it strike yon? Have you noticed any other pieces, not yet traced, which strike you as paraphrases or book-poetry? I have analysed the metre of parts of 
Beovulf, but without much result as yet, for the text has, I think, been modernized by the scribe or his authority, and that disguises the evidence. The autotype was at least as archaic as Orosius or Gregory, it seems to me. Judith is archaic in parts, and a very rich and curious vocabulary it yields. e.g. frum-garces=exactly Latin primi-pili-the foremost rank of spear-men, or rather assegai-men-a touch of evidence as to early Teutonic warfare. Did you ever think of working Judith into English?

I am sorry Shute is not better. He ought really to go away for a year. He has overworked himself for the last eight or ten years. He has had much anxiety and worry of different kinds. He is one of those fellows who would rather die than give in once he has put his hand to the work, and also unfortunately one of those who will not see the need of making the best of one's health and so being able to work on longer if slower. He will surely use himself up if he does not give his body a rest. It would be better for him in the long run. His work could be done just as well at a more moderate pace, and he would after a rest be much more able to do it with pleasure.

I can't persuade him to take a term's leave. I wish you, Sir, could. He would perhaps listen to you. It is so wretched for his wife to see him straining himself so much, and all really without need and from an over-nice conscience. He deserves a holiday after his past work. He could take one, and he ought to; there is nothing but his own determination not to do so, which stands in the way.

He is a very dear old friend of mine, but I would not ask you to speak to him about his health, if I could hope that my words would be of any use. I am, dear Colonel Lumsden, yours very faithfully.

$\Lambda$ little rest, in the form of a change of hard work, was due before grappling to Origines. Amongst all German scholars, Vigfússon and Powell chiefly honoured the brothers Jakob and Wilhelm Grimm, who not only made an epoch in philology, but were scientific founders of folklore, and gathered it in their Märchen for readers of all ages. The centenaries of their births were now at hand; and on January 1, 1885, every teacher in Germany was 
bidden to tell his scholars something about the brothers Grimm. It was the moment for the colleagues to issue through the Oxford Press an aftermath of papers and dissertations on Germanic matters: and towards the end of the year came out the thin volume entitled: Grimm Centenary: Sigfred-Arminius and other Papers. Some of those written by Vigfísson were in the nature of appendices to the Corpus: one, the title essay, broached a view identifying 'the Arminins of history with the Sigfred of tradition' and of poetry. In the 'Prologue in Berlin', Vigfússon describes, with vivacious sharpness of memory, the interview of twenty minutes he had had with Jakob Grimm twenty-five years before. Powell contributed three chapters: one is an ordered collection, of the kind he liked, of the "Traces of Old Law in the Eddic Lays'; a second is a verse translation of the Danish 'Ballad of Sir Ogie' : the third is an 'Epilogue in Oxford'.' It is a pity Powell never wrote at length on the folk-ballads of Britain, whose accent he caught so well and without falling into the usual adulterate diction. His note ${ }^{2}$ on ballad in the Corpus makes us wish this the more. 'Sir Ogie' is, I think, his only attempt in Scots. The 'Epilogue' shows how he kept the heart of a boy, and it could only have been written by a happy man.

It was late in 1884 that I first knew Powell personally. The place was the library committee-room of the Oxford Union, the business the ordering of new books. The persons were young graduates, not quite knowing how to buy. A man entered, carrying an old high hat, wearing a serge suit ; sat down, jerked out a quick nod of greeting, saying nothing for a time. Suddenly, after throwing many quick shining glances rom through his glasses, the newcomer laughed at something : a laugh loud and far-spreading, but mellow and happy. I think it was to brush away some proposal for a book that was unsuitable: we soon

1 See vol. ii. pp. 395-100, and pp. 311-4.

- Corp. P'oet. Bor., vol. i. 1p. 503-7. 
learnt to know this form of argument, though good reasons were forthcoming upon pressure. Powell seemed abreast of all the knowledge that on such an occasion was wanted. He threw forth yes or no with a word or two of praise or distaste, and his advice was taken. He was a born chooser and buyer of books, leaning sometimes to indulgence and finding pleas of a curious but real kind for works and authors at the first sight surprising. This meeting began a friendship, and henceforward much in the present record of Powell is at first-hand.

In 1885 Powell did patriot service to scholarship. He took a weighty, though not a publie, share in founding the Euglish Historical Review. This enterprise many had for years cherished as a dream : the Letters of J. R. Green between 1867 and 1876 show the efforts of that eager spirit in its behalf; but it had suffered the checks that befall in dreams. There was in England no critical organ for historical research, no burean into which the best books appearing at home and abroad would naturally flow, no periodieal where the labours of many students might converge, and where new historians could give their measure. Mrs. Creighton's Life of her husband, the first editor, well portrays the early years of the Revier and the devoted skill with which Creighton launched it. ${ }^{1}$ Before this stage Powell took a determining part. We have a glimpse of him persuading, and negotiating, and helping to shape and word. The plan had lapsed but had never been disearded. Mr. R. L. Poole, the present editor, and assistant editor from the beginning, to whom the present information is due, writes:

It was, I am sure, through Powell that the existing English Historical Review, was in fact established.

For early in the year 1885 Oxford began to move. After consultation amongst those concerned, Powell approached Mr. Bryce in the hope that his public duties

${ }^{1}$ Lije and Letters of Mandell Creighton, 1904, vol. i. pp. 333-44. 
might leave him free to accept the editorship. This proved impossible, and after more conference Powell drew up a letter to Creighton, who had become Professor of Ecclesiastical History at Cambridge, urging him to undertake the post. On Mayday Creighton came to Oxford to preach, and the final scheme of the Review was drawn in Powell's rooms. Two months later Mr. Bryce gave an inaugural dinner to consider various points of policy connected with the publication. Among those present were Lord Acton (whose admirable part in the work appears plainly from Creighton's correspondence), Dean Church, Robertson Smith, Dr. A. W. Ward, and Powell. The first number came out in the following January. Creighton remained editor for five years and a half. The words of Mr. Poole will show what Powell did for the Review, apart from his many notices and articles in its pages, which multiplied as time went on. ${ }^{1}$

All that time and later also Powell continued within the inner circle of advisers to the Review. He was frequently asked to give an opinion about contributions offered, and was consulted at various junctures. I used often to go round to his rooms with questions and difficulties, and he could always be counted upon to spare no trouble in helping me. If these appeals became less frequent as time went on, it was because the difficulties which confronted us in starting the Review gradually diminished as our experience was enlarged, and as our body of regular contributors was more firmly established. But no account of the foundation and early nurture of the Review ean be at all true or complete which fails to recognize the immense debt which it owes to Powell's self-sacrificing energy.

The summer of 1885 he spent at Sandgate, bathing and boating and in the company he liked best:

To G. Vigfússon.

Sandgate, Kent.

I have a good bathe every day, and whenever it is likely we have a boat. Yesterday I was out rowing for

${ }^{1}$ For these see Catalogue of Writings. 
three hours with my old fisherman-friend Henry Stone, who is, I am happy to say, still alive, and hale and hearty for his age-over seventy a good deal. I see a great deal of him and his blind brother Richard Stone, whom I have known all my life, and it is very good to talk to such men. Henry is a very fine fellow, full of knowledge of the sea : he has sailed all orer the British seas, been a pilot at Deal, and on a yacht at Isle of Wight, and fished from here ... I don't know that I have anything more now to tell you. It is so jolly here that I have nothing to write about.

He was also glad that the History of England from the Earliest Times to the Death of Henry VII was now cleared and published. For eight years, through all the work with Vigfísson, it had been, interruptedly, preparing. The joumey over the original anthorities had been long and exhaustive, as the letters show. The book had been dropped and resumed, and was at last pushed through. It was to be Powell's only substantial piece of purely historical writing. It was part of a series of three volumes (the other two were not from his hand), originally described as for 'the use of middle forms of schools', and covering together all English history. Powell's volume, reaching to the end of the Middle Ages, filled less than 400 pages, close-printed. The regular historians may be left to judge its particular conclusions and opinions; the following are but the sensations of an unprofessional reader.

In judging the facts and realizing the currents of history Powell's temper was scientific, though he had not yet stated (perhaps not even to himself) his rigid theory that ethical judgements are beyond the historian's province. His knowledge was great, and he did his utmost to draw the materials for erery sentence from the first and best originals. But in presenting history his craft was more that of the painter than of the narrator. This was strange, for he told a story well in talk, and had been busy translating, from the Norse, some of the best of all mediaeval stories. 
But his own story of English history is less artistic than what he says during its arrests and interludes: it moves slowly in comparison, though lit up with many traits and anecdotes. He was, like all writers for such a purpose, cruelly hampered in scale, and he may have omitted too little. It may be for this reason that the book somewhat baffles the usual boy or girl, unless there is a good teacher to help in the presentment. What remains on the mind, and distinguishes the history from others of the same scope and purpose, is not the narrative so much as the portraits of character, his summaries and retrospects of the wholetempered as these had to be for young readers-the huge gusto in describing modes of life, diet, and custom, and the brief excursions into the history of language and letters. In his pictures of kings and personages Powell's model was in part the saga, as appears when he speaks of Henry $\mathrm{I}$ :

Henry had a comely face, dark curly hair, a high brow, and large eyes; he was not tall but strongly built. His voice, like his father's, wonderfully deep and strong. A good man of business, wise in planning, and cautious and patient in carrying out his designs, fond of learning (whence his nickname Beauclere) and with a taste for art, but selfish, hard-hearted, and grasping; Henry's greatest title to our praise lies in the stern strength of his rule.

One attraction of this little book is the skilled use made of poetry to illuminate history. In the chapters on England in the fourteenth and in the fifteenth centuries, little-known ballads and alliterative romances, Latin and English verse medleys, Chaucer and Langland, lighten the page; the words are given with as little translation as may be. Much lore is housed; and Powell evidently revels in the paragraphs on architecture, dress, and weapons-his boyish hobby. All this gives charm and life to the enforced compression of his survey, and raises it far above the crowd of bread-winning and often 
mind-destroying manuals that flood the class-rooms. No doubt it is, like much else he wrote, an earnest of gifts and learning that never found fully coherent expression. In other ways it throws light on himself. There reigns throughout it his curious attitude to moral judgements. He does not mince matters, or spare epithets, but he inclines to find counterpoising virtues, to see value in the net historic effects of a character that has many admitted blemishes, and in general to trace a total drift towards progress and goodness in phenomena that at first might seem merely evil. This was Powell all over, and as he lived on one could trace the donble process, by which his condemnations and dislikes grew sharper, while his faith in the general result of things grew brighter. Thus in his last page we read:

The awful black Death, which had seemed so relentless and crimel in its attacks, turned out in the end to have been one of the chief means of changing the old order of land owning and tilling for an easier system, and of making men in their own interests do tardy but needful justice to their fellows.

The process had been fully explained in an earlier chapter: and the end of the whole matter Powell finds in the words of Whitman, 'the only man,' as he said once, 'whom I would cross the water to see.'

The whole story witnesses to slow but steady upward progress. We have been trying to trace the birth and infancy of a great people. We have been, as the poet says-

Noting the efforts of heroes-

Is the deferment long? Bitter the slander, poverty, death?

Lies the seed unrecked for centuries in the ground? lo, to God's due occasion

Uprising in the night, it sprouts, blooms, And fills the earth with use and beanty. 
The conclusion, then, must be that of the poet:

Roaming in thought over the universe, I saw the little that is good steadily hastening towards immortality,

And the vast all that is called Evil I saw hastening to merge itself and become lost and dead.

This was the creed of Powell at thirty-five, 'in the mid pathway of our life,' and so it remained always, in spite of some personal inducements, such as the death of friends and illness, to think the contrary.

Hopefulness of this order, moreorer, led him to inspire many good works, and enhanced what will be seen more and more, as his life passes, to be his peculiar skill,almost his profession-of discovering aptitude in others. The following is but the first of many letters written to younger friends in search of their own line of talent. The advice, as will be seen, was adopted to good effect.

\section{To Miss Ida Furnell.}

Bedford Park [1886].

There is one thing I wanted to talk to you about, but had not time at Oxford, so I will put it here in ease I forget it altogether. That is: It would be well for you to make yourself a real authority on some special branch of your subjects (probably foreign language or literature would be the best), and to work thoroughly at that, besides your broader and more general work: perhaps ultimately to write upon it. There is nothing like a hobby to keep one's interest alive. It doesn't matter what it is. (Arabic would do very well, for instance.) But a special study of a man or a period is very helpful. It makes one see the real things of value in other periods. Suppose you took up Provençal poetry. It would amuse you to learn the tongue. You could some time go to Arles or Toulouse and hear it spoken and learn it orally as well. There are plenty of Provençal troubadours to study. The Lives of the troubadours have never been translated into English. Then you would, apart from the mental gain, become more valuable. You would be an authority (you also could sell what part of your knowledge you chose, in articles or books), and you would have an interest 
besides the everyday ones of your profession. You would use your gift of translation, in translating the poetry.

The field is large and needs workers.

Don't be discouraged by difficulties at first: one's early misfortunes and stumblings are often the helps to better things than are sought at first.

The next letter shows at the beginning how Powell was never bound to any party, and therefore deserted none : the end shows that he had already conceived the creed he set out long years afterwards in his Note on Omar :

To J. M. Mackay.

Christ Chureh, May 28, 1886.

You are playing the Tory game by losing patience, I think. How will that grand seigneur Hartington or Goschen, or such a demagogue as Chambcrlain, save any one? Gladstone is often wrong, has many faults, follies, and fantasies, but he is worth all the rest put together, and he means to rip the whole question up. I don't care about the bill as it stands, but I don't want wholesome reform to be stopped by a Whig Cave or a Tory Cabal. But all polities are damned rot. We want honest, clearheaded fellows who will speak the truth and stick to it. Trevelyan is a really good man and honest, and him I respect.

By the way I am very proud of a letter from Zola. I wrote him about one of his novels, and he wrote me such a jolly little note back. ${ }^{I}$ I feel sure he is a big man. Daudet is all gas and gush (sewer-gas and facculence), the other man is earnest and means business. ...

Fare thee well, thy letter was good. I am plunging heavily into paper-setting-and-reading for two months, and I hate it. I want a week's quiet and sun and rest, but these things are not for speech-dividing, flesh-devouring man. The gods indeed will give him peace and rest in time, but in such wise that we see not the blessed light of the sun any more, and the rest they give and their peace is of a kind that endureth, neither is it broken by dream, nor cut short in any way by awakening. So as for man he must do his work while he is yet in the midst of turmoil, with such pains as he may, and be content to

${ }^{1}$ Containing thanks for the 'yoignée do main' Powell had sent hinı over the sea. 
have at least seen the sum and smelt the grass and loved fair women and good wine and the face of friends. Yours ever faithfully.

N.B. If he is not content it does not alter matters at all. Hence the philosophy of these sentiments.

In this and the following year he is full of sallies against Oxford. To the end he would thus speak in certain moods, and to those who knew him well it was clear what he meant, and what he missed in the place. His words are without prejudice to the Oxford friends and comrades whom he liked, and without any kind of personal discontent at his own somewhat overcharged life. But collective Oxford, the hesitations of the place, its sensitive pretensions, its indefinably oppressive atmosphere, physical and conversational, were felt by Powell as by many others. For one thing, as may appear later, he never belicved much in the Oxford system of teaching, and he himself had for a long time not the best undergraduates to teach. But this apart, he testified to his feeling by his weekly or fortnightly flight to the home and surroundings where he felt really himself. But he never left Oxford for good or, traceably, desired to do so. The ancient city has about it much of the 'Ewig-weibliche'; it recurrently both 'draws us on' and repulses. We do not allow strangers to speak of these things, for they camot understand them. Later we shall hear Powell's balanced judgement on the place. Meantime he says that Vigfússon 'is one of the righteous men who save our respectable alma mater from the punishment that follows lost opportunities'. He also writes :-

\section{To Oliver Elton.}

Sandgate, Aug. 15, 1886.

Try and get hold of .Johnstone: I want to see him. He is a great loss to Oxford. . . The place is full of howling jackals and crocodiles, a sort of Nile valley with evil spirits walking up and down it, and I shall now be alone, a kind of hermit of the 'Thebaid, tempted of the Devil of Respectability. 
There are two dear old men here I have known since I was two years old: one eighty-three, the other seventyfour ; the latter blind and a fiddler, the other a fisherman. They tell me tales of the old world, before the flood of railway, steam, electrics, nerves, \&c. : such wise old views of life, such patience and content and cheery constancy; a perfeet pattern of chivalry the elder, who has made all kinds of sacrifices for his brothers. I get a smoke with them every night, and when it is finished we go fishing, the elder and I. Baby is fine, cuts about on the beach, and sleeps and eats like a top and puppy combined.

That year went peacefully on, filled with routine, with work at Origines, with examining, and with the summer visit to the Sandgate sea. The letter's of this period often speak of two cherished friends of Powell, who are now no longer living. The Johnstone named already was Arthur Johnstone, who had just left Keble College, and was all but unknown to official Oxford. His friends, amougst whom Powell at once ranged himself, thought of him as one of the finer and stronger spirits Oxford had produced or permitted in the early cighties. After a strange Odyssey, Johnstone, a passionate soul with the artist's senses and appreciations, developed a genius for musical criticism, and this he afterwards exercised in Manchester for eight years. He was to die young, at forty-three, in the same year as Powell himself. A few of the letters to be quoted from Powell to Johnstone hereafter will throw light on both men. ${ }^{1}$

There are glimpses, too, of the circle that had gathered about Powell at Bedford Park: references to Dr. Todhunter, the poet and dramatist, and especially to James Sime, best known to German scholars as the biographer of Lessing. Sime gave no measure of himself in print, though his Lessing is the best book in English on its subject, and his little sketch of Goethe has more wisdom and tact

- For more on Jolnstone and his friendship with Powell I may havo leave to refer to a posthumous selection from his writings: Musical Criticisms, by Arthur Johnstone. Edited, with a Memoir, by Henry Reece and Oliver Elton. Manchester, 1905. 
than many big books, English and German, on Goethe. He was soundly and rarely equipped, with a Scotch philosophical strain in his composition. He was free from push or self-seeking, and worked much at moderately paid unsigned journalism. Further, he read for publishers. 'His character,' said Powell truly, 'was greater than anything he did.' He was very modest and natural: one does not often in a lifetime meet men of finer unalloyed cliay. He was fair-haired and slender, with something abstracted and delicate in his look, 'elvish,' as Chaucer says of himself, and he walked very lightitly. He gave good practical Scotch counsel without any touch of cynicism. His mind dwelt by choice on poetry and the larger forces of intellectual history. He was a chosen companion of Powell's, in whose richness of nature and continual unexpectedness of view he delighted. He felt, as every one who reflected felt, that Powell was harder to understand the more he was known, and he never professed to find the key; though this made no difference to his faith in Powell. When he died Powell was stricken, as will be toll, and wrote his only extant elegy in verse upon a friend. ${ }^{1}$ The letter that follows, written to another friend, who has furnished much of the best of Powell's correspondenee, gives a picture of rigorous work and also of the restlessness that we have seen Oxford provoking in him. The book on the Eddic songs was not proceeded with, and no trace of it remains.

To W. P. Ker.

Bedford I'ark, Sept. 22, 1887.

We have got one vol. done and are pegging away at another, the last of the Origines Islandi[c]ac-Landnamabok, Libellus, and the Bishops' Lives all done-re-edited text and first English translation of all three. The next volume is all the early sagas. It is very jolly doing it, but hard work to get it really as one wants, pitly and exact without mock archaism.

I have a book, too, well begun ${ }^{2}$, to be an edition in

1 Vol. ii. pp. 386-7. $\quad{ }^{2}$ No further trace is found of this book. 
English of the Eddic songs, like Cheyne's little book of the Psalms. It is that, I hope, will get about, and give people who won't read the Corpus a taste of the best remains of the North. ... .

How are you? I wish you were in Oxford, but you would not be as good a man probably. If I were not tied like - I would go over to Ireland and help Dillon and Davitt all I could. But this is, you see, an occasional and abortive spasm of virtue. Have you read Dr. Philips, and G. Moore's Mummer's Wife? 'They are both worth reading and have power in them. Of course they are not pleasant, but why should they be?

The two great sources of the happiness, which Powell had so far enjoyed, were his home and his work with Vigfússon. Since the death of his father in 1877 he had suffered little serious bereavement or loss. He was in the full tide of methodic labour at the studies nearest his heart; he had had eleven years of this labour, and thirteen of married life. Before he was forty he was to lose both his wife and his 'master'. Mrs. Powell-'the best person I ever knew' he wrote in 1901, 'in disposition and gentle consideration for every one'-died somewhat suddenly in the New Year of 18s8, leaving him with his little daughter and two step-daughters, one of whom consumption had doomed. He wrote to his friend Professor Mackay :

Christ Church, Feb. 16, 1888.

You will have seen in the papers the death of my dear wife. I should like to see you. You ought to have come and seen us when you were in town. My wife liked you. If you will let me know when you can come I will give you a bed at Ch. Ch. I think it would do me good to have a talk with you abont things. (I have settled all the history from 1703. Tout will do it.) I am stumned with the shock and only realize it when I am alone for a little. I have had to do so much that happily I have been little alone this week. You can fancy what it all means.

His code, his instinct, and the practice that he commended in others who were in like case, was to make little sign 
and to go on with life and daily work, and this he did. The shadow cast was permanent. His friends feared he was eating his heart out. But his vitality was great, and he went on. Twelve months later he had to face the passing of Vigfússon. There is little record of this time of pieties, eventful with sorrow. In March he was working at the memoir ${ }^{1}$ of Richard Shute, who had died in 1886. He did not seclude himself, it was not his way. We have a note upon one of his rare visits to the theatre:

To G. Vigfússon.

Bedford Park [no date, but 1888].

Hogg and I went one erening to Sarah Bernhardt (that is the only intellectual anusement I have had), and she is a genius, no mistake about it: a voice like an angel, and exquisite skill in the whole performance. Shakespeare must have had such a person in his mind when he drew Cleopatra. It is a wonderful piece of art, and I am glad I have seen her; one sees the possibilities of drama. How Goethe would have enjoyed getting such a woman at Weimar for his theatre!

Vigfísson and Powell had got far with the Origines, and had seen most of it into proof. The old scholar had lived a spare, regular, healthy life, immersed in his toil. But he was marked down by a disease, painless yet implacable-cancer of the liver. He was well eared for in Oxford, and his friends rallied to him. He lay some time in a nursing home. He did not suppose that he was dying, but Powell knew it, and his last letter to Vigfússon, in form a Christmas greeting, ean be given fully, and there is no adding to it.

I'riory Gardens, Bedford Park, London, W., Dec. 12, 1888.

Desr Doctor, - I shall be up in Oxford on Wednesday or Thursday to see you. I am sorry to hear you are not much better. I have been thinking of you all the day when I have not been playing with my little girl. She sends her love to you.

I shall be glad to see you again. I lave known you

${ }^{1}$ Reprinted in vol. ii. $1 \mathrm{p}$. 350-61. 
longer than any friend I have save Henry Stone, and you have done more for me than any one except my wife and my mother.

I can tell you this now, writing at Xmas time, for one does not talk of these feelings.

I am anxious about you, and I hope that I shall have a better report when I come.

\section{I am with best wishes, \\ Yours very faithfully,}

Fredk. York Powell.

Please thank Nurse for writing me.

Between Vigfússon's death (Jan. 31) and funeral he wrote :

To W. P. Ker.

Christ Church, Feb. 2, 1889.

It is all over, the wise good kindly man is dead, painlessly sleeping. His disease was mortal, cancer ; hence it is better that it has come a little quicker than was looked for. It is weary work, even when as with him there is no pain, on a deathbed, so I am glad it is over, since it was to be.

I will give you, when I see you, one of his books as a token and memory.

He will be buried to-morrow, and I shall be more lonely than I have yet been in Oxford, though every one is very kind, and I find that he was more loved and respected than I had known.

I will give you a photograph of his picture, which Paget did for me: a fine oil sketch, as he sat working with me two aftemoons in Bedford Park, he speaking, I writing, and Paget painting swiftly and hard all the while with the painter's inspiration on lim, and Paget's wife working children's clothes and talking now and then, and the children rumning in and out of the room; one of the brightest days since my dear wife went from me.

There was a good young Welshwoman nursed him at the Acland home, and he liked her, and she understood his ways, and I don't think lie felt at all lonely. I was with him as much as I conld be every day.

I think it is all right, but it is hard at the time. But I have been far happier than most men, and it is fair that 



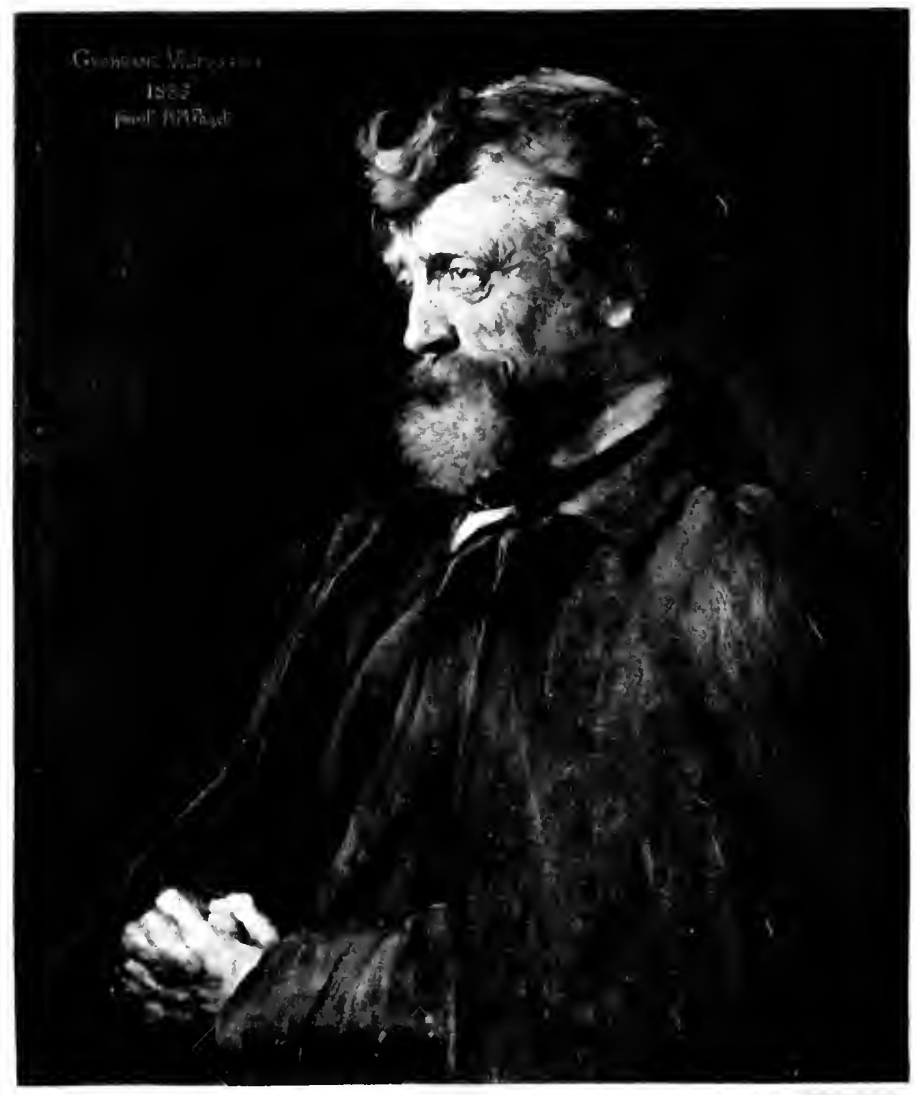

quotrandisfusin 
I should have my sorrows too. He said one day, 'Life would be a very poor thin thing without sorrow,' and it is true. I am happy to have had such a friend at all. I wish you were here. I should like to talk to you over it, but it is perhaps better I should have to work, with less time for talking and thinking. I an yours faithfully.

Here fittingly may come the rest of the manuscript fragment already cited. It is not included in any of the three memorial notices published by Powell on his friend ${ }^{1}$.

He never talked about things he had not a real interest in, but would keep silence till the eonversation changed to some subjeet he knew, when he would join in in a vigorous way. He would laugh heartily and frankly as a child at a happy jest or quip ; and he was distinctly a cheery man, never allowing himself to be east down by anything that did not turn out as he wished. He would not talk at all of persons he did not like or trust, but if pressed would say why he did not care to speak of them and pass on to other topics. He was scrupulously fair in argument and in judging men's acts, and made great allowances for weakness, but when a man held himself high he expected him to act up to his pretensions, and his hearty contempt for fraud of any kind was a main [trait] of his character.

He had a very wide range of literature at command. Among his favourite books was Goethe's Gedichte (which he preferred to Faust, and in which he specially commended the pure and sweet lyric quality). He knew his Shakespeare well and was especially attracted to Burns. He eared little for novels, save Scott and a few other exceptions, but read a good deal of poetry. The French drama interested him, and above all Moliere. He did not care much for any second-rate work, looking on it as mere waste of time to read it. I don't know any one who had a surer judgement as to the merits of an historian or critic or poet of high class. He liked Vinje's work, and thought very highly of Ibsen's later work, not caring for his saga-dramas. He hated that sickly sentimentality, which he saw was the curse of Germans and those Scandinavians who sought for leading in Germany. He

1 See Catalogue of Writings and rol. ii. pp. $341-50$.

I. P. A 
thought Seandinavian authors should look to France as far more fruitful in ideas, and more artistic, and less given to the faults which beset the Scandinavian author. He was very generous to young inen, and encouraged them, and bore with their follies very kindly; and he would be very gentle to men who were disappointed and ill at ease with the world if they were honest workers, but he would not put up with sham or pretence or lying or dishonesty of any kind. He was one of the most generous of men, and really liked giving better than receiving. I remember, when I came into his room, his joy at some good bit of work that had been sent him, and which he was eagerly reading in his quick exhaustive way. He was not lavish of praise, but when he gave it it was meant and was worth having. His letters were, like all else about him, very characteristic, full of idiom and with happy remarks, and brief vivid descriptions of men and things and places. I used to look forward to his letters. Natural things, people's lives and trades and ways interested him. I remember his delight with the Norfolk farmers at Yarmouth, and the Orkney boats, and the fishermen in the west of Scotland. He had no taste for society, complained of long English dinners, and the set feasts and ceremonials indoors never pleased him. When he went to Sweden, it was the break-up of the dinner, and the talk that followed, which he recalled with pleasure, and the meeting of old friends.

He liked walking, and was not easily tired; he knew all the walks round Oxford; and I have often been with him to such favourite walks as Forest Hill, Wytham, and over the hill past Iffley. The rising ground to the east of Oxford was his main resort when he was doing the Dictionary, but later on, when he came to the west of Oxford, he usually started by Port Meadow or on the Woodstock Road.

The death of Vigfússon was a turning-point in the life of Powell. It was a blow cunningly struck at his affections and pursuits by the powers that first give and then confiscate; and he always lived as much in his affections as in his brain. It changed the nature of his writings, and his habits as a writer, and after some years we almost feel that it has changed his calling in life. The partnerships of authors, when both are strong men, seldom 
prosper. The scholar is often solitary-minded, loth to concede, a hoarder of his own rewards and credit. But the curious felicity of Powell's league with Vigfísson needs no further showing. Their letters are without a clond. Powell knew he was bringing into due publicity, better relief, and truer order, the thoughts of the chief Scandinavian scholar of his time. And, as we have seen, he had done much more than that; both in his translation and his contribution he had spoken for himself. Vigfússon knew and richly acknowledged the service thus rendered to himself and to Norse learning. Together they had brought out Sturlunga, the Reader, the Corpus, and the Grimm volume. They had also carried far the great collection they called Origines Islandicac, which grew under their hands to include not only the documents of the immigration but many parts of the classic sagas. They had therefore achieved more than they might have dared to hope of the plan they had laid before the Clarendon Press in the beginning of 1884 .

Origines did not appear till 1905, a year after the death of Powell, although most of it was in proof in 1889. It is therefore still before the critics. It is published with lists of corrections, most of which Powell marle himself, and with his indexes completed by another hand. It has not his final revision. This delay has kept the use of Origines from other scholars who have meanwhile wronght independently over part of the ground : and translations of several parts of it into English, such as the Eyrlyyggice and Laxclecle sagas, which we now have in Powell's English, have appeared before his version, though it was made earlier than they. Landuama-bóli has also been edited fully in various texts. Histories of Icelandic literature, Dr. Finnur Jónson's in Demmark, and l'rof'essor Mogk's in Germany, have come ont, and in other ways Norse learning has advanced. The precise effect of all this on the originality of the book must be left to the specialists to estimate. It is, however, clear that in its 
main idea and achievement it has not been forestalled or antiquated, and it remains a gift to the historical scholar and saga-readers, lay or learned. One can see something of its range and accomplishment without pretending to judge or venturing to praise its erudition, and withont making improper claims for it.

The settlement of Iceland is told in a body of annals and pedigrees that are not, narrowly speaking, literature. There is a contest over their authorship, but Vigfússon and Powell assign most of them to the historian Ari. They form a systematic history, laid out, in the case of the Landnima-bók, on the simple and happy plan of coasting round the island and chronicling the immigrant families in geographical order. The first book of Origines is oceupied with these records. Here, as thronghout the volumes, is a mass of critical learning and theory, containing the conchusions founded on Vigfísson's lifelong study of MSS. Wherever new texts are thought to be wanted they are made, and the spelling is put back into that prevalent at the date which is assumed by the editors for the earliest text of all. Where no version, or no sufficient one, existed in English at the time, Powell made it. The second book is a gathering of all the matter dealing with the early law, custom, and constitution of Iceland-a complex and unique growth due to the surprising constructive talent of the colonists. A third book gives the anthorities for the change of faith, which ran its own course in Iceland, begetting its own compromises, its special poetry and legend. With Cristme Saga and the lives of the earlier bishops the ammals pass into literary form. The Bishops' Lives, indeed, are nearer to ordinary biography, which relates the life and fortunes of one person, than are the secular sagas, where the story is often that of a group of families, or the doings of a whole firth-side or valley. The fourth book returns to the pagan age. The earlier methodical documents of the foundation are not the only light that we have on that age. Later 
born, but dealing with the same world, and forming the human and dramatic commentary on the annals, pedigrees, codes, and rituals already recited, are the classic stories of unchristian Iceland. Origines includes 'especially such parts of them as appear to have a real historic basis, or are valuable as records of early custom '. ${ }^{1}$ There are the traditions of the heroes and their kindreds, for a long while orally transmitted, and at last edited with that union of positive detail and imaginative finish which makes the saga-form solitary in literature. The total web of these tales covers much of the settled country-side in the island. They vary far in colour, structure, and power, revealing a difference of local temper suggesting that which grew up between the hill-sundered states of ancient Greece. And, as in Greece, there is for long the same absence of anything like collective or national history. ${ }^{2}$ Taken together, they show how quickly the Icelander improved the native and original skill, which led him not only to institution-building, but to the creation of the 'prose epic', which is unlike anything found amongst his German or English cousins. Vigfússon and Powell pass clockwise, like Ari, round the island, starting from the south, and marshal for their purpose nearly a score of sagas, or self-contained portions of sagas. And these include some of the best things in the old language: but instead of trying here to sum up their contents, Powell's specific contribution may be touched upon.

The labour was shared much as before; that is, it is often indistinguishable. The textual part is substantially Vigfússon's, while the ordering, the English, and many of the literary criticisms, portraits, and parallels are also Powell's. A good example of his style is found in the

'See the excellent prefatory note (not by Vigfússon or l'owell) to Orig. Isl., vol. i.

2 See review by W. P. Ker on Orig. Isl. in English Historical Review, Oet., 1905. 
description, donbtless founded on labour and talk in common, of the hero of Holmverja Saga.

Had this saga been preserved in its original form, it would have been one of the most beautiful of all, weird, pathetic, and tragic to a high degree. The hero's character is firmly and clearly brought out-the child of parents of antipathetic temperanents, which mingle strangely in his own character, a man torn by interual storms, brooding with black melancholy at times, thongh at times full of sunny kindness and generosity. A Northern Saul, his fate erer dogging his heels, from the omen that accompanied his first steps (when the tottering child grips his mother's precious necklace to save himself, and the string snapping, the precious beads fall and are broken, calling forth his mother's curse in her hasty passion at the loss of her heirloom), to the misfortune of exile that his misplaced mercy brings upon him amid the presages that crowd about his end. ${ }^{1}$

Some examples were given in our last chapter from Powell's prose translations of Northern verse. Those who cannot turn to the Origines may also care to see the kind of English that he found for the prose of the sagas. There is one typical seene of vendetta, legal haggling, and barbaric irony. The old warrior Haward, in the saga that bears his name, had a son Anlaf, who was killed brutally by the insolent great man of his district, Thorbeorn. The saga ends with Haward's vengeance; but meanwhile he comes to the moot to claim eompensation in money for blood, and a just man, Leot, negotiates in due form. Thorbcorn, at the slaying of Anlaf, had wrapped part of his head in a kerchief and saved it earefully.

Haward answered [the messenger], 'I am not at all willing to go and have to bear Thorbeorn's foul wrong and shameful speeches.' .. . [The messenger' says,] 'Leot will stand by thy case.' He went then, but rather against his will. They came to Leot. He stood up to meet him and welcomed him, and sat him down by him.

1 Orig. Isl., vol. ii. p. 45. 
Then he said: "Now do thou, Haward, begin from the beginning and tell all that has passed between you and Thorbeorn.' And he did so ; and when he had made an end of speaking Leot asked Thorbeorn whether things had passed so. Thorbeorn said that it was certainly so. Leot said : 'Did any one ever hear of such foul wrong? There are now two choices before thee, Thorbeom, one that I break off all our bargain, the other that thou let me alone to deal with and decide the ease between you and Haward.' Thorbeorn agreed to this. Then they went out of the booth. Leot called a number of men about him, and they stood in a ring; and there stood in the ring knots of men that had come together talking orer the case. Then Leot said: 'I cannot sentence thee, Thorbeorn, to pay as much money as would befit thy deeds, for thon hast not so much, therefore I will sentence thee to pay three weregilds for Anlaf's death; and for the other shameful wrong which thou hast committed against Haward, I will offer thee, Haward, that every harvest-tide and spring, thou come to me and I will honour thee with gifts, and I promise thee this moreover, that I will never cast thee off as long as we both live.' Then Thorbeorn said : 'I will agree to this, and pay it at leisure at home in the hall.' Leot answered: 'Thou shalt pay all the money here at the Moot, and pay it well and promptly, and then I will pay one weregild of it.' And forthwith he paid out his weregild in good money. Then Haward sat down and poured it into the skirt of his eloak. Then Thorbeorn came forward and began to pay, doling it out bit by bit, till one weregild was paid, and then he said he had no more. But Leot then bade him not shirk the payment. Then Thorbeorn took a knotted kerchief out and unknotted it, and said: 'Surely when this is put in he will not think that he is underpaid.' Then he flung it into Haward's face so hard that the blood fell from him at once. "There are the teeth and jaws,' says Thorbeorn, 'of thy son Anlaf!' And when Haward saw them tumbling down on to the skirt of his mantle, he sprang up in a fury of wrath, so that every penny rolled off its own way; he had a staff in his hand, and he turned to the ring of men, and laid the staff so hard to one man's breast that he fell down on his back without more ado, and lay there long in a swoon. But Haward sprang through the ring of men withont stopping and came down far ontside, and then walked home to the 
booth like a young man. But when he came home to the booth he conld not speak to any one, and cast himself down and lay as if he were sick. ${ }^{1}$

The 'stalk of carle-hemp' in these personages pleased Powell deeply. He was unlike most of us; he had nothing to get over before loving them, he could put away by instinct and withont effort all those later moralities and amenities, which in their due plane he also appreciated. It was the first commandment in his historical decalogue that nothing can be understood without this kind of flexibility. Quite a different play of imagination pleased him equally well, as a last instance may show. Answering to those poems, cited already, which mirror the fading of the old faith into the new, are some of the prose legends, which present the same process at the moment of the uncompleted change, in a vision just as poetic. One of the best of these is the anecdote of Thidrande, the son of Hall. Thorhall, a diviner, has foreshadowed some evil threatening Thidrande, and has given strict warning one winter night that no man shall stir out of doors.

Thidrande was serving the guests, for he was meek and lowly now as always. And as men were going to bed, Thidrande gave his own bed up to a guest, and cast himself down on a bench outside next the crosswainscot. And when almost all men were asleep, there was a call at the door, but no man made as if he heard it; and this happened thrice. Then Thidrande sprang up and said, 'It is a great shame that every one should feign to be asleep ; surely these are guests come.' He took his sword in his hand and went out, but saw no man. Then it came into his mind that some of the guests must have ridden on first to the house, and then gone back to meet them that rode behind the rest. Then he went along under the wood-pile and heard the din of folks riding into the house-garth from the north. He saw that there were nine women all in black clothes and with drawn swords in their hands. He hearl also folks riding from the south

3 Orig. Isl., vol. ii. pr. $263-5$. 
into the garth. There were also nine women all in bright raiment and on white horses. Then Thidrande was minded to go back to the house and tell men of the sight, but now the black-clad women eame up first and set upon him, and he defended himself manfully.

But a long time later Thor-hall woke, and asked whether Thidrande was awake, and got no answer. Then he said that it must be too late. Then men went about the houses inside and then ont of doors, and it was moonlight night and frosty weather, and they found Thidrande lying wounded, and he was carried indoors. And when men gat word of him, he told them all that had appeared to him. He died the same morning at daylight, and was laid in an howe after the old way.

Afterwards there were held enquiries of the movements of men, but there were none known likely to be 'Thidrande's enemies. Hall asked Thor-hall what he thought would come of this wonderful portent that had happened. Thor-hall answered, 'I do not know, but I can guess this, that these women ean have been no others than the fetches of you and your kinsmen, and I think that there will come about a change of faith here, and that very shortly there will come a better faith hither to this land. And I believe that these fairies or spirits of yours, who follow the old faith, must have known of the ehange of faith beforehand, and therewithal that ye and your kindred would east them off: and it must be that they could not bear to get no tribute of you before, and therefore they have taken Thidrande as their own share; but the brighter spirits must have wished to help him, and not been able to come in time to do so. Albeit ye kinsmen that shall hold the unknown faith, which they forebode and follow, shall be blessed by them.' But Hall felt the death of his son Thidrande so much that he eould not rest any longer at the homestead at Temple, and then he moved his dwelling to Thwart-water. ${ }^{1}$

One of Powell's college friends says that 'his prose was full of cadence and beanty'; and so it is. For his versions from the antique he finds a delicate rhythm and dietion of his own, which are naturally different from those of his original writings, and moreover come to their best much earlier in

' Orig. Isl., vol. i. pp. 41\&-19. 
his life. That highly archaic and biblical element, which William Morris often mixed, with as lovely and umretarding an effect as Spenser, into his own English, Powell uses much more lightly and sparingly. The old words and phrases are but sprinkled amid the plainer tints and darker grain of the style, like touches of strange colour by the illuminator in the margin of a manuscript.

The biographer has to face the long delay of Origines, which Powell always meant to finish and bring out. No doubt he ought to have done so. Yet if so much of the gift is unimpaired by years, there is the less need to explain at length. He worked at the book from time to time, but unfortmuately procrastinated the last touches in the desire of making it as perfect as he could. He often speaks in his letters of his hope of giving them. He was sensitive in dealing with the work of Vigfússon, he was always dissatisfied with his own, and he missed the double harness in which he had pulled so long. His life became charged with duties, interests, and counter-attractions. He often had to do remunerative work in spare hours, even when he was professor, and his teaching both before and after that event called hearily on his leisure. He was certainly one of the men who require companionship if they are to finish those prolonged tasks of which they are intellectually capable. The delay of Origines mattered less than might have been feared. But it was only a sign of that change in Powell's mental career to which I have alluded ; and this change may be the more freely described, as I am convinced that it could not without injustice to him be treated as requiring apologies.

In his prime of force and fullness of knowledge, from his fortieth year till the end, he brought out only two books. One was his translation of the Frereyinga Saga, the saga of the Faroe Islanders, which he drafted as a boy. The other was a brief translation from Omar Khayyàm, with a preface. Besides, he wrote a few literary essays, endless reviews, some personal sketches of a memorial 
kind, and a number of short prefaces to the books of others. The best of these, it is hoped, are saved, together with a few verses, in the present volumes. He also wrote many letters, a selection from which is given here, and which some will think the best of all his writings. It does not dwarf him to print these gatherings and remainders; they improve our sense of his power. But it is clear that they are only fragments of a spacious curve, which they partially indicate, but which was never completed. There has been a tendency to talk about the pathos of his unrealized gifts; I cannot join in that chorus. The truth is that Powell realized himself in another way altogether, in his predestined way; and though many good books may thereby have been lost, I am not prepared to be sorry, considering what he did, and what after all he was.

There were lamentations that Powell never grappled with any of the long labours for which he was equipped. But this may be to ignore his business in life. We do not rate a man by that part only of his doings which bears his signature. The historian of literature and scholarship is not the Recording Angel. A man's life is the whole of his experiences, and is judged by the sum of his actions and by the impression that he leaves. His contributions to pure knowledge are soon absorbed, and generally forgotten. He survires-in the sense of learing his signature-whenerer he expresses himself perfectly. Now Powell had much of the man of science in him, and much of the artist. But he had little of the assertive, fame-loving instinct, and of the kind of will and concentration that goes with them. $\mathrm{He}$ liked to be unidentified. He had the passion for obscurity; as others have that for adrertisement. He printed his best things in penny papers without his name, often not even seeing what was printed, or in limited issues of private editions or rare magazines that soon perished. Or he did not print them at all; they have been dug up out of his papers. He had no desire to give the world his measure, no ambition to score credit. He did not despise credit, he 
was pleased and amused when his work was admired by any one whom he regarded. He had nothing at all of the esoteric attitude, which leads some to trust only a very few friends with a sight of what they have done: a perfectly good and proper attitude in certain natures; but it was not Powell's. He did not think ambition low; he watched it, and judged it fairly by its temper and fruits, but he had little of it himself. He did not believe he could utter his inner self on any scale beyond that of a brief essay or paper. Once he said as much; and indeed he put a piece of his soul into the little preface to his Omar. But one of his deeper instincts was certainly to distrust the life that is staked upon reading or writing books or winning glory for them. He thought he knew too much about books to suppose that they were worth all that. Hence he cared the less to produce, or to be known to have produced. As a tree buds and sheds its leaves, he flung off reviews, articles, addresses, and letters, sometimes for money, sometimes for self-relief, or to fight for a cause he harl at heart; and as for securing them, the utmost he often did was to paste some of them into a scrap-bookfortumately saved-with emendations for his own pleasure. Other men made books : Powell made himself.

He united in happy balance two kinds of nature that we usually see only in separate persons. We know the connoisseur in living, whom no theory keeps from his delighted contact with experience, from the enjoyment of fair things. He takes care, and lives long, and ends contented-contrary to the vulgar moralist's view, which lays up a Marah penance for him. For he lives in thought, in art, and even in friendship. He may be a good critic and what is called a good man. He does not much care to give pleasure to others, but he often does so, because he is happy. If his programme fails at all, it is because he does not easily forget himself, and a man who does not do that is frustrate. We know also, and half honour, half pity, the sheer self-sacrificer. The current ethic tells us to be 
ashamed of ourselves if we do not admire him without reserve; and it is remarkable how the better sort of man of the world-how 'everybody'-and not merely the moralist, acclaims him as on a higher plane than the ordinary. And this he really is ; but he loses many of the good things eaptured by the connoisseur; often his senses are untrained, and the face of the earth, his habitation and last resting-place, is comparatively blank to him. He feels he would be wasting his divinely given time if he allowed too much play upon his eyes and other senses. He may exist in the intellect and spirit, in admirable works of charity, in public labours, in eauses. We honour him for what he has sacrificed, but we doubt if he is in the right. He may not always give satisfaction to those nearest him, but much of the good work of the world goes down to his credit. Beside the waster, he is indeed a man : but he has missed much in his life. We need not live long before coming on each of these types in their extreme, and seeing that reality, not fiction, is here the great caricaturist.

Powell had in him something of both these men. Few who enjoy life so thoroughly can have given themselves to the service of others so inveterately. He was temperate ; he felt the force of Joubert's word, 'De quels ravissements nous privent nos intempérances!' But he was temperate by instinct and not from this calculation. He lived much in his eye, in colour and line; not so much in sound; much in talk, langhter, and wit. He was, to be sure, intemperate in one thing, namely in giving himself to his friends, and to unpaid labour of all sorts. But he was rewarded by this excess; he forgot hinself, he eseaped the curse and the ebb-tide mood of comoisseurship, just as he did the curse of overstrain and soul-searching and consequent dullness. His letters will show how thoroughly he lived, and the change I an trying to indicate is, that about this date he ceased in any systematic sense to produce, but chose rather to live. In this he was right; but the story would be one-sided and the ontline false if it were not 
explained how deep he went in self-oblivion. I am sketching a man with faults. They were chiefly due to fullness of life and mind; the worst of them, I believe, was a readiness to be distracted by shining side-paths and new quests before he had finished the thing he had in hand; but Powell's real profession, during his latter years, may be here noted. His mind teemed with desiderata, with a list of 'felt wants' : he had a continual vision of tasks, in art, in history, in letters, that were waiting for the performer. He made it his business to watch for that performer. He was ever scouting the frontiers of knowledge, pegging out new territory, and finding the best settlers. He thought it his business to know what a man was worth. His pleasure was to find out for a youth exactly what he could and ought to do, to make him appreciate the fact, to spare no encouragement, whilst avoiding flattery, and to find practical means to realize the scheme. He would see him, would talk, with a humming-bird rapidity of change, upon anything - the prize-ring, Dante, Japanese colour, the army-until he came to the point ; then he might let a word fall that made a perpetual difference to that young friend. One he would send to history, another to law, another to Italian or Provençal, another to marriage, with his jerkedout formula 'Why don't you...?' He was not like a priest or a diplomat; he laid no traps to lead up to the conclusion; but he reached it, and he made it seem part of the natural pleasure of existence to take his counsel. Some persons he would not look at or advise at all, and he turned away from them and did not care whither they went. But his strangest triumphs were with somewhat selfcentred, even stony characters, who bore away his suggestions and laboured at them. They might indeed not be very grateful. He was prepared for this, though he would express himself at the time firmly on the subject. If they came again he would help them again, just as he would repeatedly help, without sufficient prudence, those who begged him for money. But most of those whom he aided 
saw something of what he was, and held to him. The influence could no more be weighed than a beam of light, and can as little be described: you cannot describe light in printer's ink.

To speak more closely, Powell gave his best years-being weak in the will to express himself in long and concentrated works-to finding and fostering talent in persons near him, to helping them towards the right enterprise, and to looking after his friends in every possible manner. After thus much commentary the biographer can let the succecding years speak for themsclves through Powell's letters and actions. The letter's happily become more abundant. At the close some other traits may be noticed; for his character was complex, with a changeful and vehoment surface, and camnot be wrapped up in any formulae, even if its main lines come clearly out. He certainly came to live even more than before in his friends, and it was his lot to lose several of those he prized most; so that the cordage of his heart and nature was harshly tried, and the note of sorrow, in no common strain, is oftener heard, shadowing his buoyancy though not conquering his faith. 


\title{
CHAPTER IV
}

\author{
LIFE, 1889-1894
}

Teutonic Heathendom. Saxo Grammaticus; Powell's habits of work and punetuality. School of English at Oxford. Declines suggestion to move to Liverpool. Views on Scottish history. Dreams; the railway station; The Little Man. Canon Liddon. Manchester landscape. Ibsen's Rosmersholm. Zola's Thérèse Raquin. Blake's Book of Los. Lyra Heroica. Reviewing on Manchester Guardian and elsewhere ; value of Powell's reviews. The Rosicrucian dream. Letters : Rabelais Club ; bookbinding. Visit to Cornwall. Portuguese literature. Dante. Visit of Paul Verlaine deseribed; Powell on Verlaine. Visit of Stéphane Mallarmé. Bruno and the Pope. First visit to Ambleteuse. Notes on Powell's life and habits at Christ Church; and on his tuition in law and life.

VIGFússon had gone, but the spirit of their common labours was freshly active in Powell, and he was busy with more than one piece of work, besides Origines, that should serve as an aftermath to the Corpus and the Recuder. On April 21, 1889, he had given a lecture at South Place Institute on Teutonic Heathendom, as one of a series delivered by special scholars on various religions. This he put into shape and printed in the volume entitled Religious Systems of the World. He took some care over this brief summary of the Northern pagan cults. It is closely written, without much of the freedom and colour that glow in his later articles; but it is scientific and readable, and we have reprinted it. ${ }^{1}$ The translations of the two poems included differ, Thrym's Lay in particular, from those in the Corpus; they are not in prose, but echo the alliterative lilt of the originals-an experiment more often practised to good effect in German than in English ;

1 In its revised form : vol. ii. pl. 221-11. 
for instance, in Grein's old renderings from the AngloSaxon. We may wish Powell had oftener explored the powers of this measure, which is known, in its smoothed and modernized form, from William Morris's Love is Enough, and keeps more of its ancient martial elatter in Tennyson's Brunanburh. Our ears are not so well tumed to this primitive four-beat cadence as it deserves:

Wroth was Wing-thor when he wakened, And missed that mighty hammer of his. . .

The bench was set for the women that evening,

And ale borne round in the house of the Ettins [giants]:

An $0 x$ whole, eight salmon,

All the dainties cooked for the women.

But this, if we are ever to feel the old Germanic verse, is the right way to give it in English.

Powell now proceeded to inspire a translation, the aim of which was to present yet more of the early Northern material to English readers. It was all in character that he should perceive the need of the work being done: that he should seek a friend who in his opininion could do it; that he should find a learned body to father and pay for the book, and a publisher to issue it; that, refusing reward, he should write a long monograph by way of introduction ; and that he should have to be intereepted by his friend from describing the result as 'your book'. The old heroic tales, religious myths, and social phenomena of Scandinavia are not stored only in the Icelandic records. Many of them are set down in a Latin chronicle, which serves to check or supplement the native writings. This is the Historia Danica of Saxo, a Danish clerk of the latter half of the twelfth century, who is known as the 'man of letters', or Grammaticus. Nine books out of his sixteen are given to mythical and mostly prehistorie matter, which is threaded on a partly legendary list of the Northern kings. One story is that of Amlethus, prince of Denmark, who feigned madness in order to avenge his father's slaughter on his uncle. It was transmitted to 
Kyd and Shakespeare through Belleforest, the French translator-of-all-work in the mid-sixteenth century. But there are many other heathen tales which are saved by Saxo, or saved in a variant form; they are set down by him in a Latin that is rhetorical and inflated but often sharply picturesque. By this good Christian reporter they are duly rationalized, when they relate to the gods; but they honestly retain most of the original outline and colour, and with them are woven up inmmerable traits of early law, custom, ritual, morality, and faith. Saxo, therefore, following in the wake of the native classies, is an indispensable informant. His Latin is mediaeval, of the type that is modelled on the decadence: it is odd and full of traps, so that he is much less troublesome to read in a translation. But there was no translation except in Danish, and at the time none even in Danish since the eighteenth century. Powell had written, about 1886, to Colonel Lumsden :

Have you read Saxo? We sorely need an English epitome of that work, the earlier epic part I mean. The plain historical part we can leave to the Danes (Bishop Absalom and all that). It is really such a storehouse of .legends that it is a wonder it has not been englished already. A. Holder will bring out a cheap text this year. The common old edition is good but cumbrons, and the editio princeps a charming book but hard to get, a really beautiful bit of printing.

Powell caused the Folklore Society to put the translating of the mythical books into my hands. He wrote the bulk of the introduction, 'some considerations on Saxo's sources, historical method, and folklore,' extending to more than a hundred closely packed pages, and costing much labour. The book came out in 1894: his commentary was kept on the stocks during the interval, and is fastidiously done. He uses his favourite procedure, drawing up classified lists, under many headings, of Saxo's references. He ranges beside these the parallel 
matter from the rernacular, and from folklore and history at large. He reviews the conchusions of specialists like Rydberg and Olrik, and indicates his own. His range covers political and social institutions of all sorts; statute and custom-law; war and marriage, proverb and popular science, the pagan pantheon and under-world; the nature and worth of Saxo's anthorities. The result is a full statement of Saxo's contribution to Northern lore, and though parts of the subject have been further explored since by others, his work keeps its freshness and value. It was the kind of theme he came to like more and more. The study of folklore drew him increasingly; it was his pathway (with Dante and the prophets at the other end of the scale) to the comparative study of religions. He saw in it the key to the struggle for existence of the higher spiritual elements in early history. He stood outside all religious beliefs, but he thought them developments of folklore in this deeper sense of the term, and in this way he took religion most seriously. He also, it may be added, helped the translation at a hundred points to a greater correctness and to a better language and cadence. Powell's lapses in punctuality beeame, as I have said, a myth amongst some who knew him; a comic piece of folklore, with its che mixture of truth and lies and fancy. It may therefore not be impertinent to give some first-hand witness on the matter. In his overcharged life, the work had to wait some time; but this did not matter, the translation was a laborious aftair and took the leisure of a few years. At times the MS. was lost amongst his papers (he seldom (lestroyed a paper), and some time was spent in seeking it, but it always reappeared. On receipt of material-and this applies to anything I sent him in after years-he would usually send back a sheet of comments, praise, and corrections, by retur'n of post. Sometimes he would write a letter instead, showing how hard he was driven by his engagements; but commonly, on the heels of this, came the information after all. In his own work he liked, often 
craved, the stimulus of companionship, and some weeks that we at last spent together may have enabled him to get the business off his mind. While thus engaged he worked from morning till night for weeks. Allowing for a few idiosyncrasies-it was both heartless and impossible to hurry him-I have never worked with any one more business-like. Plans of his own, it is true, he might take up, and let fall into confusion or drop altogether ; and for a publisher he would never make haste until he must: but in helping others Powell was a methodical man.

The next letter shows him in a brighter mood than had visited him since the death of Vigfísson.

To W. P. Ker.

Christ Chureh, May 5, 1889.

I have read latcly Flaubert's Correspondence, vol. 2. It is fine reading; the struggle over Bovary from day to day very interesting; the pains, the diseouragement, the hope, the slow and conseientious progress, the honesty of conscience never content with any but the best work; it explains the marvellous art and almost absolute perfection of the book, and shows the cost of 'genius'. I am hoping to get to Paris for a few days, in two months hence, and to see Goncourt and Champfleury and Rodin. There is a good picture-show at the New Art Club (Dudley Gallery, Egyptian Hall); you would like it better than the Academy, I fancy, though the Academy is rather good. Freeman is back, thinner, wiser, and happier at having got through a huge lot of his Sicily.... It is 'fine and hot' (as the murderer entered in his diary some years back), and the place looks lovely-such masses of meadow-flowers: the birds in full chorus in the morning about my bedroom; and the poplar's rejoicing in gold bronze (at the approaching anniversary of the republic, I suppose, for ' 93 is within hail of ' 89 ).

I think if we don't carry the Mod. Lang. School soon, we shall form a Syndicate and grant certificates ourselves, some few of us here, and let the University go hang and be damned. I dare say it will be the right thing, and certainly lots better than whips and pamphlets and speeches and all the rest of it, which gradually sickens the sonl and tires onc of the whole thing. Here one is well paid to teach 
people who don't want to learn, and thereby enabled to teach people who do pretty cheaply. It is a funny but perhaps just arrangement, and life is full of such ironies.

The last sentences refer to one of the changes for which he wrought actively in Oxford. He took his share in pressing it, but it dragged on a long while, and the Honour School of English Language and Literature, of which the Modern Language School above named was an abortive draft, was not to be organized for practice till 1894. The question vexed Powell at intervals; and when the vote for the School was finally passed he wrote some lines that still keep their pertinence. I will give them instead of trying to trace Powell's share in the academic struggles and compromises, which are ever dreary reading to those unconcerned. In our Northern University, then a federation of three Colleges at Manchester, Liverpool, and Leeds, the same struggle was going on about the same time, against the same prejudice, and with a like result. Powell's language is longsighted: others were better fighters in the imperative but disgusting strife of committees, for which he was not built. But we shall presently find him clearly pointing out some of the things that are worth striving for in universities.

It is wonderful that this School was not set up long ago. But it may not be the worse for having been deferred, and Oxford will be able at least to try and make up for lost time. For after all, there is no inherent reason why the study of the tongue and works of great Englishmen should be left to Germans and Scandinavians and Dutch. There is much work to be done yet in the editing of English unpublished texts, and in determining the chronology and conditions of a good many famous English works. Criticism of the objective kind barely exists in England. It is not conceivable that our people will always rest content with the wretched melodramas now furnished them, or observe the absurd conventions that dominate dramatic structure and romance. That language and literature may be studied by a few, and the mass of the nation remain ugly and vulgar in their taste, Germany has abundantly proved; but one cannot help hoping that English 
culture, poor and weak as it often is, may yet permeate a little deeper. The newspaper is still 'open to talent', and Meredith is welcomed in a cheap serial. It is at least remarkable that the most elassic literature of modern nineteenth-century Europe, that of France, owes much of its perfection of form to the systematic study of the French language and literature in French Schools. Such a study is impossible without properly trained teachers. And our love of the formless, the elumsy, the vulgar, is not so patriotic (as it is in Germany) as actually to hinder an adrance. It is almost impossible to avoil anguring favourably from this well-considered forward step of a University that has always exercised a great influence on the English world of thought and on English fashion of expression. And English literature is one of England's greatest treasures, for it is true, that Irish proverb:

\section{'A word is more lasting than the riches of the world.'}

The advanced schools of English in the varions Universities of England, Scotland, Ireland, and Wales, if they have done something to raise the pitch of learning and teaching through the country, must do far more yet if they are at all to honour such expectations of their founders.

Later in this year (1889) Powell was privately urged by one of his friends at University College, Liverpool, to come forward for the chair of English Literature which had there fallen vacant. He was at many points well fitted for such a task. He had already taught the subject to the students of the Women's Association at Oxford. He lad a knowledge of many literatures, he had insight into both the Latin and Gemanic tempers. He had an ear, and a soul for forr, and a personal style, and in his judgements he was not afflicted by authority. His opinions and preferences were strangely assorted, he had indulgences and aversions all his own. 'There would have been more spur' to pupils in Powell's caprices than in the mechanical fairness of the humdrum teacher. But he declined to come forward, he would not make literary teaching his pro-

2 Journal of Erlucation, Jan. 1894. 
fession. He was first of all an historian, and he was rooted in Oxford.

His letters show plainly why he stayed. They also mark his lifelong conception of what a university should and may be. Its first work is to further knowledge and to train those who will do so. This ideal he shared with his corresponcient, then and now the professor of history at Liverpool. In other letters and in his Bangor address of 1902 it is again held up. Powell's tie with Liverpool was always stronger than with any other of the new foundations. He warmly approved its efforts, which in 1903 were successful, to turn a mere federal college into an independent chartered university of the historic type. Those who strove locally for this enfanchisement, he heartened with his own faith and confidence through years of stress and obstruction. Robert Alan Mowbray Stevenson, later one of his most cherished friends, was in Liverpool from 1890 to 1893 ; others remained there or settled there partly at his instance. Later we shall find him visiting Liverpool: his name is alive in its new university, and some of his books rest there. Already, in 1889 he indicates the kind of self-devotion that may be required of a 'provincial' professor, as well as his good reasons for remaining in Oxford nevertheless.

To J. M. Macliay. Bedford lark, Sejt. 25, 1889.

I think at present I am doing more good at Oxford, and have got more hold there, also at present I have heavy calls on me, and as I have never been able to save a sou, I need a better whack than $£ 500$. I can make abont $\mathfrak{E} 600$ now, not all at Oxford, true, but still through my Oxford connexion, etc. Next, I am backing _- and if you could transfer your interest to him it would be a good thing, unless you stand yourself.

To J. M. Mracliay.

Berlford Park, Sept. 29, $188 \%$.

If I felt I could do the work really to my own satisfaction, I would have stood: but I lo not, money or no. I think I can do more good in Oxford in small ways; 
I hope, at the Press, the Taylor, and with a few men in college, and anong the mattached and women who have to be teachers (otherwise I hate 'educated' women, silly bosh-writers and miserable poetasteresses, conceited, ugly). I put the money down to you as one argument, but I honestly don't think the money weighs much with me. I have all sorts of faults, I am almost as casual as you are, I hate the ideal of exam. passing, I don't care for stupid folks who ought to be clerks to manure-carts instead of wearing black clothes and sitting at desks scribbling out commercial damnation. I like people who can tolerate me, and I am ready to do my best for them, but I don't like the man with an ideal of getting on, and becoming a 'merchant prince'.... Well, then, I think a college like yours wants men who like precisely the work, who will throw themselves into it body and soul, and who are prepared at some risk and inconrenience to themselves to give up twenty years to the cause alone.

I agree with you, I wish to God my own country Wales had got its University and were quit of Stinkomalee ${ }^{1}$ and its Exam. Local life is the thing to encourage everywhere, real local life, not 'prosperity' and 'wealth' and 'brass'.

Now I am not fit for this Mission, but — is ... I am afraid you think I am making the gran rifiuto, but I don't like to fail and it euts me up, and I don't think I should be really successful in such a post, and therefore it would not be honest in me, apart from all other considerations, to take it. I have since you wrote thought carefully on the whole question, and while I take it extremely kind in you to have urged me to stand, and personally regard it as the greatest compliment you could have paid me, I do not think of doing so. I am yours faithfully ever.

What he says here of the learned life he often repeated in his talk. He always felt that in England learning has two chief enemies, who cut off her young and promising recruits. One is the double drudgery, first of teaching purely for examination, and then of proceeding to examine. The other enemy is vulgar, or shop, ambition. This interested him less than anything in the world, though not less than

1 The University of Lonc.on. 
it merits. It is, of course, the vice of the scholar-class as much as of other classes, and when a scholar, or one who might have been a scholar, takes to it, he often makes it a point of honour to outdo and even startle the children of this world by his dexterities. 'A don,' said William Morris once, "who thinks himself a man of business will sometimes do what no honest merchant would ever do.'

The next letter arose out of a discussion as to the right pattern of a new university in England.

\section{To J. M. Maclir!?.}

Bedford Park, Oct. 2, 1889.

There is agreement in our ideals of a University; but not German, in God's name and the devil's! Scottish with all their faults, or French or Spanish, but what man worth giving a hand to ever owed anything to a German University? Nothing you can say of poor old Oxford could induce me to think of a German ideal . . Exceptions of course, but they owe their gifts to good men and women, not to their stupirl, idiotic, Govermment-ridden institutions and méthode. France is better; they may be bad, but the spark never dies among them at any rate. My idea and your's is not a mere lecturing or examination body, but books plenty and on many subjects, and good men who know and ean use them to talk about them. No building (save for the stinksmen and anthropotomists) save library, readingroom, and a few big rooms for lectures of the right sort. Students who like the work, or else the place and the companionship. (The good young mom, how bare he is, how bad to butild fiom !) It onght to be a (profine) communion of those who know a little already and those who wish to know as much as they (students), with the others' help, can get.

Powell remained firm against friendly pressure: his decision was doubtless right. Besides the reasons that he offers, he did not care for the face of Iancashire. And the Thames at Kew and IfHey, the chalky coists, the larger share of smulight, the tenderer lines of the mpland, and the fuller flowering of the Southern valleys, were much to him; he lived more than most men, and much 
more than many professional artists, in what he saw. There were also the libraries in Bloomsbury and Oxford; he must be near them for his work.

Here may be quoted some lines written rather later to a candidate for' a Scottish chair. Powell had felt, ever since he sat for' his 'Schools', that 'Scottish history is yet to be written', and he went fully with his correspondent into a general plan for such a history.

I think you will in your new chair, if as I hope you get it, be able to do for the new generation what Skene did for the old. A history of Lowland Seottish literature wants writing, freed from that filthy cant that bedaubs so many books written north of Tweed and from that absurd Patriotismus which disgusts the impartial. You could do this and I hope you will. ... I hope you will give an inaugural lecture on Sir Hew Eglintom, whose place in British literature has never been adequately acknowlerlged.

I do not know whether you know Gaelie, but you will have tine and leisure to learn it, for if you are professor you can drop some of the examining work, and I trust you will. Your young years are too precious to be wasted in looking over papers. You must be learning while the zeal and love of learning is still warm in you. Don't waste your time examining: there are plenty of dull dogs who can do that well enough, and who having families are driven to it. You might, with a knowledge of Gaelic, solve many problems of British literature which are left, because few men know Gaelic and British literature properly, so as to be able to trace their reciprocal influences.

Yon must excuse me advising you. I won't do it again, but I do so loathe to see men who are capable of spiritual life led away by the irlea of getting on, getting rich, getting 'biggety' as Brer Rabbit lias it, and I know the temptations. But you have at present a capability for and pleasure in work, and I hope you will be able to resist them. And I'd sooner do many things than lift a finger for a professor who 1 thought would not love his subject for itself.

In the same year he had a turn at Spanish, which he had learnt as a boy. 
I have been reading some Spanish lately. If you have any opportunity at Baltimore, learn Spanish. There are some fine works in Spanish, new and old. Even their South American poets are not to be despised at all. They are far better than any of the North American poetasters (whom they call poets there). There is a woman poet, Mercedes Florez of Columbia, who writes really fine verse, judging from the specimen I have seen. There is a good Spanish grammar, by an American, I fancy of Johns Hopkins, and a good spanish idiom-book. Any dictionary will do.

One other letter remains from 1889, written to the poet and friend whom he had met in boyhood on his Spanish travels, and whose verse came peculiarly home to him. In his words there is a breath of sadness; they are those of a man whose earliest happiness is behind him, who has shut his first volume. A little later he exclaimed, with a briefer laugh than usual, 'To-day I am forty.'

\section{To Wilfirid Sccuren Blunt. Christ Chureh, Dec. 6, 188\%.}

I just want to write and thank you for the extreme pleasure your New Pilgrimage has given to me. I did not write to tell you of the sympathy which I and many others felt for your battle for Ireland, because that was duty, and you did not and would not care for thanks for that, though your self-sacrifice well deserved it.

But this book of verses has touched so many feelings in my memory, for I too was once in Areadia and knew its joys and woes, which live in reflections, thronging about me (nearly all that is left of the pleasant days that are gone for ever), that now I cannot but in a line just note my gratitude. I don't suppose you care about fame, but you have certainly written things that will not perish.

To W.P. Ker.

Christ Church, March 4, 1890.

I have not had any more very good dreams. But I dreant the other night that I hurried out of the British Museum to call on some people, and found that I had a B. M. book in my pocket. However, I concluded to go back later and deposit it at my seat surreptitionsly. In 
the meantime I was asked to take an invalid lady to the Railway Station. I of conrse consented. On leaving her in the waiting-room to go down to the platform to make inquiries for a train, I found on the platform a respectable young woman I knew eloping with an officer. I stopped her going by the train, and on the officer's expostulation and assault we eame to blows. I was arrested, and as I had only $2 s$. 2d. on me and this B. M. book, things looked black for me, when I woke. There's a dilemma, a hard case. What was to be done? One could not bribe the copper, one could not frighten or borrow from the invalid lady. I was not sorry to wake.

The young woman in the brown spotted fancy dress has not turned up yet. I am looking out for her with mixed feelings of respect and awe.

'He preached of Elijah going up in a cloud, Of Lazarus walking about in his shroud, Of Jonah living in the belly of the whale: But that's better living than the County Jail.'

Isn't that good? Do you know the ballad?

This is the best place for another dream, put on record some years carlier (perhaps 1885) by Dr. John Todhunter at Powell's dictation. ${ }^{1}$

\section{THE LIT'TLE MAN}

I was staying for the first time at the house of an old friend, whom I had not seen for some years. It was late in the evening, and we were sitting in the smoking-room taking a last pipe together before we went to bed. The room was panelled with dark wood, and the furniture was old. I felt sleepy as my friend talked, and gave short answers, when I became conscious of an unpleasant feeling of vague discomfort, for which I could give no reason. This grew upon me more and more, till my sleepiness fell off me, and I began to wish that my friend would propose our going to bed. A feeling of fear, which seemed in some mysterious way to proceed from the room, was in fact gradually mastering me.

${ }^{1}$ It was first printed, not in its original form, in 1904 in The Greensheaf: sce Catalogue of Writings. 
As I was trying to find some pretext for escaping, there was a knock at the door, and my firiend's butler came in with spirits and tumblers. He was an oldish man, who had been long in the family. We spoke to him, and my friend asked him to sit down and have a glass of spirits and water with us, which he did. After a little more talk we got up, intending to go to bed. The smoking-room was on the first floor, at one end of a long drawing-room, into which it opened by a door, a second door leading to a landing. We all went out on to this landing, where the candles were; but as I was turning to the great oak stairease, my friend suggested that we should go and say goodnight to his aunt. I agreed, and we went back into the smoking-room, and through the long drawing-room, which I could see by the moonlight, the blinds being up in three or four tall windows, though the moon itself was not visible. As we passed these windows I could see the gardens, and a misty meadow beyond, against which the small, black, clipped trees of the terrace showed hard and distinct. The furniture was of the beginning of the century - a harp, a large old-fashioned piano, chairs with flowered tapestry seats, and a light earpet with large flowers. There was a white marble mantelpiece, and the walls were painted in dark, reddish-brown distemper, which seemed a little faded. A few water-colours were hung at wide intervals upon the walls.

Passing through this room close under the windows, and through a door opposite to that by which we had entered, we came into a boudoir, just like the smokingroom, but furnished in the same old-fashioned style as the drawing-room, and lit by two large windows, in one of which the blinds were up. There were two candles burning on a little table, and a fire in the grate, in front of which sat a pleasant-looking old lady with grey hair, in a lace cap and purplish satin dress. A maid with a baby in her arms was sitting at the side of the room opposite the door by which we had come in. I was introduced to the old lady, sat down beside her, and we began talking, our faces to the fire, our backs to the candles.

I had totally forgotten my feeling of discomfort, and was interested in our conversation, when I noticed that the light in the room had become dim. The glow died out of the fire, leaving it dull ; and when I looked round the candle-flames had dwindled to the blue. I stood up, 
and saw my friend and the butler standing together at the door, holding it ajar, and craning their heads round it to look into the drawing-room, whence a bright light proceeded and fell flatly about their feet. I ran up to them. 'What is it?' but they motioned me back. 'You had better not look!' said my friend. 'Ol, nonsense!' said I, 'I want to see!' Pushing past them, I went into the drawing-room; and there, a few paces in front of me, I saw a spare old gentleman in a dress of the time of George Il, pale blue coat, pale yellow breeches, silk stockings, buckled shoes, and ruffled wrists. He stood in a pantaloon-like attitude, in his right hand a thin, polished, brown stick, which struck me as being of about the fineness of the thin end of a billiard cue. I conld see nothing of his face; bnt the end of his nose, which must have been long, was just visible beyond the profile of his chcek. He stood in the midst of an oval of light, such as I have since noticed thrown by a tricycle lamp on a dark roat.

He walked slowly along to the wall, his footsteps making no sound; and as he drew near the wall, I observed that wherever the oval of light fell, the decoration of the floor and wall changed to an earlier style. 'The wall within the light now appeared a pale green, with pancls of pale tinted landscape, bordered by rococo scroll-work. In the centre, at the bottom of a panel, was a nymph reclining by a stream amidst reeds. The old gentleman stood before this panel, raised his stick, and rapped the centre of the tuft of reeds with snch irritable violence that the stick snapped, and about eight inches of the end fell on the floor ; but all this without making the slightest noise. Immediately afterwards the light went out, and the decoration fell back into the flat red tint. But I had kept my eyes fixed on the exact spot upon which the old gentleman had rapped, and, rumning forward to the wall, I clapped my hand on the place, which now showerl like a grease spot, a little darker than the rest of the wall. 'There, there!' I said; 'If you break into the wall to-morrow you are sure to find something.'

But as I turned excitedly towards my friend, who I thought had followed me, I siw that he was still standing with the butler half behind the door. Between me and them I conld see nothing; only, on the floor between me and them, flitting silently about, were two small ovals of 
light. I knew that these marked the somnlless footsteps of the old gentleman, now become invisible.

A horror, such as $I$ had felt in the smoking-room, now suddenly came back upon me, but in far greater force. How I got back, past those footprints into the boudoir, I don't know. But I can remember standing by the fire near the old lady, who had risen to her feet, and looking round at the window, wondering whether it would be possible for us to escape through it; but I judged the height too great-at least twenty feet from the gromd.

IIy friend and the butler were still at the door; and again I saw the great flat light, now brighter than ever, at their feet. They were as terror-stricken as I was myself. 'What shall we do?' said one of them; and after' a minute of silence my friend and the old lady began reciting in earnest but shaken voices some versicles of the Litany.

For a moment I thought perhaps their prayers might avail us; but at the end of the second verse I was completely panic-stricken as I heard the words, 'Good Lord, deliver us!' slowly and distinetly repeated in a grating, mocking, old man's voice, from the other room; and, with this venomous echo still in my ears, I woke.

In acknowledging a book sent him by his old college friend, Powell wrote:

To Canon E. G. Punchard. Bedford Park, Mareh 22, 1890.

I am glad to have your book. I have read it with much interest and have sent it on to my mother. I think it is very good English, as you wish for my opinion. I don't agree with it all, as you may imagine, but I think you have put your case well. I don't think it matters who Clurist was as long as one tries to imitate him in his noble life and self-elenial. I think your gospel is better withont all its miracles and mysteries, and I feel like that old woman of Cairo who went about with a waterpot and lantern to put out hell and burn "I) heaven, that man might do good without hope or fear.

Have you read (I see you have read The Mystery of Pain) the books of Hinton Junior? If not, order them from your bookseller; they are published by Swan Sonnenschein, and are full of suggestion. Fourth-dinensional and spiritual and with curious and beantiful ethical ideas. 
I am glad you speak of Spinoza, the biggest Jew from Judah Haléry to Daniele Manin : the only Jewish prophet since John the Baptist and the Apostles. Do you know Pollock on Spinoza?

That is a beantiful book of Irish saints translated by Whitley Stokes. It is worth reading. You must come and stay with me a day so that we can talk some time.

That poor little Jewess who killed herself left some pretty verses (Amy Levy) worth reading.

Have you read Watson's verses? He does very well and is concise. Modern poets take too little trouble to boil down and therefore will perish by the hundreds like jellyfish on the shore; a little gritty shell survives.

I don't think I have much news, as you and I talked over most of the old folk. I heard yesterday from[who] is well, and ministering to a hopeless set of landlords in Ireland, very kindly sots and idiots-nice folk to have the management of a fine people full of charity and hate and imagination and sympathy and instinct and obedience, who see through folly in others very quickly. The whole Irish question is in this character question, as it seems to me. I am yours faithfully, with all good wishes.

Powell's personal ties with men of opposite faith were also shown by his friendship with Canon Liddon, whom he regarded highly for his honesty of intellect and natmre, and whose death, in this year, he had to lament. The two men were at snch extremes of thonght, that they came together, it may be, more easily than persons of almost similar doctrine, who are apt to think of minor differences. Their ground was also that of a common hmmour and sympathy. More on Liddon's talk and accomplishments can be read in the paper ${ }^{1}$ that Powell wrote on their colleagne Dodgson ('Lewis Carroll'). It is reported of Liddon that he thus spoke of Powell to a startled elergyman: 'I would sooner' be in his shoes at the last day than in those of many a bishop.' 'The following letter gives Powell's mind on Liddon. It further indicates the concessions he was willing to make to the appearance of Manchester, where we had lately gone to live. Verlaine calls it 'noire et

${ }^{1}$ Vol. ii. pp. 361-7. See too vol. ii. p. 393. 
splendide'. When Powell came there, he missed his allowance of sunshine, and once, pointing to a picture in a shop window of a gloomy darkened landscape, he exclaimed, "that should be labelled "Midsummer Day in Manchester".' But he had an eye for the curious beauty of the working quarters, and used to stop and look at the low blood-coloured sunset shining on the wet cobbled streets that run east and westward, as the shawled millgirls pour out after work.

To Mis. Oliver Elton.

Bedford Park, Sept. 15, 1890.

I think the mill-liands are very picturesque, and the evenings with chiaro oscuro effects are fine- 'tormented' a little, but with a kind of tragedy of industrious effort mocked by dull fruition (making of wearing-stuff for negroes who are hetter without it, and Maoris whom it kills with consumption to wear clothes and the like). But it is all with some unknown purpose, I suppose (though your husband won't admit that, luxurious pessimist as he is). . . I I am rather miserable about Liddon. I liked him so much; he was such a courteous and really good-hearted unselfish man, withont a scrap of false dignity, and full of humour: certainly one of the best men I have known. I saw a good deal of him of late years at odd moments. He used to walk at night round and round the quad to get rid of insomnia, and I often eame across him then, and he was interested in coins and of course in Dante, and we had lots of common topics. I wish good people didn't die so soon.

In the following, after giving a long and excellent list of the mediacval English poems, amounting to many hundred thousand lines, which a literary teacher ought to read, he goes on :

To Oliver Elton.

Isedford Park, Oct. 1, 1830.

I am glad you have got outsile the town: one camnot produce anything but turbid stuff (though it may be stroug of course) in a dark and foul-aired place.

r. P. I

K 
God's curse upon the plumber!

A weary man is he?

He wilna lay his drain-pipes richt,

But oh, he'll tak his fee!

God's curse upon the painter!

He bides wi' me o'er lang ;

His wages they are noways sma, His paint it stinks sae strang.

God's curse upon the builder !

The Deil's gude friend is he.

I would the builder's foul body

Were hangit on a tree!

You can add verses on the paperer and the baker and the milkman-all sons of Belial beyond question.

We are all glad to get news of yon all, so write to some one of us whenever you get a spare two minutes and have any news. My work goes on slowly and 'hooly'. I have got an Examination which I am pleased about at Xmas, and I shall have a little more leisure this term I hope. I would sometimes I could quit the rontine teaching and get to teach people who wished to learn, but I put this down to that 'original or inborn sin' which makes us dislike what we must do and wish other people would do it for us, and so puddle on, wondering ever and anon what good it is.

To another friend he gave counsel which he was fond of enforcing on the young:

Bedford Park, Dec. 27, 1890.

Now as to living on literature. It can be done if you can live cheap and have a little money of your own; otherwise not. You will have to work at journalism or hackwork to earn money, and you might as well be a banker or stockbroker. I should say, Go in for your business whatever it is, and make letter's your hobby. Give all your spare time to it, and you will enjoy both it and your business. As soon as you have leisure I will introduce you to Cotton of the Academ!. He will send you books to review, I dare say. It is good to do something of such work.

Meantime have a good time this vacation and amuse yourself. And with good wishes for the New Year, I am yours very faithfully. 
The year 1891 was busy with reviewing and routinc. We have some notes of his casual recreations.

I am not lazy, but I get stupid sometimes, and then I only do what I am obliged. I have been fencing a good deal, and I have got a decent riposte now by dint of practice, which is a pleasure to me. It has kept me going through a rather dragging term.

He knew both the craft and the literature of fencing well, and had enough practice to enjoy the sport and to follow a bont closely and estimate a fencer's form. He was better in defence than in attack. He shouted with langhter whenever he was hit. Sometimes the room would be cleared on a Sunday, his freest day, and the correctly clothed visitor was startled by the sight of Powell at play in a red shirt, sash, and flannels. He went now and then to the theatre, and especially to Ibsen's plays, which were then rife in London: 'Ibsen is the boom here,' he wrote. Like Vigfísson, he preferred the poems, Brend, Peer Gynt, and the lyries, as nearer to the Northern genins, but would hardly look at the early quasi-romantic or would-be historic plays, which he felt were a hybrid. The modern plays in prose he watehed attentively from the outside. What his friend Johnstone called their 'haggard and ghastly' element interested him, I think, chiefly for the execution. He said one thing that the fanatics, if they survive, may ponder: 'Ibsen does not bind himself to his characters.' In February Rosmersholm was played at the Vaudeville Theatre: the next letter refers to the leading part of Rebekka West, which was created in England by Miss Farr.

\section{To Miss Florence Frerr. Christ Church, about Fel, 1891.}

I onght not to bother you with a letter in the middle of your work, but I thought I should like to congratulate you on your begimning of serions work. I think you have made a very good begimning. You will play easier and with 
more assurance on Thursday, but you have got over the worst now: you will be able to make all the use of the talent that is in you. You have got the right view of the character. It only wants the 'accentuation': that will come now that you know the effects you can produce. I know the discouragement that comes to one when one thinks that one might have made more of this or that, but you will not give way to that. It is the inevitable consequence of mental and physical effort. I wish I could come up on Thursday, because I am sure it will be a great success for you. I am glad you have such a good press, as it will show you that others besides your friends think you are capable of a great part like this you are playing. You must be very tired, so you mustn't think of answering this.

I was glad the support you had was so good. Seen from the front, Kroll was very adequate, and had 'got the note'. Rosmer was passable enough, quite the gentleman, and not cutting off all sympathy with a weak character, as I feared he might do. Altogether the cast was enough to show the possibilities of the play.

I wish you all luck on Thursday, and I am very confident of the result. Don't be afraid of being too energetic, let yourself go.

I am yours very faithfully.

He will be heard speaking of Ibsen again. He relished irony, but he preferred humour, caring more for the erossplay of thought that comes from love than for that which comes from hatred or disenchantment. Irony of a different sort from Ibsen's, and as tragie, he found in Zola's Thérise Raquin, which he saw acted this year: he thought the play better than the novel. Later in the same year he is asking about Maeterlinck.

\section{To Oliver Elton.}

Bedford I'ark, Oct. 9, 1891.

I had a grand night Friday: we went to the Independent. It was Zola's Therise Rarmin. Fine acting, and it went well. It is a good play, simple and well-balanced and interesting. Every one was there, Todhunter, Wilde, Mrs. Aveling, \&c., an amusing house. I think it would take at the East End, with a little more comic business perhaps, and firmly and broadly aeted. Todhunter is 
disappointed with it after Ibsen: but there is room for both.

... I have had a fortnight with Freeman, who was very jolly and kind, and I did a good turn of work there. I saw a lot of churches, and heaps of drawings Freeman had made of architecture all over England.

Frecman he was soon to lose. They were familiar friends, and when Freeman came to Oxford in 1884 he was no doubt the scholar nearest to Powell's heart of any in the place since the death of Vigfísson. He was not in the least put off by Freeman's bluntness. The two articles which we reprint (in vol. ii) show Powell's affection and admiration. He was pleased with Freeman's praise of his books for children and his other work: it is only to be regretted that so few memorials remain of their acquaintance.

We have seen Powell as a boy learning to draw by copying the figures of William Blake. On his Oxford walls hung some of these careful facsimiles. In 1874 he discovered a short, hitherto unnoticed 'prophetic book' by Blake in the British Museum. This was The Book of Los, which the editors had confused with The Song of Los. No other copy appears to exist of this original, and no transcript of it earlier than Powelr's. In July 1891 he had published the poem, with a preface, in a magazine of exquisite ambitions, The Hobby-Horse, whose purpose was 'to deal, chiefly, with the practical application of art to life'; but there were also admitted 'illustrations and poems, as well as literary and biographical essays'. Powell told with immense laughter how the editor had once refused a contribution from Mr. Gladstone on the score of its insufficiency in style. He did not try to explain the inner meaning of the The Book of Los, seeing that the edition of Messrs. Ellis and Yeats, with the key to Blake's system which it propounded, was soon to appear. His affection for Blake throws some light on his mystical strain. It was there, with all his scientific temper and 
Latin love of clearness. But he found more satisfaction for it in art, such as Blake's, than in reasoned exposition. It was a thing he would rarely talk about. But he definitely thought that the mystics furnish something valid, whatever it may be, to human experience, and that they must be allowed to put it in their own way: they spoke best, perhaps, to the eye. He did not attach their revelation to any particular belief, nor did he find his mystical instinct disloyal to 'that most serene, most invincible, most illustrious Princess, Reason', whom he served.

Another note shows his equally ready interest in mediaeval verse and in modem crime; his essay on the Newgate Calendar can be scen in the next volume.

To W. P. Ker.

Christ Church, Nov. 16, 1891.

I see notice of a Háfiz which seems good. Maeterlinck I would like to talk about. I haven't got any of him yet. Is he good? The little bit I read seemed excellent. I have a good set of Verlaine to show you, and I have bought some new Provençals and Middle High Dutch; and Medwin's Byron, and a beautiful trial of Madeline Snith and of Palmer of Rugeley, and autograph and cases of Mrs. Yelverton, the "wronged' Thérèse. Henley' on Milton is not quite so happy as usual. Why bother with that man of Gath, Besant, Milton's own Philistine?

$\Lambda$ bout the same time he is 'awfully sorry for Parnell'. His own strong individualism in ethical matters, and his dislike of nonconformity with its 'conscience', made him reprobate Gladstone's abandonment of Parnell: and he wrote (on the ontside of an envelope):

What a nation of humbugs we are, in our newspapers at all events. . . . There was much to respect in him, and he was free fiom cant and the palaver which the dissenter loves and gets from the liberal all hot.

$A$ letter of the end of 1891 shows him in relations with the Netional Observer and with its editor, who scems to have sent him a copy of Lyra Heroica, that admirable 
garland of English song. A piece of the review of Villari's book on Machiavelli is among our reprints.

To W. E. Henley.

Christ Church, Nor. 18, I891.

I am afraid that I am not competent to do Gardiner, and I would rather not do it. I don't know the period really, and it deserves treatment by an expert, as Gardiner is a most painstaking and deserving man and a seeker for truth without prejudice.

As to Villari, I will do it with pleasure, but I have not the book: if you send it me, I will read and return it all safe.

Your Heroic Poems I am glad of. I wish Kipling would cut ont the two first verses of his Flag of England: the rest is very fine, and the seolding pettishness of the two first verses jars, though I understand the provocation to writing them : but he will not do well to keep them. All the other verses, especially the two last, seem to me most excellent both in expression and spirit.

I should miss with pleasure Lochinvar, Longfellow's Ship, and Arnold's Rustum. I should like another bit of Meredith or even more. I don't feel Harte's Réveille or Bullet-Song to be genuine, though the last is clever: Beeching's Pretger is very good. Fon might give us a bit of your own. Why is Usher's Well left out among the ballats?

But perhaps these are individual impressions, and there is all the rest of the book to revel in. But I do grudge the pages given to that excellent translator (Coplas) and amiable gentleman, II. W. Longfellow. And John Brown is certainly worth far more than Barbere. (what a farce 'American literature' is, bar the great man Whitman!). Can't you squeeze in a Burracli-Room Ballad or two in your next edition?

I think Peacock deserves a place, and Kingsley's 'Barum! Barum! Baree!' But this is all too long. I am gratefully your's.

I love Marryat, and would add 'Poll put her arms akimbo'. And there is surely a falsetto note in Procter's Sea. Don't tronble to answer this; I liked your book so much I couldn't help writing about it rather fully.

In these years, more is heard in Powell's letters of his toils as a reviewer. In the eighties he had written often 
for the Academy. The editor, Mr. J. S. Cotton, though he has long since retired from his post, is remembered by every one of his contributors who knows the meaning of the word gratitude. He was the friend and heartener of many young authors. In this paper Powell wrote many signed artieles, chiefly on books dealing with English history, and, as he notes in his scrap-book, 'most unsigned notices of things and books Icelandic and Scandinavian.' Later, many of his eritieisms appeared in the National Observer, and some in the Pall Mall Gazette, and in many other periodicals. But his commexion with the Manchester Guardiun began about 1890 and lasted with hardly an interruption till his death. The amount he sent to it is prodigious; and his best presswork is in its columns. He was never more than half in sympathy with its liberal and humanitarian views, and latterly he drifted, or rather consciously passed, far away from them. But he found that it was one of the daily papers that aimed at real and well-informed eriticism and gave room and a free hand for its utterance. The reviews he eontributed range far indeed. In the years 1892-6 they include Mazzini, Warwick the King-maker, Portuguese history, Charles V, Ignatius Loyola, Machiavelli, Thiers, Columbus, Joan of Arc, Madame de Krudener, Parthia, Napoleon, Mahomet, Esthonian poetry, Gibbon, Cromwell, Alfred, the Barbary Corsairs, Winchester, and Döllinger. This is only a selection, and he often went on at the same pace in after years. By far the greater part of all he was henceforth to write came out unsigned in the press.

As we read through the list of these reviews and articles, it is hard to repel the sadness caused by such an apparent expense of noble power, which might and should, we are tempted to say, have centred on an adecquate purpose, if the will had been able to conquer the serious but not insuperable motives for distraction. He was forced, no donbt, to improve his income by press-work. But these countless notices might have been done, sufficiently if less 
well, by men without the powers of Powell. These scraps and sallies of commentary on the historical works of others show by their very goodness that he was too good to write nothing or little else. It seems a disconcerting Fruetidor and Messidor for such a man's life. Many little fellows, who carry out their determined task, and are not in peril of dispersing their powers through over-width of sympathy, ean at first sight elaim to commiserate Powell. But they are not his judges: his real judges would be minds of equal scale and insight, who have actually managed to husband their force for large triumphant works: not a numerous tribunal. And these might be likelier than the others to pause in their judgement: to value more truly what has actually been saved : and to give a juster opinion as to what human achierement really consists in. They would look through to the soul and mind which are visible in these fragments. Failing any such right to pronounce, we may here only offer some considerations to temper the first impression of waste.

Powell's reviews are often not formal criticisms at all, though when he chooses they keep severely to the book in hand. Nost book-notices serve their turn, but do not call to be republished. But often Powell does not review the book in hand: he writes, out of his own lore and enthusiasin, on the subject of the book. This was complained of; but it is well for us, since his words did not die with the occasion. And often they are not even a formal study of the subject. They are like his letters or his talk: they give, better than anything, the inpression of his talk, which no one ever reported; and in that way they are still fresh. They differ from his talk in that they are not rapidly prepared or improvised; they are responsibly written down. They remain apercus, inspiring overtures, sudden swift panoramas, sallies on historic persons and on life at large. The seed is not sown in long straight furrows for the regular harvest, but wind-drifted into waysirle clumps and woody corners, 
which are rarely visited and easily forgotten and overgrown, muless some gathering is made of what flowered there. It is the case that he often failed to see in print what he had written for the daily press, and forgot it as he forgot the talk of last year's symposimm. He did not much care to see it, though he latterly spent some time in saring what he could and pasting it together. He did not neglect it because he thought little of it, but because it was simply part of his general radiation of energy. He was as wasteful as Nature, and had the same sudden fits of economy. He never showed a sign of repenting that for fifteen years or so he somewhat failed in 'concentration'. In this he simply acted out his character. For us the question is, not whether' we feel bound to repent vicariously for him, but what is the present value of the best that he thus scattered broadcast. It comes up for consideration in the present volumes, and 1 do not try to forestall a verdict. But his scope, of insight as well as of actual knowledge, is manifestly so rare, and his mind so hospitable to usually incompatible sympathies, and his attitude so much his own, that the expert student, even without gleaning any circumstance unknown to him, must be struck by the fresh lights and angles in what Powell says: and when he passes outside his own province he is likely to be still further informerl. The style of these vagrant papers must also, I think, be rated high: it is hard not to read them; and they are not what Powell was scornfully apt to call 'joumalism'. In a letter which will be given later he calls Froude and Matthew Arnold 'journalists'; he means sciolists; he means, rightly or wrongly, that they are not duly informed persons, or not primarily eareful for truth, or that he thinks their style radically common. I do not think it at all dangerous to quote such judgements on 'journalism' in face of the fact that Powell spent himself on the press. Ultimately, the issue is whether the stuff and the form of what is here presented 
of his writings is high in its own kind. It must be remembered, through the remainder of his story, that reviewing was one of his steady activities, especially in vacation.

Early next year he had another dream. The poet came to the surface in his sleep ; the load of the historian and savont was lifted, leaving just enough of the antiquary and comnoissem to give sharpness of line and the right costume. Unhappily only the three dreams I have given are recorded.

To W. P. Ker.

Bedford Park, Jan. 18, 1892.

The fools have altered the day again, so Friday 22 is the right day after all.

I always find if I write at once and answer letters, I have to bother my correspondents and write often. It is a positive disconragement to virtue.

There is a curious house here, white in Italian style, thick walls, studio, and all complete: cost $\$ 500$. It is a curiosity. When you come over you must see it [Slictch]. This isn't right perspective, but it gives an idea ... — built it. The other architects are furious, but it is original, cheap, and decidedly comely. When you settle in the comntry, you must build one in a cormer of your estate, overlooking the sea, for your friends. You will be in the Old House, and your wife will not improbably object to stale tobaccosmoke over the whole place. We shall go and see you after breakfast, and we shall dine with you, and reel home to the white house, which will be a guide to us through the gloom.

I dreamed the other night that we were all going over a great old house, now a curiosity shop, with heaps of last-century things of great beauty. By and by in the great salon the dealer pointed to a little rococo stand, something like a writing-table, and asked me what it wass. He opened it, and there was a little Rosicrucinn altar, and lights and dlugs to burn, and book of incantations. I called a lady who was there and who knows about such things and she sat down to work it. She muttered charms and burnt incense while we sat quict in front: then she 
got up, went into an alcove dais at the back, and sat quiet in a huge chair. Suddenly her face and hands turned charcoal black, then sparks of fire flashed from her eyes, mouth, nostrils, and ears, and a line of bright light ran romd her eyelids. We were horror-stricken, but ere we could stir the light died, the black went off, and she came down laughing off the seat towards us, her proper self. Here I woke.

\section{To Oliver Elton.}

Bedford Park, Jan. 20, 1892.

I was solry your stay was damped by your aunt's death, and the sad necessary last offices, which are not pleasant, but truly dutiful. However, life and death are so mixed, overlapping continually, and one is glad to do something for a good woman, even though it can profit her little when it is done.

Paget is all right. We went to Chorleywood together, with C. [his daughter], taking Mme. Tussand's on the way. The 'Apolian giant' (Polish giant) pleased her, also the General TomThumb, and the Death of Nelson. There is a fat mistress of George IV which (or who) is really splendidly done and characteristic, also an old lady and Voltaire grecting each other. They were selling sweets in London done up with black ribbon - 'mourning chocolates.' 'Quel peuple, mon Dieu!' To-day we are sane again, and money-grubbing as per usual.

There are no more news. Mackay is corresponding vigorously with me; the grumbling of the volcano, which I hope will end in an eruption from the Liverpudlian crater southwards. _- is active, like a headless ant, busy to no end, or to only one end, and, one might say, the latter end. Hoping you are all desenrhumés, I am your singular good friend.

A letter, chiefly given to Saxo and the Northern Hamlet-saga, closes with his usual picture of the friends who were about him in Bedford Park, and of their cheerful life.

To Oliver Elton.

Bedford Park, Jan. 31, 1892.

We are jolly here together. Yeats is well, Orpen has his lrish book done, Paget pegging away at theatre 
'blocks' for Graphic, Todhunter pegging away at fitting Schiller's Mary Stuart for the modern stage, by unmelodramming it and poetizing it. — engaged all day, nipping about like a lamplighter, and going up to London to the theatre late of an evening to shake off the influence.

The following lines were written while he was making his Impressions and Reminiscences for the St. James's Gazette on Freeman, who had died on March 16 .

\section{To Mrs. J. R. Green. ～' Christ Church, March 16, 1892.}

I can't write a very good letter, for I am very miserable about Freeman. I liked him very much, and he was exceedingly kind to me in every way. Since Vigfísson died I have had more help from him in the way of talks than from any one, and he was (beneath his controversial aspect and his idiosynerasies) really a most lovable person, childlike and simple and direct and zealous for history and for the truth as he saw it.

\section{To W. E. Henley.}

Christ Church, May 2, 1892.

I must thank you heartily for the Book of Verse ${ }^{1}$ you have been good enough to send me. I have thoroughly enjoyed it, and I shall look to be reading it very often.

The London Poems I like best. I can wholly enter into them. I think you have managed so that the poems put one into the mood which the realities force into one. I can see the scenes as I read them, as I have seen them so often and with the very feelings you pourtray.

I am glad that there is a chance of your coming to Oxford ere long. I hope to renew our acquaintance there and I shall be happy to help you to see what you choose of the place.

I am yours very faithfully.

To Oliver Elton.

Examination Schools, Oxford, June 18, 1892.

Thanks for your letters. My paper will show you that I am not free of hard labour yet. I will try to get down to Manchester one or two days and do the rest of the work with you.... 
Mogk I have read and Symons. I don't think them at all good: they don't understand what the myth is. It is all unhistorical and subjective, their system, save in a few points. Rydberg has instinct and imagination, but he is a little too apt to see identities. However, he has grasped the fact that we have parallel myths in our records-as we should a mioni expeet from the fact that the Teutonic nations and federacies are made up of many different tribes and clans with their different sacra and traditions. . . .

I am glad you are going to the Jesnits. ${ }^{1}$ There is much to be learnt from them. They know human nature, and manage to make use of poor creatures we waste and throw away. I think Loyola was a great man in the sense of [possessing] power, but I don't love him, as I do Francis, and I have no worship for institutions and organization. I like individualism. But the Jesuits' drill, as drill, is the ablest devised yet.

To Herbert Fisher. $\quad$ Examination Schools, June 19, 1892.

Good Maister Fisher,

Therewith greetinge. It grieneth me to hear that thou hast done thyselfe a hurt whereby $y^{\text {on }}$ art soe let and hindered $\mathrm{y}^{\mathrm{t}}$ all hope of that mary meetiug ${ }^{2}$ we had denised is done awaye with to $\mathrm{y}^{\mathrm{e}}$ regret of vs bothe. Herewith I sende thee a draftte of the earde or plotte $w^{\text {ch }}$ if thowe approue prithee returne to me for the imprinters ve. . :

Further inasmuch as the precions and wholesome writings of our patron were in especial composed for the healinge and behoofe of his patients I connend thee in this thy intolerable accident to set thy mind to their perusal being assured that thou wilt finde in them much comfort to thy head and limbes, for eheerfulness of heart is indeed a very elixir a panacea and very toward in that contexion or knitting together of the corporal celles $w^{\text {ch }}$ is to be aceomplished in thee as quicklie as maybe.

I $w^{d}$ have come to thee remembering that Brother John in certain of his discourses greatly urgeth us to works of mercie as visitare malculos and being mooned by natural and kindlie compassion and sympathie for thine invalescence.

I A visit to Stonyhurst College is referred to. For the Jesuits, see the article on Loyola, vol. ii. 1''. 146-9.

2 'The Oxford Rabelais Club, founded in P'owell's rooms, is alluded to. 
And indede I truste surelie to visit thee when this opmes examinandi of mine be onerpast, till when I pray God have thee in his goode keeping. And no more at this present from thy singuler good frende and well wisher.

To Mrs. Oliver Elton.

Bedford Park, July 15, 1892.

To-day I have been sitting all afternoon with Yeats, he doing big picture of me, I reading the Débicle; which is fine, sad, crowded, and with all the heavy weary miscrable feeling a war gives conveyed in it. No exaggeration, no false sentiment, the wretched emperor treated almost chivalrously (which is better than the abuse of men who would gladly have cleaned his boots for him). I have not yet had courage to do my papers, but I have written many letters and I have done an article.

The next letter shows him alert to the technique of the bookbinding craft :

To Miss MacColl. July 19, 1892.

Please don't at all mind about the book. I think it ought to have a green cover, and leaves laurel, as it is all about Lamra.

The source of Sorga, the rill, is perhaps suggestive of wavy lines, and Petrarca gives [the] idea of a rock smitten by the rod of sorrow and gushing ont into a silvery waterspring. You will I have no donbt be able to hit on something simple and Laura-like in the cover. The first pages want washing and mending.

I am seeking a Tasso and Boiardo, and then I shall have the Italian set of octavoes, and I must make a little case for them all ... My garden is full of marygolds, and the grass copper-green after the rain, but it is cold, cold for summer. 'Why is it Igdrasil?' It ought to be Yggdrasill (which means Woden'shorse, which again means gallows or gibbet, which to the Northerner had a elothes-horsey sort of look). Y Y $/ \%$.

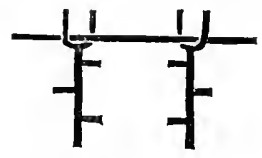
was a name of Woden. Drasill is an old word for horsehence Yggdrasil. 'This world-tree was also a gibbet.

\section{To Oliver Eltom. Bedford Park, Sept. \&, 18:12.}

It [University Extension] is a good movement, if only for the Universities, but it wants a lot of work. Leetures are not much good save as an occasional stimulus. 
Got a nice little Aldine Lactantius (1515) and Tertullian's Apol[ogia] yesterlay.

Have you read $A$ Son of the Fens by Emerson? It is first-class ; we are all 'raffoling' over it here.

Poor Nettleship ${ }^{1}-$ a good fellow and dutiful, honest and kind and generous of his time and care for others. A good death too, worthy of a philosopher.

Did you see that Saga-incident: the head spun off a man at table by a single sword-cut, so that it fell aboard? Cf. Orkney Saga.

\section{To Wilfirid Seawen Blunt. Christ Church, Nov. 18, 1892.}

I must just write you a line about your Esther. It is splendid. It gave me the same pain and pleasure that one has in reading over old love-letters and brooding over days of hope and sorrow and joy that are gone for ever.

You have the real poet's gift to the full of moving your hearers. Some lines make one's heart beat.

If I saw you I should be less able to say this, so I write it and there is no exaggeration in it.

I am grateful to you, though some of your verses cut deep into old wounds. I am yours very faithfully.

In January of 1893 he describes himself as kept in for a fortnight with influenza and deprived of tobacco, but as 'not otherwise bad, so I haven't much to grumble at'. He sat

amusing myself of an erening after work with Balzac. Eugénie Grundet and Pons I had not read for years. They came quite fresh to me: they are really tremendous. I think every time I read Balzae I put him higher both as a novelist and as a thinker. He really understood his time, and so understood something of all time.

In April, after writing his review of the Life of Madame de Krudener (see vol. ii. pp. 124-5), he took a brief run to France, having ' good weather at Boulogne, two lovely days in Paris (three picture shows and the Dahomans and a museum)'. 'The chronicle becomes scanty here, but in June we have another communication to a fellow-member of the Oxford Rabelais Club, founded in his rooms.

1 R. L. Nettleship, of Balliol, rlied of exhanstion on a snowfield on Mont Blane. 
Goode Mayster Greene,

Ye be sorely to blame in that ye devote to the Life Politique ${ }^{1}$ the taleaunts that were bestowed upon yowe to thende that ye shoud folowe the Life Reasonable or Mental. Wherfor I cannot holde yowe excusid in that ye have neglectid the Suivance of Alcofribas Nasier and have not the time requisite for the consideration of the questions that be mooned by the perusal of his Bibliothecque. Howbeit out of that lovingkindnesse which is enjoinid by thensample and command of that Maister I holde yowe free of that youre obligacioun, and I woude only praye yowe to do as far as ye maye what in yow lieth to the prophit and weal of our Societic. And so Gode have yow and youre Universitie in his holie keepinge.

These from youre heartilie affected well-wisher

Fredericke Yorke Powelt.

A long letter is now given almost in full, as it so clearly reproduces Powell's ordinary talk when it turned on books, with all the sudden darts and zigzag allusiveness that distinguished him.

To W. P. Ker.

Christ Church, June 6, 1893.

Your letter is as kind as ever. I was very disappointed, but the Devil entered into $\mathrm{M}$ resolution at committee which much concerned a man I owe much to, so I conld not leave and let my friend go down the wind. I knew you wonld forgive me if I for once put duty before rlecency. I see your list is out today. I liope to see you ere long; next O. V.2 you must be my guest anyhow if yon are in town.

As to me, 1 have read Une Vie ${ }^{3}$ twice; it is terribly sad :

1 Mr. Greene, the translator of Omar into Latin verse, olselves in explanation: 'I was lusy at tho time collecting signatures for a petition against those elauses of the Home Rulo Bill which proposed to disfranehise Dublin University and hand it over to the tender mereies of the Nationalists, and so (I suppose) did not write a pajer for the Rabelais Club,

2 "The Odd Volumes', a society of wits and anthors, to whom was read and presenterl Powell's paper on English Alleyory.

3 Guy de Manpassant's tale.

I P I 
and tonches one up in the raw places. One is like a cat in irritating one's sores. I have read a lot of little Italian Sonneteers, Ruscelli's collection. I have bought Campbell's own Petrarch, a jolly edition, Mesnard's of Padova. I have read this Scottish poem that struck me greatly, by Glassinberry, The Nine Worthies. Has he been republished? He is a good 'un.

Ane uther exampill suth to say

In summeris day full oft is sene

Thir emotis in ane hillok lay

Rimmand oute before thin ene

With littill weit thai wit away:

Sa worthis of ws all I wene

May nane indur over his day

Bot all overdrivis as dew bedene

That on the bery bidis bene

And with a blast away will be :

Quhile gis are gray quhile ar thai grene!

This warld is verray vanite!

Isn't it fine? and as direct as Kipling.

The Scottish minor poets of the fifteenth and sixteenth centuries have never been rightly appraised. . . .

Johnstone [is] a fine fellow, very interesting, whom you would like I know: a musician, doomed for the sins of others (for he is not a great simer) to be a dominie in Edinboro', where he is consoled by an old Frenchman who can talk and understand ; and they have, with one or two more, a little French club. Each pays sixpence a night for exes, and you get simple refreshments and sound conversation.

The old professor consoles me a little as to examinations, but as to lecturing I misdonbt me more and more, and as to cramming I never believed in it. Any man can learn if he sets his mind to it, and one ean teach all one wants, or the man can learn or use, in a very few hours, in an ordinary case. Besides, books are only part of learning.

l read a curious book on the Manning murder, with biography of Patrick O'Connor and comic adventures in the style of the Hindoo-beloved Reynolds: also a good book of stories, Chubs of Loudon, 1848. The Romance of the Rose, pt. ii, I have gone through again with consider- 
able pleasure; and I got a jolly little translation of Horace, seventeenth century, and read most of it. Maugis of Aspremont is the last Chanson de Geste, I have not tackled it yet.

Morris and Case have beaten Jackson handsomely ${ }^{1}$, which is satisfactory. I am sorry this is so long, but it is not so very badly witten in the hand as usual, so I shall send it, all seraps as it is.

I shall be glad to get to quiet work again,-sun and a bit of sea. I am yours faithfully.

\section{To Miss MacColl.}

July 12, 1893.

Many thanks for the Petrarea. I like it very much, and I think it a great feat to have bound it so appropriately. You ought to have put your initials on it. I am looking forward to the Dante. I should like to see the design for it before it is put on. Green moroceo will suit it admirably, so if you have any of that good skin left please keep it. No other colour but green would do, as Dante is always (like Petrarch) dwelling on that colour. I want some emblem of Beatrice, a crown of stars say, where the garland is in the Petrarch. SOME STARs I want, because 1)ante's poem ends each section with 'stars', and I want som F FAME to typify the pains of the Hell and P'urgatory, and I think the sturs and the flame are really necessary, and the nume of the book. It is in far better condition than the Petrerea. I must try and get a grood Pulci and a good Boiardo, and I think then I shall have to have a little ease for them. I have a Homer, but as it is in four volumes it is a big affair. I do not want the Dante till January. I shall make myself a birthday present of it.

The back simply (like the Petrarea) done with A Lous and date. I am hoping you will have a very good time after your work, and I am yours very gratefully.

Powell this year managed to spend the summer in the way he liked, by sonthern waters. Once away, his letters are full of the pleasure of life and of his delight in colour, 'the sonl's bridegroom,' as the veteran poet calls it. Te was in July at Broadstairs, working still, but bathing and walking, reading 'Marguerite, a young French beginner',

1 Architectural controversy over restoration of St. Mary's spiro at Oxford. 
the writer of La Force des Choses, with interest; and was happy in the company of his friend the painter, Mr. H. M. Paget. He also had his own child with him, 'the sun and water and wind helping her all they can.' Mr.P. H. Emerson, of whom he speaks in the next letter, he used to call "The Real Emerson', and once wrote an article ${ }^{1}$ in an undergraduate's magazine in his honour and seriously at the expense of Ralph Waldo Emerson, as well as of American authors at large; nearly all of whom, except Whitman, he despised. After Broadstairs he went on to Cornwall.

To Oliver Elton.

Liscaion, Craffhole, S. Germans, Cornwall, Aug. 24, 1893.

Here we are, C. and I, among our own people, the 'West Welsh'. We come home end of next week and are at your command then. The sooner the better after Saturday week therefore.

We had a jolly time at Broadstairs, and I met Emerson, as I told you, I think, author of Son of the Fens. He is an interesting man, a great boatman and gardener, a doctor and a littery gent. Very diffident and yet very confident. Astonished to find that any one shared his ideas on life and things. His photographs hare mimaginable beauty; they are like the most beautiful Whistlers. I was perfectly astonished at their extraordinary charm.

This place is just a clover-field and a village street from Addleshaw's. He and Stanley both here, neither quite well just now, though the place agrees with them. They have had Roden Noel, a quiet, beautifully courteous gentleman and a really fine fellow, for a day or two, and Horatio Brown, the Venetian historian, a real good sort, cheery, broad-faced, shock-headed, tumble-dressed, with them. So we have had good talks and cheer. The sea here is splendid, and there is not so much rain as I always fancy you come in for in Yorkshire and North Wales, only a shower or two of five minutes since we have been:bright sun, a sea limpid and blue-shadowed, clean clear sand, red and brown rocks, samphire metal-green, exquisite turf, and beautiful little combes and fertile fields sloping up and down. We had a day's sailing, and next week we are going to have a day or two in a steam launch,

1 Part printed, vol. ii. 1P. $318-19$. 
I hope, up the Tamar... We were with the Pagets and my godson, who has persistently refused to be 'grizzled', as he calls it, breaking from the church door and going thence unbaptized to eat his christening cake.

From his youth up Powell had an interest in Portugal and its history and verse, as is shown by the sonnet on Camoens and the review ${ }^{1}$ that are now reprinted. He liked the famous letters of Marianna Aleoforado, the seventeenth-century 'Portuguese Nun', deserted by the stony French officer, Chamilly, who first published a translation of her Letters in his own language. Powell had discovered a rare transposition of them into Popian English verse, and this was printed by the most recent English student of Marianna, Mr. Edgar Prestage, together with a prose rersion. In September Powell wrote to Mr. Prestage in reference to his obituary poem on Anthero de Quental.

I am really very grateful to you for your kind gift and dedication. I have given one of the two copies you gave me to $\mathrm{W}$. Yeats the poet. The poem is very strange and beautiful, and I think you have caught the spirit of its half-mystic, half-Heinesque inspiration. ... It is a golden mine you are working, sou will find many nuggets.

A letter of later date on the same scholar's versions from de Quental may follow here:

\section{To Edgar Prestage.}

March 12, 1894.

You are right only to give a selection. The poet is so melancholy, that more would become the caterwauling of misery; whereas in a selection such as yours, the melancholy is not so much felt. People who are rery sorry for themselves (however nolble) come near being ridiculous and are not to be held up too long at a time to public admiration. You have given Quental a fine English garb and pretty form, your printer has served you well.

$$
1 \text { Vol. ii. pp. 149-j̃. }
$$


Powell's impulse instantly to enlist and encourage any young student who showed a bent of his own is well seen from the aceount which Mr. Prestage has sent me: it is a typical case.

My relations with York Powell arose in this manner. Early in my time at Oxford (I was up at Balliol from January 1888 to 1891) I attended a lecture annomced to be given by Professor Freeman at the Taylorian. Freeman was, however, unable, for some reason, to be present and York Powell read it for him. The subject was Portuguese history, but I forget the exact title. I spoke to York Powell afterwards, and he invited me to eall on him at Christ Chureh. Just at this time I was corresponding with Sir Richard Burton, who encouraged my bent for Portuguese literature and suggested the authors I should read. York Powell had no intimate acquaintance witl Portuguese, but he knew his Camoens, his acquaintance with whom was not limited to the Lusiads but extended (if my memory serves me) to many of his so-ealled minor works, such as the marvellous somnets. He joined his encouragement to Burton's. He knew the field was a promising one, and the fact that no Englishman was tilling it made him urge me the more to take up the work seriously. I forget who first suggested a new English translation of The Letters of a Portugnese Num, whether it was he or I, but I know that his admiration for the Letters made him welcome the idea, and that he revised my MS. version, introduced me to Nutt, arranged for its publication, and saw it through the press with me. He was delighted with its success; the copies were all sold before long, and to this first edition of 1893 there succeeded a second in 1897, and a third. York Powell showed the same interest in my English rendering of some of the Sonnets of Anthero de Quental. He again went through and revised the MS., and after rejecting some, finally selected for publication the sixty-four published by me in 1897. I owe it to his emendations that my version was less unworthy of publication than it would otherwise have been. The little plaquette on the death of Anthero was also submitted to his revision, and it left his hands the better for his labor limre. 
The following refers to some translations done for an undergraduates' journal :

\section{To Oliver Elton.}

Bedford Park, Oet. 8, 1893.

The Dante I like, but there is but one shortcoming (for me) in the verse. There is no stop regularly at the end of each tercet. This is one of Dante's effects. He never runs on without a reason. His favourite tercet is

= with the third line broken, the sense ending halfway and a kind of clenching or riveting clause occupying the last half of the third line. Often too three tercets make up a kind of group, and he does this also with intent and emphasis.

I like your vocabulary very much.

[Write]

1. 109. 'And, while I gazing stood, I there beheld.'

1. 672. "That here and there the stars cane forth in hearen :'

because he never ends a verse with 'stars', save for some emphasis, and does not so here.

I think you have sometimes made a legitimate point by inverting the order of his clauses. He sometimes puts last what in English we should put first, and this you have seen and made use of. It is this curious Italian inversion that makes even literal English versions read so awkwardly, if it is kept to without any discrimination.

You are quite right too in making your students feel that the Purgatory should always be read side by side with the Hell. I wish you had also gone further and shown them the Heaven of the Meek and Peace-loving.... All this is badly expressed, but you wished me to tell you what I thought, and I do it as you wish. You will understand, I hope.

Powell's mind was full of lante, and he read him more, I think, than he read any other great poet. Dante satisfied his strain of fierceness, and his other strain of tenderness, and his Latin sense of form, and his profound love of the chain-rhyme with its harmonies ever renewed after suspense. Ile was well-schooled in Dante-learning, and 
wrote several papers for the Oxford Dante Society, including 'Dante and Milton', 'The Iconography of the Divine Comedy', and also on the 'Determination of the authenticity of the Canzoniere Poems'. He took some share in editing the Canzoniere for the Oxford Dante, but seems to have worked under pressure and left some textual errors. Another paper was on 'Books on Dante still wanted'; and he drew up, what may not have existed before in English, a guide to books for beginners in Dante-study. In 1891 he gave a set of lectures at the summer meeting of the Oxford University Extension Socicty, and was pleased with the special thanks he got from the students. He spoke on the Vita Nuova, and gave notes on the text, metre, form, and style of the Divine Comedy, as well as on its topography and philosophy. He would sit down at a literary society, or among his friends, and pour out about the poet: at such times he was at his best. Happily a few ${ }^{1}$ written words of his upon Dante are rescued, and they give some key to the precise spiritual attraction of the poet for such a temper as his, on another side so deeply naturalistic. But Powell's mind was like a lighthouse, revolving and casting different lights in succession from the same central fire. When he objected to 'idealism' he was not thinking of the great prophets and visionaries, but of sentimental intellects, amongst whom he ranked modern radicals of the type of J.S. Mill, in whom he found a poor allowance of human nature, or Emerson, in whom he found sandy inconsequence and rague culture. Alfred and Langland, Dante and Mazzini, were to lim the men who had seen concrete reality the closest, and who also harboured the safest and highest of dreams, which they built on that reality. When he came to Macchiavelli and men of science, he did not trouble to try and solve logically any discords that they may seem to present with the other order of mind; but he seized rather upon 
points of affinity, such as the common dream cherished by the three great Italians for a single and a stable Italy.

In November Paul Verlaine eame to England, under the persuasion of friends, to give a few lectures on himself and his poems. He has described his visit: a translation of his article will be found in the Sazoy for April 1896. After London he drifted to Oxford, and tells how he lunched with Powell, and how Powell afterwards presided at his lecture, with its array of students, 'grave,' so Verlaine puts it, "with the majesty of young or' matured learning.' Professor Charles Bomier, who was present, thus narrates the luncheon party and Verlaine's talk:

Je revois la scène, la grande chambre donnant sur le Broad Walk rempli d'ombre: de vagues élèves effarés, venus pour admirer un poète en chair et en os, arec la sensatiou d'une partic de plaisir un peu risquée; Powell marchant de long en large, fumant, riant; et Verlaine! Mais non le Verlaine du 'Concert rouge' ou de tel café du quartier; quelle transformation! On lui arait dit, sans doute, de bien se tenir devant le public d'Oxford, d'être 'sage', et il l'était avec un effort comique. Dans sa face de bon silène génial passaient des fissures de rire et de sournoiserie : cela l'anusait éridemment de jouer un rôle et de porter un habit de soirée, une fois en passant. Il causa tout le temps, mais arec beaucoup de demi-teintes, grises comme celles de son portrait par Carrière ; il parla de ses souvenirs de maitre de français et de dessin dans les écoles anglaises, de son rôle de Censeur de la presse pendant la Commune, et de son drame sur Louis XVII; celui-ci disant, en parlant du geôlier Simon :

'Il avait tous les traits de mon cousin Philippe,'

vers qui, d'après Verlaine, lui aurait attiré l'inimitié de la famille d'Orléans.

Dans le fonds immuable d'Oxford se résorbent les quelques visages des étudiants; seuls s'y détachent en lumière Verlaine, causant, et divaguant; Powell qui apprécie de son grand rire.

Verlaine was fond of Powell, and often asked after him in writing to English friends. Powell, who had all 
Verlaine's works nobly bound, had a plan of publishing in England an edition of his selected poems ; and Verlaine would write, we hear, to ask how it was getting on and whether he could 'toucher' something on account. It never did get on, it never came to anything; but, as thongh in retrieval, five year's later Powell wrote some prefatory lines to a portrait of Verlaine by Mr. William Rothenstein, published in a limited edition. Part of this note may be here given: the passage from Lucretius on the interaction of body and spirit may rank high amongst happy quotations.

Verlaine's own work was intensely personal, and it is not mere idle euriosity that makes his readers desire to know the outward presentment that his spirit wore. That this outward presentment was signifieant none that beheld it conld deny. Nor was the poet himself umaware of this. Long ago the great epicurean gave his warrant for portraiture :

Implexis ita principuis ab origine prima

Inter se fiunt consorti praedita vita,

Nee sibi quaeque sine alterius vi posse videtur

Corporis atque animi seorsum sentire potestas,

Sed communibus inter eas conflatur ntrimque

Motibus accensus nobis per viscera sensus ${ }^{1}$.

So that you have here a piece of biography all the more vivid, perhaps, in that it is not expressed in mere words, and certainly all the more consonant with the poet's wishes. He has told, in his own verse, what he wished to tell in words, finkly, and no other memoir is needed. But one is glad, by the powerful help of the skilled crayon, to recall from the past the living image of the man that, among the foremost poets of our time, has been at once the most natural, the most exquisite, and the most sincere.

1 Lueretius, De Rerum Natura, iii. 331-6: "With first-beginnings so interlaced from their earliest birth, are they [mind and body] formed and gifted with a life of joint partnership; and it is plain that the faculty of the body and mind cannot feel separately, each alone without the other's power; lut sense is kindlen throughout our flesh, and blown into flame letween the two, by a joint motion on the part of both (MIunro's translation). 
Powell's love and understanding of Latin art and Latin letters had to pay a certain indemnity in the form of a picturesque and comically vehement aversion to the Germans. Ten Brink, the Dutch-born, German-trained historian of earlier English literature, had been praised to him, and he took occasion to lash out once more. It was not impossible to lead him on to this topic. Somebody once said to him that it was refreshing to plunge into the cool waters of German erudition, after too much sentiment and disorderly writing. He said, with some bitterness, 'Yes, it is like a plunge in a tank:'

\section{To Oliver Elton.}

[End of 1893].

Ten Brink is good, he was beginning to see, what the rest of them over the Rhine as yet ignore (the learned), that literature is not only sounds and dates and influences but style and meaning and the living word.

I send you a very close turning of a little bit of Verlaine I did in France. ${ }^{1}$

Yeats and I hold ont bravely (fine old Sadducees!) ats regards angels and spirits, sare the Angel, Islington, and the 'strong waters'.

Motto for Froude : e pur si muove.

Et ego inter poetrs minores, he wrote on sending another serap of verse; and he read the minor poets freely if with wonderful speed. In another letter late in 1893 he speaks (as he often spoke) of

that pure gem of Shairp's, The Bush aboon Traquair, a poem which I would have riven a lot to be able to make; and ... I have read a lot of Roden Noel's verses lately; they are frightfully irregular and often faulty, but they often hit one very hard. Ile has a real poetic gift.

This year may close with two letters; they are written on the principle of 'Rejoice with them that do rejoice, and weep with them that weep', except that Powell did

1 The poem from Sagesse is printer in rol. ii, p. 414. The other allusion is to the talk of some mystical and spiritualistic friends. Powell disliked hrth kinds of 'spirits', in spite of what he sitys hero, with equal heartiness. 
something more than weep. The first is to a friend who had, by permission, named his first-born son 'York'.

Hurrah, I am glad. I shall be delighted to have a child of your wife and yours bear a name of mine. My grandfather York was a very clever and good physician, and a pretty Spanish scholar, and a handsome man, and came of an old stock, and I have always been glad to bear his name.

I remember how happy I was, when C. was born, to see her with my wife. You are really to be envied now. A child is better than all the books in the world, for it is a living poem.

Dill was here this week, very jolly. He and I both agreed that the last part of the Odyssey was the best bit of Greek in the world, and also that Thucydides rarely told a story well. I put this in because you will probably not altogether agree with it, and it will recall you to earth to argue about it.

We shall all rejoice over your happiness. I don't think you could have done a kinder thing than paid me this compliment. I wish I were more worthy of it. It is really not so easy to be good as to be good-natured.

The other is to a younger man who was threatened with disabling illness.

I am glad you may smoke, as it is a comforter, and you will have a few black hours to face.

Though I don't talk to you about it, because we usually make merry when we meet, I appreciate your pluck, and I know that you are fighting a hard fight. It is so hard to realize that one must take care of oneself when one is young and full of life. I wish I could help you more, but no man can really do much more for another than bottlehold and cheer on. One has to face the music oneself. However, I hope you will find me a willing if not a skilful second as long as I can be. The good thing is, you have made a good friend in-, I am sure. She is a person who can be trusted down to the ground, I think, from what I know of her.

Take it easy.

On the New Year, 1894, he made a sonnet (rol. ii. p. 391), adding, 'One is not very gay at New Year'. Only forty-four, he speaks as one whose life is beginning 
to be in the past, but who has no complaint to make. But the zest for life soon returned upon him.

In January 1894 Saxo was cleared, the last sheets dismissed. He was none the less busy: heary reviews impending, the new English School engrossing him. He wrote to a friend who was proposing a learned work for the Clarendon Press and who had asked about the arrangements for the Cormus as a parallel.

I did my work on it gratis for love of Vigfússon and they made me a present. I never asked, nor do I know, what Vigfússon got. It wasn't much, I am certain, because these books cost a lot to print, and of course do not sell largely.

If you proposed such a work the Press wonld give it earnest consideration, I know, and I am sure they would try to give you as good if not better terms than the ordinary publishers. But I can assure you there is no money to be made out of learned books of this kind. You will get fame (if that is worth anything) and the pleasure of having forwarded your subject (which it seens to me is worth something).

On February 28 Stéphane Mallarmé came to Oxford to deliver a lecture, which Powell had been instrumental in arranging for him, at the Taylorian Institution; it was in his elliptical, remote, and profound style, on 'La Musique et les Lettres'. It was an ordinance that all such disconrses must be given in English; and to meet this formal necessity ('la clause locale') Powell made a translation with heroic rapidity one night and read it to a small gathering: the delivery by the author in French before the full audience took place next day. Mallarmé thus relates the occurrence :

Lat Trayloricun Association inangurait une suite ctrangère d'auditions, qui désigne nos littérateurs. Je n'oublie . . quel homeur avivé de bonne grâce me fit mon ani, de trois jours et tonjours, l'historien York Powel [sic], de Christ Church. La veille il voulnt lire, en mon lien, it cause de ma terreur devant la clause locile, sa traduction 
admirable d'un jet conduite en plusieurs heures de nuit. Le charme, et la certitude, de l'entreprise, étaient répandus, dès cet instant: anssi, attribué-je, à un égard rétrospeetif pour ce maître, l'intérêt saluant la démarche, que, le lendemain, je devais en personne. J'ai pu me figurer l'heure, d'une fin de jour d'hiver, anx vastes fenêtres, pas l'ennui, qui frappa latéralement une compagnie avec gôtt composée ${ }^{1}$.

Powell has left his own word on this meeting:

I had Mallarmé here to lecture for the Taylor. He was delightful; and we are as thiek as thieves. He made me langh with the most delightful reminiscences of queer Parisian types. He is a charming man ; beantiful manner and speech.

An eye-witness describes how Powell invited Walter Pater to his rooms to meet Mallarmé, perhaps his nearest brother-in-arms among the craftsmen of prose. Mallarmé taught English in a lycée; Pater was deeply versed in French; but neither would venture on the language of the other master. They regarded each other in silence, and were satisfied, while Powell's voice was heard in alternate tongues. His French was good, rich, and instinctive, if not always formally right: he had the sense of the language as a fencer has 'le sentiment du fer'. Mr. Charles Whibley writes the epilogue:

I remember, when York Powell did not acknowledge the little book, Mallamé thonght he must be offended, and could find no other ground of offence but that he had called Oxford 'imposant' and Cambridge 'intime' ; 'entre qui pas de ehoix.' However, he was consoled when I told him that Powell did not always answer letters by return of post.

Here may be added another tale he told of Pater. Powell was once offered Rodin's bronze, 'The Man with the Broken Nose,' on easy terms. 'I thought that Pater' would like

1 Oxford, Cambridge: La Musique ot les Lettres. Par Stéplane Nallarme, 1895, 11). 27-8. 'The original lecture is also printed in Studies in European Literature: being the Taylorian Lectures, 1889-1899. Oxford: 1900. 'The translation by l'owell lemains, but is umpublished. 
the first refusal of it, I brought him to see it. Pater came in, and looked at it withont a word, then gave a kind of shudder. He thought, you know, of the ideal of manly beauty as somewhere between nineteen and twenty-three. He said, thanking me very politely, "I don't think I could bear to live with it!"'

The bronze remained on Powell's table to the last.

\section{To Oliver Elton.}

[Early in 1894.]

Politics seem a kind of dry-rot to such fellows as it destroys any vestige of understanding or uprightness they may have had, leaving the bare skeleton of eonceit gibbering and mowing in a corner. Ast ad meliora.

Look at Gli Eroici of Bruno, Dialogue 4. In the sonnet of the hounds of Actaeon you will find the origin of Hamlet's ' $O$ that this too too solid flesh would melt!' (Hamlet i. 2), and in the comment Bruno seems to say that the suggestion came from S. Paul?

The moon sonnet, Dial. 5, reminds me of imitations in English: but the whole set of dialogues is full of things that struck Shakespeare, and were used by him.

I have great hopes of Gardiner succeeding Froude. Dicey is anxions he should, and his word counts for a good deal, as he will talk to the right people. It has begun, the heavy drip of the autumm rains, to-day. It is not unpleasant. But it brings the leaves down : my grass is emerald green, with pale gold sprinkling of the almondtree leaves. The creeper is turning in the Park; there are some exquisite bits.

I will send you Bruno directly I get back to Oxford. I have not forgotten. I am yours very faithfully.

Why not give a lecture on Bruno some time? If you liked to come to Oxford and give it, you could have the Taylor room. It is worth doing. It wants doing. ' $\mathrm{Al}$ lons! camerado' (as the good grey maker has it). 'The Nolan must be arenged upon the foul faith that martyred him!

\section{Pope lornitur: Clement VIII.}

Another friar that dares to think and write! Feteh faggots quick and set them well alight And pop him on, no matter what he says, And see that he's reduced to ashes, quite. 
A good priest spealis to his fellow-priest.

What would become of you and me and God And God's own church and all her rerenues If we let such a knave as this go round about Persuading folks to think? The bare idea Gives me a chill; and yet this fire is hot And roasts him soundly. What a stubborn brute! He will not even now admit he's wrong.

So much the worse for him, the taste he's got $O$ ' the fire,- though it is hot: I swear, my gown Has quite a smell of singeing on't. One sees As well from here. This taste he's got, I say Is not to be compared with what he'll feel To all eternity. Thank God for hell!

Signed: the Jingle-monger.

The next letter shows him reverting to the book that had been the first and was to be the last of his Icelandic labours, the translation of Fereyinga Saga with its commentary. It did not come ont for two more years. The allusion is to a course of lectures given upon the sagas by his correspondent.

To W. P. Ker.

Bedford Park, April 11, 1894.

I am glad, I would all the Lord's people were prophets of the Sagas. I hare just to-day finished rerising F(ercyinga, which I did when I was 17 , and I want to publish it if I can get a man to do it properly. It is a beautiful story, one of the good ones.

The 'prose epic' is only highly developed in Iceland and Arabia as far as I know. The Irish gare it to the Icelanders. It does not occur out of Iceland in any other Scandinarian land.

I pray you to remember Vigfússon in your sermons and to explain to them what a noble fellow he was. I miss him sadly. . . It is the Irish influence that spoilt Icelandic poetry and made Icelandic prose. In lecture iii give a good word to Swerre and his dictated saga.

To Oliver Elton.

Christ Church, $\Lambda$ pril 21, 1894.

It is quite true. He [Aubrey Beardsley] is old and has the cynic view of age. His illness makes him old, and the 
feeling that his time is short. He has a phantasmic eleverness, delirious fantasy ; the lines are like the lines one is troubled with in fevers when one loses one's head. But there is an exquisite feeling for pattern in much of his work, that is really distinguished and fine.

In July Powell struck a mine of pleasure, which he returned to explore almost every summer of his life. Ambletense, in the Pas de Calais, was to know him well during the next ten years. His visits there with his family were the crown of the year to him, and he always drew some of his friends with him. He became a centre in the Hotel Delpierre. His letters and poems inspired by Ambleteuse are the best commentary.

To Oliver Elton.

Ambleteuse, July 29, 1894 .

We are over here for a month. We have about $2 \frac{3}{4}$ weeks to run. It is rery pretty, close to Boulogne, about ten miles. A comntry of sandhills and fields and wild flowers and mushroons, curious cottages, very solid and good: red roofs, whitewashed stones, green shutters [slictch]. The colour of the sea and clouds is exquisite; pearly grays, blues of the purest pale cobalt and ultramarine, and turquoise blue and green. Clouds clean and soft and white and gray dum and browny black; the clondscape changing continually; the grass and herbage on the sandhills gray-green and steel and dull transparent black green, against the delicate yellow of the fine sand.

A fine old fort built by Vauban on the sea, with a guardhouse on top, of beantiful red orange brick (like Hampton Court) which shows where the stuceo has fallen. The fort itself stone, with warm lichen. A great bay stretehing from Boulogne to Grisnez. Beautiful country walks over meadows, and by the rivers; marshy bottoms full of flowers. How you can go North with France open to you I don't know.

It may be well to pause here for some record of the picture Powell left on younger and friendly observers, especially during the years before he beeame professor. His collegiate life and occupations could not be better 
presented than in the following note by Mr. H. W. Blunt, Student of Christ Church.

He was Law Tutor, looked after Indian Civil Service candidates (old system), lectured on Pass Political Economy, and saw something of the history men, though not responsible for them.

His lawyers were poor material, usually regarding the school as a soft option for the Pass Schools; and I fancy they got something more than they bargained for from Powell-sometimes inspiration, not necessarily on law lines, and reluctantly enough received. More often, though very nice to them, he scarcely knew what to do with them, and the evasive sort got mislaid. The I. C. S. people got a good deal of their teaching from outside, of course, but they liked Powell and he them. They flocked back to him on their furloughs. As to the Pol. Econ., one of our people, who had been a clever if slack honour man, being obliged by ill health to take a pass, told me that Powell's lecture was the one real thing in intellectual matters that he came across in Oxford. If the men did not attend regularly, however, and write papers regularly, Powell had no sort of gift for harrying them, forgot them in fact, and his absent-mindedness made him a quaint tutor for pass men.

As to hours, he was violently unpunctual. Rose late, breakfasted very frugally if alone (how abstemious he was when not exercising hospitality has not, I think, been noticed, but buttered apples often served him where another man would have dined); reading the while, except when interrupted by a stream of visitors, publishers, distinguished foreigners, people who wanted something or other of him. Here the eordiality and generosity come in. If he had not been himself so quick a worker the waste of time would have been appalling. But, if eager to help any sort of promise, he was stem in his judgement of the work when done, as he was eurionsly inflexible in his judgement on certain types of character. In the late morning he lectured and took pupils. I don't think that he took to reading The Times in Common Room between 11.30 and 1 till he became professor.

His afternoons were spent in meetings, or in seeing people, as in the after-breakfust rush, never in exercise, though he would go to look on at boxing or fencing, of 
both of which he was a quite admirable judge. In the late afternoon, if not pupils, work : i.e., writing, reviews, prefaces to people's books, his own books. He never called reading 'work'. 'Don't take a lot of books away with you, if you want to do any work.'

Then dinner. Sometimes Common Room after, but he was not at his best as a talker there. He wanted the definitely friendly background. 'Then, either' chat in somebody's rooms, till, say, 10, and four or five hours work after, or work till 12 or 1 , and then a prowl to find some one up : yarns and free talk till about 3 , then some reading before he got to sleep. Hence irregularity in morning hours. I remember his marching off with Gissing's Born in Exile after 1, and my finding it on my breakfast table. He passed a close cross-examination in it afterwards. There was a cock in the Camon's garden, overlooked by Powell's bedroom, which erowed at all seasons, a vice said to have been produced by Powell's candle.

Week-ends he passed in London, save when he had guests in Oxford, and he sometimes entertained guests when himself away.

Later, when he was freer, his Thursday seminar as professor was one of the great institutions, and professorial work took the place of tutorial. At the end he was librarian at Christ Church. Years before, he said that he thought he had had every book in the library through his hands.

You speak of his learning. One curious phase of it was a surface current of interest in nearly all novelty, side by side with the deeper love of learning, which was a driving force into learning all abont a variety of subjects, in any one of which he was quite first-rate.

His ummethodical character led to waste of time, as well as the demands of all and sumdry upon him.

His modesty was the most exasperating of his qualities. He had his warmest word of approval for patience.

His feeling for the dramatic quality of a yarn, and visualisation of it, were characteristic. The human element in it, the psychology, apart from approval or disapproval, had an inexhanstible charm.

His langh and his pipe are the things superficially associated with him : the latter only at night, and never over certain kinds of books.

It was the magnetism and the elusiveness of a series of 
unexpecteds that was most characteristic. The picture that lingers with me is one of short-sleeves, a pile of books to be reviewed before morning, and therefore an alternating attention between a drawing from an old master in front of him, which he would then take to bed lest his servant should light the fire with it, and a two-day-old erening paper.

I can always recall a phrase or two of Powell's except when I try. This too is characteristic.

For another kind of note the reader is in the debt of one of Powell's law pupils at Christ Church, Mr. W. L. Mellersh, now of Cheltenham. I have spoken somewhat lightly of Powell's calling as a legal tutor, and he assuredly deserved some larger one; but his tuition was not sterile, and we can watch him in the act of teaching and giving counsel. The stray pensées gathered by the care of Mr. Mellersh were not, of course, meant for print, but are worth saving: they are flying leaves that show the drift of Powell's mind about this period.

When I went to Oxford in 1891, as I was destined for the law, I deeided to take Pass Mods. and Greats and to read privately as well, and for this purpose I was put into the hands of Y. P. as a special tutor. He was on my staircase, and I got to like him so much, and found in him such a fund of kindness and sympathetic interest, that I took the liberty of appropriating him as my tutor generally : and he remaincd such, and my personal adviser, until I left Oxford.

One great point about which I camnot speak too much lay in his responsiveness and outspokenness in the course of conversation. His reply was always immediate, and there always was a reply, so that one knew what he was thinking, and such a course on his part broke down the stiff relationship of master and pupil, and enabled one to take him into one's confidence.

Looking back upon him as a tutor, I consider that he was not a sufficiently close reasoner to make one a good lawyer: but I derived enormous benefit from his lectures and lessons on Political Economy, and it was through his teaching that I gained the personal congratulations of the examiners on my paper on this subject in the Pass Schools. 
What struck me so was the ease with which he enabled one to take a wide grasp of a situation, whilst bringing ont all the salient and important points, sweeping away in so many words pages of unimportant detail as unnecessary except to be merely glanced at. His enunciation, too, of leading principles, compled with the delightful examples he gave to elucidate them from a practical point of view, left most vivid pictures in one's mind, and were obviously arranged so as to make one think them ont for oneself on future occasions: and certainly this was the result achieved.

As a general friend and adviser he was always at my service, always ready to make an appointment, and seemingly never in a hurry when he kept it, so that one felt that for that period one had his undivided attention. It was soon after I first knew him that he impressed upon me the importance of taking notes, not so much when reading through a book, but after picking up scraps of information, e.g. after a conversation. As a result I have his views on many subjects, written down immediately after I left him. The method he recommended was an ordinary half sheet of note paper (since such was always at hand) folded in three and put by with others in a box : containing the information thus :

\begin{tabular}{|c|c|c|}
\hline $\begin{array}{c}\text { Souree of } \\
\text { information }\end{array}$ & Subject-matter & Date and place \\
\hline
\end{tabular}

With regard to his sayings that I copied down, I may merely say that these are all notes of advice deliberately given, or opinions and information deliberately woven into a conversation, and not mere casual sayings. The majority of them were taken down after my last interview with him as a pupil, luring my last night at Oxford, in .June, 1894, when he very kindly placed two hom's at my disposal and talked to me abont my future : some of the other sentences are from a conversation of August, 1898.

\section{Political and social work.}

'Thinking is more useful than reading.'

'If prejudiced, read opposite arguments first, then real the other side of the question, and finally form your own opinion.' 
'If speaking, make short speeches, and put them clearly.'-As examples he cited Cobden's pitlyy arguments, Abraliam Lincoln's speech, Robert Lowe's speech at the time of the Reform Bill. As an example of the contrary he cited Bright's speeches, and stated that they left impressions of brilliancy rather than material upon which the mind could work.

'Ask questions everywhere, and put the results down as notes at once : no knowledge is useless.'

'I approve of all work done for' the poor: it all helps ; but try and get hold of the children, you can make more impression upon them.'--This opinion was given when discussing school and college missions, men's and boys' clubs, \&c., in which I was interested: he gave it again in a letter ${ }^{1}$.

'Do not flatter poor people : point out to them the fact.'

'If socialism is to come it will do so gradually; the world is not yet ready for it [1894], the reason being that people are not yet sufficiently trained in this direction.'

'Benevolence without seience will in the future be almost useless: and the man who will come to the front, if a crisis calls for one, must be a scientific politician.'

"In the present age, what Gladstone calls the "dreadful military spirit" is not nearly so harmful as the "love of Mammon", which he also stigmatizes. It is the love of Mammon, and party motives or the "jumping cat" which ruin our political system, and we might even be better without a Parliament.'

\section{Advice to me as a solicitor.}

'A closed mouth, but an open mind and face; make other's talk.'

'Read more law-books than seem absolutely necessary.'

'Help poor clients by persuading them not to go to law.'

'A solicitor must know something about everything.'

Religion, conduct, $\mathbb{E} c$.

'Keep out of theological disputes: all decent people have practically the same religion.'

'To some people it is a necessity that they should be bound down by some religious dogma. With me that is impossible : still I feel that life is not all a joke, but further than that I camot go.' 
'A curious part of the world is that we must make plans for the future, and go on just the same, and we may die to-morrow.'

'As regards life, there are two things that history shows: eventually the most complex forms in nature die out: and, the more civilized nations become, the greater is their tendency to lessen the number of children.'

'It is a question of great moment to what extent we are to follow nature where she urges us on, or where she checks us : in other words, to follow nature or our own impulses.'

'I look upon a runaway marriage as foolishmess ; but for' a young girl to marry an old man is wickedness.'

'Every man onght to marry, because he is not properly educated until he has been married.'

'You will find that in spite of more numerous troubles you will get much stronger as you grow older.'

'Keep up yomr interest in natural history, antiquities, and music; and mix with other people who take an interest in such things: they are always the nicest class of persons.'

In addition to his kindness, and his wide grasp and knowledge, what impressed me were his simplicity and love of simple things, especially in nature, and his fondness for hearing about children. Shortly after I knew him he introduced me to Howitt's Boys' Country Book (1840) as one of the best books ever written on country life, and quite one of his favourite books. About a year later I had the privilege of becoming a great friend of a little girl of eight years, a member of a comty family near Oxford, who was clever and delighted with the comitry and everything commected with it. The Professor was always interested in her, althongh not meeting her, and wrote ont a little statement for me to give her, in praise of Howitt's book. I lave mentioned these faets partly to explain a letter of his in 1894 which I enclose, but chiefly to bring ont, if possible, the delight which his massive brain took in simple things. He always impressed upon me to keep the child's letters, and I sent him some to read in 1894, and you will notice how pleased he was with them: in fact he afterwards satid that they should be published. It is somewhat irrelevant, but I may perhaps mention that there was so much in common between the characters of the Professor and the little girl, that I wrote some verses 
about them, in which I made a point of the simplicity of the nature common to them both. Sad to relate, they both died within a few months of each other.

He saw the verses, by the way, criticised them, was pleased with some of them, and then stated that every one should write verses, even if he conld not pursue this occupation further, since there was nothing that trains the mind better, with a riew to appreciating the great works of the poets.

After I left Oxford, until shortly before his death, I always found him the same, always kind, sympathetic, and interested in me personally and particularly in talking about everything that was nice in the world and tended towards progress; and it always seemed to me that it was this very sympathy and interest that really prevented him from tying himself to any one particular creed.

The ehange that followed soon after in his academic fortunes opened a new and difficult chapter in his life. 



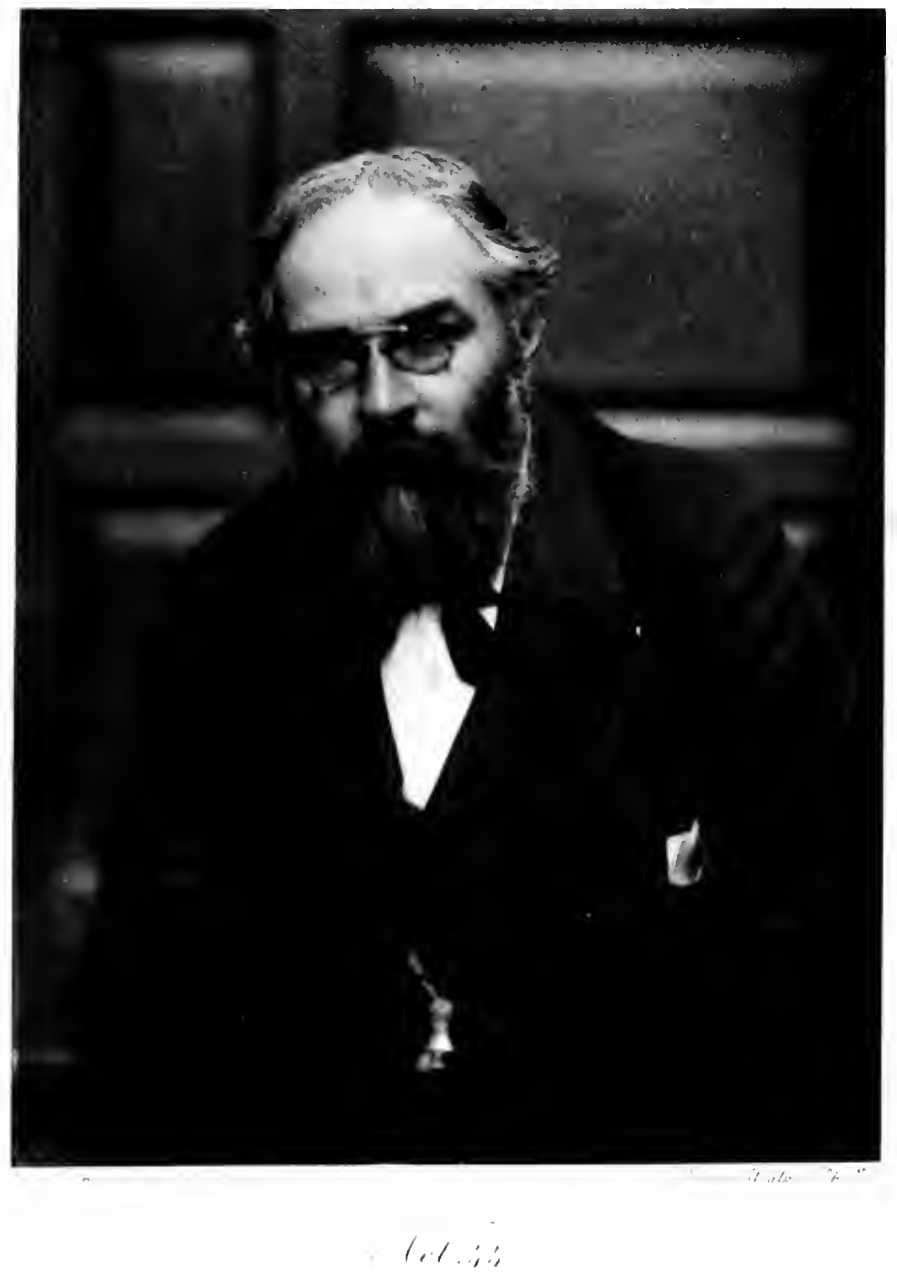




\section{CHAPTER V}

\section{THE REGIUS PROFESSORSHIP. WORK IN OXFORD}

Opinion on Froude. Position in Oxford: movement for Powell to be Regius Professor of Modern History. A mislaid bill from the Prime Minister. Acceptance of offer: misgivings on congratulations. Mr. William Hines: note on Songs of Labour. Letters of acknowledgement. On proposed memorial to J. R. Green : Irish history : attitude to Ireland illustrated. Death of Sime. Inaugural lecture, its fortunes: extracts. Address at Reading on the study of history. Ties with the College at Reading. Powell's conduct of the Chair: what he did not effect. T'estimonies, 1895-9, as to what he did effect: pictures of him in the lecture-room and out of it. His part in university business: Clarendon Press and 'Taylorian Institution.

Froude, who had held the Regius Professorship of Modern History since 1892, died in October, 1894. Powell had not called on him, or known him, or sought his acquaintance, but he by no means fully shared the attitude of Freeman towards Froude. He had not thought him dishonest as an historian: but his aversion towards Froude's mental processes was complete and profound. He strove to deal him exact justice, though he took no hand in any controversy in which Froude was engaged. He tried in vain, he says, to persuade Freeman that Froude was sincere in what he said. But he thought him untrustworthy in his presentment of facts, evidence, and reasons.

Mr. Fronde cannot be held up as a model to the young historian, for he handles his authorities as a wilful bahy does her dolls. . . There have been better books this seitson, but it is as readable as any that the British public is likely to come across for a long time ${ }^{1}$.

1 Review of Froule's Divorce of Catherine of Aragon in Nationul observer, 1891. 
And in an article urging firmly that Gardiner should be the successor to the chair, he wrote on Froude what he thought would be the judgement of history :

The demon of inaceuraey, of mistake, of reckless statement stayed by him all his life in all that he wrote. His persistent half-avowed disregard of fact was an ingrained constitutional and ummistakable characteristic of the man. It was this that angered men like Mr. Freeman, who understood prejudice and its effects, but could not stomach careless disregard or reckless perversion of fact. But this curious incorrectness is, of course, by no means so rare as Mr. Freeman supposed. It can coexist with personal piety, with religious zeal, with the strongest patriotism, and it has often been found in conjunction with these qualities. It is probably a mental rather than a moral defect. . . . We must accept men as they are; and while it is probably a subject of regret that Mr. Froude did not choose the fertile plains of romance or the enchanted forest of politics rather than the rugged acres of history, one must admit that he has not followed his mistaken ehoice wholly in vain. He has roused interest over 'the spacious days of great Elizabeth'; he has got the general reader to turn back to the times of 'that great king Henry VIII' ... He cannot be ranked with the thinkers, sealed of the tribe of Thucydides or Machiarel or Tacitus, any more than he can be reckoned among the followers of such men as Ducange. His place is with those who have made history the handmaid of rhetoric, a mere department of belles-lettres, a kind of pamphleteering on a great scale. . .

To form a correct estimate of the man himself, and even of his influence, is as yet almost impossible, nor is it our function. His works and his style have been sufficiently long before us to enable some sort of estimate to be formed with eonsiderable impartiality. It would be an ungrateful and indelicate endeavour to try and do more. One is not inclined to resuscitate the controversies of the past-religious, political, or historical-over a newly-made grave. And we may allow the dead man's works to speak for themselves, for he never lacked the courage of his opinions, and could always present his own case so that there was no need for apologists to come to his succomr. His work as Professor was conseientionsly performed, with his full strength, and down to the last. His interests were 
keen, his attitude dignified. If he were not the ideal of a Regius Professor of History at Oxford, the blame must lie with those who appointed him, not with himself. It is as a man of letters he made his mark, good or bad, in English literature, and it is as a man of letters he must ultimately be judged ${ }^{1}$.

Powell is there, after his wont, trying to say as much good as he can for one whom he dislikes and distrusts, but betraying the strain on his charity. He never cared for Froude's style, and the utmost he could say for it was that

no anthologist of the future will feel justified in refusing to admit 'specimens' culled from Mr. Froude's writing among their examples of characteristic 'Victorian' prose. If good judges may be trusted, the one work of his that is certain to survive is the apologue in which he has best displayed his picturesque talents. To have written one work that is of permanent literary worth is surely not to have lived in vain ${ }^{2}$.

This, no doubt, is extreme: Powell may have been warped here by his engrossment with the purely seientifie view of history, and by his suspicion of the writing of history considered as a fine art. And there is little sign as yet of any sympathy with the general attitude, patriotic, imperialistic, conservative, of Froude. We shall see how in the next ten years l'owell's own bent in this direction came out or deepened. Thus he was afterwards led to make certain concessions, though his language becomes stronger as to Froude's methods; and at this point may be quoted a subsequent letter where the change appears.

\section{To J. B. Yeats.}

Jan. (;, 1902.

I have never 'defended' Froude. I said his theories were generally right but defended by lies. . . . I don't like his style. It is jonmalistic and slipshod, but it is immensely admired by journalists (wrongly). I don't know anything about his honesty, save this, that he did his work well

1 Manchester Guardian, Oct. 22, 1894.

2 Ibid., 'The 'apologue' may be A Siding at a Irrilway Station, first published in Froser (1897) and then in short studies, rol. iv. 
at Oxford, and gave good lectures, and generally did his duty even when he was not in good health. I don't think he was dishonest. He did care for his ideas, but (like your friends the Jesuits) he bolstered up what he took for truth with lies. I never liked him, but I don't want to judge him unfairly or unjustly.

The feeling that Gardiner should be offered the chair was gencral; but he felt that his proper work would be interrupted, and declined. A movement then grew in Oxford in favour of Powell, which proved successful. He was now forty-four. His labour with Vigfússon had spread his reputation among scholars who attended to Icelandic. But the importance of the subject was still little understood; and his work had been as much literary as historical. He had written a volume 'for the middle forms of schools', which did not resemble a piece of historical inquiry on the great scale, though behind it lay the toil we have recorded. He had never officially tanght history at Oxford at all, except during the brief spell at Trinity, when he was supposed to have failed, and except when he had lectured as deputy during Freeman's absence in Sicily. He had also in 1889 finished Freeman's course on the Bayeux Tapestry. He had had private pupils at Christ Church in history, where he was lecturer in law. Nor was he known to be busy with any definite task except Origines. He had not made public his clear-cut theory as to the province of history and its divoree from ethics. He was not known to lecture well. His gifts for organization, academic politics, and the fray of committees were eren less apparent. He had no zeal for examination results and labels. He was unobtrusive, and regarded the lust for promotion and social importance as a dull comedy. The reading public hardly knew of his existence, except through his little manuals for children. Many of his fellow-historians in Oxford might have considered themselves as rivals for the Regius chair. Yet, when it was known that Gardiner would not come forward, there was 
a kind of acclamation among them in Powell's favour. Public opinion already marked him for a future professor ; and the wish for his appointment, should Gardiner refuse, was general, if not universal.

His learning was already something of a legend. It streamed out in his talk as from an unquenchable spring. Every one could learn from him : it was clear that he had in his head the material for many books. He was already known as a counsellor and inspirer. If he could not drive and drill, he could guide and encourage. He could find historians, whether or no he wrote histories. If he was not a committee-man born, he gave sound advice, he had liberal views on policy and reform. His gifts would have their right scope, if he found leisure and recognition. Moreover he was a man to work with; palpably singleminded, amenable to reason, void of assumption, free from craze. His play of mind and sympathy was surprising; men felt it radiating from some source that was denied to themselves. He was full of the unforeseen, of cross-lights, he was always growing and leaving himself behind. Altogether, he was the man for the place, he was the biggest man available. Oxford society is a sensitive web; it responds to influence of this kind, even when it only partly understands it. Some words from an obituary note on Powell may be given in illustration.

All through the early part of his career, York Powell, though not officially oecupied in teaching history, had been the chief influence amongst the younger students and teachers of history in Oxford. Some of us who were young graduates in the eighties remember him as a frequent chairman at the meetings of the now long defunct Historical Seminar, an Lissay Society in which both senior and junior men took part. On these evenings, though the art of set speech-making was not that in which he excelled, he brought together what was valuable in the preceding discussion, and his alertness of mind and astonishing range of information enabled him invariably to throw new light upon the matter before us. One occasion may be men- 
tioned. The subject was the contest between Henry II and St. Thomas. Few topics could be supposed to appeal less to Powell's choice. Yet when the paper was read and the talk ended he sat in judgement and summed up with masterly ease and knowledge. On one at least who was present his statement of the archbishop's case left an enduring impression for its appreciation of motives, and for its insight into the deeper principles underlying the struggle. The fact deserves recording, for Powell's mind was so keen to feel the life and movement of events-how men looked, and talked, and dressed-that one sometimes thought there was no room left for an interest in principles. And, indeed, the times when he showed this interest were not common ${ }^{1}$.

An historian was Prime Minister at the moment, and had the direction of the Crown appointment. Lord Rosebery's offer came in an envelope which in the expert opinion of Mr. Heath, Powell's devoted little elderly dim-eyed 'scout', unmistakably contained a tradesman's bill. It therefore did not invite attention. On the contrary, it was put behind the clock (another version says in a top boot), along with other bills, and lay unopened for a fortnight. Then an inquiry from the Premier's private secretary brought the document to light.

The offer for a while alarmed Powell's modesty. He was not elate. He was little satisfied with what he had already done, and was not sure of his fitness for such an office. He disliked public appearances, and his native self-mistrust was not easily laid. Money profit was hardly in question. The income of the chair, nominally $£ 900$, was much diminished by the shrinkage of the rents of the endowment. Thronghout his tenure it averaged about $£ 660$. The benefactions of Mr. Rhodes to Oriel ${ }^{2}$ College, of which

1 Oxford Magazine, May 18, 1904 (unsigned).

2 Mr. L. L. P'rice, of Oriel, has been good enough to furnish the detail. The normal pay would have been $₫ 300$ from the University chest, $£ 200$ from the college as 'ordinary fellow', and $£ 400$ more from the college ont of its corporate revenues : $£ 900$ in all. But agricultural distress perforce reduced the $₫ 200$ to an arerage of $£ 160$, and the 
Powell now became a 'professor fellow', and his ties with which will be chronicled in another chapter, came in the last year of his life ; they would indirectly have given him the full professor's income, but he did not live long enough to enjoy this improvement for a year. Thus Powell would be little richer, if at all, for the preferment ; but he would be freed from teaching the alphabet of law. $\mathrm{He}$ would be richer in leisure; he conld not refuse the chance of greater influence and concentration. He therefore accepted the offer, but his ensuing letters show in what mood he did so.

To one friend he wrote:

Very many thanks for your kind letter, which has encouraged me. I often despaired over my work. I felt it was so far below what it might have been, but I was so pressed with work and want of leisure : but I did what I could.

\section{To another :}

I was never ambitious, and I never thought this post would have been offered me, and I hesitated a good deal over taking it, and I hope I decided right. I am glad, at all events, you think so.

To another, Professor Thomas of Haverford College :

It has been an anxiety as well as a happiness, and a deep regret to me-this appointment. My wife, whom it would most have pleased, is no longer with us. Her death has made my house very different, and my life too. You, who saw her, will know this even from the short visit you paid us [in 1886].

$£ 400$ to a fixed sim of $£ 200$ : the authorities having power to make this latter reduction if certain other clains in their view took priority : as, owing to the dwindled rents, had to bo the case. Powell, it should be added, was relieved from part of the statutory number of lectures owing to this inability of the eollege to make mp the fill income, and was placed on the footing, as regards that number, of professors whose stipend is on a lower scale. (In fact, ho lectured oftener than by this arrangement was necessary.) 
To W. L. Mellersh. Christ Church, Dec. 27, 1894.

I like the letters immensely and return them. The picture of the unfortumate youth taking a header in his clothes is beautiful, and would enlarge finely on a magiclantern screen. You must keep these carefully.

I am very glad of having been any use to you, for one despair's sometimes of being any use at all. I should like to see the verses. C. liked the letters and langhed over them merrily. I am glad Howitt's ${ }^{1}$ book is appreciated. It is a gem in its way, and a good way too. Your congratulations I thank you for, and I only hope that ten years hence I may be able to congratulate myself.

My lore to the Urling Smiths.

I am most glad you are making yourself useful to other people. It is a fine piece of education, and if you help poor folk to help themselves, it is a great gain. Try to get at the young ones: they are more plastic, and may be materially assisted both in head and belly.

I can't write more now, but I wish you many happy ycars (and happiness is largely of our own building or destroying) and good fortune, and lots of jolly children of your own.

\section{To Sidney Lee.}

Christ Church, Dec. 24, 1894.

Your letter is very kind. I value your verdict. You hare done a mighty work for English history, and I envy the feeling of satisfaction with which you can look back on so many well-spent hours. You are the Regius Professor in London, whoever may be at Oxford; gratia Dei if not gratic Regince.

I will come with pleasure, 8th, 7.45, at Reform Club. I am, your's faithfully.

You must let me write an article for you some time, so that my name be in the Liber Vitae.

\section{To T. H. Warren.}

Bedford Park, Dee. 24, 1894.

I think your letter is one of the kindest I have had. I have thought of the [Horace] Club, and I have often thought of Vigfiusson and Freeman. I had a good deal of

${ }^{1}$ For the allusions in this letter to Howitt's Boys' Country Book, and to the verses and picture by a child, sce Mr. Mellersh's reminiscences on pp. 166-7. 
hesitancy over the matter, and I hope I did right in deciding as I have done. It is a grave matter to follow men like Freeman and Stubbs, and I know how grave my shortcomings are, but $I$ have put my hand to plow, and must do my level best anyhow.

The kindness of my friends heartens me up on one side, but firightens me on the other, and I know I shall need their indulgence more often than I can earn their applause.

I wish you many happy New Years and a happy Xmas, and am thanking you for your kind letter very heartily. Yours faithfully.

One inhabitant of Oxford whom Powell held in special regard was his firiend $\mathrm{Mr}$. William Hines, whom he would call 'one of the most sensible men in the place'. Hines lived by sweeping chimneys, and also by the profession of a herbalist: but his true calling was polities and oratory. He was at first an 'old radical', and consorted with radical dons and citizens; but latterly he inclined to socialism. He had a fiery sympathy with country folk and the poor, and plenty of sharp practical sense. $\Lambda$ born speaker of the open-air kind, his changeful metallic voice, mobile hairless face, with strange sagacious wrinkles that seemed to have been gathered in the elf-world, and clear gray-blue eyes, were known on the rillage-greens and platforms round about. To him Powell wrote:

Dec. 29,1894 .

My hearty thanks for your kind letter, and my best wishes for you and yours during the coming year and many to follow.

I hope I shall be able to fill the post without lowering the standard of work that men like Freeman led us to expect from it. There is one thing certain: it will in no way diminish our friendship.

Mr. Hines had put together a penny garland, Somgs of Labour, collected out of poets firom Shelley to William Morris: and before resuming Powell's letters, the preface that he wrote for it in IIines's behalf may be resened here: 
This little book of songs has been put together for labouring men and women. It will give them songs to sing at meetings, at work and home, and the music for each bit of verse here can be easily got; many of the tunes are known to nearly every child.

Some day the compiler hopes to put together a bigger book with more songs, and some good pieces that will do to recite; but meantime he hopes, and he has some reason to believe, that this little book will be welcome.

It is time labouring folks had their song-book. There is no other way of keeping up good fellowship and brotherhood between labouring folk than by song and music. There are plenty of songs of pleasure, and of war, and of religion: why should there not be more Songs of Labour?

The men who wrote the songs in this little book were of many different classes, plowmen and gentlemen, artists and schoolmasters, authors and labouring men, but they all alike have felt that those who toil in England have not as yet the just recompense for their honest labour, and they have all alike felt that if those that toil are but true to each other and to their hopes, there is yet assuredly a good time coming in England for them; and the compiler earnestly hopes that the good time may come soon, and that this little book may be of some help to bring it by putting hope and independence into working people's minds. ${ }^{1}$

This deseription of the authors of the songs might express the variety of Powell's friendships : the next letter is to Bishop Creighton.

It is good of you to spare time to write me. I feel the burden I have chosen to take up is a heavy one, and must be. I don't enter on my path with any other feeling than that of hoping to make a few students at Oxford, to go on with the work you and Stubbs and Freeman and Gardiner liave done and are doing. You have helped us at Oxford so much : I am sure the Eng. H.R. is doing good, and but for you, Poole and I could never, I think, have put the thing through.

I should never have accepted this post if I could have

1 Labour Songs for the Use of Working Men and Women. Compiled by William Hines. One P'enny. Abingdon. [1893.] 
persuaded Gardiner to have taken it, but he found it would be incompatible with his work.

I wish you were not a bishop, but teaching history by word of mouth every now and then as well as by book. You are the kind of ideal Oxford men look for as professor. I have no clain on the Historic Muse save that which a charmed and fascinated suitor imagines he has on a beautiful lady.

Life is pretty full of humour, but I feel this work before [me] is serious, and I hope I have done right to take it up. I tried to decide honestly. You have always shown sympathy for me: I hope you will not forget that I shall need it more now than erer : for though I don't much care what my enemies say, I do care about my friends' opinion very much.

Pardon my long letter, and the awkward way I put things that I would fain put well, and believe me, yours very gratefully.

\section{To Herbert Greene.}

These to his singular good friend Mr. Herbert Greene his poore Servant to command and well-wisher sendeth.

Amice mi quia mihi impossibile est apte et rationabiliter et sapientius tibi respondere, I betake myselfe to our good commone tung in the $\mathrm{w}^{\mathrm{ch}}$ I haue more skill, howbeit the measure thereof be but of a moderation; and chiefly and at the inception of this myne humble pistyl I would thank thee hartily for thy goodlie picked phrases and choice Ciceronity of Latyne (in the w $^{\text {ch }}$ surely I envy thy attainment and exceeding rediness) employed in my poore behalf, a thing certainlic of greate honour to me, and to my friends moste exceeding pleasant. And next I would exhort thee diligentlie to flee all public readings and discovrses at large and inauguralitieral ceremonies, and I do hereby charge thee not to present thyself on any occasion when I am compelled by the duties of my cathedral post (if a man may so speak) to harangue them that sliall come to me by reason of youthe, follie, idle curiosity and inquisition (motives unworthie of thy true and Khayamatic sapience and virtuous philosophie). I charge thee, I say, to void and quit and withhold thee from that place and time. For surely there be times when the inner doctrines may be in private fitly discrssed and treated between maisters, such as thou and I be, 
whereas for the unlerned and lewed much superfluity of speche is needful, and that pithie laconismus that ravished the soule of Plutarch, and the more delicate sprite of Plato himself, cannot be used or aimed at.

Thirdly I would commend thee freelie, my friend, in that in obedience to that subtile and exquisite poeme of the maister physician, Francis, thou art studiouslie given to the parfyte and patient occupation and diversion of ball-play, without which indeed the Englishman doth shortly wither and perish miserably, or by superfluity of nurture take flesh and fall into a subspheric or toplike form that is greevous to behold and tiresome to him that is so clothed about with a too solid and extensive mortality.

Wherefore, my good friend, commendation, exhortation, and declaration of gratitude being the three points of my discoursing, and they being performed duly, my subject is as it were fulfilled, and my pen may cease her labour.

But ere she be left to her rest, I would bid thee not place thy hopes touching me too highe. This charge is no light one that I have taken upon me, and I am a man to whom an ant is a burden, thongh my will be goode. And these thinges I tell thee lest thou by expecting great thinges should despise the small profites that haply may come of my long-continued toiles and laboures.

And so I praye God have and holde thee in his safe keeping-thy frende F. Yonk Poweld.

From my poor House at Christ Che this 27 th of December. [1894.]

\section{To Wilfrid Scawen Blunt. Christ Church, Jan. 14, 1895.}

Your letter has given me great pleasure. I have such respect for your beantiful work, that a kind letter from you has a real value to me. I think you have many greater claims to the post I hold than I have, for you have been making history and preaching it, while I have only been researching into the far past: but I have not forgotten to read every word I could find that you have published, and if I could get a year's free time I would learn Arabic. Eastern things have a great fascination for me. I get hold of anything Arabic or Persian that is translated, and your story of the Mare was a boon to me. I hope you will do some more. The Arabic old 
poetry seems to me exceedingly beautiful, and the prose romances are more like my own Scandinavian Sagas than any other form of literature is, and I naturally take great pleasure in them. One of my hopes is that some one will give us a beautiful English version of the Kitab-al-Aghani, which seems to me one of the great things in all literature.

Poor old Potiphar! I am afraid I sympathize more with Zuleikha than with him or Joseph. It is pretty of the Teutonic poets to give her satisfaction in the end and 'reunion with the beloved'. She is a little harshly treated (as was ineritable from the point of view of the narrator) in the Bible.

It must be delicious in Egypt now. We have had more light than we have had for years in winter, these last months, but cold and wind lately, and even the finest winter here is but a pale beauty to the southern warmth.

I don't know if you know how many of the young men admire and cherish your work. I am always coming across them. I think the Proteus sequence, Esther, the Bullfighter, the poem on your home in England where you and your daughter are together, are the favourites...

I need not tell you how glad I should be to see you at Oxford, where I have a room at your service, with such rough fare and quarters as Colleges supply. Again thanking you for your kind expressions, I am, yours faithfully.

The next letter was written to Mrs. J. R. Green in reference to a proposed memorial to her husband '. The closing sentences give an idea of Powell's more than ever crowded days. He was arranging his new work as professor.

Christ Chureh, Jan. 23, 1895.

The best memorial for Bodley would be, I think, either a picture (engraving or other) taken in life, or a medallion or low-relief portrait. $A$ bust is an awkward thing to place in a good light, and takes much place in a library, so that the temptation is to put it up high, out of a truc light. $\Lambda$ medallion or low-relief morlelled in elay or cast. in bronze is easily well placed and seen. It is usually better not life-size for the kind of object you have in

1 Projected casket in honour of J. R. Green, to be designed ly Mr. Alfred Gilbert, the sculptor; the idea was not carried out. 
view now-perpetual exhibition in a famous historic place. It can be mounted so as to give plenty of room for inscription and dedication, \&c. Such a thing by Gilbert would, of course, be a treasure to Bodley's Library.

I am not speaking officially in any way, of course. I have no authority. I can only tell you what I think myself. I am not much in favour of memorial portraits in oil or water-colour ; they so easily lose the resemblance, while keeping, of course, a certain vague likeness that is only puzzling. I think a medal or the like often more successful. I have known striking likenesses modelled from photos.

A memorial tablet I don't like the idea of. A casket to hold the MSS. with a medallion at the top (not bigger than this line in width-the medallion I mean) would do very well.

I think you would not need to go to Paris at all. If Gilbert made a medallion and designed a simple casket, he would know where the cast in bronze could best be made. They cast well in Italy as well as Paris, and he has had great experience of all such work, and can be trusted to know.

As to myself, I am winding up arrears, trying to make a fresh start, and tackle something. It is a mistake to think of listening to me. I don't lecture well save by accident (I don't know whether I ever shall)-it seems unreal to me, unless I know that people care for and understand the subjeet: and I don't know or care about them, and feel like hitting a pillow. I can talk [at] a small lecture all right and enjoy it. But public lectures are rather absurdities now that we have books, save occasionally to emphasize or expound something into which one puts one's personality.

... They want an organizer at Cambridge who would carry the School over its early difficulties at once with a rush, and strike out an independent line, and get people to like and hate him.

Your third point I confess puzzles me. Irish history is a terrible thing. The Irish hate the plain unvarnished truth about anything they really love and care for, and those that care for plain nuvarnished truth hate the Irish usually, and the result is that the historians (like Lecky) miss their mark by their stifl attitude. You must be 
prepared for abuse in plenty, whichever side you take. A good history of mediaeval Ireland is really wanted, and it is less a battle-ground than any other part of Irish history. Any one who eares for truth and loves the Irish and will write on history does an immense service to Ireland and England too, that I am sure of. But you know all this. I can't advise you really. I only know that when I read what Irishmen usually write (always excepting Lecky and Prendergast) about their own country it saddens and siekens me-the blind party spirit, the disregard of fact, the blatant sonorous stuff: and one can only get rid of this by having something better put in its place. A history of Ireland in three volumes, eheap, and clear, and as unprejudiced as it could be, would be a boon (but it would never pay, there would be fierce attacks and worry without end) and a true martyrdom, - a bearing witness, against men and devils, of the realities.

But I think mediaeval Ireland is safe strong ground, and, while clearing away much rubbish, would give a good departure for later work.

Todhunter has just done a sketch of Sarsfield he lent me to read in MS. It is very good, especially in the battleparts. He has done the Boyne and Aughrim better than any one else has yet done them, truly, and withont being blinded by notions.

I hoped to have seen you at Christmas, but I was first choked with things to be done, and then got a cold that made me glad to sit still a bit, and then [R. L.] Stevenson died, and I had a lot of pupils to see, and C. to take about, and work here to arrange. The time flew positively : but I am not forgetful and hope to see you soon. . . . This is a babyish letter, full of repetition, \&c., but I think you will understand what I mean, though it is talked rather than written.

The last letter may introduce some other things that Powell wrote about Ireland during these years. He loved her, he came partly of a sister nation, he answered swiftly to the touch of Irish talk and faney, he was one of those Englishmen whom Irishmen more than tolerate: some of his closest friends were Irish, and often 'rebel'. He had been all for Home Rule, as we have seen: would have liked, earlier, to 'go over and help Parnell and Davitt all 
I can'. He had held by Parnell, and had resented Gladstone's abandonment of him. He disliked, even with passion, the Irish public men who spoke evil of Mrs. O'Shea, and refused to speak to one of them. He thought the reaction of the Irish on the English genius beneficent, and we shall reprint his address on the subject given many years later. He learned the Irish tongue, and promoted the movement for its furtherance, as well as the revived study of the old literature. His trip through Ireland will be described hereafter, and the zest with which he went everywhere. He was a good friend and admirer of that country.

Nor was he this the less, because to read her history and to be in Irish company seemed to bring out John Bull in him. Amongst ordinary Englishmen he seemed foreignsouthern or 'Celtic', with his swift emotions and witty intuitions, and quick dark eyes. But amongst the Irish, a stubborn, underlying, judicial tone-that of the historiancame out; he paused and discriminated sharply. His English patriotism was often roused, and took care of itself well enough against what he thought misconstruetion, as his letters of 1901 and onwards will duly show. Now, in 1895, he is chiefly anxious to have the whole truth about Irish history, which neither side had as yet shown itself qualified to write. Some remarks put together from reviews of 1894-6 bring this point home. The first of them opens on a constant text of Powell's : he would hardly talk about 'race' at all, and thought that 'bogus' uninformed race-theory is one of the great estrangers of peoples.

Much misehievous nonsense has been talked about ' race', and descendants of Cromwell's Ironsides and James's Scotch settlers have been eredited with every evil 'Celtic' quality. It is not so much race as circumstance that has produced and kept up the passionate elements in Irish thought and feeling. 1798 and 1842 are not so very far oft, and the sons and grandsons of the sufferers of those dates have had but short time to learn forgiveness and forgetfulness; and the long ficree land war has hardly ceased, and the ashes of religious persecution are searcely cold. 
In another passage we are at the sources of his sympathy :

. . The absurd fizzle of 1848 , whose real heroes were men like Davis and Mangan, whose words are still of power, while the honest absurdities of Smith O'Brien and Fergus O'Comnor are justly fading into oblivion. . . . The [Irish] peasant has been more cultivated, more refined, more open to the delights of imagination, happier in his family relations; children have led more natural joyous lives, the aged have been better loved and more kindly cared for ; there has been less of the snobbery and pursepride that beset wealthy communities. The sour dull doumess that repressed natural pleasures over whole classes of the community for many decades in this island has been unknown in the Celtic parts of the sister isle.

The wish in the third passage is prophetic. The Irish Text Society is founded, Powell was one of its presidents: the movement has grown and marched since he wrote, and will be referred to again.

Is it too much to hope for the establishment of an Irish Text Society? It should publish in handy, clear-printed form the unpublished texts of each division of the tongue, early, old, middle, and modern Irish, with rersions, if possible, into plain Euglish or Latin, as may be most convenient. There is matter enough unprinted to keep such a society going for a century. It is a disgrace to Irishmen that they have neglected their own tongue, and contented themselves with the thin culture to be drawn from rhetorical English speeches of Irishmen from the end of the last and the early years of this century, and with a few verse translations that smother half the beauties of the original. It is the alien and the immigrant in Erin that have done most of the work that has rendered the oldest MSS. available to us. It is a Frenchman who is making the Irish laws accessible to the student of ancient institutions, and an Englishman who has secured the printing of mpublished texts and traditions, which Irish publishers will not attempt. It is no use disputing where the fault lies for all this, if it is not being bettered. No amount of board schools or material prosperity will make up for the loss of the wealth of beauty and true culture that was wrapped up in the old poems and traditions that are dying out 
perforce with the old tongue. . . . [Bnt]' the day of storm is not the day of thatching', and those who care for the Irish tongue must bestir themselves ere it be too late.

. . . The author's plea for the study of the Celtic literature and remains in these islands, as a fruitful subject of research and as a patriotic duty, should be taken to heart by the Universities of Wales, Scotland, and Ireland, as well as the English Universities, which are, indeed, far more awake to their duties in this respect than those of the Celtic countries : witness Dr. Kumo Meyer's excellently edited texts and faithful translations in this very book. ${ }^{2}$

In March, Powell was sadder for the death of James Sime. He had suffered no such blow since the loss of Vigfússon six years before, and was to suffer none such again till six years later, when he lost R. A. M. Stevenson. These three men, whom he could spare perhaps worst of any, he outlived. The verses that are printed hereafter he wrote upon the burial of Sime. ${ }^{3}$ His letters show once again how much more than most men he lived in his friends, both when they were with him and after they were gone.

\section{To Oliver Elton.}

April 2, 1895.

I have been in much trouble about Sime. I miss him dreadfully. He was unfailing in one's quandaries and stumblings in life, by reason of his sympathy and sincerity and his complete lack of selfishness of any kind. It did one good to be with him, and he made oue feel better possibilities were in one than one had suspected. I think there has not any one died in Bedford Park that will be more regretted, or so much.

The burial was sad of course, but not so sad as I feared. One felt that the toil was over, and one's mind was full of loving memories of the man. ... That study of his, I was

${ }^{1}$ Review of Donglas Hyde, The Story of Gaelic Literature, 1895. This and the other extracts above are from The Manchester Guardian.

2 Review of A. Nutt, The Celtic Doctrine of Rebirth, 1897.

${ }^{3}$ Powell also wrote on his friend in the Dictionary of National Biography, vol. lii, pl. 253-4: 'He had planned a history of Germany on a fairly big scale, but the claims of his everyday work and his premature death prevented the realization of the scheme, for which his wide reading and sound judgement eminently qualified him.' 
only in it with him a short time back, and he cheery and heartening me up over my coming work at Oxford, and now it is all over. I am glad you knew him and Vigfússon. They were of the Company of Truth and Charity.

\section{To Eduard Clodd.}

April 4, 1895.

I haven't had such a loss as Sime since Vigfússon died. A fine, delicate, sympathetic man. A man both pleasant and comforting to his friends and full of charity to all. I never heard him speak ill of any man. I miss him terribly. I used to go round to him once a weck at least when I was at home and we talked on till the small hours. It was good to be with such a man. He drew the best out of one, saw the better possibilities in one, and heartened one up. Death 's busy dropping shots, and somehow picks the best of our little company first.

The Bool: of Enoch keep till its use is fulfilled to you. The Bool of Jubilees is coming, and there's a good book on the origins of monachism, Philo's treatise de Vita Contemplativa (a beautiful example of keen English scholarship) by Conybeare, just out. You will find good pickings in it, but of course the bulk of the book is for professional specialists, and discussions of textual criticism. The purport of the book is striking. Eusebius got round it by a bold assumption. The modern apologists can't do that now. Have you read Howorth's excellent letter on the Septuagint? He has made some discoveries over Ezra and the later prophets that are of lasting moment.

Isn't 'argon' and 'helium' fine? We can make our German friends sit up now and then. You can't help being patriotic and hopeful over such things. So much German work is sham and insincere whenever one tests it, and they brag so over their work. They sicken me as the Americans do. I am getting more and more jingo.

Is Allen still frightened over his book ? ${ }^{1}$ I tried to reassure him. There is nothing new or startling in it, but he has managed to catch the Philistine's ear. It is silly to bother about 'answering' his critics and he does not do it well.

He is such a good fellow and so earnest, and so deaf to the comic sicle of things that he has always an open place to be attacked in-and it hurts him.

1 The Women who Did. By Grant Allen. 
Have you read Emerson's Birds, Beasts, and Fishes of the Broads (Nutt)? It is excellent. What days are you at the Savile?

The public lecturer is a poor relation of the actor and the teacher; theirs, no doubt, are the nobler callings; but Powell underestimated the Iecture as a means of letting light and air into half-awakened or stagnant spirits. His own motive power told at closer quarters; at this time of his life, it secms to have been dispersed and lost when he, faced the public. Eight years later, his style had gained in authority, and his elocution in slowness and confidence, though he never had the brazen, professional front and voice. He was afterwards able to hold seven hundred Manchester working-men, who are hard to please, without rhetoric or effort for an hour and longer. The Survey of Modern History that he wrote for those hearers in the last year of his life is more telling in arrangement, and has a larger sweep of vision, than anything else he did of the same kind. Now, on April 25, 1895, he had to give his imaugural address as professor in the Examination Schools; he did not care for the task. Froude had accustomed the Oxford audiences to his skilful and compelling performances, into which he had put his best-all his simplicity, transparency, and pictorial skill. Powell came in with a very plain tale: he misreckoned his time, was troubled with his notes, and stopped abruptly after half an hour. Oxford went away disappointed and baulked; the lecturer had 'not given value': he was known to brim over with information and ideas, and his hearer's had come largely for mental entertainment, for literature. When he had jerked ont his earnest adrice that they should look to the calendaring of state papers and the exploration of local archives, and closed with the eulogy of three recluse scholars whose names they dimly knew, they conld hardly believe that it was all over. There is no sign that Powell thonght he had missed fire, muless it be that he did not print the lecture in the customary way a compressed 
newspaper report is all that remains of it; which he put in his Scrap-book and headed, 'My Inaugural of thirty minutes.' Read now, we see that it sets forth elearly and well, though too briefly, his hopes and fears for historical study, and the spirit in which he was to set about his work as professor. The omissions are also significant. There is no hint of any philosophy of history, no reference to any theory on that matter, Hegelian or Comtist. Nor, again, is there any trace of the sharp opinion, which he must already have formed, and afterwards uttered on all occasions, that history has nothing to do with ethical judgement and is a branch of pure science. This opinion is only latent in what he says about the reformed methods of study. Nor does he touch on the literary side of historical writing. He does not praise the style of his forerumners, nor does he lay down, as afterwards, that the man of letter's as such has no more to do with the historian's work than with the biologist's.

Much of the address ${ }^{1}$ is praise of persons. After a tribute to Freeman, it proceeds :

Of his suecessor it is more difficult for me to speak, as I never knew Professor Froude, but I hope I can appreciate his careless courage in maintaining his views, the easy skill with which he set those views before the public, and the steady devotion he displayed in the duties of his office among us down to the last. Two, happily, are still with us; one, Mr. Goldwin Smith, the Paul Louis Courier of our times and tongue, self-exiled too long from the spot that knew him best; and the other, Dr. Stubbs, whose gigantic and persistent work lanks with that of Coke, and recalls the renown of our learned Bishops of old.

Then, after due honour paid to Gardiner and Thomas

1 The report is in the Oxford Chronicle, thence copiel into The Academy of May 11. The passages quoted in tho text have been put back from reported speech : this may properly bo done, as the extracts show signs of correction and approval in the Scrap-hook. The whole is not quoted, as the Survey, which opens vol. ii. infira, may be taken to supersede it. 
Arnold, Powell tells the Oxford historians what is required of them:

First, I put the absolute need of orderly collection and registration of facts as acknowledged by all students. We have hardly done, perhaps, so much in England as might be done in this direction, though the shelves which bear the Government series and different societies' publications, and the long ranges of that biggest and most useful of modern English histories, the Dictionary of National Biography, might plead eloquently in our favour. But much remains to be done, and no country is so rich in documents. Thousands of important papers dating before the Reformation are as yet uncalendared and unread. Every year the pioneer work of the Historical Commission discovers further treasures, and points the way for workers. A few year's' skilled labour, and this vast material might be rendered at least accessible. The publication of a few cartularies, a case-book, and an incomplete set of year-books, has largely rendered possible that fascinating history of English law which has lately done so much honour to the sister University. Our economic knowledge of the fourteenth and fifteenth centuries is largely due to those sturdy volumes of Oxford Accounts which we owe to Thorold Rogers. There is no lack of power amongst us; what we want is the opportunity and the organization. The crying want at present is that of local archives, worked by trained scholars, and this the country might justly be called upon to supply.

Two years later we shall find Powell earnestly pleading in detail for an École des Chartes, or at least for a modest comnterpart thereof, in England. Now he passes on, and next calls on anthropology, as the handmaid of history, and as furnishing a mass of matter once regarded as 'the waste product of the human mind'. He pays his tribute to the work of men like Mayne, Lyall, Gill, Codrington, and Campbell, who had garnered such material from India, from the South Seas, and from the Highlands. To come

to understand that in the past there were people (and that the vast majority of people living to-day might be classed with them), whose reasons, when they reasoned, were 
entirely different from those that would influence us, is already to have learned a valuable lesson. The Middle Ages are further off from us than the second century, and the Australian black fellow is more antique than the Parthenon or even the Pyramids. To read the records of our own ancestors, even in their own handwriting, is hopeless, withont we try to understand their habits of life and mind. Homer and Aristophanes, the Parthenon and the Mycenae tombs, give us more knowledge of the Greek mind than we can get from any historian alone, and the papyrus with an old folk-tale lets us see into the life of the ancient Egyptians as no chronicle could. Béowulf gives us more English history than Asser's Life of Alfred.

Besides this lore, which is 'part of modern history, the history of peoples under our flag', there is economic history, as in 'the serried pages of Charles Booth's tremendous study of modern London'; and the history, as yet unwritten, of the making of the Empire-of our colonies, of our Eastern possessions; and local history, and legal history, and the study of foreign history in England; in each field he names the labourers. A single sentence is given here to the educational aspect of history : the idea is worked ont at length in the Bangor address of 1902 : and his Lecture by Letter to the boys of his old school, written a few months later, is a pleasing sequel.

As to the educational aspect of history, what we want in children's schools are books on the lines of Plutarch rather than Eutropius, giving the more salient personalities that have made England into a United Kingdom and built up the Empire. I can name no better authority for this opinion than that of Gencral Gordon and of John Brown of Harper's Ferry.

Of the Oxford School of History, in whose struggles he has borne a part, he only says that he will saly nothing. He ends with his word of public honour to his three friends :

To the living I hope I have already acknowledged $\mathrm{my}$ debt, but there are those whom I would fain have thanked 
to-day-my comrade, Richard Shute, most faithful of critics ; my friend, James Sime, ever suggestive and sympathetic ; and my master, Gudbrand Vigfússon, of whom I may speak as his disciples spoke of the sage of old, that of the men they had known he was the best, the wisest, and the most just; all three men alike in their untiring devotion to and zeal for that Truth which, in the words of the Irish proverb, is 'the historian's food'.

We can see Powell's fuller mind concerning the scope and methods of history in another address that he gave, about a year later, at the first meeting of the new University College in Reading. He strongly approved of this institution and its purposes. The University Extension system, with all its faults and occasional big words, commanded his prescient sympathy : he saw that it had both an ideal and a practical element: he often lectured for it, and he was ready with coumsel and encouragement when wanted. The new eollege had partly sprung from a lecturing centre, and had ties, through its principal, Mr. Mackinder, with Christ Church. Mr. Mackinder, and his suceessor Mr. Childs, write their memories of Powell's relationship with the College. The former says :

University College, Reading, owed its foundation in 1892 to the action of Christ Chureh, Oxford. As you know, Powell's personality was comting at Christ Church with greater weight each year, and although he did not originally take the lead in deciling the action of the Honse, I do not think that I use too strong an expression when I say that latterly he made the danghter college at Reading one of his hobbies. Whenever, as Principal at Realing but still resident at Oxford, I wanted sympathy or an idlea to solve some difficulty, I used to go round late at night to Powell's rooms. He always saw things imaginatively, and had the most inspiring faith in our fundamental idea of bringing the influence of lummane studies into close association with the technical instruction which necessarily occupied a large place in such a College as that we were engaged in formding.

It was Powell who emphasized, if he did not originate, the iflea of giving a local tum to our study of history, and 
I would that he had lived to see the book ${ }^{1}$ which my colleague and successor, Mr. W. M. Childs, has produced for the school children of Reading. It was to Powell also that the new College owed the idea of combining on its armorial shield the three shells of Reading Abbey and the engrailed cross of Christ Church.

But his interest was very far from being limited to his own subject of study. He always took a great delight in our art department, and often dwelt on the fitness, in the midst of the Thames Valley, of encouraging design as applied specially to pottery and wood.

Many were the occasions on which he joined us in our Common Room, and not a few the characteristic little addresses which he gave to one or another group of our students. His portrait to-day hangs in the Staff Common Room, the memorial of a friend from without who was regarded as one of ourselves. The dead friends of the Institution are assembled on the walls of our Council Room, but every one who knew Powell will understand what I mean when I say that we all feel that we have put him rightly not there, but in our place of relaxation and friendship, beside the portraits of the oldest member and honoured father of our Teaching Staff and the first porter of the College, a veteran of the Crimea and the Indian Mutiny, who was a feature in the life of the first three or four generations of students.

To this Mr. Childs adds :

I can truly say that one or two conversations I had with him on the subject of local history were of great stimulus and help to me. He made one feel that the effort to reconstruct and present as a whole the life of a town like Reading was a piece of historical work well worth doing both from the standpoints of research and of civic interest. But then he harl to an extraordinary degree the faculty of being more interested in the things one was trying to do than one was oneself. It was the same about the College. I have always felt that no one had an ideal for that place more alive, more interesting, or more magnetic, than York Powell. The possibilities that other people scouterl, and about which we ourselves might not always be confident,

1 The Story of the Town of Reading; a First Sketch for Children. By W. M. Childs, M.A., lieading, 1905.

$$
\text { x. P. } 1
$$


were for him matters of robust conviction, fortified as usual by a detailed knowledge of all the difficulties that had to be surmounted. Whether the point under discussion was local history or whether it were the College, his generous and informed sympathy was like that of no other man.

Powell was asked to give his blessing to this Extension College at its first public assembly. A report is saved of his address, which has some special traits of interest. $\mathrm{He}$ not only struck the cliord of local patriotism and local research, but he also uttered, so far as appears for the first time, the principle he was to iterate to the end.

Efforts are being made to give not only a thorough historical training, but also to foster a real historical spirit, which does not consider history as a mere thing of books, a thing of facts and dates. Facts and dates are of course all important, but it does not follow that all facts are enclosed in books. History, to be of any use, must be scientifically conducted and scientifically based. The method of history is not different from the method of physical sciences, and history can only be properly taught so long as that method is listinctly followed. The historian has to train himself in the patient observation and collection of facts, and then in the higher task of trying to put together these facts and of trying to see what their real meaning is. ${ }^{1}$

Here he says that history is a science; he does not yet say, though he doubtless feels, that it must have nothing to do with moral sentences, with imperatives. It is, he proceeds, a necessary study for the voter, for the citizen, for the artist; the new college was linked with an art school. A library, an archaeological museum too, werc necessary implements. The wholc speech breathes a renewed impulse to inspire and appreciate ; and this, rather than any organized plan, was the effect on Powell of his preferment. He thought of his new status more as increasing his obligation to help others than as affording leisure to himself for original labour. His finally de-

1 Report from the Berlshire Chronicle, in Scrap-book; words also replaced in direct speech, as before; and Journal of the College, 1895-6. The italics are not in the original. 
reloped views on historical method and teaching will be discussed liereafter.

Powell held his chair for nine years, till his death. He accepted it with misgiving, and entered on it with a weighty notion of his duties. His tenure was marked by no profound changes in the history teaching of Oxford. The Honour School grew and flourished in its own way; research was a little more organized at the end of his office than at the beginning; but his successor, Mr. Firth, had to open his own career with a grave public protest against the methods of historical teaching in the university. Powell was not, and did not become, a popular and frequented lecturer: it was often said that he could not lecture at all. He did not gather round him a serried numerous band of young investigators. He did not become a captain of organized research, like Mommsen. He did not publish any historical work of larger compass than a short article or address. He had, as professor, few visible annals. All this was said by his critics, for he had plenty of critics and even enemies. It is, moreover, true. Those who knew him away from Oxford, or who, not knowing him at all have followed his record thus far, may ask what, after all, he did and what he was.

He was a spirit!

Here the biographer, who is not a professional historian, was himself far off, and could not see Powell at work in Oxford, has to fall back on quotation. The words of some who lived in the place and felt the influence are the only direct testimony. They do not come from men of the same age or cast of mind, and the variety of their response to Powell tells a good deal about him. But they are all persons in whose experience and growth Powell counted, and they are now all in the historian's vocation. They are not a multitude, and some of their witness has come to light by chance and shyly. It would have more than satisfied Powell; much of it is of an impalpable kind ; but then he was a spirit. It is also in some cases practical and definite, 
helping to decide the career or special task of the speaker. It must not be forgotten that his work for his chair was only part of his work for Oxford, and that Oxford was only a part of his life. His letters will show how his mind was ever at play, far afield, on poetry, on pictures, on national affairs, on the doings of his friends. His ruling passion and rare achievement was to live; and this, no doubt, was a distracting element. In such a man, probably, Oxford found both more and less than she bargained for; but she had chosen with a true instinct. I put various reminiscences together, and foreshorten the course of years, before resuning the thread of Powell's letters, in order to leave a single image.

But before proceeding to quote it is well to see what was Powell's ordinary sessional programme and routine as Regius professor. He lectured each term, and had two courses current. One, which he gave in his rooms, was on the sources and authorities for earlier English history. He would reach the Conquest by about Christmas, proceed to the end of the fourteenth century until Easter, and in the third or summer term cover something like another century. This course was repeated almost every year. How he conducted it will presently be told by some of his hearers. He rightly thought it the bed-rock of his labours as professor of history. It was little attended, and made no public mark, partly because of his lack of the usual sort of expository skill, and partly owing to his highest quality, namely his insistence on that groundwork of research. The student must first of all know the originals, and their relative value, and where to find them. To this aim the average pass-hunting, and also the honour-hunting undergraduate, was indifferent, nor was it in the tradition of the local teaching. There were also Powell's public courses. He seems duly to have given one set of six or seven lectures in every term, with a respite during one term in 1897 . These lectures will also be described. The topics range far, and may 
be classified as mediaeval, Renaissance, and modern. Early British history, the Danish invasion, feudalism in France and Italy, and the historians of the fifteenth century; Machiavelli, Mary of Scotland, and the Tudor monarchy; the history of Canada, the history of the colonies, the English statesmen of the eighteenth century, and finally 'Some events in modern history', which included the Commune and the rise of Japan : all these titles occur, and few of them are repeated. Powell does not seem to have planned any one of such courses as a foundation for a book; none of his notes for them are saved, and they were not written out. For all his contempt of lectures, the unacademic ones at Bangor and Manchester, which are printed hereafter, prove that he arrived at no small mastery of the arts of survey and presentment. But he was more spurred to writing by the sight of a volume on his desk than by the appearance of students with notebooks. His reviews may resemble the best of his spontaneous speaking in cap and gown. In later years he gave literary lectures to the women students: there will be some record of these, and of the fervour with which they were received.

The rest, then, of this chapter may record the independent impressions left by Powell as an historical teacher by several of those who knew him during his last ten years.

The first note is written by Mr. Owen Edwards, Fellow of Lincoln College, who was a pupil of Powell's as early as 1886, and who also heard him lecture as professor. Mr. Edwards has memoranda, now twenty years old, of a course on 'Old English law from the charter's and poems', which shows how Powell's discourses, at first view mazy and pestered with detail, fell on scrutiny into a clear order and revealed a ruling thought. His Welsh culture and zeal for Wales are also stated with anthority.

York Powell's lectures were very unlike most lectures given at Oxford during my undergraduate day's. The usual 
lecture was a careful epitome of the most approved books, and was attended by crowds of men. In my attempts to imbibe knowledge I had to do heroic things-I stood in a draughty corridor one day trying to catch the voice of the lecturer from the crowded room; another day I was fortunate enough to get in, and to have a seat on the coalscuttle. I inquired for less popular lectures, and I was told by some of my fellow-undergraduates that if I went to York Powell's lectures I would get plenty of room, as he was 'the worst lecturer in Oxford, and perhaps in the world'. I went, and found two men in his lecture-room. The lecture was certainly unlike anything I had ever heard before. His voice was musical-but, instead of the flowing periods I had tried to hear in other lecture-rooms, there was a jerkiness, a rambling, a want of method which made the lecture appear at first a mere pouring out of what happened to come to his mind.

He had no notes, though the lecture was one mass of details, involving continual quotation of lines and half-lines of Anglo-Saxon poetry. He did not seem to have arranged his matter too carefully; he spoke rapidly, and occasionally with nervous hesitation, from the vast stores of knowledge which impressed even the mind of an undergraduate. He did not apparently want us to take notes-he was so modest that he seemed to take for granted that we knew all those things. I took notes, however; and found, in arranging them afterwards, that there was always a definite line of thought connecting the bewildering multitude of facts and quotations and impressions he so prodigally showered upon us. He aimed at arousing our interest, and at sending us to the literature of Dane and Angle and Saxon to make our own discoveries. In his own kindly way he made us believe we could be real students. If he found we took an interest in any special aspect of the subject, he continually asked us to help him. My knowledge of Welsh was continually utilized. York Powell never lost an opportunity of leclaring himself a patriotic Welshman, and his knowledge of Welsh seemed to me to be very thorough.

From his lecture-room, at the end of the hour, we adjourned to his library. We left it full of the desire to buy books. In his lectures and conversation, we saw how the historian worked; we were not only brought to know what things were, but made to see how they were found. 
His lectures on English place-names, on the history contained in Anglo-Saxon law-terms, on Danish military terms, were full of freshness and life. Those on the Danes were certainly the most interesting, the most inspiring, and the most new I ever heard. None of the things he said could be found in a book; but there could be no doubt about their truth; he showed us how he got them from chronicle, or saga, or place-name. He not only made history intensely interesting, but he made the search for truth more interesting still.

He very rarely criticized any other historian, but he opened our eyes to material which was very destructive to nearly everything we had read before. With regard to original authorities, he taught us to seek for the truth they contained; and he distinctly discouraged any kind of destructive and barren criticism. He had the modesty of the discoverer; he made us believe, without stating it definitely however, that it was a waste of time to criticize when there was so much truth we could discover. In his own lectures there was much dogmatism of a kind; but, somehow or other, it was based on a very large toleration.

He seemed to think there was some truth in everything, and some good in everybody. It was for this that he taught us to seek. The wildest legend yielded some truth; and the most despised men had some good in their lives. His natural generosity and sympathy made him a good judge of character. I know some historians who can describe the character of a mediaeval king or baron with the greatest ease, but who cannot judge the real character of men they hear of or see every day. York Powell sent me to a chronicle to test his view of the character of an earlalways expressed with great vigour ; he sent me to living statesmen or historians, supplied with a full description of their characters, and I was always profoundly impressed with his unerring judgement. He made me realize how much more profound and clear-sighted the sympathetic mind is than the critical.

Every man was judged according to the standard of his own time: York l'owell was rarely tempted to take a man centuries out of his own time and judge him according to modern ideas. His blazing indignation against oppression, political or intellectual or social or religious, and his manly defence of the despised, brought occasional bursts of eloquence into his lectures. - But a hearty infectious 
laugh very often came as a confession that he was departing from the rigidly historical method of inquiry. He made us feel that in the history of the world wrong is gradually set right; his apparent changes in politics were due to his intense sympathy with those who are ground down.

The next note is from Mr. Herbert Fisher, of New College.

My acquaintance with York Powell dates back to the summer of 1889. I had been elected to a Classical Fellowship at New College in the previous October, and after a little experience of philosophical teaching was inclining to take up Modern History as a study. Somebody-I forget who-told me that I had better consult York Powell, then a law tutor at Christ Church, but very famous for his learning; and to York Powell I went. My interview with him was decisive. He took me round his shelves, pulled one book out, then another; advised me to read Maitland's edition of Bracton's Note-book as a specimen of the best modern work; told me that I should find Bond's Handy-book for verifying dates of use; and finally instructed me to go to the Ecole des Chartes, the finest School of History in Europe. He spoke of everything with such knowledge and enthusiasm, that I who knew no modern history at all, and had been somewhat inclined to look down upon it as inferior to Greats, became awarc that it was, in Powcll's conception at least, as wide and animating a study as a man conld devote his life to. Of course I was quite unfit to follow Powell in all his breathless and bewildering recommendations, given out with the brisk emphasis which was characteristic of his speech; and I may perhaps here remark that he never seemed to realize that other people were less learned than himself. I have heard him talk to undergraduates just as he would talk to professors, assuming always that they would naturally be interested in everything which interested him, and passing from topic to topic with an artless mobility vouchsafed only to minds as teeming and as simple as his own. As he always said what he thought, and said it with conviction, it was a safe assumption that his hearers would be interested. He must be among the few men of lcarning who have never bored any one, not cren an undergraduate. 
When I returned from Paris to take up teaching at Oxford, I used to pay regular weekly visits to those wonderful rooms in the Meadow Buildings at Christ Church, with their stacks of folios and quartos and octaros and duodecimos, and their delightful litter of miscellaneons curiosities: and here Powell would hold forth de omni scibili, and rarely let me escape without an armful of volumes (generally of French or Italian mediaeval literature) taken down from his shelves. I once learnt incidentally from him that when lie was an undergraduate he used to go to the Taylorian to read the Library shelf by shelf, and some such omnivorous eapacity he was wont to postulate in his friends. For a young tutor struggling to get up his work for the Schools, it was not at once obvious where Aliscens or Marie de France came in; but Powell was wise in insisting upon the refreshment of miscellaneous reading and the absolute necessity of developing on wide lines, and I never left his rooms without feeling that he had given me new eyes.

Powell's historical influence in Oxford was mainly of an informal kind. He was by nature the least didactic of men, and state occasions got on his nerves. The most impressive discourse which I ever heard him deliver was an address on Machiarelli given to the Palmerston Club in an undergraduate's rooms. I suppose on that oecasion his audience cannot have much exceeded twenty. Powell came in about half an hour late, when the atmosphere was already thick with smoke, sat clown before a little table, took out of his pocket a small square inch of erumpled paper (which so far as one could observe he never consulted) and then started away, and held us all spellbound for an hour and three-quarters. There was no vagueness or surplusage or lack of proportion, or indeed any of the failings which one expects to encounter in an informal discourse. It was all strong, nervous, and pointed, full of judgement, of fine intuitions, and it comprehended every side of Machiavelli's work. It gave one the impression that he had mastered his man, and all the literature round about him. None of the professional lectures which I heard from him, struck me as equal to this. In cap and gown, standing at a desk with an unknown audience before him, his touch was less certain, his manner less assured. Had he written his lectures out in full, this nervousness would no doubt have been overcome; but Powell's appetite 
for the last book was too strong to permit of his writing much, and so his lectures, though brimfull of information, were rather formless and desultory. I heard him lecture in one term on the opening of Japan, on the French Commune, and on the Seven Weeks' War. He talked from a few notes, abundantly enough, but with a hurried, nervous movement, and without any clear plan. His material was splendid; his views fresh and unconventional; there were fine picturesque touches, and gleams of humour, and many keen sayings; but it was all very tantalizing. With a little more arrangement, a little more concession to the common art of exposition, with a little thinning out of the small facts, and a little more insistence on the large ones, what lectures those might have been! As it was, they just failed to be effective, unlike his talk, which never failed. My impression is that he was too sceptical of generalizations and ambitious labels and so-called 'laws' of advance ever to make a popular lecturer. It was always good to hear him declaim against the people who think that Prussia has an 'historic mission'.

Neither did he hold that the historian should inculcate moral principles or deal in moral judgements. Much as he respected Lord Acton's learning, which he described to me as 'quite colossal', he thought him wrong here. He disbelieved himself in 'absolute' morality, considered it absurd to ignore the doctrine of relativity, and held like Napolcon that 'la petite morale' was often hostile to 'la grande'. 'Thus he would urge that Henry VIII was right to cut off Sir Thomas More's head, and that Sir Thomas More was right to stand up to Henry. ${ }^{1}$ of Machiavelli he was always an enthusiastic admirer, and though himself the tenderest of men, he was fond of preaching hard-headed politics. His nature was so sound and wholesome that the slightest trace of sickly sentiment repelled him. He surprised me once by the vehemence of his denunciation of Rostand. No metrical dexterity could atone for the unwholesome extravagance of $L$ 'A iglon, which he had seen on the stage with loathing. ${ }^{2}$ I tried to put in a word for Cyrano, but he shook his head and said that he couldn't stand the man, and there was an end of it. In Verhaeren's verse, on the other hand, he found beauty, and a rare and delicate sense for rhythm.

1 See vol. ii. p. 117 for a like judgement in the case of Algernon Sidney.

- See p. 322, post. 
A pupil cannot pass a cold judgement upon such a master as this. The great hearty laugh, the firm grip of the hand, the speedy, sanguine, and buoyant brain, so wonderfully charged, and yet so great and hospitable, the stores of sympathy and fun and active helpfulness-against memories such as these, no counterweight is effectual. I can understand that he may have confused some by the abundance of his counsels and enthusiasms; and people have told me that he tried to learn too many things. I prefer him as he was, joyous, profound, large-hearted, curious of everything, spurning the vulgar things which stand in the path of knowledge.

Powell's letters to the next chronicler, Mr. Robert S. Rait, of New College, will be found later: they begin in 1899. Mr. Rait wrote the tribute of a pupil and observant younger friend in the English Historical Review of July, 1904, whence I am permitted to make quotation. His account, several years later than that of Mr. Fisher, suggests that Powell had found a method of more authority, more telling and happy, in the interval, for his public prelections. Nevertheless

towards these public lectures he felt much as did his predecessor, Bishop Stubbs : they were to him interruptions to his real work. That if he had devoted more time to their preparation he could have delivered distinguished lectures and drawn large audiences no one who knew him can doubt ; but to do so would have meant the sacrifice of his own ideal of what a professor of history ought to do. It must not be supposed, however, that he either despised or neglected this part of his work. He would not have condemned another for making public lecturing his main object; only it was not the proper course for him. $A$ s it was, he lectured much more frequently than his statutory obligations necessitated, and his public lectures, never rhetorical or eloquent, were invariably wise and suggestive. They were not fully written out, and he now and then halted for the right word (without always finding it); but every lecture contained many sayings worth remembering, and he not infrequently delighted his audience with a brilliant improvisation. Thrusting away his manuscript, as if it impeded his thought, and looking sideways towards the window, he 
would, for five or ten minutes, give one of those living sketches of historical personages which so often distinguished his conversation. One's only regret is that these unwritten passages were too rapid in their delivery to be conveyed to paper.

York Powell's conception of his proper work was connected with his view that 'the miversity's business lies with advanced edncation and with research', and it was to the encouragement of research that he devoted his life. Even here, although he held that the organization of research is a proper object of a miversity, organization was not congenial to him, nor had he, at the end of his decade as professor, made any definite attempt to face all the difficulties which such a project presents. The gods had so richly endowed him ; he could inspire, and he could not but feel that inspiration is better than organization. So varied were the professor's interests and attainments, that if any student failed to obtain the right sort of help, it was due to some fault of his own. Nor would it be true to say that there has been no organization to meet the needs of research students. Powell was deeply interested in the establishment of the lectureships in palaeography and diplomatic. These he regarded (along with a command of languages) as requisite for any attempt at serious work. Theorizing on the method or scope of history appealed to him only slightly; his view was that only actual work could teach a man method and that each man's method must be his own. Example he believed to be better than precept; every term he gave a series of lectures to exemplify historical eriticism, and it was of these lectures that he used to speak as constituting the distinctive feature of his work. They were delivered in his rooms at Christ Church to small audiences, and, like all his best teaching, they were informal. There was in his nature a kind of shyness which introduced a feeling of embarrassment into his statutory prelections. Although one so often saw his familiar figure in cap and gown, as he passed from one board or delegacy to another, yet he never felt quite at his ease when he stood up in academic costume to speak $c x$ cathedra in the schools; there was often a tendency to refrain from hazarding an opinion or pronouncing a judgement. But as he sat in his rooms at Christ Church, discoursing on the sonrces of English history to a small number of interested listeners, no trace of hesitation was 
discernible. He had his books in front of him, selected either from his own wonderful collection or from the great Christ Church library, of which he was a devoted guardian; the passages he wanted for purposes of illustration were rarely marked but always readily found; beside him were a few notes to which he occasionally referred. His voice seemed to come from the middle of the books in front of him; he searcely ever looked round the table at his audience, seeming to be conscious only that here were the materials without which we could do nothing, and that he must show us how to use them.

The first lectures of the course were generally more fully written out; he began by a general sketch of the authorities available for the period with which he was concerned, telling of catalogues and collections, of publications of learned societies. Warnings followed as to typical errors in reading manuscripts of various dates; it was, of course, assumed that the student had learned the principles of palacography and diplomatic. Then came a general classification of ultimate sources; speaking of the period before the Norman Conquest, he would talk of biographies of saints, drawing special attention to the appendices of miracles and to the narratives of translations of the saint's body ; of such a history as Bede's and such an epitome as that of Eutropius; and finally of the ehroniclers and their claims upon our confidence. When state papers of any kind became available, controverted issues were chosen upon which the chroniclers were tested, and the lecturer showed on what principles the historian should rely in accepting or rejecting a disputed statement. He was never tired of insisting upon the necessity of understanding the character and the motive of a chronicler, of discovering when he spoke from prejulice or from gossip, and he would gleefully expose any instanee in which these things could be detected. The ehroniclers of John's reign always met with his censure; John, he used to say, was a bad man, but bad as men are sometimes bad; and they tried to picture him as an impossible monster of wickedness, nature's enemy. 'You mustn't forget,' he would add, with a burst of laughter, 'that Arthur was a young gentleman who began life by imprisoning his grandmother.' Many recollections crowd into the mind as one thinks of these lectures, but space forbids our adding more than one other point, the professor's estimate of the value of oral tradition. 
A song or an anecdote was to him an historical document: in these days of print, he thought, we are apt to undervalue the possibilities of human memory.

With these lectures on sources and bibliography is indissolubly associated the thought of the evening talks in Powell's rooms. Every Thursday erening during term he was 'at home' to students of history, and his table was surrounded by a small group of eager questioners, each with his interests and his manuscript. The professor would turn from one to the other, talking now of folklore, now of Thomas Cromwell, now of Indian warfare, and again of Persian literature or Japanese art. Proof sheets or manuscripts were read and annotated, a scheme of work examined and criticized, the latest books discussed and appraised. Sometimes one would find there one or other of that large band of friends linked together by no sympathy or interest except by Powell's 'genius for friendship'. Mr. Wilfrid Blunt, the late R. A. M. Stevenson, and Prince Kropotkin occur at once in this connexion. Occasionally one had the privilege of spending the whole evening with him alone, and he would answer one's questions and solve one's difficulties, or suggest work for one to undertake. A conversation of this kind he never forgot: he would return to the subject again and again. In the long vacation a pupil might be reminded once or twice that Powell was interested in his work and thinking about him and it. $\mathrm{He}$ would send a warning against prejudice of any sort, against 'an occasional expression which gives the enemy occasion to blaspheme (though I am not the enemy)'; or he would write a note suggesting something that had just occurred to him ; or occasionally a little sermon on the danger of over-work or on the duty of keeping a high ideal before one. 'The honour of the university,' he used to say, 'is involved in every production which comes from the Oxford history school.' He himself spared no pains, either in counsel or in minute criticism of detail, to help his pupils to keep this ever in mind. This kind of work he considered as the best he could render to the university.

Later evidence yet, which is naturally not so much a jurlgement in set form as an impression of the more intangible and therefore more vital side of Powell's teacling, is not lacking, and must be welcomed, in its young accuracy, 
by Powell's earlier friends, as taking us close to the emanation of the man, who was seen newly and not on many occasions by these witnesses: an impression that for us is overlaid by so many complex views of him in other aspects. The first impact of a great teacher on a generous brainthat is a precious thing to recover in language. The two writers attended his public discourses together. The first of them, while rightly confirming the admission of Powell's weaknesses in the job of formal orderly instruction, expresses all the more strongly one of his traits of imagination, namely his nearness to the past and its personages; a trait which, as we have said, his talk shared with Vigfússon's. The distances of time seemed less opaque to him than to other men; he had an odd simplicity of vision, so that all he knew of another age sorted itself at once, and lay before him in a saga-like clearness, and he viewed it without surprise; though in his expression of it there might be suddenness and abrupt transitions.

The ordinary obvious things about York Powell's lecturing are easily said; and the very various impressions he made upon undergraduates, and others also, are easily understood. He did not use notes very consistently. He never took the trouble to think out the form and manner of his lectures - if he did, he was easily satisfied. He was sometimes rather difficult to follow, for his pace varied, his sentences were often jerky, his use of foreign words, phrases, quotations, sudden and rapid. When he was lecturing, or rather talking in his rooms, upon the sources of English history, these characteristics served to impress rather than help the inexperienced student, who desired to be shown the way a little more clearly through a country that was far stranger to him than it should have been. Yet I have often found my notes of these flying utterances unexpectedly helpful ; and realized afterwards that I was learning more than I knew.

But this was only one side. The man who learned to venerate York Powell does not need to claim any special or peculiar power of sympathy, certainly has no canse for pride. It was a most humbling experience, like that of all true reverence. And reverence grew very naturally 
into affection, although it was an affection of the memory, like the affection for a river or a mountain, rather than of close and intimate knowledge. His influence was simply due, in the cases known to me, to his very obvious sincerity and true knowledge. He did not lecture or talk as most men do, with convictions that are really but logical or illogical generalizations, and however passionately held, are after all but second-hand. He always gave the inpression of having personal knowledge. In fact, this was his standard of criticism in the case of others. I remember how vigorously he praised the historical work of William Morris, how sharply he criticized John Inglesant, and denounced Richard Yea and Nay. Morris, he said, was perfectly at home in the fourteenth century, he would have needed no introduction to the Canterbury pilgrims. This was just what we felt in the lecture-room of York Powell himself. He did not trouble about anything else but the men and women of whom he was speaking. He created no atmosphere, and adopted no conscious style in harmony with his subject. He simply spoke of King John, or Machiavelli, or Catherine de' Medici, as he might and did speak of the Oxford celebrities of his day. He made his hearers feel that, if he did not know these people, nobody else did. I think that he was more at ease with worldly people, and with humanists, than with saints and philosophers. But he did not try. to criticize saints or philosophers, he simply left them; and I am sure he would have chatted quite easily with St. Thomas Aquinas at the table of St. Louis, though he might have felt rather bored in his lecture-room.

so, as I have said, he made no claim upon any particular kind of student. Any one who had real patience with history could learn from hin. If he failed to attract many, it was not due to his obvious defects of mamner, but to the hurly-burly of the schools, or to the confidence in second-hand knowledge which is so characteristic of even the best students under the present system. Or perhaps it was due to the short-sighted seriousness of our time, which attacks all kinds of men in Oxford, and finds expression either in a smart journalistic assurance or in a clull dogmatism of the mental temper. York Powell did not lecture to people like Mr. Wells's serious reader, the 'solemn impatient parasite of great questions', who insists on a 'yes' or a 'no'. 
One lecture especially lingers in my memory. It was one of a course upon historians of the sixteenth century, the most noteworthy series of lectures ever heard in Oxford. York Powell was telling us about John Stow, the antiquary, who wandered over England in search of manuscripts, and became poor in wealth in his eagerness to become rich in antiquities. The Professor spoke of the old historian's cheerfulness and curiosity with more feeling than was usual with him. I remember the short pithy sentences, the evident interest and pleasure in the old volume before him, the sturdiness of his devotion to scholars and scholarship. I think it was after this lecture, as we watched York Powell carry the great book along the High, that a friend who was with me said, 'It is all very well; but we are not worth it.'

The speaker of the last sentence is the author of the account that follows. It shows Powell in his true Oxford setting, with the meadows and the sunshine outside his Christ Church windows, all part of him, as he of it, and the eternal youth of the place thus continually baffling its stagnant age. It would be hard, I think, to describe better that which went out from Powell, and this book would be the poorer without such a picture, which came to my hand by chance.

I saw York Powell not much more, I suppose, than a score of times altogether. Until about the third term of my second year I knew nothing of him. Then, as I would not go to any lectures of the kind preparatory for the Schools, my tutor sent me to Powell's rooms at the House, to what was advertised as a weekly lecture on the sources of English history, for, I think, the twelfth century. I was the only man there, except once when an American came-about the sixth week of term-and was puzzled to find us at the Anglo-Saxon Chronicle. As I knew nothing but some of the ordinary surface political history, he first gave me a bibliographical list of things useful for the Middle Ages, and spent the other days talking as he wished-or (rarely) in answer to questions of mine-about contemporary books or persons, especially the latter. Sometimes he gave some account of MSS., families, copies extant, \&c. He used to read great extracts of Latin or 
Old French, reading very fast, and looking up and laughing suddenly. After my first list, I think I took no kind of notes, but watched him and listened. He was living then in the Meadow Buildings. You will remember the rooms. There was a great sound of birds outside. The summer air and light came in from behind me: I sat at the side of a table covered with green cloth, with chairs and rows of inkpots and sheets of paper, untouched from the first day: as no one ever came but that American once, and it seemed a great intrusion when he did. York Powell sat at the end, reading and talking and laughing-his fingers moving quickly over the pages and reaching at other books. He gathered a small heap of them at the beginning, from his shelves and the irregular files about the room. My eyes strayed over the books on the walls, mostly old books, big and little (and all, it seemed, I wished to read and ought to know).

I was very timid when I went at first. Then I felt it should not be me that was there, but a man who knew some history, and could make use of the man, and draw him on, and understand what he said. Then I settled, and very soon, into the different mood of going there once a week as to some natural and simple pleasure, as justifiably mine as the sunlight and the meadows as I walked back, and somehow akin to them-perhaps only because there always followed that hour with York Powell: but I felt the same welcome for both, and came to expect a single impression from the whole thing-his face and hands and dress, his talk and books, and the old fellows he talked about, and the meadows outside. Nothing was ever like it to me in my years at Oxford.

I went for a term to his lectures in the Schools, upon (I think) historians of the sixteenth century. The audience, besides — and myself, was some four or five people - two ladies, an elderly man who came late, an American who sat at the front near. York Powell and appeared to be doing some research. The company was doubled one day by the entrance of a party, who seemed from their dress to be motoring. — took a good many notes : I took very few. Powell began with some general matter on the epoch, and the prevalent political ideas, and the classes of people, and their attitude to government and the questions of the day. It is not quite so new to me now : but I have never heard the thing done so clearly and naturally before, as if pro- 
ceeding from personal knowledge of things, and not from any laboured research whence he had drawn his conclusions. He spoke then of various writers, English, French, Italian : a short biographical account, and then a criticism of their work. He often brought the books down to the Schools and read extracts. It was entirely unlike the ordinary lecture. Information was given, but not of the ordinary kind, nor on any ordinary plan. I might say little design was apparent, save that of giving a little of what interested him to us few people who presumably came because we knew we should care to hear what he said. I saw no great preparation of what he was to say, though he had turned up places to read to us - bits of a preface, or famous stories, or pieces illustrative of an author's mind or his life, and had slips of paper to mark them. At the end he would show us these editions, and talk of the printer, or the binding, or some woodcut, or arms.

Of the historians themselves he spoke in a very personal way, as if they had been friends of his father's or of some person older than himself who had told him frequently abont them, and in whose company he had met them: he remarked on their motives or habits, or some events in their lives, in precisely that vivid, simple, direct way that a man wonld use who had very nearly personal memory of what he spoke of, who was not particularly anxious to tell his hearers, but glad to do so, and who spoke briefly, informally, quietly, perfectly sure of what he said, and occasionally taking a little more pains than one would in an ordinary conversation to make those who listened to him understand. Once he went over to a board and drew some chalk figures to represent Machiavelli's idea of cycles. But for that, he spoke very quietly from a desk somewhat high above the floor: I used to think that posture and height (as if for an ordinary and crowded lecture) mmatmal.

This public lecture in the Schools was more formal-to use too strong a word: he was quieter there than I had known him in his rooms: and he kept more to a fixed subject or person. The room he used in the Schools might hold seventy or eighty people. - and I sat a little farther back than the middle, and looked over the empty rows of tables. I used to feel that lecture a little sad, perhaps from the empty room; partly because it seemed people might not know what he was like, hearing and seeing him only in such a lecture. I remember, at the end of one 
hour, while he was at the table below his desk showing the books he had brought, and I was watching him, he looked round, and I saw the extraordinary kindness of his eyes; I felt more as I had in his rooms, when I sat at the side of his table.

I don't think that he ever knew my name, though he knew my College, and once apologized for being in London at one of his lectures, when he said he didn't know where to send and warn me that he wouldn't be on that day. He asked me to lunch at the end of that summer term; showing me prints, and I think Japanese things, as he drew on his boots. I daresay I wasn't eating much, for he suddenly turned quantities of stuff on my plate, bade the servant see to me, and told me I must eat this and that, as if he were my grandfather.

I used to go to his rooms on Thursdays after Hall ; not very often; a thing I curse myself for now, but I had a great conscience then about reading for the Schools. You will know how he talked then, of whatever eame up, historical stuff or other things. I remember he spoke once, briefly and humorously, of his lack of interest in all theology: he spoke of how Stubbs had thought ehurch affairs should not be too fully discussed in history-something about 'touching the ark'. Once he turned on me and said, "Knox-Knox was a great man-he was a bad man.'

Things he said at these times seemed to me more valuable-apart altogether from the pleasure of hearing him -more valuable to a man reading history than any quantity of lectures one might have had. I have lived ever since on one or two of the things he said about the sixteenth century. It seemed to me the ideal way to learn history-to have books to read, and such a man's talk to listen to, and occasionally to put him a question. Pardon my saying it, I have been timid always of professional instructors, afraid of all dons, and at the same time very conscious of my own backwardness, and mistrustful and impatient of their instruetion. With York Powell, I have felt that twofold sense of strain dissolve: I did not feel that I was being instructed, or that I was stupid. I felt I was brought into direct contact with what I wanted. I eared immensely for history : that was all York Powell seemed to ask. He cared too. He knew history, and I did not: but that didn't matter, for he cared to talk 
of what he knew, and talked because he cared. Of course one felt, in an indefinite secondary way, his immense knowledge ; but that was never humiliating, never a thing to make one despondent. A man who knew more than I did might have gone to him for information. Probably I took what was going, too. Doubtless, as a student, I had other ways of getting hold of my subject, other things I ought to do. Contact with him was one way, something of the very highest importance-rare, I should think-of which, if I had missed it, I should have come to some dim idea, but could nerer have made up the loss. To my mind, now, that contact with him has become perhaps the strongest incentive to go on: it reminds me of what history is, and that I may have some hope of getting at it. I do not see what more a great scholar could do for a man begimning.

As you see, I did not know him: I saw him a very few times, in every way I was on a very different plane from him. I wish I were not, that I could praise him. As it is, I scarcely feel ashamed to confess to you that my respect for his knowledge and all his powers is never very prominent in my mind, because I have so distinct a personal affection for him. I may have no business to have it : he never knew me from any other man, I should think. Anyhow it was inevitable. I don't know what other men felt. I cared for the man first. His ordinary courtesy, the ordinary interest of his nature in books or men or external nature, came to me like personal kindnesses. And if he had ever known of it, I don't think he wonld have disliked my feeling as I did to him.

In Oxford, besides thus tcaching and inspiring, Powell did more than his duty-shift at the machine of academic affairs. An organizer, a debater, a wirepuller he could not be. He never sat on the Hebdomadal Council, which is the source of University legislation, nor did he speak, I believe, on the public bodies that debate the proposals of the Council : least of all in the strange, mediaeval Convocation, where on field-days and at fitful intervals the voters from their country livings arrive to swamp reform. He never became a scholar-politician of the type that cherishes a programme and requires place and leverage for its realiza- 
tion. He despised the smaller kind of University intrigue, monastic in its triviality, that absorbs a good many persons and makes them, as he put it, 'run round like headless ants.' It was this kind of thing that Pattison despised also. Powell, however, sat on many boards and committees, and gave them more than his due. He is described as offering sound liberal advice, as voting steadily for the larger policy, and as preferring, in minor matters, to support without more ado any man whom he trusted as an expert. He was doubtless, with his diffidence and dislike of arguing, not the man to steer through a bitter necessary debate; and of ordinary strife he took little care. When the dust was rising, he would make drawings, or write letters. Once, in a note to a friend, a French poet, he punctuated the letter with the word rixe! He had to stop and listen, the rixe was too loud to ignore; but when it was over, he took up again his discussion of fine art.

Yet he was by no means an engrossed scholar with a contempt for business. He was one of those men that are to be found in Oxford, in Cambridge, in Lancashire, and elsewhere, who are stirred by the vision of a wiser and cleaner University. He thought of it as properly the home of learning and science. He adopted the professorial point of view, which obtains over the mainland of Europe, rather than the collegiate or tutorial, which is peculiar to England. He therefore was little preoccupied with the Schools, and wished to see examinations curbed rather than extended. The Bodleian should be a place for organized study and research. The lecture, which administers knowledge ready-found, with the least possible reaction of thought on the part of the student, must be subordinated to instruction in the bases and methods of knowledge. How strongly he put this point in regard to the provincial colleges, we have heard; and he believed the same ideal was right, and the only salvation, for Oxford. He did not work alone, and the labours of 
Powell and his friends and those like them have told. As he used to say, $E$ pur si muove! With all his censure of Oxford methods, he always maintained that good work was being done there abundantly, if somewhat in corners. We hear that the unproductive kind of tutor, intent only on prizes for his young men, is dying down, and that the reciprocal shy sensitiveness of Oxford men, which, it was said, made them fear to publish, is less apparent. This improvement, however, can hardly be attributed to the system : has rather come in its despite. As to the myriad young 'passmen', Powell always felt and said that many or most of them ought not to be there at all ; but there they were, helping out the University revenues, and they must have the best provision possible made for them. His own influence in affairs was most direct where experience rather than disputation was required. He belonged, for instance, to the committee of the Oxford Historical Socicty, and went to its meetings. He was a laborious Curator of the Taylorian Institution, the home of modern language teaching in Oxford. He attended its meetings with some regularity: he always tried to fill its posts with teachers who were also scholars, and he devoted time and thought to the expansion of its library. He had much to do with the foundation and publication of the Taylorian lectures, given on subjects of forcign literature ; it was he, we have seen, who brought over Mallarmé ${ }^{1}$. Foreign literature, naturally, was one of his passions, as the catalogue of his own library shows: he had in all more than a thousand volumes at his death which are classified as Oriental, French, Italian, German, and Scandinavian.

The Clarendon Press was one of the foci of his life in Oxford. In 1885 he was made a Delegate at the instance of Jowett, who was then Vice-Chancellor, and with pealing

1 For these faets I am indebted to Mr. Morfill, Professor of Russian and the other Slaronic Languages, and a colleaguo of l'owell's in the Taylorian. 
laughter he used to relate how Jowett sent for him and explained that money profit rather than advancement of learning must be first regarded in the policy of the institution. He would add: 'Jowett, how he liated learning! But, of course, his ends were often the ends of Moses, though his methods were the methods of Machiavelli.' This was meant as a compliment, in spite of Powell's usual view of the relative merits of Moses and Machiavelli. He remained on the Press all his life and took its work with much gusto and energy. In spite of his power of immediate concentration and quick judgement, it was a great and recurring call on his time and brains. It has been publicly regretted that he spent so much of them upon the University Press instead of writing more books himself. But it was his own choice, and I think he rightly regarded it as suiting his characteristic way of doing good. The work satisfied his dislike of publicity, and his passion for detecting talent, and his ideal of a learned University. The Press was the chief, not the only, means he found for following what I have ealled his profession in life, the encouragement of the right man in his predestined task. He went constantly to the weekly meetings, often coming from London for the purpose. He not only prepared reports on proposals or works submitted to him, and unofficially edited many a manuseript, in his quick divining way, at odd hours, in bed, in the small hours, in the train; but he stood in all kinds of relationship between the Press and the author, having to consider a venture from every point of view, practical as well as scientific, and knowing perfectly that the loss ineurred on much purely learned work must be balaneed by profits in some other direction. He liked this labour and knew that it was one of the things he did well.

The kind of debt under which the Press lay to Powell was well expressed after his death in the Oxford Magazine, and may be given before taking up his chronicle as professor. 
To those who knew York Powell it is not difficult to picture the readincss of his welcome to a good book, his sorrow in producing an unfavourable report. His immense knowledge, and his dislike for a display of it, often made his judgements swift and, in appearance, offhand; and, as all his friends knew, he seemed to acquire the contents of a book by some sixth sense, which scarcely needed the help of the eye and carried whole books at once to the brain. But very often judgement was reserved, to await the result of a week's opportunities for research or for consultation with some scholar friend. And it was in his direct relations with authors-encouragement and advice in their plans and preparations, the loan of rare books or pamphlets, the liunting up of recondite references, help ungrudgingly given upon their manuscripts or proof-sheets - that he came to be, as it has been phrased by Mr. Fisher, 'like the Duke of Wellington, much exposed to authors.' 'He has added me,' wrote Mr. Quiller-Couch in the Preface to the Oxford Book of Verse, 'to the number of those many who have found his learning to be his friends' good fortume,' and in this way much of the learning that he never set forth himself found its way into the world, while, at the same time, the work of other men was improved by the excellence of his judgement and the delicacy of his taste.

Services of this kind can be rendered without the formalities of an office, without even the virtue of punctuality, and at the Press York Powell's repntation for unbusinesslike character was wholly unintelligible. Quite naturally, almost without his knowing it, difficulties and impossibilities came on to his broad shoulders, and perhaps more often than other men he confessed himself beaten. 'I can work at the thing myself,' he said, 'and I can talk to the people, but I camnot drive.' But if he could not drive, he could lead things in the way he wished them to go, and he always brought to his business the great business qualifications of knowledge of things and of men, of swift and sure judgement upon them, and of what he possessed beyond others, a tact and urbanity that seemed never to fail. He gave, for instance, great and ever-increasing assistance to the technical departments of the Press. His knowledge was not that of the mere connoisseur. He admired the bookwork of Morris; he gave a well-remembered lecture or 'informal talk' at the lnstitute upon his 
beloved Japanese prints and drawings; when he excused his non-attendance at a printers' dinner he pleaded for an improvement of title-pages. But he knew the points at which Morris had failed, and knew his own ideals so well that he could himself apply them instantly to the difficulty of the moment. Hence, when his advice was asked, he could give help of the most direct and practical kind. 'No point or detail,' writes Mr. Hart, the Controller of the Press, 'was too small for his attention, and he never set limits to the trouble he would take. Upon all matters of printing or illustration, the justification of an initial letter, the disposition of print upon the page, the degree of success of a chromo-collotype, even the composition of different inks, he was able to give instantly, or after brief inquiry, advice that was useful in practice. He gave his advice unhesitatingly and with authority, using few words and expeeting to be understood quickly, as one "professional" speaking to another. He was always cheery and full of encouragement ; it was a pleasure to be advised by him.' 1

A more formal but equally heartfelt tribute from his colleagues ${ }^{2}$ may close the chapter :

The services that Mr. York Powell has rendered to the Press since he became a Delegate have extended over a very wide field. Not only was he master of the subjects specially belonging to his chair, but he had also a remarkably intimate knowledge of art, philology, and literature : indeed it would be difficult to name any branch of literary inquiry in which he was not at home: and the Delegates constantly had recourse to him for advice on proposals of the most varied character. Nor was it for such advice alone that the Press was indebted to him. A large number of the works undertaken on his judgement were revised, corrected, and improved by him while still in manuscript, and while passing through the printers' hands. His knowledge of the details of business, both in the department of printing and in that of publishing, was extensive and valuable: and the Delegates were accustomed to rely with confidence on his judgement in all questions relating to form, quality, and appearance of the volumes

1 Oxford Magazine, May 18, 1904.

2 Memorandum of Resolution ordered at the meeting of the Delegates held May 20, 1901. 
to be issued, or to the best means of securing a good market.

He was a man of warm sympathies: and he was keen to detect promise even in inexperienced writing: and he grudged no time that was given to bringing immature work, which seemed to him to have merit, up to a standard of which he could approve.

The Delegates feel that by his death they have lost a colleague whose services have laid on them a deep obligation, and whose place it will hardly be possible to fill. 


\section{CHAPTER VI}

\section{LIFE, 1895-1898}

Work for National Home Reading Union: for Social England. Oxford. Bedford Park: death of Stepniak. Letters on Mr.G.Meredith. Ambleteuse eloudscapes. A Londoners' meeting. Opinion on William Morris. Fareyinga Saga. Iusen again. The Manchester Guardian: Survey of the Queen's Reign. Journey to Holland. Death of Henry Stone. Lecture on King Alfred. Mr. Wells's stories. Powell's increasing 'Toryism'. The Casket Sonnets. Ambleteuse, 1898.

THE record now begins again. During 1894 Powell had been re-shaping for various purposes his material on early English history. He was in full sympathy with those who have to work at a distance from teachers and the living voice, who lack prefatory training, and who ask for some direction in order to escape from discouragement and waste of force. Hence a series of papers in a periodical designed for such isolated workers, the National Home Reading Union. They are short, consisting of a sketch of the early reigns after the Conquest, together with a chart or syllabus of the original authorities and the best editions. This was a useful though unobtrusive part of his teaching, and is worth mention, to show that he did not suffer from the high and dry scholar's aversion to beginners.

He also wrote four articles in the syndicate-history entitled Social England: on the decline of the Roman power, on Britain under the English, on the Danish invasion, and on Domesday-Book. They serve to show what his history-book for schools would have been with freer scope and room; and they confirm the sense that he was more himself in picturing than in narrating. His account of the England that the English conquered is livelier than his story of the eonquests themselves. But the first three 
articles are continuous, and give a clear impression of his manner ; 'Domesday-Book' is isolated, and interposed among work by other men.

There are few letters from the summer of 1895: in June he writes in answer to an inritation from his socialist friend, Mr. Clayton :

Christ Church, June 20, 1895.

I will do a week in Leeds if I can ... I'll talk, but I won't promise to speak: I do it so badly. ... Y You must have a rest sometimes. Even an old cab-horse gets that. If you will only be reasonable and take care of yourself, you will be able to fight all the longer.

\section{To Oliver Elton.}

Bedford Park, Aug. 8, 1895.

I had to go to the Lakes last week. Well, they are good (I only saw Windermere and Rydal). The hills far off splendid, especially Langdale Pikes. I paid a pious pilgrimage to Fox Howe, which has the loveliest up-dale view. The places about were full of quiet grim Wordsworth-carrying Yankee Schoolmarms and British Schoolmistresses and a few solid-looking Nonconformists, full of the apostasy of Britain from the good old cause, and pious veneration for 'old horse-face'.

... I thought Wyndham's ${ }^{1}$ style charming. He is a nice, honest, good-looking, hardworking young chap-pity he's wrong side in politics, but a good foe is better than a friend like -

Mr. John O'Leary, the rebel Irish patriot, with whom Powell often talked at Bedford Park in the evenings, is alluded to presently.

To Mrs. J. R. Green. B Bedford Park, August 20,1895.

The seventeenth-century Irishmen were not saints, save of the old sort,

their hearts full of chastity, their bellies full of wine and ale, their tongues full of cursing, their hands full of power,

1 Alluding to Mr. Georgo Wyndham's Introduction to the reprint of North's Plutarch in the 'I'udor Translations'. 
which is the kind of way Girald the Welshman their envier describes them.

I am sure that you will be able to deal with Irishmen better than any Englishman, or even a West Briton who shuts his eyes to beauty and truth when it wears a glib and carries a sparth or a shillelah. _- actually goes so far that he denies the beauty of Irish legends, of which he cannot read a word. 'Ah, ma God! well! of coorse, d'ye see?' as Mr. O'Leary says. $H e$ is a splendid fellow. He tells me he has arranged finally or almost finally for his autobiography. I hope it will soon be out.

The book under discussion in the next letter is Shakespeare and his Predecessors, by his correspondent, Mr. F. S. Boas, afterwards professor at Belfast.

Mention Furnivall, for your conclusions as to Hamlet tally with his and not with that old idiot Gervinus. . . I like your Troilus and Cressida too, but you are too severe. Shakespeare is impatient of shams, and he blurts out the rank plain common-sense view, impatient of all the makebelieves of the age, in a moment of anger and revolt. I think you are a little hard on uncle Pandar, who is only an exaggerated nurse of the Juliet type. The folly of Troy is as great as the heroism of it all.

Your Lucrece and Venus are good too. I think it rather animal than coarse. Coarse is when crude words are used. $T$. and $C$. is sometimes coarse. There is lots of refined animalism in $V$. and $A$., but no coarseness.

I think your book will be a success. You must before finishing the Sonnets read Tyler, and also the translated works of Giordano Bruno, where you will find that Hamlet's

' $O$ that this too too solid flesh would melt'

comes from a sonnet of the Heroic Furies; and much more of Shakespeare is coloured by Giordano's thought.

Recognition, after all, had raised Powell's spirits, or set free his powers of expression. Ife was put on his mettle to write, and in the summer was active. The Defoe, the Meinhold, and the preface to Fereyinga are among his best pieces of literature : all were published within a year or two. His style becomes easier and richer, more like his talk : the letters have yet more edge than before. 
I was about my Master's business, Fcereyinga Saga, and could not come. . . . I am just translating a bit of Freroisc verse for my Farey saga. I am hating to get back to Oxford, and break my work, in which I am just getting rightly set. However, these things must be : people pay one for doing the work one really does by setting one to do something else that is not wanted but which they think important.

The Flugumyri view, how it brings back the old talks with Vigfússon, and the sagas! I have done a lecture on Defoe, an article on Meinhold, written my introduction to Fcreyinga, and indexed that saga carefully, besides a lot of reviews and a good deal of reading: but still it seems so little, with what I had hoped.

I have seen Sandwich and Richborough, however, and they are worth seeing. Beautiful Cotman view, or old Crome, from the Roman camp west over the flat where the war-smiths came up and smote my countrymen-Latins or Britons.

I have to go to Oxford next week early over an Oriel College meeting; and $I$ am in a crisis of virtue just now, reading about sailors, and so have to strive to do my duty (though the real sailor's duty is to disobey foolish orders and damn the eyes of his admiral, I am convinced). So I put off our meeting till the next week.

About this time the Manchester Guardian was negotiating with Arthur Johnstone, who was to join its staff as musical critie and make his reputation. Powell was pressing his claims, but Johnstone's own response was uncertain as yct. In the same letter Powell appears somewhat unsettled. The departure of his friends the Pagets from Bedford Park made him consider, only to reject, the idea which he carried out five years afterwards of a move to Oxford.

To Oliver Elton.

Bedford Park, Dec. 21, 1895.

One of the foci of the Park is cold. It is a great pity. To be separated by distance from friends is a very serious matter. ...

A mad world, my masters! is Oxford, a mass of seething unreality with plenty of good work doing in the midst of 
it all, by the presence of youth and enthusiasm, and absence of the money craze (comparative) and care for knowledge (wider spread there than many know). But the unrealities look so real and the realities have to be sought out.

It is well you wrote $r e$ [Johnstone], for I had not heard a word of it. You know his silence (Dean Maitland's was a roar to it) about anything he sets his mind on. What do you think of Nevinson's Neighbours of Ours? Have you read Une Passade, by 'Willy'? You won't like it, but it enchanted me in several places by its style, and one worships Monna pour le moment.

On second thoughts: you will hate 'Willy', and get a mean opinion of me if you read it, so don't.

One of Powell's most admired friends in Bedford Park was the writer known as Sergius Stepniak, the leader of the exiled Russian revolutionaries in London : a noble kind of patriot, whose writings are familiar in England, and who did much in the eighties and nineties to let in light upon the terrorist autocracy and its police. His prefaces (interrupted by his death) to Miss Garnett's translations from Turguéniev show his arduous insight, and balance; it is surprising that Powell was not more fully converted by Stepniak to admire Turguéniev's art as well as his character. Stepniak was cut off, he who had evaded many a Russian death, by gross mischance : a train, at a level crossing, stealing upon him unawares as he walked in deep abstraction. This was at Christmas-tide, 1895. Mr. J. B. Yeats relates the bearing of Powell :

I was hard at work with a model. Powell entered suddenly at 11 o'clock, and sat down silent. I wondered for five or six minntes, puzzled that he said nothing: when he wrote something on a piece of paper: it was, 'Stepniak killed.' Powell, as soon as he had heard the news, had rushed over to Stepniak's house to offer his services.

He did all he could, indefatigably, and wrote soon after: To William Hines. Dec. 26,1895 .

... I saw John Burns to-day for a moment, but had only time to shake hands. It was at the inquest over my poor 
friend Stepniak, who was run over by a train, close to his house, a dreadful accident. I had been with him the evening before; and it happened at 10.30 next morning. We are all sad to lose such a man. He was so kind and clever too, and a man one could trust and learn much from in every way. Every one that knew him liked him, and I saw a good deal of him and was very fond of him. His poor widow is in great grief, as you may well suppose. Altogether it is a great blow to us all. There are not many men left as good as he was. The good seem to be snatched away so often and the worthless left. Howerer, I must not sadden you at this time, but wish you a very happy New Year for yourself and all yours.

Mr. C. L. Dodgson ('Lewis Carroll') died on Jan. 14, 1896. Powell's sketch of him and verses on the sale of his effects are both reprinted (see vol. ii), and show an almost unexpected vein of sympathy. But the letters early in 1896 are scanty; two of the most noteworthy relate to Mr. George Meredith, whose books Powell had read and appreciated ever since the early seventies, and whom he often met and visited. The testimony of each man was, of course, unknown to the other; and that of both may here be quoted. Mr. Meredith wrote after Powell's death :

The testimony given without exception by the whole of our press to the merits of York Powell is a memorable instance of the impress of character made by a noble man upon those who at one time viewed it with some distrust. In France and in Germany it was no novelty for a man of great learning and a distinguished professor to be in open sympathy with conspirators against the lords of misrule. York Powell succeeded in teaching his countrymen that the generous feeling for oppressed peoples may go side by side with the student's labours, that hunted exiles, subsequently to become transfigured in history as martyrs and heroes, are to be taken to the hearts of the thoughtful and most eminent among us during their term of peril under obloquy. For this, even more than his accomplishments, I prized him and hold him in my dearest memories. As a friend he was invaluable; always instructive, if need were, yet more willing to listen than to hold forth. When he had to correct a blunder it was done flowingly, as a necessitated 
jump along the road of conversation, never in the manner of the irritated pedant. He could not let the error pass, but he had no frown for it. I could write pages in praise of the comrade he was, the splendid gifts I knew him to possess. I am stayed by conjuring up his shake of the head at any personal word of eulogy. ${ }^{1}$

Two letters give Powell's comment on Mr. Meredith's talent, and especially on his recent novel. The first letter was occasioned by an article sent him for his judgement. In acknowledging such things he often wrote his best; and I do not, here or elsewhere, mutilate every friendly word he wrote; it would take a very callow vanity to accept half the praise of a man who was so modest in his own case. Besides, he always criticized. He did not sit down, in the mood of the judicious schoolmaster-friend, to mix gall and honey for one's good. He let fall what he thought in a way that told without hurting. You were humiliated without pain or intent, and quickened to go on. His remonstrances were always 'done flowingly', in writing as in speech. His aversion to Tolstoi reappears in a later epistle to Johnstone. Powell often explained how and why he despised Tolstoi's hatred of war, art, science, sex, and institutions: even in the famous stories he found a 'thinness' of intellect; he saw that in them Tolstoi's later creed lurks, undeveloped, but still an irritant. Powell himself believed in civilization, and could digest its conditions and accept its price. He was not reconciled to Tolstoi either by the individualism, or by the hatred of pretence, or by the Christian unselfishness of dealing, or by the disbelief in dogma, that they shared. He himself was an individualist chiefly in the sense that he showed much reserve in judging both the sexual behaviour of private persons and the political morality of great men. On another side he was an historian, engrossed in tracing the rise of institutions and the conquests of

1 From a communication quoted by Mr. Robert S. Rait in his articlo on Powell in the English Historical Review, July 1904. 
culture. He had no nihilistic fecling against law and authority as such; but their inherent evil is Tolstoi's postulate. Powell thought, for instance, that Algernon Sidney was a martyr, but also that he was a legal traitor ; and he could not condemn Sidney's judges. Tolstoi would have treated that trial with dissolvent irony, as a text at the expense of legal justice. In Balzac Powell believed more and more, and regarded Mr. Meredith as one of the same company. So flashed his talk; and the letters are like his talk.

\section{To Oliver Elton.}

1896.

Thanks much for your paper which I enclose herewith. It has been very good reading for me. This is what I notice. I don't think Comedy the sole inspiration of Shagpat. There is something of pure Persian fantasy, of romantic sorrow in Bhanavar. As to Positivism, I think Morison was more likely to be influenced by G. M. than G. M. by him. He was very amiable and humane. He talked well and wrote flatly, I thought, but I liked him personally much. He was frank, and good of impulse and disposition, and he disliked Clericalism, which I also hate. (Isn't Zola's Rome fine, by the way? I am just full of it. I see the faults, of course, but what an historian the man is, how true his instinct! How hopeful he is in spite of all, and how well he writes at his best!)

Don't say [of Modern Love] 'misnamed somnets'. The Elizabethans would have called them 'somnets.' They are not Petrarchan sonnets but that doesn't matter. 'There is a glory of the sun, and another glory of the moon.' R[hoda] $F$ [leming] is not a patch on Richard Feverel, for real power over one.

My dear boy, we read Meredith in the early '70's at Oxford: I remember reading both poems and novels in 1870. The story is that Mrs. Carlyle begged Carlyle to read Richard Feverel. He did so, and said, 'Ma dear, that young man's nae fule. Ask him here.' When he came, as Meredith himself told me, he talked long with him on deep things, and begged him to come often. He said, 'Man, ye suld write heestory! Ye have a heestorian in ye !' Meredith answered that novel-writing was his way of writing history, but Carlyle would not quite accept that, 
though he did not argue against it, but rather doubted over it, as if there were more in it than he had thought at first.

Some of the poetry had come out in the great days of Once a Week, when the finest illustrators, Sandys, Pinwell, Houghton, Walker, etc. were working on it the great school of the '60's), whose work people are rightly collecting now.

You must specially praise Love in a Valley, the most gorgeous piece of rhythmical work and passion. You have left it out. Meredith is a great metrist, but Browning writes poorly as regards musical verse. Meredith has invented his great metres.

You think too much of Tolstoi, a childish babbler, a weak narrow-brained person; humane enough, but no thought; he has gifts, sympathies, intuitions, but lacks brain; falls into sillinesses, futilities, patent absurdities; won't face facts, is conceited, preachy (that is why he is popular here), full of foolish religiosity : 'artiste malgré lui.'

Mention the early morning walk in The Amazing Marriage, the splendid scene in the Scala, of Vittoria; the voice in the wood at even in Sandra.

Balzac if you like; a thinker, an historian, an artist, a mighty labourer; but Tolstoi docs not deserve comparison with Meredith. Don't laugh, think it over, without remembering it is 'prejudiced' I that write this.

Well and finely done, too, the last paragraph.-You might enlarge on the Earth-spirit. Try and smite out the man's creed in one or two sentences, for he is a prophet as well as an artist. He has something to tell us: "we bid you to hope'. 'Tolstoi, good God! a miserable nonconformist set of silly preachments. Meredith is sound like Shakespeare. Do bring in Balzac. Your judgement on a man such as Meredith can never be too carefully thought out. I think you have succeeded wonderfully. What I have noticed are only non-essentials, fringes, where pattern might be altered. The fabric stands. . . . The man, his dazzling dramatic talk, his beantiful clear enunciation! His love of fun and teasing, playing kindly on our foibles, stimulating, ironic, gentle too and sympathetic at the right time, proud as Lucifer, and dutiful as Wellington. 'Thank God I have never written a word to please the public,' he said once to me. But I must stop. My train will not wait. Try and decipher this. It is well meant. Cut out Tolstoi. Away with these half-baked potatoes. 
Balzac and Meredith will represent their century. Do not mention such a person as George Eliot, let her lie. She did some good work and much bad. She meant well, and she and Mrs. Grundy quarrelled, and made it up over filthy Ghetto piety ... I am boiling because I ean't sit opposite you to argue with. You have done a fine bit of work. I am glad you praised Henley. He is the only man who has really tried to judge G. M. W. Morris says, 'A clever man, not an artist.' He can't rise above the naive melodic. Yours sincerely.

To the Same.

Feb. 10, 1896.

The Amaning Marriage-one of Meredith's great successes. I remember the Old Buceaneer excited me hugely when he read it. Carinthia is glorious. Her Madge next (poor Kit, he lost what was worth having). Woodscer good, Wytham impressive even in his outline. Chillon the least satisfactory in every way. He treated his sister almost as badly as that insolent lord, slave of his word, his vanity, and his grievances. But this lord is marvellously drawn : there is something of him in us all. $\mathrm{He}$ is not beyond human sympathy, at all events. I prefer him to Chillon. The old Lady good, Henrietta a pretty pastel, Livia a delightful foil-folly in full flight, but with a balance-no lack of brains.

The 'morning walk' is a masterpiece surely : you smell and taste the dawn in the reading of it.

I am sure this $A$. $M$. will be one of the solid bases of M.'s fame. He has given time to it, I know, as well as inspiration. It is not 'difficult'. It is profoundly interesting. I hope you think this, all, but I don't want to persuade: it is pure besoin d'épanchement.

\section{To Maister Herbert Greene}

$\begin{array}{cc}\text { at his Lodginge in Mawdlin College } & \text { This 26th of March } \\ \text { Oxenford } & \text { A.D. } 1896\end{array}$

Good Master Greene These with greetinge

I am surely much beholden to $\mathrm{y}^{\mathrm{r}}$ ffiendship for $\mathrm{yr}$ goodly Gifftes!. Of a Truth those be rare Matteres of

1 Mr. Greene notes: "The "Gifftes" were :

1. Falstaff's Letters, by James White (the reprint of 1877).

2. The Adventures of Sir Frizzle Pumpkin, Nights at Mess, ic. (Blackwood, 1855).

For "Rowen and her Chalice" see Falstaff"s Letters, 1p. 81, 32, 39,80 .' 
$\mathbf{y}^{\ominus}$ Knight, and there be delicate Touches of Ananias his craffte in the Noctes Martiales. It irkes me $\mathrm{y}^{\mathrm{t}} \mathrm{I}$ haue at this present Houre noe meanes by me in the way of Acknowledgement that I might craue your acceptaunce of, and I knowe verie well that faire wordes enen though they be engendered of Gratitude and $y^{e}$ unfeigned Consideration that I bear to you ward, auaile nought in descharge of my instant Obligaciouns. Neuertheless I w not let pass this occasioun of subscribing mie selfe the Debtor of a Merrie Afternoon or soe to $\mathrm{y}^{\mathrm{r}}$ Bountie.

But Clock shall strike \& match with powder meet

Pistol shall thunder forth and bullet speed!

By Rowen and her Chalice. Wherefor marke!

Till when I praye you farewell and liue in Content and soe no more till we meete from yr singular ffrende

Fredk. York Powell

From my poore Chambers at Christ Church.

In the summer he went again to Ambleteuse. It may have been in this or the next year that he first took to oilpainting, and learned, with Stevenson by his side, how to set about it. One of his canvases, of a yellow field full of shocks of corn, with tender-green poplars behind it, shows the pleasure that the soft clear lines and full colours of the coast-side gave him. The next letter is in answer to one written from Dovedale. Painting delighted him now as much as anything in his life, and his practice enhanced his power of colour-notation in words.

To Oliver Elton.

Hôtel Delpierre, Aug. 8, 1896.

Now I prefer Ambleteuse to Ashbourne. First; no hills save sandhills, pale buff' and dark rich green in patches, and faint olive-yreen herbage on their sides.

Second. The sea, purple, green, to yellow-green with vivid 'painty' green stripes; bronze brown-green, delicate pearly grays and invisible purples and faint blue; a changing mirror of sky.

Third. Sky. Not clouds and mist and smother of dull gray, but real sky, open, broad, another ocean above, with 
procession of clouds, high and sunlit, with quivering greens and purples and reds and yellows all round the horizon, scaling up to intense blue overhead. It is a pleasure to lie and watch it.

Fourth. Long lines of landscape.

This is a great delight to me. I don't like the

$$
\text { MM business + mist - }
$$

Fifth. The change is greater. France is a refreshment after England, as England is after France. However, I don't want to press my advantages (which are accidental and not personal) upon you in return for your charming note, and very kindly argument $r e$ Tolstoi.

My French friends at a châlet not very far from the hotel are great musicians. I think I get pleasure out of their music, which I certainly don't out of other people's. They seem to understand the music that appeals to me (most music is mere cacophony to me, unmeaning and an abominable bar to talk). And then they dance like angels, and we laugh like mad people, all at once and quite loud, not the usual gentle smile of English people (excellent too in its way) that you are accustomed to at my house. We go there every evening, so that I barely put a pipe in after dimner, which I daresay is good for me, besides sparing backy (a precious commodity here and difficult to replace). Well, au revoir. September, please God, we meet and talk of many things.

Another letter from abroad refers to the fortheoming Lives of the Troubadours by Miss Farnell, his earlier words to whom on the study of Provençal have been quoted.

To Miss Ida Farnell.

Hôtel Dolpierre, Ambletense, July 28, 1896.

... I should like a little flourish at the end, and a commendatory somet or two in Elizabethan fashion at the begimning, of the title-page, e.g. 
To the well-skilled Translatresse.

Lady, whose polished Penne and careful Hande Have brought from out their vellum Treasuries The Lives and Woordes of high and deep Device

Of famous Singers of the Noontide Lande,

So that our English Heartes may understande,

And haply, somewhat of their Mysteries

Thus learning, be the better spurred to rise

To higher Courses than they yet commande:

We give thee Thanks for this thy gracious toil, That hast transplanted to our Northern soil

These ruddy flowers of Southern Poesy,

Such as great DANTe loved and studied well, Such as soft Petrarch, as his Verses tell,

Found full of Honey for the Muses' Bee.

\section{Ignotissimo.}

You will easily get others of the like order, such as adorn the beginning of the Faery Queene. I am yours faithfully.

In September he was back, full of talk and power and spirits. These years just succeeding his appointment as professor were the zenith of his later life. The power of production and expression was strongest, or at least most buoyant, from about his forty-fifth to his fiftieth year; after which, even before ill-health threatened, there was some increase of sternness, and, with Stevenson's death, of melancholy. He saw something this autumn of his friend Arthur Johnstone, who had now settled in Manchester. Memory dissolves together many meetings of this kind confusedly, and the reported talk of comrades, equally with its silences, is savourless to the public. But one day, known afterwards as that of the 'accidental threeman lunch', stands out clear in the mind of the survivor. It was nothing, - an ordinary Londoner's interlude. It may give for once a picture of Powell holidaying. A hasty rendezvous was made at the old floating bath, now abolished, that lay in the Thames by Charing Cross. It was a garish and breathless August mid-day, of the tor- 
GProin Sawum

"Ygn

Alpurbart

4 Taur

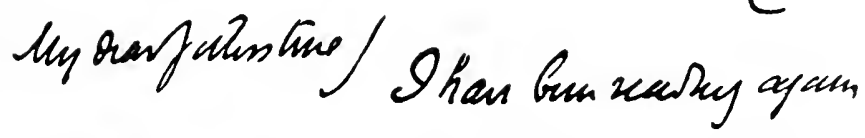

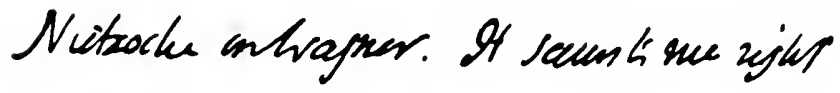
that do que thicik. Itarza suttm as

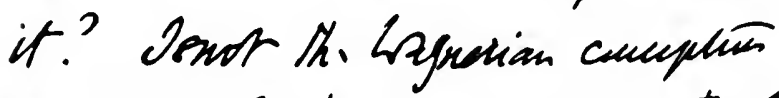

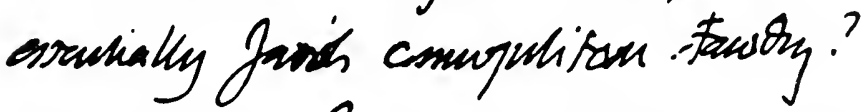
apart ofroum frum mentaubtat piecen of sually

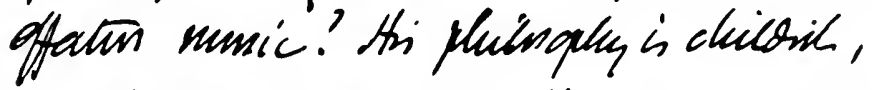
Hsi eltice vidiculmen this mifeumu abstules Stenlying. As wenth is currain. Is than a

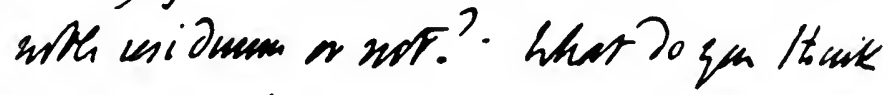
Sond mu atine

ghmullis a pmingh

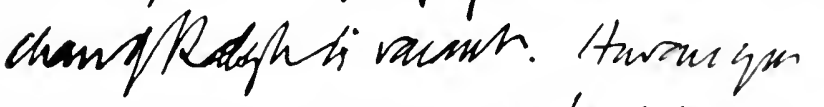
when than is menn.? qu muptus,

Anomponl. 

ridest, when the waterside flickers in the heat. There is a brutal oppression of white light; the plane-leaves are dusty and do not move. 'The full tide of human existence,' which on good authority flows by Charing Cross, is at a slack, irritable pulse; the senses are lashed and tired. The London greeting, the nod of acquaintance, is less expansive than ever: and to such influences even cordial and enjoying spirits respond. Powell and Johnstone came in, somewhat correctly attired; the younger with his slight figure, Beethovenish brow, and deliberate look, varied with steel-grey incisive flashes; the elder silent, opening his eyes wide to a dead-black gravity, until the fresh cool reflets and plashing of the bath, at this hour little tenanted, struck upon him. It was the best place in town on such a day, and the plunge restored the natural pitch. Powell, as we did not know, had learnt in youth to swim well, and, on being challenged to race a length for the subsequent Chianti, won easily. But he insisted on the interpretation that the winner should pay. In a quiet Italian cafe this idea was carried out. There was the salt of the haphazard mecting of friends eager after separation and travel. This volume would be the less impoverished had any one of us had the Boswell or de Goncourt habit of taking notes more or less stealthily, a habit which may serve the world, but not so much the good name of the note-taker: a little meanness hangs about it. 'I hate,' runs the Greek saying, 'a feast-fellow with a memory.' The talk was on books. Johnstone was a connoisseur in certain kinds of living foreign literature - the last French tale or German satiric comedy-liking what he called 'the drastic'. The manner and sequel of such conversation appears best in two notes that Powell wrote to him afterwards : they are here put together.

To Arthur Johnstone.

1896-8.

I have been reading again Nietzsche on Wagner. It seems to me right. What do you think? Have you 
written on it? Is not the Wagnerian conception essentially Jewish ; cosmopolitan-tawdry? Apart, of course, from undoubted pieces of greatly effective music? His philosophy is childish. His ethic ridiculous. His influence absolutely sterilizing. So much is certain. Is there a noble residuum or not? What do you think? Send me a line. ...

I want to hear what you think of the Russian movement of literature. I think Elton, for instance, immensely overrates Tolstoi, who has no brains at all;-considerable sympathy and instinct of a literary kind, but no reasoning power. And as for instinct I prefer Tchernichersky. If Turguéniev had been a Frenchman he would have been acknowledged second-rate, as he is, but because he is a Russian people crack him up. Have you seen Une Passade, by 'Willy'? I think immensely of it. Monna is really a pathetic little figure, in her insouciant makebelieve and absolute frankness and courage. You won't think the book hopeless I hope; it is not, to my mind, because it is so completely sympathetic. Howerer, one is never sure of one's own tastes not being an 'idiotisme' or peculiarity that other people cannot share. But I hope you will like the book; the extravagant humour of the style, even, delights me excessively.

William Morris died on Oct. 3, 1896, and was buried at Kelmscott. Powell, while yet a schoolboy, had known and visited Morris's mother in company with his own mother, and remembered her fascination for young people; 'she was very cheery and simple-hearted, and extraordinarily sympathetic in their joy or sorrow.' In undergraduate days he came to know Morris himself. He had often gone to the house at Hammersmith, crowded with books, yet so 'light and free from dust', where they talked 'about all kinds of things, especially literature'. He had also gone with Morris to Merton and seen every process.

Morris had gone over there every day for the six months previous to our visit, but he was as pleased as if he had never been there before. He knew the work from the beginning of the process to the end, and that was the reason why it was so extraordinarily well carried ont. He understood that the books he printed could not be distributed everywhere, and he was quite conseious that the 
majority of people could nerer hope to possess a book of the kind, but what he wanted to do was to make books as they should be made. They cost Morris a lot of money, but he believed they would find their way into most museums. People who saw them would be dissatisfied with the ugly printing and presswork of modern books. . . .

I saw him for the last time after his return from Norway, and then he showed unmistakable signs of death. He sent for me, and was as kind and considerate as ever. He brought out the last manuscript he had got, and told me the discoveries he had made. It was only a few days afterwards that he was laid to rest in the little homely churchyard by the Thames ${ }^{1}$.

There is also a note of interest on the poetry of Morris, which must qualify the phrase tossed out earlier: 'He can't rise above the naïve melodic.' Powell was not deeply in sympathy with all the work of the school, though he paid tribute to Christina Rossetti. Of the paintings of Burne-Jones he would say, 'I see that it is his dream; but it is not my dream.' But Morris's verse was a part of Powell's youth, if not in the same measure as Swinburne's :

Nearly all of us can remember a time when we took up some kind of a book or poem which we had never seen before-a thing towards which one had leaned in one's dreams, but had never grasped. It was this feeling of freshness and pleasure that came upon one in Morris's works. Jason, The Defence of Guenevere, and parts of The Earthly Paradise seem to stand the strain of criticism. The Death of Jason is one of the great achievements of this century, whilst there is a kind of haunting music about The Defence of Guenevere quite distinct from that of any other work of the eentury. 'The best part of The Earthly Paradise strikes me as an attempt, and on the whole a successful attempt, at putting a great prose story into verse. As to The Dream of John Ball, it is a great thing to have an historic imagination so strong as to be able to present such a living picture of the past.

1 This and the other sentences quoted are from a lecture Towell gave on Dec. 3, 1897, at Manchester College, Oxford. 'They are in a press report that is saved in his serap-book, abridged but corrected and approved by his hand, and replaced, in the text supra, into direct speech. 
There is but a word of Powell's reported on Morris's political characteristics. He was in accord with many of Morris's aims, but cared little for the method of propaganda, 'speaking at street corners,' which, after all, was not Morris's strength, because he often spoke ineffectively.

We remember his extraordinary faith in progress, his very wide political sympathies, lis hatred of injustice, and his impatience with the competitive régime which falls upon the people who do the bulk of the work.

\section{To Miss Hines.}

Oct. 11, 1896.

It was sad to lose Morris. I saw him only a little while ago, and he was dreadfully changed, but as clear-headed and kind as ever. I knew that he was doomed, and it only took a few days to bring the end.

The gathering at the station was very representative,Kropotkin, Graham, Armenians, Grahame, Burns, Dearmer, Jo Clayton, Crane, Frampton, W. Richmond, lots of workmen from Merton and Hammersmith and other parts, a good many pressmen, Catterson Smith and Cockerell who had been nursing him most devotedly, Sparling and many more. It was all spontaneous, and I think every soul there was truly and heartily sorry for the friend and teacher they had lost. I am glad your father was able to go to Kelmscott. . . . I am just off to see the Arts and Crafts exhibition, which Morris did so much to forward. I am, with love to your father, F. YoRk Powell.

To W. P. Ker.

Bedford Park, Oct. 10, 1896.

... Poor Morris, he did not want to die. That damned and altruistic street-corner business did the mischief really. He ought to have lived longer. He was very like Freeman, and I liked him a good deal. Honest, childish, busy, interested in good things and worrying at the damned folly that makes this world worse and uglier than it might be. He said, 'I don't believe there is a man in England whose friends love him as much as mine do me.' 'I am so silly to give you all this trouble, and I am not so patient as I ought to be, but you must forgive me, I don't mean to be unkind.' He had the old English ballads read to him up to the last. "There is nothing like the best of them in any language!' We saw him off at Paddington, a lot of people 
of all kinds and conditions; parsons, poets, painters, sculptors, workmen, agitators, refugees, M.P.'s, art students, and his own private friends. There were many laurel wreaths, and he deserved them, I think. It was all very homely and spontaneous: you felt it was not lip-service.

He told me he once wrote 300 lines of verse in a day. Last time I saw him, about a fortnight ago, he showed me his last purchases, such splendid 14th and 12th century English MSS.! Truly such things make it 'hard to leave them'.

But this is the gate we a' maun gang Intil the mirk alane.

My Fcreyinga is printed ; I expect it out in a few days. Your copy I will send you. There is some of you in it. Your book I gave to the Porter at Gower St. Gate, a rather amiable Peter. My oldest friend, to whom with Henry Liddell I dedicated the book, is dead, aged 93, a fisherman at Sandgate. I wish good people lived longer. I am yours faithfully.

The edition, a version of Frereyinga Saga, the last of Powell's writings on the matter of Iceland, and the only one of them that he wrote single-handed, had been first translated by him, as has been seen, in 1868, the year of his matriculation. It is inseribed to Dean Liddell and to Stone. He had revised it

for the help of $\mathrm{my}$ kind and regretted friend F. S. Pulling, when he began to read lcelandic with me in 1874. It has, of course, been again revised, indeed almost wholly re-written, for the present edition. ... [The story] is one that has always given me especial pleasure to read and to remember, and accordingly 1 have been bold enough to dedicate my version of it to two of ny teachers for whom I have a profound regard, as a token of a grateful desire to do them honour. And I am glad to have their names printed at the head of the little book that, however unworthily, does, at least, first set forth in English the life and death of certain memorable inhabitants of the far-ofl' lonely little Atlantic archipelago that the Iceland-bound voyager sometimes beholds as 'a wonderful vision in changing mist-a sudden revelation of shiny sea' with the dark castles of islands 'standing up out of it, and large streamers 
blowing away from their tops like flags'. It is true the men and women, of whom this story tells, lived and died long ago, but surely they were of those whom the pious poet would not have us willingly forget-

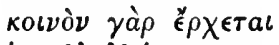

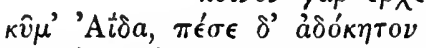

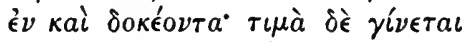

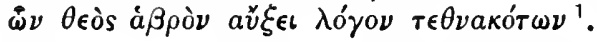

The virtues of Powell's English translation are the same as in Origines, and need be little exemplified here. The rough but complete draft he made in boyhood has of course long vanished in the two revisions. The style is plain, but it has the half-discernible tints and lines, like those on a moth or stone, that Powell in his later years came to command. It would not be easy to imitate.

Thorgrim the wicked went down to the shore that morning, and he had a pole-axe in his hand. As he went by he saw red clothes sticking out of the seaweed heap; he pushed away the wrack and saw a man lying there. He asked him who he was. Sigmund told him his name. 'Low lies our lord,' said he, 'but what hath wrought this?' Sigmund told him all that had happened. With that his sons came up. Then Sigmund prayed them to help him. Thorgrim did not answer at once, but began to talk to his sons in a low voice. 'Sigmund has so much gear on him, as it seems to me we have never owned the worth of, and his gold ring is mighty thick. The best thing we ean do, it seems to me, is to slay him and then hide his body ; it will never be known.' His sons spake against it for a while, but at last they were of the same mind. Then they went up to where Sigmund lay, and eaught hold of his hair, while Thorgrim the Wicked hewed off his head with the pole-axe. In this way Sigmund, that was so good a man in all ways, lost his life. They stripped off his clothes and gear, and then dragged him up under an earth-bank

1 The Tale of Thrond of Gate, commonly called Fareyinga saga: London (Nutt), 1896: pp. xxxix, xl. The verses are from Pindar, Nem. vii. 43: 'For upon all advanceth the billow of Death, and falleth unexpected, yea, even on the expectint; but honour eometh for them whose name God enlargeth to be fair and delicate when they aro gone.' 
and buried him there. Thore's dead body was cast ashore, and they buried it beside Sigmmnd, and hid them both ${ }^{1}$.

The introduction is of Powell's best. There is the favourite sorting and arranging under heads-War, the Sea, Home Life, Trade, Dress and Personal Description, Political Life and Law, Beliefs, Saws - of all the references: an account and translation (reprinted by us) of the Frereyese ballad on the tale; an analysis of the varions layers of the Saga, some of them of the elassic time and 'the right Odysseian vein', others bits of ingrafted folklore in a different style, others giving only late fictitious and flimsy matter. When these points, and those of chronology, genealogy, and the like, are disposed of, Powell allows himself a free pen, and the sympathies of the natural man.

One cannot but admire the stubborn crafty old fox setting all the good powers of heaven and earth cheerily at defiance through a long and laborious life. Only great skill could have rendered the pious hero Sigmund so attractive as he is throughout the story without destroying all sympathy for his treacherous foe and destroyer, Thrond; but in his fidelity, his unselfishness, his mercy, his marvellous prowess and his guileless speech Brestesson is still, like Béowulf and Gunnar, a real man, not a mere Tennysonian lay-figure... The women Thurid and Thora are wortly of their mates; courage, patience, the instinct to know how and when to act, are theirs for generations. Thurid can even master her tremendous pride in order to win her revenge, and Thora keeps her presence of mind in the midst of the greatest dauger to her child, and saves all by her stratagem².

Powell, we see, 'cannot but admire' both parties to the duel, and this attitude perplexes both those who dislike admiring anything but goodness, and the cynical observer, who loves force, and judges merit by vietory, though he is less amused when goodness is victorious. But Powell 'admired' both saintly goodness and the

${ }^{1}$ Fcereyinga Saga., pp. 51-2.

$2 I d$., pp. xiii, xiv. 
'crafty old fox' in conflict, even when the latter prevailed. His love for the saints was, however, not simply that felt by the religious mind; he really admires, at least as much, the artist who makes the saints real in spite of the superior interest of the son of Adam their enemy. Nor does he admire the strength of 'Thrond, or of Napoleon, cynically and in their own spirit; nor yet, again, in the spirit of the literary person who-or the woman in whom-genuflects before brute force: of that malady he was quit. He admires them, as the natural man does, for their qualities-for pluck and cumning; and, as a good Darwinian, for their power to persist; as a dramatist might, for their grouping and colour in the scene; and as an historian, because they, and not the saints, make the tough web of history. Afterwards Powell put his dislike of ethical judgements into a sort of formula, which he said was to bind at any rate the historian: and we shall see that to saddle him with this formula, literally taken, as expressing his own habit, is unjust and untrue; because he overran with ethical judgements to the last. But the dramatic, the tolerating instincts grew stronger too; both instincts, the ethical and the dramatic (or scientific), grew stronger ; and if they did not finally harmonize, the fault may be less in Powell than in the difficulty of the human universe.

In the same year he wrote to a friend who had suffered bereavement and was in search of a literary task: here again two letters are pieced together.

I think some period of French History would probably be the most interesting and fresh. There is William of Tyre and the Crusader. There are the chronicles of the Jeanne d'Arc period. There is the Jean Lebel and Froissart period. There are the Wars of Religion, the work of d'Aubigné, de Thou, \&c. There are Mme. de Sévigné's letters. 'The letters of the Regent Orleans' mother. 'The memoirs of the Napoleon time. There is the widest choice.

As to Euglish books. There are two that interest me immensely. One is Clifford's Common Sense of the Exact 
Sciences, and the continuation by Karl Pearson, Grammar of Science. Yon will find these really useful in getting any general ideas about anything. They seem at first sight to be mathematical, but they can be understoor by a person like myself who has had no mathematical training, and I find them fascinating, as well as helping to clear away a heap of useless theories, and giving one fresh ideas.

There is Villani, and Dino Compagni, that are wortl reading, and help one to a comprehension of Dante's surroundings. Dante is also, if one likes him, a very enthralling study.

I can quite understand the need (after such a loss as you have undergone) of something to give one's mind to work on. — told me, when he lost his little girl by an accident, that but for taking up the history of the he thought he should have become quite melancholy, to insanity.

Do you know Latin? I think you do; if you do, there are several books worth reading in it, both chronicles and older books. Cicero's Offices, De Amicitia, De Senectute, ete., all very pretty imitations or rather adaptations of Plato's Dialogues, applied to personal subjects. Pliny's Letters are interesting too.

[Later.]

... I hope you are really feeling better. You must take care of yourself. Your life is not useless, and one must fight against mere grief (I know it is easier said than done), and cherish remembrance which does not injure one's eapacity for being of use. But you know this and practise it far better than I do. So I needn't have written it, only I really sympathize with you, for I know how hard life must have been for you for many months now. Even the sminght does not seem as bright as it used to be.

To Mrs. Shute.

Bedford Park, Dec. 1896.

I must hear about this list Ibsen. I was entranced with Little Eyjolf. ${ }^{1}$. . I Im devoted to a man who really interests me as he does. Those wretehed creatures of

${ }^{1}$ As played at Arenue Theatre, Nor. 1896; Mr. C. Thorpe, Miss Achurch, Mrs. Patrick Campledl, Miss Farr, and Miss lonlins actingr for all or part of the rmu.

r. P. I 
his on the stage he makes real, and no bad acting can spoil this impression. I fecl for their troubles and sins and mistakes because they are of the same flesh and blood, and where they fall I should stumble too. It is so real, one can't belicve it not true, and it is true nearly always. Almers was just the 'partikiler damfool' (as Artemus says) that he would have been when he lived. His wife real too. Asta I thought charming, inefficient but excellent. (The child and she were the best acted.) It was his miserable tonch of 'culture' and his badly fitting clothes that made it all the more real; one despised him, and felt that after all he was a better fellow than one was oneself. Ibsen's plays have a little way of bursting through one's self-deceptions and vanities, and letting cold air and light in. It isn't comfortable, but it is good sometimes, to see the worst clearly, though one does feel such a mean hound as one walks out of the theatre, having had the interview with one's Nathan. I suppose David, even, felt like that after the fabula de te narrotur. I don't know whether it has any very lasting effect, but at the time it is always an amazing spiritual experience.

When a man gets one like that he is above most of one's criticism. His splendid stagecraft and knowledge of his art and swift flashes of insight blind one to the defects that one only finds ont by aecident afterwards.

I want to see Ghosts, the greatest play on Heredity since Aeschylus and Sophocles.

What is this last play (last in all senses, for they say he will not write again) about?

I can see the comic possibilities of parody in Ibsen as I can in Shakespeare and the Bible and Whitman, but it doesn't in the least lessen my respect and appreciation of any of them.

After I went last week I couldn't think of anything else for about three days (except when actually working).

Please excuse all this Ibsen, but I am just brimming with it.

In March, 1897, l'owell read the Epic and Romance of his next correspondent, and reviewed it in The Academy.

To W. P. Ker.

Christ Church, March 23, 1897.

I am glad you are pleased. Hind asked me to do the article or I should not have had the opportunity. You 
will be pleased to see $O$. Elton's opinion umprovoked. You see I urge and egg you on to further endeavour. You ought to do French Song-German mimnesengItalian early sonnet and song-Dante-the Romance prose -Graal, Tristan, Lancelot, Merlin, Mort Arthur, Perceval, the whole caboodle, in fact, of the matter of Britain, from the literary point of view.

I am horridly worried over the 'Reign of Victoria' for' Manchester Guardian. It is difficult to do really with any bite in it, and it wants thinking. . . . However, please the pigs (relic of Celtic imagery) I shall hope to put it through and go and see Elton at Manchester for a day or two....

I have been reading Genesis again with the new lights. It is a jolly sight more intelligible. There are some good tales in the 40 [10?] Wazirs [Viziers] that explain some facts left out. Ham was drowned, that is why Canaan with the folly of extreme youth got into trouble. It is a story to explain the difference of the two genealogies, possibly.
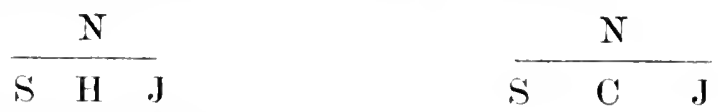

I expect you haven't seen this:

Noah looked out of the window of his well-appointed bark, And said, as he gazed intently across the waters dark, To Sh. and H., and .J., 'My boys, I wasn't wrong, Here comes that dove with the olive-branch;

I :m yours faithfully.

Now we shan't be long.'

The 'Reign of Victoria' was a long Survey, which Powell was to write over his signature for the Manchester Guardiren, to be published on the day after the reign ended. On this piece of history he spent much, and lost some, labour. His connexion with the chief Liberal paper of the North had been long and friendly, and lasted till his death. But at other times he always wrote for it as a reviewer, never as a chronicler of English history at the point where history merges into living polities. In their fight for many social and edncational reforms the Radicals had his lively sympathy. But he disliked more and more some of the 
historic figures of their party, and he was already sealed a votary of the newer imperialism. He could not be labelled: his stock of opinions was his own. I think that the work of composing the Survey brought out the divergence in a way that neither sicle had realized. He took pains with it and said just what he felt, relying on his signature to relieve the Manchester Guardian from answering wholesale for his opinions or adopting them. But in view of the declared faith and convictions of the newspaper, the dissidence proved to be too great. There was awhile a deadlock. Powell conld not have signed an edited article: yet there was often substantial harmony of view, and such work conld not be wasted. Finally, Powell withdrew his signature, handed over his material, and ceased to be responsible for the form in which the Survey was published-a form that is therefore not here to our purpose. The misreckoning was painful at the time, but the solution was on the whole the fair one, and showed a mutual respect for conviction.

Powell retaincel the first proofs of his article as he wrote it, put them in his scrap-book, and corrected them largely when the affiir was over. His changes are of much interest, and show his hostility to official Liberalism rapidly and deeply intensifying during his later years. Epithets are sharpened, shatlows blackened, judgements become more summary. As his corrections resemble in form and precision corrections for the press, I an sure that he would have been quite ready to print and sign the Surre! in this its final form, though, of course, there was no opportunity of doing so. Some of the striking passages are therefore reprinted '. They include a panoramic view of the state of England in the year 1837, as well as a series of his favourite 'lightning portraits'. 'The narrative chapters, which suffer from enforcel rapidity, from the difficulty of colouring a familiar tale afresh, and from the want of space to reason out some of the jurlgements and adjectires, founded 
though these were on long consideration, have not been reprinted. The panorama and the portraits are in their nature impressions, and to them the same objections do not apply. They show Powell's freshmess of thought and his synoptic instinct as happily as anything that he wrote, while in the paragraphs upon arts and crafts and letters he is faithful as ever to his own sensibilities, and ever ready to disconcert or displace conventional verdicts, sometimes by heroic lissent, sometimes by light but equally fatal turus of phrase or reserves of epithet.

Hallam, the elegant and interesting compiler. . . . Newman was beginning the literary career which was to endow English prose with some glorions oases of spontaneous dietion set in wastes of arid ineptitudes.

The article, moreover, is a strange commentary on Powell's conception of history as a scientific and judicial analysis where no ethical judgement may intrude. $\mathrm{He}$ is true enough to his principle of letting the facts, as he read them, speak for themselves, and of not judging the makers of history by purely domestic canons. He is not hampered by the formulac of either party, as the extraets show. But it would be amusing to fiame a definition of the word ethical, which would exclude that element from his description of Distacli as 'a man withont scruples, but not without honour', or of Lord John Russell as one who was 'untrustworthy', and who 'maintained his position by cumning and self-assertion', and, 'like other mediocrities, profited by the failings of better, wiser, and stronger men.' This is not precisely achromatic, or a mere description of canse and effect, thongh it may be true. Powell here writes as a passionately interested contemporary observer might have witten. The period was too near at hand, after all, it may he said, for other treatment. Still, if we took his theory verbally, he would have had little right to praise even King Alfied for his moral virtues. Common sense, and the profoundly spiritual nature of Powell, forbate such a conchusion. In 
his own practice and that of all other historians of his school, praise is never stinted; and so the theory might seem to work out only on one side, namely, that they are often chary of blame, but not of honours. It has to be said that Powell was consistent up to a point ; for he was equally reserved in blaming a man of his own time, like Bismarck, or of the past, like Napoleon, if only he thought him a mighty force that on the whole made for advance. What his theory seems to come to, therefore, is a plea for a freer and larger view of historic good and evil than the common canons of personal morality supply. This, however, is a very different thing from the theorem that the historian treats of a non-moral or 'anethic' man, just as the economist assumes an 'economic man', impelled only by profit and loss considerations. To this point I shall revert.

Two letters to a friend with whom he found himself more and more in political sympathy, a writer of note on military and imperial affairs, nay here be forestalled. After these lines to a Conservative imperialist comes a letter to a socialist.

To Spenser Willinson.

May 21, 1897.

I am trying generally to get the Army weakness realized among those who can help to do something.

The philanthropist is generally a person seeking excitement in unwholesome and dangerous ways. He had much better go on the turf or the Stock Exchange. He would do less damage. I dread Philhellenes and Philarmenians too, of the professional kind. . . .

The Historical Review was founded in my old rooms at Ch. Ch. We have a good training school now. A man can learn 'Diplomatique', Palaeography, and Historic criticism, and Bibliography, at Oxford; and these are keys. We also try and teach him to write. We can't do more.

$$
\text { June 5, } 1897 .
$$

... I can't see anything in German foreign politics at present save a desirc to claim as much of our trade as she can, and an earnest effort to get a position from which she can offer France and Russia bribes: but I think she 
is securing her position in the Balkans with a view to the inevitable crisis that must come when Fr. Jos. II dics. I wish we could come to some decent understanding with her, as she is a permanent power, in spite of the little Emperor's vagaries.

\section{To Joseph Clayton.}

March 12, 1897.

... I don't agree with you as to Norwich beer, which when old I like immensely. Ask any old Norwich people about Jem Mace. He is well remembered in publics there. I well remember the Maid's Head. The place for pretty girls is Ipswich: they are the beauties of the East, as Taunton girls are of the West. The dialect you are hard on too. You must read $A$ Son of the Fens, by P. H. Emerson, 'that fare to be a masterpiece!' as the natives say. They are sly and braggarts, but they are good fellows too in many ways.

Isn't - _ the man who did a bit of time? Hines used to like him ; 'a rare festive chap' he said, if I remember' right. Come again, dear boy, next term, and we'll go over the MS. of your introduction together. . . . I am writing this in committee and in the midst of talk, so can't be very smart. I have done a sonnet on a Glove Fight which I will send you when it is done. Take care of yourself. Send me any verses you write.

In May he stayed in Manchester, and looked delightedly at the English water-coloms in the Whitworth Gallery: He was in spirits, as the following, written on his return, may show.

To W. P. Ker. Christ Church, May 11, 1897.

On Sunday I harl a jolly afternoon with the — s : they have got a house at Ćhelsea just past the bridge. It was an enchanting outlook: Whistler, Manet, Descamps at different hours of the day.

This violent popular rejoicing gives one happily some time in quiet, and so 1 am delighted. The children's feast ten year's ago on 22 .June was splendidly well done liere. I hope to see it done again.

I am surprised at the exeellent style of Gardiner's Cromwells Place in History. The excellence of the contents is not surprising. He ripens like old ale in the 
eastern counties. You must read this book. It is full of good things. I am struggling to get things finished and hope to see you with a good conscience on the $25 \mathrm{th}$.

The holiday of this summer is described by Powell himself :

To W. P. Ker.

Bedford Park, Sept. 2, 1897.

I have been away on a yacht to Holland with C. and friends; the yacht schooner 250 tons, a beautiful boat, dry as a bone and very stiff in a breeze, and easy to steer and handle: good crew and captain: fine weather, only one gale. We saw much: Delft, Haarlem, Hague, Rotter-Amster-dam, Antwerp, and their collections. The Rembrandts beyond all praise, mirificques. The Dutch delightful people, ealm, solid, most beautiful well-behaved children, in exquisite costumes of real Tenton flavour : bare-armed women like Freyja, tall, big, broad of beam and full of breast, just the right women to breed from, without any damned culture, and only mad upon cleanliness and steady regular work, in a quiet capable way: cheery too.

The country beautiful, with long horizontal lines of blue and green, and gold, and green and blue again, broken by masts and red roofs and tall slaty spires, the rivers and canals avenue-garnished, the squares basins, the streets canals, the beauty of quiet painted barges instead of rattling waggons and cabs and earts. It was good weather, and it all took my fancy immensely : there is real poetry in it too, mexpressed apparently by any Dutchman except by brush. Belgium is beastly now, in spite of its great treasures ; a dull stupid crapulonsness overhangs it. Holland is brighter, cheerier, wholesomer. I don't wonder now how well they fight! I saw lots of fine portraits of the great admirals. I saw the graves of Tromp and Heyn, and Silent William, and best of all Ruyter (their Dutch Nelson really), and I saw the models of their old ships and gums and forts. And I heard Haarlem again, which is beautiful to see as well as hear; and I saw the cows in jackets and the sheep in eaps; and the green paint, and brass waterpots and milkcans, and the dogearts with real bow-wows in them; and the great whitewashed, empty, bepaved, brick Cathedrals, with tombs of real heroes where the altars had been; but their sonls 
did not cry out, but possessed themselves with Dutch patience till the last trump should muster them to the battle of Armageddon, or any other stress when God would be glad of a few men who had not feared to die.

But still these people are not of our blood so nearly, somehow, as the Northmen you have been among. They have a kind of devil, that is lacking in these valiant Boeotians, and they are not so solemu, stem, or Calvinist: they have a feeling for something beyond order and tidiness in aestluetic, though they have never had a respectable painter or a poet since sigurd.

I like my cousins in Holland immensely, but I feel more sib to the Northermers.

Your description of Lofoten is fine. I can see them. They must be enchanting in their way, cod's head and tails or no. There is a fine can de Javelle smack abont a Dutch canal, by the way, that takes your breath away the first time it bestinks your. I will put no faith in Murray as to Norway savours henceforth.

By the way, did you ever taste smolied eel? It is better even than smolied salmon, but camnot be used so long, as it is rich. It is worth knowing about, and a grand incentive to Rhine wine. Dutch cellars are good, and beer quite fair. Well, this [is] enough for you to struggle over the bat writing of, so I conclude. Hoping to see you when you come back, I am yours rery faithfully.

\section{To T. F. Tout.}

Bedford Jark, Sept. 29, 1897.

The colonial history of $\mathrm{N}$ [ew] E[ngland] is indeed very molovely ; the best people and their struggles with nature one does not hear of: their accursed ministers and mendacionsly impudent politicians 'fill the historic canvas' . . And then fellows like that overrated Hawthorne and Irving make poetry and sentiment of a set of hard-gutted lying bigots. I agree with him who wished that instead of the P. F. landing on Plymonth Rock, Plymouth Rock had landed on them. - Have you read Mrs. Behn's play on Virginia? it is very good (her work is good and she is an adorable song-writer).

The letters for 1897 have been few, but this year Powell lid some of his best press criticisms on the slorter seale : he wrote as steadily as ever for the Mamchester Guendian, 
and six extracts can be read in our second volume. The Byzantine Empire and the Saracens, the Jews in the Middle Ages, Gibbon and Napoleon ; there is a preference, visibly, for big subjects, so big that they can only be treated in a paragraph, by aperçus and flashes, as Powell treats them, or else in a tome. The signal sympathy, of an historic and equitable sort, shown to the mediaeval Jews, was in defiance of Powell's natural instincts, for he did not often care for the Chosen People, and was restless in some cases when dealing with them personally. In other periodicals he is found also reviewing mediaeval epic and romance and the 'Celtic doctrine of Re-Birth'. Most of these writings, as has been explained, must be judged in the light of brilliant penetrating talk, or rather as letters of his best, than as formal handlings, or as fragments of new knowledge: and, judged as they ought to be, they will stand the test. Next year came the note on Verlaine already quoted, and the passage ${ }^{1}$ on Turguéniev, whom he had seen and admired, a splendid, noticeably calm, and overtopping figure, receiving his honorary degree at Oxford.

In 1897-8 Powell raised his voice for the plan he had always cherished and had hinted at in his inangural address - the establishment in England of some comterpart, or instalment, of an École des Chartes. On June 17 he read a paper before the Royal Historical Society, which is printed in the Society's Proecedings on 'The École des Chartes and English Records'. A begimning had already been made: at Oxford there were the lectureships in palacography and diplomatic, and his own instruction in sources. There were isolated series of lectures at Cambridge and at the London School of Economies. There were some opportunities for a young student, even in England, to learn how to read and translate, how to interpret and duly value, a mediaeval document; though in comparison with the École des Chartes, which is sup)${ }^{1}$ Vol. ii. pp. 309-11. 
ported by the state at no extraordinary expense, these opportunities were, in the British way, disorganized and uncoordinated. After describing that institution, he says:

It gives an advanced historic education ; it fits a man for a practical comrse of scientific research : it keeps up a real standard of historic learning, and it turns out a great deal of first-class work-theses, reports, monographs, and treatises.

One of the advantages of the school is that a man who holds its regular diploma as Archiviste paléogrophe has certain posts kept for him in the archires, in public libraries, academies, and the like. In England, howerer, there were no such posts, and no machinery offered for the more advanced training. In a weighty passage Powell makes protest:

These establishments have admirable officials of their own, whom they have trained for their own work; but that is all, they have no means of doing more. This is not enongh. In this comtry we have literally univalled stores of mannseript historic material ; for, owing to the blessings of insularity and that good fortune that has spared us the destruction which has swept away so much abroad, we have had no Thirty Years' War, no foreign invasion, no violent domestic revolution to deplore. Time, ignorance, and bigotry have, of course, done their work, quietly, persistently, and relentlessly, but they have spared much.

And this mass of documents has real scientific worth, the economic, legal, and social history of England are yet to be written, and this manuscript pobulum, as yet only partially known and in no kind of way exhaustively used, will supply the materiat.

He then deplores the fewness of the labourers for such a harvest, and above all the absence or inadequacy of machinery for dealing with county and local records. He had 'heard from a Chancellor of the Excherner" the objection that such work 'concerns only a few specialists'.

As if the books taught in your board schools, the books studied in your miversities, on which all your own know- 
ledge of the history of your own comntry is based, were sent down from Heaven, instead of being, as they are, the work of a few specialists. You have established armies of teachers. From whom are they to learn but from these few specialists?

Powell then proposes the outline of a scheme. There should be courses given at the British Museum and the Record Office to teach the practical duties of an archivist; also bursaries created for selected students of promise, the best of whom might look forward, after certification, to reserved posts in these institutions or in other libraries. Moreover, such trained investigators should be made use of as scholars and custodiaus of county archives. A natural centre would thus be formed for local history and archaeo$\operatorname{logy}$, to which documents of interest would drift and where they would be available for' study. 'Ten such local offices would provide for the needs of the comtry for a time at all events.' And the trainband of such students would meet a national need, as well as saving some of the useless, endless trouble entailed upon historians in their search for documents.

Next year l'owell returned to the question, in a preface contributed to the English translation of the Introduction to the Study of History by MM. Langlois and Seignobos :

We in England have much to learn in this subject of history from the French. The French archives are not so fine as ours, but they take care to preserve their local and provincial documents as well as their national and central records. They give their arehivists a regular training, they calendar and make accessible all that time and fate have spared of pre-Revolution documents. We have not got further than the provision of a fine central Record Office, furnished with very inalequate means for calendaring the masses of documents already stored and monthly accumulating there; though we have lately set up at Oxford, Cambridge, and London, the regular courses on palaeography, diplomatic, and bibliography that must constitute the prelinmary training of the archivist or historical researcher. We must have more trained archivists at the 
disposal of the deputy-keeper of the, Rolls, we must have such means as the Bibliothèque de l'Ecole des Chartes, for full reports of special and minute discoveries, for handlists and the like, before we can be considered as doing its much for history as the heavily-taxed French nation does cheerfully.

Nothing was done at once. Two years later, in August 1899, in consequence of such representations, a Committee was appointed to report, and three years later it reported, but no legislation has followed.

The letters of 1898 are largely personal and descriptive.

Bedforl Park, Jan. 14, 18:98.

I am one of those persons who think a beantiful body more lovely as a rule than a beautiful soul, but I can't make out how anybody can help seeing the beanty of Miss Kingsley ${ }^{1}$. Her extraordinary talent and motherly goodness give her a grace and a very real beanty which shines through her face and actions, so that an artist who deals with realities conld never miss it. __ and _ deal with fancies; they only take enough reality to prop their fancies up, and only such realities as will be useful to their fancies : hence their funny blindness. They shut themselves off from reality, and miss it of course, but they are real artists in their own line and good little fellows.

Every year Miss Kingsley lives she will grow more beantiful, and when she is 40 she will be much hanrtsomer than Mrs. - - I I was tremendously struck by her: and when one knows how good she is and minselfish and simple, it explains how great the charm of her company is. She is so real, none of the varnish that one gets so tired of, and I liked her voice. The voice is the thing that hardly ever deceives you, I think. Orchardson or Sargent onght to paint Miss Kingsley. Is there a photo of her published?

The death of Dean Lickell on January 18, 1898, drew a tribute to both him and Stone the fisher.

1 Mrs. Green comments:- 'Mary Kingsley, the $\Lambda$ frican traveller, whom Mr. l'owell met at my house. 'The first thing that struck him about her was her attitude in sitting, slightly bent forward, with her arms, he used to say, curved like the arms of a mother.' 
... Yes, I liked the old Dean. 'He was always wery good to me,' and he was a just man and kindly, and a good scholar, and a handsome gentleman. I am sorry not to see him again. He had a very gentle smile that was pleasant to see, and he liked talking abont old times. He told me how he had talked to and known Grace Darling. She came from his part, up, far up on the east coast. And he and Harry Stone (to whom with him I dedicated Frereyinga trans.) were the only two people I knew that had seen her. She talked broad Northmmbrian. She was not tall, and like the young queen in the face. It was a plucky thing, but it lay more in the readiness than the actual danger, Stone told me: he saw the place, and he was the best boat-sailor and fisher I have ever known. She was very modest about it, and always said it was nothing grand. Hemry Stone was perhaps a grander man still than the Dean, because he had had harder lines, and he came throngh just as finely. $\Lambda$ little man, broad and strong and keen-eyed, a handsome face and a fine rich voice, broad Kentish. He lived to be older than the Dean, and died the year Fereyinge trans. came out: but he weakened greatly the last year, and was dozing a lot, but as clearheaded as ever when he was awake, and no loss of memory that I can see. I don't know why, but I often think of them together, the Dean and Hemry Stone. I knew Henry from the time I knew any one, and of course I liked him, but it was his brother Charles I loved. He died some 20 years ago, an old man. Henry was a little more stern, and I used not to like to tronble him, when I grew up, to talk muless I saw he wished to, but Charles 1 could get to do anything I wanted. The other brother was blind, and a fiddler, and a follower of 'Tom Paine, a funny queer talker, humorous and satirical as becomes the crowder, but not so clever or wise as his brothers, but an interesting man too. I would like to talk of these men, they were a fine family. I learnt a lot from them, and I might have learnt more, if I larl not just never thought forward, but I daresay I enjoyed their company more for taking it uaturally. But they were fine examples for youth, so truthful, self-respecting, free from silliness and prejudices (save the fiddler), and men looked up [to] justly by all that knew them. The old parson at Anthany by Devonport is 
just such an one, a strong little man, honest, practical, wise, tolerant, and an honour to know.

But this is enough. Your kind word about the Dean has drawn all this out of me. You needn't read it through; but I can tell you those men were men to remember, and they were not the kind of men one meets every day. I think it does one good to remember them. I am yours faithfully.

To W. P. Ker.

Christ Chureh, Jan. 26, 1898.

All received safe. I have wanted the Franks casket ${ }^{1}$ bit for years. How did you get it? I think I can read it in a little time. I read 'Wada', but we have lost the story of Wade, so that it is difficult to find it out. He was the kinsman of Wayland, who is on the other side. The assheaded Johnny looks like an oracle (the press), and the soldier (Roberts) is standing astonished at its blazing futility (it has 2 brands in its hands). The horse, the man in the car, the three conspirators. As we have Egil (= Tell) we might have three valiant conspirators-the horse and the ass and everything that is his.-But, seriously, it is Wade's story, which is lost--as Wade's, - but probably exists either in a Skrök-saga or a fairy tale somewhere (it must have been good); and the verse I see is good alliterative verse, three lines I think. I hope therefore that I or one luckier will soon muravel the riddle. I am yours faithfully.

To W. P. Ker.

Bedford Park, 1898.

... What rot the French talk about Bismarck, who was worth $x$ Gladstones. If the French had let the Germans alone they would never have suffered fiom Bismarck at all. He was very good-natured to them. We haven't had such a man since Chatham and Warren Hastings, but we've had lots of little Bismareks luckily that have made colonies and things, that the Kimberley and Co. tried to destroy.

I don't know yet whether Germany was worth making (it doesn't produce anything but philology and senti-

1 The famons whalebone casket, most of which is in the British Museum (the fonrth side, not yet completely explained, being in Florence), is covered with carvings and runes. An exhlaustive disenssion by Prof. A. S. Napier, with photographs, can be seen in An English Miscellany, mesented to Dr. Furnivall, Oxford, 1!101, 1'. 3362-81. Prof. Napier's interpretation does not bear ont the view that Wade is mentioned. I'owell's letter is given for his allegorical rendering of the pieture. Slirök-saga, falbulous saga. 
ment; their only poet is a Jew, and their only writer of real power a soldier), but he made it. Even Moltke (a bigger brain) conld not have made it without him. I am glad Carlyle lived long enough to know about him. I am yours very faithfully.

I am reading poetry in the intervals of work, and South Sea stories.

To a Friend.

Bedford Park, 1898.

Yon must not think reading books is elever. It very seldom is any cleverer than drinking beer, and the effects are not so pleasing generally. Thinking right and reasoning sanely is elever, and nothing but that; and expressingoneself elearly and fitly. All else is useless baggage and lumber and 'superfluity of naughtiness'. When people are kind and sensible and quick to see things they are clever. Books have nothing to do with cleverness, so don't ever complain of not being elever again. If you knew how I despise and loathe women that read books and think themselves clever, you would know I am speaking the truth in all this. ...

Poor Empress'! She was a born artist and liked the right things, horses and trees and the sea and fine buildings and the real poets. She put up a statue to Heine when the rotten German public would not subscribe for one, because he langhed at their follies and had a pension from Louis l'hilippe. Poor little paralysed Jew man, I only wonder his mockery was so kindly after all. The Bavarian line has produced the only artist kings of this century. They are not very good kings, perhaps, but they know true art from false, and that is the reason they are not popular. It is not convenient for their countries when kings see the truth by instinct. Well, here I must stop). . . .

In Jume he gave another public lecture ${ }^{2}$ of note, this time at Winchester and on King Alfred. The millenary honours to Alfred were due in 1901: already preparations were in sight. 'The movement for the commemoration included open meetings and addresises. On .Jume 16, Powell spoke before the Dean and Mayor and citizens of Winchester.

"Empress of $A$ ustria, murdered on Sept. 10, 1898.

"He laad spoken on the subject in the New Islington Hall, Ancoats, Manchester, on Nov. 14, 18:T, anl lectured in the same place or Nelson, Oet. 2\%, 1898. 
The lecture is reported at length, and some of it is quoted hereafter. The same ground is surveyed in the article (both are reprinted, vol. ii, pp. 201-220) done for the North American Review in 1901. The lecture is the more stirring of the two, though less finished in the form that remains to us. The whole of Powell's heart went out to the first of the English prophets; he quotes amply from Alfred's own comments and sayings, inlaid in his Boethius and elsewhere; and the lecture is an almirably-ordered and ardent sketch. Powell's reply to the rote of thanks is saved, and it gives a key to his now-intensified political feeling, to his growing 'Toryism'. He honestly felt that the country was living too much on its legend, and might soon again be tested, and that the qualities of the great founder were more wanted than ever:

I count it an honour and a pleasure to be able to come here in Alfred's own city, and speak about him who was certainly one of the best Englishmen who ever lived. I am one of those who think that if we are going to keep this country great, we should have sometimes to think about her great men (applause). Chinese Gordon used to say that the right book for young officers to read was Plutarch's Lives, and I am quite sure that the right books for young Englishmen and Englishwomen to read are books which tell them about the great Englishmen and Englishwomen of the past. The next twenty-five or thirty years will in all probability be years in which England will be greatly tried, and I do not think we can do wrong to look back at such men as Alfred and see how in their day-and a very dark day it was for England-they managed by courage, by perseverance, by never knowing when they were beaten, and by sticking to what they knew to be right, to pull the country through (applanse). And I hope there will always be English men and women who would be ready to do their duty and to do it cheerfilly: I trust there will be, I feel sure there always will be. But we must not expect the smooth time we have had the last fifty or sixty years '.

1 Report in Hampshire Chronicle, Juno 18, 1898: corrected by himself in serap-book: words here turned into direct speceh as beforo on p. 189 supra. 
Powell's belief in biography as the right form of historical reading for the young, for soldiers, and for many others who are not professional historians, appears again ; he is fond of repeating it. This trait, and the note of augury, distinguish his words from those that might come from any patriotic soul. He was fresh from his labour of writing his Survey of the Queen's reign, and felt that the time of peace was ending. The Boer war, when it came, seemed to him to justify his previsions, and made something of a crisis, as will appear, in his political opinions.

The summer at Ambleteuse, meanwhile, was passed greatly to his mind: we have his longest sketch of his observations there:

\section{To Miss Geoghegan.}

Bedford Park, Sept. 4, 1898.

I promised to write to you, and I have not done so, but I hope you will forgive me. I have been having a holiday in France. The place is Ambleteuse near Boulogne; we have been there before. It is among the sandhills, very open and a fine sandy shore. I have got the children here, and it suits them very well. There is only one hotel, where we live, Hôtel Delpierre. Stevenson and his wife and children are here, and other people I know and have met before. Please tell your brother, who I hope is well, and to whom please give my love, that I have taken to oils. I have now done about 13 or 14 landscapes from nature, just impressions, taking all the care I can to get the tone, and not trying to finish at all yet. I am gradually getting to know more of the palette and the dodges, and, I think, getting to see more truly, and get it done a little better than I could at first. I paint with Stevenson and his wife. We all go out and get some good place, and just sit down and peg away for a couple of hours or so, as long as the effect lasts. It is tremendously interesting, and I have got a lot of pleasure out of it. I shall bring some of my daubs to Oxford and show to your brother, and if you will let me I shall come up one day to Cumnor and have a turn at it in your field. I can only do very simple things. When I try complicated ones I come to 
grief, because I can't put down properly what I see (though I can draw sufficiently), and I try to get too much detail into it and make a mess. 'There, that's all about my new toy.

You would like the people. Such a pretty orangehaired blonde, young and unfaked and quite spontaneous, with a nice fresh voice, who sings very well and is very childlike; her husband a nice young fellow, good-natured and pleasant, son of an old friend of mine. Then Stevenson, prince of talkers, full of amusing paradox which is not paradox, but the unvarnished and slightly comic truth, naked and not at all ashamed, her hair yet dripping from the well which she usually inhabits. Mrs. Stevenson, who is very good-natured and good company. Two excellent schoolmasters, one very young and ready to play with the boys, the other, his brother, serious, an honest fellow and conscientious in his work, and knowing a certain piece of history well and enthusiastically. A Scots barrister, well-read, a good talker, fond of argument, a Fabian and a Radical, rather amused at my being so 'jingo'. (I was glad about Omdurman, we had champagne the night we got the news.) Then there are French folk, some priests and clerical professors, who play and sing well. French Catholic families, very devout, polite to us heretics and atheists, with nice children: one lot were all dimpled and flaxen-haired like little English children, with the best-natured baby (except C.) I ever saw. C. is grand with all here. Then we had some oldish English girls, empty-headed and good-natured, but sighing for niggers and a band and a little dress-parade. $A$ bourgeois English family with admirable children, great pals of C.'s, mother enjoying her'self and really happy, but always grumbling at the hotel people as a matter of right, in true British matron style.

Then visitors come over for a meal ; bands of shouting Frenchmen with their families, egg-faced girls, and enormons wives, and rather thin-legged boys, and plump little maids ; and sets of priests, polite and well-mannered, and looking as though they seldom washed. And old gentlemen, with friendly pretty manners and beantiful banalities in choice French, who sometimes drop into the table d'hote. And the village people are old friends; the tall baker who drives a private bus, the fisherman who drinks, the excellent shopkeepers whom we eall Madame 
Whiteley, and Mrs. Marshall and Snelgrove, who sell jam and fishing nets, and rice and bérets and writing-paper, and tobacco and flannel, and spades and pails, from the same stuffy smelling shops; and the waiting girls, one goodlooking and thick-headed, the other good-looking and quick-witted; and the slowly served dimner and breakfastthey last 100 minutes sometimes, and we talk, and read, and eat bread and argue between the comrses, which are simple enough, but quite good enough, though the ehildren eat chocolate and sweets greedily between meals. And so, hoping to see you both in Oetober, and with best wishes, I an yours sincerely.

The book by Dr. Comparetti on the Fimnish epic, alluded to in the next letter, was reviewed by Powell, and we save a piece of what he wrote. ${ }^{1}$

\section{To W. P. Ker.}

Bedford Park, Jan. 2, 1899.

I have almost given up making good resolutions. I do as much as $I$ can and then just live for the day, like a brute beast ...

... I met-at the Rembrandts yesterday. By the way, notice 55, one of Ld. Leconfield's pictures, a real beauty, any amount of distinction as well as noble painting. But the drawings too are lovely, and there is the $U r$ windmill, grandfather of all Constables. This man was really the greatest Aryan painter that ever lived, of our branch. We must let the Latins have a bit of Velasquez.

I have been reading Comparetti's Kalevala (the commentary) and Miss Hull's Cuchullin book, and 'Glengarry's friens', and so on.

Have you seen the lithographic exhibition at Kensington? Or have you been Burne-Jonesing? R. A. M. S.'s lecture on 13.-J. is very good, sincere and discriminating, and with his beatiful turns of phrase.

I haven't much else to tell you, but I want to know if Queen Maboccurs anywhere in Spenser (especially $F$. Q.). I can't find it, and I thought I knew my $F$. $Q$. Eiton doesn't know of it. I think the only allusion, original, to Q. Mab is W. S.'s, and that he must have had an Irish nurse from Sligo or Commanght. She is 'Queen of the side' there, this old Boadicea, with her lovers and children and hosts and husbands and eattle and gold and jewels. 
She and Fergus and Cuchullin are the glories of the old cycle. Graine is as a whiff of zephyr beside her S. W. gale.

But if you know a Spenserian allusion to her let me know. I have a desperate power of forgetting, as it may be there is one.

This year he wrote, and published in a very rare periodical called The Quarto, his article on Daniel Defoe. It is one of his most fervent pieces of writing, the fullest of delighted praise. It is an appreciation, indeed, rather than a criticism. The awkward passages in Defoe's career are bathed in the sumshiny sort of tolerance that was Powell's natural mood towards his friends. He does not go into the still obscure questions of Defoe's life, and hardly glances at them. He felt, with a true instinct, that there was a core of somdness and honesty in this strange figure, who was prone to 'work in the earth so fast'; and of all artists none were surer of Powell's praise than an artist in the vernacular. I think he really loved such a writer more, though he did not admire him more, than the masters of a larger and fuller orchestra of language. Defoe was 'a bourgeois genius . . . the noblest Philistine that ever lived'. Powell so detested the bourgeois and the Philistine! and yet he is delighted to fund something to say even for them: one of them was noble, at any rate, one of them was a genius.

In 1899 comes the first of several letters to Mr. H. G. Wells, whose prophetic dreams and scientific fantasias Powell warmly greeted and encomaged. He read The War of the Worlds eagerly in its serial form, and the Surrey spots where the Martians alighted won for him anew and as if an historic interest. Sandgate, where Mr. Wells had settled, now had new as well as old pleasant memories for Powell. He would set, as the letter shows, the prose of Mr. Wells for translation, I suppose into French or Latin. 'Bob,' here and always, is Mr. R. A. M. Stevenson. 
Bob is very well and coming to stay with me this week. I have some caviare and some wine from Ithaca awaiting him which has been given me. Tim is heavier than ever and looks as he could strangle half a dozen snakes of the ordinary Zoo type. ... I heard your praise from our Vice-Chancellor [T. Fowler] the other day, and as he isn't a bad judge, I thought one might take his case as an index of many more, and so tell you that some of your sales must go down to the account of the ancient University. I shall continue to set $T$. M. [The Time Machine] and $\boldsymbol{W} . W$. [The War of the Worlds] in 'unseens', so that you will continue to be academic.

How is Conrad and what new work is he at? Your new one is exciting.

If you see Henley please give him my love. A lot of his old contributors gather at — of a Saturday, where with much bad language and a humorous earnestness they discuss the books and men and sometimes (I regret to say) the women of the day and town . . .

I hope the sea is sparing your cottage (which if it lasts will be celebrated-like the one in which Blake saw visions of angels-some day as the place where you saw strange imaginings) till your abiding place, Voysey built and Wells planned, is done. Please remember me to Mrs. Wells, and if you have any more photos like those you sent Marriott W[atson] to spare, think of yours faithfully.

The next letter, occasioned by a mere mistake, tells much of Powell's political drift and sentiment, which appear in more fully reasoned shape in his later Thoughts on Democracy and his paper on Ruskin. He was already at many a point an aggressive Tory, bursting often into angry fire, writing and speaking with vivid intensity, and refusing to argue. As future letters will show, some of his Radical friends were disconcerted and piqued, but they felt that he had long been verging on Toryism, and that his antipathy to its opposite had long lain far down. This bent, as I have said, was brought ont clearly by the Boer war; in his attitude and temper towards that he went with the mass of the nation. It was a natural evolution. 
After one or two discussions most of us buried the difference as hopeless. But whether we liked the change or not, it was not 'backsliding', and the expression had never been used. Some of his friends thought that the Toryism of Oxford had seized him; but in so far as he loved Oxford, he loved it by natural affinity; he was no Tory of the common-room type. And his attitude to the popular judgement in politics was compounded; he had the Liberal's love for the people, and the Tory's distrust of it. As for religion, none of us had ever for a moment thought him changeable, and of the fear that we thought so he was quietly relieved amid laughter. I cannot regret the misunderstanding (cleared at once), which led him to declare so plainly his natural and unalterable temper towards what he called Mosaic morality and oriental doctrine. Later, mention must be made again of his wonderful peace of intellect, which suffered him to live with friends of every faith without any chafing on either part.

\section{To Oliver Elton. \\ Bedford Park, Jan. 17, 1899.}

I just want to write you a word. — tells me you are troubled about my 'backsliding'. I want to reassure you at all events on the religious side. As long as I have any sense or sanity do not believe that I shall go back to superstition, which to my mind is 'l'Infâme'.

As to politics I think (but this is perhaps the Toryism of advancing years) that $I$ have advanced. I have been misled by formulas (half-true), by party-cries ( $\frac{1}{4}$ true), and by all the mists and mirages. I have the same objects as you, but I don't see my way by the Grond Liberal Trunli $R y$. or even the $G^{d}$. Rad. Express. There is such a lot of humbug about party, that though I acknowledge party government as a useful invention, I can't stomach the program, and I think I can do better outside.

I have been abroad enough to know that our English ways are not the only ones (nor the worst either). If the 'good old Cause' is the Truth, as I believe, I think I am as much set on it as ever, but I don't care for the game of abusing the 'ins', and then when in abusing the 'outs', as much as formerly, and I don't regard the party as an end, or believe that one eamnot wish to get healthy houses and 
stop pauperism without loving Kruger and voting against C. D. acts and desiring to stop Capital Punishment and the sale of alcohol. I am all for Darwin and I abhor Rousseau and all his works. I am only stating to you my position-you see it is not far from your own.

I see that great clianges are at hand, and I think that with so much at stake as we have for the next 50 years, we must be prepared to make a good many sacrifices if we are to come out 'top-dogs'. So I am prepared to sacrifice the 'nonconformist conscience' (which — says is almost a necessity); Labouchere; Sir IVilliam Harcourt (whom I would employ as a 'rit'-baiter); John Morley (whom I would put back to journalism); and a lot of other things. You will not think the ship of state safer for losing these several Jonahs, but I do, and if they make the (LiberalRad) whale sick that swallows them I shan't mind; it will certainly be the better for being purged on the shores of Joppa.

I don't find I love the House of Lords more, but that I love the H. of C. less. I don't love the Church rubbish more, bnt I have even less toleration for the Soc. Jes. and the Calvinist. The teeth of the Church are drawn. Giant Pope is weak but still cruel and still cumning. Giant Calvin has plenty of victims every day and poisons English life. I long ago renounced all the Jewish baggage and old clothes of any kind from Jahveh to Paul of Tarsus. I mean to be as decent a heathen Aryan as I can. I would sooner worship Thor and Frey than the Golden Calf or the Golden Snake or the good gentleman that massacred his enemies' children and kept Nethinim as a means of profit. So don't despair of me as a backslider. I am always yours sincerely.

This letter is not meant to be a trailed coat-tail but really a reassurement.

At the same time he wrote upon a bad book, the name of which is immaterial, as the prophecy is already accomplished:

To Mrs. J. R. Green. Bedford Park, Jan. 17, 1899.

is the most unmitigated rubbish. It is really sickening to see such stuff cracked up by greater fools than the man that wrote it. However, it will soon go down with the tide along with many other dead remains of malodour, 
and we shall be quit of it. Nothing can make bad work last, but it gives one a feeling of almost despair when bad work is so praised by those who ought to avoid it by instinct. The one immortal human quality is certainly folly, but it lends a variety to human nature which makes us nobler if not so lofty as the angels, so perhaps it is all for the best. . . .

I wonder if Taylor knows anything of Dermody, who was as an Irish poet, above all save Mangan of the people before Fergusson; 'necrly an Irish Burns,' as one eritic, an Englishman, says. Also does he know the poems of one Ashe, whom Yeats pere hopes to find Irish? He is a really good man, Ashe. Have you read Hardy's poems? they are excellent.

The next letters refer to a project that for some unknown reason stopped half-way. Nevertheless, I give them, partly because they are an instance of Powell's ethical attitude as an historian, partly in the hope that some adequate scholar may take up the enterprise where he broke it off. He wished to print an edition of all the poems of Mary Queen of Scots; these were to include both her admitted poems and the disputed Casket Sonnets. He was to adduce his intemal proofs, from likenesses of diction and style, that the admitted and the contested poems were by the same author, and therefore by Mary. There remains, partly in proof-sheets but ehiefiy in MS., the full text of the poems as he proposed to print them. Unluckily, no word, beyond what is found in these letters, remains to give an cppuratus criticus showing any collation of MSS.; nor is there any prefatory or explanatory matter. Powell's work, as to the text, would therefore have to be verified again from the beginning by an independent journey through the MSS. He may have put the matter off' and lost interest in it. 'Henderson' is Mr. 'T. F'. Henderson's book, The Casket Letters and Mary Quecre of Scots (1890).

To R. S. Rait. Bedforkl l'ark, Jan. 6, 1899.

Many thanks for the Henderson. I have devoured it. I have read the letters carefully and I can't help feeling 
sure they are Mary's. The sonnets are a curious sequence -set of 12, the last imperfect. They alone prove Mary's affection for $B$ [othwell]. Of course her works may have been tampered with, but they are too good, both letters and poems, to be forgeries, forged so quickly. Mind you, I don't think a bit the worse of her for despatching that 'pocky' fellow, though the treachery is sickening to our ideas, but not to her contemporaries, who would have felt she must take her revenge as cunningly as possible. It was her love for B., not the taking off of $D$ [arnley], that ruined her. She was a fine woman with it all. But we cannot blame Eliz. for her action to her. The Scots nobles were a most ignoble lot. I think Henderson's theory, or another as easily devisable, will account for Crawford. I don't trust Morton as much as Henderson does. I expect 'the casket with the two F's' is the real one. The whole conduct of Mary is very womanly, but her daring and pluck are her own. . . There are a lot of misprints in $\mathrm{H}$ [enderson's] edition of sonnets.

Have you got a copy of the Rochelle edition? Has it got the missing lines and the end of sonnet XII? If so please send them to me. When we get back to Oxford I will show you a lot of curious points I have noticed. If you have a copy of Uzanne's 'Livre' somnets, please send it to me. I want to compare them. They should be in the peculiar form which she employs here.

To R. S. Rait.

Christ Church, Fob. 6, 1899.

I have an idea of publishing Mary's Sonnets in a tiny and pretty edition, as I have now gradually got at a better text than before, with the sonnets in Le Livre (which I will send you to-morrow if possible). What do you think of it? The Arts school at Reading might print it, I think, perhaps in italies with red bits and initials.

\section{To Oliver Elton. Bedford Park, April 11, 1899.}

I have I think proofs (proofs from internal evidence that convince me) of Mary $Q$. of Scots having written the Casket Sonnets. I an editing those Sonnets and all Mary's poems together, so that persons may judge for themselves. The coincidences of rhyme and vocabulary are too striking to be accidental, and the Sonnets are too good (in spite of Brantôme and Ronsard), when they are in a decent text, to be forgeries. 
I wonder no one has tried these texts. They certainly astonished me by their results when I tried them. I had only hoped to get negative results, but I think these are stronger than I could have looked for. Daniel ${ }^{1}$ is printing the little book. When it comes out you shall have a copy. It has interested me to spend a few hours on it. I wasled to it by having to edit Rait's little book on Q. Nary (which you must get), and as it was all rague talk I could find about these Sonnets and no one had really read them or gone into the question, I began getting the text right and then comparing them with Mary's acknowledged poems.

\section{To R. S. Rait.}

Bedford Park, April 19, 1899.

As to the Casket Letters, I think the Scots version quite the most important; it has enabled me, for instance, to restore the lost and mutilated French version. The English translations, if you like, as they are contemporary. I don't see any harm in giving [the] French-all, if there is room. We will talk it all over.

I have decided to print the whole of the poems of Q. Mary. It only means about 7 pages more, and I do this because (1) they have been left unedited. Sharman's is the old corrupt text, with poems not hers included. (2) They confirm the belief I had by the proof of comparison: and half the poems used in the accepted genuine poems (of about same number of lines) are found in the Casket Somets: and the ones most used in the accepted poems are most used in the sonnets. The eareful comparison of style and vocabulary has left no doubt in my mind as to the genuine character of the Casket Somnets. The letters seem to me genuine too, but this is mere impression, and absence of anything to move suspicion. But in the case of the somnets here is a definite fact of great and (under other hypotheses) [unlikely] coincidence of rhyme, which nust be explained away by the Mariolaters.

I don't like the woman a bit the less because I am sure in my own mind that she was in at the taking-off of Darnley. It was not an unrighteous act, and her motives were probably sufficiently mixed to enable her to justify herself in her own eyes.

1 'The Rev. C. H. Danicl, Provost of Worcester College, at his private press. 
The allusion in the next letter is to Mr. Henry Simon, of Manchester, a well-known merchant of free and public spirit, who had lately died :

To Oliver Elton.

April 17, 1899.

Poor Simon, an Israclite indeed, a man I liked; he behaved perfectly the only time I saw him. There would be no Judenhetze if there were many more Jews like him, who think more of humanity than their accursed religion, and who can even pity Christians whom their beastly countrymen only despise ... . I an finishing up a lot of little jobs before tackling the finishing of Landrama-boe and getting that off my hands. . . . I have begmn Don Quixote again, and I am reading Jón Thorkelsson's pióssögur og Munnmeli, pt. i, just hot from Iceland.

So long - !

To W. P. Ker.

April 25, 1899.

Have you read The Wind in the Reeds (W. B. Yeats)? The best of it is really good, I am sure. W. B. Y. has the lyric gift that turns a few English words into a line that clings to you and that you cling to.

To H. G. Wells.

Christ Church, May 20, 1899.

You are too good. I ought to be sending you books. I got it with great pleasure (I love having presents) and I set to work and read in spite of interruptions, and I could not leave it till it was finished and the little birds were just whimpering as they woke in the false dawn. You have got the man's confusion and 'strangery' in the midst of the vortex of fresh sights and somds and circumstances. You made me believe it all. I am like the wicked elder. I should like to see a pleasure-city just for once, and I should like to ride an aeropile, and to have a clean dinner, and I should loathe the 'galloopping' machines. Like newspapers, they will come, however. I like their frizzed hair and funny dresses, making the worthless classes picturesque. I think I should prefer occasional war to the grinding industrialism, though probably if one had tried war one would not. Two or three executions produced by shells close to one and a sore foot and a little of Algiers roast timned beef would give one a sickener of it. The Eadhamite, the moving roads, the swing cables and the heights come in with great effect. It is like a wild dream, 
the scurrying along corridors, the altemations of flash and dim groping darkness. It helps the whole dizzy whirl to be realized. But you know all this. However, I must congratulate you on a very difficult piece of work [When the Sleeper Wakes] performed so deftly and convincingly.

How are you? I hope God has given up the habit of taking you to himself in small sections of which you once, most justifiably, complained. I have just been itching every fine day to get to Sandgate and see you and Jim, but $I$ had ten dlays in bed with erysipelas and that ate into my leisure. However, I mean to come as soon as I can possibly and have two or three days sailing with Jim in the day, and talking and hearing you talk, of the evening, if you will let me bore you so far:

Please remember me kindly to Mrs. Wells, who was hospitable to me at so short notice, and believe me yours gratefully.

The summer went at Ambletense in sunshine, bathing, painting and talking as usual. The 'funny quiet place in among the sand-dunes' had become a third home after London and Oxford. Some passages from a letter written thence recapture an echo of the charm, and the casual arrowy sentences bring back Powell's talk, now silenced, almost to the point of illusion.

\section{To Mrs. Marriott Watson.}

Ambletcuse, Aug. 19, 1899.

We bathe most days and it is very warm and nice.

I have done a fair amount of painting and not much work, but I am beginning to want to work.

Our friends are all absorbed in the Aftair, which is more interesting every day. I wish Dreyfus wasn't a Jew, one wonld be still more indignant with his persecutors.

The Lesson of a Master, or A Lesson of the Master, and other tales by Hy. James, I have just read. It is a real suecess. It is of oldish date, but excellently done.

The motor-car's here remind me of the Rumpanor', but 1 am the old gentleman that says 'Oh God' and much else, as they come rushing and smelling along. The French are mad over them. I have been to the Fair at Boulogne which is as jolly as ever.

1 Imaginary mechanical toy, invented by little boy, of ols man lying abed, and thus exelaiming when beetles devoured his coverings. 
The Hardys are here and several nice people, we spend our evening at the $\mathrm{F}-\mathrm{s}$ usually. We laze away much of the time very happily and unhistorically.

The 'Park' seems far off and London millions of miles away. The world is so different here.

This is a stupid letter. I am very sleepy, after a Sunday midday déjeuner, and I can't hit on anything interesting.

I have got a jolly silver ring, fisherman's pattern (so that so far I resemble his Holiness Leo XIII), and I am thinking of a blouse of blue and baggy blue trousers and carpet slippers-the complete ouvrier. They are so good for painting in.

The next two letters were occasioned by the sequel to Powell's History of England. This was completed from 1509 to the present day, in two more volumes by Professor Tout. Powell wrote a number of comments on Prof. Tont's manuscript, among which come the following. The last paragraph tells in brief both why Powell admired his country, and what he hoped or feared for it.

To T. F. Tout.

Ambleteuse, Aug. 24, 1899.

The vorst type of Italian statesmen are those that for what they regard as moral purposes (the influence of the Church, \&c.) juggle with their own ereed and murder and massacre in spite of their own consciences. A Machiavellian, if he is an honest man, follows his conscience strictly ; he follows what he regards as a right aim, and he pursues this by whatever seems the best means to gain it, and he does this because he thinks it right. Bismarek and Napoleon, right or wrong, are the perfect Machiavellians of this century.

'Progress in art, hygiene, morality, \&c.' ; I should leave ont 'veligion'. It is as if one said progress in superstition or mania or measles. Surely earnestness and morality are true religion, and not cults. It is far more important to be clean than what is ealled 'godly'.

To T. F. Tout.

Ambleteuse, Aug. 26, 1899.

For God's sake let us not be mealy-mouthed over J. J. Rousseau, le prophite chu finux, the 18th century Mahdi, the begetter of more follies than can be counted, 
the most absurd of all teachers. The 'good he did' was being done without him (as M- would say), the evil was largely his own. ...

The point [is] that we have, like the Romans, trained ourselves to administration, to the work of civilization, to the using of vast tracts of the world for producing food and necessities, to settling the temperate zones with white people. We have rendered piracy impossible, we have policed all the seas, we have done much to put down barbarity and cruelty and ignorance everywhere, though we have faults enongh of our own, and are saved by a fine civil service and a parliament that possesses its common sense. We want a really good system of education, which will be very difficult to set up and keep going, and we want better standards of life, less snobbery and less cant and much less superstition and fashion: much more careful physical and hygienic culture, more leisure and more feeling for higher things and discontent with secondhand stuff of all kinds, especially in literature and art.

In October, a book of mine upon seventeenth-century literature drew from Powell one of his letters, full of cordial encouragement and of talk about the writers themselves, with a statement of his points of difference. We see how he resembles a French more than an English critic; he can forgire almost anything to talent, and he is as chary as Montaigne in condemming character. Aphra Behn, Defoe, La Fontaine, are all creatures of imperfect clay in the eye of the censor; it is not, so Powell seems to say, the business of the art critic to judge their faults. Each of them can write, their writing endures, their faults are now immemorially old and dead. We have here his epilogue on Defoe. Mrs. Behn's Oroonoko is the novel referred to, with its heroic coloured gentleman and romantic heroine. To Pascal Powell was often averse, and was once heard to call him 'mad', which no doubt was an intolerant opinion.

To Oliver Eltom.

Christ Church, Oct. 10, 1899.

Poor dear Aplera. I think she is more original than you allow her to be. She wrote lovely songs which Blake loved. She anticipated Uncle Tom's Cabin in far better style. She wrote some excellent descriptive plays. Her 
pictures of life, for example, are exeellent ; a good, if not an over-modest creature.

Bumyan:... his prose intoxicates me with pleasure. I read bits over and over again, they sound to me something of exquisite rusticity, like an old country song. I put him high as an artist at his best.

Defoe, too, I think you judge justly. But the delight of him! I don't think him a bad man at all, either, if you judge him ethically. The True-Born Englishman has some excellent lines, though he could not scan. His novels are excellent, and exceedingly modern in part: The boy's vagrant life, the waiting-maid, the adventuress, that 'blessed woman' Moll Flanders above all. He can be pathetic even to a true pathos. He is a fine fighter, never hits below the belt. He is a real economist, and his faults were those of the journalism of his day. I prefer him to Thackeray, and surely he did much more. He had character. By the way, do you know old Tryon? Such a bully prose writer at his best.

Your La Fontaine most appreciative and justly so, though you are too hard on the man. The extraordinary skill of his verse, his new rhythms, his internal rhyme, his alliterations, are hardly excelled till we come to another naif malicieux, Verlaine. For instance, La F. splits the alexandrine into 3 with great effect, as no one before or after dared to do till our own days. His sense of rhythm also is far greater than any French poet's of lis century or the next; he can write poetic periods as none of the great dramatists of France could. He is more astonishing the more one knows him.

You ought to have had Pascal to do. Brunetière is wrong certainly as to him and Descartes. It is Descartes and Gassendi that tonch Moliere. What had he, the sane melancholy humorous disenchanted man, to do with Pascal's sensitive hair-splittings and question-begging and bitter controversialities? He was a Lueretian: what would he have cared for the empty air-clauses of the Pensées? I would give more for half a dozen more of Molière's Pensées than [for] anything of the sort from Pascal. Here you frown-and 1 stop.

To a Young Historian. 1899.

$\mathrm{M}$ - wrote me about the Knox. You must make it a model edition to justify my backing-best text (with 
variants if any of importance), good brief notes (like Henley's), matterful, at end. Good brief introduction, giving facts of life, dates, \&c., list of portraits: brief account of editions, bibliography, and very short crisp indication of value of book and of man. (Pity K. of France did not hang him, I often think, but I admit - - !)

You have an easy and safe reputation to make with such a book, a real chance for a young historian. You must spare no pains and no work to make it such that you can go before any set of your own countrymen, and say, 'Weel, here's ma Knox !' with perfect certainty of honest applause.

It is a serious business to do such a book well, and it will lead you to much beside temporal secular success, which is really a means, though there are plenty of people (such as _ 's paper) who make it an end.

I don't know why I am in the serious vein, but I am not often in it, and I want to put things squarely to you for once, as I see that you have it now in your grasp to do really good work in history. ... You ought to go abroad and get French and German thoroughly into you, and don't come back to teach here till you have something serious to teach, and a good book such as this done. We must have a talk about form and size, \&c. when it is done. You will find $\mathrm{M}-$ a fine fellow. I am yours faithfully.

On being asked to support a movement for the protection of buildings in Oxford, he made answer :

\section{To Sydney J. Cockerell. Christ Church, Nov. 20, 1899.}

The City .... are responsible for a mass of abominable outrages; their ideal is to make the place 'a factory town, independent of the University', on which they cadge and batten, and which they take every opportunity to slight and annoy ...

The University and Colleges contain dozens of men anxious to keep and uphold old buildings. I don't know one on the Town Comncil. The treatment of Carfax Church, of the old Nixon School, of the dozens of old houses pulled down and replaced by vulgar _ buildings, since I have been at Oxford, shows the Town's respect for antiquity. Of course, Colleges like New, and Oriel with its disgusting King Edward St., have done badly in the 
past, but the new element in all the Colleges is as 'antiscrape' as you could desire...

I am always willing to protest publicly (all I can do) here against any College, or private person, pulling down the old City, and I will make inquiries on the matter, and let you know.

To H. G. Wells.

Christ Church, Nov. 27, 1899.

I have just been reading your book ${ }^{1}$. It interests me very much. I see that you have the same hope we all have, the only hope, Knowledge. You foreshadow a time when Capitalism is overthrown by Science the (last delusion possibly, but the only one worth trying by thinking animals). Have you any thoughts of trying a sketch of such a state, where people work for knowledge as they do now for money, and when they live up to it more closely than most of us do to our 'respective superstitions'? It is the only future, better than the present, that I can foresee. It need not be selfish, and selfishness is the one accusation brought against it. It would be jolly hard to write about.

Do try another glimpse through the Mar's crystal. I like that story so much.

The miracle man I don't care for at all. It seems to me just farce, too flimsy for a story almost. It would be comic on the stage probably. It makes one laugh heartily once. I don't mean it isn't elever (I could never have written anything half as clever), but that I like your other stories far better.

When I go to Roehampton, I think of the flying stages, and Richmond Hill and Banstead downs are consecrated to the Martians. I just hear the name of Woking Common, and $l o$ ! the pit and the fire and the hideous polypods from Mars.

You have made even 'Primrose 'Ill', as Mr. Q. calls it, romantic with associations.

So naturally I crave for more of the Time-Machine element, and less of the miracle-man. There is lots of fun in the others, got in by way of irony and allusion.

Now how are you? I am trying to get a ray to come down and see my mother and stop a night, and then I shall come over to you, and we will have a real talk again.

1 Anticipations. 
Bob [Stevenson] is very poorly, has had a near squeak with that damned 'flu.' He is ordered away for a seavoyage of some months. I hope to see him off shortly. I don't want to lose him. It is a great blank for me when I don't see him. I am, with best wishes to Mrs. Wells, yours very faithfully.

How is Jim Pain?

Do you like him?

I am very fond of him.

The next letter, written to the same friend, is more ominous about Stevenson. He is ordered away, and seems to mend; but will require great care, 'or there will be a complete breakdown, or death.' The greatest berearement was imminent, that Powell was yet to suffer. Meantime he writes about a child.

You will like $\mathrm{T}$ - He is a rum little chap-a philosopher, affectionate (which is not usually the case with philosophers), good-natured, full of energy, delighting in noise, the slave of a hammer, the votary of drum and trumpet and blatancy in music, delighting in stories of all kinds, and a persistent draughtsman, to whom I owe a picture of the A. M. B. [Absent-Minded Beggar] which you would admire. I have copied it exactly [figure]. There is nonchalance in every line.

Mr. Crawley, his next correspondent, had inquired about a course of rearling in older English and mediacval history, with a view to equip himself for higher School teaching.

To J. A. Crawley.

Bedford Park, Oct. 9, 1899.

You must read the originals, or at least translations of them, to realize or to know anything of the old times: Froissart, Joinville, Malory's Mort Arthur, Piers Plowman, Dante, Matthew Paris, Giraldus Cambrensis, 'The Wallace, Barbour's Bruce, Minot (Hall's edition) O. E. Chronicle; Browulf (there are several translations), Life of Edward Confessor, William Malmesbury, Robert of Mt. St. Michael ; Lives of Thomas Beket, Life of Iunstan, Bede, Gildas, Asser, Chanson de Roland, Aliscans, Reynard the Fox; the Chronicle of the Cid, Jocelyn 
of Brakelonde, translations of the Icelandic Sagas. These books will give you some idea of what these forerumers of ours thought about: they will put life into your outlines. I am yours faithfully.

In 1899 he poured out reviews and articles. The chronicle may be given, to show a typical year of work. He wrote on Irish and Scandinavian books in Folklore; on Cervantes in the Morning Post; on Elizabethan sailors, on the Sidneys, on the Georges, in the Manchester. Guardian. He wrote, further, his article on Vigfússon in the Dictionary of National Biography; it is the most shapely of his tributes to his friend. He also published, in The Windmill, some curiously literal blank verse translations, from the chanson of Warin of Lorraine. I have not reprinted them; he does not seem to find his metrical power except in rhyme. He wrote the preface, already quoted, to the English translation of Langlois and Seignobos' Study of History. But the most noteworthy of his papers (he did not write on this matter before or afterwards) was on the Armenian problem as it stood in 1898. His friend M. Avetis Nazarbek is well known as one of the poets of his country, and as the centre and leader of the exiled Armenians in London. M. Nazarbek wrote in French an historical romance of the Armenian massacres, Through the Storm, which was put into English and published in that year. Powell's preface can be read elsewhere ${ }^{1}$ : it shows how far his English imperialism was from blinding him to the claims of an old, tenacious, and oppressed Eastern people. He was never a cynical politician, though he could sometimes speak like a truculent one. Neither does he identify himself of necessity with the Home Rule opinions, as we should call them, of M. Nazarbek. The essay is a good example, it may be thought, of the historical spirit, as Powell at his best conceived it, applied to a burning political question.

1 Vol. ii. pp. 194-200. 
The same temper is seen in an indignant letter which he wrote in July 1899 to the Manchester Guardian on behalf of a Servian savant, Milenko Vesnitch, a distinguished professor of international law at Belgrade University, and a well-known authority on that topic. It was the moment of the alleged plot against Milan the ex-king. Radical journals in France, Germany, and England proclaimed that the plot was sedulously planned by Milan himself in order that he might colourably crush the opposition, which included the intellectual pick of Servia. There, the liberal press was prohibited, and outward news intercepted. Amongst others Vesnitch had been deprived, arrested, and imprisoned as an accomplice in the 'plot'; he was now menaced with court-martial, and this under police rule could only mean short shrift and the absence of legal justice. Powell did not know Vesnitch personally, but his information came from a good authority (whom he names in a MS. note). He did not even prejudge the nature of the plot or the action of Vesnitch. His letter is curious as well as generous: his sympathy with a man threatened with an unfair trial is crossed with an appeal to the political interest of the persecutors, and with the admission (characteristic of Powell always) 'that reasons of state' might under other circumstances have furnished some excuse for their behaviour. The Manchester Guardian backed the letter next day in a leading article. Professor Vesnitch, on Sept. 27, 1899, was sentencerl to two years' imprisonment, with what sequel I have not discovered.

One cannot suppose that the death of an innocent man whose career has cast honour upon his nation's university can be necessary to King Milan, though one can very well understand that to the political police who work things any honest and capable man is a nuisance and a stumblingblock. At all events, there can be no danger to King Milan, one would think, in giving Professor Vesnitch a fair trial under regular legal forms; and this, and this only, 
can satisfy those who, out of Servia, know the character and attainments of the accused. They want a fair trial for him, and a public trial, and if this is denied they will want to know why. If King Milan's advisers could at one blow destroy all opposition to him, they might plead raison d'état, as Gamaliel and others have done in the past (not without formidable arguments on their side, as the late J. S. Mill more than once acknowledged); but this, from the peculiar circumstances of the Balkan Peninsula, is plainly impossible. As they cannot destroy all that they would, surely it would be wise for them at least to spare the innocent. The Russian is at the gate, and there is no better pretext for his interference (as was surely proved in the case of Poland) than flagrant injustice, indiscriminate persecution, and the shedding of innocent blood.

Throughout 1899 Powell's interest in the Irish literature and language had been quickened in various ways. The Irish Text Society was now founded, as he had presciently hoped, and the first volume of its publications appeared in July, with a prefatory note by Powell, as chairman, on the work of the Society.

It is of high importance that the great mass of MS. Irish literature of the sixteenth, seventeenth, and eighteenth centuries, now exposed to the risks of destruction, much of it being in single paper transcripts, should be rendered safe and accessible in print. Much of the inner history and thought of the Irish people is enshrined in these frail papers. . . . If, in the next twenty-five years, with far more copious and more interesting and valuable material, we can do for Irish Literature, new and old, what the Early English Text Society has been able to do for old and mediaeval English Literature in the last twenty-five years, we shall not have existed in vain.

This was not Powell's only contribution to the cause. All that year and for long after a surprising contest was waging in Ireland, stirred by the concurrent revival of Old Irish studies in the hands of special scholars, and of the modern Irish speech, under the auspices of the

I Manchester Guardian, July 27, 1899. 
Gaelic League; which itself was guided by some of the same scholars, and principally Dr. Douglas Hyde. Before the Vice-regal Commission on Irish Intermediate Education, the value of the vernacular as an implement of mental training had been called in question by more than one member of Trinity College, Dublin. Further, the old Irish literature had been slighted by the same speakers on the score of literary poverty and of 'indecency' - no less! The Gaelic League and Dr. Douglas Hyde took good eare of their case. Their retorts, full of wit and skill, do not come into this history except so far as Powell struck into the fray: the nature of them will appear from two of his letters, first printed in pamphlets of the League. It was actually necessary for Dr. Hyde to gather testimonies, collectively irresistible, from Celtic scholars of Irish, Welsh, English, and German origin; and this in rebuttal of the ignorant charge against one of the richest and finest of mediaeval literatures. The expert evidence proves to any jury without prejudice that the accusers would in consistency have to deprecate the study of Middle English for fear of the Wife of Bath, or that of Old Norse because of a poem on the backstairs occurrences of Asgard. Powell wrote on both the literary and the educational question. From his first letter some lines may be taken on his favourite text of a bilingual training, of which his own command of French had made him feel the advantages.

\section{To Douglas Hyde.}

Christ Church, Feb. 9, 1899.

I am convinced that if the English in Ireland and the English and Scots settlers in Ireland had chosen to encourage the study of Irish, they would have made things, politically and socially, much better and easier: There is still time to do much in this direction if the Govermment is wise and shrewd.

I am not, as you know, a mystic or' a believer in 'Celtic glamour', or the rubbish (good-natured fantastic rubbish, but still rubbish to my mind) that is being talked now a good deal, and I don't like it becanse it is based upon a lot of idle theories that can't hold water or fire or any 
other decent element, and I am not writing you as a politician and I have no 'row to hoe'. It is as a scholar and as one that has a practical acquaintance with education and with schools and schoolwork, that I state my deliberate opinion that it would be a very grave and a very retrograde step for the Royal Commission to try and do away with the study of Celtic as a school subject. It is a good subject, a useful subject, and a subject that, far from being discouraged, should be encouraged by any who really care for education in the true sense in Ireland.

You are at liberty to use this letter, and I hope you will do so if you think it likely to do any good.

I will ask a friend of mine here who is one of those who have studied the bilingual question in Wales to write to you. His words should at least command respect. The Basque bilinguists are certainly not the least forward and energetic of the Spaniards. The Provençal, Alsatian, and Breton bilinguists have produced some of the greatest Frenchmen. The Scots Highlands have sent us many of our best administrators, merchants, men of leading. The bilinguality of the Jew is certainly not an element of failure or a hindrance to him.

The second letter is quoted here in full : it contains one of the most musical and tender passages of Powell's prose.

\section{To Douglas Hyde. Oriel College, April 5, 1899.}

Mr DeAR Dr. Hrde,-If anything I can say is of any use, pray make use of it. We are fighting shadows, but apparently they have to be fought by throwing more light on the matter still.

In the first place : the example of bilingual Wales is not to be got over. It is proved clearly and ummistakably that it is better to teach children the English through their own tongue; i.e., that they must be taught their own properly -how to read and write it correctly, and then, having acquired so much, they are able to learn how to read and write English well, much quicker and better than if their own tongue were tabooed in the brutal and needless fashion which certain of the T.C.D. people press for. Now, if this is true, and the Welsh example, I think, is acknowledged to prove its truth, what more does your case need?

However, there are two points your adversaries have tried to make-one that one camnot teach and examine, 
because papers cannot be set, and because reading books cannot be supplied. Now, the papers I have seen prove that for examination purposes Irish is quite as good as Greek or English, and it is a mere absurdity to suppose that because Homer and Plato wrote in Greek, Greek is necessarily for the examination of children in grammar, \&c., a better instrument of education. As it happens, Irish is singularly well-fitted for an instrument of education as far as grammar, syntax, analysis, \&c. [go].

As to the reading books, I am confident that you yourself could at once supply (and I hope that, setting aside other work for the present, you will print such a work at once) a thoronghly good reading book in prose and verse, without anything 'silly, superstitious, or indecent' in it. There is plenty of poetry, such as children shonld learn by heart, plenty of fine stories, and plenty of anecdotes that, put into simple modern Irish out of the older tongue, would please and enrich the mind of the child, naturally curious abont the past of his own people; and about the great men of the past he hears talked about. I found plenty of good Irish and Welsh and Scottish stories, as well as English, to put into my Readers for elementary schools. There are saws and proverbs, too, children's ditties and jingles, and a whole lot of available matter that we in England use in our elementary Readers, existing in abundance in Irish.

Lastly, I come to a point I have not touched on before, but which, to me, is of high importance. It is a sad and bad thing to cut away a whole nation from its past by blotting out the tongue that enshrines so much that is dear, and deservedly dear, so much that is sacred, and deservedly sacred. If Irishmen are to forget the tongue of their fathers, do not let us of this generation bring on such a catastrophe, for catastrophe it wonld be. All the charm of the old peasant life, the accents that gave voice to its joys and sorrows, the simple wisdom of the poor man's experience, the inherited mental culture that an lrish peasant has, and that gives him in his poverty that acute appreciation of the real things of life (the things that are worth more than gold or silver, or even lands and cattle) - these will be largely destroyed by the destruction of the old tongue, and they camnot be replaced. This is a serions matter, as it seems to me.

You could put this last point better than I can, and it ought to be put very strongly. I am sure that there are 
men of all parties, thoughtful and far-sighted men, who can see and feel the danger of this obliteration of the past. I would willingly see much forgotten in Ireland that Irishmen choose to remember ; old feuds, old prejudices, old lies, and old pieces of cant and charlatanism that are immortal as struldlurugs. But for Irishmen to consent to forget what is best for them to remember-the cradle song of their mothers, the hymns their grandmothers sang, the wise, quaint talk of the elders, the joyous verse and the sad mourning verse of their own poets, and the whole fabric of their folklore, their folk wisdom, their own names, and the names of the hills and rivers and rocks and woods that are so dear to them-seems to me incomprehensible.

To keep all these things, one would pay a price; but one can keep them for nothing; for, as it is known, by keeping the old tongue, the task of learning the necessary English is not made more difficult, but actually easier.

I don't want to make this question a personal one, and I have kept all names out of it, but I must emphatically contradict the statement of $\mathrm{Dr}$. Atkinson, so far as his comparison between the Greek and Irish papers produced (1897) [goes] and my opinion is based upon considerable experience in the examination of schools and in the methods of class teaching.

The point as to difference of Irish dialects may be met by the example of Greek, the 'Greek' of to-day, of the New Testament, of Plato, of Homer, of the dramatists, of Sappho, of Theocritus, of Herodotus-all differ widely in dialect and grammatical forms; but who makes that an obstacle to Greek teaching?

As to 'lowness of tone', all that is mere prejudice, as far as I can see. We all know that the New Testament, because it was in a provincial vernacular, was regarded as 'low in tone', and vulgar Greek. It has, however, real beauties of its own, as the most rigid scholars would now admit.

The Koran was not in the fine tongue of the poets of the days of darkness, but it has become, like Jerome's low Latin and Paul's low Greek, a standard of culture.

All this talk about 'lowness' is a piece of special pleading, an appeal to personal feelings, and not to any standards of eriticism. I don't think that a distinguished scholar is necessarily an infallible literary critic, and just as I should follow Wallace or Crookes in biology or physics, and 
refuse to accept their judgement in the case of 'mediums', 'table-rapping', 'visitations', and the like, so, while bowing to Dr. Atkinson on questions of Sanskrit or Old Irish, I should not be disposed to take his verdict as final in matters of criticism of school teaching, or the ethical value of phrases in Modern Irish.

I am not writing to raise or maintain controversy, but simply because I feel that an injustice and a real wrong will be done if the properly inspected and properly regulated study of Modern Irish is to be discontinued in Ireland. I am not a Roman Catholic, or an Anglican, or a Presbyterian. I am not urging this matter because I hope or fear that the teaching of Irish will injure or help any political party. I am not an Irishman, but an Englishman, and I have no private quarrel with any one concerned in this question. If I were an Irishman by blood I think I should feel the stupid absurdity of this plan of killing Irish even more acutely than I should a plan for extirpating whole country-sides of Irish, for it is a plan the success of which will irreparably injure a number of people without compensation being possible. I am, yours faithfully,

F. York Powell. 


\section{CHAPTER VII}

\section{LAST YEARS IN LONDON : 1900-1902}

R. A. M. Stevenson; affinities with Powell; view of 'culture'. Death of Grant Allen; Powell's tributes and political feelings. Death of Stevenson; letters. Ambleteuse; letters on boxing, French poetry, and the 'historic heaven'; letters in verse. Writings of 1900. John Ruskin; Association with Ruskin College. Preface to Gisli Súrsson; Thoughts on Democracy. Powell's 'Toryism'. 1901; letters; L'Aiglon, Lefroy's Poems. A Note on Omar, and Quatrains. Letters on literature; Browning, M. Arnold, \&c. Horoscope. 1902 ; visit to Eton; and (April) to Ireland; Leeture in Dublin; tour described. Article on Lord Acton. Address at Bangor on The Study of History in Universities. Visits to Liverpool and Rugby, to Ambleteuse and 'Templeuve.

THE friends of Robert Alan Mowbray Stevenson declare their want of words to deseribe him, and a stranger cannot begin to do so. No biography of him or of his mind as yet exists, and the newspaper articles, which he let fall like petals from some noble and luxuriant tree, are ungathered. His chief memorial is to be found in his book, The Art of Velasque (1895), and in the letters that Powell wrote after his death. The two were aequainted only seven years, but they were neighbours in London and met constantly. They had the same youthful magnanimity of sonl, and the same entire freedom of intelligence, to keep them from the arrest of growth, 'deep almost as life', that may overtake middle age. They looked on the world and on art in somewhat the same way; and we may read something of their common view, put forth clearly and without Powell's vehement heat, in an early chapter of The Art of Velastrue:

Both men, for one thing, were naturally pagans: they were averse to the current religions whenever they 
thought about them, though they did not devote much time to doing so. Powell records his friend's views with amused sympathy: the remark about 'Jewish remnants' recalls a famous one of Carlyle to Tennyson.

Bob used to say that he would have nothing to do with a religion of so alien a character as Christianity, full of nasty Jewish remnants, and that he refused to have anything to do with their old God and $\mathrm{X}$ Commandments, and if he wanted Commandments or Gods he would make them himself: which seems to me a very reasonable and historic view.

In common, too, they set little store on books in comparison with life, Powell because he knew books too well to value them amiss, Stevenson because he saw the danger of books to the artist. They both threw themselves upon life, they trusted experience : and, paradox as it may falsely seem, it is men of just such a temper who, once in presence of a work of art, inquire, not how much it ean edify them concerning life, but how it is executed. Life comes first ; but in art teehnique comes first ; art is technique. Idealism, spiritual exaltation and emotion without adequate form, are of no use in art; they were the most alien thing on earth to both Powell and Stevenson. Of the two, Stevenson puts this point the more keenly ; for Powell could tolerate, if he could not ignore, want of poetic accomplishment, if, as in the ease of Roden Noel, the poetry spoke to him. But 'culture', 'idealism', high intentions and false expression, they disparaged. Nor did either care for methodized philosophy, though Stevenson writes of it in a juster strain, seeing that it is the voice of a recurring order of mind ('the black-and-white mind') which is of some importance to the world. Powell thought the philosophers a 'mouldy gang of self-deceivers', and was the less of an historian for so thinking. This was one of the few fields where his intelligence appeared at times to be blank. Himself, he had not 'the black-and-white', but 'the coloured' mind. At times only; for he was always eager 
to make an exception for Plato, Aristotle, Spinoza, Bruno, or any thinker whose greatness did not seem to depend upon his formal system. This is only to say that both men cared supremely for expression. Stevenson's words may be quoted for their excellence, and also as showing the fundamental masonry of one conviction that Powell shared with him.

Under a mistaken conception of culture as the key of all the arts and sciences, intellectual people too often feel obliged to pretend an interest in arts for which they have no natural inclination. They insufficiently distinguish men born to take pleasure in the abstract and speculative from those born to love the concrete and sensuous - the blackand-white from the coloured mind. They cannot believe that the least taught ploughman whose senses are in tune with the pulse of nature may make a better artist than the man of loftiest thought who is encased in nerves insensitive to the quality of musical intervals or the character of shapes and colours. The man of abstract mind apprehends great ideas presented in the abstract medium of literature, but in the concrete of painting he is easily deceived by associations with words into spending his admiration on mean forms, on foolish labour, on purposeless colour ...

The man of culture ... hates matter; because owing to matter the imagination in each art is a gift whose absence cannot be compensated for by one of the other imaginations or by the abstract intellect itself. Imagination in words is not imagination in colour or form, as the cases of 'Turner and Goethe amply prove. Without matter there is no art; without matter there is no stuff in which imagination may create an image. Sentiment is not imagination : spirituality is not artistic feeling. ${ }^{1}$

Stevenson proceeds to set up, in his clear sensitive way, his defence of certain underestimated principles of painting. But this love of the 'concrete and sensuous', of shape and colour, was also a characteristic of Powell, who in his own ealling of historian shows it everywhere, though for the learned rather than the artistic purpose. All this com-

\section{The Art of Velasquez, ch. iii.}


munity of spirit riveted the bond. It is only as the life of Stevenson draws to a close and passes that we realize the intensity of Powell's love and appreciation of his friend. He thought of him always, and for a year after his death continually eased his heart, as will be seen, by writing about him.

For the first months of 1900 the anxiety was grave. Sterenson rallied more than once, and was to go to Italy, or to 'settle for the spring in some country place with green and trees and paintable nooks and purviews'. In March his health improved. They were both 'furiously patriotic' over the war.

\section{To his Daughter.}

Christ Church, Feb. 7, 1900.

The Yeomanry went off from here the other morning, early, and the Dean went down at 6 to see them off: he is their chaplain ; and at 3 o'clock, when they marched down to the station, hundreds of undergraduates and townsfolk with torches marched with them. I did not hear till it was over, or I think I should have gone.

I wrote to Mr. Wilson, whose son is killed, to suggest that there should be a tablet put up in the church to his memory. He is very pleased, and I hope it will be done. Poor fellow, he is the first boy from the Park killed in the war. I think we should be rather proud of him.

I should like all brave deeds done by boys and girls of Bedford Park to be put up in the Park chureh.

The weather is still cold, colder each day, and the snow not yet melted.

Meantime, as the end of Stevenson slowly became more certain, Powell had to chronicle his memories of his old friend, Grant Allen, who had died at Venice in the previous October. They can be read in these volumes ${ }^{1}$; but the mood in which the spring found Powell is recorded in a letter written to Mr. Edward Clodd, Allen's biographer. He is there seen numbering his dead with a kind of terror: he had himself four years to live, and during them his expression becomes ampler, intenser, more edged than

${ }^{1}$ See post, vol. ii. pp. $68-79$. 
ever before. The reference in the first sentence is to the letter on Allen he wrote for Mr. Clodd's memoir.

\section{To Edward Clodd.}

Bedford Park, March 28, 1900.

I have knocked it about shameful, but it won't want any more mending. It does not seem quite so poor and inadequate to its purpose as it did when I sent it to you, and I hope it reflects in its blurred way the real Allen I knew and loved. When I think of him and Shute and Sime and Gleeson and my dear Master Vigfússon and Charles and Henry Stone and Walter Ferrier, all gone, I feel that though the noble fellowship of the Round Table where I had an unworthy seat is broken up and only one or two of us left on the quest of the Grail in following the bête glapissante like Pellinore, yet I have had good friends, I have met men I am proud to think abont, and if they have cared for me half as much as I have cared for them, I have not been badly loved.

But these gaps in the ring of our lives are too many, Clodd, and I tremble now when I hear of a friend's illness. I know now how short a time one has to pass with those one loves, so few years, such a brief tale of days; opportumities snatched from the daily business and the daily cares, but the only gold beads in the chequered necklace of one's life. I am so glad I never had the slightest even momentary feeling of coldness in the course of my friendship with any of these men. The hours I passed with them were sumny and unclouded. That is much to remember. But it was to their gentleness, not to mine, that I owe this pleasant memory. They were patient and generous and gave me credit for more than one was worth. But I really loved them all the time and I think they must have felt that.

You have got some nice bits from [Mr. Andrew] Lang. What a good creature he is, how generous he is, and how fair. It was Allen that made me know him first.

To Spenser Williuson.

March 31, 1900.

Parliament is ridiculous and contemptible, the Irish government is too cowardly to act and cripple the traitors who are trying to embarrass us and to intrigue for foreign intervention. The nation behaves well so far as it can, but we are too stupid to be aware of our danger 
and force Parliament to action and the Departments to energy ...

You must hammer away. . . The navy is not being prepared as it ought to be, and we have so little time. Why, only three months now, at best, for if intervention, and of course war, comes, it will come like lightning. You have done wonders single-handed. You are leading public opinion now. Take care of yourself. You must not break down before the moment when you will be still more useful to the country.

T'o D. S. MacColl.

Bedford Tark, April 2, 1900.

I am trying to get — to appoint a really good man as professor at —, but 'Universities are such fools'. They love mediocrity, electroplated mediocrity, so safe, so easy to work with, so respectable, till the gilt wears off, and the nasty flashy metal underneath spoils one's zest. . . When shall we learn as a nation that middling well only does in religious and parochial work . . . and is absurd in art or science or literature? We are a stupid people.

But don't, my dear NacColl, imagine that the future of us will be to Whiteleyize the world. If I thought that -but I don't, 'the youth at which I am dedicate' don't think so either or mean so. You see how infectious la leaute politique is.

I went to Magda the other day. Mrs. Pat really excellent, and having grown 'plumper' (a word she would probably scorn) is very good to look at as well as to listen to. The play is very good on a German standard, and fair, quite, on a French standard, most refresling on an English standard. Sudermann is good, but Hauptmann is better and original. S. has the old conventions and the old stock company, but he plays the game with talent. H. has ideas, and a higher (far) feeling for art.

The $N[\mathrm{ew}] \mathrm{E}[$ nglish] $\Lambda[\mathrm{rt}]$ Club is on the job on Saturday. The Piccadilly show (water-colour) was most deplorable, degraded, miserable, silly stuff, stupid and unobservant and cooked and niggled beyond all one conld have feared even: I wanted you back to slate them with all your might, and a sjamboli of the most terrible cutting power. The wasted energy, the stupid lack of knowledge that could be got so easily, the whole dull hopelessness! I came away absolutely ashamed of my countrypeople. But $I$ have seen other kinds of stupidity in France which 
I loathed more, for it was 'clever'. Our folly is never 'clever', and so I consoled myself cheaply, as one does at a pinch. The boat-race was a procession, Cambridge a magnificent erew. I am getting on with my work, greatly happy, for there is lots of light and sun, and I don't mind the cold east wind.

Sterenson died on April 18th, and Powell took him to burial in Edinburgh. Some unfinished verses, too broken to quote, and many letters to common friends, show the strength of his regret. 'I can think of nothing else all day when I'm not actually working, and I can't work always.' He now felt more than ever that he was 'a lonely person in some ways', and he found relief of a kincl in letter-writing, for he could not talk much about the matter. His grief was always clear-minded; he sought no anodynes. The loss made him older; he clung to life more tenaciously and less gaily. He was not resigned, but there was no rage against fate in his grief, and no theorizing or attitude. This, the third or fourth, and the last, of his heavier sorrows found him prepared, but left him shaken. The mere void of the long-accustomed weekly talks was dreadful.

His conversation was one of the joys of my life, and I looked forward to it from week to week across a desert of work to an oasis of pleasure.

Stevenson was to Powell the spirit of youth and of golden free imagination, endowed with a magical gift of words: and one of the tributes that he liked best was the memorial poem by Mrs. Marriott Watson, for some of the stanzas word his own feeling:

Yon are not here, and yet it is the SpringThe tide you loved, compact of sun and rain, And all sweet life and colour wakening, Losing your touch the world falls grey again. With you we strayed through faïry palaces, Threaded green forests dark with ancient trees, Solemn with pomp of immemorial shade, Where by still pools the wood-nymphs bathed and played : 
Unconscious as a happy child at play,

Of all forgotten splendours you were free, And all the present wealth of night and day 0 , you, and you alone, could lead the way,

Yours was the key.

Yours was the golden touch, O loved and lost, Or ever the wintry years that bring the firost Could blur your radiant spirit, you are fled. Eld shall not make a mock of that dear head, Nor Time account you with his tempest-tost.

Young with imperishable youth you sped:

Yours is the peace, ours the unnumbered cost.

To J. M. Mackay.

Bedford Park, April 24, 1900.

You will ere this have seen that all is over, even the burial: I took him down to Edinburgh Sunday night and at 10 on Monday morning he was laid with his father and mother at Calton Hill in his own place.

It's no good trying to console ourselves or any one else for this loss. You loved him and I did too, and this is no light grief for either of us. Mrs. Stevenson has done everything possible, but the P.M. showed that he could not have lived longer or happily with the vein disease he had all over him.

If you had been in England Mrs. S. meant to have asked you to go to Edinburgh with him. She will tell you this. But it all came too soon. He died on the 18 th at 11 a.m. without pain or sense of death. I would sooner know he is lying there at rest with the old Castle and Arthur's Seat at his feet, than I would have had him live tronbled and weary and weak as he was in the last week of his illness. He always hoped he would never be old. He has his wish.

Everybody that knew him loved him, even those who could not appreciate the extraordinary talents he possessed.

I have known the best talkers in France, and I have known Meredith, but I never heard either so magical as Bob was, and his gentleness and humanity and generosity were beyond all our praise. . . .

I wish you had been with me at Edinburgh, but it would only have made you feel bad too, and I felt bad enough as it was.

'He was too good to live, I suppose,' as - says.

When I see you I must have a talk. I haven't felt so stummed for years. He had that sympathy that you just 
[feel] going through you, and the roots struck deep. Well, as long as we two think and breathe we shall remember Bob. I am yours always faithfully.

[Later.]

... Life is beautiful and pleasant, but we pay for it when it is marked by these sad stages, and it must be as we live on. I don't think there was ever a more lovable man than Bob was.

'Three dead men have I known and this is the last of the three'-a 'prince of courtesy too', and with that gentle Welsh generosity of soul I knew in my father only as in Bob.

To Mrs. Reece.

Bedford Park, April 25, 1900.

... You have no idea how good Stevenson was, how wise and how magical his talk was. He was like the kind keeper of the Enchanted Garden, who let you in to play there and let you eat the strange, beautiful fruit, and even drink of the charmed springs; and now the friendly Doorkeeper is gone with his golden key, and I shall never walk in the Enchanted Garden again. I am like the men in the Arabian Nights that remembered and neither could nor wished to forget. I have had many good friends, but Stevenson was the most human of them all, and so one clung to him. But I'd sooner know that he is lying at rest on Calton Hill brae than living, worried by pain or weariness; and he would think so too. You will think this letter sad, but I cannot help it, and you will forgive it. The man was worth many tears, for he had real greatness in him-the royal qualities that make a man great. ... It is the price we pay for life to lose by degrees all that makes life life, and I am not grumbling: I only feel it hurts sometimes.

\section{To D. S. MricColl.}

Bedford Park, April 25, 1900.

Thank you heartily for your kind letter. Well, there he lies with his own people, Father and Mother and Grandfather, in his own place on the slope of the hill that he often looked on Elinburgh from, and we are left to our poor thin memories of a glorious friend and a gentle kindly wise man.

It has been a bad time for me, and for that poor ehild Margaret and her mother it's been far far worse. And 
they have done all that could be done, patiently and hopefully and cheerfully, and it's all in vain.

I can't think of Bob as gone. I expeet to see him and hear his voice whenever I cross his threshold or stand in his garden. I have had more happy hours with him than with any of my friends, I think. It was a privilege to know him. He had a large royal kinduess that extended to every one he came near, and never failed, and so unconscious of his eminence that his humility was astonishing.

My dear MacColl, we shall never see his like, or meet any one with his own gifts, gifts that gave such intense pleasure to others. We know, you and I, what the joy was of the Mermaid, since we have known Bob. It's like being maimed to miss him. We shall never pass again into the Garden of Fancy of which he alone had the key, and our life will be the poorer.

Next my own closest kin came Bob in my thoughts and heart. I'm just stupid and dazed with the knowledge that it's all over. You know what the feeling is. I am yours very faithfully.

\section{To Kuno Meyer.}

Christ Church, May 11, 1900.

It is a fair place where he lies, with a view he loved and thought much of. He can't see it, but he wished to lie there, and I am glad he has his wish, though had it been possible for him to live happy and well, I would, I think, have given gladly anything to save him and keep him with us; but that could not be.

I miss him every day I go home, as you may imagine. I knew I was very fond of hin, but I hardly realized how much I loved him till he was gone.

\section{To his Daughter.}

Christ Church, June 22, 1900.

I was at Bath yesterday on College business. It is a pretty little old-fashioned place, all stone, and set in a sort of bowl of green hills, the houses climbing about in long rows like white caterpillars. The streets large, white, and broad, with very good shops and a fine old Roman bath, with beautiful ballrooms and bathroom close by, and a fine old church. I came back this morning. On Sunday I am going with Carr to see Devonshire House in the afternoon. If you see the Pall Mall Mag. for .July, there is a good article on Bob by Henley, very nice. . . . I had —_ down 
with me here last week for a day. His boy ran away from school for a lark the other day.

\section{To Oliver Elton.}

Bedford Park, July 12, 1900.

I have had a real bad time, but I am worrying through. $I$ felt Bob's loss and I do still. He was a very rare man both in talents and character. He made me think, and he gave me intense pleasure by his marvellons talk. It was not waste talk, but fertilizing, when the soil was capable of growing anything. One got so fond of him too. I daresay I've said all this to you before, but if so, forgive me. I think of him whenever I sit down to write to anybody I care about. I wish you had seen something of him. He was not like me, he was really a good man, but his ethics were not those of the Presbyterian or Anglican Church; he had not a trace of the Nonconformist Conscience, but he would have come very near the standard of the 'Hilltop talk' of J. C. . . .

I am working on slowly, but still getting along a bit. If I can only get a fortnight's peace I can do a lot: but just as I feel desirous of work, exam ${ }^{\text {n. }}$, private business, \&c. come in and I am crippled of part of my time. We all suffer, I know; I don't think myself otherwise than highly favoured by the gods ; I'm not grumbling. I hope I never do, I have no reason to: I only mention it as a kind of excuse for my working so slowly.

In the summer he went to Ambleteuse, and in its sumshine and its hive of old acquaintance recovered some brightness, though it also revived his desiderium.

To Mrs. Marriott Watson.

Ambleteuse, Aug. 12, 1900.

You may fancy how I miss Bob here. 'I can hardly play alone,' like the little child. I saw a view to-day that he would have gone wild over, the most serene and rich in colour I have seen here. It is almost hopeless to describe, just the red roofs in a calm soft heavenly evening, one of the most beautiful of the kind we have here. It had a sort of poignant peace that brings tears to the eyes. I do wish he had seen it. I must try and do it. If I can only get some of the light richness into it,-but it would take a big man to do it even a shred of justice. We have had rough, blowy, cold weather till yesterday and to-day, when it was delicions, the bathing nice, the water warm. 
... It is nice going down to the French friends in the evening Sometimes they play and sing, sometimes they talk, sometimes they draw. They are always very merry and full of gaiety, making all the little incidents of life amusing. It is a complete contrast to the stiffiness of ordinary English 'society', which is a solemn game wearily played.

Your garden must look fine. The gale burnt all the trees here; they are bronzed in a curious way, but there are plenty of flowers where there is shelter. The sands are beautiful, one walks about bare-footed on them. There is a soft purple haze in the distances, whenever it is fine, that is good to see.

\section{To W. E. Henley.}

Ambleteuse, Aug. 18, 1900.

I have been meaning to write to you for a long time, but I am a great paver of hell, many excellent mosaics of mine adorn the infernal floor. I wanted to tell you how I liked that article on Bob. I don't think it said a word too much. He was one of the two or three best men I have known, real aristoi. His wisdom and his humanity and his gracious and unselfish consideration for every one can never be forgotten. I have suffered and I still suffer from losing him. In the last six years I have seen a good deal of him; before that I only knew him through report. . . . I shall certainly never see anything approaching him again, or hear such talk. It was a blessed thing really to know him: I am glad I had this great good fortune.

I saw your kindly allusion to our talk at Barnes. I daresay you are right; the glamour of the reports of the Nonpareil's fights possibly led me to put him higher than first class. His astonishing two-handed dexterity and marvellous quickness and instinctive knowledge of distance appear markedly in him ; and he could hit hard too, because of his quick hitting, not of his strength. If he had been two stone heavier! but-

'Belcher's walk'-don't you seem to see it?

I saw a boy once, who was a natural boxer and walked in the ring as if he were an animal, naturally, lightly, with instinctive adaptation to the moment, now quickly, now quietly, now firmly, now trippingly, his feet and hands in indissoluble union. He walked up to his man, sometimes, as I imagine, Beleher did. It was pretty to see; an uncle of his had tanght him first when he was a small chap, and 
he seemed born to it, and all the others clumsy and patient learners. ...

I hear of you occasionally from Blunt and others, and I tell them to give my love to you. I hope they do. That you are better and full of work is the last news I had. I hope this state goes on and betters.

The weather here is lovely. I read and write, and bathe, and sometimes daub. There are one or two people here, mostly French, whom I like, and we talk sometimes. I think of Bob a good deal, he was here several years with me. I am your's very faithfully.

I am trying to write on Machiavelli just now.

Other letters from Ambleteuse show its requickening influence. He worked and read and began again to paint, strolled and talked and played games in the evening, helped the old postman ('I am always on tap when he comes') to decipher the English names on the letters, and saw his painter companions, MM. Van Rysselberg and Thaulow the Norwegian. The first words in the next letter refer to the versions from Maeterlinck, Camille Mauclair, and Paul Fort (printed in vol. ii. pp. 414-17):

\section{To Mrs. Marriott Watson.}

Ambleteuse, Sept. 8, 1900.

Here are three translations for you I did to-day. I hope they may please you, they are very close to the originals. They would set to music very well, I think, in the French, -very simple old-fashioned airs. The Maeterlinck is just like the Prince's Progress of Ch. Rossetti, but all done in 20 lines. It is a beautiful book, that Douze Chansons of his-(I was lucky to get the first edition of it when it came out).

I am glad you like — and are having a gay and festive life, and that Marriott and Dick are well. The $-\mathrm{s}$ are very nice. She is beautiful and the children too. I do like good-looking people, though I know there are good people who are ugly, and I know some and like them, but it is ' with difficulty' at first.

I have got hold of a modern French Anthology and discovered some new poets. I'll bring you the book to show you when I come back. There are some old favourites too. I have marked some good bits in it, and some comic ones. 
Les cors, les cors, les cors-mélancoliques!

Isn't that funny? And it's by a good man, Laforgue.

Isn't this good, by Hérold (last three lines of a sonnet)?

Et l'austère ferveur des cantiques pieux

Monte, morne soupir, vers le ciel immobile,

Cimetière éternel où reposent les Dieux.

And this, the beginning of another, by Hérold too :

C'est un val odorant des lauriers, où la lune

Fait trainer et mourir sa caresse d'argent

Tandisqu'an ciel gai d'un crépuscule changeant

Les sidérales fleurs s'entr'ouvrent une à une.

Isn't that Keatsy?

And these of Guerrin are good-Wordsworthy of the best :

Et puisqu'an fond tout est des mots, rien que des mots,

Savoir au moins les mots divins qui font pleurer!

Isn't this a fine beginning, Corbière's best picee almost?

Bénite est l'infertile plage,

Oì comme la mer tout est nud;

Sainte est la chapelle sauvage

De Sainte-Amne de la Palud.

They ring in one's head : they seem to me exquisite.

Isn't there 'pomp' in this of Fontainas (who translated Samson Agonistes and Comus)?

Et bientôt ses yeux voient à l'horizon, très-calmes

Au pas de leurs chevaux et lui tendant leurs palmes,

Les rois qu'il a erus morts marcher dans le soleil.

And this is his:

Le rêve est malfaisant, et vivre c'est assez.

This is the end of a pretty piece of Gregh. It is like Louis Stevenson :

Mon Dieu! Comme devant les choses

On est ébloui du destin!

Comme on est pareil à des paurres

Devant un splendide festin!

Comme on t'adore d'un coenr simple !

Comme on te retrouve ici-bas

Partout dans la vie ample et sainte, Mon Dieu, qui n'es peut-être pas! 
This of Jammes seems to me good too:

Pourquoi donc parlons-nous et parlons-nous? C'est drôle. Nos larmes et nos baisers, eux, ne parlent pas, Et cependant nous les comprenons, et les pas

D'un ami sont plus doux que de douces paroles.

My letter is full now and I must send it off, as I have a lot to write to-day (work) and I had a play-day yesterdaywent to Etaples, lunched with Dudley Hardy, and saw his last pictures. A magnificent landscape such as Bob would have liked [ink outline]; fine, golden-green colour, quiet, glorious, and full of poetry.

We come back next Wednesday, I hope. Let me have a line if you have time to tell me if you like Paul Fort's piece. I am yours very faithfully.

Not long after comes another letter of regrets. The son of a clergyman well known to Powell had committed suicide, and he wrote to a common friend :

Poor $\mathrm{J}-$, one of the finest fellows that ever stepped. He is one of those people I remember most clearly of $\mathrm{my}$ friends. I used to watch him for the pleasure of looking at him, he was such a manly, honest fellow.

The best go, that is the worst of it. Death snatches the ones we try to keep. Happily they have no further pain or regret or any longing, but only unbroken peace. I don't like to think I shan't set eyes on J _ again ... I have written [to his father], I could not help it, but what ean one say? I rebel against death taking the best. But the Vicar is happy, he knows not only that they are free from all pain, but he looks forward to seeing these very sons. IIe is a brave man, but these things must shake him, and her, poor woman : I dare not think of her grief, for she knew J_- 's goodness better than any of us could, and she must have loved him more than any one else. It is frightfully sarl. Take care of yourself. I am yours faithfully.

IIe came back, I think, with a permanently sadder texture of mind, but with an embroidery on it of newly bright and cheerier colours. Work, begun with fresher nerves, revived him. 
I don't think I have much to tell you. I have been reading the poetry of the $O$. T. these last few days. I always do in the Vacation some time. It is a holiday. I make emendations some time, and get a bit nearer the original, as I think. I have been working at my lectures and at other things . . . I went to B. M. the other day and did a bit of reference-hunting as usual. I have all sorts of plans and no time, as usual, but I get a little done from time to time. I hope my jibe at Comte won't make F. Harrison angry. Comte is so conic, he always makes me long to fly at him. However, l suppose it don't matter one jot.

I saw the pictures in Paris and Loie Fuller and Sada Yacco, and I dined at a really good old-fashioned Restaurant-Dépré, and felt I laad not lived so long in vain.

On December 12 he writes once more of Stevenson; this time to Mr. Francis Dodd the painter :

Yes, Stevenson's death is a great and serious loss to me. He was a man one got to like so mueh. He had an extraordinary faseination, and his talk was pure glamour, enchanting and wise and humane. I never heard any one talk so well and with such delightful witcheraft. IIe really knew, and he could tell. Only a few know, and very few of these can tell save to one or two in their lives.

Do you care for T. E. Brown? Another friend of 's who is gone this year. He was a man with a gift of verse and thought of the olservant, sympathetic kind : a rare man, and his best verse is as good as possible.

What are you doing now? How goes the art? How are the EItons and Johnstone?

Towards the end of this year he wrote to a young historian a letter of counsel which rapidly shifts to a notable picture of the 'historic heaven' ; it recalls Sainte-Beuve's famed vision ${ }^{1}$ of an elysium of 'classic' writers, but Ileine more. The names of the celestial historians, anthropologists, and observers are much the same an those Powell

1 'Qu'est-ce qu'un classiqne?' in Causeries du Lundi, rol. iii. 
mentions in his various surveys and addresses on modern history.

... Take care of yourself, don't overwork, and for 'Goddes luve' do not do any pot-boilers. Research and hard work, my dear sir, must be your game; till you arrive, anyhow. But I don't want you to be an immoral arriviste, but to make your way by mquestionable work, and not by coaching those silly boys through their silly Schools.

I write in jest, like Rabelais (but a long way after), but I mean it earnestly. I want that pretty Sister of yours to be proud of your success some day, and you to feel that you have earned it by your righteous work, and not by pot-boiling or cramming. You can do it, and if you take care of your health and refuse the kingdom of this world, you will enter into the historic heaven, and meet Machiavel (who will solace you with 'inappropriate talk'), Sarpi (who will astonish you with his piercing wit), Aristotle (who will be with us and not with that mouldy gang of selfdeceivers, the philosophers so-called); and there will be good company and good talk, and on Sundays I hope to be allowed out of hell to foregather with you all and have a wee drappic. But the plain female historians will have a place of their own well concealed ..., and there will be a few 'weel favour'd hizzies' supplied to us who may solace us in the intervals of high talk. There's a future to look forward to. Gardiner will have a quiet arbour with Firth on the Delectable Mountains, out of sight and hearing of Machiavel, whose ideas he don't share; and Freeman will have a place of his own with Stubbs. (Froude will be with journalists in a kind of Eternal Club, where the men drink and sneer at each other and tell old stories and quarrel and enjoy themselves after the journalistic kind.) There will be many mansions, though the number of historians will not be very great, for many are called, few are chosen. Charles Booth and Mayhew and Gill of Mangaia and White of New Zealand and Bleek and Colenso and George Gray and old Howorth and a lot not generally acknowledgerl will certainly be there, and a lot of pot-boilers will not be there. And there will be a little hole with the lid on, and - will go there sometimes and listen to the howls of - and - far below, and he will not have any more pity than Aehilleus had for the man that slew 
his friend, and he will be happy in the happiness promiser to the saints by the mediaeval theologians 'in hearing and beholding the sufferings of the wicked'.

And I should like to have the happiness of that kind as regards Uncle Paul and Steyn, but we can't, at least we don't, have all we want in this world, and it will probably be the same in any other world we may find ourselves in.

Do you know what Orran said when he came back from the dead? It shocked S. Columba so much, he put him into the grave again with a heavy stone on top of him to stop his truthful tongue.

The same renewal of cheer is heard in a letter to a friend:

Wi a copie of Andy Shirref's Poems.

The Buik I send ye's no complete :

But I've nae had the luck to meet

In ha' or mairket, store nor street,

With ane completer ;

But then ye ken that Andy's feet

Limp'd like his metre.

IIis honest phiz, nae doubt, ye ken, And hoo he blinkit whiles he' amang men

Ate, drank, and upheld, but and ben, With whiles a visit

To honest Lucky's tappit henSae ye'll no miss it.

Ye sent me guid King Jamie's Rhymes, Maist superfine for sic rude times And grandly emprinted: Man, how prime's

Their state that has them!

Poor Andy's morlest Muse nor flies nor climbs: Puellam admitte castam!

About this time he acknowledged a printed lecture on Madame de Maintenon and the education of girls, and I quote from his letter, as before, for the sake of the remarks that accompany his praise. Siccitas is 'dryness of heart', into which the theologians of the Old Faith show singular and sombre iusight. 


\section{To Oliver Elton.}

I am very glad you speak up for manners. The schoolgirl has generally worse manners than the schoolboy, who is brutal out of savagery and shyness, but she is rude because she thinks it fine and is conceited.

Your touch about the siccitas is very true. Why does not some philosopher, instead of writing rubbishy metaphysics ('which I don't believe there's no such thing') give us an analytic account of the casuists, who were, like Mohammedan lawyers, very able men making the best of a bad job?

What are you doing? If you see Johnstone please thank him for his kind and full letter. I did not write him out of idle curiosity, but now Bob is gone I have no one here to ask what I want to know about music.

\section{To H. G. Wells.}

Christ Church, Dec. 18, 1900.

I was going to write you to tell you how good your bike article ${ }^{1}$ was . . . I am following your moon-rakers with joy. I can't imagine what is coming, or how or when, or anything. You keep your secret always, like the good story-tellers of our childhood.

Term is nearly up. Some day you will see a coated 'form' struggling up the windy path that leads to Spade House, and the King and Queen of Spades will, I hope, receive this 'form' and lend it an hour of talk and idleness.

In Spanish cards the Spade is an Espada,-sword, which makes a lovely sign [ figure] and will do for your weathereock, grasped by a hand, say, like Excalibur, in samite, mystic, wonderful. [Figure with colours 'red', 'silver', dc., noted.] . . I think David is the K. of Spades in the French card. His portrait, harp in hand, and Bathsheba in eye, would adorn your room mightily. He was pretty low on Uriah, but apart from that he was too good for a Jew and a most creditable person and (as far as one can judge from the fragments that remain) a poet.

I shall expect to see a page dressed as the Knave of Spades as porter at your gate and beneath the tree I planted.

1 In the Fortnighily Review, on military cycling. 
To a Friend.

Dec. 19,1900 .

To an admirer of Chaucer who fled from a banquet held in the poet's honour.

Amice mi,

Come tell me why

You left us all forlorn :

Had you forgot

The day or spot,

Or held our feast in scorn?

The Chaucer crew

Expected you

To toast the daisied Bard :

Your vacant place

Was my disgrace, And _- joy was marred.

Had it been I

That let Time fly

And missed my friend and meal,

Men would have smiled :

'He's just a child, His brain turns like a wheel !'

But you, sad man, They'll sternly scan, Refuse each plausive plea.

"Tis all pretence,

His reverence

For Good Old Jeffrey C.!'

F. Y.P.

Christmastide was not without festal moments. This letter was written to Mr. Wells, on the occasion of his entering his new dwelling at Sandgate, Spade House. ${ }^{1}$

'The spade is mightier than the pen' [sketch of spades with hands and legs].

6 Priory Gardens, Bedford Park, W. London; Dec. 22, 1900.

My deAR WeLis,

Many thanks for your card and many good wishes to you both. I like the name Spade House immensely and I hope you will have the best of times there.

${ }^{1}$ Superseription and signature kept here as in letter. 
$\mathrm{T}$ - has broke his head with a coal-hammer, which he was swinging with Infant Herculean strength, and the head met his head, and his head bled a good deal, but it was thick and he's not really hurt.

Will you give my love to Jim [Pain] when you see him? Sunday I shall rush down and see you all.

I like your pictures of your activity. It is fun fixing up everything in a New House. One goes to sleep tired and happy and feeling good.

I wish Bob were alive. I am always wanting to hear him talk about books I read and poetry and life and pictures. I miss him a lot every day. . . .

Is — in quod yet? Hell to his soul! I am always hoping to hear of his evil death. I am sure 'a bad savour' will come from him, as from that pagan knight in the Mort Arthur, when his head is cut off by some avenging tile or wire.

Your bike article was prime. I told you so before, 'but what I say twice is true.' I can't waste your time any more, but you will excuse this much and believe me

Yours very truly,

F. York Powelt.

We are in woolly sea-fog here to-day, not very thick but clammy . . Poor Oscar! He suffered more than he sinned . . . He was a kindly maniac, though his mania was an unpleasant one, and the tower of Siloam fell rather heavily on him, all its weight.

You will have a flag-staff won't you, and a flag with a white ground and a big red cover, the real English flag? I shall look out for it.

\section{To Francis Dodd.}

Bedford Park, Dec. 25, 1900.

This is delightful: the picture of Henley a great advance, I think: not so tight or troubled; more flow, more distinction, character and composition. Of course I have no right to praise or blame, but that is how it takes me. I know the struggles you speak of in your letter, and the glimpses of heaven. The arts are alike in this, that there are like difficulties before the 'paperstainer' when he has to describe and suggest and make his impression impress the reader, and the painter or sculptor. But one gets this quickest from painting, that one learns to perceive soon the beauty of this world and the interest of it, and 
the infinite suggestion and sympathy of it all in certain lights and moods. The literary man is prone to pan out on character and thought, and soon to miss the colour and form and true significance of circumstance and moment as it shows in nature. The clild feels this; I was never quite satisfied by certain books if they were not illustrated. Pilgrim's Progress, for example, was maimed and halt, onelegged and one-eyed without a man like Watson or Wal Paget or Selous or some one who had really visioned it ont concretely. Then I enjoyed it to the full. Robinson Crusoe and Mamon Lescuit and a lot of other fine books. But I don't eare for illustrations of Shelley, and the illustrations of Shakespeare are hopelessly inadequate, nearly all: nor are they wanted; Shakespeare wants living figures, Irvings and Keans and Salvinis and Duses and Bernhardts and Terrys. Shelley wants ghosts or diaphanous nacrous forms, smoke-thin and floating.

I don't know that the Puritan training is so harnful. The natural reaction is so delightful-feeling rid of it like a bad illness, and getting it behind for ever, and enjoying the fresh savours and scents and air, and the renovation that some illnesses cause. It is like coming out of a dark gap in the hills into a comntry of woods and waters and the sea in the distance. It is a training at all events, only dangerous if too prolonged. I had myself no difficulty with it. It slipped off my back (far easier than Antaeus' burden), but I have known persons who struggled fearfully. The vile thing launted them like an incubus and tried to strangle them.

The less to interrupt the letters of this year, Powell's most eloquent piece of published writing has not yet been mentioned. His article on Jolen Ruslin had appeared in April, in the Birmingham periodical devoted to Ruskinian ideas, Saint George. It was a funeral cloge, and it must be read closely to see where Powell now stood both in matters of art and of social politics. Like all intelligent admirers of the schools and principles that Ruskin ignored, he never stinted his honour of Ruskin as an artist and critic. The warmth of his language fails to disguise a great deal of discrimination. He had given the paper as an address before the Ruskin Society of Birmingham on Jan. 31, and x. 1. 1 
may not have been at one with all his hearers when he declared that Ruskin

too often mixed ethical matters that do not concern art at all with his art criticism, always to the delight of the Philistines but not always to the pleasure of the artist. Though even here it is certain that in treating of the social aspects of art he did great service, and took up the consideration of difficulties that had not been overcome or even fairly faced since the days of Plato.

The paragraph on Ruskin's English shows the highest reach in beanty of Powell's own English; but it was Ruskin as a prophet that he honoured chicfly. He points out clearly the historic fact that the measures of a socialistic nature, 'National Education, National Hygiene, National dealing with the housing of the poor,' and many more, which are now in sight, or are at least matters of practical debate or imminent proposal, were all preached by Ruskin in the days when he was slighted.

Powell also had a main hand in the shaping of a new foundation that arose in Oxford to the memory of Ruskin. On Feb. 22, 1899, he had presided at the inaugural meeting of Ruskin College, held in the Town Hall. This institntion, founded by a generous American, Mr. Vrooman, is planned to educate a certain number of working men, resident in the College, in the study of social and political problems and also in their philosophical gromndwork. 'There are courses, given by a permanent staff, on economic and industrial history and administration, and also on logic and ethics: and further teaching is conducted by correspondence with those who camnot come to live. Some of the students have already become trade mion officials, or poor law guardians, or teachers, or Labour members of parliament. The residents lead a communal life, and the students manage all the work of the house except the cooking. The College is maintained not only by private gifts, but by funds from all kinds of trade associations and unions as well as co-operative socicties; and it has quickly 
grown, for there were last year thirty-four working men of various trades living within the walls. In this way such men are able almost for the first time to share some of the intellectual chances and enjoyments that the Oxford system tends to keep for wealth and caste. Ruskin College was not founded in the lifetime of Mr. Hardy's Jude the Obscure; else we might hare missed the sharpest etching ever drawn of Oxford from the point of view of the pariah resident.

This brief account has its place in a chronicle of Powell : it is easy to see why he threw himself into the canse of Ruskin College. He approved, in the spirit of Ruskin, of the simple and genuine life at which its members aim. He must have regarded it as a happy and hopeful element in Oxford, and as something of an antidote to the worst Oxford tendencies. But beyond all things he must have hailed it as, in its own measure, the kind of antidote he desired to see to the risks of democracy. 'An ignorant democracy cannot last long.' Science, knowledge, training: these things, if merely in self-preservation, and to prevent themselves perishing as the unfittest, the leaders whom the people chooses from its own ranks must give themselves. It is an ideal, and a sound one, and all the better for modest beginnings. Powell did all he could for Ruskin College, even shouldering some kinds of work for which he had scant natural liking. Mr. Dennis Hird, the Principal and one of the chief teachers, records Powell's service expressively enough:

From the first, lie was a member of the Council, and when the College was incorporated, as a limited company not formed for commercial profit, he was one of the original seven signatories.

When the founder returned to America, Powell took an increased interest in our work, and allowed me to go to Christ Church and consult with him at any time, and he placed any of his books at my disposal. I used to call, as a rule, just before ten in the morning, when I would find breakfast waiting. On learning that some one had called, 
he would appear in pyjamas, fresh from his bath, and with a vigour that somehow I always associated with the Vikings. He would say, 'I am sorry to keep you waiting, I will be here in a few minutes.'

In that marvellous way of his, he always knew what we were doing, and what the last number of Young Oxford (the magazine not of the College but of Mr. Vrooman) contained, and the character and value of any particular article. It must not be supposed that he was merely just rising when I called. He had a habit of getting up about seven, and reading or writing till after nine, before he came out of his inner room.

He was able to explain to the best Oxford men what the new movement stood for, and so rendered us great service. Soon we had other distinguished men on the Council. When he moved from Christ Chureh to his private house, he sent many of his books to our library. In 1902 we received a blow, because the house we rented was sold and we had to turn out. He took an active part in finding new premises, examined sites, plans, and reports, and got them through our Council, in that year. We then had no suspicion that he was not as strong as he looked. After we took possession, in 1903, of the property we had bought, it was soon discovered that we ought to build, so as to be able to accommodate more students. He then consented to become treasurer of the building fund, and signed the appeal. But, unfortunately, we had not proceeded far in this difficult undertaking when he was stricken down.

Ruskin College, as will be seen, engaged Powell's practical sympathies in the last weeks of his life, and he has his share of honour for the good that it may do. His Thoughts on Dcmocracy, to be described presently, were meantime, in the latter part of 1900, taking form. And the year is also marked by what may be called his last word on the matter of Iceland. For in July he had written another brief note, in the form of a preface, to the poetry of a new writer, Miss Beatrice Helen Barmby, whom he had never known personally, and who had published nothing in her lifetime. Miss Barmby had died recently, leaving behind her some prose tales, translations from Icelandic and German, a number of original lyrics and narratives in 
verse, and a single tragedy, Gisli Sursson, which gives its name to the volume introduced by Powell. Part of her life had been broken by illness; but she had learned Icelandic, and the sagas were her best inspiration. Gísli Surrson is based on the Saga of Gisli the Outlaw, known for some time to English readers under that name by the translation of Sir George Dasent. Did we not know what floods of verse appear, and in how sorry and bewildered a state is English criticism, indemnifying its apathy to merit by its incense to middling or fatally accomplished stuff, it would be a matter for surprise that this poem, highinspired and nobly wronght, should have failed of public recognition. It is, indeed, not rare that a woman should appreciate and love heroic matter; but it is rare that a woman should execute and create it; yet this Miss Barmby did, and Powell said so. I shall not forestall or weaken his praises, the reader can turn to them ${ }^{1}$. They are not an instance of his friendly indulgence, for he was a stranger and the writer was dead; nor of his general good-heartedness, or of his readiness to hail any one zealous in his own faroured sturlies. They are an instance of his perception of talent. His words are not indiscriminate ; he states clearly which of Niss Barmby's verses (some of her translations and lyrics are as good as Gísli) he likes more, and which he likes less, and why. She was only beginning. But her hold on blank verse, to name nothing else, should have shown the critics what was alrealy within her powers. 'The book' in the following sentence is Gísli.

To W. P. Ker.

Bedford Park, Dec. 20, 1900.

I am delighted with your father's letter and glad he liked the book and thoight my prefice not inapt.

Trench's book" is out. There are good lines in it, but I think lyric rêverie more his line than epic of the idlyllic kind. And I wish he had not suffered from 'Celtic gilimour', and seen his polyandric camnibals in a filse 'Tennysono-Yeatsian light. But when he writes about leves he

1 Vol. ii. pp. 262-70. 2 Deirdre Wed. By F. H. 'Irench. 
is nice, he is the Laureate of the Leaves, he understands them beautifully and finely.

Raleigh's Milton is very good.

I have just finished again the Tavola Ritonda (which is really Tristcu). It is handy as completing the tales Malory leaves untold, but there is not enough about Lamoracke de Galis, whom I always admired. But Tristan is not quite spoilt by the precious Italian. And Isotta la bella e bionda is as lovely as ever. Mare dies of fat in a cage on a tower 880 feet high. The spear that killed Tristan was sent by Morgana la Futa to Marc. I wish some one would publish the Lancelot and Tristram parts of the Romanees. We have the Graal and Merlin, but the part before the Graal and after Merlin is to seek in a text. Haven't you a pupil or conldn't we egg on to it?

I see they have found the Master's Fifth Book ${ }^{1}$ in an original text. I want to see that in print.

Have you read Rowe's lyrics in Oxford Poctry-Booli? 'Angel king of smiling morn.'

To H. G. Wells.

Jan. 11, 1901.

It is heavenly weather, and the sky just lovely to-day in between the showers. I know how it smells in Sandgate, 'salt and fresh,' and not too keen to be delightful, and I wish I was at your room window or in the garden, looking out at the sea.

Have you met Jim Pain, the boatman, yet? He is a very noble fellow, and you will like his voice. Remind him to give you a photo of himself for me. I hope to run down some Monday and see you again if I may. I shan't be often wasting yonr time, as we live so far off, and I have not forgotten your promise about Oxford.

I won't inflict more of my handwriting on you now, but begging you to remember me to Mrs. Wells, and to give my best love to Jim Pain when you sce him, I am yours very faithfully.

I have only one quarrel with you-it is that you seriously shortened one year of my life by the War of the Worlds. I kept looking forward for the next number, and getting quite impaticnt with the passing hour. I nearly went to see you to ask you what the end was to be, for I never guessed it.

${ }^{1}$ Of Rabelais, Pantagruel. 
The death of Bishop Creighton ${ }^{1}$ moved Powell to an expression of regard :

To Mrs. Creighton.

Christ Church, Jan. 16, 1901.

I know it is no use, but I can't help writing to tell you how sincerely grieved I am by this greatest of losses that has come upon you and your children.

Every one that knew your husband will long feel it and never forget him. His work as an historian will be a lasting monument to his ability, his courage, and his abiding zeal for truth. His indirect services to History are no less. We were, and are, very prond of him at Oxford, where his work and example have left persistent traces. His brilliant and suggestive lectures; his kindly help whenever we needed it, especially in the matter of the English Historical Review, which has been of such immense use to all English students of history, and served as a model for the American Historical Review ; his beautiful little books for younger students, and the ungrudging sympathy he always gave to good work without a shade of partiality ; these, and his unerring judgement in the difficulties a scholar has to encounter, will be remembered long and gratefully.

For myself, I owe him the great kindness of giving me my first opportunity of writing on history; and I know how extraordinarily kind and tactful he could be in giving most useful and necessary eriticism ; by which I have greatly profited, for it was a fine lesson for me to have my prentice work gone over by his advice and correction.

He was always kind to me, and I have always had a strong feeling of attachment and admiration for him. It was impossible for me to sec him as often as I should have wished (we were both too busy), but I often wished that I could have talked things over with him that turned up firom time to time, though it was impossible.

I think it is no small thing for him to have maintained the highest ideals of the history student, and to have given so fine an example of devotion to Truth in his works, resisting all temptation to be drawn aside by any political or other consideration. He stands firm where so many of the greatest German and French have fallen miserably and turned their backs on Verity. I am sure there are hundreds of people who have been helped by his words and

1 Part of his obituary note on Creighton is printed, vol. ii. p1. 50-2. 
example-people who may have only seen him once or never seen him at all, but who have reason to be deeply grateful for the influence he exercised so wisely and generously and unselfishly, but, I fear, at huge cost to himself-the one person he never spared.

You must not think of answering this letter, which is, I feel, too long, but I owe so much to your Husband and the Study we both cared for that I could not refrain from writing it. You will excuse me and believe that I am, with the truest sympathy, yours very faithfully.

This year he wrote his Thoughts on Demoeracy ${ }^{1}$, a short and fierce but a somewhat vague warning in the Ruskinian spirit against the dangers of popular rule. Whatever he may have thought in 1870, Powell now looked on democracy, not as the highest form of polity attended with its own lisks, but as a necessary evil that, unless checked and palisaded off, would be ruinous to England. He ends his pamphlet by saying that 'an ignorant democracy cannot last long': an article that was part of his faith in science, and is palpably true even without it. But Powell's faith in the power of democracy to see and stem its own ignorance was a tender shoot indeed. Once (1896) the words of Byron were quoted to him: 'Blood will be shed like water, and tears like mist, but the peoples will eonquer in the end. I shall not live to see it, but I foresee it.' He broke into sharp laughter and exclaimed: 'I hope to God the peoples never will conquer!' He thought they would never be fit to conquer. In this sense he was a Tory, fast-bound and immutable. But he was not a eynical Tory. He had a fervent sympathy with the working classes, he respected the efforts of Morris to help them, and he believed that the slow process of partially educating them was not entirely hopeless. In his Thoughts on Democracy, and in all his remarks on politics at this time, there is a kind of vehement indefiniteness. It does not appear that he tried to grapple in detail with any political or social problem. He had

${ }^{1}$ As a preface to Mr. Charles Beard's Industrial Revolution. For reprints see Catalogue of Writings; for the article vol. ii. pp. 334-40. 
read more deeply in sociology than most scholars and men of letters, and the excursions of a noble and singular mind cammot fail of interest, but he was less at home in this province than in history and art.

Powell's Socialist friends on the one side, and his Radical friends on the other, were afflicted by his supposed change of front. The first were certainly mistaken, for though his fecling towards war and militarism was opposite to theirs, he leaned, I think, towards a kind of aristocratic socialism. To 'nationalize' land or education meant that the democracy must find the sense to choose and obey a few sagacious administrators. The Radicals had more right to be surprised, when the friend of Valles and of Stepniak was transformed into the defender of the Boer war and the president of the Oxford Tariff Reform League. He seemed to have 'become a Tory in his old age', as one of them put it, or to have 'gone over'. But the change was only the natural growth of his lifelong instincts, stimulated by the passions of the war, and by the conviction, right or wrong, that the country might have to fight for its existence. Powell had never been an English Radical. He had always, so far as can be seen, detested and despised Bright and Mill. He only half-liked Gladstone, and could not forgive his desertion of Parnell and his alleged desertion of Gordon. He never liked nonconformists, hmmanitarians, or preachers of universal peace. Yet he could honour Mazzini, and remained, or becane once more, an Irish Home Ruler. The truth was, that his assortment of opinions was his own: in politics he rode his own course across comtry, he did not seek a rigid or logical body of articles; he had profound emotions and intuitions, and was little concerned to reconcile them with one another. He found himself tending more, no doubt, towards 'Toryism. The letter, already given, of Jan. 17, 1899, shows that he felt he had been deceived by some kind of political mirege, but that he had come out of it. But I doubt if he ever underwent any violent alteration of mind. His anti-American 
prejudice grew stronger: he thought America was the visible scene of the failure of democracy. The letter to his friend, Mr. Beard, lecturer in history and public law in Columbia University, for whose book he had written his Thoughts, shows where he now stood.

To Charles Beard.

Bedford Park, Jan. 12, 1901.

I was rather anxious to know whether you approved, though you gave me carte blanche handsomely. I am extremely glad you don't think what I said out of place. It is so hard not to 'preach', and I dread 'preaching'. But this is a time in this country when plain speaking has become a duty one dare not shun at any risk.

Choate has sent me his Lincoln. It is very good, and it contains the Gettysburg speech and the best bit of the Second Inaugural.

I can't stand Washington (whom I would have hanged had I caught him) and I don't care for Jefferson, who apes the Girondin too much, but I humbly reverence such men as John Brown and Abraham Lincoln. How often I have re-read in Whitman (the one poet I envy you) the elegy, the lament, and the prose lecture, on Lincoln! And in the New Plutarch that will come, The Lives of Noble English-specting $\mathrm{Men}$, these two will have their places as shining examples for every citizen.

I shall be up on the 18th and again on the 20th. I hope you will be in Oxford then. I should like to have a talk with you.

Isn't Defoe fine? Did you know that passage ? ${ }^{1}$ I love it greatly.

I can't get as much work done as I hoped, but still I have done something this vacation. What have you been reading?

I wish you all happiness and luck and health for this year and many to come, and am yours sincerely.

To Mrs. Marriott Watson. Christ Church, Narch 15, 1901.

The Beard preface is only a kind of 'lay sermon'. He wanted me to do it. He is an old pupil of mine, and the nicest American I ever knew.

There is nothing new here [Oxford], which is perhaps as well. I went to Radley on Thursday and we had a good

${ }^{1}$ See vol. ii. p. 340, end of Thoughts on Democracy. 
time. I saw their 'trial eights' have a turn with a good College racing boat. It was very pretty indeed, and the grey day became beautiful. I am yours very faithfully.

The next extracts show the old underlying regret, with the surface pleasure in work and life re-invading. There is always something new in Powell's praise of Stevenson.

\section{To Oliver Elton.}

Christ Chureh, Feb. 9, 1901.

Friday is my busy Press day. I can't come ; I am sorry, I should have liked it.

It is a great satisfaction to know you and Bomnier and Mackay are all at Liverpool pulling together and pulling your weights. I hope great things from Liverpool. Here all is confused as yet in London and at Oxford. . . . One must really be 'bred and born in the briar-pateh', to understand and care for Oxford. She is a "stony-stepmother', like her street.

I have done a long review of Gierke. ${ }^{1}$ You must read the book, it is luminous and classic. Here is a bigger German than we have seen lately : tant mieux. . . .

I miss him [Stevenson] dreadfully. He was a man who helped one instinctively and without preaching or advising. His talk was the most wonderful you can imagine, and not aimless. It made one think of mercy and truth and the real things in a finer way. But there was no damned idealism about it. It was like fine poetry, exciting and pleasurable and extra-mundane, and yet it touched human things so truly and gently and deeply. I think of him a lot; he comes naturally into one's thoughts. I don't think of him as dead, but as if he had gone on a journey : and I wish he were back and [I] could talk over things with him. . . . It is nice to hear Ml's. Stevenson talk about him. I understand why the companions liked to hear Ayesha talk of the Son of Abdullah.

I don't know why I bore you with this, but one must either talk or bust sometimes, and as you are not here I write.

Mrs. Emery² was here last night. She is now an E!!!!ntologiste, and she has alsobeen experimenting in the hamonizing of the saying of verse with a backgromend of music. It is pretty and effective. I thought that it was a curious and

1 See vol. ii. pp. 137-42.

2 Miss Florence Farr, on whose playing of Ibsen parts see pp. 131-2, supra. 
happy success. You get a kind of Greek effect. It is only good verse that is worth doing this way.

Take care of yourself and Mackay. Come South soon, and don't waste your holidays on the stony, rainy, sunless North, as usual. I am yours faithfully.

Remember me to - . ('Damn him,' as Melbourne' says, 'I like the fellow's looks.')

By the way, I like Melbourne much ; the more I read of him and by him the more he delights me : very human, very sane, very wise, no cant at all.

To Oliver Elton.

Christ Church, Feb. 18, 1901.

Mrs. _ _ talked a lot about __ , her unending pluck and kindness. She really was a fine ereature. She looked like an upper housemaid, but she had a noble soul, and it shone through, and her voice was pleasant, and you felt she was one of the best and rarest, when you had been with her for five minutes. I admired her tremendously, and so did Mr's. - - You know how big real people make one feel better, and inclined to put away all pettinesses. Well, she had that quality. ...

Johnstone will miss you : a little beneficent tyrant and Jew-smiter-more power to him.

Professor MacMullan, of Belfast, one of Powell's companions at Ambletense, had lately died. Mr. Boas became his successor in the chair of history and literature; and Powell wrote a letter in which his firm and true conviction as to the nature of University teaching is again evident.

To F. S. Boas.

Christ Chureh, April 15, 1901.

You are succeeding to a man of singular beauty of character and of an original and able mind. I an sure it would be felt deeply if you, having read his excellent little Senilice (a translation from Turguéniev, published last year by Simpkin Marshall), could allude to that and his academic work in your lnaugural. He was a fine, sound-hearted, carnest man, singularly handsome and kindly, with an amiable but distinctive character of his own. I don't know whether you knew him or liked him. I met him at Ambleteuse, and we saw a good deal of each other for two months on end.

1 Lord Melbourne, on whom see vol. ii. pp. 184-5. 
Next try as soon as you can to get some arrangement for severing Literature and History. The sooner you begin the row the better. It is no use sitting down under it. Both camnot be taught together now without exhausting unduly the teacher and preventing him from advancing his subject. You will find Dill anxious, I have no doubt, to help in any reform such as this.

I have written this just as it comes to me, you will excuse the somewhat curt presentation. I am not wishing to dictate or even force advice, but I am just trying to put it all as briefly as I can, as I would do in talking. You will make allowances, I know, as you have done before, for my brusquerie.

I hope you will find the work pleasant and the students care for learning (some of them at least). Take care of yourself, don't trouble orer trifles, or think you are not doing enough for your students if you don't cram each particular one with sugared pap (such as he or she thinks she would like) with a patent bottle and monthpiece.

Do what you think best and nothing else. I am yours faithfully.

\section{To Mrs. F. S. Bocs.}

Bedford Park, April 15, 1901.

You will make your son an engineer if you are wise, and not a professor, though both are necessary. One knows too much and too little as a professor. But still one likes it. This is not grammar, but truth.

Set the child to learn Irish. It is a great thing to be bilingual in youth and helps one all one's life. Next to Irish, French is useful to an Englishman, who has to try and understand other people without changing himself.

Don't let your husband smother himself in lectures (as his too delicate conscience will make him do if you don't look out). One Kyd is worth a bundred lectures. Don't let him waste his time over pupils who ean teach themselves if they wish but find it easier to get others to teach then.

Powell now had and used a chance of speaking outside Oxford for one of the arrears of reform that he most desired to see redressed within it. On April 19 the Congress of the Societé Nationale des Professeurs de Frominas en Angleterve met at University College, Realling. Sir Richard Jebb, who was to have addressed the large 
audience, could not come, and Powell spoke in his stead. He chose for his subject the condition of modern language studies in Oxford. After touching on the commercial aspect, he dwelt at length on the scicntific.

Whatever has to be done with regard to giving the ordinar'y Englishman a sufficient writing and speaking knowledge of French, Spanish, Italian, German, and even Russian, the meeting of that need must be connected in the University with provision for the other-and what some might consider the higher-needs of those students who wish to be penetrated with the culture of other races and tongues than their own, and of those who purely from the student's point of view desire to be acquainted with the scientific structure of the varions languages of modem Europe. It is now some time ago that one of the most distinguished men Oxford produced in my time, and one of the men who were distinctly at the head of educational reform and progress when the advocates of those things were few and far between, and when those who did care something for progress and education limited themselves to the idea of examinations for prizes-an ideal which we have now more or less put behind us-it was then that the late Mark Pattison gave a very famous and beautiful address in which he pointed out the real need there is for Englishmen to acquire a knowledge of one or other of the neo-Latin tongues. He said, rightly, that there is in the Romance languages a large element present of form and logic, and that there are many characteristics interpenetrating their literatures which are absent in English literature. The knowledge of French is the best possible corrective for a person who has been brought up with only a knowledge of English history, poetry, art, and art theories. The beauties of the Romance languages, Pattison had pointed out, are those with which we are very little acquainted. Since hearing that appeal, I have laid it to heart, and have never tired of persuading those pupils of mine whom I think capable of doing something in the world of science, letter's and art to lose no opportunity of acquainting themselves with the literature, the art, and the culture of France.

Powell then reviewed the resources and hopes of Oxford for modern language study :-the single chair of Romance 
Languages, with its shortened funds; the raluable teaching and library at the Taylorian; the Union library also, with its sound tradition of buying foreign books; and the college libraries, some of which did the same. He told how the adrocates of change in their efforts to found an honour school of modern continental languages had once been 'beaten on the post', but were still striving to retrieve this defeat; a purpose achieved since Powell spoke.

If we can turn out five or six men and women each year, trained on the right road for criticism, we shall create a real public opinion sufficiently active to ensure that proper attention is paid to these important subjects. . . All we want is a simple decree of the University to admit men to that examination, which is now, euriously, confined to ladies. . . . Further, no University in the kinglom ought to admit a student until he or she has shown at the matriculation examination sufficient knowledge of some modern language (as well, certainly, as of some classical language) to enable them to read an ordinary book in that language.

All this may seem eurrent coin; but the older Universities do not yet insist on a modern tongue being presented at the entrance test. The meeting was in due sympathy, and passed strong resolutions in accordance.

Mayday, 1901, found him buoyant, writing to ask one friend for the poem of Little Liwa that uas smothered in the hay, and adorning a note to Mr. Wells with a picture in ink and chalks of a moon-dweller, founded on the description of the Selenites in The First Men in the Moom: a being with six insect-legs, the front ones brandishing a spear and a pipe, with a bullet-like stomach, hat-like ears, and eyes with projecting antenna processes; the moonherbage sprouting below.

I like the Moon-book. I an excited to know the end. Your books shorten the years unduly. I like the ant-like people and the blue streams and the twitterings. How is Jim [Pain the boatman]?

1 The report (in indirect speech) in The Reading Mercury, $\Lambda_{1}$ ril 27 , 1901, is not in the Scrap-book, but is a careful one and nay have been taken, by its look, from MS. 
A little later he is writing on a book of Scottish history to its author :

It is right to look on old relics with veneration, but the Union has been so good for both countries that it is folly to cry it down, I think.

Local independence is a noble thing, but it has its sad drawbacks, and personal freedom, letters, and progress generally have gained by local independence being partly sunk in a bigger empire.

The work done by Scots in India, New Zealand, Canada, Australia, and the Cape is fairly the result of opportunities given by the Union.

I like your book and am grateful for it. I learnt a lot from it.

But I am so convinced that historians have a duty to pure truth, that I shrink from any appearance of partiality and the colouring it gives; and so I write in warning, though I know you are trying to be as fair as possible: and, but for an occasional expression which gives the enemy occasion to blaspheme (though I am not the enemy), I think you are very fair.

You will not misunderstand : it is a danger I point out rather than any real fault I see.

\section{To Eric Maclagan.}

Christ Church, May 24, 1901.

When you went I made a monosyllabic sonnet. ${ }^{1}$ It isn't good (I think perhaps I could make another better, if it were really worth while), but it may amuse you as a curiosity. Yours very faithfully.

I enclose the book. ${ }^{2}$ It $i s$ clotted bosh-curious mixture of humbug and gush.

The child to whom the next letter is written will be found receiving a series of such communications next year during an illness.

Ch. Ch., Oxford, 30. 5. 01.

My dear Tim,- You will be able to read this now yourself. I could not get to see you last week as I was too busy. I hope to see you next week.

You will be glad to have your cousin with you. It is good to have some one to play with.

1 Printed vol. ii. p. 394. $\quad 2$ A bad novel. 
I hare seen sereral dogs and cats this week, collies, terriers, pugs, and Irish and Scoteh terriers, and fine black and yellow and grey cats.

How is your mother? Take eare of her.

I was not able to be at home for C.'s birthday. I hope she had a good day.

I hope the knife cuts now all right. I ground it down. It is very hot here still.

Though it rained last night the volunteers had a day's exereise yesterday and afterwards a dimer. They looked very well and marehed well. How is Mrs. Warren? Remember me to Jane. I am your friend, Jollyman.

In June, Powell went to Glasgow, among the representatives of Oxford at the Jubilee of the University, and there received the honorary degree of LL.D. It was the year of the Exhibition, and he was all the while amongst friends and pietures, the two things he liked best. A very distinct passing glimpse of him is given by a lady who was his fellow-guest. His state of mind in a gallery-' the other pietures did not seem to exist for him '-was his natural one at all times, anidst books and persons everywhere. His faculty of brushing away and ignoring 'the others' saved him much waste, left him freer to admire, freer to make the best of every good moment, Omar-fashion.

I remember nothing definite that he said; only an indelible impression remains of foree and geniality and inextinguishable laughter. One lived for two days in constant langhter, good humour, and pleasant exeitement. He sat opposite me at dimer the first evening, and I soon noticed that we all turned to him with our best stories: I suppose we halfunconsciously looked forwarl to his delightful laugh. Going upstairs I said to Miss _ -, 'Like Jupiter Ammon with a dish of Puck.

He and Miss — and I stole away from one of the functions to see the pictures. The Exhibition was particnlarly strong in French impressionist painters. He knew everything about pictures, my companion and I no more than other educated people, but the eomrtesy of his attitude of mind was perfect: you felt that we were three equal comrades, exploring a world new and delightful to

x. P. I

$\mathbf{Y}$ 
us all. He went straight for the things that belonged to him, the things he liked; the other pictures didn't seem to exist for him, he had no time to waste on disapproval or mockery. He was very anxious to show us the architectural work of Wilson-architectural, but really pictorial in colour and feeling. A head of Mrs. Norton by Etty interested him very much. Among the French pictures was one of some desert scene, all blacks and browns and tawnys:'delightful, smooth, and glossy,' he said, 'like the fell of a wild beast.'

About the same visit another who was present writes:

I was there, and I never saw him happier. It was a glorious time, splendid blue weather, Glasgow full of light and colour, clean-washed, with the Exhibition in the Park under the College hill, on the other side of the Kelvinlarge white showy buildings, and all sorts of faney houses dotted about the grounds; just the sort of careless thing that he enjoyed. The acartemic life was transfigured : you saw Doctors of Divinity, even, walking about in their glory, gowns and all, among the holiday people.

I think he was very glad to have the hon. degree : it was a sort of surprise to him. He was very unworldly, and it came to him as something fresh and delightful that people should want to honour and decorate him. I remember we travelled South together, and how happy he was looking at the country-Ben Lomond clear as we came out of Glasgow, and all the Clyde and Annandale country showing well.

\section{To Mrs. Marriott Watson. $\quad$ Christ Church, June 5, 1901.}

I promised I would tell you about $L$ 'Aiglon. ${ }^{1}$ Well, it's the most tedious stupid rubbishing play in the world, unredeemed and clotted rot. Sarah played like a team of blood-horses with all her might. Coquelin did his best with an absurd part.

It lasterl, and one could not go till it was over, one was fixed to see it out: but the folly of the rot, worse if possible than Hugo's rubbish: 'mon père'-' nos gloires'-'la France'-' la garde '- 'vieux grognard,' \&c., \&c., \&c.

Sarah screamed and cooed and whispered and yelled, and shouted and measured the whole gamut, toute la lyre; but it is impossible to make it seem for one moment a good play. I thanked God publiely that I was an Englishman 1 By M. E. Rostand. 
and not as those — furriners, who could listen with pleasure to such immeasurable absurdity.

I was very glad I saw it and saw it well. Sarah was really wonderful. She positively skipped in one bit and really looked a young thing.

She was nobly welcomed, but it was meant for her, not for the piece.

To W. P. Ker.

Bedford Park, June 30, 1901.

I can tell your feelings at getting back in June, when Scotland is very fair. I get it when I escape to the sea in certain places, and I begin to understand what the Swiss soldiers used to die of when they could not get back to their own homesteads and smell the upland air and the smoke and the cow-byres.

I sometimes look forward now to the dream of a bungalow near the sea. But who knows where his marai shall be? [i.e. marcte, Mangaian for 'sacred grove, memorial burying-place'.]. . .

\section{To Oliver Elton.}

Bedford Park, July 12, 1901.

I meant to tell you of a poet, who has written well and elegantly, with a distinction and delicacy rather rare: Holmes, Silence of Love, John Lane, London.

It is distinctly good.

Let me have your mind on it when you have read it.

Then to-day I came on another, whom perhaps you know. I had only seen some lines quoted, but I got the volume given me to-day.

Lefroy : Life and Poems: ed. by Gill : John Lane, London. He is a kind of clerical J. A. Symonds by nature: heart weak and condemmed to death; he bore it bravely ; cleric malgré lni, but faithfully and without tergiversation of mind or body. Born a pagan, of three generations of parsons of a Huguenot family. A Keble man with 0 of Keble about him. Broad Church of Robertson of Brighton type ; musenlar Christianity ; a worshipper, in reality, of plastic beauty in motion. He would have understood half of Rodin: a curious study. He did not know his real position, tho' he reveals it in his somets. Some of them are excellent (as simple as Blunt's, but they have not the aristocratic touch of Blumt's, which has a beautiful flavour of its own, with its sensitive pride and self-study, of a more primitive and healthier kind). Lefroy's Greek things are 
as good as Hérédia, in a lower, quieter, Theocritean, Anthologic key. I think you will like one or two really.

I can't settle down to work yet. There are a lot of fagends I am doing. I shall feel it imperative soon, I know, meantime I am doing tiny duties.

Jack [B. Yeats] gave me two beautiful stencils to-day: they are very good: the 'metal man' in the channel at Sligo, pointing out the 'fairway' for ships, an iron figure of a sailor painted like a figurehead. It is charmingly felt and given.

Bomnier, most excellent, sent me a gorgeous piece of orange Japanese stuff, a precious joy.

... It is the end of -'s philosophy to be happy and make others happy; not a bad one, and better at all events than the Jewish and Christian gibberish about God and Israel and true Churches, though I suppose if the communion of saints ever meant anything, it must mean that.

People as often astonish me by their goodness as by their badness, tho' some badness is so hateful, it destroys all possible desire to look at it any longer, and one wants the broom of fire to sweep it alive into the pit.

Poor Bob! I know he's at peace, but I wish he were here, well and happy, but I should be listening to him tonight instead of writing as I ought to you.

\section{To F. P. Barnard. $\quad$ Bedford Park, July 13, 1901.}

I went to a boxing tournament yesterday at Wonderland, Whitechapel. Some very good boxing indeed, well-conducted and orderly. Any amount of cleverness and pluck. The round-arm swings and hooks are not so pretty as the old straight left, but the upper cuts are beautiful and the counters as quick and good as ever. Fine lads, with good faces, nearly all; some very well made, some spidery, some too short in the arm, but useful in short punches. Most of them well made; good back and shoulders nearly all. Yon must go some Saturday when you go to town, and sit with the bookies, and hear their improving conversation before the show begins.

This year was friendlier than 1900 . He came to Liverpool in the spring and saw many of his friends. He paid a visit to Mr. Wilfrid Blunt, in the New Forest. The holiday at Ambleteuse was full of sun and talk and sketching: and so the summer went. 
I am very lazy, sleeping a good deal. . . . I have read the Shakespeare sonnets through again, and I am sure it is Pembroke and Mary Fitton. ... The food is quite fair, the weather divine, the company fair, and the wine rery passable. So we ought to be happy, and most of us are.

\section{To Oliver Elton.}

Ambleteuse, Sept. 12, 1901.

We are here for about ten days more, I suppose, if the weather holds as we hope it may. It is exquisite here. I grudge hours indoors, but must do some work. I have gone on with my sketchings. They are mere attempts at transcription of the real, through fairly-trained eyes but with an untrained hand.

Another glimpse of Powell at Ambleteuse will be appreciated. Mr. J. A. Twemlow, a scholar working for the Record Office in the mediaeval archives of the Vatican, had made his acquaintance ten years before while studying history at Christ Church, and had been encouraged by Powell in his eareer. With him he had seen Verlaine in his Paris lodging in 1894. The following happy reminiscence of a flying visit to Ambleteuse in 1901 is contributed by Mrs. Twemlow :

Une seule fois j'ai vu le professeur York Powell, et cette occasion reste gravée dans ma mémoire. J'avais fait déjà deux voyages de Rome en Angleter're sans le rencontrer. La troisième fois encore, en 1901, j'ai appris qu'il n'était ni à Oxford ni ì Londres. Il allait done me fuir pour tonjours, ce vieil ami de mon mari! La destinée m’a épargné cette nouvelle cléception. Le professeur nous a écrit qu'il était en France, à Ambletense, et que si nous passions par Boulogne il serait hemrenx de nons recevoir. Qui fut dit, fut fait: nous sommes arrivés tard i $\Lambda$ mbleteuse, vers dix heures du soir. De l'antichambre de l'auberge nons pouvions entrevoir la salle-it-manger anx tables desservies. Mes yeux se sont fixés sur un monsieur qui était assis ì la tête d'une longue table, et dont la personnalité dominait les autres. Grand, fort, noir, sil cascquette et son costume de marin, tont en bleu foncé, donnaient a cet homme, un des plus beaux que j'ai jamais vus, un 
aspect de capitaine de navire. Pendant que je me demandais à laquelle des deux marines, anglaise ou française, appartenait cet officier-'C'est lui,' me dit à voix basse mon mari, en suivant mes yeux. Je n'oublierai jamais mon étomnement. Je ne pouvais pas croire que ce marin était le professeur York Powell. J'en avais tant entendu parler, et j'y arais si souvent pensé, que j’avais fini par m'en faire un portrait bien loin de la réalité. Je ne sais pourquoi je mattendais à voir un homme maigre, raide, sévère, au longs cheveux, à la barbe grise! Je n'ai guère eu le temps de revenir de ma surprise qu'on nous a déjà annoncés. Vivement le professeur s'est levé, en s'avançant vers nous, les bras ouverts, comme pour nous envelopper. 'Vous êtes vraiment gentils,' a-t-il dit d'un français le plus pur, et aree l'aise et l'affabilité d'un homme du monde-'c'est très gentil d'être venus jusqu'ici pour me voir. C'est charmant. C'est lì la petite?' en soulevant dans ses bras ma Madeleine de quatre ans pour l'embrasser. 'Ma fille s'est retirée dans sa chambre, mais vous la verrez demain matin. T., allez conduire Madame à sa chambre, elle doit être fatiguée. Descendez ensuite, et nous boirons quelque chose ensemble.'

Le lendemain matin il a fait servir notre eafé-au-lait dans le jardin de l'hôtel, et c'est là qu'il à présenté sa fille. Aussitôt notre déjeuner fini, le professeur nous a proposé un tour sur la plage, où il m’a montré malicieusement une tour d'où Napoléon $I^{\text {er }}$ visait la lointaine proie qui ne lui était pas destinée. Tout en nous parlant, il n'oubliait pas Madeleine, dont il remplissait les mains et les poches de cailloux et de coquillages.

Le moment du départ arrive. Mon mari vent offrir quelque chose à la bonne vieille de l'hôtel qui nous aide à monter dans la diligence. 'Mais oui,' dit-il, avec sa franchise si naïve, 'mais oui, vous pouvez lui donner quelque chose. Donnez-lui vingt sous. C'est mne bonne vieille, il y a longtemps que je la connais, je l'aime beaucoup.' Nous partons, et il reste à la porte de l'auberge, droit sur la route ensoleillée, en saluant toujours avec sa casquette bleu foncé de marin, jusqu'à ce qu'il ne pût nous voir. C'est là que je l'ai vu pour la dernière fois, et que je le verrai toujours.

All this pleasure refreshed his powers; his hold on life strengthened, and his passion for seizing the golden moment 
and finding words for its special quality. He uses more and more often his favourite medium for its record, the dashed-off portrait of eharacter, of which so many examples come in his historical and other reviews. The date is too recent for many of these to be quoted from the letters. $\mathrm{He}$ is always perfectly faithful to his feelings, only concerned to express them, and they are always unexpected. There is astonishing tolerance and indulgence: there is aquafortis, more than ever, in mexpected places. We have again the sense of a high, melancholy mind, working upon its intense joy in the play and surface of life, and solving its discord of impressions by a saving humour.

The reader, here as elsewhere, can estimate for himself whether mine is a true analysis of Powell, who this year printed the quintessence of his wisdom of life, his confession of faith, his religion, in his Note on Omar. In 1897 he had published twenty-four translated quatrains in The Pageant. They were 'impudently misprinted', he says, 'by a pirate in the United States, where the laws as yet permit such dishonest and uncivil dealings'. The exercise remained a favourite one: from his papers have been saved some more stanzas on the same model, and his private and familiar thoughts ran often into it. He knew, I am told, some Persian, but he worked closely from the French prose version of M. Nicolas and the English one of Mr. McCarthy. It is fair to say that some of the best of these experiments, which are all in FitzGerald's measure, might have been from the hand of the founder. But the new thing is Powell's Note. From purely internal signs, and perhaps questionably, he tries to trace the presence of two distinct authors, two souls, in the extant epigrams of Omar.

One can hardly imagine the agony of earnest piety, that undoubtedly at times thrilled Verlaine, and the impudent, cruel gaminerie, that Villon often gives way to, co-cxisting in the same man with the calm science, deep humour, and kindly tolerance of Shakespeare and Rabelais. 
If there are notes of recklessness and also of religious intensity in Shakespeare's Sonnets that make us hesitate thus to discriminate the Omar poems, at least such a theory brings out the whole range of their emotion. It is the Rabelaisian and Shakespearean Omar that Powell loves best: he reads into him, one may say, or draws out of him, his own creed of noble epicureanism, which does justice to the gifts of the world and of the spirit alike.

He was alive to Opportunity. To-day, if ye will hear his voice, to-day! Will not the future be the better and richer for the memories of past pleasure? So surely must the sane man feel.

Such was Powell's own natural instinct, which in these his later years became a conscious and deliberate one; and now, at the height of his life and power of enjoyment, he gave it phrase. He was not long to follow it in his temperate, often childlike way, without a struggle. It was to stand by him when submitted to the sharpest and clearest test, that of the physical illness which soon was to come upon him: and it will appear that under such a test his pleasure in colour and landscape and flowers, like his pleasure in friendship and in doing good, were only confirmed, and that they held till the last, when the 'citadel of life yielded'. As he says of Omar :

He was born free, he was too healthy to permit the eternal verities to crush him into wanhope and gloom.

Severai of his letters after his return are on literature. In his judgements he was unaftlicted by authority or by the curious batterer standards of reviews and handbooks. Few men were surer that the wisdom of tout le momele, if it be worth hearing on some counts, is folly in the field of art and letters. But he had nothing of the esoteric ; he did not believe in a contracted caste of refined judges with himself as pope. He often found out little obscure writers, and wonld write on them again and again till he had drawn an expression of opinion. His friends smiled 
at his indulgences, even at his indulgence to themselves; and it seemed that he sometimes admired things not worth notice, while he would be blind to the saving or mitigating elements in an overestimated favourite. Thus his likings and aversions struck capriciously on the ear. The letters will prove this to each reader, according to personal taste. He cared least of all for the mid-Victorian celebrities, whose vogue had been high during his own youth : Tennyson, Browning, Matthew Arnold as a critic, and George Eliot. Ruskin was the chief exeeption that he made. But in all this he followed his inmost sensations, and wrote without desire for paradox. It has to be added that often he was right; he divined a quiet unregarded talent, whether of his own time or of an earlier century. He tried hard to be just. One of the following letters was written after he had received a lecture on Tennyson, which was in part a piece of iconoclasm. He shared the mean opinion expressed in it of Tennyson's ideas and thinking capacity: and this he greeted in his letter with a shout of pleasure. But he loved the real Tennyson, and walking by the Thames at Strand-on-the-Green or Chiswick, would exclaim, 'There, Tennyson could have got that!', as he watched the water.

\section{To Oliver Elton. Christ Churcl, Nov. 30, 1901.}

T. Hardy has just brought out a new volume of really exquisite verse. Do try and review it. There are metrical effects there both new and beautiful. I am enchanted both with the style and matter, both extraordinarily sincere. It seems to me a big book.

$\Lambda$ gain, have you read E. Ilolines, Silence of Love? It is a sonnet-sequence, classic and clear-cut with some lovely groups of lines, delicate and quiet and full of grace. This too is a notable book.

\section{To Oliver Elton.}

Bedforl Park, Dec. 1901.

I should like to see Browning carefully considered, because I think I am unjust to him sometimes, and that there must be something I don't see in him that makes 
people care so much for him, people I mean who have some sanity. Tennyson I was always just to: his jewels of landscape and dream-thought always ravished me from a boy till now. Browning I could not away with, and I read him with heavy groans when I was thirty, first completely; The Ring and the Book (Pope and girl and villain only); the few bits 'mad and bad and glad', and stray lines like bits of burnished silver shining out of a dark tarnished muddle of metal. Swinburne has not the joie de vivre: he lives in an afternoon, looking on a far-off sea. There is nothing of the morning about him. But his metrical power (though it rarely, very rarely, touches the intimate note that thrills us in Vergil, Tennyson, Sappho, and Verlaine) is excellent in its clangour and long notes. . . . That last comparison of yours - there is real pathos in it. There are few things so pathetic as old gardens: they make one's soul quiver at times. There is a pathos as of human things suffering and appealing, by a look and a moan; no voice, no cry.

To J. B. Yeats.

Bedford Park, Dee. 17, 1901.

... Do they know in Dublin who Fiona Macleod is? She, or he, las done some few beautiful things. Hardy has a fine lot of verse just out, beautiful metrically as well as in content. He rhymed much young and burnt much. I think he has poetry in his soul of a curious particular kind.

\section{To J. B. Yeats.}

[End of 1901.]

Matthew Arnold was a poet at times; he never knew his business as a critic; he was a mere journalist, scrambling through by mother-wit; and that is why the journalist adores him, as he does Froude, who leapt at views nearly always rightly (when he had no prejudices) but supported them when attained by cheap rhetoric and fictitious arguments and forged docmments . . . but the journalist thinks him a great historian and a noble man of letters, whereas he is a very clever and keen-sighted journalist. I daresay $\mathrm{D}$ - won't agree with this, but it is borne in upon me more and more, and I struggled hard to really put the man in his proper place. He wasn't altogether a bad man (which I never could get Freeman to understand), but he was unable to back properly, or would not take the trouble 
to back properly, theories that were mostly right. (Of course I am only talking about English theories, and I leave out the Irish question : I am not trying to steal a march upon your.)

The infant is away, and I am rather flattened out by work I am struggling with: but Johnstone came yesterday, and he talked with me about music and artists and the game of life and art and the things one likes to talk about.

Many other letters now follow written to Mr. J. B. Yeats, the Irish artist, whose house Powell much frequented, usually at midnight, in Bedford Park. Mr. Yeats had mored to Dublin, and the letters continue their evening colloquies, and so in a measure their common life. Mr. G. Pollexfen, the brother-in-law of Mr. Yeats, had received the necessary details for the casting of Powell's horoscope, without his name. The acknowledgement of two years later can be placed here.

To J. B. Yeats.

Bedford Park, Jan. 5, 1902.

I was born at about 10 a.m. 14th Jan ${ }^{y} .1850$ at 43 Woburn Place, Bloomsbury, London. So if you like to tr'y Geo. Pollexfen with a horoscope these are the details. I will tell you whether he guesses right or no about my life. ...

My little Japanese man, the tempter you have seen, gave me a Kaliemono, a langing picture, of carp in a stream with willow and wisteria and a yellow flower overhanging them, and petals of the yellow flower dropping into the stream and deceiving the hungry fish. I liave been reading Kolioro, Lafeadio Hearn's book. It is a book you would like....

Did yon see that brave thing of the woman Mrs. Elizabeth Coghlam, who eaught fire, and ran out for fear of setting fire to the room where children were sleeping (she was of course burnt to death). 'That is heroism pure and simple, and what a elear head at such a time! By God, these things show the way man is rising, and there's no damned idealism about it all. "Why ever' did you run out?' 'I did not want the children to be burnt.' 'There's a New Year's glory to think of, a new saint and martyr. 
I must acknowledge your cousin's [sic] interpretation of my horoscope is extraordinary by the coincidences-

$$
\begin{gathered}
\text { to name only a } \\
\text { few }
\end{gathered}\left\{\begin{array}{l}
\text { one girl child. } \\
\text { early marriage. } \\
\text { heart disease. } \\
\text { employment. } \\
\text { friends faithful. } \\
\text { dark hair and complexion. } \\
\text { jovial disposition. }
\end{array}\right.
$$

You said I should be astonished. I am.

As to the - I don't say they are not efficient in their way. I don't deny their usefulness. I simply say they are profoundly uninteresting, which you would not deny yourself in cold blood. They are a kind of white Chinese.

If by idealism you mean aesthetic feelings, there are few people who have so little of it (as a rule) as Irish Protestants: and I think you will find that sceve in the motter of acting very few Irish Catholics have ever been distinguished for it, since the 13th century.

But believing in things that do not, never have, and never will exist, is inculcated by the R. C. Church, and this cammot result in anything good. Yon can't build on lies.... A people that prefers lies to truth cannot do good, in so far as they do so. You know that as well as I do. If you prefer the pope and a set of ignorant and bigoted priests to the chmsy (often stupid) but honest and right-willing govermment you have: if you prefer all the foulness of celibacy, all the ignorantism, all the mendacity and dishonesty, that has half-killed Spain and Italy, then turn Catholic and go the whole hog: that's the root of the matter. Yon know well that ont of the Garrison has come every Irishman that has done anything of note (save O'Donovan and O'Curry and probably Hyde). Priests caring for education! What they want is places to be able to give their own degrees [from], and then boycott all other degrees, and oust every protestant from every teaching or local government appointment. P'riests desiring knowledge!!! 'The 'ten commandments!' Why, you don't believe half of them yourself. What have you to do with a Jewish religion? It was a pity that girl found Moses at all. 
In Amicum F. P. Ursidurum.

Salutationes nunc novennales scribo,

Nam in Winandermeram non confestim ibo ;

Me domi laborantem retinent negotia, Quum mihi potiora sint cum amicis otia ; Potins mihi fuerit sciurum ${ }^{1}$ observare,

Vel tecum colloquium tenere hilare,

Ergo non iratum te in me monstrare debes;

Indulgentiam laudat en Tabulator Cebes!

Scribebam Povillus F. Eboracensis vir obscurus.

One day in December he went to Eton.

\section{To Perey Addleshaw.}

Christ Church, Dee. 11, 1901.

The queerest old-fashioned old-world sort of place, very picturesque and comic and homely, no swagger at all-tin cans in College for beer, and plain food at House dimner.

I was disarmed of my old Rugby prejudices, and charmed by the boys and masters, and glad too, for I am sure it is not rotten, whatever it is.

The castle is much grander than I thought, and more 'castly' than I supposed. I only saw the outside. We must go and see it together one day.

\section{To Ladly Young.}

Bedford Park, Jan. 10, 1902.

I haven't much news for you, I'm afraid. I have been to Richmond this afternoon. The river was all misty, and the trees, and when it got darker the sky was pale violet, and all the lamps tiny points of yellow in the grey soft wool of the mist. It was very pretty, and the air soft, and the gromd smelling autmmny rather than wintry. I missed the friends I went to see, but I was quite happy with my walk from lichmond to Twickenham. The river is very high, nearly up to the towpath. ...

I go back soon to Oxford and the grinding of the mill. It is pleasant work, but one always hungers for results, and results come so slowly.

There are some nice fellows there, when one gets the chance of 'getting at' them. The time goes quickly there: one's day is so full, the evening comes, and one seems to

1 Mr. Barnard notes: "Thero were a number of squirrels in our wood at Windermere, which he was fond of watching.' 
have done nothing; and I suppose it will be so when the last evening comes. It is the law.

The house at Eton, I hope, has turned out well. The view from the first-floor front was very pretty; the tiny garden opposite, and the dark trees, and the fumny old street, with the boys like white collared ants, with beautiful faces, all swarming to and fro. I shall not forget the first view of Eton, and am yours gratefully.

Mr. G. Winthrop Young, the son of Lady Young, comments on this Eton day, and completes the picture.

The visit referred to in this letter remains with me as the most vivid impression I have of Mr. York Powell's singularly fascinating personality. His sympathy for the general atmosphere of Eton was only equalled by his interest in all the details of the starting of a new house and a new work. The arrangement of the books suggested several anecdotes illustrative of his difficulty in finding a house solid enough to 'carry' his own library. 'That is probably one of your best books,' he said, pulling out an early edition of Montaigne,-' one of the best books, andit really belongs to me!' He pointed to the name on the flyleaf: 'An ancestor of mine, who dispersed much good literature, some of which I have recovered.' This led on to a brilliant talk upon French literature, more especially of the modern poetic school, with whose aims he seemed peculiarly in sympathy. I have still a reminder of this conversation in a small volume of recent verse, which arrived a few days later, endorsed with his marvellous 'face' signature. A stroll through the College buildings and the sunlit playing-fields turned the current of talk into the comparative value of athletics, ranging from diskthrowing to diving. To refute my heretical contention that fencing was a finer exercise than boxing, a small passing Oppidan was enlisted for purposes of illustration,- to the huge delight of both. 'The small boy, in 'change', sparring half seriously with the burly professor, his high hat well back on his head and his eyes twinkling with fum, made a delightful picture. As he left the school yard he stopped:- 'It is all a wonderful engine for impressions, but it is like a child; it seems not to know what it is effecting ; it is playing with its power.' Looking back at the playing-fields he added-'but it is playing beautifully!' 
Bedford Parls, March 2i, 1902.

I am working half the day, and fooling about the other half with friends; rather jolly while it lasts, but work looms ahead, enormous, like a monster of the deep, or an iceberg of appalling height and depth and weight and chill.

It has to be collared somehow.

I have some things to send Frank, a noble seal inter alia. ${ }^{1}$ If you would but come up you could bring them to him. I am afraid of the post.

The spring is slowly forcing its way out, with gusty showers and gleams of light.

I must stop now, tho' the devil with the left green eyc ${ }^{2}$ is luring me on to write instead of working.

I have just ordered a lovely glass ball, perfectly turned. I have a passion for them. I have longed for years for one and now I hope to have it. I got one imperfectly turned, with a flat place to stand on, $2 / 6$ the other day ; but that was only a makeshift, though it looks pretty. I am going to stop now. How does your painting go on?

In April, after seeing his friends in Liverpool, Powell visited Ireland. His interest in her fortunes and hopes had not failed. For the political movement his feeling was compounded of good wishes and detachment. His enthusiasm for Home Rule, if it had never been dropped, had at times been at a stand. He felt he did not know enough of the country at first hand to form a doctrine. Probably the attitude of the Nationalists during the Boer war had given him pause. His letters reflect his open, somewhat waiting attitude; but the trip in Ireland was to revive his confidence. We have seen his ardour for Irish lore and letters. Besides, he had come, as he judged, upon traces of an ignored and unwritten chapter of "Irish influence on English Literature', and now went to Dublin to give an outline of his conclusions before the lrish Literary Society. The evidence he had gathered has

I Great seal of Queen Elizabeth, given by l'owell to Mr. Iarnard, tho brother-in-law of his correspondent.

2 Favourito silver ring worn by Powell, shaped as devil's hear, witl right eye a ruby, and left eye an emerald. This demon and his moods were a frequent subject of remark. 
unluckily not been saved; but he believed he had discovered the mark of certain Irish metrical forms and other elements in the English popular song of the sixteenth, seventeenth, and eighteenth centuries. The inquiry still awaits a bilingual scholar. As so often, Powell, instead of writing or speaking a reasoned monograph, pointed out an unsuspected path of inquiry. He also found that the general play of the Irish genius on English letters had been understated, or rather hardly stated at all. He pointed to the throng of Irish-born translators like Cary and FitzGerald, to the work of Irishmen in such fields as English extravaganza and burlesque, and to the impress left by Irish writers upon English fiction. His sketch has been partly saved, and can be read below. ${ }^{1}$

The lecture was given on April 7, in the quarters of the Irish Literary Society in St. Stephen's Green. 'It went all right,' he wrote, 'and pleased.' The report shows it was much acclaimed : it was 'a pleasant surprise', according to one speaker, Count Plunket: 'the sympathy with our ideas and idcals showed a bond of blood' between lecturer and audience. Powell was perhaps the chief English scholar who had heeded and warmly welcomed the new literary life of Ireland. Well pleased, he started on a journey, of which there is happily a vivid clironicle from the pen of Mrs. J. R. Green.

After his lecture in Dublin Mr. Powell and one or two other guests spent three days in Meath with Mr. James MeCann, a leading stockbroker in Dublin and Chairman of the Grand Canal Co., who was just then beginning, in the last three years of his life, to develop his sehemes for bringing back life to the waste lands of Ireland. He arranged one of those delightful excursions for which he had a real genius. We went by train from Dublin to Drogheda, drove to Monasterboice, were towed on a barge along the Boyne canal to Navan (a voyage in which Mr. Powell enjoyed the inventive hospitality of Mrs. McCann with the utmost admiration), spent the

${ }^{1}$ Vol. ii. pp. 297-301. 
night at Teltown, and drove the next day to Kells and St. Kieran's Holy Well.

I think that Mr. York Powell enjoyed these days as thoroughly as he had ever enjoyed anything in his life. He commended himself to every one by his characteristic sympathy with every side of the life that was going on. He was as much interested in visiting the polo ponies with the young men, as in inspecting the ruins, or watching the various industrial schemes of Mr. McCann for the development of the town of Navan and the agriculture of Teltown, where some of the finest land in the world was being broken up for tillage for the first time in the memory of man. As we walked about Navan, Mr. McCann would show how the grass grew up to the very walls of the houses, while the shops were full of potatoes from Holland, butter from New Zealand, bacon from America, vegetables from Belgium-not an Irish product to be found anywhere, and the men standing hopeless and hungry along the walls. He had devoted himself to a heroic effort to alter this state of things, by dividing plots for tillage, forming a bacon factory, and timber works, and building boats to carry away the produce on a canal which had long been absolutely vacant. Mr. York Powell was presently immersed in these schemes. No better opportunity could have been imagined for seeing at once the versatility of his sympathy and the range of his knowledge, for here everything was fresh, and his mind was ready to welcome every impression from the new surroundings. His remarkable faculty of learning was admirably shown in these few days. Among other things his mind was opened to the new political impressions. He had always shown a certain colduess or even irritation as to Irish aspirations and ideas, which in a mind so sympathetic as his could only be due to want of immediate contact with the people of the country. But under the influence of these days the whole of this prejudice disappeared as he listened frankly to everything around him. I remember his telling me after this tour that he was satisfied the remedy for Irish ills would be to give the land independence, with Mr. McCann in authority to carry out his schemes - canal transit, new tillage, stopping of emigration, the planting of people on the good lands, and the preservation of their ancient monuments! He became in fact an 'Irish Irelander'. 
It is impossible to say which scenes interested him most. On the drive from Drogheda to Monasterboice he was especially delighted with the car-driver's description of a man who was always known as Pope —-, because he had gone to join the Pope's forces in Italy for a time, 'and indeed he had a face like a Pope on him, so that whatever he said you could never know what he would be thinking.' By the roadside we passed a little thatched cottage, which was a sort of wayside public-house: and there the driver told us how Lord used to get off the car as he was being driven home from Drogheda, and go in for his refreshment; 'and so', said the driver, 'he would get sitting on the hob, and when he came out what with the black and what with the drink I would not know him, and I would just tie him on the car and take him home-a dacent little man indeed he always was.' It was supposed that the Plan of Campaign would be successful on the estate of this gentleman, and it was started vigorously and would have done well, said the driver, but for Lady — , whose father died at the height of the strife, leaving her $£ 60,000$; which, being a very resolute lady, she determined to spend on subduing the tenants. She therefore got a battering-ram and thought she would like to see it at work, so she had it brought up to the castle yard. 'Well,' said the driver, 'we just gave one tap with it on the stable wall to show her ladyship how it wonld work, and I give you my word she had to pay $\& 500$ for that stable : it knocked the roof off it.' The tenants were finally evicted and new men brought in from across the Ulster border, who, however, never prospered in that ruin that had been made, though all rents were remitted to one after another in turn. "How could they be a good sort when they would come in like that?' said a very poor old woman who, under the Round Tower and the ancient Crosses, was praying in the churchyard as her people before her had prayed for 1,500 years.

As we drove from Monasterboice to the site of the battle of the Boyne, he remembered that the great Irish conflicts from the time of Cuchullin had been fought on that famous dividing line of the river Boyne. We passed by the majestic burial-places of the kings, and the famous castles overhanging the river: at one of the locks we asked a poor old woman what was the castle on the top of the hill close by. 'I do not know,' she said, 'there do 
be coming strangers from England that take photographs of that ruin and the waterfall, things the aborrigines would never think of looking at.' His enthusiasm was perhaps greatest at the great Rath of Navan, where he recalled all the story of Deirdre, to the delight of his hearers.

The night was spent at Teltown, and we saw the next morning the famous raths and burial-mounds there, the unique mound where the king used to sit while the lower ground below it was flooded with water for some kind of naval games, the old church of St. Patrick, and a Norman Castle; and heard the mysterious legends of the people. He was much interested in the story of the white owls and white hares that haunted the fields of Teltown, and the tale of a boy who inadvertently trying to shoot one had fallen senseless for hours. Also the story told by the old lady in a cottage under the shadow of a Norman castle by the Blackwater, who in her youth lad lived in the Castle itself till it became too ruinous, and had constantly heard the steps of the spirits, the 'poor souls without a settlement' from the cruel Norman days, that haunted it, and many a time blew out her candle: 'Don't mind them,' her father used to say: "they will do you no harm if you take no notice.' At Donoghpatrick, the site of a church of St. Patrick on the Blackwater, he observed that the 'Rath' given by the Irish king to St. Patrick was of the older oblong form, while the new Rath built hard by at 'leltown was circular, and suggested that the king had probably decided to make for himself a fortification of the newest fashion and had given the antiquated one to the saint. On the visit to St. Kieran's Well he immediately noticed the forms of the pins which held the seraps of rag to the tree, and detected some which he judged to be a hundred and fifty years old, and others of about seventy years.

On our return to Dublin John O'Leary joined us at dinner. Mr. Powell spoke to me on the last day of his life about this journey in Ireland and the dimner at the Shelburne, saying that after John O'Leary had left, a comntry squire-evidently a sportsman-had come to ask who the very distinguished man at table was, so greatly had he been struck by Mr. O'Leary's presence; an incident which Mr. York Powell mentioned as a quite extraordinary tribute, seeing the kind of stranger from whom it canc, to the effect produced by Mr. O'Leary. Mr. Powell added that 
he himself had never seen a man of such distinction of appearance, and that his mind was perfectly suited to it. 'He has a mind like that of a child,' he said, ' which every now and then strikes down deeper to the very heart of things than any mere intelligence can do.'

I spent some hours with Mr. Powell on the last two days of his life. He spoke of a number of his friends, among them Professor Ker and Dr. Kmno Meyer, and in every case with an appreciation and an affection that is now delightful to remember.

I have only known two men who had Mr. York Powell's range of sympathy. There was nothing, however different from his own tastes and pursuits, which was sincere and good of its kind, that he did not value and commend. The loss of such a friend is the greatest loss that could happen to those that knew him.

\section{To his Daughter. $\quad$ Standard Hotel, Dublin, April 11,1902.}

I have been having a beautiful time too. Well, I had a delightful journey over and got here in a fine sunrise. Then I gave my lecture and did all right. On Sunday I went out to Howth with Yeats to see some people called Hart, and dined there: they were nice and kind. I saw some N. Zealand flax growing there : it is like aloeplant; and some funny woolly-headed palm-like trees, also from N. Zealand, and a beautiful collection of heaths. Then on Tuesday early off to Drogheda by train; then to Monasterboice, to see a round tower, and some most beautifully earved crosses, very old, and two old churches, more than a thousand years old ; and a most amusing carman we have, telling stories of Collier, the robber, and his imp. By car to the river Boyne; up the Boyne to Navan in a barge; a lovely river, more beautiful than the Thames above London even. Then to Teltown by car.

Then, next day, walking about to see old camps and a castle, and an old chureh, and some fine cattle, and some young horses: and in the afternoon to Kells; and there was Columba's stone house, and a round tower, and many crosses of fine old Irish work, and some curious old gravestones: and then to St. Cieran's well, where we drank water and ate cresses. It is a lucky well, with a huge arch standing over it, and it has fine water, and the people who go there to be cured bathe and drink, and then put a bit 
of their clothes, and fasten it by a pin to a tree, and as it decays the illness dies away. Then we went to an old churchyard, where there were more crosses of the Old Irish, and an Ogham stone - a stone with the old writing on its edges: the first found in County Meath, only a twelvemonth ago. It was probably fourteen or thirteen centuries old. Then home to Teltown. Next day, off to Tara, where we lunched; then to Trim to see the castle, and thence caught the train to Dublin.

\section{To Mrs. Marriott Watson.}

Donabate, Co. Dublin, April 12, 1902.

This is a beautiful country. You have no idea how charming, and the people have "shown me no small kindness'. I have seen a river twice as lovely as the middle Thames-the Boyne. I have seen the three great royal palaces of Old Ireland-Navan Fort (where the Deirdre Tragedy took place), Teltown and Tara. I have seen Kells, Monasterboice, St. Cieran's, a holy well, with rags pinned to the old, ash above it, and the great mound that the God Angus Og lives in at Dowth, and the Hill of Howth, and lots of 'raths', old forts and churches, and a newly-found Ogham stone found in a grave dug for a 'peeler'.

The policemen are splendid here. It is a pleasure to see them.

The horses are fine.

The cabins are like French cottages.

The grass is like the grass in a park.

The air very full of light.

The cattle fine and the sheep too.

The people are delightful to talk to (entirely irrational on all questions as a rule); there are a lot of really able men here, and some very pretty women. I think you would like it. I am sure you would have liked going up the Boyne on a barge, with seenery twice as fine as any between Oxford and Chiswick, mile after mile, in perfect peace, no tourists, nothing to disturb the quiet, smilingfaintly, gentle, soft-coloured scenery.

The place where K. Cormac is buried at Rossnaree is a fine headland over the river : but I will stop, the post is going. I am yours always sincerely.

Powell returned to Liverpool by boat from Dublin, arriving in the early hours of a fine spring morning. He drove 
up from the landing-stage, but would not disturb a sleeping house. He took the cab to a small and clean tavern, where the cabman accepted rum ; and was found encamped, reading, on his baggage, in the garden of his host, when the working day awoke.

The early part of the next letter refers to the article ${ }^{1}$ he had written on J. R. Green for the Quarterly Review. It had cost him much consideration, as his words show.

\section{To Mrs. J. R. Green.}

Bedford Park, April 21, 1902.

I was delighted to get your letter. The only thing that troubled me was whether you would think it an accurate and adequate presentment. Stephen's book ${ }^{2}$ is so good, that (with the papers you sent me) I could get at a portrait, but I was afraid, though I might get the outlines, I might have missed the expression. I am glad I have been able to do better than I thought I should.

It is very difficult also to make anything living out of the conditions I had to work in. One hour with him, and I could have put in some touches that would have appealed to those that knew him better than anything I have done.

You could have done it much better than I could. You write better, and you know the subject best of all. . . .

I only took the matter up for two reasons: one, I wanted to give my poor testimony to Green; two, I wanted to do whatever I could, as I knew you wished me to try it. ...

I must thauk you also for those busy pleasant days with McCann, who is the most practical man I saw in Ireland, and certainly one of the kindest and most hospitable. I wish he were governing the country. He is a man to be trusted, I think.

I can't form any theory about Ireland, but it is certainly very foreign in many aspects. It does not seem to me dead at all, in spite of the drugging of the Catholic Faith, but very much alive in many ways. There is plenty of hope, too, much faith, and a sort of one-sided charity that is a peculiarity. Hospitality is nobly carried out, and kindness in ordinary life very great and noticeable. I can't judye at all. I am trying to see.

${ }^{1}$ Vol. ii. pp. 52-68. $\quad{ }^{2}$ Letters of J. R. Green, by Leslie Stephen. 
I went to Liverpool afterwards, and to Carlisle,-a clarming place, with remembrances of our friend Creighton about it still. It has beautiful bits, lovely soft red-pink stone, hard and fresh and new, unbattered and eternally beautiful in itself.

I saw O'Leary again. . . . He was very pleased with Stephen's Life and Letters, and spoke repeatedly of them. He is the most reverend figure in Ireland I have seen. We had a grand finish to the dinner; it only lacked you. O'Leary talked fine, and Yeats drew him, and Taylor and I listened and answered and asked questions, and we went on till eleven.

When he left, a fine-looking man, like an officer, about 40 , came up and asked who that most distinguished-looking man was, and was very pleased to hear it was J. O'L. He said he had never seen a finer or more remarkable head : and he was not a Nationalist.

\section{To F. P. Barnarel.}

Christ Church, May 7, 1902.

I hope Acton won't die. He is a good and learned fellow, and he knows a hell of a lot no one else knows. He ought to be made to dictate memoirs for six months on end and nothing else. He knows more recent history than any one, now the Queen is gone.

But in Jume Lord Acton died, and a few sentences may be given from a memorial article by Powell to show his regard for the chief spokesman of the opposite school of historical thought in England. Almost at the same time, in his address at Bangor, presently to be mentioned, he had expressed his view : he 'must continue to differ' as to the place of ethies in historical judgements with his 'distingruished Cambridge colleagne'. In his article he does courteous justice to Acton's position.

He has been for half a century the friend, adviser, and confidant of some of the most acute political minds of the age, a position to which his studions youth, his wonderful memory and ever-increasing learning, his somnd and acute historical judgements, and his wide knowledge of men and movements entitled him. He chose to give his riper year's 
to study and to sacrifice his well-earned repose to the selfimposed task of teaching history to his students at Cambridge, a duty which he has diseharged with an unselfish fidelity, devotion, and ability worthy of all praise. He has been stricken down in the midst of his work. . . . He has died in harness. It is but seldom, even in England, that persons born to ease and with a marked capacity for a successful political career have chosen to devote much of their time to the pursuit of knowledge for its own sake, but among the striking examples of those who have done so the name of Lord Acton must be placed. . . .

Personally he was a man of great attraction. His beautiful and simple courtesy, his easy and well-based talk, his fund of experience of men, things, and books, his marvellous memory and clear and definite expression delighted every one who fell into converse with him. ... His curious religious position did not interfere with his scientific pursuit of history, though he would never allow that 'Science for the sake of science' or 'Art for art's sake' were safe maxims, and he would argue with quiet and polite irony against those who (rightly or wrongly) contended that history as a science has nothing to do with ethic save to furnish its teachers with convenient examples. ${ }^{1}$

In June Powell came north again. On the 20th he visited University College, Bangor, and gave his address on the Study of History in Universities at the closing public ceremony of the session. It sums up the convictions of many years, and is reprinted (rol. ii. pp. 80-95). One peculiar article of Powell's educational faith may be noticed here.

He begins with his programme for the study of history in schools. Nothing could be more opposed to the German or even the English practice than that which he recommends. Instead of pleading for more hours and more historical information, he pleads for less than is actually given. A Plutarchian foundation of biographical history: plenty of illustration by plans and portraits; a few fixed dates; 'some working knowledge of the successive eras of British history,' and lastly, 'a sound idea of the

1 Manchester Guardian, June 20, 1906. 
order of the main events of real consequence' : some knowledge of the history of other peoples which is all to the good; and 'the elementary facts of geology and geography'; that is a sufficient outfit for the pupil arriving at the university. Instead of spending more time on history at school, let him know 'two languages other than the native speech', and be able to write 'sensible English correctly and clearly', with possibly a little mathematics. Eren at the university, history is not rated high by Powell for purely educational purposes, or for what is technically known as pass work. Law, logic, and political economy seem to him as good subjects for pass pupils as history, or even better.

To some this may appear a curious and gratuitous sacrifice of one of the most powerful of all educational implements in dealing with the average boy or girl. It may also seem to imply a false distinction between pass work and advanced or honours work, as if there were two castes of mind. It is easy to say that the school-boy or the 'pass' student can find no more absorbing study than the past of his own land and of the world, if only he be fitly taught. Nothing should educate him better as a citizen, or be a less reparable loss if overlooked. But Powell would probably have answered that the business of historical study was not to make citizens but to make investigators. We come here on the difference between the two great camps of teachers. I do not fully know how he would have argned this point, and it may be hardly fair to press it. But it is fair to recall his own witness to the educative effect of history in fostering true and disinfecting false national sentiment. The historical teaching of France and America has at times done so much harm, that it is elear that a different and less distorted presentment would have done mimaginable good, not merely to the scholar, but above all to the average man and woman. The rest of the lecture is a spirited and often splendid plea for historical research in universities, with proper teachers, libraries, courses, and appliances, and a reinforcement of Powell's theory, which he hammers out 
with increasing clearness, that history is a science and not a branch of ethics.

From Bangor Powell came again to Liverpool: his summer itinerary is given in brief:

\section{To F. P. Barnasd.}

June 23, 1902.

I have been to Bangor in N. Wales, to deliver an address : and to Liverpool to speak at a presentation of a portrait to a friend, Mackay, who is really founding, or getting founded, the University of Liverpool. . . . I am going to Rugby on 7th July, so that after that I shall go to Carlisle and there write my Beweastle Cross article, and then bolt over to Ambleteuse, I hope.

I hear there is a prospect of improving —_s position. I hope this may be done. It will be a great pity if he is allowed to be kept out in the cold.... If the University is to become a reality, not a mere lecture and exam.-shop, you must encourage and keep such men. You can always get a 'gerund-grinder', who will help 'crocks' through exams., but will not inspire any thought or real picee of knowledge into any human soul ; whereas to know this man is a piece of real education to a young student.

You can only establish real seminars by means of such men, and get a little real University teaching done, as we hope it may be at Liverpool, for you can't mean to make your University a place of mere 'cram and exam.' type.

This man (like — and - and Bob) is one of a rare class-people who really live and think and write. They must be upheld at all hazards by people like you and me who care about realitics.

I need not tell you how pleased I was to be able to come and assist at that dinner. I owed you thanks I had never expressed before, and I meant what I said then. It was a jolly gathering, and one that I shall not forget, especially your tribute to Bob. I knew him nearly seven years, and I am sure he would have rejoiced at seeing things so changed in Liverpool. He sowed the bread upon the waters then, but the results are beginning to show. 
Soon Powell is found cheerfully seeing and buying pictures-'a water-colour of Chiswick Old Church, 18th century, very pretty and characteristic,' and a fine 'skypiece' of 'one of the old water-colour men'. Not long after, he went to Rugby.

\section{To Mrs. Marriott Watson. Christ Church, July 9, 1902.}

I just write to tell you I have been to Rugby, or I should have been with you last week, as I hope to be next, one day. We had a good time, the child and I, and we saw all my old school haunts and the Tom Brown places: and I saw old Temple, my head master, and heard him make the best speech I ever heard from him, about Clough and Mat. Arnold, two of our Rugby 'makers', whose medallions were put up in the chapel. There is a place left for Landor, I am glad to say. Clough was a good man, I believe, but he was a bad poet, not a poet at all. I send you a picture by Pamela C. Smith with some lines ${ }^{1}$ I wrote to it. I hope they will convince Dick, whose sentiments I hope and think they express.

How is Marriott? I hope better. How are you? Did you see the rainbows and sunset yesterday? Best of this century, I thought. I have no pen, and am writing this in the train: please forgive the writing, worse than usual.

This was his last physically happy summer, though not his last summer, at Ambleteuse amongst his friends. His health had not begun to vex him, and the sum shone often.

It is often showery, but it is very nice; sunny gleams, lovely landscape, soft air, beautiful sea, and good company and frugal fare-just what I can do with. One's time slips by only too fast. This world is sometimes a very pleasant place.

The evenings passed in 'costume balls', and in 'feasts, picnics, and sports'. An interlude to which he looked back with pleasure was a visit to his friend Dr. Bomier, in Picardy, some letters to whom will be quoted presently. Powell seemed to be putting into practice his Omaresque

1 'The 'lines' referred to are The White Cot in Weary Wood, otherwise The White Witch in Weary Wood. (Seo vol. ii. 11. 391-2.) 
principle of seizing the 'golden moment' rather than caring for the 'futile future'. His favourite place was by the waterside :

The sea's soft call is in my ears,

And that's what I like best,

as he writes in a poem, one of two or three, that Ambleteuse drew from him.

To F. P. Barnard. Hôtel des Bains, Ambleteuse, Aug. 22, 1902.

Have you been painting? I ought to have been at it to-day, it was so fine; but I slept, it was hot and I was so lazy. The weather here is worse than yours, as I see you have had much sun and little rain : we have had plenty of rain and little sun : but it is very healthy, no colds, fresh air, and enough to eat and drink, and a roof over one : why should one grumble? I dare say God would like to have a change sometimes, but he can't leave things and go on a holiday, or the devil would get loose. So we're probably better off than he is, after all.

$\mathrm{H}-$ and $\mathrm{H}-$ the painter are here, both very good fellows... so one can get decent talk now and then. The commonplace bores one increasingly, when one has been spoilt by good talk. ...

Two large families of godly respectable Britishers also inhabit the hotel and regard the other lot as curious and so Bohemian, because we don't dress for dinner, and laugh a lot, and do not join (I regret to confess it) the Sunday service they have set up, collection and all. Isn't it funny? But we are all very polite to each other, and there is no quarrelling. I work nearly every day, but it gets on slowly.

To F. P. Barnard.

Ambleteuse, Sept. 18, 1902.

I have been to Lille, or rather through it, and saw Bovines; and I stayed at Templeuve, such a pretty typical Picard valley, old Abbey land till the Revolution: my friend, Ch. Bonnier, is writing its history. He can trace nearly every family back to the ' 90 's and many much further. He has got all the particulars of the Government sale of church lands which took place there first in '91. It is very interesting: a fat, gray, clay plain covered with cultivation, and little clumps of trees round red tiled farm- 
buildings; granite causeways (nothing else will allow of winter travel, the loam is too thick): a huge garden; harvest rery late, oats carrying now (cut up six weeks ago, some of them). Near Bovines are the great marsh-flats, all good land now (cut and drained by careful channcls and waterways), beautifully tilled. Rain would make the trenches very heavy for horses and men.

\section{To F. P. Barnard. Christ Chureh, Oet. 22, 1902.}

C. wants to know where the GHost is ? ${ }^{1}$ She is sure there is one among the fixtures, which the Crown will hand on to you. Is it a bl- $-\mathrm{g} \mathrm{Num}$, or a sheeted gibbering White Ladye, or a blood-boltered Elder of the Duncan type, or a black dog or a white, or a headless horse or horseman? We WANT to Know, as the Americans put it.

I wish you all luck as a Castellan. I wish you had the power of pit and gallows, and could hang the Pro-Boers, and drown the scolding old maids and squabbling parsons and tub-thumpers-but those good old days are in abeyance now. I am yours very faithfully.

The end of 1902 brought a change, which is the beginning of the last chapter in Powell's life.

1 Alluding to St. Briavel's Castle, Mon. See next chapter. 


\section{CHAPTER VIII}

\section{OXFORD : 1902-4}

Migration to Cxford; reluctance and regret. Letters on The Wings of the Dove. Celtic evening at Liverpool: speech. Powell and mysticism. Moving house. Change of political view. Portrayal of Powell in fiction. Pictures and painters. Letters to a child. Teaching at Somerville: testimonies. Irish discussions. Visits to Knole and Gorleston. Signs of illness. Hard work : articles on Mr. Swinburne and Mr. Kipling. General Survey of Modern History. Edward II at Oxford. Last stay in Ambleteuse. Death of Hines. Stay at Folkestone. Tradition and its Conditions. Last visit to London and pictures. 'T'he Oxford garden. Last letters: spring. Note on Schopenhauer. Closing days; death; burial at Wolvercote.

Powerc's life and affections had vibrated between London and Oxford for twenty years; but in Oxford he now felt that his lot lay. The weekly journey to town had always been to him, distinctly, a process of going home. But many of his friends had now left Bedford Park, and some had died. For this and other reasons he determined to settle in the north of Oxford, in the new quarter that has become a red-bricked, roomy-gardened colony of the old, pent, grey city; leafy and flowery in the good months, and light of soil, with its fair share of retreat and silence. The honse he at last pitehed upon, Staverton Grange, in the Banbury Road, had flowers and a space of grass garden, and could hold all his books, so long seattered between two eities. His letters show the regret with which he uprooted himself from Loudon. The first of them ends sadly but begins gaily. His friend, Mr. F. P. Barnard, was on the point of taking a lease from the Crown of the Castle of St. Briavel's, in Monmonthshire, which stands on 'higl levels', 800 feet above the Wye. The 'devil' of the silver ring is again invoked. 
Three cheers: what luck. Hooray!

When the barons built homes like St. Briavel's,

'They filled them with ill men and devils,'

So the chronicler says ;

But in these humane days,

You will hold there more innocent revels.

But I hope that there's one of the devils

'That may still be a guest at St. Briavel's,

Whose green eye so bright,

Shows the signal 'All right'

And befits him to shine on high levels.

So when I, the most lucky of derils,

Come to visit my hosts at St. Briavel's,

I shall not be bereft

Of the friend on my left

As I join you at tenpins or kerels.

There are too few rhymes for me to go on in this lofty strain, so I simply wish you all luck in your new home. I know the place: I was there when I had a reading-party at Llandogo years ago, and lamented the fact that no one of intelligence held the old place.

The wardenship of Dean I hope still goes with the castle. It will be fine for you to be the Forestress of Dean.

I must find out the life of St. Briavel and get it printed.

I keep the plan and the photo. I don't think the library safe above the coals, unless, as I suppose, the basement is vaulted; if so, it is quite safe.

What a splendid time you will have arranging things! It will really be a joy to see the old place put in real order by folks of taste.

The fons inclusus and hortus sigillatus will be fine things.

Your guard-tower will be a delightful place. You look towards Wales and the hills 'from whence eometh your help', as a Book (you have no donbt once read) puts it with a certain elegance of an archaic and primitive era. You will have the Wye,

"Via duleis, via grata,

Via bis per diem inflata,

Via multum, vae! pochata' [poacheel] 
as the poet hath it, close by ; Tintern within call; Monmouth within call; Harold's outpost forenenst you, and the curious Gloster table-land behind.

By the way, there is a house by the wayside, with firs near it, a lonely gray house, I always meant to make a grim story about. I wonder if you have noticed it. It is a few miles out of St. Briavel's. Inspire Frank to write on St. Briarel's. In the Gloucestershire Archcological he will find, if I remember right, much on St. Briavel's.

C. and I have got to go to Oxford to-morrow to choose our new house. It is cruel work changing, and leaving friends, and the little old home in London where I have been happy and sad and seen the seasons pass for 22 years: but it has to be. I am yours very faithfully.

Late in November he wrote :

To Miss Geoghegan.

I am engaged in changing house. I leave Bedford Park at Christmas. It is a great wrench. I can never be as happy again as I have been there. One's first fifty years are the happiest, as Bismarck said. However, I hope to have some quiet happiness still, with the child, in Oxford. It is necessary to move, and I must face it, spite of my catlike love for the old place and all its sweet and sad associations. But I am not writing as cheerfully as I meant to : you must pardon this. I hope you and the black heifer and the $\operatorname{dog}$ and the garden are flourishing - in front of the sea and the herons, with those lovely trees, and the lucks and chickens, now big, crowing and quacking beasts, and happy as ever they were in their fluffy coats. ... I have done a little painting away in France, but I hope next year to send you something you may be willing to hang up some time in Donabate. It is beautiful here now. We had a day on the river last week, cold but not too cold, and perfectly delicions under the bank where the trees were green and gold like spring. We could not believe it was November.

An earlicr note tells his attitude towards the dwellers in Oxford, whose affection for him he did not ignore :

To Mrs. Shute.

Ambleteuse, August 21, 1902.

There they live, in regular ways, which I hate : they dress for dinner, which I loathe: they are punctual, and give up 
the blessed moment for the futile future, and so on. But they are good to me and tolerate my ways (as the Moslim tolerate madmen, considering that Allah must have them in special favour), so I hope it will be better than it seems, but I greatly dread it. The Sundays were times of real refreshing before.

The flitting took some while: meantime he is found writing on the 'phantom epic' of the seventeenth century, and the tales of Mr. Henry James.

\section{To Oliver Elton.}

Christ Church, Dec. 9, 1902.

I think du Bartas is rather an epic success, but what pricked the bubble was really Voltaire's gigantic failure; and the excellent burlesque Hudibras, and the far better Folengo's Baldus, and even the wretched Pucelle showed that the weakness of the thing was apparent whenever a man determined to laugh at the convention.

[The] Wings of a [the] Dove is excellent, and gave me several hours of brain-pleasure. He really gets better every time, I think, the great Hy. James. He is a fearful and wonderful creature: the delicacy of his study of impressions has never, I think, been surpassed. He has described moods no one has ever portrayed before. $\mathrm{He}$ has heaps of faults, but much must be forgiven him.

\section{To Charles Bonnier. Christ Chureh, Dec. 12, 1902.}

Les Wings of a Dove-extraordinairement bien. On s'imagine la lettre de Milly la chose la plus exquise. Et on ne sait pas ce que sera la fin de tout ça. Ça vous donne des problèmes sans fiu. Voilà ce que peut faire un homme de génie avec nos conventions misérables. Il en tire des suecès surprenants et des tragédies de [grand] pathos. Ces loques qui nous 'médrapent' si salement, il les fait superbes dans ses demi-lumières, menaçantes même sous certains aspects. Il est vraiment très-fort. Ses filles sont très-vraies. Et c'est véritablement l'expérience la plus difficile-ce qui est preuve absolue de génie-la création des femmes. (Dieu l'ajournait, n'est-ce pas? Il voulait être sûr de lui avant de faire cet acte suprême.) James et Meredith et Hardy peuvent le faire, James avee ume délicatesse frêle et un opalisme Whistlérien, un dessin si vibrant et nerveux.

Et quel joli paysage-son 'setting' à Venise, la piazza, le palazzo, la petite chambre à louer à Venise, et ce sacré

$$
\text { х. p. } \mathbf{A} \text { a }
$$


père de Kate, qui est si nécessaire cependant-le roman aurait manqué de richesse sans lui-et qui parait ces deux fois comme un souffle de l'inferno.

On pourrait en causer des heures, des jours. À vous sincèrement.

A few days after this he was again in Liverpool ; he came to speak his word for the endowment of Celtic studies in its new University, for whose hopes and fortunes he eared strongly to the last. That University was made possible, in its full activity, by lay zeal and gifts : and one of the many plans astir, at this time of its formation, was to appeal to the large Welsh and Irish population of the city, for a professorship of Celtic, into which the existing honorary readership, held by a known scholar, could be turned. To this end a dinner was arranged in the University Club. It was a Celtic evening: Principal Rhys, of Jesus College, the only other professor of the subject in England, presided, and Powell eame too. $\Lambda$ number of Welshmen and Irishmen of note in the city were present. The occasion may be eited here, as Powell had its object at heart, and one of his few semi-public speeches, which is also one of his latest, ehances to be on record. He struck, as it proved, a note that found effective echo. He spoke as to men of business who expected confidence as experts in their own line, and who should be ready to give the same confidence to experts in scholarship. After touching on the special purpose of the meeting, he went on :

Although we come before you as men who are really out of the world, not in practical life, but leading a contemplative existence-although God knows it is active enough sometimes-I should like to say that you must to a certain extent trust us when we tell you that there are a certain number of people whose work cannot be measured by the ordinary standard. The expert scholar is a person who is necessary for the teaching of teachers, and we all acknowledge that we must have in England really efficient and organized teaching. 'The Germans have it, and the French learned the lesson in a very painful way in the war of 1870 . 
They have taken the lesson in the most honourable way, and there is now no place in the world that has better organization or is better educated than France. They learned the lesson. We have eertainly had a lesson, and I hope we are going to take advantage of it in the same way as the French. It is absolutely necessary, if you are going to hare good teachers, that you should have experts such as Professor Meyer to teach them. You must take your experts, and believe us when we tell you that the value of men like Professor Meyer, who are not perhaps dealing with practical matters, but who show teachers the proper methods and put the right spirit into them, is very great indeed. It does not matter whether they are teaching mathematies, or Welsh, or Irish ; it is the scientific methods they inculcate. If you can get a man who knows how to interest his pupils, and who cares for his subject, that man will produce good pupils, and those pupils will be and will produce good teachers.

There was other good speaking, but Powell's words were seen to have told, when one of the Welsh visitors, explaining that he was engaged in commercial pursuits, and that all he knew on the subject of Celtic studies he had learned that evening, added that Powell had struck the keynote. Amongst the commercial class there was, he said, a widespread feeling that there was no utility in such a subject as Celtic ; that it 'is one of those dreamy subjects that may be of some service to professors who are interested in it, but to the general community is of very little nse'. The speaker added that he had been convineed by Powell's speech, and promised and gave the matter practical attention. In such ways a beginning was made for the aim in view.

The move to Oxford was to be only half over by New Year's Lve, and he wrote meanwhile:

To Mrs. Marriott Watson. Christ Church, Dec. 22, 1902.

Here we are: the house half-painted, quarter-papered, piles of our beds, books, chairs, pictures, and crockery in the midst of every room ; a painter and paperer circulating round this central group. C. and I and our friend the 
chimney-sweep [Hines] ordering chaos, stirring tohu-bohu, and evolving order out of an awful mass of antinomian fragments. We live on sandwiches (to which I add raw brandy), we go home dog-tired, we rise early, we live thro' the day. We look forward to a week like God Almighty's when he started on his ill-omened enterprise of creation. When we sit down and say Behold it is very good, seems years away. But if it is still fine and warm we shall live thro' it I trust, and rejoice like the saints in our beds for days and nights afterwards.

To Oliver Elton.

Staverton Grange, Jan. 6, 1903.

I send you the [Bangor] address I promised : you care for all matters educational, so I don't mind asking you to read it. It represents opinions I have been coming to for years, and I hope it will hold. The present thing here is indirectly useful, directly a sham. . . .

I have been here ten days nearly, the sound of the hammer never out of my head hardly. I have shifted over 6,000 books, and it isn't over yet, and all the pictures, and much of the furniture. I have only had one chill and feel otherwise well and jolly, but I do want the workmen out. They are so terribly slow. They work well, honestly enough, tho' stupidly, are nicely behaved, quiet, \&c., but they get on your nerves at last, like naughty children.

Johnstone wrote me, but not about $M$. G. [Manehester Guardian]. Do not let him drop that. He could do splendid articles on Teaching. He could visit schools as commissioner. He could give a series of articles on Pleasure Cities, he could write on society in Russia, Germany, France, a heap of things.

As yet there was no omen of failing health, though trouble was near. A little later he returned to his theme, which oppressed him much at this time, of the misdirection of teaching force at Oxford :

To Oliver Elton.

Staverton Grange, Jan. 18, 1903.

I am really glad you like the historical program I have sketched. It is what I have been thinking over a long while and got at last on to paper, as clear as I could, for teachers. 
The schools here are dragged down by the desire to have masses of pupils and the dread of losing money by lessening the number. The most they do teaches them how to write a precis (nothing else) on other people's facts. For the love of God don't let your new school follow this model; insist on thinking. It is painful but needful. To make a good precis, even, is something if it is made out of one's own facts, but we have not even that. Of course it doesn't hurt the best men. It just wastes their time, but it is pure humbug, and rot with the 3rds, 4 ths, and bad $2 \mathrm{nds}$, and it is not history but memorizing. I could talk a long time on this, but sat sapienti. . . .

Here in the north [of Oxford] like Lucifer I have set my throne.

How go the mystics? I have an old translation of part of S. Teresa de Jesu, which I will show you, and the vision of S. Brigitta of Sweden (very Dantesque and of inordinate length), but the physiological part of it is all that interests me generally. Do you know the Fis Adamuaiu (Revue Celtique some time back)-Adamman's vision of hell, \&c. It has a rapport with the eschatology of the Solarliog and is one of the best of the old lot-Tinugdal and Co. The Visions in Baeda are curious because of the physiological descriptions of the visionary's feelings. I am yours ever.

Despite his remark about physiology, Powell at other times granted more to the mysties than he here confesses. There were many talks on the matter. He seemed to take their revelations and ecstacies chiefly as symptoms; he approached them through art and letters rather than through theosophy or personal affinity ; and chiefly valued, as in the crowning case of Blake, their play of imagination. Still he thought they harl something to say that no one else could say; and when it was pleaded that this must be brought into rational terms to be of any avail, his instinct for expression inclined lim to reply that the mystic must be left to use his own terms, on pain of our losing his message. He says that Omar had 'passed the marshy reek of mysticism by', but this was written in yet another mood.

Another letter written about this time refers to an eflort made to renew the stained glass industry in Ireland. 
I an much interested by Miss Purser's scheme. There is a big market for glass in Ireland and Irish America. If they would only buy their church-glass and images in Ireland instead of the abominable Belgian monstrosities, the money would not be quite so much wasted as it is. Good leading and plain colour are wanted. It is a pleasant, beautiful, and often lucrative art. The glass factory people have no good designs; _ and __ are abominable, and they are about the best. 'Architect's glass' is not always much better.

I have some glass in this house which almost provokes nausea ; I had to take out a lot, but I can't afford to take all out yet, so some remains to sadden me and remind me of the sad side of humanity.

I don't understand why Miss —— was angry. My remark on the Irish newspapers was either true or false (and it is not a point of patriotism to defend the bad) and a matter for argument not sentiment. And I have never said anything about Ireland, save to register my sense of the universal kindness I met there from every one, and the charm of the places I saw. I thought the Boyne more beautiful than the Thames. I thought Teltown and Tara most impressive, and deeply interesting. I was not disappointed of any I saw. What is there in this to make any one angry? I put it down, because I don't like to be thought to spy out a land and then abuse it injustly (not in a spirit of 'patronage', which — fancied once he detected in me!). I am sure I am fairer to Ireland than you are to England, but I won't go into that, though you strive to wake the embers of war.

\section{To Charles Bomier.}

Staverton Grange, Feb. 19, 1903.

Mon cher ami,

Je suis heureux de voir de votre lettre que ça va mieux et que l'influenza vous a quitté.

D'abord, Wings of a Dove est immense (quoique je ne m'explique pas ce qu'était devenu l'argent ${ }^{1}$ ). Oui, c'est m évènement. James est bien le plus grand depuis que Meredith cesse de produire. Et il est seul dans son genre, aussi seul que Rodin ou Memier on Monticelli ou aucun

1 Current jest against an acquaintance who, after realing the novel, had only said, 'but I can't make out what became of that money!' 
des ' grands solitaires', oiseaux de l'espace, des nuages, des éclair's, des couchers et des levers de soleil. . . . Mon cher, le changement de maison était terrible. tait pas. Pendant six semaines il trainait, et quand j'arrivais le 20, il y avait beaucoup, beaucoup ì faire, la peinture, les papiers, la réparation des petites choses, etc. etc. Et il traînait encore, poli, gentil, gai jusqu'au chanson, mais refusant de nous quitter ; il faisait très-peu chaque jour, reparaissait toujours très-tard, s'en allait d'assez bonne heure; enfin il fut impossible de le déloger. Enfin, bien tard dans janvier, il évacuait lentement et en mauvais ordre la position si longtemps tenue 'avec une insistance digne d'une meilleure cause'. J'ai pu ranger mes livres, commencer de mettre de l'arrangement dans les papiers, préparer mes lectures, et écrire quelques lettres, et voir quelques amis.

Maintenant, franchement ça me donne plaisir que vous trouvez bien mes vers. ${ }^{1}$ Ils étaient écrits ì un moment oì je me trouvai pénétré du sentiment essentiel du lieu, et c'est ca que je voulais exprimer tant que je pouvais. Il fallait être très-simple, car le sentiment du temps, du lieu, de mon état d'âme, était très-peu compliqué. Je suivis ce qui se produisit, d'abord rhythmiqnement, dans ma tête, et ça coulait à la même musique. Que vous avez trouvé ces lignes passables me plaît, car je les trouvais expression de ce que je voulais exprimer. Je suis à vous sincèrement.

A week-end visit to Cambridge drew the following:

\section{To Charles Bomier.}

Staverton Grange, Feb. 26, 1903.

Cambridge est plus beau qu'Oxford; oui, j'en suis sûr. On a laissé les vieux coins, les morceaux de ville, les petits publics, les maisonnettes de petits bourgeois du $16^{\mathrm{e}}$ et $17^{\circ}$ siecle. Il y a des petites bâtisses ravissantes, des coins féeriques, on se frotte les yeux : 'est-ce que ça existe encore?' On a trop bouleversé Oxford. C'est triste. Cia était très-bien dans le temps. Il n'en reste que cette petite rue près la rivière sur la route de la gare.

Three letters to Powell's friend and pupil Mr. Clayton, written just after the move to Oxford, have a special

1 The verses written at and coneerning Ambleteuse in the summer preceding: see for the text, vol. ii. pp. 388-90. 
interest. In one of them he speaks of the movement of his political ideas. Mr. Clayton, a Socialist, had expressed concern at what seemed at first a vital change in them. In another letter he praises his correspondent's Life of Father Dolling; he admired a really good priest perhaps all the more quickly for not sharing his doctrine. In other passages he speaks of a story of Mr. Clayton's, Grace Marlow, in which he himself and his talk were incidentally sketehed -sketched, I think, so naturally that a quotation will be given.

\section{To Joseph Clayton. Staverton Grange, Feb. 19, 1903.}

I don't mind being portrayed. You will be so kind to me that my friends won't recognize it, and as for my enemies I don't care. You must add to good novelists James, who is better than Hardy, even as an artist, and ranks next to Meredith. Then there is H. G. Wells, Conrad (who is splendid, read his Lord Jim, Nigger of Narcissus, Youth), and others I could name.... Why bother about the gentry? All sensible people, village or other, must learn to amuse themselves rationally and cheaply. The best amusements cost very little, while bad amusements are costly always.

\section{To Joseph Clayton. $\quad$ Staverton Grange, March 15, 1903.}

This is [a] very good book about a very good man. You did well to write it. I envy you in that you knew Dolling. I wish I had. He would have done me good. I don't mean to say he would have altered my ideas, but I think he would have made me better. It makes one ashamed to know of such goodness and unselfishness. It is a good thing such men live, they save the world from rotting in these great cities. But it's no use talking of them. They are the real saints and they deserve a heaven. You have told the story very well, and you understand the man and his conditions better than most people can or do. You must tell me about him when you come. He is a man to think about and remember.

It is quite true ; all great men are simple. Bob Stevenson was. Mallarmé was, and Meredith is. They are frank, direct, considerate often and so reserved, but never two- 
minded and always seeing the real thing and not its wraps and swaddling-bands. $\mathrm{B}-$ my friend, the wisest man of his years, is quite simple and direct. I don't see how these great people could be otherwise, for they have all hated shams since they were born, and refused to deal with them. ... I get more sick of parliaments and less liberal and more Nietzschean every day. I want more sense and less sham. By the way bishops are not as bad as you think. I knew three pretty well : they are just, hardworking, and struggling men, overworked, and human enough, and no guile I could see in them. I don't understand how a man of sense can hold their creed, but I have seen enough to know they are all three better men than I am, though I have an historic mind and can judge of evidence and they can't. So I can't condemn even bishops wholesale. . . . I have learnt more from you, Jo, than you have from me by a lot. I am always yours gratefully and sincerely.

\section{To Joseph Clayton.}

Staverton Grange, April 15, 1903.

Very good indeed. I have just read it through, and C. is reading it now. It is in a good spirit, and it is wellobserved. I can see that great part of it you have known and felt, and some of it you have gone through. Your women are all right. Mabel is very good, not exaggerated, and really human. I've known them exactly like that, awfully good sorts, honourable and kind and really unspoilt save by the drink; for that, when they take to it, rots their wills, and they sink then. What I like is the way you made Grace the same woman all through, when she is schoolmistress or nurse or housekeeper. That is right. She only knew more, but her heart was the same.

My dear Jo, I'm not going over to the rich. The only hope, though, is more knowledge, more sense ; it is understanding we lack as a nation. The rich are such disgusting fools, they often can't even amuse themselves. The women are the worst. But it isn't because the poor are poor I like them; it's because they are likable. We want to have the best ruling, the wisest, the healthiest, the strongest, whether they are 'rich' or 'poor' doesn't matter. But l do distrust the bourgeoisie lot. Old Booth and Rowntree are better, though they are the historians of the twenticth century, and I want to get them honorary degrees. . . . It is absurd, but this Oxford ought to acknowledge such work as theirs. Booth has really done a big thing, anatomized a whole big 
town of six or seven millions, given us the facts in a handy form. Now we ought to be able to go ahead.

I am glad — is a good man. I hope to God H[ouse] of C[ommons] won't spoil him and swell his head too much. It's a bad atmosphere. I hate the sham of it more and more.

I don't think I've changed at all in my basal ideas, but I see throngh forms more than I did, and I am impatient at times of the 'accompaniments', 'the usual trimmings.' But I'm all right as to Socialism. I'm not going back there, so don't worry about that.

The passages in the story that introduce Powell, and the words he is made to say, are of course not actual reports, but are conceived, as any friend of his will agree, in character. The tale about the tippling undergraduate was current. The rooms in the Meadow Buildings had now, on his transplantation to Banbury Road, been given up, with a regret second only to his regret at quitting London.

The hour was late, but it was never too late, to call on Mr. Bedford Knight, the one don with whom Colman had any unofficial intercourse. A great personality was Bedford Knight,-a man of keen scent for all deeds of simple courage and pity, confessing to a frank love of life, and holding vast stores of human knowledge. A remarkable tutor, too, who had been known to sit up all night with a pupil given to heavy drinking, to talk him sober, and leave him with the scanty sermon, 'Don't get drunk - waste of good liquorand the dons don't like it.' In Bedford Knight's rooms, Colman and many another undergraduate had learnt more philosophy than the lecture-rooms could impart, had heard more of the message of life and its meaning than could be gleaned from College sermons and University preachers.

Colman found Bedford Knight busy at a translation of Persian poetry, but quite willing to put the work aside for a chat. The younger man talked of his own future, and then mentioned Bilchester's coming enlistment in the Salvation Army. Bedford Knight smoked on awhile before commenting; then he said-

'Few people have common sense and religion too. Best be thankful when they have one of 'em. Better for men to have common sense, women want religion. You and 
I don't want religion. It takes us all our time to do what we can to help those in our way, and to keep from hurting people, and to play our part in the world. Bilchester was always a conceited fool, conscientious in his way, but a damned ass too. "Holy Bilks" the ungodly call him, don't they? What does he know about the sufferings and troubles of working people? Still, thank God, that when a man hasn't common sense he at least has religion to keep him from being a cur.'

They sat and smoked until the comntless towers of Oxford proclaimed two o'clock. . . .

.. Exiled revolutionists-men of action, not doctrinaire reformers-and militant agitators of the labour movement were of Bedford Knight's friends. Many an anecdote too of the champions of the old Prize Ring he related, anecdotes of the homely kindness of the great prize-fighters, and how when they left the ring they were wont to retire to some wayside inn and support wife, child, and parents. ${ }^{1}$

Letters follow to various friends full of talk about letters and art. He is in sympathy with the movement to set up Stevens's Wellington monument in St. Paul's (the head is ' un morceau digne du plus beau Rodin'); he is about to try the 'Raffaclli colour-sticks' for his own work; and is delighted with a picture from his friend Mr. Dudley Hardy, of which a photograph arrives. He laments the death of Gaston Paris: 'c'est toujours un bon de moins dans ce monde où les braves gens sont trop éparpillés.' He is busy with lectures, reviews, proof-sheets: and he welcomes the early spring in his garden :

It is cold and bright and sumny to-day, and I can see my little crocuses from the window. They are rather shy of coming up, and some can't rise at all, but still a good lot have appeared: I hope for more.

To D. S. MacColl.

Staverton Grange, March 11, 1903.

It is cold and bright here, I have no leisure till the end of this week, then I am coming up for a pasear to I condon, where I hope to see you. But why don't you run over here

1 Grace Marlow, by Joseph Clayton. Iondon: S. C. Brown, Lang. ham \& Co., pp. 20-22. 
for a week-end? We can put you up. The house is big and airy and light and we can talk a bit. It would do you good. ... We have Raffaelli's colours in already, which shows the rapid march of civilization. Your trees must look fine; and the sombre greens of the park, with the clear blue cloud-trodden sky above, I can imagine from your window.

\section{To F. P. Barnard.}

Staverton Grange, March 22, 1903.

I have bought a big water-colour, very swell indeed, by a man who signs [monogram]: 'Needwood Forest.' Who is 'R. G.'? It is in full darkish colour and is really tremendously fine. It knocked me all of a heap when I saw it. I am sure you will like it. I can't get any one of the ordinary to understand it, the dammed fools: however it's lucky, for if they had I could not have bought it. I am sure it is worth $£ 150$ if it is worth a sou.

Now tell me the name of your man you send your watercolours to to be taken care of : for it wants remounting, and I want some one I can trust to see it. It is really fine. I just hug myself over it, but I shall be more pleased when you see it, because I know you will appreciate it.

\section{To Miss Ella Pollard. Staverton Grange, April 2, 1903.}

I have just been for three days to the New Forest to stay with an old pupil. It was very jolly, lovely walks and views, excellent wine, and the weather not too hot or cold or windy. I came back very well.

Do you take in the Studio? I have got Miss Macbeth's Huntress that was printed in colours there some months back. There isn't much new here. We had a frost last night, north wind came on suddenly: I fear for the young buds. In the N. Forest the gorse, primroses, blue and white periwinkles, and daffadowndillies are magnificent: the birch is just turning purple, as it does before it buds out.

I have just bought some of the Raffaelli colours. Hardy says they are very jolly to use, and he was painting with them last Sunday (I regret to say) when I went to his studio for a little quiet and improving talk.

You ought to come and buy spring clothes at - and -'s. There is a 'beautiful-nammered person' there, so C. tells me, who sells in the most gentlemanly and undergraduate way (but the young women there are, I am afraid, 
very plain). The shop is in full glory of spring hats (such a size and splendour), hasty-pudding bag blouses, bell skirts, and confections of most alluring kind. C. will pilot you through any department, ergo bring Frank and come. Yours faithfully.

A series now comes, addressed to the young friend already mentioned, who was laid up after an illness, and who gave Powell the name by which the letters are signed. Powell easily put himself at the point of view of a child, having, like R. L. Stevenson, a sharp memory of his own early likings, dreams, and sensations.

MY DEAR TIMMY,

Staverton Grange, April 2, 1903.

Thanks for your pieture, I hope you are better. Ask your mother to let me know how you are, and give my love to Margy. C. sends hers and wants a letter from Margy. I went down to the New Forest last week and it was very beautiful-such heaps of flowers, periwinkles and primroses, and the gorse was all out blazing yellow, and I saw doves and pheasants, and we heard the screech-owl and blackbirds and heaps of birds of all kinds.

It was fine weather, and we walked about nearly all day. The little girl has a pretty pony and rides very well. She plays the fiddle too, but she does not like her lessonbooks. She is pretty and amusing, her hair very light; she has grey-blue eyes like Rosa __ s, her name is Maud.

The second boy is very good at engineering, making electrie machines and things like that. One day he hid in the dog-kennel and no one could find him till his brother George saw the poor dog trying to get in and whining because he could not, and there the boy was all in the straw among the bones and fleas. I shall be glad to hear you are better.

Remember me to Mr. Baker.

$$
\text { I am your old friend, }
$$

JOLLYMAN.

MY DEAR TiM, April 8, 1903.

I hope you are feeling better and have less pain. It is very cold here, but to-day the sun is shining, and as the windows have all been elcaned we can see the light clearly. 
C. is scrubbing and dusting and sorting out things in a very busy way. I am working.

I have been trying the Raffaelli colour-sticks. They are very amusing to work with, you just cut them like a pencil and draw on the canvas or board with them, but one must be a good painter to get good effects.

How are Mr. and Mrs. Warren? Remember me to them please.

C. sends love to M. and wonders when she is going to write to her.

I hope you will be able to read this.

I saw Uncle Dudley and Cameron last week, very well both. Cameron and he had done a good poster-I think I told you about it-for Bovril.

The flowers are coming up now : our peony is beginning to show. We have about five kinds of flowers up alreadycrocuses, daffodils, daisies (camomile), wall-flowers, and some flowers I don't know the names of.

There is a house near us like Noah's ark. I like it, but the stupid Oxford people think it ugly [slictch]. Red brick, and red tiles, white stone round the windows, and a white door.

$$
\begin{aligned}
& \text { I am your old friend, } \\
& \text { JoLLyMAN. }
\end{aligned}
$$

April 19, 1903.

My dear Tim,

I am glad you like the books; I am sending you another not quite so good, but it may help to pass the time.

I hope you will soon be well and strong again, cutting about and hammering and punching the ball.

IIenry James sent his love to you and asked if your hair was still eurly. I said yes.

$\mathrm{C}$. is staying away with __. I am (like the gentleman in $M($ aud) waiting here at the gate alone.

It is still cold, but my crocuses and gilliflowers don't seem to mind it. I saw such a fine greyhound yesterday with silky skin. It was tied up at the station and I stayed with it a bit and talked to it, and it was very friendly: poor beast, it wanted to be ruming about with the horses. I hope it did not have to wait long. C. sends her love to your babies and so do $I$.

We send our love to your mother. 
The soldiers are out drilling now, and there are lots about the streets of men-o'-war's-men on 'furlough' or 'leave' as they call it, looking very jolly rolling along with their young women and their backy. "They all love Jack.' Write when you feel inclined.

I am always your old friend,

Jollyman.

My dear Timmy,

April 26, 1903.

I hope you are feeling better and free of pain, and that you will soon be able to draw and read in bed. We had a rice pudding yesterday and I thought of you. I went to Manchester last week and saw some nice pictures and some beautiful pieces of embroidery; some were thousands of years old, Egyptian, and as fresh as if they were new-made. There is no damp there in Egypt, and everything keeps in the dry sand.

There were some beautiful Norwegian jewels too, silvergilt, like my ring but bigger [drawing], fine crowns that brides wear, and beautiful belts like this [drawing], of silver-gilt, with little things like silver bowls, this size [drawing], very small, hanging to them; they sparkled beautifully, and there was a Japanese bronze bowl with its stand of elephants and dragons. It was 10 feet high, and lots of other things I forget. I saw a lot of dogs of all kinds and a jolly black cat with a thick bushy long tail, and one or two nice fat rosy babies, just the sort you like. We have lots of blackbirds here. One sings on the same tree every day and does not fly away when one goes past. He begins early and sings till after sunset.

It is raining very tiny drops and all the flowers are glad. The first leaves on the chestnuts here were all killed black by the frost, but the new leaves are coming on again now.

I am your old friend,

C. sends her love.

Joluyman.

My deAR TIMMY,

April 31, 1903.

It is quite April, all showery here, and little tiny drops like weeny glass balls hanging from the neerlles of the fir-trees, and the eats rumning all wet out of the rain.

C. sends her love. She has J. staying with her. 'They went in a Canadian canoe yesterday [dracing]. 
The boys have begun to play cricket here. I went to see Mrs. S. yesterday; she has two big clutches of yellow chicks [drawing], absurd fluffy little things, with hens, and a clutch of 8 turkeys sitting under an old speckled hen : they are striped black and white like little kittens [ $\mathrm{draw}$ ing of chicken], very pretty, cheeping and picking and moving their heads as they call, like pigeons do. Tell your mother the cider shop is gone and I don't know 'where they have laid it'.

Close by where it was in Portland Road there is a beast and bird shop and a little red caivi sitting up in a nest of hay. He was pleased to see me and rubbed his nose against my finger. I liked him very much. He looked like the picture, a very cheerful companionable little beast. [Drawing of caivi looking through bars.]

That's all the news I have. I saw Uncle Dudley and Cameron. They sent their loves to you, and Cameron, who is grown big and looks grown up, said he would write you. I am your old friend, JOLLYMAN.

At this point we have a last glimpse of Powell as a teacher, not of history but of literature. He had earlier given up lecturing to the Women's Association in Oxford, but in the spring of 1903 he visited Somerville College, and gave discourses, or rather informal causeries, on French literature. Several of his pupils have sent descriptions of them; and as the teacher's voice, like the actor's, fades irrecoverably away too soon, there is the better reason for saving some of their recollections. The discursiveness (varied with strict method), the leisureliness, the power of opening new and wide horizons, that marked Powell's handling of history, are here also: it is plain in what sense Powell was a great teacher, as well as in what minor sense he was not a teacher. The lectures, we hear from one report,

were arranged to be a series of portraits, or rather of portrait-sketches, of the lesser, as well as of the more important men of letters. He sat and talked about them as if they were friends of his, just choosing the facts in each man's life that made him live as he was put before 
you. He didn't let you hear anything about a man's work till you had been properly introduced to the man himself, but when he had done this he gave the work its place, not only in its century, but in the whole history of French literature : often, in the case of the more important works, in the history of European literature.

\section{And from another :}

The abscnee of all utilitarian views lent an added charm. For him and his audience literature was the object of study, not preparation for an examination. I well remember the day he came in to the lecture room and began abruptly. "You will have heard that Taine is dead. I think you will like to hear abont him.' And the Victor Hugo lecture turned into a delightful canserie on Taine, making real to us the man and his method by numerous personal touches and recollections.

Schools were imminent, and Taine was not on the syllabus, but that was no matter.

\section{A third speaks of}

the unfailing source of inspiration which the remembrance of his own methods has proved. Some of our lecturers put us on our mettle to disprove their very justifiable assumption of our ignorance. Professor York Powell put us on our mettle to justify his assumption of our knowledge. Many can and will bear witness to his mnstinted appreciation of good work, and to the chivalry (no other word so well describes it) which characterized his rebuke of careless or shipshod fulfilment of what he looked for from us.

The last note, in its clear vivacity and precision, recording as it does an actual hour of Powell's discourse, must be given fully: it is written by Miss Cécile Hugon, of Somerville College.

All Professor York Powell's pupils looked forward to their weekly coaching with a feeling of extreme satisfaction. We regarded this lesson in the light of a delightful excursion into a world of romance otherwise practically closed to us. There was nothing formal or set about his teaching, and a coaching with him usually took the form of a lively conversation in which he did most of the talking.

$$
\text { r. P. I B b }
$$


The nominal subject of the lesson formed a peg on which to hang the discussion. We were never told anything obvious, dull, or easily accessible in books, and facts and persons were presented to us in such a way that we immediately longed to become further acquainted with them.

But what interested us the most was the way in which he could conjure up for us the whole spectacle of human life in a very few words. There was something Shakespearian in his manner of presenting the whole of a period or movement. He would talk about the philosophic tendencies of a period, and at the same time not omit to describe its taste in haberdashery and the nature of its meals. Thus in tracing the rise of the 'sentimental movement' he pointed out that the temper of the age was as much expressed in the simpering pictures and languishing movements as in the literature and style of conversation then fashionable. In the same way the 'minor characters' of his conversation, the people accidentally alluded to, were made real by reason of the Homeric precision of the epithets applied to them.

I began to work for Schools with Mr. Powell in the Hilary Term of 1902. The nominal subject to be studied was the course of French literature from 1660 to 1715 ; but at almost every coaching the conversation ended by drifting into side channels, and we often found ourselves talking about wrestling tricks or Byzantine architecture when we had begun with Seneca or Paseal.

The following is a description of a typical coaching.

We (I and another student) had sent the Professor schemes of an essay on Corneille and Racine during the course of the week. These were now returned to us, and the corrections made gave rise to a discussion on the respective tragic methods of the two dramatists. So far the coaching proceeded on conventional lines. Then Mr. Powell began to talk about the actual representation of a seventeenth-eentury tragedy, and the pleasure of the afternoon began for us. First of all we were transported without more ado into mid seventeenth-century Paris. 'There we proceeded to the Hôtel de Bourgogne, saw the beruftled crowd, and heard the fine sonorous alexandrines declaimed by a Roman hero in a full-bottomed wig and buckled shoes. It was pointed out to us that there was little bye-play, and that the actors had a tendency to stand on one spot and recite their part, while those who 
were not actually speaking stood awaiting their turn in a manner which would nowadays be considered frigid; then, it was only thought stately. Mr. Powell thereupon gave us an amusing description of the appearance, manners, and quaint affectations of the audience. He defined 'le bel air' and 'le bon ton', and pictured to us the ridiculous exaggerations which sometimes characterized the fine gentleman of the period. This led me to show him a certain book of seventeenth-century travels I possess, because the sublime arrogance of the noble author, as expressed in the preface, is a fine instance of the temper of mind alluded to. This preface he read with great appreciation, and then proceeded to explain the illustrations to us, naming the Indian idols depicted and telling delightful anecdotes about the Eastern worthies mentioned in the text. When we got to some pictures of the Tower of Babel 'comme elle estoit au commancement suivant le sentiment de l'Autheur', and 'comme elle est maintenant', he threw back his head and laughed so that he was heard on the next landing.

A remark about the type of the book led him to talk about early printing in general. He said he preferred Aldus to the Elzevirs, and told us that the Latin type habitually used by the former was cut from the handwriting of Petrarch. Here there followed a digression on Petrarch, who was, he said, 'an acquired taste.' This digression was followed by another on Michelangelo's sonnets, especially that on the death of his father, and we were told which were the best Italian editions in which to read them. Thence he went on to speak of MSS., especially illuminated ones. The Flenish Books of Hours in the Bodleian were described, and we were told that it was easy to distingnish English from foreign illuminations, because the former nearly always contain patehes of that bright and cheerful green that one somehow associates with Chaucer. He added that French illuminators preferred a clear light blue in combination with a kind of claret colour, and that the eflect of these two colours in conjunction was very happy. I think he had a great liking for France and most French things. He then went on to describe to us how he had been able to determine the date of a valuable MS. by identifying the coat-of-arms in an initial-letter-illumination, which every one else had either overlooked or mistaken for a mere ormament. At this 
juncture he suddenly remembered that he was at that moment due at a meeting at the other end of Oxford, and so the coaching came abruptly to an end. The next week, however, we reverted to the subject of printing, for he brought two Elzevirs, one Aldus, and two examples of very early English and French printing for us to study at our leisure. He seemed particularly pleased when we admired the delicate tail-piece in the Aldus, and I do not think he ever came after that without bringing some beautiful or interesting book for us to look at.

In speaking of the Jansenists, Mr. Powell alluded very frequently to Pascal, for whom he seemed to have a great admiration. He particularly agreed with Mr. Pater's description of the Pensées as 'a pattern of absolute unencumbered expressiveness'; and at the bottom of an essay in which I had attempted to draw a parallel between Pascal and John Henry Newman he wrote: 'Newman is only a good writer by fits-he is often slipshod, incorrect, and childish in expression. He has no brain : Pascal had lots.' On returning me the essay he took the edge off this severe though just condemnation by speaking of the personal charm that had always characterized Newman, adding that on the occasion of their last meeting he had been greatly struck by the Cardinal's appearance, which resembled that of 'a beautiful and aristocratic old lady'. I remarked that I had lately read a Life of Newman, and that led Mr. Powell to speak of 'Lives' in general. He asked whether' I had read North's Life of some Cambridge scholar who had died of over-eating, and then went on to speak of Pepys's inimitable diary, and the dull life led by Mrs. Pepys ("poor wretch').

Although my coachings with him only lasted for one Term, he continued to help me a great deal with my reading, and also with the ballad I was trying to edit. He used to come rushing up the narrow stairs that led to my rooms, sit heavily down on the fragile chair in front of my writingtable, and go through the notes of the poem in question. He used to make a few corrections in his beautiful and often illegible writing, and to laugh at the spelling faults I could not refrain fiom making. He would then prowl round my little sitting-room and look at the few old things I had, and always manage to tell me something fresh about them. I once showed him a piece of carving representing scenes from the New 'lestament. He looked at it for about 
half a minute, and then said that the mount was modern and of very indifferent workmanship; that the top part of the carving was seventeenth-century French work, by a really clever artist ; and that the lower tier had nothing whatever to do with the rest of the carving, as it dated from the early sixteenth century, and was an example of Italian work of the very best kind. When he finally went, he usually took some part of the preface with him to correct at leisure, or to show to one of his friends "who knew more about the matter'.

But besides being kind and helpful in this way he imparted a great interest to one's life by airling and abetting one in learning new things. He once came to tea with me, and, it transpiring that I was very fond of fairy tales, he immediately began to tell a terrible Japanese story about a demon in the form of a huge spider. This was followed by some wonderful Icelandic legends, full of splendid phrases such as "the red gold gleamed on the hands of the Norsemen'. On being asked where such stories might be read, he replied that many of them were not published in English. Then he added: "You ought to lear'n a new language every year, and Icelandic would be a good one to begin with.' (He implied that it might be learnt 'at any odd hour', as Italian was to be learnt by Milton's ideal schoolboy.) Soon after he presented me with a translation of some Icelandic poems, and a volume of Morris's translation of the Heimsliringla. In giving me these, he said: 'I will send you some little books of fairy tales you are sure to like ; they are very exciting.' (I rejoiced.) 'They are, of course, in Icelandic, so you had better begin to learn it at once in order to read them.' 'The bribe arrived the next day; but not being either Milton or York Powell I have not succeeded in learning the language 'at any odld hour'.

The letters now resume: about painting, Iceland, his new garden. Mr. Jack B. Yeats, an artist like his father Mr. J. B. Yeats, was now bringing out a monthly Brock Sheet of printed drawings coloured by hand. 'The page, or' sheet, was a composition of these pictures and of the poems by various hands, original or translated, which form their subjects. Powell contributed several of the translations; they are from French, Irish, and Danish. 
To Jack B. Yeats.

Staverton Grange, April 8, 1903.

Here is a short one, a ditty of an Icelandic poet of the sixteenth century.

\section{The Dark Poet.}

This we say of Sigurd blind:

He made songs of every kind;

He saw neither sum nor wind;

Yet his songs are sweet, we find.

From the Icelandic. F. Y. P.

A frock and belt-knife ; a brewer's knitted cap; breeches and brogues of skin.

A land, treeless, with sea and sky and hill and rock everywhere, and patches of sweet grass at the foot of the glens, where the river runs into the sea ; many birds.

If you want houses, they must be low-gabled houses roofed with turf, built into the hillside; turf walls round a little home field [slietch] : no trees, no regetables, nothing but grass and wild flowers and birds. Yours faithfully.

The next letters are to Mr. Yeats the elder :

To J. B. Yeats.

Staverton Grange, April 11, 1903.

Many thanks for your letter in the Leader. You ought to write them a series of short artieles on various artistsWatts, Sargent, Corot, Nettleship, Wilson, and others. It would have a really good educative effect, I think, and anyhow it would put the truth before people who would take it or leave it as they wished. You could do it for your people better than any one;-the real importance of art, even to a democracy, though they won't see it and prefer to elect gasbags and live like pigs both in your country and mine just at present.

You who believe in missionary efforts would, I am sure, feel the work congenial. I have often wished I had written down things you said on art, when I got home after talks with you.

It is a pity not to have your philosophy of art stated by yourself: so there's a dear man, sit down and do it in fragments, and put it in the Leader, which is evidently a live paper, though whether most live for good or evil I can't say. (The bigotry is beastly, and points odiously to boycotting of Protestants, it secms to me.) 
But, being alive, it is capable of derelopment and making use of and training to higher things. I am yours very faithfully.

It is cold, NIV. and NE., but not unhealthy weather; the flowers are coming up and gorse splendid; trees colouring fresh every day.

To J. B. Yeats. Staverton Grange, April 14, 1903.

My love to O'Leary: he is a man I respect and have also an affection for (I don't often really love people I respect). I like to see and hear him. Wasn't that strange, that evening you and I sat on with him, and the landlord-man was so struck with him, and wanted to know who he was, and was pleased to have seen him? I went to Bedford Park the other day for the first time since I left : I hadn't the heart to go before. . . . Did you ever meet Leland (Hans Breitmann), lately dead, a handsome, anusing, real live person? I met him when I was a boy once, and now $I$ have to write about him and his writings. . . . Father Dineen I know and like. He has a power of work in him quite remarkable, and he is truthful and full of sense. I am sure, a sincere manl.

Why should you think you bore me? Character-sketches I adore. I am always trying to make them in as few words as possible, and watching whether my guesses are right, and nearly always I think better of people the more I know them, and am able to avoid what I don't like in them, and to find their unexpected pools of kindness waterlocks in what I thought was a dry river-bed. . . .

Sargent is all right, but has no soul to speak of, but such an angelie brush ; sometimes, like Baldini, a devilish brush. Watts is 'too dam littery' for me very oftell. I can't tumble to all those 'Love and Death' things; they seem to me childish and shadowy and really empty. Watts's sculpture is superb, and his portraits often quite miracnlous views of the landscape of eharacter.

The 'snake's-head' flowers are beautiful. . . . My Grange has two noble trees, a fir and a big hardwood tree, and I put in heaps of crocuses, yellow, bhe, and white, and they come up fine, and I have a growing hedge and heaps of creepers, and a bit of green at the back where one can sit and play. Come and see it. I am yours faithfully. 
The allusions in the following are to Dr. Meyer's edition of Cain Adamnain, the Old Irish treatise on the Law of Adamnan :

To Kuno Meyer. Staverton Grange, April 16, 1903.

They made good poetry, the late Munster men, and remained savages longer than the Northerners.

I suppose you will have a lot to say in your Introduction re Adamnan and the date, \&c., of the Synod.

The picture of the Irishwoman, babe and pole and knife and bag, is excellent. The women fight still in the factions, but usually bring up stones in their aprons for the men: but I had a friend who was knocked out by an Irishwoman in the Birmingham riots with a ginger-beer bottle in the toe-end of a stocking (a stocking she must have stolen by the way, as she didu't wear them); as he said, you couldn't guard it: it flicked over your arm and was extremely awkward to deal with.

To Mrs. Marriott Watson.

April 24, 1903.

The garden will be amusing you now, I expect, in spite of these killing frosts. Honesty, gilliflowers, crocuses, and riles are flourishing in mine, but everything else is blackened at the bud-end and on the young shoots. I hope for better winds and less snow in May. . . .

The Better Sort ${ }^{1}$ is delightful.

Wee Macgreegor is good.

I went to Manchester and saw a noble collection of watercolours there in a splendid light (it was actually sunny there). Such a grand show in the Whitworth Park museum. I had missed it about ten times, and now I had a chance, and it was worth waiting for.

The house is still satisfactory, I am happy to say, and when our new kitchen range is in to-night, and new boiler, we shall bake and cook like mad with much ease and comfort, I hope.

To J. B. Yeats.

Staverton Grange, June 30, 1903.

Bother A. Smith! I have lectured years on him and know him by heart almost. I know all about the potatoes and buttermilk and the porters and gay ladies. Our Cornish miners used to live on herrings and milk, and

1 Mr. Henry James's volume. 
they were strong, handsome and long-lived. Meat is not needful for stalwartness, though there are stalwart races that live on meat. Fish diet alone leads to leprosy.

I like your solicitor and his memories of Isaac Butta really fine human personality.

I must tell you a story. I like it awfully. A Scot named _- was left an estate and became a laird, asked his friends down to rejoice with him. One day they were examining a case of stuffed birds (relies of Nimrodism of last owners). "What's that bird in the middle, ? ?' 'I rather think it's a woodcock, but I don't really know.' Bystander, another Scot: 'It's not ma ideea of a woodcohk?' Third party (a man I know, after a long silence, quietly, but positively): 'Et's Gawd Awmighty's ideea of a woodcohk!' That story has given me intense pleasure. I hope you will like it.

Jack is going on broad-sheeting fine.

I don't like the Leader, though it is undeniably alive. It is hideously bigoted. I don't mind being like an oldfashioned Irish priest at all. I am tolerant in morals, and I have a childlike ferocity-and I hate and loathe 'makebelieve' that isn't my makebelieve. You will have your work cut out (God pity you) if you write fully about English and Irish mendacity. I am sure I shall agree with at least the 'weighty three-quarters' (as Edge ${ }^{1}$ used to say) of your article.

.. I I went down to my old school, now kept by the son of my old schoolmaster (such a good fellow). His sister, who used to teach me as a boy, told me (what I had forgotten) that I once fought a boy named Martin on the question whether black was a colour or not, and that we were described by the old honsekeeper as 'worse than Cain and Abel'. And now I hate arguing! I can't remember whether I thought black a colour or not, or 'on which side of the goose it was I was so awtul sound', in Breitmann's noble phrase.

... I have not read much save Claudine s'en va, by 'Willy', which is really delightful (not proper, so don't leave it about). You will like it. Claudine is such a nice person, so dull and so sane, and so cheery and attractive. 1 got a nice little book by Hiroshige the other day with pictures of the landscape (quite enchanting!) and I picked

${ }^{1}$ Gardener in Dublin, and hero of many aneclotes. 
up a great water-colour that quite ravishes my soul-a big scene full of air and wind and slopes and trees in the N. Midlands.-Jack will be a great colourist some day. He has such feeling. He is a wonderful chap and so nice to do with.

\section{To Miss Ella Pollard. Staverton Grange, July 7, 1903.}

I am elearing up odds and ends of work in the fine weather. I can sit and work all day, and then lie about and weed my lawn where the weeds (like the Universe of God in De Quincey's piece) have no end to them. I become bucolic daily. I pick off all the bad roses. I destroy bindweed. I am an enemy to shepherd's purse, and a deadly exterminator of plantains. I tie up drooping plants. I lop off suckers, I tend the tendrils of the creepers, and I sleep peacefully in a rug between these labours. If it were not for a little heart weakness I should be a person to be envied, contented wi' little and canty wi' mair. I even began painting the other day. But I have duties: papers in masses to be sorted, a room to be done up, and books to be shifted, which I neglect. Also I want to do some books, which I do not, but laze.

\section{To W. P. Ker.}

Staverton Grange, July 27, 1903.

.. . I have seen Knole (by Sevenoaks) since I saw you. It is magnificent, princely, best noble house I have yet seen in England. A deer-park, a flock of hundreds of white does, a noble stone house, and treasures of pictures, furniture, tapestry, broidery, china inside.

Finer than Penshurst, like a palace abroad, but set in the most beautiful English scenery. Do go and see it, if you have not. I dreamed of it. It was so enchanting.

... I am pegging away at times at Achillece millefolium, which plant is a libel on the name of Yarrow in spite of its virtues, for it infests my lawn 'tarrible, so it do. It fare to choak the tender grass, barn it!' I am yours very faithfully.

\section{To Miss Ella Pollard. Staverton Grange, August 2, 1903.}

I liked Gorleston. . . . The pier, 'Pinkie,' the boats, the garden, the white jumping-singers, the river, the sailormen [sketeh of sailor-men], the familiar 'site' of Gorleston, all are stamped or sealed in red wax on my white vellum memory. 'By these presents.' I am yours faithfully. 


\section{The Devil on the Ring.}

He's a starboard light in his larboard eye,

And his starboard eye is red,

He 's a regular wrong one out and out,

And there's nothing else to be said.

His silvery face and his tall goat's ears,

And his most alarming grin,

They give you the tip to look out for squalls

If you sail in the ship he's in.

But the good man thinks, when he sees him smile,

'He is making sure of me,

And I'd better beware, or he 'll snateh my hair,

And mark me down D-D.'

To Jaeli B. Yeats.

Staverton Grange, Aug. 3, 1903.

I have been away-just got the 'Nayo' and 'Theodore'1 -both excellent I think. C. is very anxious for the pixeyled maiden in the dimsies with the men in green.

The Clonmacnois-thing of Rolleston's ${ }^{2}$ is very good ; the land of roses, where all the great fighters and lovely ladies lay under the green turf sleeping their last sleep. I hope your show is a suceess every way in Dublin.

I have been to Gorleston, Suff.; such fine fishing-boats and grey sandful sea and opally sky!

I have also seen Knole, but I told you of that. We go to France next week. How is your father?

I send you the best thing Henry Kingsley, Cliarles' brother, ever did. I don't know whether it is illustratable, but here it is; it used to make me cry when I was a boy, and it makes me feel uncommon ereepy even now.

'Magdalene at Michael's gate tirled at the pin:

On Joseph's thorn sang the blackbird "Let her in! Let her in!"'... [Poem quoted in fill.]

I always liked Mary Magdalene in the N. Testament. If you find room for the little piece-it comes from II. Kingsley's Boy in Gray-I shall be glad ; but you will know best whether it ean be pictured or not for the $B$. S. [Broad Sheet].

I think it would make a fine picture by itself. I am yours very faithfully.

1 Poems in The Broad sheet.

2 Mr.'I. W. Rolleston's poem The Dead at Clonmacnois, from the Irish of Enoch O'Gillan: 'In a quiet water'd land, a land of roses,' \&c. 
Powell, now in his fifty-fourth year, had never ailed long or seriously since early youth, but in the course of May he had warning of heart trouble, which brought at first disquiet and gradually physical disability. But he did not rest until compelled, and showed no sign to the last of fearing for his life. He went on his visits to Knole, to Gorleston, and sped through all the London galleries; his pen was never busier than in his last year. In the first half of 1903, he wrote weighty reviews, some on folklore, some on the Cambridge Modern History; and also the few pages on Mr. Swinburne, which take us back to his own youth and its admirations, sifted now by cxperience but fresh and keen. In the last three months of the year, when he was visibly almost invalided, he wrote more and, as I think, better than ever. Many of the articles and passages it has seened right to save. The discriminating paper on Mr. Kipling; the poetic preface on the drawings of Miss Pamela Snith; the General Survey of Modern History, his chief manifesto on the subject; and the remarks on Mr. Lecky, all come from these few weeks. Almost the same pace was maintained when he was kept to his bed. Enforced bodily inaction strengthened his mental energy and the hold of his spirit upon life. He seemed to set a triple value on every little thing that could give pleasure or promise of pleasure to others or to himself. His creed of noble and unselfish epicureanism was now put to the test, when some of the outward sources of enjoyment were cut away; and it proved itself to be no fair-weather book-doctrine, but the expression of his nature. It would not be in his own spirit to say much of his sufferings. His letters and our memories prove that illness, while it brought no unmanly weakening of his antipathies or condemuations-surely a danger of which we may all cry Di avertant! -and still less any dislodgement from his stronghold as a 'decent heathen Aryan' (no such thing could be imagined of Powell), still set a keener edge on his affections, if that were possible, and intensificd his absorption in the cares and hopes of 
others. Nor did he cease to be considerably amused with life.

In August he waited somewhat late for his seaside holiday :

\section{To Oliver Elton.}

Staverton Grange, Ang. 2, 1903.

The sea-there is nothing like it for giving one peace and calm and air and light and natural life. I always feel better by and on it, though it isn't always comfortable, of course.

I haven't read much real good; the usual professional books and papers, that keep popping out like hardy perennials, always fresh, always (nearly), one finds, the same; but one must read them.

I have been working up odds and ends of things. I want to get away and get seriously to work, painting and writing and finishing the Origincs Islandi[c]ae.

Later in the month he went to see the performance of Marlowe's Edward the Second by the Elizabethan Stage Society to a congress of Extension students, summering in Oxford for instruction and entertainment. He was somewhat disabled; but was amused at the pleasant incongruity between the culture-seeking earnest audience and the philosophy of Gaveston and of Isabel set forth in that serenely reckless Renaissance drama. The character of the Queen, who changes her affections from Edward to Mortimer as she might change a cloak, is not one very easy to act poetically. The performer skilfully lowered the pitch, and spoke the line

\section{O, how a kiss revives poor Isabel!}

as mere lip-language, in a tone of gentle roguery. This solution delighted l'owell greatly, and he had to smother his mirtl. A bewildered intellectual seeker leaned over to him and asked 'what he thought was the poet's conception of that character?' Powell answered, 'I will tell you when we get ontside,' but added lower, 'A little French —_.'

All these days he succeeded in enjoying many things, although forbidden his tobacco. But it was clear that the calls of Oxford society even in vacation were bad for him ; 
young men coming for advice, business of all sorts, notables from abroad with introductions, expecting him to do the honours of Oxford-one, even, from the East, whom Powell's Arab courtesy forced him to accompany up many stairs : from all this he asked for flight. About the middle of the month he reached Ambleteuse for his last visit. $\mathrm{He}$ was laid up during part of the stay, but kept his eyes open :

To Oliver Elton.

Ambleteuse, Aug. 19, 1903.

The place is charming, wet or dry, the company very good, the rest pleasant: if only I can get to bask like a lizard in the sun, I shall get better, I think, though it will take time, no doubt.

The colour here is exquisite; delicate purples, greens, and fawns, with pink and blue and yellow here and there. A mighty sky, and a fine sea, and the blessed dunes, sandhills of enchanting form and colour. One gets the nostalgia of it. I have been longing for them for months, and I conld not satisfy my soul without them. The evenings are wonderful when fine; scented, soft, with noises of the sea, and breaths of salt and earth and herbs and woodsmoke and cows. I can't walk yet much.

He came back better for the moment, and wrote much; the force of his letters is not diminished, though there were intervals of rest:

I mayn't do anything, so I just fool about, looking at my Japanese prints and translating odd bits of verse.

\section{To Miss Ella Pollard. Staverton Grange, Sept. 24, 1903.}

I have done no painting, but I shall try and knock up a pieture from a sketch I took of the wrack at $\Lambda$ mbleteuse on the cyclone night. Such banging of shutters, howling of wind, crashing of tiles and chimmey-pots, min in sheets, spindrift flying fir inland and burning the roses and young twigs all black.

You had it too, I expect. The Broad Walk has suffered : the wind spun in whirls, and it has broken big trees as one could snap a earrot. The Grange has been lucky. My roses are coming out again, and my apples are fit for cooking. . . . 
If you [find] many good silver rings, think of me and let me know their worth.

I am yours very faithfully,

F. YORK POWELL,

otherwise known as 'Jollyman' and 'Ignoramus' and 'The Keeper of the Green-eyed Demon'.

\section{To J. B. Yeats. Staverton Grange, Sept. 26, 1903.}

I ought to have written you before, but I have been ill and away. I an bettering now. I have just got The Seven Woods? There is fine work in it, and it is most beautifully got up, quite delightful and a credit to the press your daughters have started. When are you going to write something yourself?

Letters on Art.

The Essential Evil of England.

The Commereial Curse, or the Curse of Commerce.

But I'd rather have a series of tales, such as some of those you have shown me from time to time. I want these unfinished stories finished and printed, and I want some of your Conversations with Tories on Art, Ethics, Literature (anrthing but politics). You can take me as your wicked 'Tory. "The Professor under the Dining-Table' instead of ' $\Delta$ t the Breakfast-Table'; or 'behind the screen'.

I am hoping to be all right at Xmas if all goes well. It is beastly being ill. One feels like a beast and wants to creep out of the way and die in a hole in a hedge somewhere out of sight. Do you know that feeling? I have always had that feeling, but I have not often been ill, so I have not been found in a hedge yet.

Powell now said his last word on the seience of history, reinforcing with sharper edge and wider knowledge the principles he had set forth when he became professor. A General Survey of Modem History he called it: it is one of the most shapely and decisive of his shorter writings, and $I$ have set it first in our volume of his rescued papers. It is a lecture in form: but he was too ill to travel, and it

1 Volume of verse by Mr. William B. Yeats, son of l'owell's correspondent. 
was read for him. The audience that heard it (October 3), one of the kecnest in England, was familiar with his presence in the New Islington Hall, Ancoats, Manchester. In two previous autumns Powell had spoken to the Ancoats Brotherhood, under the presidency of its guiding genius, Mr. Charles Rowley; on King Alfred in 1897, on Nelson in 1898. These Sunday afternoon discourses, with their accompanying music, have been for a quarter of a century a picturesque and happy element in the life of the black city. The hall holds more than five or six hundred working men and other citizens, who come week after week, respond with enthusiasm to what they like, and slip out if they are bored. Powell, when he addressed them, had taken his full allotted time, and was attentively and eagerly heard. It was not easy to believe, what we were told by some, that popular lecturing was out of his power. He talked rather than 'spoke'; talked without hitch or break, and without much modulation, though in a full voice; with a cadence, unnoticed in conversation, that was not entirely English, although I do not know its source. He always told a clear plain story, rising to eloquence of phrase, though not to rhetorical points or conventional pause-effects, and was heard with sustained attention. He neither 'lectured down', nor did he make familiar jokes, nor did he declaim.

To Oliver Elton.

Staverton Grange, Oct. 16, 1903.

My lecture was not so bad as I thought and feared it would be. — did not read it after all. I spoke some home truths.

Have you read Shaw's last book-Bermard Shaw's? If not, lo. 'There is the root of the matter in it to me. But how silly he is to sneer at Science-Science, which has given us everything that raises us from the apes (not that we are very far from that horrible beast after all). Why do people snigger? . . B But oh, he has a clear eye for lots of things. You will hate him, I am afrairl: but he makes for righteousness, and he is much more in earnest than he seems.

I am mending still and feeling better now. 
Through these months he wrote hopefully, watchingthough happily he did not know it was for the last time -the autumn descending upon Oxford and his garden: 'I am going to get a sundial; I feel I shan't be happy without it.' He was eager to get to London 'to see Phil May's things and my old pals', but weakness disallowed this hope.

To Mrs. Marriott Watson. Staverton Grange, Oct. 23, 1903.

It is splendid to be able to make such rerse. Doesn't it atone for a lot of life's little ironies and big sarcasms when you feel you have done work like this? You are quite sure to live in heaps of people's hearts and on many lips.

Poor Egil ${ }^{1}$, when he lost his sons, do you remember? he said,

I was friendly with Woden

Till he broke his friendship with me,

So I do not worship him any more.

Yet he gave me recompense for the wrongs he did me :

If I care to count up his benefits to me,

He gave me the blameless art,- the poet's song.

I think art after all is the great compensation. . . . I think I shall like the sad songs best, because I am still young at the heart, only I see more clearly than I did when I was young in the skin. But when I have read them all I shall be able to tell you more of my thoughts about them when we meet. But I liked so much the bits I read this morning that I feel I must just scrawl off this at once.

In November he managed to see the Exlibition of Portrait-Painters: nor could illness touch his delight in vision.

To Charles Bonnier. Staverton Grange, Nov. 20, 1903.

Je suis allé aux Portrait Painters, et lì vraiment j'ai eu une vive émotion: non-seulement le Madume Brsnard, un Besnard qui est fort, fort bien, mais un Orchordson suprême, le plus beau portrait moderne d'Angleterre depuis le Carlyle de Whistler : une vieille en noir assise seule dans un salon. Mais c'est d'une finesse, [d']une ampleur, [d']une

1 On Egil see the translation of Sonatorrek, rol. ii. pl. 238-40.

Y. P. I

C c 
simplicité savante, c'est un véritable chef-d'œuvre. Je m'arrêtai en le voyant, avec étonnement d'abord. Je n'avais pas l'idée de le trouver là, une si triomphante chose, et puis j'étais là, cloué en face de cette création magnifique et belle. Faut le voir. Il y a d'autres de lui bien, très-bien, mais pas du tout si bien. J'étais heureux en le regardant et un peu touché. On se souvient de ces instants, n'est-ce pas?

In December he was weary ; though most of his professional teaching had been relaxed by permission, he had worked at home. The death of Mr. Hines, at Christmas time, deprived him of one of the Oxford friends whom he most regarded.

Dec. 26, 1903.

Poor Hines, my chimney-sweep friend, is dead, suddenly and without pain. I am sorry: I liked him; but he died as he would have wished. . . . I am tired after term, and I want just a torpid time for a day or two, and then I shall have to go to Folkestone to see my mother, who is living there. I want to look at the sea.

To Mrs. Hines.

Staverton Grange, Dec. 26, 1903.

I am very grieved at the sad news Elizabeth brought back this evening.

I respected your husband very much, and liked him ever since I first saw him many years ago, and I think he was a man that did all the good he could to his fellows, and I know he helped many people in many ways. It was always a pleasure to me to see him, and I wish I had been able to see more of him lately, but I have been unable to get about much lately, as you know.

There are many besides myself that are sorry to lose their old and tried friend, I am sure. I think many of them will be wishing to do what they can for you.

I know what it is to have grief, and I sympathize with you in your sad trouble, because I understand what it must mean.

I am glad that the end came painlessly and suddenly, as I think he would have wished himself, though it comes of course as a shock to those that loved him.

I have asked Elizabeth to let me know if I can be of any use to you. You will let me know, I hope, if I can. Later on we must talk over the future. 
I think this is a loss not only to his friends and kinsfolk, but to Oxford. I have lost a real friend, I feel. Believe me yours faithfully.

To show how well Powell wrote in his last months, and how his mind never failed in decision, it may be interesting to give here some passages from some of his reviews. To Bruno he had already done honour in his letters.

A novelist might make as striking a tale of Bruno's career as Charles Reade did that of Erasmus. . . . The man himself, [with] his love of verse, his intellectual pride, his curious choice of strange vehicles in which to convey his ideas, his boldness and aloofness of view, his mathematical explorations, and Hindoo-like love of arithmetical and geometrical symbolism, his keen, fierce satire, his ready and fluent pen, and his complete absolution from the old philosophy; his extraordinary pedantry and his incongruous humour, his love of travel and his nostalgia, his ready apologies and his stubborn refusal to apostatize, is a character such as no land save Italy in that age could have produced. He was, as the true instinct of his countrymen has pronounced him, a martyr to truth. He worshipped and served wisdom, and for wisdom's sake he died a most cruel death, and renegades and scoundrels like Schopp (whom, as our author gleefully tells us, Lord Digby afterwards had soundly horsewhipped for another offence) rejoiced over his death after their kind. ${ }^{\mathrm{I}}$

Yet more notable are his last sayings on the Renaissance and the Reformation: they give his deliberate thought, and are not words of impatience. Sometimes Powell urged that the polities of to-day and those of the past should both be discussed in the impersonal tones and from the extra-moral view-poinl of science. At others, he so realized the sixteenth eentury that he spoke of it with the same passion and colour as of the twentieth. It is easy to make play with the seeming inconsistency. The attitude to the Reformation as a whole is far from philosophical. But we hear Powell's own opinion, his animating principle ;

${ }^{1}$ Review of Giordano Bruno, by J. Lewis McIntyre. In Pall Mall Gazette, Oct. 15, 1903. 
he takes his side once more; it was the side he had always taken. He is a humanist incorrigible, and a naturalist born.

The volume before us deals with the religious changes that took place between the death of Alexander VI and the death of Calvin. It is a sad period; it is impossible to sympathize with either the Papacy or its opponents. The personal characters of the Reformer's and their adversaries are often equally bad-treachery, mendacity, perjury, assassination and the most diabolical cruelty are qualities shared by the chief partisans on both sides. Dr. Fairbairn's hero, Calvin, was a detestable personality with all his genius, and less of a Christian than Loyola or even Borgia himself, if the standard of the Gospels be applied to his career. The brutality and dishonest shuffling of Luther are as obvious as his courage and force of words. It is among those who were reproached for standing aside from the parties that reason and fair play were chiefly to be found. Erasmus had faults, but he was not cruel. Rabelais was 'coarse-minded', if you like, but he was humane, and thought wisely and clearly, and made for hope and charity, even if his faith would have dissatisfied the narrow-minded and revengeful tyrant of Geneva or the Holy Office in Spain. Even the heretic Utopists, Matthys and Jan van Leyden his disciple, followed after the bloodthirsty Old Testament Kings and Judges rather than accept the lessons of the Evangel. There is blood over the whole history of this Reformation, blood and fire. It is one of the most shocking chapters in the long and unfinished story of human folly and delusion, a pitiful tale of bigoted and besotted ignorance, an outburst of maniacal hatred, a long-drawn-out reign of terror.

$\therefore$ It is good and also just a little amusing to see Dr. Fairbairn put the curé of Meudon, with his wholesome sense and sound learning, above the Genevan's vicaire savoyard and his empty pretension and sentimentality. If France had listened to her native Rabelais rather than the alien Rousseau, she would be happier and more united. That Dr. Fairbairn (whose eulogy of Giordano Bruno is excellently put) should not find in Montaigne a teacher of the strenuous life, was but to be looked for. "Where man so doubts, he is too paralysed to fight or to affirm,' says he. 'Montaigne's sympathies might be with those who worked and suffered for a new heaven and a new earth; but his 
egoism inclined him to the conventional and followed the consuetudinary.' 'This is well and truly said : yet who shall deny that Montaigne, with his donbt perpetual, his instinctive humanity, his sober pity, makes, in his own way, for righteousness? The output of the Teutonic Reformation is poor as literature or philosophy. Erasmus, Milton, Luther, Knox, were mighty men of letters, but hardly great thinkers. Erasmus and others are good scholars, and Ulrich von Hutten a powerful and effective humorist; but Bale's violence rather than his learning or his comedy is typical of the Protestant controversialist. We have none to set beside 'Telesio, the 'anticipator of Bacon', or Campanella, 'who anticipated Descartes,' nor northern Ficino or Galileo, no Pico or Landino or Poliziano: we even lack a great realist such as the much-abused but gifted Pietro of Arezzo. ${ }^{1}$

And here, to show how constant was his attitude, may be saved some words on Rabelais and Ulrich von Hutten, printed nine years before:

Rabelais was the greater and wiser man of the two, better skilled in human nature, more deeply skilled in the interpretation of the signs of the times, earnestly fixed upon the great problem of education as the key to the new era that he hoped would be happier than the old. Erasmus was the pioneer of the new culture, his work told with the clerks as Rabelais' with the laymen; and for generations schoolboys studied Erasmus as one of their Latin classies. of the third great humorist and humanist, Ulrich von Hutten, chivalrous, brilliant, reckless, observant, who united Shakespearian gift with a Marlovian life, there is plenty to be said. His work and his influence have been too often underrated. He stood up for Renchlin and Luther when they needed help: he smote ignoranceblatant, shameless ignorance - the heaviest blow of all. He taught friend and foe alike that the old position of orthodoxy was untenable. Loyola instinctively felt this, and with his Napoleonic genius organized his advance upon the new field with enormous suceess. The conqueror had tanght the conquered the one way to check his vietorious career. We have to wait for Pascal, Voltaire, and Diderot

${ }^{\prime}$ Review of The Cambridge Modern History, vol. ii : The Reformution (1503-61). In Pall Mall Gazette, Feb. 2, 1904. 
before the tables are again turned, and the new, sciencemade weapons brought up against the orthodox array with results easily foreseen. ${ }^{1}$

The truth is that Powell from first to last responded deeply and with passion-if alternately-to two different types of thought. His temper was formed just as much by Rabelais and Montaigne as by Alfred and Langland and Ruskin. He did not trouble to draw the lines of relationship between the two types, or to think of their contrast. It was enough for him that both were great and genuine; each was a prophet in his way, each an observer. You never knew which would be uppermost in Powell; only, that neither of them ruled out the other.

Here too are his last words on Transatlantic art and letters; it appears that therc are hopes for America after all.

The Spanish critic, Valera, gravely lays it down as a postulate that north of Mexico and south of the St. Lawrence one seeks in vain for art and poetry. Without going so far, it is certain that the intellectual and artistic growth of the States has been very slow till the last thirty years, when there has been a real literary and artistic awakening. St. Gaudens, Richardson, Low, Cable, Harris, are notable names, besides such Cisatlantic Americans as H. James, Whistler, Sargent, Alexander, Stuart-Merrill, Viélé-Griffin, who have been, each in his own way, pioneers in their respective arts, and have done much to lift away the reproach of lack of originality and of sincerity that lay upon the so-called literary classes of the United States; whereas before them the writers and artists of the States are but flat echoes of voices from this side of the Atlantic, with the noble exception of Whitman, a puissant and original figure, whose true greatness is even yet hardly understood by the lettered classes of his countrymen. The humorists, Sam Slick of the Dominion, Clemens, Harte, Browne, Adeler, and a swarm of lesser figures, were the first to show real local colour in their work. In the colonial days Mather, a writer

1 Review of Froude's Erasmus: in Manchester Guardian, Oct. 2, 1894. 
of high merit; Edwards, a massive theologian; and the overrated Franklin; are the most notable writers. Emerson, Longfellow, Holmes, and their fellows, attained extraordinary popularity, but cannot claim the place that many less-informed readers would fain assign to them. The extraordinary and classic beauty of Lincoln's oratory, far the finest spoken eloquence of the last century that the English-speaking peoples have known, is above all other American rhetoric ; indeed, to find a parallel to the Gettysburg speech one must go back to Pericles himself. ... $\mathrm{He}$ towers above every public man in America since Washington, to whom, as a man, he was probably superior, and in no degree inferior in the field or in the cabinet. ${ }^{1}$

After a stay in the holidays with his mother at Folkestone, where he had a relapse, he returned to London, and made his last public appearance. He was president of the Folklore Society, and gave his official address on Jan. 20, upon Tradition and its Conditions. ${ }^{2}$ This paper is an inductive plea, with examples from Irish, Norse, and Maori history, for the high and accurately memorizing power possessed, under favouring circumstance, by purely oral tradition; which, he argues, may thus have, even after the passage of centuries, a more scientific value than is commonly believed. It is written with caution and rigour; the necessary learning had lain long in his brain, and his conclusions had ripened. More than anything he latterly wrote, it conveys the sense of the loss that Powell was to his favourite branch of historical science. With his stock of lore, he could have done much else of the same kind; but his frame was not to hold out. It seems to have been the last thing that he wrote for print. The delivery of it was a strain, and he was glad when it was over. He refreshed himself by going to all the picture shows that he could. All his remaining letters are written from Staverton Grange.

1 Pall Mall Gazette, July 13, 1903: review of The Cambridge Modern IIistory, vol. vii : The United States.

2 See vol. ii. 1'l. 242-53. 
Many thanks for the stencil, and these jolly inn pictures, which I am trying to write up to. The stencil reminds me of the Captain Cuttle, little ship sign, with the middy taking a sight of the sum with his sextant.

I have been to London (I was ill at Folkestone), and have seen Peppercorn (splendid this year), the Blakes (very fine examples too and the best I have seen), the Old Masters (Lawrences and Raeburns superb), and also Conder's exhibition, which is very good. I was staying with Conder, who was very kind to me, and is doing some fine work of his own kind.

... I am better (since you ask, but I hate writing so mich about myself and my health) and recovered my Folkestone relapse. I hope to go on better. Being with the Conders did me good. It is lovely here now and must be finer in Devon. There is a hard white frost on now, which only yields when the sum falls directly on it.

To Mrs. Marriott Watson.

Jan. 28, 1904.

I have been seedy again and could not get about, but I am better now the weather is warmer. The cold fairly 'clems' me now. What beastly thermometers we become when we are ill.

There is no news here, but it looks like war.

I am pleased with W[hitaker] Wright saving us his expenses for some years and dying game. All convicts ought to be supplied with prussic acid to use if they like. It would effeet a salutary clearing and redeem their characters too.

Have you read Call of the Wild, by Jack London? Are not the pictures exquisite?

I am reading only history books now, for my sins, but I got in Judith Cladel's Rodin, which is really excellentexactly the man and his talk. It is published at La Plume office, Paris.

The Blakes at Carfax are very good indeed. You would like to see them.

To Mrs. Marriott Watson.

Feb. 4, 1904 .

We are all afloat in the Thames valley-highest floods for years; road covered, towpath under water; basements of cottages all awash; people getting about in punts; gardens covered to the tops of the gooseberry bushes, and 
the like. It is better to-day, but still it looks as if old Noah's days were coming back in spite of the rainbow.

That is an awfully good story of Marriott's-Lady Molly. C. and I both liked it immensely. The little vixen is excellent and very true to life. How the dickens does he get inside these people?

I have a new picture Conder gave me, very pretty sketch of the sea at Ambleteuse. It looks nice to-day with the sunlight and clear air.

It is lovely to-day. C. is off to a football match with a pal. I am off to committee and the rest of it till ten o'clock.

I am still seedy, but the fine weather always makes me better.

Have you seen Blunt's Golden Odes of Arabia? He dedicated them to me. I am very proud of this, as I think he is a very swagger poet indeed.

There isn't much new here this term, except the floods, and I hope they will shortly disappear.

Your 'new model' of the garden will interest us. I am beginning to think of sowing seeds. My crocuses are, I hope, soon to appear. I have some primroses in bloom. The daisies have increased terribly in the lawn, whence I took heaps and heaps of plantains, but still they come; and I shall have hours of weeding peacefully; many, I foresee, if we only get a few hours of sun later on.

I have put in broom and St. John's wort, which I am very fond of. I hope they will flourish. My hedge is beginning to grow thick and green. I am yours very faithfully.

To Miss Ella Pollard.

Feb. 5, 1904.

I have made the discovery that I am descended on one side from Montrose, and on the other that I am very near the attainted title of Viscount Dundee, my mother's family being related by marriage to the Grahans of Fintry, the representatives of Dundee, the 'bonnie Dundee'. 'This pleases me immensely. If - is to be a peer of England, I think I onght to be a peer of Scotland, don't you? a modest position, which I might be able to maintain at small cost. I will send Frank the trees. It has amused me very much, but I am delighted to find out why I hated the Camploells by birth and nature: now I know. ...

Frank must come and stay with us. We have a clean 
house so far. We live simply; alcohol is supplied free of expense; there are no family prayers, but a church is laid on near the house; and there is a Chinese professor opposite, and a man who has seen the snake-dances [illegible] within call. The soil is gravelly. The use of the gardens is allowed to inmates. Many University lectures free. Chaperones provided with due notice. With such amenities you can hardly hesitate to visit us. Gas is laid on in bedrooms and electric light in livingrooms.

To F. P. Barnard.

Feb. 27, 1904 .

Isn't it fun, the way the Japanese are giving the Russians what for, avenging the Finns and all the people the Holy Russians have bullied or brutalized? I am heartily delighted. I have not read anything very amusing lately; a few American novels, none quite good. The American woman is as hateful in fiction as in reality, as a rule : Mrs. — is an exception, and her mother.

After some weeks of effort to do his work, and attend 'only the necessary committees', he had been sentenced to keep his room.

To Charles Bonnier.

Feb. 29, 1904.

Je suis assez gai, on est très gentil pour moi. J'ai des visiteurs, et on m'envoie des fleurs comme à un toréador blessé. Je suis, je crois, paresseux au fond, car je ne trouve pas les jours trop longs. Les nuits, quand l'haleine va mal, sont quelquefois un peu trop 'caloriques', mais que voulez-vous? si on est malade il est évident qu'on a des moments d'ennui.

To W. P. Ker.

Mareh 10, 1904.

The Doctor thinks I am going on well ; he said so to-day. IIis medicine is so beastly I think it must do good.

I know J. Conrad, a great swell at writing and quite worth talking to. I think a lot of him.

Ruskin Hall is doing a deal of good. I know its work. The big Trades Unions are making levies and sending their best men up to it for education.

I agree with you over that damned railway. What brutes people are! Put my name to it, ${ }^{1}$ though I only know Snowdon from a distance. Yours ever faithfully.

${ }^{2}$ Petition against threatened new railway in Snowdon distriet. 
To Mrs. J. R. Green.

March 23, 1904.

I have done three weeks' bed, and am not very weak, so that's good, isn't it?

I have no pain, and no cause to grumble, when I might have arthritis or plague or cancer or anything.

To F.P. Barnard.

March 25, 1904.

I am mending slowly, but regret the lost sun. Yesterday and to-day cold, snow, sleet, as it is Boat Race day to-morrow and bound to be foul weather.

Yes, it is true about 'Agudo' = Hawkwood, ${ }^{1}$ the famous soldier of fortune. 'Agudo' in Italian is as near Hawkwood in Mid-English as may be.

I don't know how the time passes, but it does, and I enjoy my days: the smallest variation amuses me now. I read Palmer's trial, and Madeline Smith's, yesterday: both excellent. I got Maclagan's Jerusalem (edition of Blake's prophecy) and a good novel to read, and I slept a fair lot, which was delightful.

To Mrs. Marriott Watson.

March 27, 1904.

How are you all? I am still in bed, but mending I hope. ... Even here the spring is beautiful, and it is beginning now.

Send me a line when you have time to say how you are.

I send you a sonnet I wrote 10 years ago from my $\mathrm{Ch}$. Ch. rooms looking on the Broad Walk, when the elm-leaves were falling like gold 'patins', and the shouts of the men on the river racing, and the patter of their feet rumning down to 'the Boats', could be heard.

It wants mending, but I send it as an impression I had then, and I've nothing better to send you just now.

Take care of yourself. I am yours faithfully.

Late afternoon November, 3 Meadow Buildings, Ch. Ch.

'Warm gusty showers,' \&c. ${ }^{2}$

To Mrs. F. S. Boas.

March 19, 1904.

I look out of window on my 1,000 crocuses. This is the House of the 1,000 Crocuses now ! and see the people pass,

${ }^{1}$ Described on his tomb in Florence as 'Joamnes Acutus'. Mr. Barnard refers to Verstegan's Restitution of Decayed Intelligence (1605), ed. $1673, \mathrm{p} .335$, where this fact is mentioned.

2 The sonnet is printed below among l'owell's verses, vol. ii. p. 388. 
and I see a few people (three) every day and write a few letters.

March 29.

Thanks for your letter. Do try and get the Song of the Tipsy Hen written ont for me. I think it immense. The child will be a poet as well as a fighting man; the two best professions (next doctor and artist).

I can't write much, for I have written $\mathrm{G}-$ a longish letter and I get tired easily still, but I am very glad to get letters, so I must try and scribble a little gratefully. . . .

It is a SIV. wind, soft, showery, sumny to-day. I like it, my window can be open wide, and I can see the crocuses and the purple distances over the Cherwell. I am living in my study downstairs, my bed moved there so that I need not walk upstairs at all, which is bad for me. The trees and hedges are all a-bud.

I have an enormous pot of real shamrock (oxalis), the sort the wild Irish used to eat with cress, in my room, and it is begimning to flower ; also an azalea, white and another pink, and primroses and violets, and a lot of the pictures I like. You see I am well off, if my heart would only 'get a move on' towards perfect health. It is moving slowly, however, so I have nothing really to grumble at.

Have you read Lady Gregory's Cuchullin and Finn? They are good, both of them, and Douglas Hyde's plays are wonderfully fine, quite first-class.

Meantime, ignorant of his fate, Powell had taken up new labours. In the beginning of 1904 had been formed the Oxford University Tariff Reform League. He was disposed to favour the new agitation; and the young Oxford men, who were for planting Mr. Chamberlain's flag in the University, approached him eagerly. He did not like a public position, he felt physically weak, and he could not at first believe that he was so keenly wanted. At last he accepted the offer to become President of the League; he followed its fortunes eagerly, and its rapid progress pleased him. Enfeebled as he was, he was judged to have served it well. He was not a professional economist or statistician, and we may ask why he ventured into such a field. To show where Powell stood, some words may be quoted written by Mr. L. L L Price, a leading member of the League : they are, of 
course, those of a convinced adherent; but they probably express very nearly Powell's mind on the tariff question. I have not found any written word of his own upon it.

I had known, in conversation with him beforehand, that from the outset he felt that Mr. Chamberlain had discerned the paramount necessity of the times in a closer union of the Empire; that with all the buoyant eagerness of his nature he was convinced that this was the supreme political question of the day, to which patriots should devote their utmost energies; that with characteristic comprehensiveness he was the last person to allow economic pedantry to weigh for a moment in the balance against the graver and more permanent questions connected with the opportunities offered by Tariff Reform for Imperial Consolidation. . . .

With regard to the economic aspects of the question, indeed, he was by instinct and training inclined to deprecate abstract reasoning and to welcome concrete fact. His sympathies here undoubtedly favoured the historical treatment of economics; and he could accordingly, when the occasion came, throw aside without effort the disabling ties of an established dogma. In his Inaugural lecture as professor he passed a handsome enlogy upon Mr. Charles Booth's monumental researches into the Life and Labour of the People of London, and it was in this and similar directions, as I know, that he looked for the most fruitful developments of economic study. To the manifesto of the Professors, which dealt with Mir. Chamberlain's proposals on grounds of abstract theory, he was disposed to pay even less attention than perhaps it deserved, and he was not prepared for a moment to allow that for reasons like these such a movement as Tariff' Reform should be dismissed from the serious consideration of men anxious for the welfare, both political and economic, of their country and the Empire.

Powell, then, was a Tariff Reformer because he was an imperialist, and because he disliked abstract economics; both characteristic reasons. 'I have reason for hoping,' adds Mr. Price, 'that his tenure of this office gave him not a little pleasure in the closing months of his life.' But his time was now short.

In April, though still a prisoner, he was expecting, not 
without dread, to travel to Nauheim for its 'cure'. ' $I l$ me semble que je serai embêté jusqu'aux os.' He did not care for the Germans, with some exceptions : they and their ways were amongst his antipathies. He had no joy in the prospect of the talk at the table d'hote, though happily there would be 'Russians, Scandinavians, and English there as well, of whom one could find two or three to talk to'. Possibly, he thought, these dislikes were only a proof of illness and weakness. As it was, though enfeebled, he was not in pain; he lay with his windows open all day, 'et ça m'amuse beaucoup.' He would mueh sooner than go to Germany, have been in Paris, 'bouquinant le long des quais.' He was happy in never expecting, or so it seemed, to die. He lived in the present, writing short notes, seeing those who came to take what they, not he, knew was a farewell, and enjoying the 'fresh spring winds, fine clouds and sky, and nice light'.

To W. P. Ker.

April 9, 1904.

Many thanks. You ought to be happy among the 'merry white hares' and ptarmigan and the earth the whisky is made from. I am glad your father is better, remember me to him, please. I gang hooly hooly, but the doctor seems satisfied, so I ought to be. I am still in bed. Man, ye're luck's pheenomenal. Take eare! Give up smoking for a day or something of the kind ! . . I I have read some new things, mostly bad, and some old things, mostly good. I am not up to translating yet, or doing any work, as I feel weak sometimes, and a very little tires me. . . People who will sit and talk to me I value. I am not yet up to making conversation. Take care of yourself. I am yours very faithfully.

To F. P. Barnard.

April 24.

My mother is here, and my sister has been here, which has helped me a lot to pass the time, which grew very long and seemed to stretch like india rubber.

Amongst Powell's last fragmentary notes may be given one he sent expressing a wish that some one should be found to do an English study of Schopenhauer. One 
of the first of his letters to Vigfússon, it may be remembered, was on the same writer, whom he liked as a master of style and wished to understand as a man, though Schopenhauer's philosophy was not one to touch Powell for a moment, least of all when he might be thought to have most call to find that life was vanity. But he did not find life to be vanity at all; he enjoyed science, flowers, and friends, and having a little conversation, and considering what sort of a book should now be written upon Schopenhauer.

\section{To Oliver Elton.}

April 25, 1904.

Schopenhauer, yes. There is nothing masterly on him in English. One wants a brief clear introduction to him, placing him, showing his point of view, what to read first and what to re-read of his, and his limitations and omissions and strong sides. I think it could be very useful and certainly very readable.

- is a curious piece of psychology, like a big and fairly sensible dog, with good instincts and no human absurdities of the ordinary kind.

I am trying to read Herbert Spencer's Life this week; poor man, never happy, too self-centred. Better be Nietzsche, with fierce joys and woes and then oblivion: after all, he was human. You must do something on him (Nietzsche) some time.

\section{To Miss Ida Farnell.}

May 2, 1904 .

Many thanks for your kind letter. I am getting better at last, I think, but it is a long job. They tell me I shall be able to work again in October, and I hope to. I am not in pain, and every one is very kind, so I am not unhappy, and I get a lot of rest. I am yours faithfully.

Mr. Demnis Hird, whose chronicle of Powell's dealings with Ruskin College has been given, writes :

I visited him some ten days before his death on one lovely spring afternoon. He was full of plans for our work, keenly alive to the needs and possibilities of the movement, and concerned that men who were doing the work were so inadequately paid. In fact, one of the last things he did 
was to draw up, in his own handwriting, a scheme to reorganize the remuneration of the staff, whose work he had so greatly helped. He was ealm, bright, hopeful. I recognized that he was smitten, but I little thought that in a few days I shonld see his body committed to the earth, in the silence of dumb homage to his unobtrusive greatness.

Late in April a London newspaper accepted and printed the false news that Powell was dead. He was startled, but laughed, and begged that any obituary notice might be sent for his entertainment. He had no intention of dying, and went on writing his scraps of letter, reading a little and commenting. 'I still like good verse almost better' than anything else in the world of speech,' he wrote a week before the end. And on May 5: 'Yes, spring does not disappoint me: we have a clutch of thrushes hatched by our porch. I can't write more.' On Sunday, May 8, he was able to please his long-ruling passion of finding the right person to do the right and appropriate work. One of his visitors, Mrs. J. R. Green, interested in the furtherance of Irish learning, said afterwards, ' I came away from him, feeling there were some things worth living for, and that I was wasting half my life.' The same evening, being in good spirits, he spoke of going into the garden, and finished some letters. The attendant who took them to the post returned to find that he had died suddenly in his chair; alone, as he would have wished for the sake of others. He had once written of his grandfather, who also died with no one by : 'I think he was right.'

On May 12, under the spring sun he had welcomed, he was taken to Wolvercote cemetery, which lies to the north of Oxford. A long train slowly followed on foot, of Oxford men past and present, Church dignitaries, artists, professors; of youths, of men who had not met for long and found each other older, of men who did not know, or know of, one another. He was also followed by some of the staff employed on the University Press which he had long served. He was buried, by his own instructions, without any rite 
and without anything being said. The procedure had the dignity and rightness that he would have commended in the case of any other man who thought as he thought; and those who knew him best felt the most that it was in harmony with his lifelong mind.

The chapter may close with some words once written by Powell in a letter :

. . A coal fire makes me sleepy — the gas, I suppose, if I sit by it. Wood-fire does not, nor peat.

But I think it is good to read a bit, when one goes to bed, something one knows and likes to read again; something one just licks over the savour of, chews the end uponArabian Nights, FitzGerald's Letters. Long memoirs are only read a few pages, and then comes drowsiness, and a sort of dull soft thinking, and then one feels sleepy, and the velvet feeling comes: one falls slowly through velvet air into velvet clouds that just hold one up and prevent one falling too fast, and before one has sunk far one is asleep without knowing it-in the real dreamless sleep. 


\section{CHAPTER IX}

\section{TRAITS AND OPINIONS}

Powell's conception of written history : contrast with Lord Acton's. Origins of Powell's view. Relationship of literature and history. Powell's historical style and diction. His languages, erudition, library: acquaintance with Spanish literature. Taste in letters and mode of criticism. His love for les jeunes: indulgences, severities. Mental position in Oxford: testimonies from Oxford: Bishop Paget, Dean Strong: Dr. Charles Bonnier. Religious views. Peculiar attitude towards death. Letters of sympathy, praise, advice. Theories on the feminine nature. Description and analysis of Powell by Mr. J. B. Yeats, quoted. Personal appearance and talk. Notes on ethical standards. Perplexing attributes. Leading characteristic.

WE have partly seen how and why Powell, with all his gifts and historical erudition, left no large example behind him of the methods that he urged. He taught, and he found the path for many others. His achievement in Icelandic scholarship was signal. The picture of his written work is completed by his bricfer papers and articles, with their many flashes of long or second sight; together with that little History of England to 1509, which Lord Acton said was the best known to him upon the period. But though Powell did not produce much historical writing of a continnous kind, he said elearly and sharply and repeatedly what he thought of the relation of written history to ethic on one side and literature on the other. This theory, though imperfectly worked out and inconsistently applied by Powell, is highly distinctive of him. It is no brain-spun view : it tells us of the man and of his ontlook upon life; it gives him considerable claims as a heresiarch.

Lord Acton, as might be expected, has uttered with curious precision the doctrine in which Powell disbelieved. 
It is the office of historical science to maintain morality as the sole impartial criterion of men and things, and the only one on which honest minds can be made to agree ${ }^{1}$ . . . If King James burnt witches, if Machiavelli taught assassination as an art, if pious crusaders slaughtered peaceful Jews, if Ulysses played fast and loose, we are exhorted to remember the times they lived in and leave them to the judgement of their peers. Mobility in the moral code, subjection of man to the environment, indefinite allowance for date and race, are standards familiar from Schlegel to the realistic philosophy. Although Ranke practises moderation and restraint, and speaks of transactions and occurrences where it would be safe to speak of turpitude and crime, he kept himself above the indifference and incapable neutrality of those who held with Gerald Hamilton that there are few questions on which one may not rote conscientionsly either way. . . . There is no escape from the dogma that history is the conscience of mankind, unless for those that reject the collective growth, the canons that rivet the future to the past, and take their stand with Archimedes. ${ }^{2}$

Lord Acton condemned any historical work that appeared to neglect these principles. Dr. Creighton printed in his own review, the English Historical, the well-known criticism (of his History of the P'apacy) from which the first of the above sentences is quoted. Also, in an article ${ }^{3}$ posthumously published, he defined his own view with a skill and candour to which justice cannot here be done. He pleaded for 'as much casuistry in history as will serve to distinguish between venial and mortal sins'. The latter include, above all, treachery and assassination, together, as he seems to say, with some forms of persecution. The whole paper is a striking expression of the view that may be called intermediate between Acton's and Powell's. And Powell may have had some such discussion in mind when he explained his own position in his Bangor address.

1 English Historical Review, July 1887, vol. ii. p. 578.

2 Ib., Jan. 1886, vol. i. opening article.

${ }^{3}$ Historical Ethics: in Quarterly Review, July 1905, pp. 32-16.

D d 2 
I confess I do not look on History as a branch of Literature or a province of Ethic, but as a branch of Seience dealing with man under political and social and economic conditions, and my conception of History makes it the necessary complement to Biology and Anthropology. . . . As to Ethics, I must continue to differ wholly from Lord Acton, my distinguished Cambridge colleague, and profess that it is not the Historian's duty to try and estimate the exact degree of damnation that should be meted out to that dauntless captain and bold statesman, Cesare Borgia, or even to his capable but unpriestly father, or to play the moral judge to such men as Thomas or Oliver Cromwell, or 'that great king Harry the Eighth', or to Napoleon. I must leave such work to the professors of Ethic, to whom History at any rate supplies plenty of examples. We have no lack of philosophers, let us hear them! Of course, the historian must deal with the History of Moral Ideas as he must with the History of Religions, he must trace the circumstances under which all mental phenomena (healthy or otherwise) of the body politic originate and spread, and are furthered or combated, but he is the observer not the preacher, the biologist not the physician or surgeon. . . . The History student ought to concern himself with his documents and facts precisely as his fellow-students, chemists, physicists, or biologists, do with the objects in their laboratories. ${ }^{1}$

The case is put with equal edge in the preface written by Powell in 1898 to the work of MM. Langlois and Seignobos : ${ }^{2}$

To the historian history is not merely a pretty but rather difficult branch of literature. . . . The literary critic, in fact, is beginning to find ont that he reads a history as he might read a treatise on mathematics or linguistics, at his peril, and that he is no judge of its value or lack of value. Only the expert ean judge that. . . The formation and expression of ethical judgements, the approval or condemnation of Caius Julius Cacsar or Cesare Borgia, is not a thing within the historian's province. His business is to find out what can be known about the characters

1 see vol. ii. pp. 85-7.

2 Introduction to the Study of IIistory; translation by G. G. Berry, 1898. See p. 252 supra. 
and situations with which he is engaged, to put what he can ascertain before his readers in a clear form, and lastly to consider and attempt to see what scientific use ean be made of these facts he has ascertained. Ethic, on its didactic side, is outside his business altogether. . . . They [MM. Langlois and Seignobos] are bold enough to look forward to a day as not far distant, when a sensible or honest man will no more dare to write history unscientifically than he would to-day be willing to waste his time and that of others on observing the heavens unscientifically, and regarding as trustworthy his unchecked and untimed observations. 'Whether we like it or' not, history has got to be scientifieally studied, and it is not a question of style, but of accuracy, of fullness of observation and correctness of reasoning, that is before the student. . . .

One can hardly help thinking, too, that in schools and places where the young are trained something might be gained by treating such books as Plutarch's Lives, not as history (for which they were never intended) but as textbooks of ethic, as examples of conduct public or private. The historian very properly furnishes the ethical student with material, though it is not right to reckon the ethieal student's judgements upon the historian's facts as history in any sense. It is not an historian's question, for instance, whether Napoleon was right or wrong in his eonduet at Jaffa, or Nelson in his behaviour at Naples. That is a matter for the student of ethics, or the religious dogmatist, to decide. All that the historian has to do is to get what eonclusion he can out of the conflict of the evidence, and to decide whether Napoleon or Nelson actually did that of which their enemies accused them; or, if he cannot arrive at fact, to state probability, and the reasons that incline him to lean to the affirmative or the negative.

This debate goes to the roots; there can be no greater issue. Among recent English historians Powell seems to stand alone or almost alone in his belief that the historian has all the duties, but has only the duties, of any other man of science. In his Geneval Survey of Moderi History he is still more explicit : ${ }^{1}$

History is not a matter of Chance, or Fortune, or what the Church calls the Finger of Providence, but of Law,-

'Vol. ii. pp. 1 foll. 
Law that works exactly as it does in Hydraulics or in Botany.

This was said in his last year: in 1898 he had spoken in the same sense to a private society :

I would regard History as an absolute science, as much as, for example, Botany ; and practical politics have no more relationship to History, and no less, than, say, the art of gardening to Botany. ... It is not the function of the historian to pass judgements at all. Historical science is at present in much the same elementary stage as was astronomical science before Copernicus. ${ }^{1}$

Lord Acton had said that ethics were 'the marrow of history'. We can partly see how Powell, at any rate, was led to his doctrine. No one was better versed than Acton, not only in the facts of history, but in all European theories of politics and history. Powell's bent and reading did not draw him to this abstract field, and he suffered in one way for the loss. For he thought little of 'philosophers', forgetting that it is not so easy to avoid being one. Did philosophy, then, begin at the point where Powell might cease to think? The inference would be unjust to him. Indeed, his ideas were in the air; above all, the vaguer applications of Darwinism were one source of his creed. Darwinism turned towards optimism, - that was one of the strongest currents in his mind; he looked more and more on life and history from that point of view. He did not refine upon his simple proposition that ethics and history are separate, except to say that the growth of moral ideas, like other things, was a subject for the historian. He was sure that he thought of human conduct, when treated by the historian, as simply a field for descriptive analysis. When he could not deny that he was as much entitled, or bound, as others to praise or to blame, he said in effect that in doing so he ceased to be an historian and became a moralist. As we have seen, Powell did not always go through the form of thus changing his

1 See p. 410 post, footnote. 
robes. He does not like to blame great men, but he is constantly praising them in moral terms; and smaller men he abuses racily, not only for their follies but for their sins. Yet it is idle to fasten on these inconsistencies; he was always building up his thought, always open to discussion, and he would certainly have cleared, if not modified his theory. Perhaps he wonld have said that the historian is a juror who finds on the facts, not a judge who passes sentence. But he might also bave scrupled to grant judicial powers to the moralist. Moreover, his theory, if true, is little the worse for his deviations from it: and it is of deep interest to trace how Powell arrived at it. Besides Darwinism thus interpreted, some other determining causes appear. One was his inborn and practical mistrust of Puritan ethics. Another was his sympathy, - much stronger than Lord Acton's and so making up in part for his inferior knowledge of the higher intellectual history-with primitive, half-barbaric polities, and the mixed strong characters who bring these polities a step onwards in civilization. It is not easy for a sagaman to think that 'ethics are the marrow of history' or that 'morality is the sole impartial criterion of men and things', if by this it be meant that he must estimate Thrond or' Gudrun merely by their 'goodness'. Further, Powell was a student of folklore, and such a student incvitably tends to look on moral ideas as in a state of flux and formative vicissitude, often hardly distinguishable from custom that has outlived its warrant; while at other times ideas that are honoured as moral may be in flat antagonism to the prosperous survival of their devotees. Powell, then, was led to his view of the historian's oflice by his reading of Darwinism, by his Scandinavian studies, by his hatred of the Puritan, and by folklore. To these must be added the decisive influence of Machiavelli, his opinion upon whom can be read at length. ${ }^{1}$

It is curious to see how, thongh Powell disliked Hegel 1 Vol. ii. pp. 14-21. 
and all kinds of 'idealism', he landed in a hopeful view of history which brings him near to some Hegelians. Lord Acton may be once more quoted, for he clearly felt that Hegel's was the most imposing form of error. He expounded it in the striking sentence (not of course in technical language) :

It means that power goes where power is due, that the will of providence is made manifest by success, that the judgement of history is the judgement of heaven. ${ }^{1}$. . . If the past is not to be judged by the present [i. e. by present views of ethics] it must be judged by the event, which is [to Hegel] the verdict of the powers that govern the universe. ... Failure is always deserved, and that which perishes perishes by its own fault. ${ }^{2}$

This inference to Lord Acton secmed chaos; and yet, except for the religious language, it not unfairly represents Powell's tendency. It seemed to Acton to open the path to perilous and infinite allowances; and if that theory

means that every age onght to be judged by its own canons, the application of that sliding scale, as a branch of ethical and historical inquiry, is still in its teens, and practically of no avail : ${ }^{1}$

-or, as Powell would have put it on his side, 'in much the same elementary stage as astronomy before Copernicus.'

These are no doubt profound oppositions of theory. Yet the agreement in practice between the moralist and the naturalist is almost equally striking. Napoleon is a test case. Let the reader turn to Lord Acton's remarks on him in the English Historical Review: he does not slight Napolcon's actual significance or power. Nor is Powell blinded by the glamour of mere energy or temporary omnipotence. Both the Romanist and the secular Regius professors face the test, each with his innate sincerity; both agree that the facts must be presented undiscoloured; and both escape any mental extremes or dangers due to their respective creeds.

1 Eng. Hist. Rev., vol. ii. p. 578 (July 1887).

${ }^{2}$ Ib., vol. v. p. 309 (A pril 1890). 
Powell's vicw of history is part of his whole view of good and eril. He did not confuse them, but he secmed, like Whitman, to define evil as the perishable element in the world. It was hateful and had to be overcome; but he could hardly doubt that overcome it finally would be, and that the world normally went on pretty well despite many incidents. Once he said, 'the world is like a college: queer things may happen, but it goes on somehow, and it is best that it should.' Not that he had any false hopes about the reformation of evil individuals; there he was rather sceptical ; the solution for them was to die out. Nor had he, on the other hand, any of that transferred Calvinism, traceable in Schopenhauer, according to which there is some original knot, or constant vice, in human nature.

He also often expressed himself on the relative position of literature and historical writing. Artist though he was, no one could be harder on style divorced from science; a vice of which Macaulay and Froude were his chosen examples. In an unpublished address he puts his point.

Unfortunately, history is frequently written as a party pamphlet or as a treatise on morality; but the proper view is to treat history as an accumulation or assemblage of facts respecting humanity en musse, and not respecting single individuals. Literature, on the other hand, is concerned with the expression of human emotions in an artistic manner. A history may, of course, be a model of exposition, but that is not its true raison d'être. Such histories are usually untrustworthy and should be read for their style and not for their history. Darwin's excellent faculty of exposition is an advantage, but is not the end of his works.

Literary works afford the historian a great huntingground. They serve to fill the gaps in the records of which history is as full as is the geological record. The historian must above all things possess a scientific imagination (to use Thomson's expression). He must understand what is really impossible. The masterpieces of literature enable the true historian to live again in the past, just as a visit to the Last will enable him to project himself into the Oriental life far more than any amount of acquired 
knowledge of languages or of persons would. An actual visit even of short duration will enable him to understand what is impossible in the East. It is this insight into the life of the past which such works as Dante's Divina Commedia, Chaucer's Prologue, and Langland's Piers Plowman afford. The latter might be regarded as the Carlyle of his day. Chancer was rather to be compared to a high-class novelist of the present day. The future historian will find, in the literature of the present age, Trollope and such writers of far more importance than Dickens and Thackeray. The latter are novelists of imagination while Trollope is a novelist of observation. The writers of the tendency novel, including Zola and Mrs. Humphry Ward, will be less useful to the future historian than Balzac and Gissing. ${ }^{1}$

In such a spirit Powell used Chaucer and Langland for his own History of England. He justly felt that 'style' without science is the sin against the light. Modest himself, he seemed almost too willing that the historian's work should lose its identity, like a physicist's or botanist's, and be poured into the common fund, as without style it must. He does not add that, once the method and masonry are sound, the climax of the historian's seientific process is an artistic process ; that 'style' then, so it be not mere finish, means thinking, is thinking. In practice he assents to this ; the artist in him responds at once to good historical writing. His remarks on the styles of Gibbon and of Gardiner ('he ripens like old ale in the Eastern counties') are examples. It is natural, then, to ask how Powell wrote history himself, and the question has been half-answered already. He shares in the bent of his generation. The basis of the older historical styles from Gibbon onward tended to be Latin rhetoric; curbed and simplified in the best cases, but still rhetoric in its vocabulary, its sentences, and its periods. The half-forgotten Sharon Turner, and still more, Macaulay, are examples; Motley and Lecky are later examples, in whom rhetoric easily runs to a flaunting, garish-coloured seed. Fronde also has his rhetoric, though

1 Summary of notes, transmitted through Mr. R. M. Leonard, of an address to a private soeiety in Uct. 1895. 
it is as a rule purified by limpidity and plainness. Lord Acton has the rhetoric of epigram, sometimes monumental, often oracular. But in many historians of the later nineteenth century there is a return to plainness and native diction: sometimes because, like Stubbs and Gardiner, they were teachers; and in others, like Freeman, under the influence of doctrine. Freeman's style, touched with affected simplicity, plain in clause and structure, but too diffuse and tending to be Anglomaniac in diction, is well known; at its best, it is of excellent force and purity. Freeman did his utmost to throw over imported polysyllables and fine writing, and to go back to what scemed the genuine, oaken, Germanic fibre of the language. He probably uses as large an infusion of Romance words as any one else. The same impulse appears, exaggerated, in another writer, who is not an historian, namely William Morris; and may in his case have been encouraged by familiarity with the prose of the sagas, with its rich vivid vocabulary almost of uniform stock, and its curt simple sentences. This leaning, though the effects produced by it are sometimes beautiful, is too much founded in racedoctrine or patriotic illusion, and is too great a sacrifice of noble resources, to commend itself long. It is, however, the form that the very ancient vernacular tradition, which runs back through Cobbett, Defoe, Latimer and Wyclif, has taken in our time; and so there is some health in it.

Powell was void of any doctrine in the matter; he sometimes used an archaic word or form, especially in translating. He was well versed in the manner of Freeman, and not quite untouched by it; he was deeper dyed in saga than any Englishman, even Morris: and his touch of the child's directness of mind and speech came out in some of his earlier historical writings like the History of Emylamd, where he is intentionally simple and brief in his sentences. He writes better when at rest than in motion, his narrative is sometimes clogged, while his descriptions go easily. He takes much heed for verbal finish, constantly and freely 
correcting his draft. He is eareful to cut out the wrong kinds of echo or assonance in his clauses. In some of his critical and personal writing, such as the pages on Omar, every word is winnowed, while his presswork is less studious and has more the virtues of his letters. He was amused by a journalist who wrote of him when he was made professor, that he 'wielded a brilliant pen'. No image could be more accurately bad than that of a club or broadsword for Powell's writing, though he sometimes thrust with the point. Except in his formal histories and addresses and his technical reviews, he is apt to speak in bursts and obiter dicta. Now and then he fashions, rather than utters, a sentence.

Any one who like Mr. Barrett has traversed the woodland and midland from the broad London river to the fords of the Blackwater, and from the gentle Lea, with its peaceful memories of Walton, to the bitter marsh of Tendring with its Danish colony, and the busy, yacht-haunted, bargedotted, mallow-bordered estuary by Wivenhoe and Brightlingsea (one of the classic grounds of our finest sport, yachting), and looks back on his tramp through green lanes and white high roads, will sigh with him as he concludes his "varied wanderings through the good old county of Essex' 1 .

Powell's style is clear and alive always; his voice can be heard in it. Its fault is to be pestered, in historical writing, with detail ; some of the pages are like a crowded map. But that is a picture of his mind. He runs to catalogues and proeessions, and likes the clamour of proper names. One of his natural forms is the survey, where he stops in the story, and arrays the pageant. There are many examples in our second volume. Powell's enumerations are not quite like those of other historians: it is surprising that they yield so much and escape incoherence. After all, if they are crowded, it is with life, and with a vision not only of the main historic figures and currents,

1 Review of C. R. B. Barrett's Essex: in Manchester Guardian, July $12,1892$. 
but of by-ways and of lesser but still significant and picturesque facts. Some of his best writing was done in a rapid heat, and stands scrutiny well.

Most men who become a legend do some conscientious work in its service. Powell became a legend of omniscience, to his own disgust. His efforts to hide what he knew made matters worse. It would come out one morning that he had long since begun Hebrew, or was well seen in Old Irish, or that he could say a deal about leather. It was hard for him to forget anything he had learnt, and his mind did not cease to work upon it, as often is the case with men of rare power of memory. It would be absurd to draft a list in form of his various attainments. This book may give some impression of them. Perhaps his library, as he left it, may show best in what proportion he cared for different things. It contained between four and five thousand works. There was his full collection of old Scandinavian literature, now joined to Vigfússon's on the shelves of Christ Chureh. For modern history, he had the Bodleian hard by, and he could not afford to buy magnificently, though his store was adequate and various. But there was folklore, and antiquarian and topographical matter, in plenty; very little science; more on sports (boxing, fencing, ${ }^{1}$ wrestling);

1 Powell paid regular visits to Radley College for many years to judge in the boxing and fencing competitions; and Mr. H. M: Evans has been good enough to contribute the following note:

'As a judge of fencing, his shortsighterness was somewhat against him, but we never remember any of his decisions being eavilled at. In boxing (of which in his younger days he had been a distinguished exponent), he gave great, perhaps induo, weight to style, considering, and we think rightly, that a sound style was a suro foundation for success in the future with young beginners. We cammot recall his ever coming to Ralley except on these occasions, and it was remarkable how he carried on his recollections of the more promising competitors from year to year, though he never came across them except for a few moments in the 'ring'. He continued to julge until very shortly before his death, and we can well remember the letter of unfeigned regret ank disappointment in which he announcod his inability to conse and its cause.' 
and more works on bibliography than most private men possess. The list also shows a good many books on art, but they do no justice to the place that art ${ }^{1}$ filled in Powell's existence. Here must be reckoned his eherished gathering of Japanese pictures, many hundreds : none of his ontlay gave him greater pleasure. The courteous and smiling Japanese merchant, the 'little tempter', would often come on Sunday morning with a large portfolio, and leave some of it behind him.

He had quite as many books on literature as on history. There were endless copies presented by the anthors,scholars, beginners, young or unknown poets, or Verlaine, Verhaeren, Wilde. Translations and books of a learned cast he read with pencil in hand, praising, scoring out, or emending.

I am struck (writes Mr. John Sampson) with what would seem to point to a very unusual faculty of finding mental relaxation and refreshment in new strange studies which he could not have hoped to carry very far, such for instance as queer languages like Cree, Eskimo, Gypsy, and Japanese. His books help to explain what impressed me in his writings, unexpected generalizations and comparisons, pleasant side-lights and by-paths in the world of letters. One notices a curious interest in undercurrents of literature; and, in the English and French, the general absence of classics and standard authors, and books written round them, not to mention the works 'no gentleman's library should be without'.

In the catalogue there are more than a thousand volumes of foreign literature and philology, of the wide range just indicated. No one knows when or whether Powell took First Lessons in Maori. The East, for one who was not a specialist (though he had the elements of Hebrew and also of Persian) is curionsly well represented.

1 He also gave practical help to art and other teaching. His friend Mr. Goddard Orpen tells that 'he did much to encourage the School of $\Lambda$ rts and Crafts at Bedford l'ark' besides 'interesting himself in the Chiswick High School, of which he was one of the directors'. 
There are works, often translations, dealing with Arabic, Chinese, Persian, Tamil, Japanese ; this strain of interest appears in Powell's reviews. Among larger European literatures the German is somewhat slighted: Italian and French bulk largest. There are the names of fifty books on Dante. Much of the French is poetry and memoir. There is little fiction in that or any language; and, to quote the same expert,

that little is almost entirely examples of the picaresque novel, English or foreign (e.g. R. Head or Lazarillo de Tormes), sailors' yarns, tales of adventure for schoolboys or 'grown-ups'.

Spanish and Portuguese are prominent; and a good judgement of Powell's interest in the Peninsula may be formed from a note furnished by his friend Don F. de Arteaga y Pereira, Lecturer in Spanish at Oxford. Though not wholly on literary matters, it may be given here intact.

He spent part of the time of his youth in Spain, principally in Madrid, at abont the time of the Spanish Revolución de Setiembre (1868).

He knew the political intrigues that led to the marriage of Isabella II, also those preceding her dethronement, which he learnt there from a distant connexion of the Royal family.

The names of Montpensier, Serramo, and Prim, were as familiar to him as the different principles they represented. From that time, no doubt, York Powell's interest in and love for Spain and Spanish things sprang, an interest and love that only died with him.

He took much interest in Spanish gipsies, and spoke of his talks round their fires with them.

He conld read Spanish, Catalán, and Portnguese, and could really express himself in Spanish. He had been an Examiner for the Taylorian Scholarship in Spanish together with Don Pascual de Gayangos.

He knew the best authors of Spanish literature, though more the ancient than the modern, and was quite fimiliar with the best English translations of the Spanish classics of the sixteenth and seventeenth centuries. 
His admiration for Spanish art was unlimited, especially for Velazquez and Goya, who were in his opinion the best of Spanish masters.

He had no prejudice against any author or school, but loved the work for its real merit. His views were very broad; he scemed quite incapable of understanding that any other sentiment than that of art could find place in anybody's mind on reading or contemplating a work. Once, when the difficulty was mentioned to him of reading Celestina, one of the prescribed books for the Scholarship, in the case of ladies attending the lectures, he simply said : 'If they cannot stand it, let them not attend the class.'

He had a real pleasure in making the acquaintance of Spaniards, and was most hospitable to those who happened to come to Oxford.

His love for Spain was best shown in the efforts he made to bring Spanish literature and art to the front in England. Thus, it was he who in 1889 set the Lothian Essay on James I of Aragon, won by Mr. Raymond Beazley, and in 1894 and 1898 brought for the annual foundation Lectures at the Taylor Institution such lecturers as Morel-Fatio and Butler Clarke, who so well depicted the old Spanish life in their lectures 'L'Espagne du Don Quijote', and 'The Spanish Rogue-story'. Finally, it was he who, through his recommendation to the Editor of The Studio, brought the Spanish artist Señor Riquer before the English public in the pages of that Review.

This interest and love for everything connected with Spain was scaled on his death-bed, when he read-as one of his last books-Galdós's La Revolación de Julio, then just published, and sent to him by his friend Prof. Bywater, then in Madrid, who had only taken farewell of him-though perhaps not thinking for ever-a few weeks before.

Though he could thread his way among so many literatures, Powell, engrossed with history, scholarship, and folklore, has left too little criticism. What remains has its own beauty and value. Some of the best of it is to be found in snatches of presswork, on Béouvulf, on the Nibelungenlied, on the Kalevala; or in his letters. There is much of his own life and sympathies in the brief papers on Mr. Swinburne and Mr. Kipling. His only studies of 
the usual kind and length are those on Defoe and Meinhold; the Meinhold is full of the zest of vindication and discovery ; Powell was just the man for an underestimated writer. The historical instinct is seldom far off, and the comparison of Meinhold with other novelists of similar aim is of his best. It was this instinct that drew him to Balzac, on whom he unhappily never wrote at length. The truthfulness and depth of Balzae grow on us with years; but most English critics except Professor Saintsbury appear to dread Balzac a little, perhaps because of the fullness and frankness of his contact with life, and they end in cautious half-admissions. Some lines by Powell may be rescued in passing :-

Balzac's novels form the best history of 1830 . He alone, among French historians, has grasped the essential features of the society that revolted from the ideas of the Restoration, and welcomed the bourgeois rule, first of the regicide son, and afterwards of the Creole's grandehild. He alone perceived the dangers which eommereial greed and shameless speculation and selfish dynastic dreams were to bring upon the most artistic and most conservative nation in Europe-a nation which most needs, if it can, to respect its own high ideals, and which is ever more ready to forgive a magnificent failure than a sordid success. He alone has studied the heart as well as the intellect of the average French man and woman of his age, and shown how inevitably the new leaven of material prosperity has brought with it ehange of character. And the process of change has gone on since he ceased to write. We have seen how, under the eruel but quickening influenees of a great but not wholly undeserved disaster, the new generation has striven, in spite of the obstinate but confused memories of the past that have hampered their efforts, to prepare a noble future for the greatest of the Latin peoples. ${ }^{1}$

Writing on pure literature, Powell at first sight seems a gentle, even panegyrical critic, as kind to his authors as if they were his personal friends, and bathing their faults

1 Review of May 9, 1893, in Manchester Guardian.

r. P. I

E e 
in the glow of his own generosity. He could write of long past books as if their makers were alive, and he afraid of hurting their feelings. He did not believe in professional critics; 'criticism is only one man talking about another man.' His own method was to praise, by a patient choice of epithet, an avoidance of the wrong eulogy, a caveat, laid sometimes in terms of exaggerated modesty, against indiscriminate or wrong praise. His preface to Miss Barmby's Gísli the Outlaw is a good example, and the firmness of his touch is the more to be remarked, because the authoress was no longer living, and he was writing to introduce her noble poem to the blind public; as in admirable terms he does.

In 'Eywind Scarred-face' we have a story of mediaeval invention, due in all probability to the zeal of some bigoted clerk, dwelling on heathen obstinacy of the stupid Pharaonic or Neronian type, turned into an appeal for toleration. It is allowable to nse a story in this way, I admit, but its device and treatment jar, to my feeling, with the clear sharp note of the best of the ballads that Miss Barmby has here translated or originated.

Criticism through praise-that, after all, is the way of many of the great judges, Longinus, Goethe, Coleridge, Lamb, who have given the ereative touch to what they wrote on the creative work of others. And if the joy of life in Powell himself might so overflow into his eriticisms as to err on the opposite side to that of the Pharisee, there is at times a refreshing, booming, adverse detonationcommoner, however, in the letters-which saves his credit for nerve. It was no recreation to him to read poor stuff; and he could not understand those who did so: in this he was like Vigfússon. He thought, for instance, that $M$. Cherbuliez, of the French Academy, was only railway reading. He read anything in any tongue that made him laugh, that had wit or talent. He liked Casanova for his bravura and his historical importance, and as a type that had made the most of itself. But he once made a motion to tear in 
two and put in the fire a yellow volume that turned on incest. He amused himself either with the Pink' $U n$ (of which stacks were found after his death), and with the boxing reports in the Licensed Victuallers' Gavette, or else with solid erudite things ; and was seen on a country platform with historical folios open before him. In going through a mass of books, on a shelf or table, he reminded us of the creature in the prose Edda that was Fire and devoured not only the food but the vessel as well.

A description by Mrs. Goddard Orpen is here in place :

To see Mr. Powell examine a book was to see the working of a sixth sense, almost. He seemed to have eyes and understanding in every finger tip. The nervous hands felt the book, rapidly sorting the leaves. "A very good book-yes-see he writes well-knows his work. Ah! there's a slip, page 135-no, that date is wrong.' This is no exaggeration of loving memory, for I have seen him do it scores of times in my husband's library, rumning over new books on all manner of subjects. I never ceased to marvel at what was the power he possessed of perceiving the contents of a book. I have seen many men, elever, learned and wise men, run through books, as the saying is, but never one do it as he did.

In his eritieisms of men and art, especially of young men and of young art, whether books or pietures, Powell never shrank from risking the errors of the prophet. His look was turned towards the future; this eame from his generous contact with the young, and was the secret of his power to command their response. Some could not understand this ; they could not see that Powell's reluetanee to narrow his hopes was better than their incapacity to widen their own. His mind was restless and forward-reaching, and craved novelty and distinction: he had the passion, in this sense, for being 'up to date', for having read the last poem, the last story. He was always on the wateh for les jeunes: he was one of them himself. He foresaw early many now admitted reputations. He honoured Mr. Meredith from the first, and would talk for 
hours of Mr. Henry James's later tales, as their excellence and unpopularity increased. Mr. Hardy's iron pessimism was alien to his temper, and he admired him not doctrinally but on the surer ground of art. These of course were seasoned writers. Amongst the younger ones, he at once recognized the melodies of Mr. William Yeats amidst his reeds and tender talking waters, when they were known only to a knot of Irish friends. He noticed with delight the yet younger voices, still awaiting development, that speak from Dublin. In presence of all new writing of promise he stood far alike from the natural and honest but unfruitful and reciprocal gush of the young authors themselves, and from the distrust of the old official reviewers, and from what is worse, the occasional engouement with which they indemnify themselves. Perhaps in some cases Powell's enthusiasms were not worth sixpence; but that is a personal opinion. He was ready enough with the severity of silence. His way was to say nothing when he condemned, except in cases of popularly admired pretension. He would shut the book without a word, and never return to it or think about it. If he did not like a friend's MS. it was left at the house neatly packed without remark. He knew that bad work requires no gravedigging. It lies out, and the birds of the air make their nest of its shreds, and the beetles of the field obliterate it bit by bit : not an untender disposal to oblivion. In painting he was perhaps too easily pleased with intentions. It was a means of happiness to himself, and he was prone to admire those who had got beyond his own difficulties. But his strain of French sympathy brought him to Rodin and Degas far sooner than most Englishmen who are not trained and prescient critics. He shared Stevenson's eagerness to give credit, and to divine beauty or power in unappreciated fields. Many could see that he was indulgent, but not many could feel they had enjoyed more good pictures than Powell.

$\Lambda$ mind so ondoyant et divers, so richly variegated, 
careless of doctrinal consistency, yet with certain 'mastercurrents' that 'ran permanent and free', showing a different self to every friend, and always developing, is hard enough to fix in portraiture. Powell sometimes perplexed everybody. But one thing was plain, that Powell did not share the perplexity. He never seemed to lose his way in the bazar of his interests and opinions. He had no dogmatism of manner, but he seldom appeared to have any doubts. He once said, 'After all, things are very simple,' with much emphasis. He meant not, I think, speculative things, but the primary ties and affections of life. For himself he cared little, if those he loved and who loved him were in the way of happiness. Some of them he outlived, and his memory, naturally strong, remained lighted with their presences: an aspect of Powell that we should not gather from his Omaresque profession of faith, well as this expresses his faculty for artistic and spiritual enjoyment. He also had fixed prejudices-as many as Dr. Johnson; he was 'bitter and gay' in the utterance of them, he sported them like a flower in his coat, and they never really drooped, though his good nature and instinct for justice led him to make exceptions for many individuals, as in the case of Americans, Germans, Jews, and learned ladies-a somewhat extensive list of antipathies. He also had some very stable intellectual principles: he was unvarying in his position towards religion, death, and many matters of life and conduct. Some of these principles will be clear already, and on a few others I shall try to touch. But the plan of this book is to let others speak, and above all to let Powell speak for himself. It will therefore be convenient to quote several descriptions by persons who knew him long and well, as well as some remaining letters which do not depend for their interest on their dates or the names of the recipients.

It is natural to begin with some words from Oxford, where his position was peculiar. Though he lived in the 
shelter of Oxford and owed her much, he was not one of her typical sons, who express the genius of the place in its power and weakness. Them he did not always much admire. Newman revolted his judgement, and did not invariably charm him by style; Matthew Arnold he admired for verse and epigram, but doubted if he ' knew his own business as a critic' and said that he 'scrambled through by mother-wit'. In Ruskin he chiefly honoured what made Ruskin alien to Oxford, his passionate concern with social reformation, and what seemed to Powell his prophetic insight. He said, however, that the two men in Oxford he truly regretted not having known better were Mark Pattison and Walter Pater. Amongst his chief friends in the place were Hines the oratorical sweep, and Vigfússon the almost disregarded scholar. A reviewer of Origines says well of its authors:

It is hard to speak in the sober terms proper to bookish scholarship of these strenuous explorers of the Icelandic main, these pêcheurs d'Islande, who moved amid the urbanities of Oxford, beloved, wondered at, but never entirely tamed; like real sea-captains on shore, framed in the manners and breathing the air of a larger, freer, and more primitive world. ${ }^{1}$

Powell cut across all of Oxford's regular opinions and fashions, though he adjusted himself without visible strain, indeed with flexible sweetness and sociable gaiety, to its life. His own radiation was so strong, like some of those elements that discharge heat and power without apparent loss of store, that many of the forces round him did not reach him. He was also, as we have seen, regularly refreshed by absence. He went through Oxford, not really of it, yet never giving offence, and so made himself a greater power there than if he had been subdued to its atmosphere. Evidently all kinds of persons resorted to him: undergraduates in scrapes with women or creditors, clever girls groping for a 'subject', poets secking

1 Manchester Guardian, May 4, 1905; signed C. H. H[erford]. 
publishers, and artists seeking sitters; beggars wanting money; shy scholars who could not get on, but whom Powell helped on; provincial lecturers on their promotion, fellow-students bringing proof-sheets, youths who wished (and whom he advised) to marry despite their shepherds, foreigners who drifted in for aid or introductions or an interpreter; persons of importance on a holiday; all these knocked at his door, and were admitted : so that it was no wonder if Oxford, while it never satisfied him, loved him. Besides this, there was his life in Christ Church day by day, which he lived on terms of goodwill and affection with his colleagues. He was there under three Deans in succession, and his regard for Liddell appears in his correspondence. This happy relationship was continued ; and Dr. Paget, now Bishop of Oxford, has furnished the following notes of a long association :

It is sometimes said, in the tone of a censure on the present day, that we do not see now the distinct, original and unblurred types of personality which in bygone times were honoured with the name of 'Characters'. They live in a story here and there, to which the younger generation listens more and more critically: Strepsiades delighted in them, but they seem strange to Pheidippides: they have indeed Dr. Johnson for their Patron Saint, and till he is forgotten no educated man can deny that eccentricity may dwell with greatness: but it is said that we do not see them nowadays: it is doubted whether we should quite appreciate them if we did.

Now this is very serious; and I an glad to believe that it is unjust. There are, of eourse, large tracts of society, old and middle-aged and young, earnestly bent on becoming as conventional as possible. But still there are some sheltered spots, unswept by the dry winds of publicity and success, in which a real human being can live his life and be himself. There are our Colleges, with traditions which evoke, even in the most progressive heart, what psychical researeh would call, I think, a Subliminal Conservatism: and there are our country parishes. And in these, and, doubtless, in some other happy corners of a hurried world, it is still quite possible to be unlike other people; to 
eherish one's own tastes, to serve one's friends in every rank of life, to look at all things with a frank, fresh eye, to think ont one's own thoughts, to make up one's own mind, without considering whether its several opinions are such as usually go together. And this, I think, is liberty : the liberty in which the rich and deep and manifold diversity of character comes out: and in which a good man simply does as much as he can of that which he can do best, and gives it to his fellow-men, to take or leave, to slight or prize.

In such liberty York Powell lived and worked, and was as unlike most men as any man whom $I$ have known. If one tries to describe him, it is no use looking for any sort or group of men as illustrating what he was: no current label can be stuck upon his mind, and his views will go into no school of thought: on any subject he would say something real and shrewd and worth remembering: but it was seldom precisely what any one expected him to say. Men who did not know him well might be confident sometimes that his convictions would ensure his agreement with them, or his opposition, as the case might be : but as often as not they found that, whatever his convictions might be, their confidence was wrong. He was not inconsistent; he was not even, I think, what Aristotle meant by $\delta \mu a \lambda \omega \hat{s}$ å $v \omega \mu a \lambda o s:$ rather it seemed as though, with a rapid, humorous, independent insight, he saw vividly the greatness of something that we had undervalued, or the littleness of something that convention had made much of : and that upset the balance we had struck.

But of course I cannot judge of the distinetive character of his mind, and the peculiar excellence of his work: they go far beyond my grasp. Where I seem to stand on surer ground as I think of him, is in recalling what he was as a colleague and a friend.

As a colleague, I knew him for nearly a quarter of a century. We differed, I suppose, very widely concerning the things for which I care most of all. The reality of differences about such things eannot incleed be justly measured by the appearance: if hearts were open and desires known to us, both difference and agreement in religion might sometimes dwindle, or even disappear, surprisingly: but in all appearance York Powell and I stood, in regard to religion, very far apart. Yet, searching my memory, I cannot recall a single word that ever wounded me, or 
let me think that he thought lightly of what I held dear. In rare perfection he had the grace of a sensitive and chivalrous respect for the minds and hearts of others. His power of imagination, his knowledge of history and of the world, with the breadth of view such knowledge gives, his fine freedom from self-centredness, all helped his honest and good heart to know at once and unerringly how he should bear himself towards those who saw things in a light that was not his. It was an extraordinary skill : -and, it was something more than that.

The second excellenee of which he set us an example was unworldhiness. He used his great ability with great simplicity : he must have known that his mind was strong, his memory retentive, his learning real: but he was as one who never thought of seeking great things for himself: mambitious, uncalculating, untroubled by any wish to produce an effect. Those who have seen strong men slain by ambition can never wish that any of their friends had more of it: and I do not doubt that York Powell's work was the better, as his life was the happier, for the lack of it. But the lack was a part of the reason why out of all his wealth of learning he has left so little for men to study : he would have written more if he had thought more of the judgement of the world: and one may fairly wish that other motives, nobler than ambition, had had power to make him do what weaker, poorer men have done for their ambition's sake. But an example of unworldliness in a man of brilliant gifts is a great thing: and he was in this regard as simple as a child. I do not think that an ambitions man could ever have laughed as heartily, as delightfully as he did: and a man's laughter, as the Son of Sirach had noticed, is one of the things that show what he is.

I wish that I could write as I ought of that with which I must end this poor attempt to tell of him: I mean his genius for friendship. There is in the Upton Letters an interesting and brilliant, though rather merciless passage about the Autobiograplyy of Herbert Spencer. The writer's main point is the self-regard with which the philosopher treated all the relations of life as though their value lay in their aptness to keep him in good health. I glance at the picture because it helps me with the force of uttermost contrast to say how York Powell seemed to me to think of his enviromment. He was 
as one made for his friends, and putting all his heart into the design. His time, his knowledge, his insight, his interest, his affection-he gave them all, with a royal and boyish generosity. If you were studying, and asked him a question, he would at once give you, so to speak, all he had got upon him: and then come round the next day with a great deal more. I remember asking him once abont a point of mediaeval ethics, at which I was trying to work a little: and I seem to see him now walking into my study with an armful of books which were quite unknown to me, and just what I wanted. If you were ill and lonely, he would come and come again to sit with you : and I doubt whether in the annals of friendship there is anything to be spoken of more reverently than his unwearied tenderness towards his friend Vigfússon in his long last illness. And if you were in great sorrow York Powell would not write to you : he would come and see you, not thinking of the difficulty of knowing what to say, but thinking only (if he thought about it at all) that in that way he came nearest to you, and had the best chance of getting his shoulder under a bit of your burden : - somewhat as a child may slip its little hand into the hand of one who sits alone in grief. It was indeed a true, deep, bountiful heart that his friends-and they were many-knew in him. And the other day, when I was trying to see of which graces it might be said that Christianity had either brought them into the world or touched them with fresh light and life, I thought of gentleness, as one such grace: and immediately I found myself thinking of York Powell.

Dean Strong, the present Head of Christ Church, completes the sketch of Powell's collegiate life, and adds some fresh characteristics :

I do not remember my first introduction to Powell. I knew him by sight long before I met him; and he was known among us, the undergraduates, as a man of vast learning and somewhat eccentric habits. I do not know where his rooms were first : in 1880 he moved into a set in Canterbury looking over the garden opposite Oriel. He succeeded in these rooms Mr. A. C. Madan, Student of the House, who in 1880 joined the Universities' Mission in Zanzibar. Mr. Madan had been my tutor in my first year, 
and I was familiar with the rooms. It was soon after 1880 that I came to know Powell, through Mr. J. H. Onions, one of the Tutors, and a distinguished Latin scholar, now dead. After my first introduction to Powell, he always treated me with the utmost kindness: he was always ready to talk or lend books, and his immense stores of knowledge were then, as always afterwards, at my service. His hours were not such as suited my ways of reading, and as I had the fear of the Schools before me, I did not see so much of him then as I did after my degree. But I have always felt grateful to him for his ready friendship: there was no reason, either in the work I was doing or in anything else, why he should have gone out of his way to be kind to me.

When I came into Common Room, I found Powell a very central figure in the company. It was rather a vexed time : the new Statutes had recently come into force, and there were acute differences of opinion. I was aware of this before, and wondered greatly how Common Room was conducted in these conditions. Powell was identified with the modernizing views in the extreme form. But $I$ found that he was in the truest sense persona grata; he talked freely and brilliantly. His talk was far removed from anything like the professional good-talker, or the anecdotist : it arose directly out of the situation, and therefore is practically impossible to reproduce, and very difficult to describe.

He had, besides an immense knowledge of books, an 'extensive and peculiar' knowledge of men and of curious kinds of men. He had certain very strong prejudices, e.g. against Jews. He was in the habit of bringing strange foreigners to High 'Table - 'Powell's assassins', Dodgson called them. 'They were, I suppose, learned men as a rule, but not infrequently they were political refugees, not wholly unworthy (probably) of Dodgson's description.

His old servant in the Neadow Buildings, Heath by name, was a perpetual joy to him, though probably Powell was alone in this view of him. Heath was a pious man with a great command of hymns. One night at dimner with some literary men from London a question arose which Powell referred to Ieath. Heath promptly answered it: and Powell told us afterwards with much delight that H. had acquired quite a literary reputation in London circles.

As Librarian he distinguished himself by his work on 
the collections of drawings and of music. The former were mounted earefully by M. Gueraut and stored in boxes specially made for them. With the music Powell frankly owned that he was beyond his depth. But he recognized the necessity of eareful work on the collection: in his time it was beautifully bound where necessary, and repaired, and made ready to be properly eatalogued.

I once went for a long walk with Powell. It was a splendid day at the end of the Lent Term. I was coming in, but I met Powell just starting, and he asked me to join him, saying truly enough, 'It isn't every day that you get a chance of going with me.' We went nearly down to Sandford along the towpath. He talked all the time and said far more interesting things than I can remember. We looked over the bridge-side at a small lasher just above Iffley, and he said, as he watched the water rushing over the steps of the lasher, 'It is only the Japanese who can paint that: in the West men paint water falling in a single white mass: the Japanese let you see the bubbles and the drops.' I don't know if this is true: I always think of it when I go by the place. His rooms were adorned with Japanese drawings, in which he certainly saw more than I did.

I think his great kindness of heart, and his power of seeing his own vigour in other less vigorous minds, made him liable at times to be deceived in people. It was not possible always to trust his judgement of men. There was no man more loyal, more devoted to real learning, more ready to encourage any efforts in that direction: nor was there any man with wider sympathy for life in its various forms.

I am glad to use Dean Strong's permission to add another passage, taken from a University Sermon preached by him in the Cathedral on Ascension Day, 1904, just after Powell's death :

College life admits of great reserve between one man and another; but, on the whole, the member of a college soon reveals himself as he is. We who shared this common life with York Powell here and at Oriel know well what he was. We knew him as a true and loyal friend, enlivening all intercourse with brilliant talk illustrated from his stores of learning and wide experience of human life; we knew 
him to be generous up to and even beyond the limits of prudence, profoundly sympathetic with oppressed people, stirred to his depths by the tragedy and pain of life; we knew him to be sincere, consistent, incapable of weak and unreal compromise-and this especially in those matters where he differed profoundly from the usual beliefs of men. What was the full history of his attitude on these questions no man knows, nor ean we presume to sit in judgement upon it. If he stood outside the kingdom in this life, he was surely one who was not far from its gates. God will know all about it, and may God grant him light !

We see how Powell, thinking as he did, could live easily and frankly amongst believers of this liberal temper. His letters have already thrown some light on his religious position. It has to be stated carefully, for in one sense it was implied in all he said and did, while in another it did not matter, for it never parted him from any one whom he liked. If he sometimes said that he and his devout friends had more in common than might be supposed, he did not mean that he signed to a single one of their doctrines. Here he was as firm in his seat as a divine. He meant that humanity and charity were common ground, which can be occupied either without any creed at all or in company with any of the gentler and freer religions. All can meet in the open air. The persons he really surprised were those of his own way of thinking, who had not like him becn born free and remained calm, but had worked free and remained angry. He too conld be angry enough; but there was never a sign, by the available evidence, of any intellectual war or doubt within Powell; he was angry with something outside, with what he thought elerical encroachment (which he loathed and resisted) or ungenerous ethics. Hence he had a start over many nren of either camp. His mind was clear for essentials; he had none of the pain or harshness due to the memory of broken religious ties; he was fiee to take his joys without a donbt, and his sorrows withont an opiate, and to move easily amongst persons of opposite conviction :-more easily, 
perhaps, in some ways, than if the differences had been minuter. This view of Powell is confirmed by an independent watcher, Dr. Charles Bonnier, who left Oxford in 1900. There for many years he had seen Powell constantly on intimate terms, though he himself was apart from the routine of Oxford life. Dr. Bonnier's Ex-Voto written upon his friend must not to be abridged; it is printed by his leave in full at the end of the present volume. There are some features of Powell which this elegy dispenses others from trying to paint : the look of the rooms in the Meadow Buildings; his ways with the humble; and his humanism. On the question of religious doctrine, on the calme identique of Powell (a word that gives the whole truth), I transcribe here some lines into English :

He had ballasted himself in early youth: had tasted the peace of which the apostle speaks, that passeth all understanding. Faith and belief seem to be for certain minds the essential condition of their lives; they have taken their platform on certain subjects, and these they debate no. further ; the remainder of their brain is freed, it is available for other labours. Thus is explained the freedom of mind that is seen in certain Catholic priests. In the sciences they are intrepid; they are indulgent in all that does not come near the ark of the covenant (l'intangible). With him it was a "sound atheism' ' that took the place of such a faith. After all, it was only a shifting of the centre of certitude. He was as tranquil in his absence of faith as the mystic is in his belief. It was not 'agnosticism'; the very word has discouraging suggestions. Rather it was 'gnosticism', meaning thereby the endless impulse towards knowledge . . . and the enjoyment that it brings. . . .

The last group of letters, each addressed to a different person, throw further light on this 'decent heathen Aryan ' and his resourcefulness of heart. The first three werc drawn from him by the news that his friends had suffered bereavement. It may be worthy remark that Powell's feeling towards death was not at all that current one which supposes that human life has some mystical and

1 Words not quoted as Powell's. 
innate value. The criminal law in many christianized lands sets so high a value on life as to execute murderer's, while in others it spares them from the feeling that even the slayer's life is sacred. Charities maintain alive and in some well-being the mentally and physically unfit. It takes some courage to say that a fellow-creature, howerer useless or hurtful, is better dead, especially when it is true. It is usually left either to coarse and callous people to say so, or to very simple and untheoretical ones. Powell, neither callous nor simple-minded, had this courage in a marked degree. He would shum a friend's house sooner than condole over the loss of some one who in his opinion was an utterly uncompensated burden: 'I should be afraid,' he said to me once, 'of showing how glad I am.' Or again: 'I had a talk with Mrs. Z-, and we were glad that old $\mathrm{X}$ — was gone: he was a thoroughly bad old person': perfidious and unsound, as Powell proceeded to explain. He would not admit that human life had intrinsic value: all depended on the use that was made of it. A profitless or retarding man was a profitless or retarding animal: his disappearance fulfilled the law of progress. Powell's Darwinism was not reasoned out, but it coloured in this way his views of life and death. Perhaps, as has been suggested already, the Latin strain in his sympathies made him think more lightly of mere life. At times his views found paradoxical expression. Some one told a tale, with much abhorrence, of an English sea-captain who refused to rescue a man struggling on a spar, at some distance away on the ocean. The captain said it was his duty to his employers to be 'punctual', and went on.

Power. (pensively): I dare say that might happen oftener than we think.

The Otiers: Now, Powell, don't you think that an absolute case of human life being sacred?

PoweL.t (silent, and smoking hard, rather cornered: at last, with a twinkle): I should like to kuow first what sort of a man that was on the raft ! 
As the difficulties of a preliminary inquiry struck him, he solved the question in laughter, but the answer was not merely playful. All this, of course, would be misread if taken alone. In practice he would have been soft-hearted enough. But he judged the dead, from one point of view, by the same measure, as if they were living : from another point of view, as if they had long been matter of history. Nor did he ever show any sign, to my knowledge, of supposing (as it is put by Tolstoi, whom he disliked so much) that 'the dead are not really dead'. He had no physical dread of death, had seen many dead persons, and would sometimes speak of having done so. But his letters show that no man felt loss more sharply, or was better in consolation. Those whom he loved and thought most of in life, he remembered with an edge of affliction that nothing could blunt. They had been bright and active in this questionable world; they had died before their work was done, and their going did not visibly fulfil the law of progress at all, though probably 'it was all right'. The earth had seemed rational when they spoke of it, its hopes were more credible while they remained upon it. When others suffered the like he was not silent.

\section{To a Friend.}

Don't even in your dark hour imagine you are useless. You have made a great many people happier : that is one way at all events of making the world go round. You have the passion of kindness, which very few people really have. I like people who are beantiful and fine in body or mind or art or skill, and it is easy to be kind to them; but you don't stop at that, you are kind to people who are not interesting.

I am sure you are doing your darg all right. Never fear, yours is not the place of an 'idler' ; you are on deck in the gale most of the time, or stoking below in the heat. It all looks small, what one does; I know one often feels that (and I know others do too), but still we are all 'mprofitable servants' sometimes, and sometimes one judges oneself too hardly, in the bad hours, as one flatters oneself in the gay hours. You know, the sense of 
sympathy is what makes all living worth living: it makes love, friendship, kindness : I shouldn't be surprised to find it has made the world, such as it is. It certainly has made all trees and beasts and men. Now you've got the sympathetic temper: you rejoice with those that rejoice and weep with those that weep, and it gives pleasure, and you make the world happier, and it needs all the happiness it can get. So you mustn't stop or chuck it.

... I want you to know I do care immensely for my friends, though I don't do much for them, or show it, I'm afraid. But I would even risk their friendship, I think, to do them good. Shute gave me that example. He was a real fine fellow, and utterly unselfish and utterly courageous. It was the first loss I ever felt, his death. It drew a black line across the track. One was no longer young, in the old way. Bob's was another black line. One felt as if one had walked with an angel, and suddenly he flew away, and you knew he would not come back. . . .

And to another he wrote :

I was glad to get your letter and see you are feeling a bit better. I was really troubled to see you so unhappy and run down. I hate to see my friends worried and in sorrow.

It is quite true one learns too late, but the world, or rather we, are made so. It is quite true, too, we can only live by 'making believe' a little and not thinking too much about the process. I, like you, have found this out by experience. I am glad you have found an occupation .. that takes one out of the World of Regrets and Vain Hope and the Grief of the days that are gone. I can't help you to lighten sorrow. I wish I could. It is so sad one can't bear even a corner of a friend's burden. Each must dree one's own weird, so it is. I can only give empty sympathy. Yet I know how bitter grief can be. . . . How close the dead are to us! One lives much more by memory than one did, I find. But the living are here to care for, and that is something good, I think.

And to a third, a man whose father had died:

I am sorry to hear of your being in grief. It is nothing I can say that will help you, but I just feel I should like to tell you that I am sorry. I was awfully fond of my father, and I felt his loss bitterly, and I know your father was a great deal to you, and you must be having a bad

$$
\text { r. P. I }
$$


time. You have one consolation I had not. You have been able to be of use to your father. I never had the chance of this, or of showing him in anything but words that I was grateful for all his many kindnesses.

I am sorry your holiday has been so clouded by this shadow, that I know you were already in fear of. I hope that you will be able at least to get some rest when the acuteness of this bad news has lessened.

The only thing we can do for those that are gone is to keep them in loving memory; sorrow is vain, though one cannot help it, and mourning useless, though it is a kind of help at the time to many people.

You are luckier than those who have had their parents torn from them when they were hardly conscious of the strong ties that bound them to them.

I hope you will stay in the country and try and get a real rest, for grief is more wearing than any work, I think. . . . Don't trouble to answer this. It is not meant to be answered, I only wanted to let you know I was sorry for your sorrow. I am yours faithfully.

The next is in praise of kindness :

- I met on Saturday and he talked much of your gentil esprit and of your kindness to him. You have really done him good and given him a great deal of pleasure. Older people are always touched extremely by the kindliness of the young. I don't think there are many who realize this as you do. I always remember your kindness to $\mathrm{V}$ He too was very grateful for it. You ought to have a very happy old age, for you have made others happy when you had the chance. I don't often write seriously like this, so you will forgive me for once.

Other letters are written in a strain, by now familiar, of advice or congratulation : in one case the advice was taken.

You ought to get married, if only for the sake of the children, they are so pretty, and it is real enjoyment watching them and listening to them. If they bring anxicty and care, as they do, they bring pleasure too. It is splendid to see them pleased, and one begins to understand the old idea of God rejoicing in his creatures, for behold they are very good. Iuckily one has not his prescience, or one might not have the pleasure of the hour so fully. 
And again :

... I think you would probably do very well in such a post. You care for the work in its highest sense (the only sense a man ought to care for it in) and you have had the sense to give yourself a thorough training, which few men have done here: and you have plenty of energy and are a good man of business, conscientious and not rash in judgement. One can say this of few men, you see, and I can say all this clearly and definitely about you to my friend.

You feel, I know, the fact that History has a great future in Gt. Britain if it is properly taught ; and that improper teaching is worse than none; that exams. are not the only test of a man's work, that men ought to study for love not for money and position, and that the 'wages of going on' are the only wages an honest man can take.

I think you have the root of the matter in you, and no man will be more pleased than I shall be when my hopes of your future are turned into facts, which all can sec, that are able to see anything. Hence I feel that you are a candidate I can heartily speak for without reserve.

You must take care of your health, above all, now that you are building up your constitntion; for without health, believe me, the highest work is hard to do.

You must marry and leave this unhealthy college life, with its one-sided limitations, and this you must do anyhow. If your success helps you to so much, I shall be very glad, but do not waste your youth on mere brainwork. The best brainwork wants a deep background of sympathy. Such, a wife and children will give you, and nothing else can. Excuse my terrible 'don de familiarité', and remember always I am your sincere friend.

The next letter was written to a friend's wife upon the birth of her first child :

You must be feeling very happy. I congratulate you with all my heart. Children, happy, healthy children, are an abiding joy, the joy that lasts longest, I think. I hope your son will be a blessing to you all your life. I think mothers will always have most joy in sons after all, tho' fathers may love their daughters just as well. I hope you [will] sec your children's children.

It seems to make a place really home when the children are there. It seems like lodgings till then. You will have F $f 2$ 
endless pleasure in seeing your baby grow every day, and watching its pretty helpless ways till it begins to become independent in such funny busy ways. I think you like children and young things, and it won't feel strange to you, but as if you had really come into your own and reached real life.

Such a pleasure to you both makes me really pleased and brightens the day. Every one tells me you are a very kind and gentle-hearted woman, and I am glad you have this great blessing of a fine son, for I know it will make you very happy, and you deserve to be happy. Believe me with all good wishes yours very sincerely.

Powell's theories on women, it may here be said, were pretty well known to his familiar friends. He was much liked by women, and was chivalrous and courteous to them all. He held fast, with glosses and amendments of his own, to the view of the natural man that the proper business of women is childbearing: "the only thing they do which we cannot do at all ; other things we can generally do better. His formula was that 'marriage puts women right'. He had a heroic and simple-minded faith in marriage for all women who were capable of maternity. He had pity without scorn for those who missed marriage. This feeling was not only personal but scientific,-Darwin once more! It was an aversion to sterility, that Powell shared with Nature. He was always thinking of the stock. He had no place for wives who were unwilling to be mothers or for mothers who neglected their children. The latter were monsters : the former punished themselves, and were waste products extinguished in due course. He was also deeply alive to the imaginative and, as he once called it, the 'sacramental' side of marriage and of love; more at home, perhaps, in the Paradiso than in the Vita Nuova. There was also room in him for Tristram Shandy; he found human nature there also. And he could forget-almost - the want of looks in women, if they still had the signature of honest experience, above all if they had kept laughter alive in themselves. He wanted faces and per- 
sons with whom Nature had had her full opportunity: inscribed faces, tried persons, if only they had survived, - had come out of the stress, perhaps far from perfect, yet far from barren. The strength of his sympathetic response to those who were in grief has appeared in his letters. He liked women who talked excellently; the more pungently they talked the better, provided there were no smallness; and he also liked those on whom silence and patience sat well.

A lovely, inexperienced face, or the picture of it, had to be very lovely for Powell not to think it insipid. Young, unmarried girls might be delightful, but had not lived. On the whole, they had better not go to the theatre, unless it were a theatre blanc; not that it would harm them, but if they did there would be the danger (a reality in England) of the plays being written for them. He did not greatly believe in young feminine culture, though when he came across the aspiration he would help it with infinite kindly pains, and find tasks for it: perhaps his contempt for it was rather theoretical. But he was glad when young women revealed, as they can, a true gift, if not for high creative art, still for song (he responded to any singing, however artless, that showed a nature behind it), for drawing and painting of the delicately fanciful or pathetic order, or, as is more often found, for crafts like embroidery or lapidary work. He lavished encouragement when he was sure of the gift. This statement of Powell's creed and bent is, in the nature of things, incomplete, and others may be able to correct it: and he would have been a different man if he had not made his favourites exceptions to every one of his principles. His advice was always given in a positive, wise, and friendly spirit. A letter may be cited here that he wrote to a young lady who wished to become a professional writer and asked his advice.

... Now as to the other questions. I think you could, as far as style goes, do very well, you only want knowledge and pains, and you would easily master the requirements 
of the magazine or the journal. You could write as well from Oxford as from anywhere elsc. Or I should think you might take pupils in Literature. But I do not know the state of the demand.

As to the Bodleian, the art of copying old documents accurately is not at all hard to learn, and the copies are fairly paid, but it is a very precarious occupation, and I fancy there are people about sufficient for the demand. But I think it is better work than ordinary journalism.

As to original work, stories, novels, pay best. Poetry pays very little. Poets make their livings out of their prose, not their verse, as a rule. I don't want to throw cold water on your hopes, but to tell you plainly what I know. It is more difficult and more exhausting for women to make money by their pens by good work than for men, and they are worse paid usually, because they cut one another's prices down, in their hope for and need for work.

I see a good lot of working women and I know it is usually a hard struggle.

However, whatever you elect to do when your schools are over, I will gladly bear my testimony to your ability and power of expression. You have, I think, got a rather rare gift in your feeling for style and your appreciation of literature, and I shall be pleased if anything I can say may help you to your desires.

The great thing is not to worry and to take plenty of bodily exercise now while you can. Enjoy the present thoroughly: (no one can take away, as long as memory remains, the happy recollection of past happiness); and do not trouble overmuch about the future.

It is (you will know it if you take to teaching) a great pleasure for me to think you have trust enough in me to do me the honour of consulting me on these points. I do not often have students of such promise as yourself, and I am naturally interested in your work and wishes; and I shall always be pleased if I can be of use to you in your reading or career, and you must believe me, sincerely yours.

Powell's letters to Mr. J. B. Yeats will be freshly remembered. Mr. Yeats has contributed, besides the pencilsketch that has here been reproduced, some notes on the companion whom he knew intimately and talked with 


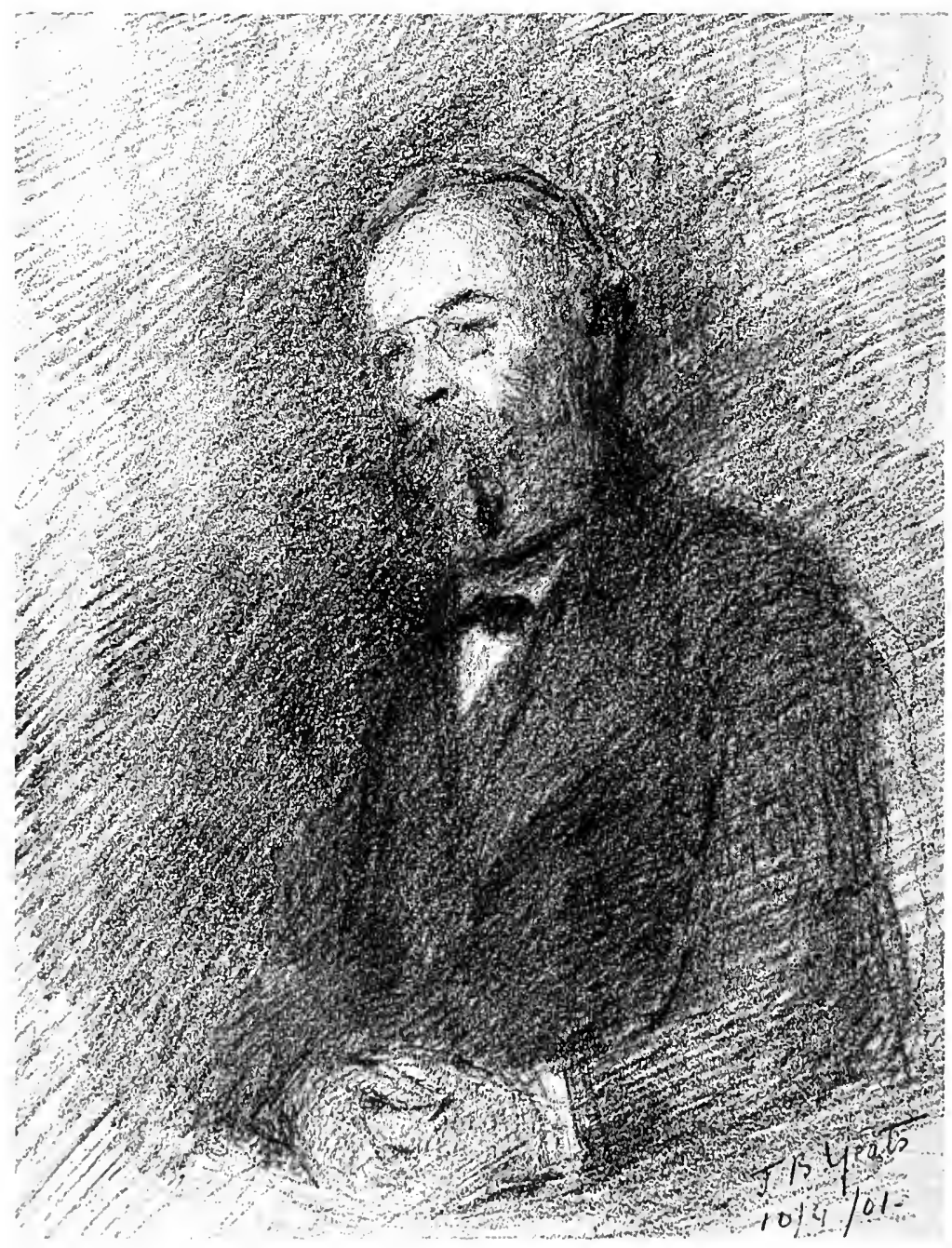


constantly for years. He has brought out many sides, chiefly the ideal side, of Powell's nature with a truth of portraiture and analysis that leaves little to be said. If he tonches on this, rather than on the more positive, hardwitted, sharp-judging, and equally essential ingredient in his friend, or the enigmatical dead stops in Powell's sympathy, the omission can be supplied from Powell's own letters and other sources. The standpoint of Mr. Yeats is not that of some of the foregoing witnesses. He is not only, like Powell, a Home Ruler, but, unlike him, is an adverse critic of England and English Toryism and the Boer war. But this want of accord only brings into relief the value of the description. Mr. Yeats does not intend an ordered discourse; his remarks fall into separate but not disconnected pensées, after the way of La Bruyère and the old Character-writers. His first words go to the heart of the matter.

York Powell was human nature itself. 'Bother intellect,' he would say. 'This was his value : he was human nature, with the gates of knowledge wide open. He knew all languages and literatures and all the schools of painting, and the whole region was traversed for him by one or two personal affections. For these last he lived; and this is the reason he so utterly despised his own learning and intellect, a feeling carried so far that at times he seemed to adore ignorance.

There is a kind of human nature, intractable, subtle, composite, that wonld devour life, sceking satisfaction for its senses or its dull will-power. But in Powell we had human nature, frank, emotional, free, seeking happiness as a plant seeks sunshine : and often it was human nature in flood — rarely a winter flood, but oftener a summer flood, overflowing its banks and sparkling in the bright sumshine. And this wonld have been so more, as the year's went by and his enemies ceased to thwart him. Ho was a Nilo seeking to fertilize the adjacent desert; a river under compulsion of the moon and the stars, insidiously, imperceptibly overflowing its banks, asking leave to flow along this chaunel, that opening; for I never once detected him 
trying to influence any one. He seemed too shy, too timid, too full of reverence. Nothing less than the compulsion of the stars would make him meddle with any man's conviction.

He was an original man because, living in virtuous England, he loved sinners best of all ; living in Oxford, he regarded learning and 'culture' not as ends in themselves but as means of self-expansion. He thought there were many things better than being a savant-for instance to be a good carpenter or a good fisherman or a good doctor. Where every one is ambitious, his only desire was happiness, that is, happiness as he defined it, and this is not always to be found in the alcove, but always in living and dying for others. But that sentence I must recall. There is nothing Powell would more have disapproved of than people living and dying for others. It would have seemed to him mere humbug, and quite impossible for a healthy person. In this I don't say he was right, but I am sure he would have so expressed himself. Yet this was his salient characteristic, that into affection for this and that person, sometimes old friends, sometimes friends of a few days, -into the channel of such affection he poured all his energies. When asked to do a good turn for a friend, alacrity would spring up into all his limbs, and he was off like a rocket. I remember seeing this and being impressed by it as something novel, never seen before in anybody else. I believe if at the moment of death he had been asked to do a man he liked some service, he would have managed somehow to live a little longer, that he might write the letter, or sign the necessary cheque, or do for friendship's sake the preface that made the fortune of your book.

I think Powell's humility was a little peculiar in this way, that he thought nothing about his own merits as compared with the merits of other people. But he was always thinking what good times he was haviug,--life and friends after his own heart, and every want satisfied. He did not think it a merit, but a lucky accident that he could open out his arms and take in great armfuls of happiness. He was almost ashamed of his faculty for enjoyment. Some people never go into life at all; and Powell was to them like a sailor fresh from many voyages, who has come to see his cousin 
the church sexton. Those people prefer the kingdom of dullness, where they make the best terms they can with fear and dullness: with neither of these would Powell live an hour, not even when he was dying, as his letters show : he always defied death and fear. For that reason he always seemed to me a healthy man living among invalids, and his health was contagious.

You remember how he worshipped any one he was fond of, a fisherman or a little child. Indeed, this trinity possessed him, affection, happiness, and worship. If he got one, he got the other two. The fleshly or pagan school of art and literature, having to do with the senses merely, brings no happiness, however magnificently it may be decorated with all the devices of the most mournful and beautiful art ; it never means happiness. The literature of the senses and the literature of despair go hand in hand. Powell's value to his friends was that he was human nature unspoiled, unsophisticated-human nature in the crystal clearness of its source, and unmuddicd either by Puritanism (which teaches suspicion and treachery towards yourself and others) or by the devilishness of aristocratic vanity and insolence. He was the embodiment of innocent joyousness ; innocent, because it sprang from the unselfish part, the affections and the spiritual desires, and for the same reasons a real joyousness.

And then the powerful brain of the man! this completed the charm. So much power and force, and all as gentle as the smile of a woman ; the brain, and the stores of invention and knowledge and thought it brought with it. And it was not merely that it was gentle; but you felt secure at having so much power on your side: you seemed to touch Mother Earth; you felt happy and at home in so much strength, so much affection. Joy and pain mingle in our lives, at one moment we smile and next we grimace; Powell saw joy so clearly that he tore it away from the other.

The most important part of his equipment for joyousness was his extraordinary power of instantaneous mental concentration. Most of us when thinking of one thing are always thinking of something else as well. Powell gave all his energies to one subject, and that was always the passing 
moment. The busy bee sunk in the heart of a flower is the true symbol of his intellect.

Living in the present with such immense gusto, he with a mere gesture, as it were, drove off all the bogeys, the bogey of death as well as the more urgent bogey of tomorrow ; and the saints themselves could enjoy his company, because his happiness was all made up of affection and sympathy and friendship, while his noble intellect, freed from all the vileness of fear, played radiantly over the philosophy appropriate to those feelings. In his company fear fled as the devil shuns holy water : you did not need to cross yourself.

A strong will would have spoiled Powell. The wild garden, blooming with every flower of every season, all growing together, would have been changed into a builder's yard, or a Manchester factory with its slums.

Of all men I ever met he was the freest from vanity, which is a form of personal hopefulness,- -hope, that is, of some personal success or glory or distinction. Powell had no form of personal hopefulness, because he was never interested in himself at all, either as regards the present or the future. Himself was a horse he never backed : but he loved praise, because he thought it meant liking. He leaned towards those who liked him, as a shy boy or girl would in a world of strangers look about for friendly faces. It seems that I told him he would have made a surpassing parish priest. I could conceive him rolling along the roads, in some western parish, brimfull of piety and visions and laughter and merriment, loving the boys and the girls and the simners of both sexes; a fervent believer of the narrowest kind, only with all his beliefs irradiated with intellect and affection : in his life no dark corner, except where loomed the English government and Protestants. And how he would have hated these last! The R.C. religion would have suited him exactly, and that seems an extraordinary thing to say. Powell's reasoning faculties were never very strong, and he could easily have put them under lock and key, and gone forth wholeheartedly to enjoy the imaginary side, the visionary side, and the human side, of the $\mathrm{R}$. C. religion. The crimes he would have forgotten, or forgiven, or even (God help him) condoned. 
When I say he was deficient in reasoning power, I only mean that he had no turn for logic, that baser form of reasoning which is the bane of the super-educated, or imperfectly educated person; but he was mighty in the imaginative reason of which education, so-called, so constantly robs a man. I always maintain that in conversiltion people should aroid argument, contenting themselves with uttering rival opinions ; for then you get the imaginative reason into play, which is as the fertilizing west compared to the east wind,-the east wind, that takes colour out of the sky and fragrance out of the flower. You know how Powell would shun argument, how he would push concession to the utmost limits so as to escape it ; and he was right. If he liked your doctrine he took it gratefully. If he did not like it he would make wry faces and pretend to swallow it, that was all. Argument is not the test of truth. Meditation, experience of life, hope, charity, and all the emotions - out of these the imaginative reason speaks. His dislike of argument was one of the reasons why you sought his company. Another reason was a negative one. He had no spite in his composition, no cruelty. However irritated, he did not wish to revenge himself. The reason why we would always submit to him was that we could not discover anything to beware of, no jealousy or envy, or even a competitive instinct of self-love.

I have a reminiscence from my daughter which I had forgotten. In 1897, the first day after her illness that she had left her bath chair, she and I walked along the High St., Turnham Green, and Powell met us. She remembers how he cireled round us, laughing but saying nothing. The first shop we came to, he rushed in and came out with a penny mug; at the next shop he did the same and brought out a penny picture post-card ; and at another shop he got a penny toy; and, finally, at another shop, some flowers. These all in succession he gave to her. I think that is characteristic of Powell; it paints him to the life; he had nothing to say, no plirases, only the offering of gifts.

I often said to him that he talked telepathically. To catch sight of him and to hear his laugh was to find yourself possessed by the Powell doctrine. You did not often, considering, hear his voice; he talked, comparatively, so 
little. But he was the air that we all breathed. He would propound no theories. I remember him so well, when he would remove his pipe and say, 'that's it', or 'that's true', or 'My God, that's true', or 'My God, that's fine'.

He always thought himself inferior to his friends, though, speaking generally, he never valued himself or others on their ethical qualities, unlike George Eliot and the typical English person for whom she writes. He never looked about for people to respect; he looked for people who would give him plenty of delight, excite his sympathy, and make themselves beloved. 'I do believe, Powell, you would not object to a murderer,' said some one to him. 'No, not if he was a really good fellow' said Powell. I believe Shakespeare was like that. He, like Powell, probably regarded these moralists as cunning rascals who wanted to strangle human nature. Powell liked life and the game of life so much that he regarded any one with suspicion who wanted to reform it. Those were a poor sort of people, and like vegetarians or water-drinkers sitting down to a feast. I believe it was this love of human nature and the game of life that made him a Tory. The Tory is more appreciative of life as it is in all its plenitude. Your Radical looks at life a little sourly.

I have heard people say Powell was hostile to ideas. What nonsense! He was a child of the ideal; only his ideas all came from love of human nature. He sought everywhere the concrete, which he could handle and love, and laugh with and laugh at. He did not care for dreams of intellectual beauty. In his Imperialism he was thinking of Englishmen and Irishmen and Scotchmen lustily enjoying themselves, first of all in fighting and afterwards in colonizing.

His Imperialism was to me portentous : without pity and without chivalry. I could never understand it. Yet even here I had only to tell him of a poor Scotch dragoon out of the reserve, called away to Africa to leave a beautiful full-bosomed Irish wife with two little children and another coming. I am glad to say he came back all right. For a short time his wife nearly lost her reason, but the Scotch elan gathered about her and took care of her. She was a splendid placid woman, like a summer sea. I remember 
telling Powell all about her case, and how Powell looked, how serious he got, and how silent. He was like Shakespeare's Hector, who in 'his blaze of wrath' would 'subscribe to tender objects'. This was a defect in Hector's warriorship. There were many such defects in Powell's warriorship.

My brother-in-law George Pollexfen, the astrologer, called him 'a Jupiter man, honourable to the finger-tips'; which means that however jovial, he was yet strict with himself. Strict with others is another matter, though this he might be wound up to, if put into careful hands, and made drunk with something like the late Boer war, and provided the victims were kept out of sight.

It seems to me that one of the foolishest ideas is people's habit of constantly looking for a complete man, a kind of nonsense handed down from Goethe. What we want is incomplete men. I like all qualities to be in excess, or rather that each person should be a specialist. Powell loved his friends to excess, and from this came everything. Complete, well-governed men have their value, no doubt; they make good clerks, look well after routine, \&e.

Powell was lovable, because he was a portion of some kind of eternal goodness, whose existence is proclaimed by the existence of such men. Isaac Butt had the same lovableness-poor Butt-superb in his weakness as in his strength.

One of Mr. Yeats's sentences suggests a comment. 'A strong will would have spoiled Powell.' This is true in many ways. Not only were his sympathies the freer for his 'want of will'; for he preserved the feminine side which is requisite to the complete man, and which in his case was free from the hysterical ingredient. His heart went out to many persons. A man with a hard stiff ambition or even a good but overmastering aim can seldom afford that luxury. Such a man is himself only when he is thinking of his aim. Powell found himself when he thought of others and of their aims and hopes. But his mind, and not only his heart, was the gainer for 'want of will'. It became a truer and clcaner mirror, as 
of glancing unflawed silver, reflecting all the kinds of truth that lay open to him. A strong will, even when its purpose is noble, can be a curse to the intellect. It often raises an opaqueness between us and the play of life ; it engages our vanity not to see the truths that are a criticism on our ambition; it gives us much to unlearn, and meanwhile life passes; it diverts us from healthy doubts to the means of overcoming hindrances. It makes us judge persons, not as wholes, not as they are, but as they bear on our wishes; if we cannot enlist them, they are nothing to us. Prejudice bred by the will is the worst. Powell's prejudices arose from a sense of what would not suit his nature. He shumned certain types and persons as he did some kinds of food. Many of his aversions are not valid in themselves; I have no desire to put in special pleading. But any such element was small in him when compared with the mass of his appreciative power; and this, again, was great, partly throngh natural gift, but also because he was little encumbered with definite purpose. Most men might suffer from so much frecdom; they are not big enough. Powell's 'want of will' never led him, be it said, to pamper himself. He was much too unselfish for that, and too distinguished-a word (vornehm) that has been tainted with cant by the apes of Nietzsche; but it comes to mind when we think of the things that Powell preferred and avoided. No doubt his powers of production were dispersed through his failure to plan far ahead; but on that point enough has been said already.

It only remains to add a few observations to those that are seattered through this book upon Powell's aspect and his talk. The portraits show him in different views and at various seasons of his life. He was of more than middle height, broad, and not over heavy for his height, though heavier when about fifty; a rapid, hasty walker until his last years, at least in cities; in the country or on the shore he went leisurely: no lover of 
hills, perhaps through some physical warning at the heart. He wore a beard from early manhood, full at first, and latterly grizzled; and glasses over brilliant black eyes, whose 'extraordinary kindness' has been mentioned; and they were also watchful and amused, pain or disapproval showing only in a tremor and faint frown. There was not what is called mobility of feature, such as is found in speakers or actors. His forehead was straight, not too high, and well-moulded, his colour, until illness came and even afterwards, ruddy-brown and healthy. The mouth and chin were much hidden, and the jaw too slightly built. It was a head of more than ordinary harmony and beauty, in youth notably so; and, in spite of a certain senatorial dignity that it came to possess, gave little clue to his profession. Sometimes he looked maritime, sometimes like a distinguished member of a foreign academy. His hands showed race, and he wore sailors' silver rings. His voice was rich and deep, but not much modulated; there was no rhetoric in it; and his utterance was quick, staccato. He spoke in brief phrases, interspersed with hesitations and the laughter that has been described already : this laughter was the first thing noticed by strangers, and gave a kind of choric effect to his talk; and he said with it what he did not care to say otherwise. It was sonorous and volleying, or quieter and muffled like a bass accompaniment: the close of his own story or sentence, and the greeting to that of others. His mirth could not offend, but it had the effect of a broom (that mighty weapon) when the conversation became too small, donnish, or stifling. Once he was with a sharking publisher, who explained complacently that he had made a good bargain with a poor author by concealing his estimate of the book offered. Another hearer wonld have frowned, or said something severe. Powell raised an exceptionally loud peal with a sharp note in it, and the creature partly understood. Mr. Yeats has noted how little he spoke in proportion to the effect conveyed. His silences, tossed- 
out oaths and curses and exclamations and eries of encouragement, and other imponderable methods, bridged the talk: and his use of the anecdote, as Dr Bonnier observes, was free and characteristic. He required the right atmosphere: in 'society', at a stiff dinner-party or' formal gathering, he was shy and ineffective; remained then silent, and could be formal and icy ; a single dubious countenance in a stranger might set him on his guard, and he was quick to see danger-signals. Amongst those whom he knew well but did not value, a gospel of polite contempt came to his aid, and his conversation would begin to play regardless of them, like a fountain in a veering wind, save for a few startling drops of spray that might cross their faces. But we might often find ourselves in a chance company of persons who were linked with one another only through Powell. He rather liked this: and his impulse, in order to foster the whole party, was to fan, as it were, each person in turn gently and sympathetically, as a good hostess might, drawing him out on his own chosen ground, on which Powell himself could move easily, though always taking (and sincerely) the attitude of a learner: until the dullest of metal showed a certain glow : and then, to prevent monopoly or monotony, he would dart to another speaker, while the first, now comparatively ready to listen, faded down to a gentle heat. Hence a picturesque variety, the whole room being brought together at intervals by a jest or epigram. Elizabethan verse, the methods of engraving or enamelling, the character of coming politicians, and the genius of music-hall artists; all these might be discussed in half an hour, the talk perhaps glancing to excess. ${ }^{1}$ What

1 'The present writer has heard him establish a contrast between Walt Whitman and the patriarch Job, in the course of which he spoke of the metrical system of the Psalms, and of Piers Plowman, and made an excursus on the rhy thmic scheme of The Song of Solomon. But to what end does one write of what he knew? Ho will live not only because he know, but because he mado others know.' (Morning Post, May 10, 1904.) 
linked it together was not Powell's knowledge, which was vast if not what foolish myth has pretended: it was rather his artistic interest in the way things are and should be done, in the faire: an interest rarely instinctive in an Englishman, but which Powell carried into the fields of dress and the erafts, ${ }^{1}$ as he did into those of scholarship or politics. Affairs, indeed, and public achievements, apart from the petty tactics and machinery he despised, seemed to present themselves to him as a kind of fine art, wherein certain results were attained only by due expert skill, the amateur and pretender being left behind by a natural law, and also the high-minded short-sighted person, whatever his intentions. It has been said already that he seldom argued: and though this might be a drawback, it made him a force, especially with logical persons who dimly saw that their logic did not carry them far enough. His mind was artistic and historic, not systematic.

At this point may be quoted some remarks on another side of Powell's talk. Mr. Herbert Fisher is again the writer :

He had an extraordinary gift for realizing and describing not only men but things and mechanical processes. About a fortnight before his end I was sitting by his bedside; and, the conversation happening to turn upon cider, he described to me with great minuteness and enjoyment

1 'We remember once that, the art of pantomine being mentioned, he was ready with a complete biography of Deburan, together with an account of the pantomime which Gautier and Charles Nolier wroto with him. This is but a single instance, taken at random, of his multifarions knowledge.' ('Musings without Method,' in Blackwood's Magazine, June, 1904.)

'This artistic interest and another are mited in a review of Dr. Jescopp's Frivola (Manchester Cuardian, Sept. 1, 1896): "Tho ghost story is admirably told, the feelings of the 'beghosted' person given with evident reality; the sense that the phantom is not a true boly comes first, followed by intense curiosity, then comes fear of its disuplearing, and dread to break the silence by speech, next a momentary loss of nerve, or premonition of horror, overcome by reasou, and the return to ordinary experienees happening as quietly and obtrusively as the disturbing phantasm itself had happened.'
r. P. $x$
G $g$ 
the different ways in which the apple is treated in Somersetshire and in Normandy. He seemed to know everything about it, the best kind of apple to use, the best way of preparing it, and all the refinements of the cider business, and how one locality differed from another in respect of this genial art. He would often take up a bit of paper and pencil and dash off a sketch of an object to which he was referring - a wine-press for instance or a jar-and say, 'It was like this'; and his skill with the pencil was just a part of his general visualizing capacity. It was an education to walk down the street with him. He seemed to suck in the contents of the shop-windows at a glance and to have an encyclopedia article ready in his hand about each of them. Even in squalid St. Clements he nearly always found something to arrest him, an old print, a tea-kettle, a battered book, and then he would stop, pass judgement in his quick decisive way, or allow himself to be drawn into commenting. It need scarcely be added that he was as familiar with the 'Realien' of Feudal Europe as he was with the crockery of his own day. Indeed his heart went out to every form of handicraft, and this was one of the many bonds which bound him to William Morris.

In judging others, Powell talked as he wrote, praising largely, and often praising persons one had never heard of without explaining who they were : but this habit did not become monotonous. 'Damn braces, bless relaxes,' says Powell's favourite poet; and up to this commandment he often acted. He damned first, and gave his reasons (usually intelligible) afterwards if asked. He was hard to turn from a dislike, he never commuted his sentences; and this was serious, because he sometimes judged at sight. Often his attitude was that of a regretful inability to take interest. The following, from a letter, expresses a frequent mood :

I don't want to blame the $\mathrm{X}-\mathrm{s}$, but that is how they impressed me: all of them ; good-natured, kindly, empty enough, with an eye ever screwed lightly in a mental telescope, pointed to the almighty dollar shining in a dark sky, - a small metallic disc with elear definition, a distinct parallax, and a period of greater or less brilliance. But you know them, I don't, and I am willing to admit that 
I may have misjudged them. I don't at all dislike them, but they don't interest me a bit. ... Human nature is very complex, though it works on a very few strings, like a marionette played by 'Old Provvy' (as — calls him) for his own somewhat grotesque and selfish amusement.

$\mathrm{X}$ - is not soul-satisfying. I can't really care for him, though I know he is a good fellow; _ too, but she is too frankly 'on the make' for me. I don't grudge people getting on, especially getting on honestly, but 'getting on' is not interesting save to the getter on; and 'God damn it, there's something better on earth than getting on', as — would say.

Original natures are best discovered by their code of blame and praise ; but to try and expound Powell's ethic would mean recommencing to describe him. Yet some points come out clearly, explaining the reserves of contempt that saved him from pure benevolence. He often quoted approvingly R. A. M. Stevenson's saying that the two cardinal sins are 'bilking and cruelty', and added ingratitude, which he regarded as worse than errors of passion. 'Dante's order is good enough for me; those who have injured their benefactors in the lowest pit.' The opposite of 'bilking', in his familiar language, was 'whiteness'. He must have plain dealing. Some have said that he was rather easily deceived in men, but this nearly always meant that he let them tax his good nature or generosity without being taken in or making any sign. His British friends were at times perplexed by his comprehension of other standards of feeling. He could appreciate a bull-fight as well as a glove-fight, being free alike from zest for bloodshed and from humanitarian qualms. He liked the technique of such historic sports : watehing-so one could think of him-the blood fall, not sharing the pleasure felt thereat either by the men or the women in the audience, but watehing that.also, in a studious way. He was indeed incalculable, said others; he, such a lover of his kind, with so many of the virtues of John the Evangelist! But these sharper elements were not the dominant ones. Latterly, he 
grew fonder of passing his judgements through portraiture, both in print and in his letters. His descriptions are seldom fierce, they end kindly whenever it is possible, as here :-

I don't think many people put so much vim into talk as does. He is a good fellow really, vain (but timid too as to his work), generous, a kind of pirate, to whom old age appears in frightful pantomimic guise every now and then in the distance, and he realizes that he can't drink or do other things so freely as he could, and sees a long vista of fights and struggles before he can get free of Execution Dock. This too has its pathos. When he is tired, one sees glimpses of this. When he is well, the king's his uncle and the world's a football; he is gloriously elate, like a gamecock. He is a man one gets to like a good deal, for all his faults are on the surface, and he is really very sensitive and touched by kindness.

Powell did not impress himself, like most persons who influence those around them, by his will, that is, through fear. He was not one of those natures that are selfwithdrawn, ready to sacrifice others to its own purpose, which may be a purpose for their good; a kind of sway most people accept if it be strong and calculated. But Powell believed in other people's freedom, which the missionary, organizing nature does not. His method was praise and encouragement, dashed with some raillery and occasional salutary blankness or dryness, though this admixture was instinctive and no part of a plan. It was regretfully said that his praise and admiration of those he liked came too easily. This might be so: but a slender allowance of modesty was enough to show them that he was praising what they would like to be rather than what they were. Persons who were not conseious of his approval described him as capricious in his estimates: but if the sun looked their way they thought he was improving in diserimination. Yet many might feel, as Ibsen's Peer Gynt did with Solveig, that they lived 'in his faith, in his hope, and in his charity'. Indeed, all those familiar with 
him might have some such impression, and state it in terms of whatever ereed they would. Their memory of him must be partly the memory of having thus existed in his mind. In terms of whatever ereed; for, once suppose a superior conseiousness in the universe, apart from what is found in man; then it would presumably belong to its nature to overestimate mail a little, knowing his latencies and possibilities, even those unlikely to be realized. Suppose, again, no such consciousness; then the power to conceive of it, even as an illusion, ean only be drawn from the sum of our aequaintance with human goodness, as displayed not only in the great founders of religions, or the procession of historie saints, or the army of martyred thinkers, but in the array of private men, who have no elaim to be world-figures, but who, like York Powell, radiate encouragement and affection with the help of a rich intelligence. 


\section{APPENDIX A \\ THE LIFE OF VIGFÚSSON}

The life of Vigfússon, with its strange mixture of learned strife, disappointment, achievement, and idyll, should be written at length, and the material lies in the following sources: (1) Notices and reminiscences scattered through his works. (2) MS. note, quoted, Memoir, pp. 32-6, 97-8, dictated to Powell on his childhood and youth ; and scrap of MS. in Danish on the same. (3) Obituary notice by Powell in The Academy, February 25, 1889, reprinted vol. ii. pp. 344-50: the account in the Memoir is to be read as a supplement to this, the best of Powell's three sketches of Vigfússon. The others are in (4) the Dictionary of National Biography, vol. lxvi, and in (5) Encyclopedia Britannica (Supplement), vol. xxxiii, 1892. (6) Obituary in Icelandic by Jón Thorkelsson in A rliv för Nordisk Filologi, 1889, 'new series, vol. ii. pp. 156-63: this is the fullest in detail and bibliography. There are also (7) Vigfússon's miscellaneous papers, and a mass of letters written to him by many persons in English, German, Danish-Norwegian, Swedish and Icelandic. I have availed myself of some notes made from these by the Rev. J. Sephton, who specially classified and arranged them before they went to rest in the Bodleian. (8) The letters and notes written by Vigfússon to others beside Powell; some of these may have been saved by his friends or their executors.

Note.-Since the footnote to p. 41 supva was printed, a note in Powell's hand has been found stating: 'I also wrote for Dr. Vigfússon at his dictation, putting his thoughts into English, \&e., Preface to Orkneyinga Saga (Rolls Series), Preface to Hakonar Saga (Rolls Series), papers in English Historical Review.' 


\section{APPENDIX B}

\section{EX-VOTO}

\section{BY DR. CHARLES BONNIER}

Manières brusques et vives, et large bonhomie; rire soudain ou face grave, une sensation de force et de bonté : e'est ainsi qu'il nous apparut dans ce décor qu'il s'était édifié, ce cadre où il avait limité sa vie studieuse en l'Université séculaire. Et, dès l'instant, la vision resta du grand appartement de Fellow (ou Senior Student) auquel on arrivait par le cloître du collège où les pas sonnaient dans le silence, avec le balancement aux fenetres des feuillages énormes du Broad Walk-l'illumination d'un décor anglais de prairie et d'avenue; des arbres vus à travers des piles de livres écroulés.

C'était là qu'il recevait ses amis et les étrangers qui se sentaient attirés vers lui-citons les grands noms de Mallarmé, de Verlaine. La grande chambre avait non l'aspect d'un musée - toutefois d'une galerie mobile qui se serait déplacée devant vous, livres succédant aux livres, cartons ouverts, gonflés de Japonaiseries, armes pendant aux murs ... et surtout sa promenade vivifiante, qui portait la lumière de son regard sur tous ces objets-le regard noir perçant l'éternel binocle.

Pour beaucoup l'abandon-forcé-de cette création sembla une diminutio capitis: il le dut sentir aussi, gagerait-on. Les murs sonnaient de ces Colloquia. Peu de lieux donnerent plus la sensation d'être habités. Même en l'y attendant, dans ces rendez-vous à ponctualité douteuse (résultats de cette vie surchargée), on y sentait encore la chaleur de sa présence et la proximité du retour. On croyait entendre le pas pressé dans le couloir, une interrogation rapide à son scout et déjà la voix vous saluait, la main se tendait.

Aujourd'hui celui qui succéda, le locataire, doit entendre parfois-s'il a l'ouie intelligente-de vagues ćchos de cette 
vie intense, qui sonna, eût dit Rabelais, pendant plus de vingt ans entre ces murs de collège.

Passer d'une science à une autre, tremplin ou ressort pour cet esprit agile, avide de savoir. Où trouver le pareil, sinon à l'époque des humanistes, tel un 'Panurge' de science âpre et gaie? A notre époque où tous se spécialisent, quand le chercheur, isolé dans sa science comme en une fosse de mine, creuse sans repos et sans joie, il était d'usage, en sa propre cité, de le considérer dilettante. Cette gaîté héroïque à chaque découverte, ce ça-ira, cette envergure; mauvais ton que tout cela. Surtout les éclats du rire vainqueur troublant ceux qui, dans quelque embrasure de fenêtre, scandaient quelques vers, déterraient quelques racines.

Tout, depuis sa propre science, celle des Sagas, jusqu'aux dessins de Steinlen dans le Gil Blas illustré-en passant par les dernières découvertes, mathématiques ou zoologiquesson esprit rapide le comprenait, choisissant dans la seience ce qui était nécessaire à sa propre santé intellectuelle, créant, dirons-nous, l'atmosphère mobile et lumineuse de ses idées.

Qui ne regretterait aujourd'hui cette joie, joie profonde conme d'un thélémite, joie active, qu'il nous fut donné de contempler? Cette admiration-qui forçait parfois au sourire même ses amis-n'était-ce pas la condition même de sa rapidité d'acquisition; la critique ne nous empêche-t-elle pas souvent d'avancer, la crainte de se tromper n'immobiliset-elle pas? Isui, avait pris son parti ; tout jeune il voulait 'jouir' de la science comme des autres joies, en extrairc tonte la sève et en laisser l'écorce aux scholars et autres animaux ì sang froid.

Aussi la santé de son esprit fut-elle sans égale; aussi, même jusqu'à la fin, s'intéressa-t-il au mouvement intellectuel; aussi vécut-il dans la science et dans l'art. Pour lui-et c'est le trait caractéristique de sa vie précieuse-les deux ne faisaient qu'un. Pareil à ces écoliers itinérants du quinzième siècle, il allait partout, non pour disputer, mais pour s'enquérir de nouvelles trouvailles. Tout ce qui était technique le passionnait. Il portait le même intérêt ravi aux procédés des artistes japonais qu'aux derniers livres d'histoire parus. Les uns, les autres-léduits par sa généralisation rapide-n'étaicnt-ils pas des phénomènes 
plastiques, des formes et des courbes, lignes d'idées ou tracé du burin?

Il s'était 'lesté ' très jeune, il avait goûté cette paix qui passe tout sentiment, et dont parle l'apôtre. La foi, la croyance, en certains esprits semblent la condition essentielle de l'existence; leur 'siège' est fait sur certaines questions qu'ils ne discutent plus, et le reste de leur eerveau est délivré, disponible pour d'autres oeuvres. Ceci explique, chez certains prêtres catholiques, la liberté d'esprit; hardis dans les seiences, tolérants en ce qui ne borde pas l'intangible. Chez lui, c'était a sound atheism, qui remplaçait cette foi, lui donmant un calme identique : apr'ès tout là qu'un déplacement de certitude. Il était aussi tranquille dans son manque de foi que le mystique dans sa croyance; ce n'était pas l'agnosticisme, qui implique déjà une sorte de découragement; le 'gnosticisme' plutôt, entendant par la l'élan infini vers le savoir, dans ce qu'il a de certain pour de rares esprits, la jouissance qu'il apporte, l'exereice libre et harmonicux, le 'sport' que dut pratiquer un Montaigne.

Changements en politique, évolutions en science: ils furent 'de bonne foy'; outre un désir de modifier l'attitude, d'éviter la crampe intellectuelle. Sa 'vive' tolérance-non flasque et trouble comme en un Renan-permettait à ses amis différentes évolutions. La raideur de l'attitude, l'intransigeance : peut-être les seules choses déplaisantes pour cet esprit souple, actif. Cela s'explique: il y voyait autant d'obstacles à sa marche, éléments réfractaires à son influence.

Pourtant son indulgence souriante admettait, chez les siens, certains partis-pris, même intolérances. Il savait s'arrêter, dans la conversation, devant les pitfalls des convictions arrêtées. Son rire montrait, tout au plus, la compassion qu'il ressentait pour cette 'servitude volontaire'. Avec un tact souverain, jamais il n'imposait sa 'non-croyance', ct pouvait causer avec un clergyman dans le common room du college, pourvu que ce füt sur des tragédies grecques, des histoires de brigands on de fellows.

Ce fut-pour celui qui écrit ces lignes votives-une révélation de l'entendre, à un déjeuner de dimanche à Oriel 
College, au milieu de tous ses collègues élevés à l'ombre de Pusey et du Movement, causer et rire comme dans une réunion de réfugiés de la Commune ou d'anarchistes.

Qui sait s'il n'en 'exprimait' pas alors une jouissance identique?

Il fut jouisseur de science profonde, explorateur de la mer de lumière, Viking des îles blanches. Initié à la science sous l'ère de Darwin et de Huxley, il se soumit joyeusement ì la théorie transformiste. Il souloit dire que les seuls livres qu'il ne pût goûter étaient les Confessions de St. Augustin et L'Imitation. Croyance à part, n'était-ce parce qu'y sont proclamés l'abandon de la volonté, l'amour de la souffrance, l'abnégation?

Son esprit n'admettait ni ombre, ni servitude; toutes ses idées nageaient dans le flot tranquille de la connaissance. Un obstacle, une barrière se dressaient, il les tournait, ne pouvant les surmonter, se hâtant de gagner unc route plus sûre. Ce fut un bon pilote, pour ceux qui -dans cet Oxford assoupi-cherchaient la parole, la direction fermes. Il les détournait des routes où leur énergie se serait brisée, leur indiquait les bouées marquant l'entrée des ports; il leur enseignait surtout la production tranquille, joyeuse. Que certains protestent, regrettent; n'avait-il pas à indiquer les routes, n'avait-il pas à 'communiquer'? Aussi il se détournait, sauvegardait les autres des sciences cachées, des cryptes où certains, comme dit le Rituel-'ont trouvé leur repos', une jouissance solitaire. Il l'avait compris: ces routes détournées, ces backvaters ne convenaient ni à lui ni à ses élèves; il restait sur la grand'route.

Combien de fois, le voyant arpenter sa grande chambre du Collège, causant avec ses élèves, scandant d'un rire son enseignement impromptu, allant droit vers le livre ou vers la citation, avons-nous pensé à la large, active, joyeuse production an grand atelier d'Anvers.

A ceux mêmes d'entre nous qui préféraient les rythmes cachés, la pénombre, il était une nécessité, un repos. Après de longues heures de travail, on le retrouvait avec la joic, l'élargissement qui viennent étendre et baigner la vision du voyageur à l'illumination douce de la clairière ! 
N'est-ce pas ici la station de pieux souvenir et de gratitude, écho des heures où nous fut permise la conmunication avec lui? A l'étranger, pour l'isolé en la ville universitaire, ces heures vespérales du Mardi-choisies en commémoration de Mallarmé-sonnaient joyeuses dans la chambre garnie où il venait causcr. Et des confidences sacrées, de sa part, furent alors transmises, quand le voile de gaité s'entr'ouvrait sur une gravité, un attendrissement mâles. Mais que vite disparu, vite recouvert, d'autant plus rare, précieux, ce Moment!

Le rire et la plaisanterie revenaient, l'anecdote drôle et pittoresque, à la Casanova, bondissait; et surtout scandés par le geste du fumeur invétéré, rallumant sa pipe, qui en un coin de lèvre relevait la forte moustache.

L'anecdote, voila encore une des marques, un de ses instruments de propagande. Non certes, la bonne histoire moisie, capital joke, dont vous régalent les Fellows au Common room; ou la plaisanterie morne qui, ne pouvant s'élever, a donné au Ciel d'Oxford sa pesanteur.

Non, chez lui, l'anecdote était toujours caractéristique, qu'il rapportât un trait héroïque des Sagas, une histoire de la Commune à lui racontée par Vallès ou J.-B. Clément, une ballade celtique, un vers décadent latin; toujours le trait illuminait et révélait.

Ainsi comprise, l'anecdote n'est-elle pas l'enseignement concentré, vivant dans son transport d'énergie? Tout cela, chez ceux qui l'ont écouté, n'a pas été perdu. De la longue fréquentation de cet esprit rare, Vigfússon, de son étude des vieilles Clıroniques, il avait retrouvé le parfum perdu du tale, embaumant, illuminant une page de forgotten lore.

Pour lui cette histoire, que les érudits ont desséchée, avait repris son sens primitif, barbare. C'était un récit, 'ce qu'on raconte'. T'rait de møeurs, coutume de tribu sauvage, curiosité d'anthropologie et de Folklore, tous étaient 'illustrés' par son aneedote.

Et c'est pourquoi les gens du peuple, de la classe dite basse, ressentaient pour lui cette sympathic qui jadis dut attirer les foules vers un Hérodote, un Froissart, les grands curieux et les grands interrogateurs, ceux qui voulaient savoir, jouissaient des histoires curieuses et rares.

Non seulement humaniste il l'était, an sens du seizième siècle, mais humain dans l'acception anglaise, et cela profondément. Les paysans et les ouvriers avec leur admirable 
tact, toujours prêts à se refermer devant l'étranger, le bourgeois, le Monsieur, allaient à lui qui allait vers eux. Et de cela combien d'exemples, deux ici.

A Oxford même, en la ville aristocratique, vivait un ramoneur de cheminées, grand orateur populaire, socialiste, ayant quelque chose de fruste et d'original comme Bradlaugh. Notre ami passait des heures à causer avec lui ; il ne se mettait pas, comme nos savants d'Universités populaires ou votre Extension Lecturer, condescendant, au niveau de celui qui l'écontait. Il s'adaptait à lui et toute sa supériorité acquise de savant, de lettré, ne lui servait qu’à ouvrir et se faire manifester cette intelligence pittoresque et hardie. En cela il se rapprochait du grand artiste que fut William Morris; il fut, cet ouvrier socialiste, leur ami commun.

A l'étranger, en France surtout où il passa les dix derniers étés de sa vie, dans un village de la côte boulonnaise, les paysans le comprenaient et l'aimaient. Cet hôtel banal où il vivait deux mois de l'année, il l'avait transformé, humanisé - et les touristes, Anglais ou Français, fuyaient d'instinct cette table où avec ses amis-cet esprit exquis parmi eux, Stevenson-il causait librement. Des familles respectables, égarées dans ce milieu, se sont levées, se sont ébronées et ont quitté la table-père, mère, enfants, à la mention du nom de Casanova. Les artistes, eux, venaient comme aimantés lui faire visite.

Même-visite inoubliable, unique-dans un coin ignoré ru Nord de la France, nous le vîmes un jour, et de ce milieu si différent il sut extraire l'intérêt, la vie. Et c'est pourquoi il ne s'cnnuyait jamais, trouvant avec sa grande labitude de 'déconvreur de sources de vie', tâtant le sol re son maquila et le caractère de son observation, dans chaque paysage, si gris fût-il, la ligne de dessin qui l'ennoblissait, dans chaque individu l'élément personmel et original.

Il savait aussi écouter, science énorme qui explique le dix-huitième sic̀cle francais, attitude recueillie ct réceptive it la fois, domnant au narrateur la sensation qu'on le suit et que sa pensée, talonnée presque immédiatement après son expression, trouvera de suite son asile, son atmosphère intellectucls. Combien de fois l'avons-nous vu, dans ces petites réunions de Christ Church, ou se promenant pross 
de la longue table surchargée de livres et de brochures, ou assis près du foyer surmonté d'un Rodin, s'épanouir et épanouir en même temps, foyer de lumière qui réfléchissait la pensée transmise? Cette science rare de l'attention éveillée, il la possédait.

C'était une de ses jouissances, une de ses facultés que cette réceptivité; elle lui permettait de humer l'histoire, l'anecdote, le renseignement rare et pittoresque ; aussi de lui conserver sa fraîcheur, préservée, intensifiée même dans la transmission. Il avait surtout un rire, un rire d'enfant à plusieurs étages, se renouvelant de lui-même à des sources inconnues de gaitté.

Il ne le possédait - ce qui arrive trop souvent chez nousce fond d'amertume, cette joie âcre qu'excite une remarque fine, inattendue, poignante d'un la Rochefoucauld ou d'un Chamfort. Sa joie était humaine, et comme ces peintres, Velasquez ou Goya, qui drapent de couleur faure les haillons de leurs paurres, lui, répandait une lueur de gaité autour de la misère humaine, l'anesthésiant ainsi, la rendant accessible à l'observation.

La mort même, cette préoccupation qui nous trouble tant que nous sommes, à cause des idées mises en nos têtes vers l'âge de neuf ans, comme disait Beyle ; cette répulsion de notre nature, il lui avait enlevé, de par son don de vie, toute horreur. Et puis, suivant l'expression de Bixiou, 'c'est si banal'; surtont, ce respect dont notre éducation mystique protège les morts, il l'arrachait comme un masque. La mort n'était pas 'respectable' pour lui ; il ne lui reconnaissait pas le droit d'excuser les erreurs ni les crimes.

En cela il était païen, et il eut en récompense une fin païenne, dans le soleil, dans le repos. Subita repentinctque, la cessation sans souffrance, l'arrêt imperceptible du mouvement. Il mourut dans son fauteuil, tandis que le jour entrait par la fenêtre ouverte, au milieu d'une lecture. Tandis qu'il pesait sans doute une idlée en son esprit, la mort vint, fut douce envers lui, et il ne l'aperent pas.

Et nous, ses amis an loin, quand nous apprimes les détails si caractéristiques, si 'elooisis', de cette mort, l'envoi du domestique porter une lettre, l'absence même de ceux qui lui étaient chers et qui auraient pu, par leur présence, lui domner un regret suprême, nous nous sommes dit: 'La mort fut pour lui l'élue, non celle qui vient en cachette et de nuit, mais la librement consentie et acceptée, la conclusion logique et attendue.' 


\section{OXFORD}

PRINTED AT THE CLARENDON PRESS

BY HORACE HART, M.A.

PRINTER TO THE UNIVERSITY 



THE LIBRARY

UNIVERSITY OF CALIFORNIA

Santa Barbara

THIS BOOK IS DUE ON THE LAST DATE STAMPED BELOW. 
UC SOUTHERN REGIONAL LIBRARY FACILITY

AA $000271572 \quad 0$ 


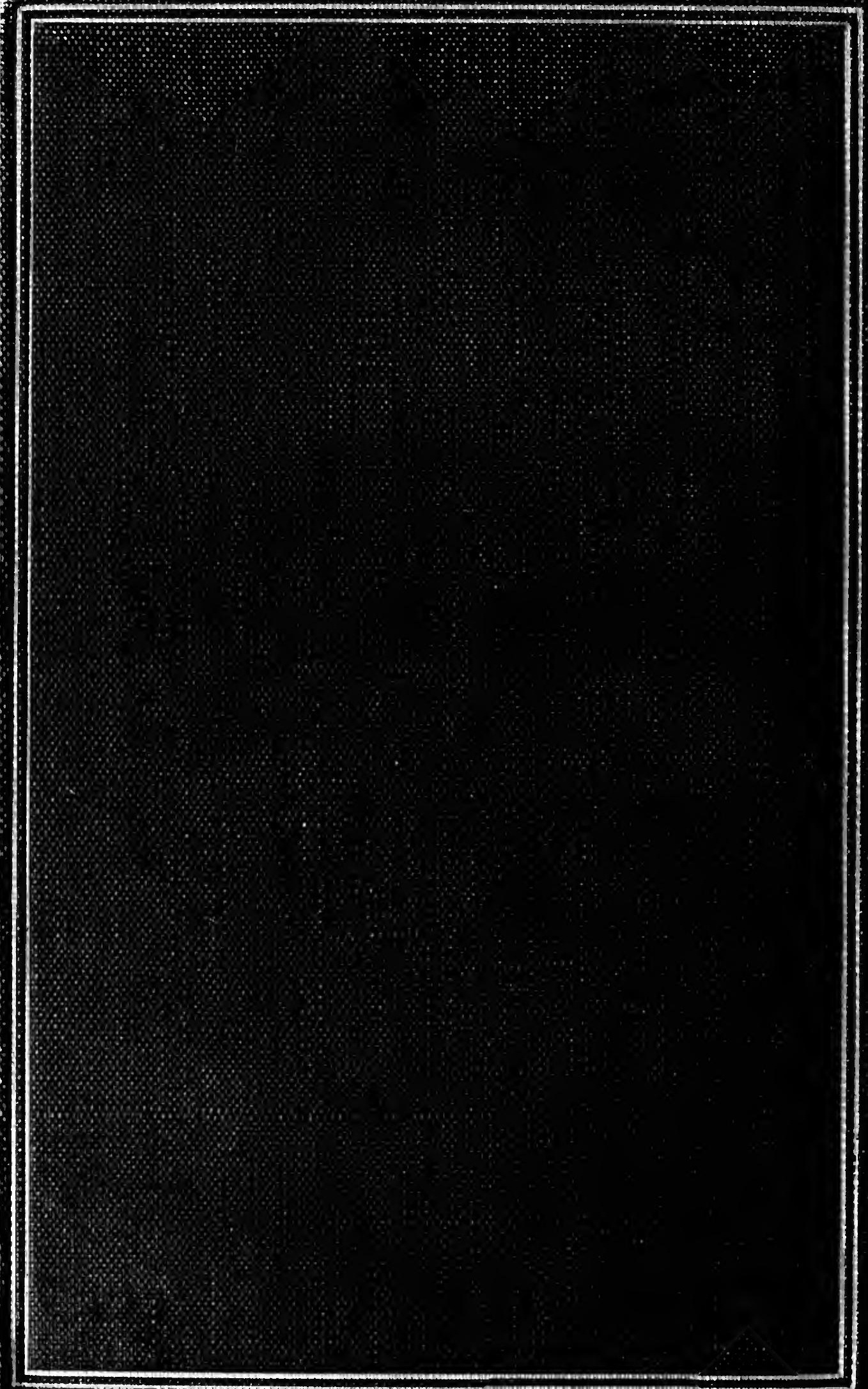

